Faculdade de Filosofia, Letras e Ciências Humanas da

Universidade de São Paulo

Departamento de Letras Modernas

Programa de Pós-Graduação Letras Estrangeiras e Tradução

Área de Estudos Linguísticos, Literários e Tradutológicos em Francês

\title{
TATIANA BARBOSA CAVALARI
}

\section{Os lugares:}

Espaços de criação autobiográfica na obra de Perec

VERSÃO CORRIGIDA

São Paulo

2019 
Faculdade de Filosofia, Letras e Ciências Humanas da

Universidade de São Paulo

Departamento de Letras Modernas

Programa de Pós-Graduação Letras Estrangeiras e Tradução

Área de Estudos Linguísticos, Literários e Tradutológicos em Francês

\title{
TATIANA BARBOSA CAVALARI
}

\section{Os lugares:}

Espaços de criação autobiográfica na obra de Perec

Tese apresentada ao Programa de Pós-Graduação Letras Estrangeiras e Tradução, Área de Estudos Linguísticos, Literários e Tradutológicos em Francês do Departamento de

Letras Modernas da Faculdade de Filosofia, Letras e Ciências Humanas da Universidade de São Paulo, para a obtenção do título de Doutora em Letras.

Orientadora: Professora Dra. Claudia Amigo Pino

\section{VERSÃO CORRIGIDA}

\author{
São Paulo
}


Autorizo a reprodução e divulgação total ou parcial deste trabalho, por qualquer meio convencional ou eletrônico, para fins de estudo e pesquisa, desde que citada a fonte.

Catalogação na Publicação Serviço de Biblioteca e Documentação

Faculdade de Filosofia, Letras e Ciências Humanas da Universidade de São Paulo

Os lugares: Espaços de criação autobiográfica na obra de Perec / Tatiana Barbosa Cavalari ; orientador Claudia Consuelo Amigo Pino. - São Paulo, 2019.

276 f.

Tese (Doutorado) - Faculdade de Filosofia, Letras e Ciências Humanas da Universidade de São Paulo. Departamento de Letras Modernas. Area de concentração: Estudos Linguisticos, Literários e Tradutológicos em Francês.

1. CH794.7.6. I. Pino, Claudia Consuelo Amigo, orient. II. Titulo. 


\section{ENTREGA DO EXEMPLAR CORRIGIDO DA DISSERTACÃO/TESE \\ Termo de Ciência e Concordância do (a) orientador (a)}

Nome do (a) aluno (a): Tatiana Barbosa Cavalari

Data da defesa: 06/09/2019

Nome do Prof. (a) orientador (a): Claudia Consuelo Amigo Pino

Nos termos da legislação vigente, declaro ESTAR CIENTE do conteúdo deste

EXEMPLAR CORRIGIDO elaborado em atenção às sugestões dos membros da comissão Julgadora na sessão de defesa do trabalho, manifestando-me plenamente favorável ao seu encaminhamento e publicação no Portal Digital de Teses da USP.

São Paulo, 04/11/2019

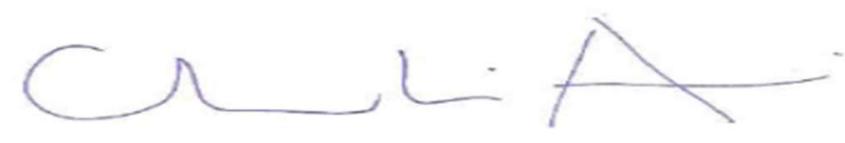

(Assinatura do (a) orientador (a) 
CAVALARI, Tatiana Barbosa

Os lugares: espaços de criação autobiográfica na obra de Perec

Tese apresentada ao Programa de Pós-Graduação Letras Estrangeiras e Tradução, Área de Estudos Linguísticos, Literários e Tradutológicos em Francês do Departamento de Letras Modernas da Faculdade de Filosofia, Letras e Ciências Humanas da Universidade de São Paulo, para a obtenção do título de Doutora em Letras.

Orientadora: Professora Dra. Claudia Amigo Pino

Aprovada em:

\author{
Banca Examinadora
}

Prof. Dr.

Instituição:

Julgamento:

Assinatura:

Prof. Dr.

Instituição:

Julgamento:

Assinatura:

Prof. Dr.

Instituição:

Julgamento:

Assinatura: 


\section{AGRADECIMENTOS}

A Claudia, minha orientadora, por ter apoiado todas as minhas decisões durante o percurso da pesquisa. Sua parceria foi essencial para que eu conseguisse chegar até aqui.

Aos colegas do grupo Criação \& Crítica, por me sentir fazer parte, ter um lugar para compartilhar alegrias, tristezas e experiências que vão muito além da pesquisa, pois conheci nesse grupo pessoas que serão meus amigos para sempre.

A Carolina Molinar, por seu afeto de sempre. A Aline Magalhães, pelo companheirismo nos projetos, congressos, nas aulas do Club de Lecture e em muitos outros momentos importantes.

Ao Leonardo Mendes, por ter compartilhado comigo muito do seu material de pesquisa, ter convivido comigo pelos corredores da biblioteca e bandejão, foi um companheiro de todas as horas.

A querida Kate, por ter compartilhado suas experiências sobre o lindo México.

A todos do grupo que leram meu trabalho, deram conselhos, fizeram críticas ou comentários sempre pertinentes, em especial o Paulo Ferraz e a Gisela Bergonzoni.

Meu muito obrigada a todos do grupo que sempre me mantiveram em movimento, seja apresentando a minha pesquisa, seja lendo a pesquisa deles, seja participando de momentos festivos. Pretendo continuar convivendo e fazendo parte desse incrível espaço de aprendizagem constante.

A Angélica Amâncio, pela parceria na editoria de um número da revista e pela disponibilidade na participação na banca de Qualificação.

A Paloma Vidal, também na participação da minha banca de Qualificação, pelas orientações valiosas, disponibilidade e generosidade nos comentários sobre a minha escrita, que me fizeram seguir adiante na pesquisa com entusiasmo.

A todos que encontrei em Congressos, Encontros do francês, monitoria, sempre dividindo comigo as angústias e alegrias de suas pesquisas.

Aos funcionários do DLM e o CNPq, pelo financiamento dessa pesquisa.

A todos os meus amigos que compreenderam minha ausência nos últimos anos e principalmente a minha mãe e a meus irmãos, Sandra e Ricardo, pelo apoio que me deram em todas as minhas decisões.

Ao meu companheiro na vida, Cláudio, pelo seu apoio incondicional, por suportar todas as dificuldades ao meu lado e por ter me dado a oportunidade de conhecer o verdadeiro amor, com a chegada do Theo. 
Eu não sou eu nem sou o outro Sou qualquer coisa de intermédio:

Pilar da ponte de tédio Que vai de mim para o Outro Mário de Sá Carneiro- Adriana Calcanhotto 


\section{RESUMO}

CAVALARI, T. B. Os lugares: espaços de criação autobiográfica na obra de Perec, 276 f. Tese (Doutorado). Faculdade de Filosofia, Letras e Ciências Humanas, Universidade de São Paulo, 2019.

O objetivo deste trabalho é refletir sobre algumas obras criadas a partir da influência de um projeto autobiográfico central do escritor Georges Perec, intitulado Lieux. Trata-se de um projeto que começou no início de 1969 e ficou inacabado, segundo a maioria dos críticos perecquianos (sobretudo o especialista Philippe Lejeune, em sua obra La mémoire et l'oblique, de 1991). Nossa análise tenta desfazer a ideia de abandono do projeto, pensando mais na sua transformação em outros modos de expressão artística. Durante doze anos, Perec desejava visitar doze lugares e descrevê-los a partir de um processo de escrita duplo: a primeira série descrita no próprio lugar, realizando anotações do que via e, uma segunda, a partir de suas memórias em relação a esses lugares. Todavia, durante o projeto, as descrições diminuem e os lugares observados passam a servir de inspiração para a criação de outros projetos autobiográficos, partindo da ideia do projeto original. Todos esses outros projetos surgem a partir de Lieux e do envelhecimento da sua própria memória, observando e descrevendo os lugares, mas também transformando-os em imagens, registros sonoros, poesia, fotografia, entre outros. Perec cria, então, uma autobiografia oblíqua, a partir da observação do outro: seja no momento em que observa o infraordinário nas ruas de Paris, seja no momento em que cria um filme sobre sua infância (é o caso de Les lieux d'une fugue, por exemplo, que não utiliza nenhum personagem como protagonista, nem mostra sua imagem), ou seja, ele cria histórias autobiográficas a partir do olhar do outro, uma espécie de autobiografia em terceira pessoa, em uma espécie de escrita capaz de representar a inquietude de Perec para falar de si mesmo.

Palavras-chave: Autobiografia, Memória, Espaços, Lugares, Georges Perec 


\begin{abstract}
CAVALARI, T.B. The places: spaces of autobiographical creation in Perec's work, 276 f. Tese (Doutorado). Faculdade de Filosofia, Letras e Ciências Humanas, Universidade de São Paulo, 2019.

This work aims to reflect on some works created from the influence of a central autobiographical project of the writer Georges Perec, entitled Lieux. It is a project that began in early 1969 and was unfinished, according to the majority of his critics (especially the expert Philippe Lejeune, in his work La mémoire et l'oblique, 1991). Our analysis attempts to undo the idea of abandoning the project, thinking more about its transformation into other modes of artistic expression. For twelve years, Perec wanted to visit twelve places and describe them from a double writing process: the first series described in the place, making notes of what he saw, and a second, from his memories of those places. Nevertheless, during the project, the descriptions diminish and the observed places serve as inspiration for the creation of other autobiographical projects, starting from the idea of the original project. All these other projects emerge from Lieux and the aging of his own memory, observing and describing the places, but also transforming them into images, sound records, poetry, photography, among others. Perec then creates an oblique autobiography, based on the observation of the other: either when he observes the infidelity on the streets of Paris, or when he creates a film about his childhood (such as Les lieux d'une fugue, for example, that does not use any character as protagonist, nor shows his image), ie he creates autobiographical stories from the other's look, a kind of third-person autobiography, a kind of writing capable of representing the Perec's restlessness to speak of himself.
\end{abstract}

Keywords: Autobiography, Memory, Spaces, Places, Georges Perec 


\section{RÉSUMÉ}

CAVALARI, T.B. Les lieux : espaces de création autobiographique chez Georges Perec, 276 f. Tese (Doutorado). Faculdade de Filosofia, Letras e Ciências Humanas, Universidade de São Paulo, 2019.

Le but du présent travail c'est de réaliser des réflexions sur quelques oeuvres crées avec l'influence d'un projet autobiographique central de l'écrivain Georges Perec, intitulé Lieux. Il s'agit d'un projet qui a eu le début en 1969 et reste inachevé, selon la plupart des critiques perecquiens (surtout le spécialiste Philippe Lejeune, dans son livre La mémoire et l'oblique, de 1991). Notre analyse essaye de réfuter cette idée d'abandon du projet, pour penser à la transformation de lui en d'autres modes d'expression artistique, qui vont extrapoler le texte écrit. Pendant douze ans, Perec voudrait visiter douze lieux et les décrire à partir d'un double procès d'écriture : la première sur place, en notant tout ce qu'il voyait et, une seconde, à partir des souvenirs par rapport à ces lieux. Cependant, durant ce projet, les descriptions vont diminuer et les lieux vont servir d'inspiration pour la création d'autres projets autobiographiques, qui partent de l'idée du projet original. Tous ces projets qui surgissent à partir de Lieux seront importants pour lui aider à réfléchir sur le passage du temps, sur le vieillissement des lieux et aussi le vieillissement de sa propre mémoire, en observant et décrivant les lieux, mais aussi les transformant en images, en enregistrements sonores et aussi en poésie et photographie, entre autres. Perec va créer, donc, une autobiographie oblique, à partir l'observation de l'autre : soit au moment d'observer l'infra-ordinaire aux rues de Paris, soit au moment de créer un film sur son enfance (c'est le cas du film Les lieux d'une fugue, par exemple, qui n'utilise aucun personnage comme protagoniste, ni montre son image), c'est-à-dire, il va créer des histories autobiographiques à partir du regard de l'autre, une espèce d'autobiographie à la troisième personne, un type d'écriture qui peut représenter l'inquiétude de Perec pour parler de soi-même.

Mots-clés : Autobiographie, Mémoire, Espaces, Lieux, Georges Perec 


\section{LISTA DE ILUSTRAÇÕES}

Figura 1. Envelopes lacrados com anotações sobre os lugares visitados em Lieux....... 27

Figura 2. Manuscritos datilografados de Claude Mauriac............................................ 30

Figura 3. Perec em frente ao número 24 da Rue Vilin ................................................ 34

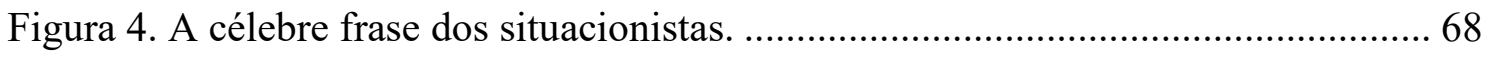

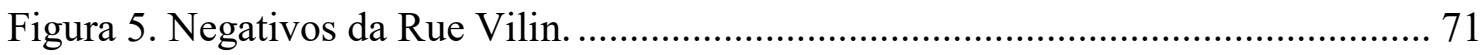

Figura 6. Perec e sua tia Esther no imóvel da rue de l'Assomption ............................... 83

Figura 7. Um dos desenhos feitos ao longo da escrita de Lieux. ................................... 84

Figura 8. Manuscritos com anotações em meio à escrita de Lieux ............................... 86

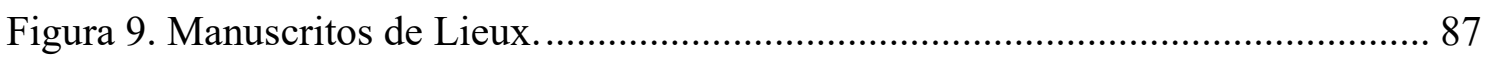

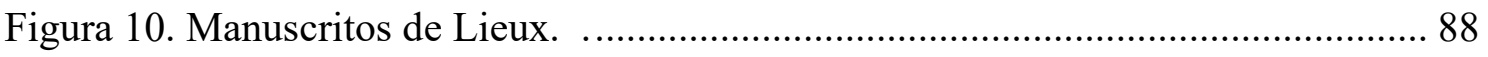

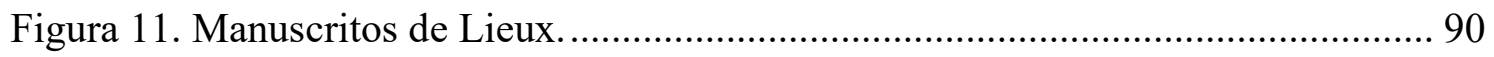

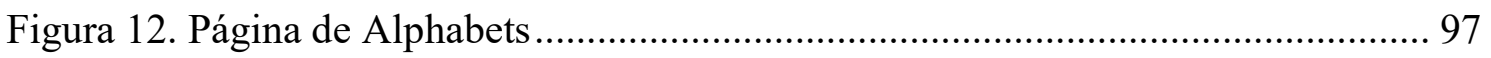

Figura 13. Exemplo de um texto de Ulcérations. ........................................................ 98

Figura 14. Comprovante da deportação de Cyrla para os campos de concentração ..... 99

Figura 15. Imagens das páginas de La Clôture.............................................................. 102

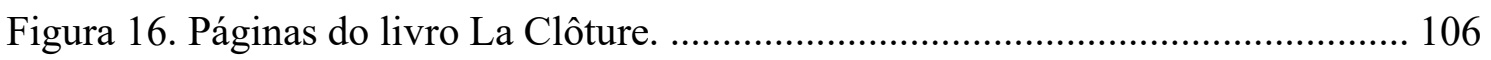

Figura 17. Montagem do texto sobre a foto do imóvel 24 da Rue Vilin ...................... 107

Figura 18. Imagens de fachadas abandonadas na Rue Vilin ...................................... 109

Figura 19. Imagens de fachadas abandonadas na Rue Vilin ..................................... 110

Figura 20. Cena final do filme "Um homme qui dort"............................................. 115

Figura 21. Cenas do filme La vie filmée des français. ................................................ 120

Figura 22. Cenas do filme La vie filmée des français ................................................ 122

Figura 24. Fotograma do vídeo de Je me souviens....................................................... 132

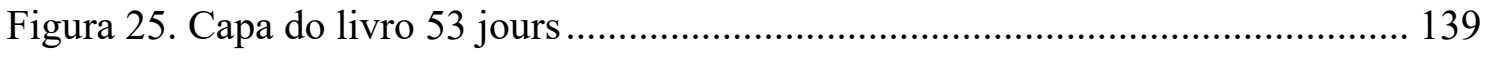

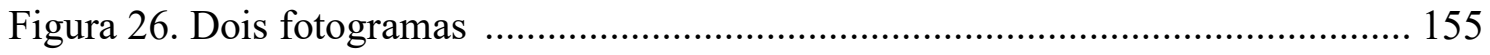

Figura 27. Cena do bairro Ménilmontant no documentário ....................................... 157

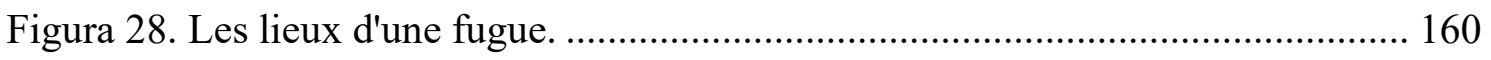

Figura 29. A cena do mercado de selos na Champs-Elysées..................................... 161

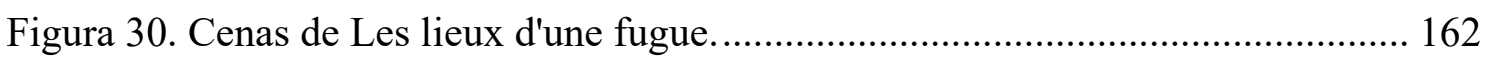

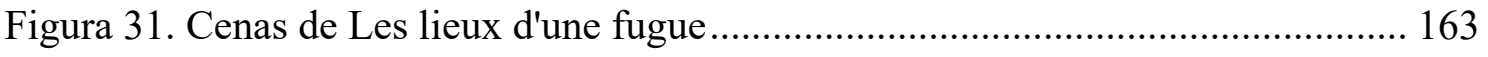

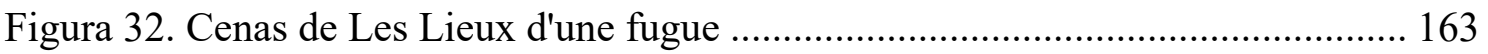

Figura 33. Cenas de Les Lieux d'une fugue .............................................................. 164 


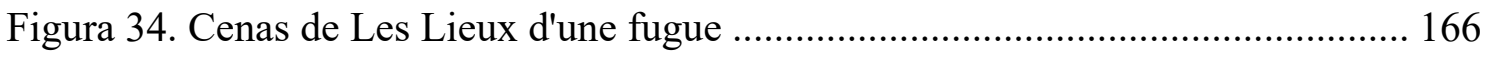

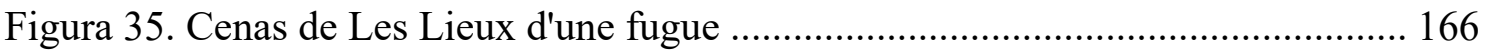

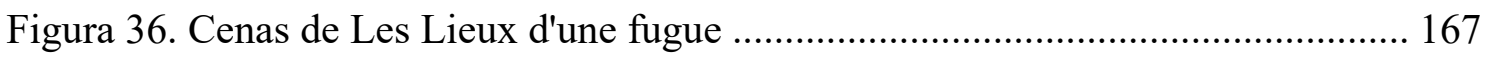

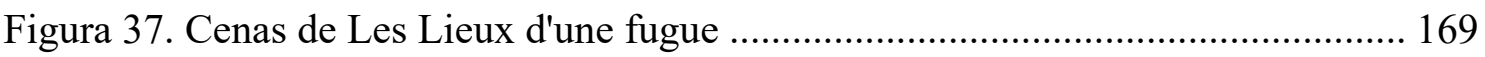

Figura 38. Texto datilografado que deu origem ao filme ....................................... 170

Figura 39. Foto da página 29 do livro-álbum Récits d'Ellis Island............................. 188

Figura 40. A clara destruição atual do lugar................................................................... 189

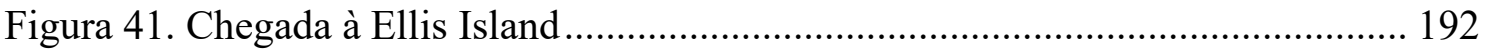

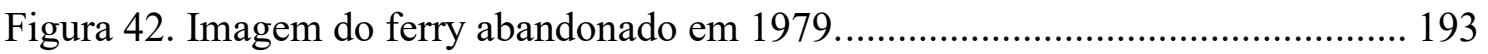

Figura 43. Georges Perec e Semyon Shimin. .............................................................. 196

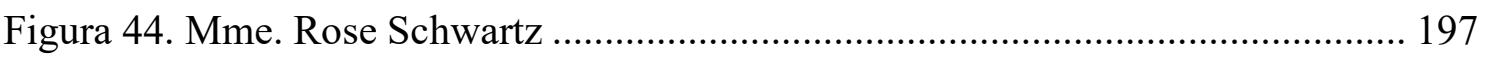

Figura 45. Perec em entrevista com Mme. Rabinovici............................................... 198

Figura 46. Decalque de um mapa da Terra do Fogo .................................................. 200

Figura 47. Cenas do documentário de Bober. ................................................................. 207

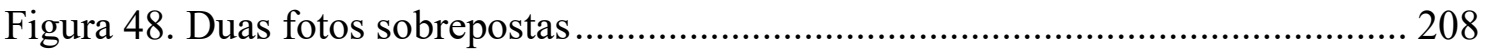

Figura 49. Cena do número 24 da rue Vilin, retomada por Bober .............................. 210

Figura 50. Bober mostra as fotos enquanto lê o texto de Lieux.................................. 210

Figura 51. Bober utiliza manuscrito de Lieux em seu documentário........................... 211

Figura 52. Bober folheia o documento esublinha o nome de Cyrla, mãe de Perec...... 213

Figura 53. Manuscrito de Lieux mostrado por Bober com as letras "SS"................... 213

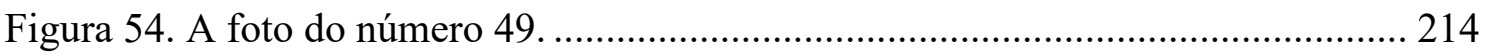

Figura 55. Trecho do livro W ou a memória da infância, retomado por Bober ........... 216

Figura 56. A foto de uma criança correndo ................................................................. 217

Figura 57. Foto de Perec, quando aluno da escola maternal ..................................... 218

Figura 58. O segundo achado de Bober................................................................... 219 


\section{Sumário}

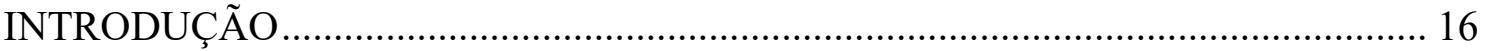

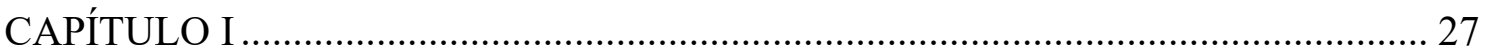

1.1. Motivações de Perec para a escrita de Lieux ..................................................................... 27

1.2. Reflexões a partir de Lieux: olhar para o cotidiano............................................................ 32

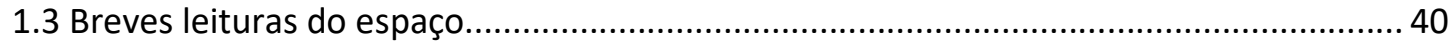

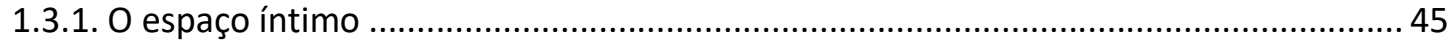

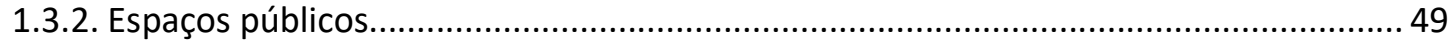

1.4.0 processo de transição de Lieux para outros suportes ..................................................... 55

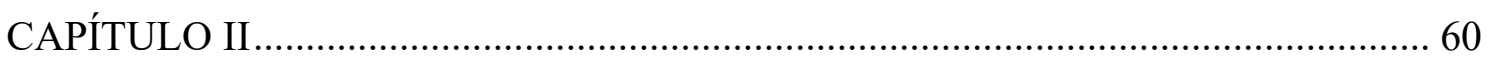

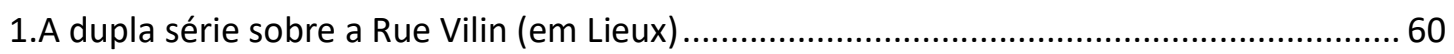

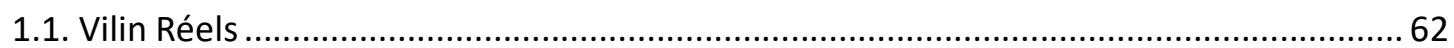

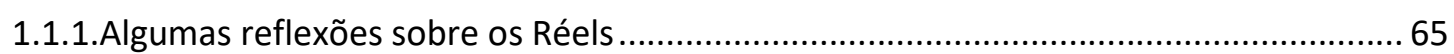

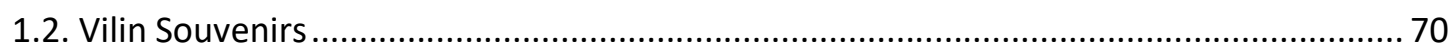

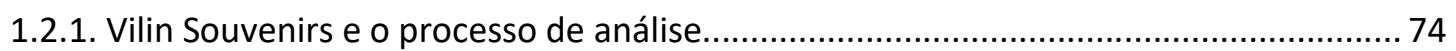

1.2.2. Escassez de lembranças, repetições na escrita............................................................. 78

1.2.3. A escrita que se transforma, as experimentações ......................................................... 84

1.2.3.1 Experimentações, rumo ao fim das "Souvenirs" ......................................................... 86

2.La Clôture: a transformação de Lieux em poesia com imagens ............................................. 91

2.1. O lugar fechado se transforma: poesia e regras de escrita............................................. 94

2.1.1. Regras fixas em jogo, autobiografia desvelada ........................................................ 100

2.1.2. O jogo com o leitor em La Clôture ............................................................................ 102

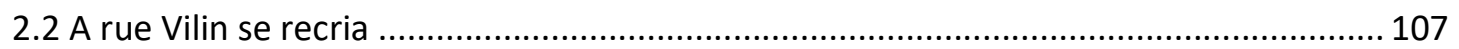

2.3 Lieux e suas constantes transformações........................................................................ 113

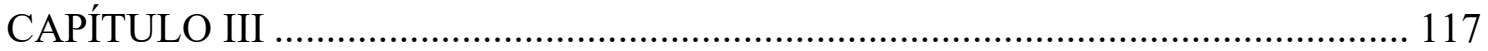

1. La vie filmée des français (1974): olhar para imagens antigas, contar sua própria história 118

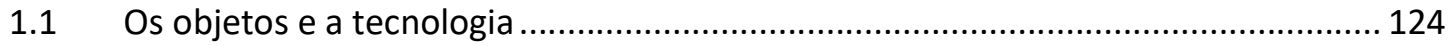

1.1.1. Inventários, listas e objetos tecnológicos .......................................................... 126

1.1.2. Objetos como representantes de uma época, de uma memória .......................... 129

1.2. A tecnologia na voz de Perec: o texto que passa a ser som........................................... 133

1.2.1. A voz como tentativa de representação de uma "totalidade" .................................. 140

1.2.2. "Capturar" o efêmero, fixar o tempo, no projeto Carrefour Mabillon ......................... 142

1.2.3. Tentativa de descrição de áudios e textos de Carrefour Mabillon ............................... 147

1.3. Re (escutando) a voz de Perec em La vie filmée .......................................................... 153

2. Les lieux d'une fugue: os lugares como protagonistas................................................ 158 


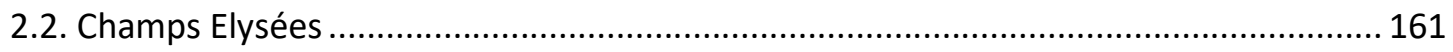

2.3. O "eu" está presente, mesmo que de relance ........................................................... 164

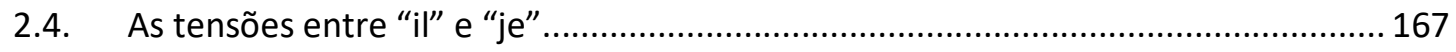

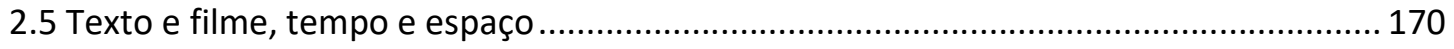

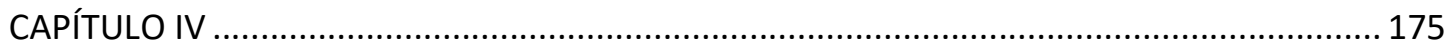

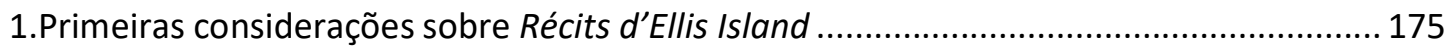

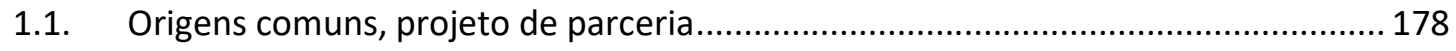

1.2.A imagem do outro: ponto de partida para o filme/livro ............................................ 186

1.3.A palavra do outro: entrevistas que contam a passagem por Ellis Island ...................... 194

1.4.A ilha como lugar na escrita de Perec .......................................................................... 199

2.En remontant la rue Vilin... O documentário que recria Lieux........................................ 201

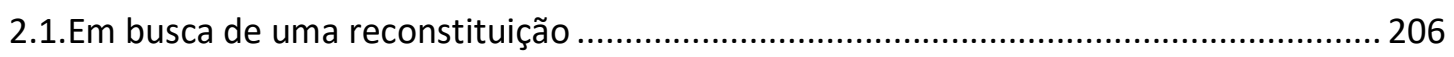

2.2. Desaparecimento do lugar, desaparecimento das pessoas......................................... 212

2.3.A sobreposição das fotos e dos tempos........................................................................ 214

2.4. Uma memória de Perec, inventada por Bober ........................................................... 217

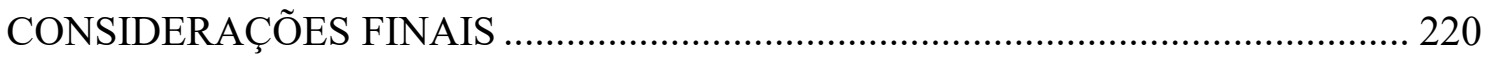

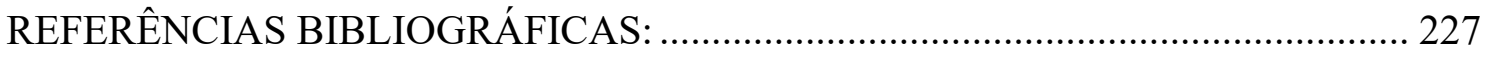

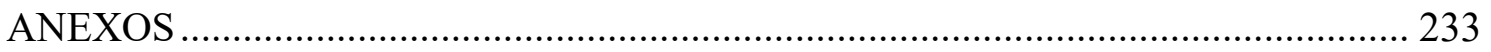

ANEXO 1- Dedicatória de Perec a J.B. Pontalis, no livro W ou le souvenir d'enfance ............ 233

ANEXO 2- Documento que atesta a adoção de Perec pelos tios .......................................... 234

ANEXO 3- Declaração de « Mort pour la France », de Icek Judko Perec. ............................... 235

ANEXO 4- Inventários transcritos e links para escuta dos áudios de Carrefour Mabillon .... 236

ANEXO 5 - A ligação entre os lugares e a autobiografia de Perec, segundo Lejeune ........... 244

ANEXO 6 - Les Lieux d'une fugue: texto original datilografado .......................................... 245

ANEXO 7 - Lista original datilografada, contendo os objetos que compõem cena do "comissariat" em Les lieux d'une fugue ............................................................................. 256

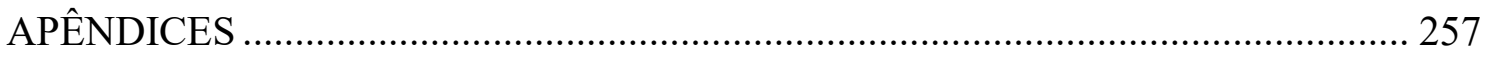

APÊNDICE 1 - Trechos de Espéces d'espaces que relatam a concepção do projeto Lieux e

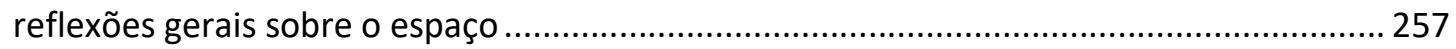

APÊNDICE 2 - VILIN RÉEL, publicado como "La rue Vilin" ................................................... 259

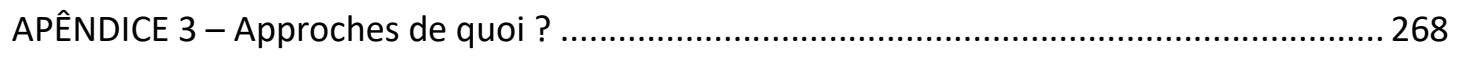

APÊNDICE 4 - Quelques-unes des choses qu'il faudrait tout de même que je fasse avant

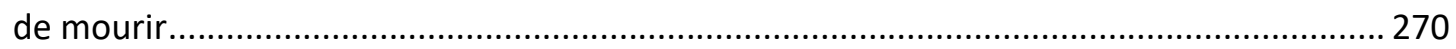

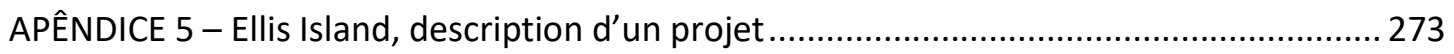




\section{INTRODUÇÃO}

O objetivo deste trabalho consistiu em realizar uma reflexão sobre a criação de algumas obras que fazem relação entre o texto literário e outras artes (fotografia, cinema, emissão radiofônica, etc.) partindo da influência de um projeto central na obra de Georges Perec (Lieux). Trata-se de uma obra considerada inacabada ou abandonada por grande parte da crítica perecquiana e que, a partir das análises que pretendo desenvolver, dá origem a uma primeira hipótese a ser investigada: contrariando os seus críticos, este projeto não será, aqui, lido como abandonado ou fracassado, mas antes como transformado em outras obras, bastante heterogêneas e significativas. Ou seja: a obra Lieux está no limiar entre a escrita e outras expressões artísticas que serão desenvolvidas a partir do projeto original, tais como poesia, fotografia, cinema e emissão radiofônica. Lieux gira em torno de outras obras, concebidas posteriormente, tendo como eixo central a descrição dos lugares e a reflexão a partir deles, realizando, assim, uma obra autobiográfica que transita entre as diversas expressões artísticas a partir da escrita literária.

O autor tinha em mente visitar doze lugares de Paris, durante doze anos, observando as mudanças ocorridas nestes lugares, criando uma espécie de escrita dupla: uma que descrevesse os lugares e outra, posterior, que tratasse das lembranças produzidas por tais lugares; assim, a investigação dos lugares seria também uma investigação do tempo e da própria memória, a partir da descrição dos "réels" (o que era observado) e das “souvenirs" (o que era reconstituído em sua memória após a visitação destes lugares).

Perec iniciou o projeto em 1969 e pretendia levá-lo adiante até o final de 1980, quando abriria os envelopes onde teria arquivado todos os réels e souvenirs ao longo dos doze anos, na tentativa de criar uma obra que tratasse do envelhecimento dos lugares e do tempo, além do envelhecimento da própria escrita e da própria memória. Ao final dos doze anos, segundo seus planos, o autor abriria os envelopes fechados, releria os textos escritos, recopiaria tais escritos e estabeleceria relações e listas necessárias para a (re)escrita do texto, mesmo que ainda não tivesse uma ideia clara sobre o que fazer após encerradas todas essas etapas, conforme confidenciaria em uma carta ao editor Maurice Nadeau: 
Escolhi, em Paris, doze lugares, ruas, praças, cruzamentos, ligados a lembranças, a eventos ou a momentos importantes da minha existência. A cada mês, eu descrevo dois desses lugares; uma primeira vez, no lugar (num café ou mesmo na rua) eu descrevo "o que vejo" da maneira mais neutra possível. [...] uma segunda vez, em qualquer lugar [...] descrevo esse lugar de memória, evoco lembranças que são ligadas a ele, pessoas que lá conheci, etc. [...] Ao final de um ano, terei descrito cada um dos meus lugares duas vezes, uma vez no modo da lembrança, uma vez no lugar em descrição real (PEREC, 1990, p.58-59) ${ }^{1}$.

Outras obras estarão presentes na discussão, visto que o tema do espaço é recorrente na obra de Perec, tanto para descrever lugares e questioná-los quanto para expressar-se sobre si ou sua história. Mas o que se pretende destacar na pesquisa é a reflexão sobre a transformação do texto literário em produções realizadas a partir de outros suportes. Talvez não fosse "apropriado" tratar Lieux com um texto literário propriamente dito, visto que foi um pré-projeto de texto não finalizado ${ }^{2}$. Ainda assim, todo o nosso trabalho girará em torno da transformação desse "resto", do que sobrou, do que ficou inacabado e, portanto, restou latente e deu origem a outros tantos projetos. Não há um trabalho literário acabado, mas uma potencialidade de escrita que se prolifera.

Falar sobre os lugares ou pensar os espaços é uma questão que surgiu de maneira bastante natural em minha pesquisa, principalmente no momento em que resolvi incorporar a obra Récits d'Ellis Island à dissertação de mestrado. Até então, eu me interessava, sobretudo, pelo romance autobiográfico de Perec, $W$ ou a memória da infância, sendo este o objeto principal da pesquisa.

Acontece que, ao refletir sobre o impacto da fotografia na criação da escrita autobiográfica, acabei reconhecendo em Récits d'Ellis Island muitos elementos semelhantes às questões presentes em $W$, no que se refere à escrita autobiográfica e ao uso de imagens que, de certa forma, auxiliam no processo de criação desta escrita. Dessa forma, as questões de memória individual em relação à memória coletiva, a construção do texto voltada para a questão do exílio, além do uso de fotografias para descrever o lugar (uma ilha em Nova Iorque onde milhares de emigrantes europeus chegaram no

\footnotetext{
${ }^{1}$ No original: "J'ai choisi, à Paris, douze lieux, des rues, des places, des carrefours, liés à des souvenirs, à des événements ou à des moments importants de mon existence. Chaque mois, je décris deux de ces lieux; une première fois, sur place (dans un café ou dans la rue même) je décris 'ce que je vois' de la manière la plus neutre possible [...] une deuxième fois, n'importe où [...] je décris le lieu de mémoire, j'évoque les souvenirs qui lui sont liés, les gens que j'y ai connus, etc. [...] Au bout d'un an, j'aurai décrit chacun de mes lieux deux fois, une fois sur le mode du souvenir, une fois sur place en description réelle".

${ }^{2} \mathrm{O}$ próprio estudo genético de Lieux, realizado por Lejeune e citado em várias passagens, tem como título "Cent trente-trois Lieux" e corresponde à quantidade de envelopes lacrados por Perec (133), número bastante inferior ao que se planejava inicialmente (um total de 288 envelopes ao final de 12 anos).
} 
começo do século XX) foram cruciais para que eu incorporasse esta obra ao texto da dissertação, pensando em como estas questões puderam de fato se articular em ambas as obras.

Assim, no início do doutorado, havia o plano inicial de aprofundar a análise de Récits d'Ellis Island, não mais me limitando às questões da escrita em relação às fotografias, mas adentrando um viés de análise que refletisse sobre a produção de documentários autobiográficos, ou seja, de filmes que contassem a história de outros como uma tentativa de escrever sua própria. Este é o caso de Perec e de seu companheiro, o cineasta Robert Bober, que criaram juntos um livro e um documentário nos quais refletem exatamente sobre a chegada dessas pessoas à Nova Iorque. Ambos franceses de origem polonesa, o escritor e o cineasta colocaram para si a seguinte questão: "O que teria sido se nossas famílias tivessem seguido o mesmo destino? E se fôssemos cidadãos americanos hoje, como seria?".

Essas são reflexões presentes no texto, que é escrito ora de maneira objetiva (quando nos apresentam as estatísticas sobre a chegada das pessoas, listam objetos abandonados, descrevem os nomes de embarcações e nacionalidades), ora de forma extremamente subjetiva (quando falam de si, da própria história, quando se questionam sobre essas histórias). Assim, o ponto central do projeto girava em torno da seguinte questão: como escrever a história do outro (ou documentar a história do outro, nesse caso) para que seja capaz de refletir sobre a própria história de quem a escreve? Cria-se, assim, um documentário autobiográfico, onde a memória do outro substitui a própria?

Em relação ao desenvolvimento da pesquisa, é evidente que meus interesses estavam muito concentrados em lidar com os dois documentários apresentados no projeto inicial. Quando comecei a analisar as motivações de Robert Bober para a criação do documentário En remontant la rue Vilin, porém, eu me dei conta de que o projeto Lieux é um dos pontos de partida para o cineasta. Estão ali, na citação já apresentada, as motivações de Perec, que serão também inspiração para Bober: seus projetos em relação ao futuro, suas aspirações para um projeto de longo prazo que o fará refletir sobre o envelhecimento dos lugares, da escrita e da própria memória.

Lembro-me que, quando escrevia o projeto de doutorado (que viria a originar esta tese), a obra Lieux ainda parecia pouco importante ou até secundária em comparação às outras obras de Perec. É curioso lembrar, entretanto, que, ao participar do Encontro do Francês em 2015 (FFLCH-USP), no qual apresentei um ateliê sobre minha pesquisa para o público presente, dividi minha apresentação, baseada em Récits d'Ellis Island, em duas 
partes. A primeira se referia à memória a partir de fotografias de pessoas, de rostos (algo muito presente no documentário); a segunda discutia a relação da memória com os lugares, o que já mostrava, ainda que sutilmente, meu interesse por esta investigação na obra de Perec: como os lugares se relacionam com a memória autobiográfica? Nesta época, eu ainda não havia feito a pesquisa de campo na Bibliothèque de l'Arsenal, em Paris, nem consultado os manuscritos de Lieux e talvez ainda me baseasse nas ideias de críticos importantes, como Philippe Lejeune, que a considera uma obra "abandonada, fracassada", como podemos observar em diferentes passagens de seu texto consagrado à gênese da obra, no livro La mémoire et l'oblique.

Um trecho do texto de Lejeune me motivou justamente a pensar o contrário sobre o texto de Lieux. O crítico parece não dar muita importância para as "transformações" surgidas a partir do projeto, já que considera que os objetivos iniciais foram perdidos. No início da pesquisa de mestrado, eu me baseei muitas vezes nas análises de Lejeune e tinha dificuldades em encontrar pontos de divergência entre as ideias do crítico e minhas próprias análises. Neste momento, considero ter superado esta leitura muito própria e conseguido enxergar um pouco além, sem apenas me contrapor totalmente a ele, mas acreditando criar um problema a partir de sua afirmação:

O novo projeto anunciado como uma "transformação" do projeto abandonado, não tem muita coisa em comum com ele. Dois ou três "lugares" migraram para outras mídias (linguagem poética, cinema, rádio). Mas não formam mais um sistema entre eles e sobretudo o tempo não é mais levado em conta, esses doze anos de observação que eram o elemento essencial e original de Lieux. (LEJEUNE, 1991, p. 202)

Lendo as entrevistas ou comentários de Perec sobre seu projeto, não é possível afirmar categoricamente quais são suas intenções ou objetivos finais. Desde o início, havia em Perec o desejo de questionar a passagem do tempo, seu envelhecimento, mas daí a afirmar que havia um sistema rígido e sem possibilidade de modificações e que, se não se seguisse exatamente e cronologicamente a ideia inicial de intercalar os envelopes não haveria mais projeto... prefiro acreditar que haja mais "obsessão" em manter o método e a disciplina por parte de Lejeune do que por parte do próprio Perec.

\footnotetext{
${ }^{3}$ Le nouveau projet annoncé comme une "transformation" du projet abandonné, n'a en fait pas grand-chose en commun avec lui. Deux ou trois "lieux" ont émigré vers d'autres médias (langage poétique, cinéma, radio). Mais ils ne forment plus un système entre eux et surtout ils ne sont plus pris dans le temps, ces douze ans d'observation qui étaient l'élément essentiel et original de Lieux.
} 
Desde o início, era evidente que as regras seriam seguidas e que havia um plano inicial, mas não seria ingenuidade pensar num projeto que não sofresse nenhum tipo de alteração ao longo de doze anos de existência? Não posso acreditar que um escritor, no auge de seu processo criativo, conseguisse manter rigorosamente esta regra fixa até o final do tempo estipulado. Portanto, não acho produtivo analisar Lieux como um projeto abandonado e muito menos diminuir a importância das obras "transformadas" a partir de uma primeira. Este é o ponto central da minha pesquisa: ao mesmo tempo em que encontro várias referências sobre lugares e espaços em muitas obras de Perec, escritas durante ou depois do "abandono" de Lieux, também percebo que, para além de textos, outras obras foram criadas, em outros suportes, o que nos faz pensar em Lieux como uma obra central, em torno da qual várias obras "satélite" puderam girar em torno, conceito usado por Jean-Luc Joly, em texto que veremos adiante.

Um exemplo claro está na citação de Perec sobre a filmagem de Un homme qui dort: ao mesmo tempo em que se mostra preocupado com possíveis atrasos, já que não consegue "cumprir" ou executar o projeto de Lieux em 1973, já que estava ocupado com a filmagem, Perec admite que muitos dos lugares que deveria estar visitando para escrever Lieux estão no filme. Não seria essa, desde já, uma transformação do projeto em outra expressão artística? Não há influência do olhar de Perec, depois da prática de observação de Lieux, desde 1969, para a filmagem de Un homme qui dort? Não, há, inclusive, uma certa renúncia ao projeto inicial em nome de outro, que está por vir (neste caso, o filme)?

Este é um dos vários exemplos que estarão presentes para nos ajudar a refletir sobre a importância de Lieux, mesmo que, neste momento, talvez nem Perec se desse conta das transformações que a obra já vinha sofrendo:

Muito preocupado, no ano anterior, com a filmagem de "Um homme qui dort" (no qual aparecem, aliás, a maioria desses lugares), saltei o ano de 1973 e somente em 1981 terei em mãos (se não me atrasar novamente) 288 textos dessa experiência. Saberei então se valeu a pena: o que espero, de fato, é apenas o traço de um envelhecimento triplo: aquele dos lugares, o das minhas memórias e o da minha escrita (PEREC,1992, pp. 76-77).

\footnotetext{
${ }^{4}$ Trop préoccupé, l'année dernière, par le tournage de "Un homme qui dort" (dans lequel apparaissent, d'ailleurs, la plupart de ces lieux), j'en ai fait sauter l'année 1973 et c'est donc seulement en 1981 que je serai en possession (si toutefois je ne prends pas d'autre retard...) des 288 textes issus de cette expérience. Je saurai alors si elle en valait la peine : ce que j'en attends, en effet, n'est rien d'autre que la trace d'un triple vieillissement : celui de lieux eux-mêmes, celui de mes souvenirs, et celui de mon écriture.
} 
Como já mencionado, Lieux não tinha uma posição central na minha pesquisa: até então, minha leitura acompanhava a análise de Lejeune, considerando Lieux apenas como uma obra abandonada. Acontece que, ao entrar em contato com os manuscritos da obra e, talvez, "contaminar-me" com as caminhadas que fazia por Paris ${ }^{5}$ e que me influenciavam, de certa forma, a começar a prestar mais atenção naqueles lugares citados por Perec, pude perceber a importância do projeto iniciado pelo autor e que, por diversos motivos, realmente não chegou ao fim. Mas, se pensarmos na quantidade e multiplicidade de obras que possivelmente sofreram alguma influência desse olhar perecquiano, que busca encontrar nesses lugares da cidade alguma história para contar, nem que seja a partir de descrições exaustivas - e que trata de questões que passam pelos lugares, pelo espaço, pela memória, e pela escrita autobiográfica -, mesmo que essa escrita aconteça, em alguns casos, a partir de outros meios de expressão que não os textos em si, a relação entre eles é patente.

Todavia, numa nova leitura, menos resistente a Lejeune, também encontrei ali traços que indicam e ressaltam a importância de Lieux para a escrita autobiográfica de Perec. O crítico, após aprofundar-se nas leituras dos manuscritos, contradiz-se em certo momento do texto, dizendo que Lieux pode ter sido não um fracasso, como vinha afirmando, mas talvez um renascimento, uma liberação necessária para que Perec continuasse sua escrita de outras formas, produzindo, por exemplo, logo após "abandonar" Lieux, uma de suas obras mais importantes, La vie mode d'emploi. Assim como Lejeune reconhece que errou ao afirmar categoricamente que a obra teria sido um fracasso, também aqui devo reconhecer que uma releitura mais atenta de Lejeune me fez entender que sua posição também mudou ao longo da escrita de seu texto crítico:

Lieux é a matriz de todo trabalho autobiográfico de Perec entre 1969 e 1975, e o exemplo mais espetacular de um novo tipo de comportamento autobiográfico indireto e plural [..] Lieux é o túmulo de um amor. Uma imensa pirâmide construída em torno de um quarto secreto. Uma massa enorme de materiais visíveis acumulados em torno de um centro (quase) invisível. (LEJEUNE, 1991, p. 146) ${ }^{6}$.

\footnotetext{
${ }^{5}$ Atividades realizadas na pesquisa de campo cumprida entre dezembro de 2015 e janeiro de 2016, prevista no projeto inicial de doutorado.

${ }^{6}$ Lieux est la matrice de tout le travail autobiographique de Perec entre 1969 et 1975 , et l'exemple plus spectaculaire d'un nouveau type de comportement autobiographique indirect et pluriel [...] Lieux est le tombeau d'un amour. Une immense pyramide construite autour d'une chambre secrète. Une masse énorme de matériaux visibles accumulés autour d'un centre (presque) invisible
} 
Interessante pensar nas expressões "tombeau d'un amour" e "chambre secrète", que nos remetem à ideia de túmulo, lugar onde se guardará os restos mortais de um amor. Mas por que tratamos aqui de um amor? Segundo Lejeune, a motivação principal de Perec em iniciar o projeto Lieux não é exatamente o que ele expõe ao editor Maurice Nadeau (a escolha dos lugares de maneira aleatória, procurando estabelecer relações entre eles e sua própria história, como vimos na citação inicial), mas sim uma tentativa de "cura" para uma ruptura amorosa. Lendo um trecho do Lieux n n 41, de 1970 (sobre a Île Saint-Louis), constatamos que há realmente uma declaração de Perec sobre suas motivações, que se encaminham muito mais para uma questão amorosa não resolvida:

Devo evidentemente notar que a escolha da Ilha Saint Louis entre esses doze lugares foi determinante (o mesmo para a concepção geral do livro) pela minha ruptura com S. em janeiro de 1969: foi ao mesmo tempo encontrar algo para fazer e me enraizar em Paris. [...] Passando uma vez por ano na ilha, talvez a reencontre, em um ano, em cinco anos; o tempo terá passado, trocaremos algumas palavras; beberemos um café em um café, teremos esquecido nossas queixas, entendido que nos amávamos etc., etc. (LEJEUNE, 1991, p. 159). ${ }^{7}$

No artigo de David Bellos, biógrafo do autor, "La pudeur de Perec" ${ }^{\text {, encontramos }}$ algumas informações da relação entre Perec e S. (Suzanne Lipinska): ela, uma mulher mais velha e experiente, tinha Perec como um de seus inúmeros parceiros, nos muitos encontros que realizavam no centro cultural Moulin d'Andé, onde muitos amigos comuns entre eles se reuniam. A ruptura foi muito difícil para Perec, a ponto de iniciar um processo de análise para tentar superá-1a ${ }^{9}$. A escrita do projeto pode também ter sido uma

\footnotetext{
${ }^{7}$ Je dois évidemment noter que le choix de l'île Saint Louis parmi ces douze lieux fut déterminé (de même que la conception générale du livre) par ma rupture avec S. en janvier 1969: c'était à la fois trouver quelque chose à faire, et m'enraciner à Paris. [...]En passant une fois par an dans l'île, peut-être la rencontrerai-je, dans un an, dans cinq ans ; du temps aura passé, nous échangerons quelques mots ; nous irons boire un café dans un café, nous aurons oublié nos griefs, compris que nous nous aimions, etc., etc.

${ }^{8}$ Publicado na Revista Poésie, no $94,2002$.

${ }^{9}$ Claude Burgelin nos relembra as diferentes fases da vida em que Perec se submeteu a processos de análise: "La psychanalyse a accompagné la vie de Georges Perec. Il a été écouté par trois des analystes les plus réputés de son temps : Françoise Dolto, en une assez longue thérapie entre enfance et adolescence, entamée après sa brève fugue ; Michel de M'Uzan lorsqu'il avait vingt/vingt-et-un ans (1956-1957) ; J.B. Pontalis, de 1971 à 1975" (p. 214), ao mesmo tempo que explica que essa última, com J. B. Pontalis, iniciou-se após alguns eventos difíceis na vida de Perec: "Au sortir d'un grave épisode de désarroi, lié à une rupture et à une tentative de suicide, il entame une psychanalyse avec J. B. Pontalis en 1971. En un moment aussi où l'écriture de $\mathrm{W}$ ou le souvenir d'enfance se bloque lorsqu'il s'agit pour lui de se lancer dans la partie proprement autobiographique du texte" (p. 215). Os dois trechos estão no texto "Perec et Pontalis - Une histoire de lettres, d'enveloppe et de destinataire", na obra Perec, Éd. de L'Herne, 2016. Disponibilizaremos na seção "Anexos" desse trabalho a imagem de uma dedicatória de Perec a Pontalis, no livro $W$ ou a memória da infância, publicado após as sessões finalizadas, em 1975 e que teve sua escrita bastante influenciada pelo trabalho de análise realizado pelo psicanalista.
} 
das tentativas de superar a questão. Bellos nos lembra o quanto Perec sempre se manteve discreto em relação a suas histórias íntimas e, talvez por isso, Lieux foi apresentado sem que se mencionasse toda essa carga afetiva e íntima como principal motivação do projeto.

Mesmo tendo como pano de fundo uma possível questão pessoal, sabemos o quão rígido e objetivo Perec tentou ser ao executar o projeto. A questão pessoal acabou aparecendo em segundo plano, como no trecho transcrito acima. O que ficou de mais evidente foi a exploração da descrição exaustiva dos lugares nas séries "Réel". Outra situação muito íntima que aparece em meio às descrições é o momento em que sua tia Berthe, que vivia na Avenue Junot, um dos doze lugares escolhidos para o projeto, falece. $\mathrm{O}$ acontecimento trágico também faz com que o autor reflita sobre o processo de escrita pelo qual vem passando e seus desdobramentos, que fogem um pouco do projeto inicial.

Ou seja, por mais que se busque uma descrição objetiva e que se siga as contraintes de escrita, em alguns momentos as questões mais íntimas, as confidências vêm à tona, mesmo que não fosse essa a intenção inicial do projeto. A partir do momento em que se propõe criar uma segunda escrita, a série "Souvenirs", realizada fora do lugar de descrição e baseando-se em memórias evocadas a partir do lugar descrito, é impossível evitar esta escrita de tom mais pessoal. Assim, as regras rígidas de escrita vão sendo, aos poucos, violadas, mesclando-se à descrição uma escrita mais íntima e confidencial, que permanece lacrada em envelopes, sem jamais ter sido publicadas por Perec. ${ }^{10}$ Assim, a ideia de "tombeau d'amour" ou de "chambre secrète" de Lejeune parece fazer mais sentido: há muitos segredos e confidências que ficarão ali, em estado de repouso, sem terem sido lidas ou reelaboradas para uma publicação definitiva pelo autor. O desejo de manter estas confidências em segredo parece se confirmar, se pensarmos que Perec somente releu e publicou alguns textos, e apenas os da série "Réels", que nada mais eram que descrições objetivas dos lugares, deixando assim a escrita íntima reservada para um outro momento que, sabemos, nunca chegou a se realizar.

O que motivou a continuidade da pesquisa, entretanto, não foi pensar na questão da objetividade ou da subjetividade da escrita, nem analisar o que poderia ter sido a obra caso viesse a ser publicada. Nosso interesse foi verificar em que medida a transformação/proliferação de Lieux em outros suportes (cinema, fotografia, emissão radiofônica) será fundamental para problematizar as questões que ultrapassam o texto

\footnotetext{
10 A única série de "Souvenirs" são aquelas publicadas por Lejeune em 1992, sob o título "Vilin Souvenirs" na revista Genesis, 1992, p. 127-151.
} 
literário, ao mesmo tempo em que continuam presentes: ou seja, trata-se da investigação dos lugares como pretexto ou ponto de partida para uma investigação do tempo e da própria memória. Para tanto, faremos a seguir uma breve introdução sobre a importância do espaço como um todo na obra de Perec, passando das motivações do projeto em direção a uma breve análise de textos escritos e suas diferentes maneiras de pensar e problematizar o espaço, tendo como referência principal a obra Espèces d'Espaces ${ }^{11}$, um livro híbrido de Perec que percorre desde questões teóricas até outras de caráter íntimo e pessoal, e que trata do espaço em suas mais diversas concepções.

Nas próximas etapas da tese, estabelecemos relações entre Lieux com obras que parecem ter sido inspiradas por ele, analisando aspectos que consideramos essenciais para discutir a questão do espaço em suas diversas manifestações artísticas.

O plano de escrita da tese foi, portanto, estruturado da seguinte forma: esperamos, inicialmente, já no primeiro capítulo, ter sido possível demonstrar a importância do projeto Lieux na obra de Perec, sua relação com o espaço e a escrita autobiográfica que perpassam vários de seus textos; entender a importância do projeto e como ele começou a se transformar, ajudando-nos a dar prosseguimento à pesquisa, indo em direção às obras que são o ponto crucial do problema apresentado. Através de outros suportes e expressões artísticas, vimos os resultados das mutações/transformações/proliferações resultantes de Lieux, que deram origem às obras que foram tratadas com mais detalhes a partir do seguinte plano:

No segundo capítulo, apresentei trechos dos textos de Vilin Réel e Vilin Souvenirs, destacando a importância da rua da infância do autor para a análise do projeto Lieux, já que pudemos verificar em ambas as escritas (tanto a objetiva, feita no lugar, quanto a subjetiva, fora do lugar) uma memória inexistente ou ainda permeada por muitas dúvidas e hesitações. Assim, mesmo descrevendo detalhadamente a rua onde Perec nasceu, percebe-se que há muito pouco a se dizer, num processo quase análogo à psicanálise realizada à época em que iniciou o projeto Lieux. Em La Clôture, o autor trabalha com questões inconclusas a respeito da rue Vilin: como não há o que lembrar, fotografias e poemas serão suas ferramentas para produzir uma hipótese do que poderiam ser suas memórias sobre o lugar. Além disso, as contraintes são mecanismos fundamentais para

\footnotetext{
${ }^{11}$ Publicado em 1974, o livro traz um texto sobre Lieux, que ainda estava em curso nesse momento. O título do texto é "Les lieux (Notes sur un travail en cours)", e estará disponibilizado na seção "Apêndices" desse trabalho. Na sequência, também será disponibilizado o texto "L'espace (suite et fin)", que trata das questões gerais sobre a relação de Perec com o espaço e o seu trabalho de escrita.
} 
desencadear essa escrita que busca pistas da memória. Lidar com regras fixas para escrever, como discutido nesse capítulo, será também uma maneira de evidenciar as ausências e perdas que, de certa forma, são o motor da escrita e, ao mesmo tempo, o motivo de dificuldade em escrever ou rememorar-se, num processo complexo que envolve escrita/memória/jogo de palavras/imagens.

No terceiro capítulo, analisei o documentário La vie filmée, que trata de uma memória com base em hipóteses (o que poderia ter sido a vida dos pais de Perec àquela época), ao mesmo tempo em que nos mostra traços das características da escrita de Perec: reflexão sobre a tecnologia e a passagem do tempo através delas, assim como em Je me souviens e outras obras a serem analisadas. Minha hipótese parte da ideia de que o tempo parece mais palpável e calculável a partir desses objetos e equipamentos que deixam evidente o momento em que estamos vivendo, ao mesmo tempo que nos remetem à nostalgia de tempos que já vivemos e nos ajudam a pensar no nosso futuro. A tecnologia obsoleta nos traz nostalgia e nos traz encantamento em relação ao passado. Perec, à frente de seu tempo, nos faz questionar sobre o tempo em que vivemos e também sobre o futuro. Com a tecnologia de hoje, como lidar com as obras de Perec? Analisamos também uma inovação realizada por Perec em 1978, Tentative de description des choses vues au Carrefour Mabillon, ao produzir uma gravação sonora dentro de uma caminhonete. Qual seria seu plano ao observar e gravar com detalhes tudo o que acontecia à sua frente? Fazer um inventário mais moderno, que dispensasse a escrita ou que a superasse? São estas algumas das questões que pretendo analisar a partir das obras apresentadas.

No quarto capítulo, fiz uma análise detalhada dos documentários Récits d'Ellis Island e En remontant la rue Vilin, retomando o projeto inicial da pesquisa, a partir da ideia do lugar do outro como o lugar para contar a história de si - e seus possíveis desdobramentos em relação aos espaços, além da ideia de acabamento de uma obra, com livro e documentário, em Récits d'Ellis Island. Esta noção de acabamento será, no entanto, extrapolada, já que continua, postumamente, com o projeto de En remontant la rue Vilin, uma homenagem de Bober a Perec, partindo da ideia de observação dos espaços e sua relação com a memória autobiográfica, tema central do nosso trabalho.

Olhar para o outro para falar de si é um movimento que ajuda Perec a contar sua própria história e é o eixo que perpassa toda a pesquisa que será aqui apresentada. Se observarmos com cuidado, os espaços funcionam de certa forma como pano de fundo para esta criteriosa observação do outro ou do espaço ao redor. Assim, constitui-se aqui um conjunto de textos que se ligam por uma questão em comum: partem da observação 
do outro para trazerem reflexões que digam respeito a si mesmo, ao indivíduo: tanto aquele que compôs as obras, (o escritor Georges Perec) quanto a pesquisadora aqui interessada nestas questões, olhando para estes diversos "outros" para também construir sua própria história, sua própria voz: aqui é o lugar da escrita, é o lugar de observar o outro e chegar às minhas próprias questões, a desenvolver minhas ideias e deixar falar minha voz, em primeira pessoa, a partir de muitas vozes que ecoam no meu texto. 


\section{CAPÍTULO I}

\subsection{Motivações de Perec para a escrita de Lieux}

Resumidamente, podemos dizer que Perec pretendia, em 1969, quando começou a elaborar o projeto, criar uma obra que fosse capaz de mostrar, ao mesmo tempo, o envelhecimento dos lugares, de si mesmo e das próprias memórias, refletindo sobre o que apenas passa, o móvel, e sobre aquilo que fica, o permanente. Lacrar os envelopes seria uma maneira de evitar "contaminar-se" com o que já havia sido escrito nos anos anteriores, como se esperasse, ao final dos doze anos, encontrar, de fato, as mudanças do tempo sofridas em todas as anotações.

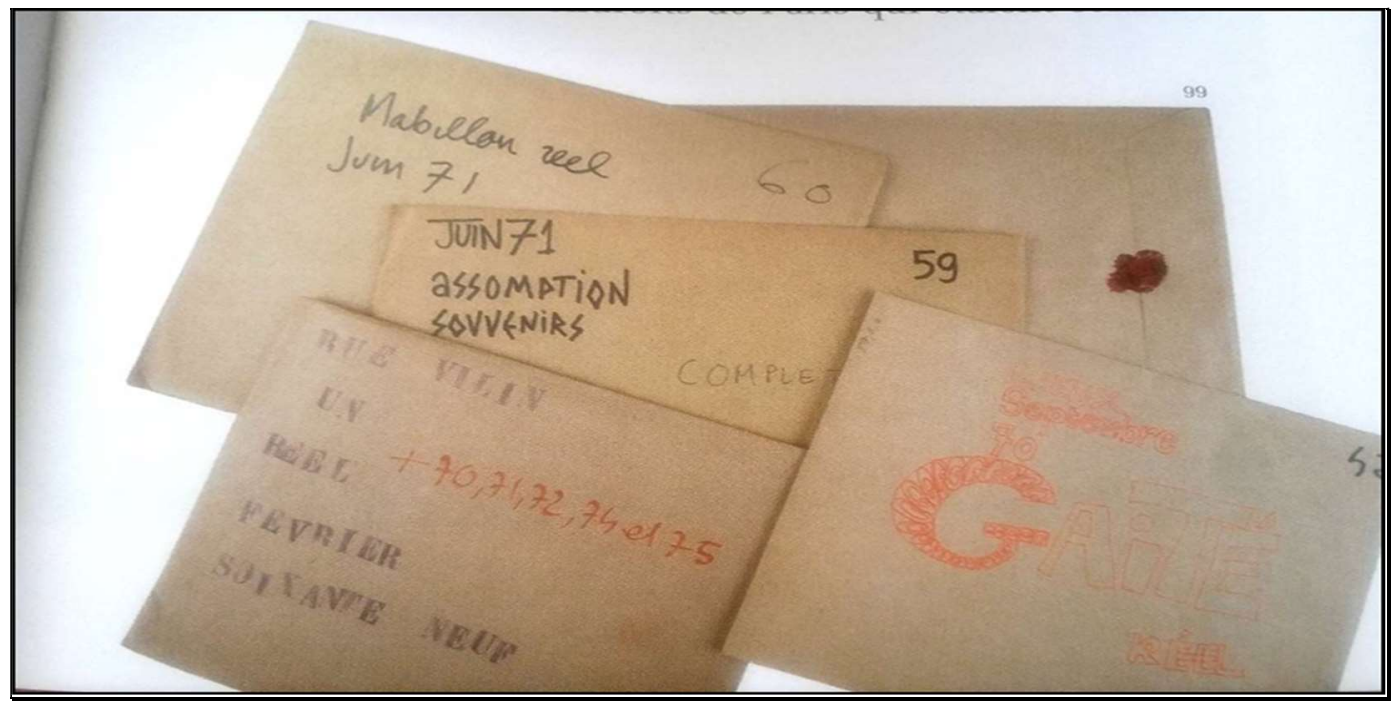

Figura 1. Envelopes lacrados, numerados e com anotações sobre os lugares visitados em Lieux.

Assim, Perec dá a si mesmo a missão de descrever o espaço urbano (mais especificamente os doze lugares escolhidos ${ }^{12}$ ), observando os lugares comuns, cotidianos, como reforça em trecho do texto "Approches de quoi?":

\footnotetext{
${ }^{12}$ Importante destacar que a escolha destes 12 lugares não impede que se escreva sobre muitos outros, não só os doze lugares, mas aqueles escondidos ("cachés") dentro dos textos, já que são menos evidentes, mas não menos importantes em sua vida. Afinal, entrecruzam-se outros lugares no momento em que escreve sobre as próprias lembranças, conforme afirma: "Il n'est pas mauvais qu'il y ait des lieux cachés, noyaux manquants, et d'autres qui ont l'air d'être inoffensifs" (LEJEUNE, 1991, p. 165).
} 
O que acontece realmente, o que vivemos, o resto, todo resto, onde está? O que acontece todo dia e que se repete todo dia, o banal, o cotidiano, o evidente, o comum, o ordinário, o infraordinário, o ruído de fundo, o habitual, como se dar conta, como interrogá-lo, como descrevê-lo? Interrogar o habitual. Mas justamente estamos acostumados a ele. Não o interrogamos, ele não nos interroga, ele parece não causar problemas, vivemos no meio dele sem pensar, como se não se veiculasse nem pergunta nem resposta, como se ele não fosse o portador de nenhuma informação. Não é nem mais condicionamento, é anestesia. Dormimos nossa vida de um sono sem sonhos. Mas onde está ela, nossa vida? Onde está nosso corpo? Onde está nosso espaço? (PEREC, 1989, p.11).

O que há a dizer/descrever sobre aquilo que é considerado banal, insignificante? Que interesse poderemos encontrar nos fatos ocorridos em lugares ou ruas que não aparentam nada de surpreendente, nada de excepcional? Segundo o autor do artigo "L'ordinaire du regard"13, Perec gostaria de congelar o tempo e fixar a história e, para isso, colocou-se diferentes contraintes ou regras fixas de escrita:

- regras espaciais e temporais: escolher doze lugares, por um período de doze anos, com um sistema de permutação que permitiria ir a cada lugar uma vez por mês, mas nunca no mesmo mês;

- regras práticas: fazer, a cada vez, uma descrição escrita, no local, depois estabelecer uma descrição a partir da própria memória, ou seja, descrever no mesmo mês as lembranças ligadas ao lugar e guardar os textos em envelopes fechados com cera.

Além destas regras, é importante ressaltar a estrutura dupla de escrita, (Réels/Souvenirs) característica que aparece também em outras obras, especialmente em W ou a memória da infância (que conta com dois textos alternados, o primeiro ficcional e o segundo, autobiográfico), como se a escrita só funcionasse na intersecção das duas escritas. $\mathrm{O}$ que acontece é que $W$ chega a ser publicada, fazendo a escrita funcionar, enquanto que, em Lieux, apenas alguns textos da série "Réels" serão publicados, impossibilitando esse funcionamento duplo planejado inicialmente.

Para além das regras fixas de escrita, outra regra parece referir-se à obsessão pelo tempo: o objetivo do projeto era de "incorporar o tempo à escrita" (LEJEUNE, 1991, p.

\footnotetext{
${ }^{13}$ Dos autores Jean-Paul Thibaud e Nicholas Tixier, publicado na Revista Le cabinet d'amateur, em dezembro de 1998.
} 
153); era necessário apenas descrever os espaços e "deixar o tempo trabalhar", sem que houvesse a interferência do escritor (p. 171). Perec afirmou nunca consultar ou abrir os envelopes lacrados (exceção feita aos poucos textos publicados posteriormente), tornando-os assim verdadeiras "bombas do tempo" "14, referência àquelas cápsulas enterradas ou enviadas ao espaço, contendo imagens e documentos que representaram determinada época, para ser abertas posteriormente.

Esta intenção de fixar o tempo parece se concretizar na expressão "Je cherche en même temps l'éternel et l'éphémère", frase do livro Les Revenentes que se repete na epígrafe do último capítulo de La vie mode d'emploi. O próprio Perec diria, a respeito desta frase, que ela era: "peut-être celle que j' aime le plus de tout ce que j'ai écrit", o que reforça a questão da fixação do tempo também em outras obras, sob aspectos diferentes. Em Les Revenentes, por exemplo, além do sentido da frase, verifica-se o processo de escrita constituído unicamente por palavras que contenham a vogal, o que se opõe radicalmente à escrita de La disparition, em que a mesma vogal não foi utilizada. As regras de escrita se emaranham e criam esta verdadeira rede de múltiplos significados, sendo a relação do tempo com a escrita presente em grande parte das obras aqui citadas.

Tratando um pouco da questão do tempo na minha própria pesquisa, faço uma pequena pausa para relembrar algo importante ocorrido no curso de mestrado: uma professora visitante, que também não está mais entre nós, dá um curso sobre autobiografia e crítica genética ${ }^{15}$, trazendo em uma das aulas uma análise sobre a escrita de Temps Immobile de Claude Mauriac. A obsessão por compor um diário durante quarenta anos, seguindo regras de escrita fixas e seguindo vários processos semelhantes aos que encontro na escrita de Lieux me motivaram a escrever um trabalho final para a disciplina, relacionando a obra de Mauriac à escrita de Lieux : a obra ainda não fazia parte do meu projeto de pesquisa, mas de alguma forma já me interessava tratar das questões ali presentes. Lembrar disso me faz ter certeza da dureza implacável do tempo: Perec não pode finalizar seu projeto autobiográfico, a professora não pode continuar seus estudos sobre autobiografia (partiu repentinamente também).

\footnotetext{
${ }^{14}$ Perec utiliza a mesma imagem para referir-se à obra Je me souviens: aos fragmentos do texto, refere-se como "minuscules 'bombes du temps', ces 'marqueurs d'époque', [qui] ne peuvent que s'effacer au fil des décennies, jusqu'à disparaître" (Entretiens et conférences, t. II, p. 236, citado em OC, t.I, p.1100).

${ }^{15}$ Trata-se da professora Catherine Viollet, que ministrou um curso sobre Autobiografia autobiografia e crítica genética, na FFLCH-USP, no segundo semestre de 2013 e com a qual mantive uma certa proximidade no período em que esteve no Brasil.
} 
Continuo a pesquisa pensando que o tempo é implacável, sim, traz ótimas experiências e muitas reflexões importantes sobre a escrita, sobre as pessoas e sobre o que vem depois, sobre o que é realmente importante relembrar. Talvez seja um pouco fúnebre tocar nesse assunto (a perda das pessoas), assim como talvez seja fúnebre tratar como objeto de estudo envelopes lacrados que mais se parecem com restos mortais, eternizados pelas marcas do tempo ali presentes. Talvez seja um pouco minha também essa obsessão pelo tempo que reconheço nas tentativas realizadas por Perec e que também reconheci no contato breve com a obra de Mauriac.

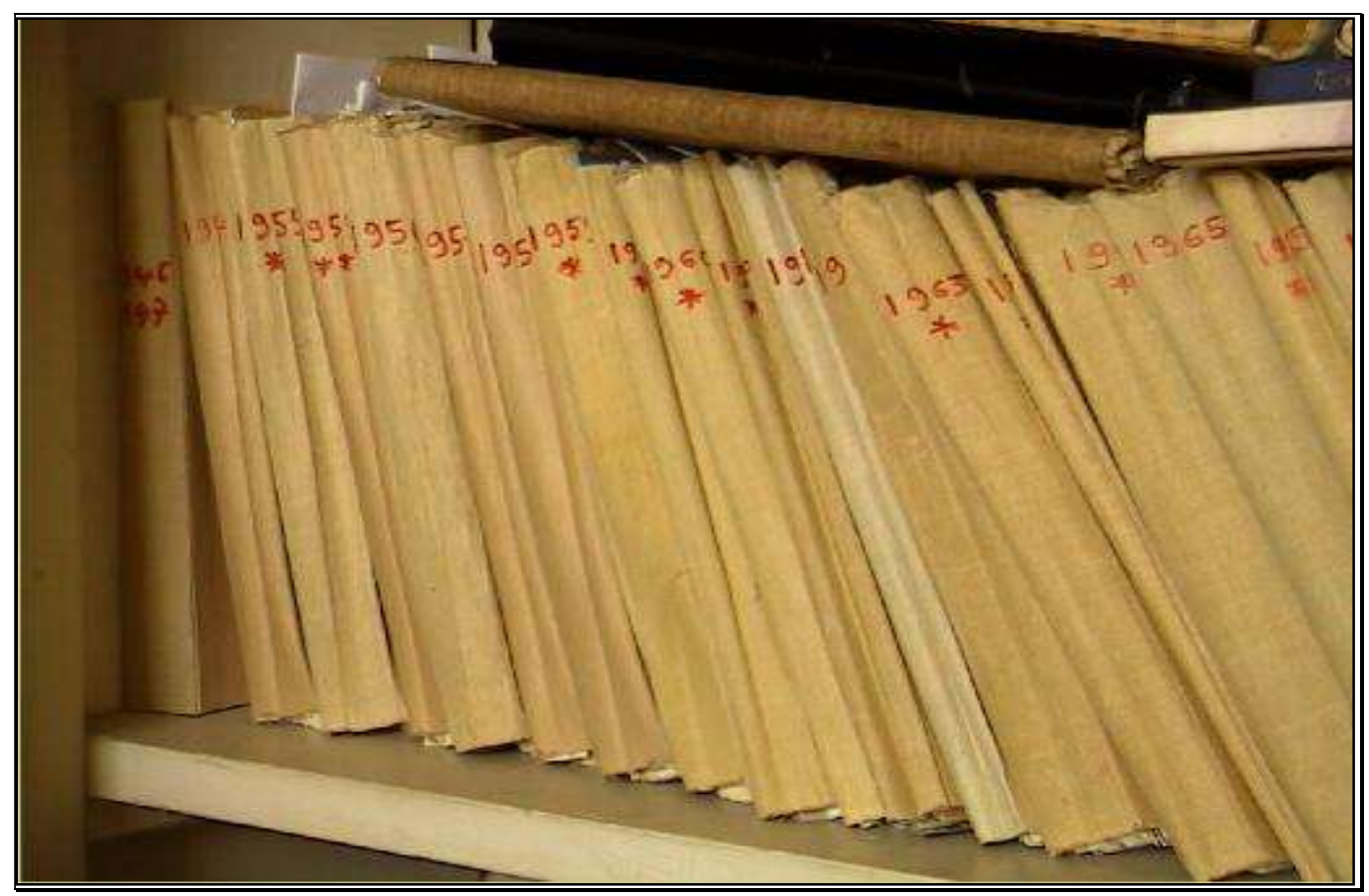

Figura 2. Manuscritos datilografados representam a obsessão pela fixação do tempo em Temps Immobile, de Claude Mauriac.

Depois de elaborar um projeto tão complexo e que envolveria tanto trabalho, vemos na fala de Perec em outra entrevista ${ }^{16}$ que parte dos seus planos não funcionava na prática, o que faria com que o projeto fosse sendo deixado de lado por ele aos poucos, não porque ele tivesse decidido abandoná-lo, mas porque talvez já estivesse prevendo a insuficiência da própria observação, da escrita (e também da própria memória) em dar conta do projeto, da maneira como foi concebido, até o final dos doze anos. Como já

\footnotetext{
${ }^{16}$ Concedida a Gerard Macé em 1979, e disponibilizada na coleção de CD's Georges Perec, dialogue avec Bernard Noël (2 livres + coffret de 4 CD), Éd. André Dimanche, 1997.
} 
vimos, e veremos ainda várias outras vezes, o que nos interessa é pensar no projeto como algo que passou por uma transformação, para que não fosse definitivamente abandonado, sendo inspiração para outras obras de Perec:

Não noto o que é realmente interessante, não sei olhar. Não sei olhar e sobre tudo não sei re-olhar. Em seguida percebi outra coisa mais grave, é que me lembrava, quando fechei as descrições anteriores nos envelopes lacrados, me lembrava do que tinha anotado. Isso era irritante porque eu notava as diferenças [...] e nas memórias era pior porque me incorporava as visitas que tinha feito como memórias. ${ }^{17}$

Por detectar essa insuficiência da escrita em dar conta de tudo que estava observando, Perec provavelmente tenha decidido convidar parceiros fotógrafos para acompanhá-lo nessas descrições pelas ruas, como uma forma de facilitar essas tentativas de "fixar o tempo". Laurent Grison ${ }^{18}$ nos explica a importância da fotografia e sua relação com a escrita de Perec:

Fotografar, descrever-escrever os lugares para guardá-los, olhá-los, apesar do tempo, com o tempo e os homens que os formam, é uma maneira de se apropriar do território jogando com a imagem e o texto, o olho e a memória. Fixar um lugar, uma paisagem na película ou em um quadro, ancorá-lo, pintá-lo para conservar, é reunir a combinação espaço-tempo-memória sugerida por Perec. Essa etapa pode nos levar a fazer perguntas de fundo sobre os modos de utilização da fotografia, e mais amplamente sobre a representação iconográfica, como vetor de apropriação objetiva-subjetiva dos lugares. (p. 279) ${ }^{19}$

E por que, afinal, Perec não consegue "dar conta" de seu projeto apenas observando e escrevendo sobre os lugares e, como sabemos, terá que incorporar novos suportes às suas obras para que consiga levá-las adiante? Se pensarmos como Kevin Lynch, em seu livro A imagem da cidade, podemos pensar na nossa própria limitação de

\footnotetext{
17 Je ne note pas ce qui est vraiment intéressant, je ne sais pas regarder. Je ne sais pas regarder, et surtout je ne sais pas re-garder. Et ensuite je me suis aperçu d'une autre chose qui était plus grave, c'est que je me souvenais, bien que j'aie enfermé les descriptions précédentes dans des enveloppes scellés, je me souvenais ce que j'avais noté. C'était très énervant parce que je notais des différences [...], et dans les souvenirs, c'était pire parce que je me mettais à incorporer les visites que j'avais faites comme des souvenirs.

${ }^{18}$ Em seu artigo "Le vieillissement des lieux", 1998. Para maiores detalhes sobre a relação entre a escrita autobiográfica de Perec e a fotografia, consultar também minha dissertação de mestrado intitulada "Instantâneos de ausências: Perec e a relação entre texto, fotografia e memória", defendida em 2014.

${ }^{19}$ Photographier, décrire-écrire les lieux pour les garder, les regarder, malgré et avec le temps et les hommes qui les façonnent, est une manière de s'approprier le territoire en jouant avec l'image et le texte, l'oeil et la mémoire. Fixer un lieu, un paysage sur la pellicule ou sur un tableau, l'ancrer, l'encrer pour le conserver, c'est rejoindre la combinaison espace-temps-mémoire suggérée par Perec. Cette démarche peut nous amener à poser des questions de fond sur les modes d'utilisation de la photographie, et plus largement de la représentation iconographique, comme vecteur d'appropriation objective-subjective des lieux.
} 
percepção como habitantes de uma cidade: "Na maioria das vezes, nossa percepção da cidade não é abrangente, mas antes parcial, fragmentária, misturada com considerações de outra natureza. Quase todos os sentidos estão em operação, e a imagem é uma combinação de todos eles" (2011, p. 2).

\subsection{Reflexões a partir de Lieux: olhar para o cotidiano}

Na tentativa de explorar todos os sentidos em sua obra, ou seja, para alcançar uma possível sensação de "totalidade" da observação, Perec vai produzir poesia, fotografia, cinema e até uma emissão radiofônica, como se quisesse, de certa forma, que seu corpo e todos os seus sentidos estivessem sendo representados ali, no espaço urbano, onde a experiência da escrita se torna física, graças a sua presença, à observação e à permanência que realiza nesses lugares. A presença do corpo na cidade se faz presente para que se possa escrever sobre ela, habitá-la de forma efetiva, como nos diz Michel de Certeau sobre os "praticantes ordinários da cidade", em seu livro A invenção do cotidiano:

Forma elementar dessa experiência, eles são caminhantes, pedestres, Wandersmänner, cujo corpo obedece aos cheios e vazios de um "texto" urbano que escrevem sem poder lê-lo. Esses praticantes jogam com espaços que não se veem; têm dele um conhecimento tão cego como no corpo a corpo amoroso. Os caminhos que se respondem nesse entrelaçamento, poesias ignoradas de que cada corpo é um elemento assinado por muitos outros, escapam à legibilidade. Tudo se passa como se uma espécie de cegueira caracterizasse as práticas organizadoras da cidade habitada (CERTEAU, 2012, p. 159).

Ao escrever sobre a cidade, ao observá-la nos mínimos detalhes, ao trazer seu corpo para o meio urbano e interagir com as mais diversas situações, não é essa cegueira característica que Perec quer trazer à tona? Não é essa cegueira que nos invade cotidianamente, visto que passamos pelos mesmos espaços todos os dias, sem observar exatamente o que mudou e o que permanece? Talvez essa cegueira faça com que percorramos os mesmos espaços, com nossos corpos, sem que nada possa ser efetivamente apreendido ou percebido.

E nesses mesmos espaços é onde poderemos encontrar respostas sobre nossas questões, nossa história, nosso passado que não mais enxergamos. Encontrar respostas pode ser um tanto quanto perigoso, pois podemos nos deparar com nossas piores lembranças e solidões, e é por isso que lemos sobre os lugares que Perec nos mostra, (mesmo que de forma objetiva), e que ali, naquela escrita, nos damos conta de nossa solidão, diante da multidão de estranhos que povoa o espaço público, já que "todos os 
espaços das nossas solidões passadas, os espaços em que sofremos a solidão, desfrutamos a solidão, desejamos a solidão, comprometemos a solidão, são indeléveis em nós", como afirma Bachelard, em A poética do espaço (2000, p.29).

Como observador dos espaços, das ruas, podemos dizer que Perec se distancia um pouco do modelo de Rousseau em Les Rêveries du promeneur solitaire, por exemplo, já que o autor ali estava nos mostrando quase que um antecessor do "flâneur", que vivia contemplando os lugares por onde passava e realizando reflexões e meditações de caráter mais íntimo. Podemos pensar Perec, entretanto, como um tipo de "flâneur pós-moderno", talvez inspirado no modelo benjaminiano do século XIX, que olha o mundo exterior, que observa "la foule informe, amorphe, qui reste passagèrement dans un café, un spectateur errant qui regarde en simple curieux les architectures urbaines et les passages" (CHANGNAM, p. 127).

De certa forma, também há uma reflexão a partir da observação de Perec, não aquela íntima feita por Rousseau, mas sim aquela em que a objetividade das descrições transfira um pouco da observação e da reflexão para o leitor. O que podemos refletir ao ler essas descrições exaustivas feitas por Perec em suas caminhadas, suas andanças pela cidade? E como estas andanças estão representadas na sua obra?

Afinal, por que Perec caminha por esses lugares? O que pretende nos mostrar? O que deseja encontrar? Pelos estudos autobiográficos já realizados sobre o autor, sabemos que a ausência dos pais é um mote central em sua obra. E, se pensarmos que as ruas que escolhe para percorrer têm ligação direta com sua história, parece impossível não associar a escolha dos lugares aos diferentes momentos vividos pelo autor, incluindo aí seus anos de infância, da qual foi privado quando se tornou órfão de guerra.

É em busca de preencher essa ausência que Perec deseja observar esses lugares. Quem sabe, de alguma forma, estar ali novamente poderá reavivar sua memória tão frágil? Sem contar as inúmeras casas pelas quais passou na infância, orfanatos e escolas, que deixaram essa sensação de que não há um lugar do qual se lembrar, mas apenas uma ausência, uma falta. Caminhar, observar, pode então ser uma tentativa de resgatar essa falta que não se preenche, conforme afirma novamente Bachelard:

Caminhar é ter falta de lugar. É o processo indefinido de estar ausente e à procura de um próprio. A errância, multiplicada e reunida pela cidade, faz dela uma imensa experiência social da privação de lugar uma experiência, é verdade, esfarelada em deportações inumeráveis e ínfimas (deslocamentos e caminhadas), compensada pelas relações e os cruzamentos desses êxodos que se entrelaçam, criando um tecido 
urbano, e posta sob o signo do que deveria ser, enfim, o lugar, mas é apenas um nome, a Cidade (BACHELARD, 2000, p.170).

Veremos que, em muitas obras, Perec se vale do coletivo para tratar de questões individuais. Com o espaço, não poderia ser diferente: como não há referências de espaços privados afetivos, a que possa recorrer na tentativa de rememorar sua infância, o autor busca, nessa multidão e na variedade de espaços urbanos, traços que o levem a refletir sobre um espaço ao qual possa pertencer, nem que seja apenas na condição de observador, uma vez que o espaço privado não fez parte de sua formação afetiva. Ou melhor dizendo: o espaço privado foi marcado por traumas e perdas, que podem ter relação direta com esta busca de espaços com os quais seja capaz de se identificar.

O fato de ter perdido os pais na guerra e ter sido adotado por tios, de ter passado parte de infância em diferentes locais e a não-identificação com as origens judias, por exemplo, são alguns aspectos que estão presentes na obra autobiográfica de Perec e que norteiam muitas de suas buscas por identidade nestas obras. Em um trecho de Récits d'Ellis Island, Perec afirma sua condição ou sentimento de estrangeiro, independentemente do lugar onde esteja:

Em qualquer lugar, eu sou estrangeiro em relação a alguma coisa de mim mesmo; em qualquer lugar, eu sou "diferente", mas não diferente dos outros, diferente dos "meus": eu não falo a língua que meus pais falavam, eu não compartilho nenhuma das lembranças que eles pudessem ter, alguma coisa que fosse deles, que fizesse com que eles fossem eles, sua história, sua cultura, sua esperança, não me foram transmitidos (PEREC, 1995, p. 59).

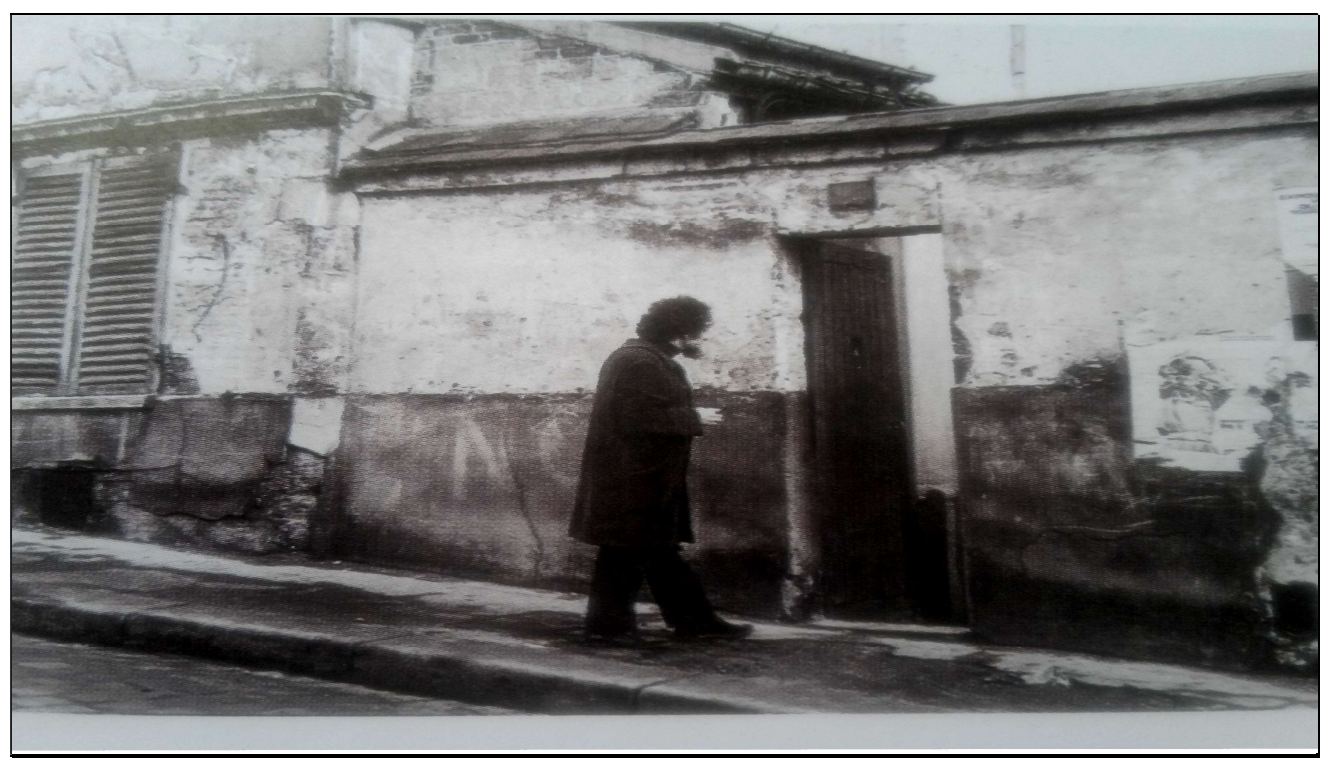

Figura 3. Perec em frente ao número 24 da Rue Vilin, endereço onde viveu sua primeira infância. 
Assim, tentar lembrar-se da infância a partir apenas de uma fachada de um imóvel em que um dia morou não traz as lembranças do passado, mas nos ajuda a compreender a busca por um passado ou um espaço privado de afeto que talvez nunca tenha existido, já que "o espaço privado é aquela cidade ideal onde todos os passantes teriam rostos de amados, onde as ruas são familiares e seguras, onde a arquitetura interna pode ser modificada quase à vontade" (BACHELARD, 2000, p. 207). Partindo desta afirmação, podemos concluir que, na ausência de um espaço privado ao qual se ancorar, Perec realizará sua investigação do espaço público em busca de pequenas pistas de uma memória inexistente.

A pergunta que se coloca é: como recuperar a memória a partir da descrição? Há o que ser rememorado? No caso de Perec, podemos observar no texto "La Rue Vilin" publicado no livro L'infra-ordinaire e que se refere à descrição real da rua entre 1969 e 1975 - uma descrição exaustiva a princípio, mas que vai se tornando, ano a ano, cada vez mais escassa, como veremos adiante.

Em seu texto "La mémoire totale des lieux", Jean-Luc Joly vai nos mostrar a importância de uma dimensão autobiográfica para compreender essa busca e observação dos lugares por Perec: é como se o sujeito pudesse reconstituir os lugares do seu passado, ou, ao menos, interrogando-os, pudesse reconstituir sua memória. Joly nos ajuda a refletir sobre esses lugares como conservatórios de memória, uma vez que algo que está no exterior pode nos ajudar a compreender a interioridade psicológica ou os pensamentos do autor; como já dissemos, trazer esse espaço exterior para a própria obra pode ser uma estratégia para que se produza reflexão sobre questões mais íntimas que, de outra forma, não seriam produzidas:

O projeto que parece então prevalecer é aquele de interrogar esses lugares "produtivos", já que conservatórios memoriais, para compensar a memória defeituosa ou ocultada ou para preparar uma memória tendendo à exaustividade. A ideia subjacente a toda operação é naturalmente que o lugar, e mais geralmente os traços ou testemunhos externos, exprimem mais fielmente a identidade que a interioridade psicológica ou os pensamentos. Perec o proclamou diversas vezes e de diversas formas. (JOLY, 2009, p. 173). ${ }^{20}$

\footnotetext{
${ }^{20}$ Le projet qui semble alors s'imposer est celui d'interroger ces lieux "productifs", car conservatoires mémoriels, pour suppléer à la mémoire défaillante ou occultée ou pour préparer une mémoire tendant à l'exhaustivité. L'idée sous-jacente à toute l'opération, c'est naturellement que le lieu, et plus généralement les traces ou les témoins extérieurs, expriment plus fidèlement l'identité que l'intériorité psychologique ou les pensées. Perec l'a proclamé à diverses reprises et de diverses façons.
} 
O autor do artigo nos dá um exemplo bastante efetivo de como essa observação do espaço pode funcionar como "produtora" de uma escrita mais íntima, no caso de Perec. Ele menciona um documento consultado no Fonds Georges Perec em que o autor, em uma entrevista, afirma ter se lembrado de uma memória de infância a partir de um passeio por Paris, quando a lembrança parece ter surgido "bruscamente". Segundo Lejeune, "le choix de lieux 'personnels' transforme Paris en une sorte d'arbre autobiographique" (1991, p. 157), ou seja, na falta de uma árvore genealógica à qual se ancorar, Perec se vale de Paris como uma espécie de mapa autobiográfico, onde percorre pedaços de sua história e memória.

Vale lembrar que, em Perec, a lembrança surgida bruscamente e citada há pouco se refere àquela que dará origem ao texto Les lieux d'une fugue que, mais tarde, será transformado em documentário, e é uma das obras já apresentadas aqui e que faz parte daquelas a serem analisadas com mais detalhes nesta pesquisa:

Fugi aos 12 anos e curiosamente, esqueci totalmente esse episódio marcante de minha infância. E esqueci durante 20 anos... até o dia em que, passeando no mercado de selos da Champs-Elysées, toda a história me veio bruscamente à memória (JOLY, 2009, p. 174). ${ }^{21}$

Joly também vai nos explicar que o termo "memória dos lugares" pode evocar diversos sentidos na obra de Perec, uma vez que podemos encontrar textos de cunho mais sociológico e de descrição exaustiva (como é o caso em Les Choses), mas que trazem em si características autobiográficas (o nome da rua onde os personagens moram, ou a viagem a Sfax que Perec também fez, como o casal protagonista). De outro lado, temos textos onde se aplicam o mesmo método de observação (como é o caso de Lieux e Lieux où j'ai dormi) que aparentam finalidades bem distintas: o primeiro nos remete a questões coletivas do espaço observado e faz reflexões sobre o futuro quando resolve guardá-los para serem consultados posteriormente, enquanto o segundo é de caráter estritamente individual (lista de lugares onde Perec dormiu ao longo da vida, no passado, que são também fontes para investigação de sua própria memória).

É como se Perec se colocasse numa série, dentre tantos outros na multidão -como se quisesse representar nessas escritas uma certa contemporaneidade, a partir da

\footnotetext{
${ }^{21} \mathrm{~J}$ 'ai [...] fait une fugue à l'âge de 12 ans et, curieusement, j'ai totalement oublié cet épisode pourtant marquant de mon enfance. Et je l'ai oublié pendant 20 ans... jusqu'au jour où, me promenant dans le marché aux timbres des Champs-Elysées, toute l'histoire m'est brusquement venue à la mémoire.
} 
velocidade de informações ali descritas, a partir de um sujeito fragmentado, próprio do indivíduo moderno, travando tensões entre aquilo que é íntimo e o que é público. Contar a história do outro passa pela própria história, então é possível estar inserido nela, como um grande projeto de investigação do infraordinário, conforme já definido pelo próprio Perec no texto já citado de "Approches de quoi?".

Esta diversidade de sentidos que Perec pretende alcançar quando lida com esta velocidade da escrita, simultaneidade entre o que vê e o que deseja registrar, está fortemente ligada a outra característica da obra perecquiana, a vontade de "totalidade": o autor desejava, ao longo de sua obra, criar livros que tratassem de temas comuns, mas que fossem completamente diferentes uns dos outros, como se buscasse alcançar essa ideia de totalidade de temas a serem produzidos em seus livros. Investigar diferentes tipos de lugares, sejam eles privados ou públicos, poderia também expressar, de certa forma, este desejo de totalidade?

Perec afirmava o desejo de encontrar em sua obra essa espécie de "totalidade do mundo", como já vimos, a partir de quatro grandes interrogações que se colocava: é claro que muitas de suas obras perpassavam entre uma ou mais dessas "categorias", mas seu objetivo parecia quase "enciclopédico", englobando diferentes gêneros e interrogações a partir de diversos projetos literários simultâneos, como vemos no texto "Notes sur ce que je cherche":

\begin{abstract}
A primeira dessas interrogações pode ser qualificada de "sociológica", sobre como observar o cotidiano. [...] a segunda é de ordem autobiográfica [...] a terceira, lúdica, retoma meu gosto pelas regras de escrita [...] a quarta, enfim, concerne o romanesco, o gosto das histórias e peripécias [...] De fato, me parece, além desses quatro polos que definem os quatro horizontes do meu trabalho - o mundo que me cerca, minha própria história, a linguagem, a ficção -, minha ambição de escritor seria a de percorrer toda a literatura do meu tempo sem jamais me sentir voltar sobre meus passos ou de retornar para meus próprios traços, e escrever tudo que é possível a um homem de hoje escrever: livros grandes e curtos, romances e poemas, dramas, livretos de ópera, romances policiais, romances de aventura, romances de ficção científica, folhetins, livros para crianças... (PEREC, 1985, p. 10). ${ }^{22}$
\end{abstract}

\footnotetext{
${ }^{22}$ La première de ces interrogations peut être qualifiée de "sociologique": comme de regarder le quotidien [...]; la seconde est d'ordre autobiographique [...]; la troisième, ludique, renvoie à mon goût pour les contraintes [...]; la quatrième, enfin, concerne le romanesque, le goût des histoires et des péripéties [...] En fait, me semble-t-il, au-delà de ces quatre pôles qui définissent les quatre horizons de mon travail - le monde qui m'entoure, ma propre histoire, le langage, la fiction -, mon ambition d'écrivain serait de parcourir toute la littérature de mon temps sans jamais avoir le sentiment de revenir sur mes pas ou de remarcher dans mes propres traces, et d'écrire tout ce qui est possible à un homme d'aujourd'hui d'écrire : des livres gros et des livres courts, des romans et des poèmes, des drames, des livrets d'opéra, des romans policiers, des romans d'aventures, des romans de science-fiction, des feuilletons, des livres pour enfants...
} 
Joly nos lembra que essa diversidade trouxe diferentes rumos para cada uma dessas obras, como "avatares" de Lieux que surgirão ou, se pensarmos num caso extremo, a descrição de um lugar privado que será a representação concreta desse desejo de totalidade: La vie mode d'emploi, um imóvel com seus diversos personagens, histórias, descrições e tentativas de dar conta de uma literatura que abranja, de alguma maneira, a ideia de totalidade ${ }^{23}$, nem que, para isso, o espaço precise ser povoado de muita ficção. Lembramos que nosso foco é pensar na obra Lieux como uma espécie de texto "central", em torno do qual circularão textos ou produções "satélites", como nos explica Jean-Luc Joly no artigo acima mencionado.

Outra questão que nos parece bastante pertinente, além do desejo de uma obra totalizante, refere-se ao pensamento crítico do cotidiano ao qual Perec nos submete, já que faz parte de uma geração que vivenciou determinados acontecimentos na França, como nos explica Derek Schilling ${ }^{24}$ :

A relação entre a obra de Perec e o pensamento do cotidiano no pósguerra e mais a frente convida a uma resposta: pode ser que depois de maio de 1968, como afirmava Lefebvre, a vida cotidiana na França parecia cada dia mais uma simles lista de coisas a fazer ou a comprar, lugares para ir e tarefas a executar. É provavelmente a esta evacuação progressiva da espontaneidade da vida cotidiana que pensava Lefebvre em 1981, quando se perguntava: "Há uma vida cotidiana, ou uma morte cotidiana?" $(2006, \text { p. } 178)^{25}$

Se a vida cotidiana na França se tornava cada vez mais um constante fabricar de listas de "coisas a fazer", impossível não pensar em Perec como representante desta geração: o pensamento crítico do cotidiano influenciou toda sua obra, se pensarmos na quantidade de listas e inventários produzidos por ele, em diferentes momentos de sua carreira como escritor. Assim, essa busca que passa pela observação do espaço urbano (e

\footnotetext{
${ }^{23}$ Devemos deixar claro que a questão da totalidade não é o que move esta pesquisa, e sim a proliferação do projeto Lieux em outras obras, visto que o desejo de totalidade vislumbrado por Perec é no mínimo utópico, comparado talvez à ideia de Livro de Mallarmé. A ideia de proliferação da obra nos parece mais razoável, visto que ela se expandirá para diferentes suportes.

${ }^{24}$ Em seu livro Mémoire du quotidien: Les Lieux de Perec, de 2006.

${ }^{25} \mathrm{La}$ mise en rapport de l'œuvre de Perec avec la pensée du quotidien dans l'après-guerre et au-delà invite une réponse : peut-être est-ce parce que, après Mai 1968, comme le signalait Lefebvre, la vie quotidienne en France ressemblait de plus en plus à une simple liste de choses à faire ou à acheter, d'endroits où aller et de tâches à exécuter. C'est vraisemblablement à cette évacuation progressive de la spontanéité dans la vie quotidienne que pensait Lefebvre en 1981 lorsqu'il se demandait : "Y a-t-il une vie quotidienne, ou une mort quotidienne?"
} 
também do privado) foi, em muitos momentos, representada por extensos inventários e listas, numa espécie de tentativa de esgotamento e exaustão, seja do lugar, da escrita ou da própria memória.

Michel de Certeau, citado por Marc Augé em seu livro Não lugares, traz-nos uma interessante definição sobre a prática do espaço: segundo Certeau, esta prática significa "repetir a experiência jubilosa e silenciosa da infância: é, no lugar, ser outro e passar ao outro". Assim, Augé vai nos afirmar que estas experiências jubilosas da infância se encontram nas mais diversas situações, desde as lembranças de uma primeira viagem em família até "o reconhecimento de si como si mesmo e como outro, que reitera a do andar como primeira prática do espaço e a do espelho como primeira identificação com a imagem de si. Todo relato volta à infância" (AUGÉ, 1994, p. 78).

Estes não lugares são aqueles também chamados de heterotopias por Foucault ${ }^{26}$, que os define, em linhas gerais, como uma "espécie de experiência de união ou mistura análoga à do espelho", opondo-os à ideia de utopia. Ou seja: ao mesmo tempo em que o espelho é um espaço irreal (ligado à utopia), este mesmo espelho existe na realidade e exerce uma espécie de "contra-ação" à posição que ocupamos, já que percebemos nossa ausência quando nos vemos refletidos nele, configurando assim a noção de heterotopia. A partir do olhar que dirigimos a nós mesmos, em um espaço "virtual” que está do outro lado do espelho, podemos, de certa forma, reconstituir-nos naquele lugar em que nos encontramos.

Podemos partir para uma primeira afirmação, então, de que os relatos de Perec sobre o espaço estão, de certa forma, ligados a uma tentativa de relato de sua própria infância que, por diversos motivos, não chegou a se concretizar de fato, pelo menos não quando teve a ideia do projeto Lieux. Portanto, o caminho que se seguiu, a partir daí, foi encontrar um percurso, mesmo que externo, para desenhar o próprio percurso, incompleto e lacunar. Tendo como aliado apenas o espaço da página, e a partir dele, Perec pôde "recriar" este espaço urbano e caótico e ligá-lo a sua própria memória. Perec escolheu, portanto, o discurso da cidade, a linguagem da cidade para escrever sobre si.

Observando-a, contemplando-a, pôde também contemplar e observar a si mesmo, criando assim uma linguagem capaz de dar conta de sua constante busca, como nos ensina Barthes, em seu texto "Sémiologie et urbanisme": "La ville est un discours, et ce discours

\footnotetext{
${ }^{26}$ No texto "Des espaces autres - Hétérotopies", referente à conferência proferida no Cercle d'Études Architecturales, em 14 de março de 1967, publicado posteriormente na revista Architecture, Mouvement, Continuité (1984).
} 
est véritablement un langage: la ville parle à ses habitants, nous parlons notre ville, la ville où nous nous trouvons, simplement en l'habitant, en la parcourant, en la regardant" (BARTHES, 1991, p. 265).

A linguagem presente no texto escrito poderá dar conta da busca empreendida por Perec? Faremos, a seguir, um breve percurso de leitura sobre o espaço em algumas importantes obras do autor para, enfim, retornar a esta questão, quando tratarmos da transição/transformação/proliferação de Lieux para outros suportes que extrapolam o texto escrito.

\subsection{Breves leituras do espaço}

A partir de inúmeras possibilidades de definição sobre o espaço em Espèces d'Espaces, publicado em 1974, Perec vai nos conduzindo a uma reflexão que começa no âmbito privado e chega ao exterior, até o infinito do universo, como demonstra na escrita sobre a sua própria localização espacial:

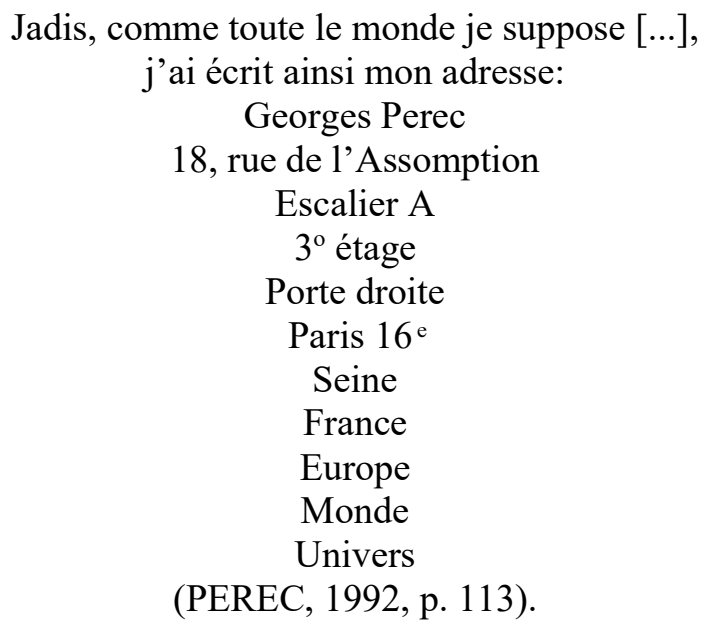

Numa coletânea de textos intitulada Espécies de espaço, uma clara homenagem ao célebre livro perecquiano, encontramos um artigo de Edson Rosa da Silva ${ }^{27}$, que vai comparar essa busca incessante de Perec a uma espécie de escavação: o título do artigo já nos remete à ideia de que o ato de escrever está diretamente associado a uma "escavação" dos espaços, conforme nos explica o próprio autor:

\footnotetext{
${ }^{27}$ Sob o título "Inventário e imaginação - Escrever/escavar o(s) espaço(s) etc.”, de 2008.
} 
A metáfora da escavação parece insistir em uma forma de reencontrar aquilo que, embora enterrado, continua a alimentar a memória, e que não retorna de forma simples, mas que traz e deixa consequências. Repensar o espaço em que vivemos é escavar esses espaços que, com toda a certeza, nos comprometem. [...] Nossos espaços, nossas casas, nossos quintais, nossas ruas estão repletos de inumeráveis restos mortais de seres e coisas que, uma vez remexidos, muito nos assustariam $(2008$, p. 310$)$.

Em complemento a essa ideia de escavação relacionada à escrita, podemos pensar numa citação de Perec em Espèces d'Espaces (p. 20): "Há poucos acontecimentos que não deixam ao menos uma marca escrita": ou seja, podemos então pensar na possibilidade de escavação de espaços como acontecimentos que deixarão marcas escritas, especialmente ligadas às questões da memória, numa tentativa de "reencontrar" aquilo que está enterrado, como numa investigação arqueológica. Assim, lembrar de fatos e escrever sobre eles é então produto dessa escavação, desse encontro com ruínas, fragmentos de uma memória que pode surgir a partir deste trabalho.

Na seção "La page", vemos a epígrafe de Henri Michaux utilizada por Perec: “J'écris pour me parcourir". Perec já nos dá pistas de que a escrita terá essa finalidade de construção de um percurso a partir da página, ou melhor dizendo, um percurso que se constitui a partir do espaço da página.Vejamos o que o autor diz sobre o espaço da página: "Eu escrevo; eu habito minha folha de papel, eu invisto nela, eu a percorro. Eu suscito os brancos, os espaços (saltos no senso: descontinuidades, passagens, transições)" (PEREC, 1992, p. 19, tradução minha).

Habitar a folha, aqui, remete-nos ao sentido de criação de um percurso do escritor, percurso esse tanto de escritura de palavras quanto de "escritura de brancos". Estes brancos, segundo Perec, são as partes do texto que deverão ser completadas pelos leitores, ou seja, além do espaço escrito da página, há também o espaço das margens, os brancos, o espaço da leitura. Assim, a escritura da página não consiste somente no seu preenchimento com letras, palavras ou frases, mas também a escolha de espaços que possam servir de margem do texto ou de criação de espaços de leitura. A definição de Perec refere-se também a um espaço perdido:

Ao colocar a produção de página como produção de brancos, ele está nos dizendo que a página cheia, que a página escrita, está perdida. $\mathrm{O}$ fato de Perec afirmar que ele escreve para criar brancos significa que ele escreve para que o leitor escreva. A página perdida é então perdida para o leitor (PINO, 2006, p. 123). 
Já no seu texto de apresentação de Espèces d'espaces, Perec chama a atenção para esse elemento (espaço) que, por nos ser óbvio, acaba esquecido: "O problema não é inventar o espaço, menos ainda reinventá-lo. [...], mas interrogá-lo, ou, mais simplesmente ainda, lê-lo" (PEREC, 1992, texto de capa, tradução minha).

Assim, interrogar o espaço, lê-lo, seria uma forma de refletir sobre a escrita, sobre as marcas que essa escrita pode deixar? O que significa interrogar esse espaço? Como podemos, através da escrita, pensar na definição de suscitar os brancos? Podemos pensar que os brancos, aparentemente sem função ou sentido, não são apenas meros suportes para a escrita. Se a escrita é uma forma de habitar o mundo, como diz Perec, escrever é fazer algo sobreviver, deixar uma marca, um traço em alguma parte: "Escrever: tentar meticulosamente manter alguma coisa, fazer sobreviver algo: arrancar algumas sobras do vazio que aumenta, deixar, em algum lugar, um rastro, um traço, uma marca ou alguns signos" (PEREC, 1992, p. 123, tradução minha).

Quando Perec escreve sobre a página, sua escrita já se apresenta como se quisesse transgredir este espaço. Na leitura dos trechos, os brancos são extremamente presentes, como se solicitasse ao leitor que os complete, que os leia, que os interrogue. Um dos exemplos deste uso transgressor da página pode ser facilmente verificado, quando folheamos o livro:

J'écris

J'écris: j'écris...

J'écris: "j'ecris...

J'écris que

j'écris... etc.

J'écris : je trace des mots sur une page.

Lettre à lettre, un texte se forme, s'affirme, s'affermit, se

fixe, se fige :

une ligne assez strictement ho

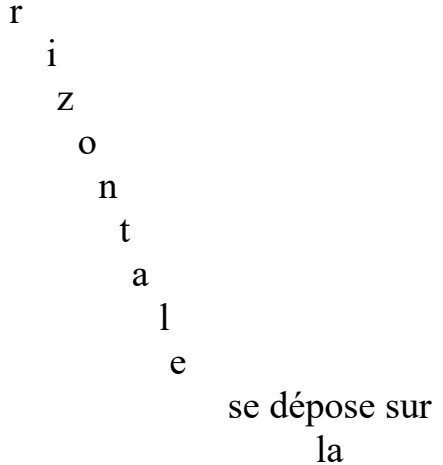

feuille blanche, noircit l'espace vierge, lui donne un sens, le vectorise (...) (PEREC, 1992, p. 17). ${ }^{28}$

\footnotetext{
${ }^{28}$ Optei por não traduzir esta citação e a seguinte, já que a configuração da página seria diferente da apresentada nas versões originais.
} 
Partindo do espaço da página para a diversidade de espaços evocados no livro, quando se trata da observação de espaços (que é recorrente em sua obra), Perec se posiciona como alguém que procura, de maneira quase "ingênua", encontrar o excepcional naquilo que é banal, cotidiano, evidente, mas que constantemente nos escapa aos olhos. Para Perec, ao observar os espaços, na seção "Travaux pratiques", parece desejar dar alguns conselhos para quem deseja realizar o mesmo tipo de observação, como vemos a seguir:

Observer la rue, de temps en temps, peut-être avec un

Souci un peu systémathique.

S'appliquer. Prendre son temps.

Noter le lieu : la terrasse d'un café près du carrefour Bac-

Saint-Germain

l'heure : sept heures du soir

la date : 15 mai 1973

le temps : beau fixe

Noter ce que l'on voit. Ce qui se passe de notable. Sait-on voir ce qui est notable? Y a-t-il quelque chose qui nous frappe?

Rien ne nous frappe. Nous ne savons pas voir.

Il faut y aller plus doucement, presque bêtement. Se forcer à écrire ce qui n'a pas d'intérêt, ce qui est le plus évident, le plus commun, le plus terne (PEREC, 1992, p. 70).

Esse sentimento de busca incansável por aquilo que não podemos enxergar de forma evidente, no entanto, torna-se uma espécie de desejo de estabilidade ou completude, como vemos no capítulo final "L'espace (suite et fin)": "Gostaria que existissem lugares estáveis, imóveis, intangíveis, intocados e quase intocáveis, imutáveis, enraizados; lugares que seriam referências, pontos de partida, fontes" (p. 122, tradução minha). Neste momento, Perec parece desejar algo quase inalcançável e, por isso, talvez, seus projetos que envolvem os espaços são sempre mutáveis e transformados.

O espaço que deseja é talvez utópico, já que imutável. E o próprio autor, reconhecendo no projeto de Lieux que pretende investigar as mudanças dos lugares, entra numa certa contradição. Como se esse lugar inalcançável fosse, de fato, aquele ao qual não teve acesso na infância e, por isso, seus pontos de referência são mutáveis, sofrem alterações, transformam-se. Aquela referência da infância não existe, então toda busca parece girar apenas em torno desse desejo de segurança inexistente: "Meu país 
natal, o berço de minha família, a casa em que eu teria nascido, a árvore que eu teria visto crescer (que meu pai teria plantado no dia de meu nascimento), o sótão de minha infância cheio de lembranças intactas...” (p. 122). O fato de o trecho estar escrito assim, no condicional passado, já nos remete à impossibilidade de sua existência, como conclui adiante, rumo ao final do livro:

Tais lugares não existem, e é porque não existem que o espaço se torna questão, deixa de ser evidência, deixa de ser incorporado, deixa de ser apropriado. O espaço é uma dúvida: tenho que marcá-lo sempre, designá-lo; nunca é meu, jamais é dado, é preciso conquistá-lo (PEREC, 1992, p. 122).

Para reforçar ainda mais esta impossibilidade em relação aos espaços, faz-se interessante observar não só a citação que encerra o livro como a ilustração que o inaugura: um mapa vazio, explicado no livro A memória das coisas, por Maria Esther Maciel, e sua respectiva referência ao poema "The Hunting of the Snark", de Lewis Carroll, que

conta a história de um capitão de navio que comprou para seus tripulantes um mapa vazio, que representava unicamente o mar, sem "o mínimo vestígio de terra", o que causou satisfação em toda a tripulação, que convencida de que os demais mapas continham meramente signos convencionais, muitas vezes incompreensíveis, achava o mapa em branco o melhor, o mais perfeito (MACIEL, 2004, p. 43).

Assim, escrever sobre o espaço, levantar questões importantes a seu respeito e ainda assim abrir o livro com uma ilustração "em branco" deve querer dizer este vazio, esta impossibilidade, esta dificuldade em olhá-lo, em interrogá-lo que muitas vezes é evidenciada por Perec ao longo de sua escrita do cotidiano, criando assim uma espécie de “cartografia impossível” do espaço, representada aqui pelo exemplo da ilustração.

Outro texto importante para nos ajudar a refletir sobre o espaço na obra de Perec é Tentative d'épuisement d'un lieu parisien, que parece ter sido uma maneira de colocar em prática os “conselhos” dados pelo próprio Perec em Espèces d'Espaces. Publicado com apenas um ano de diferença em relação ao primeiro texto, este segundo traz uma descrição exaustiva da place Saint-Sulpice a partir de três cafés diferentes (Tabac SaintSulpice, Fontaine Saint-Sulpice e Café de La Mairie). Escrito nos dias 18, 19 e 20 de outubro de 1974, o texto faz uma espécie de revezamento entre estes três cafés e a própria praça, visitando-os em dias e horários diferentes, numa real tentativa de "esgotamento" na descrição destes lugares. Esta prática está fortemente relacionada ao projeto Lieux (apesar de não incluir nenhum dos dozes lugares escolhidos para tal), principalmente se 
lembrarmos que o primeiro envelope "Réel" (Carrefour Mabillon, janeiro de 1969) foi escrito justamente a partir da observação feita de três cafés diferentes. É claro que, neste caso, há apenas a inspiração de Lieux, visto que as regras fixas do projeto já quase deixado de lado não são aqui aplicadas, nem em relação à oposição real/lembrança e muito menos na disposição do tempo. Escrever três dias seguidos vai totalmente contra a ideia original de Lieux (descrever o mesmo lugar todo ano, uma única vez), mas a prática parece apontar para uma transformação do projeto anterior: ciente das dificuldades encontradas na produção de Lieux, Tentative d'épuisement... parece mais uma tentativa de correr contra o tempo, de condensar (o que antes pretendia se fixar ao longo dos anos) em apenas três dias.

Para dar conta dessa velocidade que não consegue mensurar, a ideia de Perec parece ter sido "encurtar" a distância entre seus escritos sobre um mesmo lugar e refletir sobre esse esgotamento, tanto do espaço quanto do tempo, restrito, curto e, por que não, mais desafiador? Aquela ideia de aguardar anos para a publicação também não está presente neste projeto. No ano seguinte, 1975, o texto já estaria publicado em um volume de Cause commune.

\subsubsection{O espaço íntimo}

Um espaço bastante privilegiado nas reflexões contidas em Espèces d'Espaces, o espaço do quarto (e, mais precisamente, da cama), será uma espécie de produtor de memórias e lembranças em outra interessante obra, Lieux où j'ai dormi: o movimento duplo de Lieux (réels, souvenirs) mais uma vez estará presente: Perec vai escrever textos ${ }^{29}$ em que descreve minuciosamente quartos onde já dormiu, para em seguida evocar as memórias (segundo ele, abundantes quando se trata desses quartos) que se ligam a este espaço fechado, privado e, pelo que vemos, bastante produtivo para a escrita autobiográfica. Importante ressaltar que sua semelhança com o projeto anterior, Tentative d'épuisement..., refere-se à questão da descrição exaustiva, mas aqui o espaço sairá do público (de um café, de uma praça) e irá diretamente para o espaço fechado, privado. Comecemos pela epígrafe da seção "Le lit”, d'Espèces d'Espaces:

\footnotetext{
${ }^{29}$ Os únicos textos publicados efetivamente estão em Penser/Classer, de 1985, no texto "Trois chambres retrouvées".
} 
Longtemps je me suis couché par écrit Parcel Mroust

De maneira nada sutil, Perec se "inspira" no incipit de $\grave{A}$ la recherche du temps perdu para iniciar seu texto sobre o espaço da cama. Nota-se até um certo bom humor, no trocadilho do nome do autor da epígrafe com o nome de Proust, o que parece querer nos dizer algo, como Perec diz, efetivamente, quando discorre sobre a importância da cama como espaço de produção de memória, como vemos em alguns trechos d'Espèces d'Espaces:

A cama é então o espaço individual por excelência, o espaço elementar do corpo. A cama: lugar da ameaça não formulada, lugar dos contrários, espaço do corpo solitário repleto de seus haréns efêmeros, espaço encerrado do desejo, lugar improvável do enraizamento, espaço do sonho e da nostalgia odipiana. [...] Gosto da minha cama. Gosto de ficar estendido nela e observar o teto de um olho plácido. $(1992, \text { p. } 27)^{30}$

Curioso pensar nas inúmeras entrevistas e até obras em que o autor afirma ter muita dificuldade em se lembrar do passado, como na emblemática frase inicial do capítulo autobiográfico de $W$ ou a memória da infância: "Não tenho nenhuma memória de infância". Estas declarações são totalmente opostas àquelas dadas pelo autor no que se refere à produção de memória relacionada aos momentos em que está no quarto, deitado em sua cama:

Me basta simplesmente, quando estou deitado, fechar os olhos e pensar com um mínimo de esforo em um lugar qualquer para que quase instantaneamente todos os detalhes do quarto, do lugar dos portas e janelas, a disposição dos móveis, me voltam à memória, para que, mais precisamente ainda, eu sinta novamente a sensação quase física de estar de novo deitado naquele quarto. (PEREC, 1992, p. 31) ) $^{31}$

É como se houvesse uma transformação, um processo de criação totalmente favorável quando ele está deitado na cama, no quarto: é neste momento que o autor declara ser capaz de resgatar e reviver muitas lembranças, desde as mais banais até as

\footnotetext{
${ }^{30}$ Le lit est donc l'espace individuel par excellence, l'espace élémentaire du corps" [...] Le lit: lieu de la menace informulée, lieu des contraires, espace du corps solitaire encombré de ses harems éphémères, espace forclos du désir, lieu improbable de l'enracinement, espace du rêve et e la nostalgie œdipienne [...] J'aime mon lit. J'aime rester étendu sur mon lit et regarder le plafond d'un œil placide.

${ }^{31}$ Il me suffit simplement, lorsque je suis couché, de fermer les yeux et de penser avec un minimum d'application à un lieu donné pour que presque instantanément tous les détails de la chambre, l'emplacement des portes et des fenêtres, la disposition des meubles, me reviennent en mémoire, pour que, plus précisément encore, je ressente la sensation presque physique d'être à nouveau couché dans cette chambre.
} 
mais essenciais de sua vida. Como uma espécie de "madeleine" proustiana, segundo as palavras do próprio Perec, fica clara sua íntima relação com as memórias evocadas no quarto, na cama e sua intenção de associar, o tempo todo, sua prática de rememoração aos moldes de Proust; ou seja, o célebre autor serve de modelo e inspiração para a escrita autobiográfica de Perec:

O espaço ressuscitado do quarto basta para reanimar, trazer de volta, reviver as memórias mais fugazes, as mais inocentes coma as mais importantes [...] É talvez porque o espaço do quarto funciona para mim como uma madeleine proustiana $(1992, \text { p. } 34)^{32}$.

Segundo o artigo de Danielle Constantin ${ }^{33}$, Perec cita o projeto de escrita de Lieux où j'ai dormi na famosa carta escrita à Maurice $\mathrm{Nadeau}^{34}$, portanto não há como precisar a data de início dos escritos. O projeto, entretanto, parece ter origem em outro intitulado "Lieux où j'ai couché, ${ }^{35}$ iniciado nos anos 60. Perec descreve seu projeto como um “catálogo de quartos cuja evocação minuciosa esboçará uma espécie de autobiografia vesperal" ${ }^{\prime 36}$, e que talvez um de seus modelos tenha sido a obra Nuits sans nuits de Michel Leiris, além da clara influência proustiana.

A estrutura binária novamente estará presente, como já mencionado, sendo constituída pela descrição dos lugares, seguida de lembranças que eles evocam. Inicialmente, a obra de Leiris pode ter influenciado Perec a escrever sobre seus sonhos, mas este projeto logo foi transformado e transferido para outra obra, La boutique obscure - 124 rêves, constituída apenas de textos que relatam seus sonhos, ideia abandonada no projeto Lieux où j'ai dormi. Perec também afirma a Nadeau que o projeto tem como princípio, assim como em Un homme qui dort, inspirar-se nos primeiros parágrafos de $\grave{A}$ la recherche..., de Proust, como também já foi mencionado.

Lembrando que o título de Un homme qui dort é inspirado em uma das primeiras citações de À la recherche: "Un homme qui dort tient en cercle autour de lui le fil des heures, l'ordre des années des mondes" ${ }^{\text {37; }}$ além disso, o espaço de ação (ou de não ação,

\footnotetext{
${ }^{32}$ L'espace ressuscité de la chambre suffit à ranimer, à ramener, à revivre les souvenirs les plus fugaces, les plus anodins comme les plus essentiels $(1992$, p. 33) [...] C'est sans doute parce que l'espace de la chambre fonctionne chez moi comme une madeleine proustienne

${ }^{33}$ Intitulado Sur Lieux où j'ai dormi, de Georges Perec.

${ }^{34} \mathrm{O}$ texto integral da carta foi publicado no livro Je suis né, em 1990.

${ }^{35}$ Este programa, intitulado "Auto-portrait", está no Fonds Perec (folio 119,12) e não é datado, mas, a partir do estudo de Lejeune (1991, p. 30), pode-se crer que foi escrito entre 1961 e 1964.

${ }^{36}$ Esta citação e as seguintes estão presentes na referida carta de Perec a Nadeau.

${ }^{37}$ A autora do artigo afirma que Perec leu Proust na seguinte edição: Marcel Proust, À la recherche $d u$ temps perdu, vol. 1, Paris, Gallimard, coll. "La Pléiade", 1954, p. 5.
} 
se preferirmos) do livro se passa quase que totalmente no quarto, onde descreve metodicamente e monotonamente objetos e detalhes que nos remetem à sua própria situação emocional: uma espécie de constante estado de sono ou dormência.

Perec pretende, portanto, em Lieux où j'ai dormi, estabelecer uma memória "produtiva" a partir da descrição destes espaços fechados e íntimos, partindo de uma experiência de "memória totalizante" análoga à de Proust, transformando cada quarto descrito em uma espécie de "mordida" na sua madeleine. É claro que a estratégia de escrita de Perec não é igual à de Proust. Partindo do que Danielle Constantin vai chamar de "escrita com processo" em Proust, esta será a "escrita com programa" em Perec, ou seja, se na primeira estratégia a memória parece aparecer como algo involuntário e não planejado, em Perec há claramente um programa pré-estabelecido, inclusive para selecionar quais quartos ele vai descrever, e como seguirá o projeto, numa espécie de inventário, tão comum em seus manuscritos preparatórios.

\footnotetext{
TROPEA

Italie

Aout 1965 [...]

la chambre est grande/ gd lit de milieu, carrelage / volets fermés à cause de la chaleur $[\ldots]$

[...] Nous entendons assez bien les uns les autres. Je lis tte la Recherche. Ne fais que ça. [...] J'ai à peine travaillé, un peu à Un homme qui dort (dt le titre est au début ds Proust.

23h dimanche Rue de Seine 13.9.70.
}

A partir da leitura do esboço, compreendemos o processo de rememoração a partir da evocação de um lugar. No caso acima, um lugar em que ele dormiu em agosto de 1965 o ajudará a recuperar a memória cinco anos depois, data em que escreve o esboço. É como se fizesse uma leitura de micro-souvenirs (para usar o termo de Constantin) de seu passado a partir das lembranças evocadas (inclusive lembranças do que escrevia à época) pelo quarto/casa onde passou uma temporada.

A ideia de "memória totalizante" parece, na prática, não funcionar aqui: o que vemos são pequenos fragmentos de situações cotidianas, não necessariamente importantes ou essenciais na vida de Perec, o que faz Claude Burgelin afirmar que Perec é um "anti-Proust" 38, ainda segundo Danielle Constantin. A memória de Proust (proliferante e excessiva) contrasta com o "fracasso de memória” observado em Perec.

\footnotetext{
${ }^{38}$ No livro Les Parties de dominos chez Monsieur Lefèvre. Perec avec Freud - Perec contre Freud, Paris, Circé, 1996, p. 73.
} 
Uma citação de J.B. Pontalis (psicanalista que atendia Perec à época em que escrevia Lieux où j'ai dormi), usando o pseudônimo de Pierre para o paciente, em seu livro L'amour des commencements, trata da questão da descrição dos quartos em Perec:

Os quartos de Pierre: quanto mais os vejo se encher de objetos, mais eles me parecem vazios; quanto mais a topografia se fazia precisa, mais se estendia o deserto; quanto mais o mapa se povoava de nomes, mais estava mudo. Só havia relíquias, não havia ninguém [...] A mãe de Pierre tinha desaparecido numa câmara de gás. Sob todos esses quartos vazios que ele não parava de preencher, havia aquele quarto. Sob todos esses nomes, o sem nome. Sob todas essas relíquias, uma mãe perdida sem deixar o menor traço. (PONTALIS, 1994, p. 171). ${ }^{39}$

A leitura de Pontalis é comovente e nos faz refletir sobre uma questão fundamental na escrita autobiográfica de Perec: a morte da mãe, provavelmente numa câmara de gás. Na língua francesa, "chambre" pode significar tanto quarto quanto câmara, o que torna a reflexão ainda mais fúnebre e tocante. Assim, enquanto Perec (ou Pierre, como Pontalis prefere manter anônimo seu paciente) tenta "preencher" estes quartos, com todas as descrições exaustivas em busca de uma memória, ele parece estar, na verdade, ainda em busca desta "chambre" (câmara) vazia, o lugar de morte da sua mãe. Como se preencher cômodos exaustivamente fosse uma tentativa de suprir esta ausência, que, sabemos, parece uma tentativa constante na obra de Perec.

\subsubsection{Espaços públicos}

Je me souviens é uma obra que trata, de certa forma, de uma acumulação de "relíquias" semelhante ao que acabamos de ver em Lieux où j'ai dormi (na citação de Pontalis a ideia é bastante presente), mas a diferença principal é que a descrição exaustiva de lugares públicos (Tentative d'épuisement...) e privados (Lieux où j’ai dormi) vai levar Perec a essa acumulação de descrições (no espaço público) e objetos (no espaço privado), que será extrapolada nas próximas duas obras a serem apresentadas: tanto Je me souviens quanto L'Herbier des villes partirão dessa ideia de acumulação de pequenas relíquias

\footnotetext{
${ }^{39}$ Les chambres de Pierre: plus je les voyais se remplir d'objets, plus elles mes paraissaient vides; plus la topographie se faisait précise, plus s'étendait le désert; plus la carte se peuplait de nom, plus elle était muette. Il n'y avait là que des reliques, il n'y avait là personne. [...] La mère de Pierre avait disparu dans une chambre à gaz. Sous toutes ces chambres vides qu'il n'en finissait de remplir, il y avait cette chambrelà. Sous tous ces noms, le sans nom. Sous tous ces reliques, une mère perdue sans laisser la moindre trace.
} 
(bilhetes de metrô, entradas de cinema, panfletos, anúncios) que funcionarão como produtores de uma memória.

Se, nos dois casos anteriores, houve descrições exaustivas de um lugar público (a Place Saint-Sulpice) e outros privados (os quartos onde dormiu), o movimento aqui acontecerá de maneira semelhante: em Je me souviens, as relíquias serão documentos e arquivos de cunho público, que funcionarão como motores para um escrita autobiográfica "coletiva": para entender ou apreciar todos os "Je me souviens", o leitor precisará, de certa forma, ter feito parte daquela geração ou, ao menos, contextualizar-se com o momento em que foi escrita.

Outra diferença é que Je me souviens é uma obra acabada e publicada, enquanto L'Herbier des villes (assim como Lieux où j'ai dormi) foi um projeto de "longa duração" e que ainda estava em andamento, sem nenhuma publicação parcial. O que nos mostra aquilo que questionamos anteriormente: as obras de caráter mais coletivo e público parecem ter sido privilegiadas por Perec (ou foi nessas obras que o autor encontrou maiores condições de finalizar a escrita). Nos projetos mais íntimos e pessoais, entretanto, parece haver certa demora ou resistência na escrita, algo que talvez, tenha resultado em dificuldades para concretizar tais publicações. Não há como afirmar exatamente como funcionavam esses processos, mas o que sabemos de fato é que muitos desses projetos ficaram inacabados e desconhecidos do grande público leitor.

Je me souviens, ao contrário de Lieux où j'ai dormi (que parecia funcionar como uma espécie de "madeleine" para Perec), pode funcionar como uma "madeleine" para todos, ou seja, o que está em jogo na escrita é algo que pertence não só a Perec, mas a toda uma geração, que reconhecerá no texto que repete a anáfora "Je me souviens" exatas 480 vezes e que se inspirou na obra I remember de Joe Brainard, publicado em 1970 e apresentado a Perec por seu amigo Harry Mathews alguns anos depois ${ }^{40}$. Não podemos

\footnotetext{
${ }^{40}$ Perguntado em entrevista sobre o que teria motivado a iniciar a escrita de Je me souviens, Perec afirma: "Des I Remember de Joe Brainard. C'est le livre d'un jeune peintre américain qui a rassemblé huit cents petits souvenirs personnels commençant chacun par 'I remember'. En fait, c'est une autobiographie déguisée où la seule rhétorique est cette répétition de la même formule. Brainard m'a donné la forme, la manière dont $\mathrm{j}$ 'allais entreprendre ce travail que $\mathrm{j}$ 'ai envisagé comme quelque chose de beaucoup plus anonyme. Un soir, j'ai commencé par jeu, après un dîner, à dire : ‘Ah, je me souviens'”. Percebemos que somente a fórmula da repetição parece ter sido a inspiração de Perec, não o conteúdo, uma vez que seus $J e$ me souviens são mais ligados à memória coletiva, como ele explica, do que às memórias pessoais, como no caso de Brainard. Na nota explicativa do texto da entrevista há, inclusive, uma menção ao fato de Perec ter muita expectativa sobre a obra, apresentada a ele por Harry Mathews, ao ponto de ter se perguntado como alguém ainda não havia tido tal ideia. Porém, ao ler a obra de Brainard, sentiu-se decepcionado por encontrar apenas lembranças de caráter íntimo, como "ses fantasmes plus intimes, divers épisodes à caractère sexuel ou l'évocation de relations conflictuelles" (Entretiens et conférences, vol. I, p. 215 e notas de rodapé 2 e 3 ).
} 
deixar de pensar em Je me souviens como uma espécie de "fusão" das escritas de Lieux (que consistiam em separar os "réels" dos "souvenirs").

Aqui, Perec parece confrontar ou misturar as duas fontes (o que observa e o que se lembra), tornando a escrita coletiva e íntima ao mesmo tempo; ou, melhor dizendo: é como se a fusão das duas memórias pudesse produzir um efeito de leitura ainda mais interessante na obra.

A falta de contextualização temporal talvez seja um dos grandes desafios de leitura da obra. Sabemos, a partir do que nos conta Lejeune (1991, p. 243) que os Je me souviens eram datados quando faziam parte dos manuscritos; ao publicar a obra, essas referências temporais são eliminadas, o que torna a produção e a leitura dos fragmentos contínua e, ao mesmo tempo, atemporal.

Nos manuscritos, ainda segundo Lejeune, é possível seguir a história de uma memória que se forma, ao mesmo tempo em que o projeto se desenvolve (o texto levou quatro anos para ser concluído). É um trabalho que questiona também o tempo, como em Lieux, mas estas marcas temporais desaparecem no texto publicado, fazendo com que o leitor tenha uma participação mais ativa, buscando em si mesmo as referências para muitas das informações e dados ali compartilhados.

É curioso pensar nesta suspensão do tempo e nas "aparições" repentinas de memória, o que leva o livro a uma heterogeneidade, uma não-linearidade do tempo, uma multiplicidade de assuntos e épocas que se cruzam: novamente, o leitor é quem deverá organizar esta "bagunça" estabelecida pelo próprio tempo para que consiga fazer sua leitura "funcionar". É como tentar lembrar-se das próprias memórias: não há uma sequência lógica para tal; assim como na leitura, tudo fica numa espécie de "emaranhado" que precisa ir sendo descoberto e codificado pelo leitor. Uma das questões mais interessantes no livro é que, ao final, também há páginas em branco para estimular o leitor a escrever os seus próprios "Je me souviens", confirmando a ideia de compartilhamento entre leitura e escrita.

Voltamos, novamente, à ideia de um projeto “duplo" de memória: se, de um lado, podemos pensar num grande inventário de coisas banais e sem importância, de outro, podemos pensar na ideia de compartilhamento da escrita e da leitura. São pequenos pedaços do cotidiano, distribuídos ao leitor para que desfrute como preferir, como o autor avisa na quarta capa: 
Estes "je me souviens" não são exatamente memórias e sobretudo não saõ memórias pessoais, mas pequenos pedaços de cotidiano, de coisas que, tal ou tal ano, todas as pessoas de uma mesma idades viram, viveram ou partilharam. ${ }^{41}$

A temática da coleção de "relíquias" evocado por Je me souviens reaparece em L'Herbier des villes, e nos remete à ideia de coleção e, mais especificamente, à palavra herbário, que em português significa coleção de plantas dessecadas. Se pensarmos num "herbário das cidades", quais seriam essas plantas a serem recolhidas e catalogadas? Logo nos vem à mente, de novo, a obra de Rousseau (Les rêveries du promeneur solitaire), que andava pela Paris do século XVIII recolhendo espécies botânicas que o ajudariam a refletir sobre o presente, o passado e o futuro, como no projeto Lieux de Perec: a última obra de Rousseau, assim como As Confissões, será uma tentativa de busca e reflexão sobre si mesmo diante das críticas externas à sua vida e obra. Caminhar pela cidade e refletir sobre a caminhada, imaginando o que resultará deste processo num futuro, lembra ainda mais a ideia de "envelhecimento dos lugares, da memória e de si mesmo", objetivo principal de Perec na concepção do projeto Lieux:

Todos os meus cursos de botânica, as diversas impressões do local, os objetos que me arrebataram, as ideias que nasceram, os incidentes que foram misturados, tudo isso me deixou impressões que se renovam pelos aspectos de plantas cultivadas nesses mesmos lugares. Não verei mais essas belas paisgens, essas florestas, esses lagos, esses bosques, essas rochas, essas montanhas, cujos aspectos tocaram meu coração: mas agora que não posso mais correr por essas felizes localidades só posso abrir meu herbário e logo ele me transporta para lá. ${ }^{42}$.

Os devaneios de Rousseau, em busca por respostas para suas dúvidas mais profundas, estão fortemente ligados a estas relíquias (neste caso, botânicas) que serão recolhidas para serem apreciadas no futuro e, possivelmente, trarão as lembranças desses passeios e o ajudarão em sua própria reflexão sobre o passado, sobre o momento em que

\footnotetext{
41“'Ces 'je me souviens' ne sont pas exactement des souvenirs, et surtout pas des souvenirs personnels, mais des petits morceaux de quotidien, des choses que, telle ou telle année, tous les gens d'un même âge ont vues, ont vécues, ont partagées".

${ }^{42}$ Tous mes courses de botanique, les diverses impressions du local, les objets qui m'ont frappé, les idées qu'il m'a fait naître, les incidents qui s'y sont mêlés, tout cela m'a laissé des impressions qui se renouvellent par l'aspect des plantes herborisées dans ces mêmes lieux. Je ne reverrai plus ces beaux paysages, ces forêts, ces lacs, ces bosquets, ces rochers, ces montagnes, dont l'aspect a toujours touché mon cœur: mais maintenant que je ne peux plus courir ses heureuses contrées je n'ai qu'à ouvrir mon herbier e bientôt il m'y transporte.

Fonte: https://fr.wikisource.org/wiki/Les_R\%C3\%AAveries_du_promeneur_solitaire/Texte_entier.
} 
foram recolhidas. Esta "colheita", na estratégia de escrita utilizada por Perec no caso de L'Herbier des villes, não será de espécies botânicas, mas seguirá a ideia de uma coleção que possa ser "dessecada" e observada futuramente, numa espécie de criação de "relíquias urbanas", já que o projeto se constituirá de um “conjunto de envelopes, dossiês, cadernos, nos quais estão guardados ou acumulados sem nenhum tipo de classificação, prospectos, fotografias, cartões de visita, correspondências além de alguns raros tickets de metrô e outras entradas de espetáculo", conforme define Raoul Delemazure em artigo ${ }^{43}$ que descreve detalhadamente os objetos e documentos que constituem o projeto, inacabado e não publicado.

Perec vai se utilizar dessas "relíquias" que têm relação com os espaços que frequenta para realizar, assim como Rousseau, uma espécie de reflexão sobre sua própria identidade. A primeira tentativa de criação do projeto se intitulou "Choses que j'aime", dossiê ao qual acrescentou centenas de papéis, fotografias e prospectos por um período aproximado de dois anos (entre 1976 e 1978), imaginando formar uma espécie de autorretrato constituído por elementos que foram coletados na cidade. Ou seja, trata-se de uma identidade que se constrói a partir da vivência nesta cidade e que, inevitavelmente, relembra-nos da reflexão de Perec sobre o tempo em Lieux, que parece ser a mesma reflexão sobre o tempo no projeto de Rousseau mencionado acima, como nos explica Starobinski:

O deslocamento do tempo permite uma pseudo-relação de exterioridade entre vários momentos do eu; a página escrita hoje será destinada por antecedência a um eu futuro que buscará o seu vestígio [...] O que é hoje presença de si para si, plenitude do sentimento, deve procurar forma na linguagem e fixar-se para o futuro como um horizonte de memória antecipado (STAROBINSKI, 1991, p. 284).

São estes "vestígios" ou "relíquias" recolhidos na natureza, de um lado (Rousseau) e na cidade, de outro (Perec) os responsáveis por esta relação entre os tempos, por uma reflexão futura do que está sendo recolhido e escrito hoje. Não por acaso, ambos os projetos são inacabados (ainda que, no caso de Rousseau, o livro tenha sido publicado), e isso talvez por uma ânsia de descrever e coletar dados de um presente que está sempre se renovando e nunca se esgota. Por isso, trata-se de uma espécie de "escrita infinita".

Após o dossiê constituído ao longo de dois anos, um novo se iniciará ainda em 1978, com o título "Les choses communes, l'herbier des villes". O título muda, mas o

\footnotetext{
43 "L'herbier des villes de Georges Perec: un tas de reliquats", a partir da página 203 dos Cahiers Georges Perec 12, de 2015.
} 
projeto parece o mesmo. Novamente, vemos a tensão que se instala entre os projetos duplos de Perec: intitulado inicialmente de "Choses que j'aime", de caráter mais pessoal e íntimo, apesar de contar com material coletado da cidade, da rua, o projeto entra para a série de "Choses communes", ao qual já estão vinculados Je me souviens et Lieux où j'ai dormi, de caráter coletivo, impessoal, que remete ao cotidiano, ao banal, àquilo que se deve enxergar mesmo que pareça insignificante. Em entrevista concedida ${ }^{44}$ em 1979, Perec explica seu projeto futuro (ou seja, ele ainda estava em fase de coleta que, como vimos, havia se iniciado em 1976):

Para o Herbário das cidades, um livro futuro, eu repertorio essas coisas inofensivas da vida cotidiana, recolhidas, colecionadas ao longo dos dias : notas deixadas sob a porta, certificados de limpeza das chaminés, telegramas, alguns envelopes, faturas. ${ }^{45}$

Delemazure afirma que, mais do que o produto de uma simples coleta, L'herbier des villes é uma espécie de triagem: um autorretrato que se constrói a partir de algo tão banal quanto um cesto de lixo, de onde podem ser retirados documentos que "contam", de certa forma, uma história, uma situação, a partir do que ali foi encontrado. Prova disso é um artigo de jornal encontrado junto ao dossiê, que trata da questão da "importância" de documentos a serem encontrados no próprio cesto de lixo:

Deixar falar os pequenos papeis

Reservar um dia para examinar o conteúdo de sua lixeira. Você se surpreenderá em descobrir uma verdadeira mina de ouro de matériasprimas. O papel, por exemplo! Bom ano, ano ruim cada indivíduo despeja 109 quilos de lixo. Isso não tem nenhuma razão de ser já que é possível reciclar seu próprio papel usado em casa... $\left(2015\right.$, p. 206). ${ }^{46}$

Interessante pensar na ideia de que esta coleta seja uma tentativa de lutar contra o esquecimento, contra os traços que restam de uma história, como se ela tivesse uma dimensão maior, que remetesse mesmo à conservação de uma memória que pode ser a qualquer momento jogada no lixo, colocada de lado, literalmente esquecida. Num texto

\footnotetext{
${ }^{44}$ Entretiens et conférences II, p. 107, 108.

${ }^{45}$ Pour L'Herbier des villes, un livre futur, je repertorie ces choses anodines de la vie quotidienne, rassemblées, "collectionnées" au fil des jours: notes glissées sous la porte, certificats de ramonage, télégrammes, certaines enveloppes, factures.

${ }^{46}$ Laisser parler les petits papiers. Prenez un jour le temps d'examiner le contenu de votre poubelle. Vous serez surpris d'y découvrir une véritable mine d'or de matières premières. Le papier, par exemple! Bon an, mal an, chaque individu en jette 109 kilos. Ce gâchis n'a plus aucune raison d'être depuis de qu'il est possible de recycler son propre papier usé à la maison...
} 
sobre o processo de psicanálise realizado com Pontalis, Les lieux d'une ruse, Perec afirma:

Esse pânico de perder meus traços era acompanhado de um furor de conservar e classificar. Eu guardava tudo : cartas com seus envelopes, ingressos de cinema, bilhetes aéreos, faturas, talões de cheques, convocações, periódicos, catálogos, feltros secos, isqueiros vazios, até os pagamentos de gás e eletricidade relativos a um apartamento no qual não morava mais há seis anos, e às vezes passava um dia inteiro triando e triando, imaginando uma classificação que preencheria cada ano, cada mês, cada dia de minha vida (PEREC, 1985, pp. 69-70 - negrito meu). ${ }^{47}$

Podemos ver tal tentativa de acumular papéis, objetos e documentos, associandoos às mais variadas épocas da vida, como uma espécie de arquivo íntimo e pessoal repleto de informações banais que talvez nada digam para quem os lê, mas que podem ser como um relicário para quem o compôs: se analisarmos bem, tanto em Je me souviens, quanto em Lieux, e aqui em L'Herbier des villes, a coleta e arquivo de documentos serão imprescindíveis para o processo de escrita. Delemazure afirma, ao final do artigo, que L'Herbier des villes não pode ser considerado uma autobiografia, mesmo que indireta ou oblíqua ou incompleta, como $W$ ou a memória de infância, mas aquilo que ainda resta dessa memória: "pulverizada pela história, uma identidade em migalhas" (DELEMAZURE, 2015, p. 212).

\subsection{O processo de transição de Lieux para outros suportes}

Vimos, até aqui, algumas obras que tratam da investigação dos espaços para compor a escrita autobiográfica (mesmo que às vezes de maneira indireta). Vimos também que estes espaços funcionam diretamente nessa constituição da memória. A seguir, menciono os únicos cinco textos de Lieux que foram publicados por Perec, agrupados sob um tema comum: "Tentative de description de quelques lieux parisiens", recebendo cada um deles um título e um meio de publicação diferente:

\footnotetext{
${ }^{47}$ Cette panique de perdre mes traces s'accompagna d'une fureur de conserver et de classer. Je gardais tout : les lettres avec leurs enveloppes, les contremarques de cinéma, les billets d'avions, les factures, les talons de chèques, les convocations, les hebdomadaires, les catalogues, les feutres secs, les briquets vides, et jusqu'à des quittances de gaz et d'électricité concernant un appartement que je n'habitais plus depuis plus de six ans, et parfois je passais toute une journée à trier et à trier, imaginant un classement qui remplirait chaque année, chaque mois, chaque jour de ma vie.
} 
1. Guettées (Les Lettres nouvelles, $\left.\mathrm{n}^{\mathrm{o}} 1\right)$;

2. Vues d'Italie (Nouvelle Revue de psychanalyse, $\mathrm{n}^{\mathrm{o}} 16$ );

3. La rue Vilin (L'Humanité, $\mathrm{n}^{\circ}$ du 11 novembre 1977);

4. Allées et venues rue de l'Assomption ( L'arc, $\left.\mathrm{n}^{\mathrm{o}} 76\right)$;

5. Carrefour Mabillon (Action poétique).

Se pensarmos em termos práticos ou editoriais, só são privilegiados, nestes cinco casos, os textos da série "Réels", como já observamos anteriormente: como se aquilo que se observa fosse, de certa forma, funcionar melhor como texto "acabado" do que a série "Souvenirs", que parece não ter atingido um modelo ideal desejado no início do projeto, talvez pelo caráter "imperfeito" ou "insuficiente" das próprias memórias evocadas ${ }^{48}$.

Assim, a ideia inicial do projeto vai se dissipando, uma vez que estes textos da série "Réel" não mais se relacionarão com os textos respectivos da série "Souvenirs". O impacto do tempo, porém, ainda permanece, já que os "Réels" serão, de certa forma, imagens fixadas ou congeladas de um tempo que já passou e que foi ali registrado. Numa narrativa convencional, a descrição funciona como uma espécie de suspensão do tempo, que aqui será a estratégia única de escrita dos textos, como já vimos anteriormente.

Mesmo que grande parte da obra não tenha sido publicada, entendemos que o exercício de escrita do projeto levou Perec a refletir sobre tudo o que vinha escrevendo até então (e, inclusive, levou-o a outros projetos que não só se relacionavam com esta escrita, mas também a extrapolavam). Há uma afirmação de Perec que deixa claro como o projeto se transformou e tomou outras direções em sua obra como um todo:

Esse projeto [Lieux] deveria se estender por doze anos está praticamente abandonado e transformado : os « lugares » relacionados a ele são abordados segundo diferentes perspectivas : assim escrevi um poema (La Clôture) sobre a Rue Vilin, fiz um filme (Les lieux d'une fugue) sobre o cruzamento Franklin-Rooselvelt, e considero uma emissão de rádio sobre Mabillon. ${ }^{49}$.

\footnotetext{
48 Philippe Lejeune publica, após estudo genético, em 1992, na revista Genesis, o texto de "Vilin Souvenirs".

${ }^{49}$ Ce projet $[$ Lieux $]$ qui devait s'étendre sur douze ans est pratiquement abandonné et transformé : les "lieux" dont il était question sont abordés selon des perspectives différentes : ainsi j'ai écrit un poème (La Clôture) sur la rue Vilin, j'ai fait un film (Les lieux d'une fugue) sur le carrefour Franklin-Roosevelt, j'envisage une émission de radio sur Mabillon. Esta citação está no manuscrito intitulado "Tentative de description d'un programme de travail pour les années à venir", de dezembro de 1976, reproduzido no Cahiers Georges Perec 1, em 1985.
} 
O trecho revela uma consciência, por parte de Perec, da transformação que seu projeto vinha sofrendo, já que afirma que Lieux foi praticamente abandonado $e$ transformado, abordado a partir de outras perspectivas. É neste momento que fica ainda mais clara a ideia positiva de abandono do projeto, no sentido de que vai se transformar, dar vida a outras obras, outras maneiras de criar. Notamos que, no momento em que escreve sobre isso, Perec ainda não havia realizado a experiência radiofônica do Carrefour Mabillon.

Em algum momento, o desejo de fixar/congelar/conservar o tempo, dando conta dessa ideia de obra "totalizante", parece escapar daquilo que o próprio autor consegue enxergar ou anotar: a escrita em cadernos, numa velocidade mais lenta, observando a passagem do tempo, parece não satisfazer mais o criador do projeto. Ele quer dar conta desse tempo que passa rapidamente, quer entender essa velocidade e a efemeridade das coisas observadas, quase se como tentasse captar em "tempo real" tudo aquilo que está observando ou vivenciando. Prova disso é o manuscrito que escreve à máquina ("Junot Souvenir", février 1971, passado a limpo em abril, segundo Lejeune:

\begin{abstract}
A máquina de escrever elétrica é uma revolução na escrita: escrevi muito mais rápido que à mão, sem esforço, quase como pensei. $\mathrm{O}$ problema seria ter um pensamento; enquanto isso, é agradável (tranquilizador?) escurecer o papel : EU TRABALHO! (LEJEUNE, 1991, p. 179) ${ }^{50}$.
\end{abstract}

Assim, continuar a escrita, num ritmo que dê conta de todas as coisas a observar, da velocidade com que tudo passa, da efemeridade do tempo e dos espaços, faz com que Perec "migre" sua escrita manual para a escrita da máquina e, num segundo momento, migre também seus projetos para outras mídias, como suportes para seu processo de escrita, que possam auxiliá-lo a dar conta desta tentativa de "totalização do real", usando estas ferramentas complementares à escrita a partir de outros suportes (fotografias, cinema, rádio), numa tentativa de alcançar a velocidade do que pretende anotar, de como descrever o real da maneira mais fiel e simultânea possível.

Se, por um lado, descrever exaustivamente os lugares in loco ou forçar a memória a produzir imagens de um passado que não se pode mais reproduzir parecem ter, de certa forma, motivado Perec a "abandonar" o projeto inicial, mais interessante nos parece

\footnotetext{
${ }^{50} \mathrm{La}$ machine à écrire électrique est une révolution dans l'écriture : j'écris beaucoup plus vite qu'à la main, sans effort, presque au fil de ma pensée. Le problème serait d'avoir une pensée ; en attendant il est agréable (sécurisant ?) de noircir du papier : JE TRAVAILLE !
} 
refletir sobre os "desvios" da obra, que foram se desenhando a partir do momento em que novos projetos ou ideias começaram a ser colocados em prática por Perec. É possível pensar que, dada a ambição do projeto inicial, Perec se viu rodeado por um material bruto que precisava ainda de um aprimoramento para dar vida a novos projetos, a novas escritas. É possível pensar também na impossibilidade do texto isolado para recompor tais ambições de tentativas de reconstituição da memória. Como já venho discutindo ao longo da pesquisa, as imagens parecem, de certa forma, indicar essa "parceria produtiva" com o texto, como se aquelas pudessem "preencher" a possível incompletude deste.

Voltando à questão colocada no final da introdução: o texto escrito pode, então, dar conta das ambições do projeto de Perec? Posso afirmar, agora, que a linguagem do texto escrito será parcialmente capaz de dar conta do projeto, pois verifico que Perec parte da escrita realizada em Lieux e seus lugares comuns para um nova posição: ele deixa também seu lugar confortável, ou seu "lugar-comum" de escritor. A princípio, enquanto tenta cumprir suas metas estabelecidas ano a ano, Perec circula pelas ruas e praças ou senta à mesa num café, observando e escrevendo suas notas que, futuramente, acabarão se transformando em conteúdos lacrados dentro de envelopes e ficarão, então, em estado de espera. Aos poucos, o projeto de escrita dos textos perde fôlego e os gestos de escrever, passar a limpo, classificar e conservar documentos dá lugar a outros movimentos: no caso da Rue Vilin, por exemplo, as inúmeras anotações feitas anualmente, pouco a pouco, foram se reduzindo até que se passasse de uma extensa descrição, inclusive passada a limpo, no primeiro ano de projeto, a apenas uma frase, na última anotação:

27 setembro 1975

por volta de 2 da manhã

Quase todo o lado ímpar está coberto por muros de cimento. Sobre um deles um grafite: TRABALHO=TORTURA

O que podemos refletir ao ler estas poucas palavras finais? Algumas possíveis respostas para a associação dos termos trabalho/tortura nos parecem possíveis: a) Perec pretende problematizar o próprio ato de escrita, o projeto que não avança; b) Ele faz referências às mortes dos pais na guerra, nos campos de concentração; c) É uma espécie de ato concreto que encerra a escrita de Lieux, fazendo-nos refletir novamente: Lieux é uma espécie de palimpsesto, ou seja, um texto escrito para "ser apagado", dar lugar a outros, funcionar como ponto de partida para outros? Ou, indo um pouco além, Lieux é uma tentativa de romper com o ato de escrita e partir para outras ações/intervenções 
artísticas? O projeto parecer ter proliferado, a partir de determinado momento, para mais ações do que obras escritas, negando o livro para conseguir superá-lo e seguir adiante com outros projetos.

O que se vê, com o tempo, é que novas configurações artísticas estarão presentes. Perec produzirá um comentário de voz fictício para um documentário de TV, escreverá poesia à luz de fotografias tiradas no bairro onde viveu a infância, realizará produções cinematográficas: é o movimento do escritor partindo em busca de novos projetos artísticos. Quando realiza a emissão radiofônica (Tentative de description des choses vues au Carrefour Mabillon), ele registra sua voz enquanto observa o movimentado cruzamento em Paris e repete o procedimento de Lieux, mas desta vez sem o bloco de notas, escapando de seu lugar-comum de escritor. A velocidade da voz gravada torna-se mais dinâmica que a escrita do texto que, como acabamos de ver, vai se tornando cada vez mais escasso:

\footnotetext{
É na implosão da especificidade no interior de um mesmo material ou suporte que aparece o problema mais instigante dessa aposta no inespecífico, explicando, aliás, a proliferação cada vez mais insistente desses entrecruzamentos de suportes e materiais como uma condição de possibilidade - dir-se-ia de horizonte - da produção de práticas artísticas contemporâneas (GARRAMUÑO, 2014, p.15-16).
}

A reflexão que se desenvolverá, a partir deste ponto, refere-se à proliferação do texto escrito, que se espalha em muitos outros pedaços e dá forma a outras produções em diferentes suportes, evidenciando uma característica bastante contemporânea que já estava presente na obra de Perec nos anos 70. O texto e a literatura proliferam, ampliando a importância do fazer literário e seus possíveis desdobramentos. $\mathrm{O}$ espaço se abre da literatura para outros meios, enquanto a escrita se desdobra para além dos seus limites, como se entrasse num campo expandido, evidenciando a questão da inespecificidade da literatura e questionando o novo lugar (frágil) deste (não)escritor. Assim, ele parte para novos projetos sobre os quais ainda não tem pleno domínio, mas que funcionam para dialogar com os textos produzidos e a necessidade de extrapolar essa escrita que, sozinha, parece não mais ser suficiente para expressar seus anseios artísticos e autobiográficos. 


\section{CAPÍTULO II}

Dando sequência ao trabalho, após apresentarmos detalhadamente a importância do tema do espaço para a obra de Perec e suas motivações para o início da escrita do projeto Lieux e suas respectivas transformações, traremos com maiores detalhes, na primeira parte do presente capítulo, análises de duas importantes produções dentre os textos realizados no projeto Lieux: a dupla série Réels/Souvenirs da Rue Vilin. A partir desses textos, refletiremos sobre a importância do projeto para o desenvolvimento da escrita autobiográfica de Perec. Na segunda parte do capítulo, apresentaremos a obra $L a$ Clôture, um livro composto de poemas e fotografias, que serão analisados como parte do processo de transformação do projeto Lieux em produções que saem do suporte do texto escrito. Veremos as relações diretas entre as reflexões contidas nos textos de Vilin Réels/Vilin Souvenirs e suas transformações para a realização de La Clôture, sobretudo a partir do uso de imagens e de regras fixas de escrita, as contraintes (frequentemente utilizadas por Perec em muitas de suas obras). Veremos também como tais regras funcionam como uma espécie de jogo para o leitor e, ao mesmo tempo, como uma chave de leitura autobiográfica da obra.

\section{A dupla série sobre a Rue Vilin (em Lieux)}

Comecemos com os textos sobre a Rue Vilin nas séries Réel/Souvenir de Lieux. Como já dito, a primeira série se propõe a visitar o lugar uma vez por ano, enquanto a segunda será realizada em qualquer outro lugar, mas tratará de evocar memórias referentes à rue Vilin.

A série Réel está publicada no livro L'infra-ordinaire ${ }^{51}$, enquanto a série Souvenir foi publicada por Philippe Lejeune na revista Genesis. ${ }^{52}$ Segundo Bertharion, ao escrever as duas séries, Perec buscava mobilizar tanto os vestígios do lugar quanto reconstruir sua própria memória, partindo da fórmula de Ricoeur:

\footnotetext{
${ }^{51} \mathrm{O}$ texto integral será reproduzido na seção "Apêndices" desse trabalho.

${ }^{52}$ Genesis I, 1992, pp. 127-151.
} 
A linguagem tem a tarefa de "voltar da marca à coisa marcante", do presente físico ao passado memorial, para interpretar (fazer falar) esses restos do passado e inscrevê-los num quadro de cronologia personal confiável. Os reais são assim descrição de traços, e os sovenirs as voltas no tempo, na memória. (BERTHARION, 1998, p. 233). ${ }^{53}$

Também podemos justificar esta obsessão de Perec por documentar, classificar, organizar e envelopar como um gesto de preservação de uma história coletiva, que também será a tentativa de preservação da própria história. Os lugares serão, para Perec, os lugares de memória, no sentido que conhecemos a partir de Pierre Nora: "os lugares de memória nascem e vivem do sentimento de que não há memória espontânea, que é preciso criar arquivos...". Ao definir a memória arquivística, Nora também nos ajuda a entender a obsessão arquivística típica de um autor contemporâneo a ele, como Perec:

Ela [a memória arquivística] se apoia inteiramente sobre o que há de mais preciso no traço, mais material no vestígio, mais concreto no registro, mais visível na imagem. O movimento que começou com a escrita termina na alta fidelidade e na fita magnética. Menos a memória é vivida no interior, mais ela tem necessidade de suportes exteriores $\mathrm{e}$ de referências tangíveis de uma existência que só se vive através delas. Daí a obsessão pelo arquivo que marca o contemporâneo e que afeta, ao mesmo tempo, a preservação integral de todo o presente e a preservação integral de todo o passado. $O$ sentimento de um desaparecimento rápido e definitivo combina-se à preocupação com o exato significado do presente e com a incerteza do futuro para dar ao mais modesto dos vestígios, ao mais humilde testemunho a dignidade virtual do memorável (NORA, 1993, p. 14, itálicos meus).

Justificado este processo de arquivo de Perec (que, sabemos, está presente em praticamente todas as obras e projetos de escrita), iniciaremos nossa análise, então, pela primeira série. Podemos deduzir, portanto, a partir das ideias de Nora, que Perec realmente necessitava de suportes exteriores, já que não havia memória espontânea, e que o sentimento de que a Rue Vilin está prestes a desaparecer também marca este processo de escrita, de tal forma que, como veremos, inúmeras vezes o autor comenta só ter ido definitivamente ao lugar (na tentativa de registrar obsessivamente todos os seus detalhes) ao descobrir que este seria demolido em breve.

\footnotetext{
${ }^{53}$ Le langage a la tâche de "remonter de la marque à la chose marquante", du présent physique au passé mémoriel, pour interpréter (faire parler) ces restes du passé et les inscrire dans le cadre rassurant d'une chronologie personnelle fiable. Les réels sont ainsi les descriptions des traces, et les souvenirs des remontées dans le temps, dans la mémoire.
} 


\subsection{Vilin Réels}

O que vemos nos trechos transcritos abaixo são cenas de um bairro em pleno movimento de transformação, ou, porque não dizer, de destruição. Veremos nas anotações anuais de Perec uma série de adjetivos que nos lembram destruição, fechamento, fim, encerramento: aqui, a ideia de La clôture ainda está em fase de experimentações, quer dizer, ainda há apenas meras descrições sobre um lugar que se encerra aos poucos, ano a ano. Os itálicos acrescentados por mim ao texto original trazem essa ideia de algo que está prestes a chegar ao fim. Perec então tem o papel de documentar, testemunhar, registrar os últimos movimentos e acontecimentos de um lugar que, ele bem sabe, brevemente não mais existirá. Os trechos grifados nos trazem as impressões, sugestões ou informações autobiográficas do texto. Os primeiros anos de observação contam com descrições de praticamente todos os números da rua, independentemente de fazerem parte de sua história. Perec traça um panorama geral da rua, tentando captar todos os detalhes de maneira obsessiva e detalhada, especialmente nos escritos dos primeiros anos. Privilegiarei a transcrição de trechos que se referem mais pontualmente ao número 1 (residência dos avós) e ao 24 (onde ele viveu com os pais), para verificarmos de que forma Perec observa e descreve tais lugares, tão intimamente ligados a sua infância.

1. Jeudi, 27 février 1969 vers 16 heures

Sur la gauche (côté impair), le n. 1 a été ravalé récemment. C'était, m'a-t-on dit, l'immeuble où vivaient les parents de ma mère. Il n'y a pas de boîtes aux lettres dans l'entrée minuscule. Au rez-dechaussée, un magasin, jadis d'ameublement (la trace des lettres MEUBLES est encore visible), qui se réinstalle peut-être en mercerie à en juger par les articles que l'on voit en devanture. Le magasin est fermé et n'est pas éclairé. (p. 15-16).

Au 24 (c'est la maison où je vécus) :

D'abord un bâtiment à un étage, avec, au rez-de-chaussée, une porte (condamnée); tout autour, encore des traces de peinture et audessus, pas encore tout à fait effacée, l'inscription

\section{COIFFURE DAMES}

Puis un bâtiment bas avec une porte qui donne sur une longue cour pavée avec quelques décrochements (escaliers de deux ou trois marches). A droite, un long bâtiment à un étage (donnant jadis sur la 
rue par la porte condamnée du salon de coiffure) avec un double perron de béton (c'est dans ce bâtiment-là que nous vivions; le salon de coiffure était celui de ma mère).

$\mathrm{Au}$ fond, un bâtiment informe. A gauche, des espèces de clapiers.

Je ne suis pas rentré.

Un vieil homme, venant du fond, a descendu les trois marches qui menaient à "notre" logement. Un autre vieil homme est entré avec un lourd ballot (de linge ?) sur le dos. Puis, à la fin, une petite fille. (p.18-19).

Aqui, vemos que a descrição objetiva prevalece, a despeito de se tratar do imóvel no qual viveu com sua família na infância. Notamos que o trecho "Je ne suis pas rentré" não traz nenhum tipo de reflexão mais íntima ou particular, não há comentários adicionais ou sequer justificativas para a tomada da decisão de não entrar, não observar por dentro o imóvel. Esta frase nos lembra o início do livro $W$ ou a memória da infância, com a afirmação precisa: "Não tenho nenhuma memória de infância". É como se esse lugar de infância, visto agora como adulto, reafirmasse a enfática frase. Se não há lembranças, também não há motivos para estar dentro do imóvel. Estar ali dentro não será suficiente para recuperar as lembranças perdidas: o que resta é apenas observar, detalhar tudo o que vê hoje e tentar, ao máximo, recuperar o que está sendo visto aqui e agora, já que é impossível recuperar as memórias dali.

A inscrição em letras maiúsculas COIFFURE DAMES será de vital importância para a nossa discussão aqui: tanto pelo fato de aparecer em diferentes versões em capas, quanto por representar, como veremos a seguir, um pouco da escrita presente em $L a$ clôture. A porta em que se lê a inscrição revela uma importância para a reflexão autobiográfica de Perec no projeto. Em vários momentos, ler a inscrição "encore visible" significa que o lugar ainda se preserva, mesmo que precariamente, como o lugar onde sua mãe viveu e trabalhou como cabeleireira, antes de ser deportada para Auschwitz. Imagens desta porta e deste imóvel serão predominantes para a pesquisa, por representarem esta ideia de fechamento, de encerramento, mas, ao mesmo tempo, também de relíquia, de local depositário de lembranças, mesmo que escassas, perdidas, em processo de destruição, assim como o próprio imóvel em si. 
2. Jeudi 25 juin 1970

vers 16 heures

$\mathrm{Au} 1$, il y a un magasin d'alimentation fermé et une mercerie encore ouverte. Au deuxième étage, un homme est à sa fenêtre.

$\mathrm{Au} 24$, dans la courette, il y a un chat sur une soute à charbon. L'inscription COIFFURE DAMES est encore visible. Affiches du PC (p.25).

Ao lado de cartazes do Partido Comunista, deixando clara aqui a observação de um tempo, de uma época, tão fortemente marcada pela política na França, a inscrição do salão permanece, como se estivesse num mesmo movimento de resistência (associado ao partido?), como se fosse quase um manifesto, um pedido de socorro, para um lugar que está prestes a ser destruído. A anotação, a observação e o processo de escrita acabam completando este ciclo de resistência, este movimento de negação ao esquecimento.

\section{Mercredi 13 janvier 1971}

Au-dessus de la porte du n. 1, il y a un fronton triangulaire. Le magasin de gauche, peint en bleu, avec une tente rouge déchirée pendante, est fermé. Le magasin de droite vend peut-être des fournitures pour tailleurs. (p. 26) [...] dans la cour du 24, des poutrelles de métal ; des ouvriers en face réparent un toit (d'un immeuble rue des Couronnes ?) Au loin des grues. (p.27)

Du 36, une dame sort : elle vit là depuis 36 ans ; elle n'était venue que pour trois mois; elle se souvient très bien de la coiffeuse du 24 : -Elle n'est pas restée très longtemps. (p. 27-28)

4. Dimanche 5 novembre 1972, vers quatorze heures

Le n. 1 est toujours là. [...] (p. 28)

24 toujours intact (p. 29)

5. Jeudi 21 novembre 1974

vers 13 heures

Le 1 est encore intact. [...] Le 18 et le 22 sont des cafés hôtels encore debout, ainsi que le 20 et le 24. Rien au-delà du 30 [...] (p.30). 
A descrição começa a se tornar cada vez mais escassa, como que se adaptando à ideia de ruína e destruição próximas. Parece mesmo uma espécie de confirmação às avessas, algo que ainda está lá, mesmo que saibamos que, em breve, não estará mais. As expressões: encore intact, toujours intact, encore debout ilustram bem essa ideia. Juntamente com essa consciência de que tudo está em vias de se destruir, o projeto segue também em vias de se tornar cada vez mais escasso. Não há mais novidade, nada a ser acrescentado. Os olhos veem aquilo que já foi visto anteriormente, a escrita se torna mais rápida e menos detalhista. A tentativa de Perec de encontrar algo banal e ao mesmo importante vai dando espaço a textos mais curtos, mais repetitivos e menos descritivos, compostos por poucas e breves frases. Em algum momento, a simples observação passa quase a um processo mecânico de constatação dos fatos, apenas.

6. 27 septembre 1975 ,

Vers 2 heures du matin

La quasi-totalité du côté impair est couverte de palissades en ciment. Sur l'une d'elles un graffiti:

TRAVAIL $=$ TORTURE

\subsubsection{Algumas reflexões sobre os Réels}

O trecho final reproduzido acima é bastante significativo, pois afirma o que já era possível identificar nos anos anteriores: se trabalho=tortura, se não há mais o que ser observado, se nada mais pode ser reestabelecido, se não foi possível estabelecer uma conexão com o lugar, nada mais o motiva a continuar o projeto. São apenas suposições que nos indicam o que pode ter motivado o fim do ciclo de visitas à rue Vilin, e do projeto Lieux. A inscrição trabalho=tortura não deixa de ser, também, uma possível alusão aos campos de concentração. E sobre eles também não há o que se falar. Toda a obra autobiográfica de Perec trará, de maneira indireta, resquícios do trauma vivido em decorrência da morte dos pais na Segunda Guerra Mundial. O pai, morto em combate e a mãe, deportada para os campos de Auschwitz, são o centro de toda a sua dificuldade em escrever sobre sua infância. Portanto, há que se considerar esta imagem reproduzida dos 
muros para a escrita de Perec como uma alusão aos campos, inclusive pela semelhança entre a frase "Trabalho=tortura" e o portão de entrada dos campos, que trazia a inscrição "Arbeit macht frei", uma frase em alemão que significa "o trabalho liberta". No trabalho autobiográfico Récits d'Ellis Island, que trata especificamente da migração de refugiados de guerra, a reflexão sobre a perda dos pais se confunde inclusive com a perda de suas origens judaicas:

Em qualquer lugar, eu sou estrangeiro em relação a alguma coisa de mim mesmo; em qualquer lugar, eu sou "diferente", mas não diferente dos outros, diferente dos "meus": eu não falo a língua que meus pais falavam, eu não compartilho nenhuma das lembranças que eles pudessem ter, alguma coisa que fosse deles, que fizesse com que eles fossem eles, sua história, sua cultura, sua esperança, não me foram transmitidos (PEREC, 1995, p. 59).

É importante destacar que o segundo capítulo da minha dissertação de mestrado trata com detalhes da dificuldade de rememoração da infância e do uso de fotografias dos pais para a criação de uma "memória autobiográfica ficcional" na obra $W$ ou a memória de infância.

Além da relação direta das frases apresentadas por Perec em Lieux (Trabalho=tortura) com a frase dos portões dos campos, ainda é possível pensar numa outra relação, que será aqui apresentada brevemente: a relação de Perec com as ideias situacionistas, grupo que teve um papel político importante nos anos 60 na França e que teve Guy Debord como um dos fundadores da Internacional Situacionista. Cineasta e escritor, Debord teve A Sociedade do Espetáculo publicada em 1967, obra que alcançou maior notoriedade a partir dos eventos políticos ligados aos movimentos estudantis de maio de 1968, em Paris. Apesar de Perec não ter participado ativamente desse movimento, ele fez parte de um grupo politicamente engajado nos anos 60 (denominado La ligne génerale). Em ambos os grupos, encontramos algumas convergências e, entre elas, a influência das ideias de Henri Lefevbre, conforme afirma o autor Mathieu Rémy: ${ }^{54}$

Os dois escritores eram uma mesma fonte de inspiração, na pessoa de Henri Lefebvre. Este foi uma das maiores influências da Internacional Situacionista de Guy Debord, pelo menos em seus primeiros anos. Lefebvre soube apresentar uma versão renovada do pensamento marxista porque se interrogava muito rápido sobre urbanismo, cotidiano e alienação, assuntos que irrigaram o pensamento

\footnotetext{
54 Matthieu Rémy, "Georges Perec dans l'air du temps situationniste", Archives et documents
} situationnistes, $\mathrm{n}^{\circ} 4$, automne 2004. 
situacionista e que encontraremos em filigrana nas ficções e ensaios de Perec. $(\mathrm{p} .4)^{55}$

A cegueira do cotidiano, insistentemente questionada por Perec, também parece ser uma das indagações de Debord, sobretudo neste trecho em que trata da questão da alienação:

A alienação do espectador com proveito do objeto contemplado (que é resultado de sua própria atividade inconsciente) se exprime assim: quanto mais contempla, menos vê; quanto mais aceita se reconhecer em imagens dominantes da necessidade, menos compreende sua própria existência e seu próprio desejo.(DEBORD, 1967, p. 30). ${ }^{56}$

Também podemos destacar o trecho da obra de Lefebvre, Introduction à la modernité, que explica as inquietações dos situacionistas e nos faz pensar nas semelhanças com o próprio pensamento de Perec em relação à cidade: “c'est dans le cadre et le milieu urbains que peut s'exercer l'activité créatrice de situations, donc d'un style de d'une façon de vivre. Ce groupe a donc concentre son attention sur la description des villes" (LEFEBVRE, 1962, p. 337).

Outros depoimentos, de terceiros e do próprio Perec, também nos ajudam a estabelecer relações entre ele e Debord. Sobre essa relação, David Bellos ${ }^{57}$, biógrafo de Perec, afirma: “(...) peut-être Perec entendit-il parler de ce mouvement par Henri Lefebvre, qui eut la bonne et la mauvaise fortune d'être le professeur de Debord dans les années 50 ; à moins qu'il soit tombé sur l'une ou l'autre des irrégulières publications de Debord à La Joie de Lire; ou plus simplement capta-t-il les notions situationnistes dans l'air du temps".

Há ainda um trecho de uma entrevista de Perec, comentado na edição Entretiens et Conférences, onde o escritor evoca o conceito de "deriva" dos situacionistas a um jornalista do Télérama; Ribière e Bertelli assim o reproduzem: “(...) on peut noter que le questionnement perecquien à propos de l'espace urbain n'est pas étranger aux théories psychogéographiques et urbanistiques des situationnistes ${ }^{58 "}$.

\footnotetext{
${ }^{55}$ Les deux écrivains eurent une même source d'inspiration, en la personne d'Henri Lefebvre. Celui-ci fut l'une des influences majeures de l'Internationale Situationniste de Guy Debord, au moins dans les premières années de celle-ci. Lefebvre a su donner une version rénovée de la pensée marxiste parce qu'il s'interrogea très vite sur l'urbanisme, la quotidienneté, et l'aliénation, sujets qui irrigueront la pensée situationniste et que l'on retrouvera en filigrane dans les fictions et les essais de Perec.

${ }^{56}$ L'aliénation du spectateur au profit de l'objet contemplé (qui est le résultat de sa propre activité inconsciente) s'exprime ainsi : plus il contemple, moins il vit; plus il accepte de se reconnaître dans les images dominantes du besoin, moins il comprend sa propre existence et son propre désir.

${ }^{57}$ D. Bellos, Georges Perec, une vie dans les mots, Paris, Seuil, 1994, p. 300.

${ }^{58}$ Quatrième note de bas de page dans "Georges Perec. Les Paris d'un joueur", Propos recueillis par
} 
E, para complementar, vide um trecho de entrevista do próprio Perec, citando diretamente os situacionistas:

Trabalho lá fora voluntariamente. Faço um pouco como os situacionistas há alguns anos: parto de um lugar que é em geral suficientemente longe daquele onde moro, e então ando muito tempo tentando não seguir os caminhos que conheço ou entrar em pequenas ruas. Às vezes isso pode ser incrível. ${ }^{59}$.

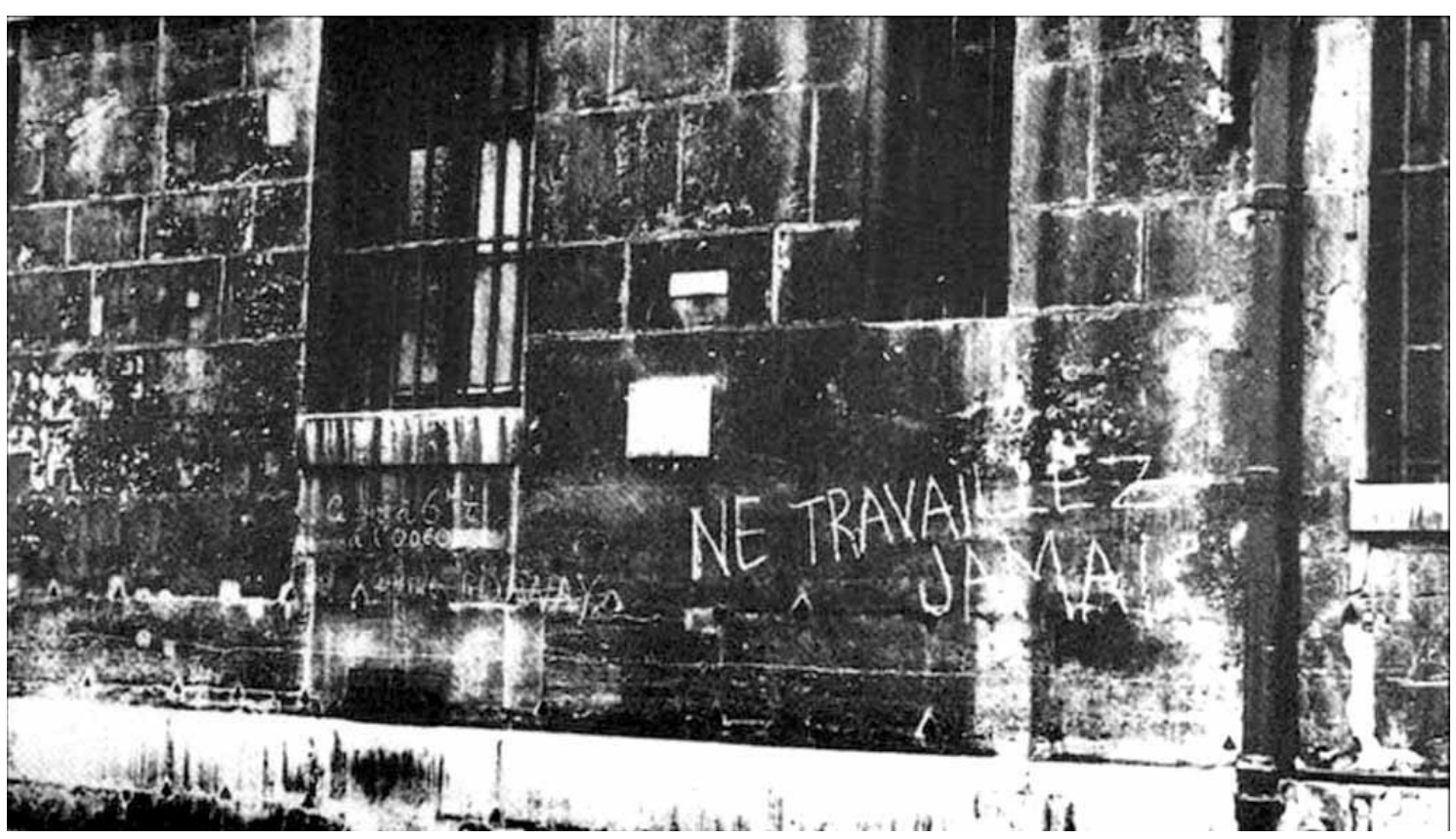

Figura 4. A célebre frase dos situacionistas. Fonte da imagem: https://thedisorderofthings.com/2013/06/13/workand-the-politics-of-refusall

Além dos depoimentos, temos ainda a inscrição realizada em muro da rue de Seine, em 1953, atribuída a Guy Debord, e que também ganhou novos significados com os movimentos estudantis de 1968. Perec fez parte da mesma geração, que contestava os preceitos de uma sociedade capitalista e de consumo e que nos leva, novamente, à inscrição final de Lieux (Trabalho=tortura). Todas essas evidências nos fazem pensar nessa possível convergência de ideias entre Georges Perec e Guy Debord, traçada aqui brevemente para ilustrar um período bastante conturbado na França, mas que trouxe

Jacques Renoux dans G. Perec, Entretiens et conférences, II, Paris, Joseph K., 2003, p. 129.

59 Je travaille volontiers dehors. Je fais un peu comme les situationnistes il y a quelques années : je pars d'un endroit qui est en général assez loin de celui où j'habite, et puis je marche très longtemps en essayant de ne pas suivre les chemins que je connais ou de prendre les petites rues. Parfois, ça peut être étonnant. Georges Perec. Les Paris d'un joueur", Propos recueillis par Jacques Renoux dans G. Perec, Entretiens et conférences, II, op. cit., p. 129. 
consequências artísticas para toda uma geração. Perec e Debord parecem não ter se conformado com uma arte mais tradicional, e todas as mudanças políticas e sociais pelas quais a França estava passando foram também uma motivação para terem se lançado às ruas, num movimento de ação que parece ter sido uma bandeira comum para os artistas.

Para recapitular e retomar a relação entre os campos de concentração, sua obra autobiográfica e o projeto Lieux, ressaltamos: Perec acaba de publicar, neste ano de 1975, seu mais importante livro autobiográfico: W ou a memória da infância. Mais um ciclo se fecha. O autor falará sobre os campos de concentração, de maneira oblíqua, como já observado, num texto ficcional, que compõe alternadamente a obra junto de um texto dito autobiográfico. Na leitura do livro, as partes se intercalam e descobrimos que não é possível tratar diretamente da questão autobiográfica na parte destinada a falar sobre sua vida; a solução encontrada é tratar do tema de maneira ficcional.

Com o fim dos trabalhos de Lieux, no mesmo ano de 1975, o fantasma da infância parece ter sido explorado suficientemente na obra autobiográfica. Lieux passa, então, a assumir a função de suporte de iniciação para outros trabalhos. O caráter autobiográfico, ou mesmo o fantasma das memórias, voltará. Aparecerá claramente nos poemas de $L a$ clôture, neste capítulo; no filme Les lieux d'une fugue, no capítulo seguinte; e, para encerrar, no quarto capítulo, o tema infância-judaísmo será definitivamente explorado em Récits d'Ellis Island, de maneira bastante explícita.

Antes de partirmos para uma tentativa de leitura dos poemas de La clôture, restanos, ainda, refletir um pouco mais sobre estes fantasmas que rondam a infância de Perec. Se, na parte anterior que acabamos de apresentar, as anotações não passam de meras descrições objetivas desprovidas de qualquer emoção ou nostalgia, o que vemos na série Souvenirs é, praticamente, o movimento oposto: aqui, as indagações sobre o lugar (a rue Vilin) torna-se apenas pretexto para o questionamento a respeito de seu passado e suas lembranças (vividas ou imaginadas). Perec sai do espaço físico (está em diferentes lugares agora), apenas refletindo ou idealizando as memórias da rue Vilin. Não precisa mais se valer da observação das ruas (em ruínas) nem tampouco preocupar-se com detalhes objetivos. Agora, a ideia é deixar tomar-se pela emoção e levantar hipóteses, pensamentos, dúvidas, contradições sobre a própria infância, mesmo que não chegue a conclusões muito importantes. Mais uma vez, como em "Vilin Réel”, o banal, o desimportante, aquelas pequenas migalhas de vida serão aqui desenhadas e reconstruídas, num ir e vir de lugares que o fazem viajar de volta à rue Vilin, nem que seja, ao menos, pelo caminho da imaginação. 


\subsection{Vilin Souvenirs}

Percebemos pelo trecho do texto de Lejeune, na descrição do material de "Souvenirs", que, além da imaginação, Perec se valerá inclusive de uma série de fotos, tiradas no momento das visitas para a série "Vilin Réel", que acabamos de analisar. Este material acabou ficando junto das anotações das "Vilin Souvenirs ${ }^{60 "}$, o que nos faz pensar que as imagens da rua, mesmo que não mais pessoalmente e sim pelas fotos, ainda terão influência nessa escrita originalmente desprovida de "estímulos"; ora, se a proposta de Perec era escrever as "Vilin Souvenirs" em um lugar neutro, onde pudesse evocar as possíveis memórias da rue Vilin, quase à procura de uma iluminação ou lampejo à maneira de Proust e sua madeleine, no final das contas até mesmo as fotos, que provavelmente foram retiradas do envelope de "Réels", já aberto (e também publicado, como vimos), acabaram servindo como uma espécie de estímulo para essa escrita não tão espontânea quanto gostaríamos que fosse, uma vez que se trata de evocação de memórias da infância.

No envelope ele colocava também os negativos e as folhas de contato das fotos tiradas na rue Vilin em 25 de junho de 1970 pelo seu amigo, o pintor Pierre Getzler, por quem se fez acompanhar no dia em que lá esteve para escrever seu "réel". O envelope "réel", estando talvez já selado quando obteve as fotos, ele as guardou para o envelope "souvenir". (p.128) $)^{61}$

Além de se apropriar deste material de outro envelope (Réels - Vilin), Perec anota também a data e o momento em que as fotos foram tiradas, provavelmente para que, ao manipulá-las, pudesse relembrar-se de algo vivido neste dia; assim, temos juntamente com os negativos das fotos a inscrição como segue, num papel à parte:

\footnotetext{
${ }^{60}$ Importante pensar no trocadilho da expressão Vilin Souvenirs com aquela "vilain souvenirs", que traz em si uma carga bastante pejorativa, já que pode ser entendida como "memórias ruins, feias", exatamente como em todos os momentos em que Perec se refere às próprias memórias de infância, que afirma não possuir. Parece-nos menos uma coincidência e, sobretudo, um uso consciente da expressão por Perec. (agradecimento especial a Gisela Bergonzoni pela observação feita em um dos seminários apresentados por mim, no grupo de pesquisa Criação \& Crítica, e que levantou essa questão bastante significativa, além da relação de Perec com as ideias situacionistas).

${ }^{61}$ Dans l'enveloppe il mettra aussi les négatifs et les planches-contacts des photos prises rue Vilin le 25 juin 1970 par son ami le peintre Pierre Getzler, par lequel il s'était fait accompagner le jour où il s'était rendu sur place pour écrire son "réel". L'enveloppe "réel", étant sans doute déjà scellée quand il a eu les photos, il les aura gardées pour l'enveloppe "souvenir".
} 


\section{Photos prises par}

\section{Pierre Getzler}

en juin 70

(le jour de Vilin réel) (p. 138)

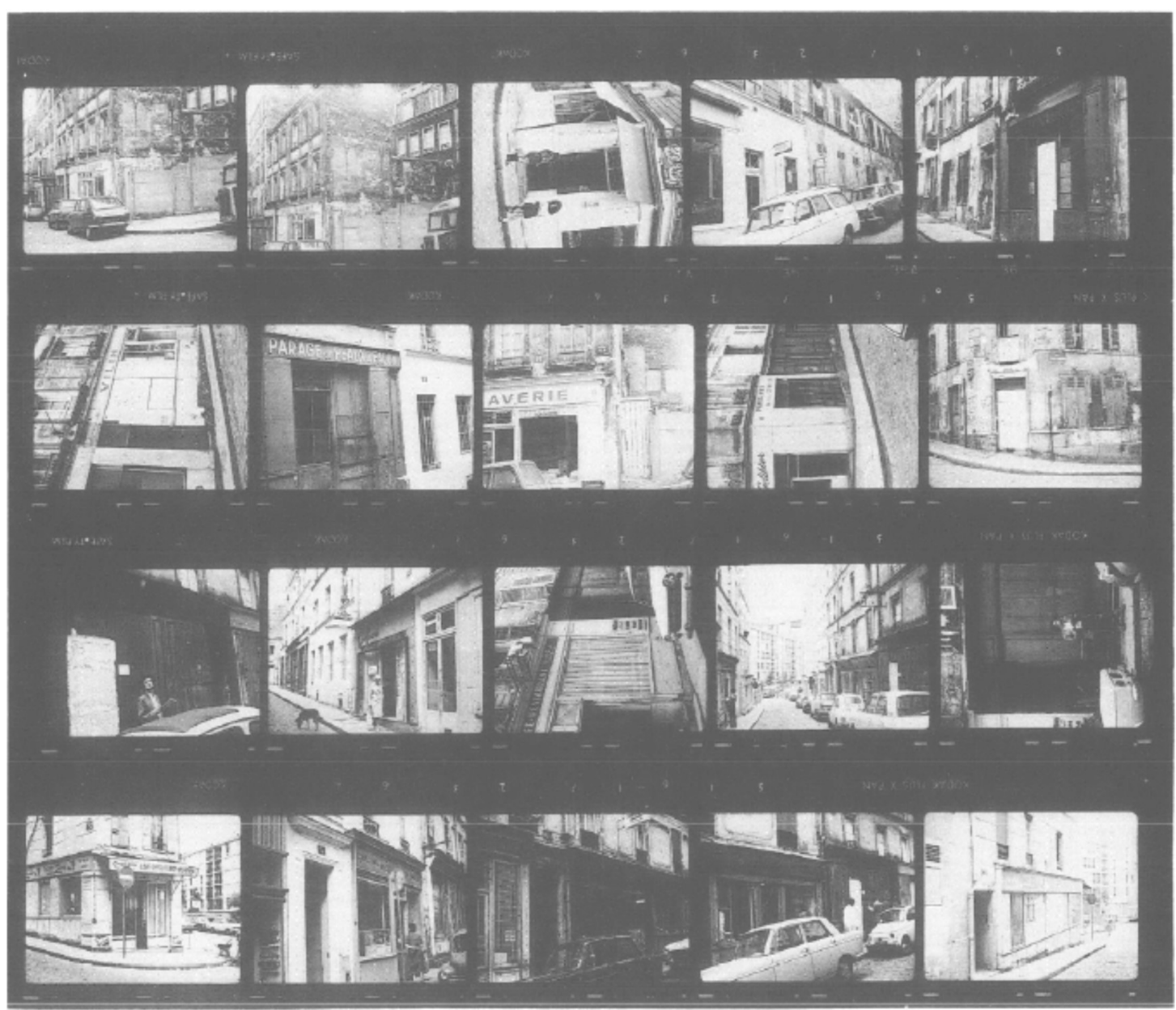

Figura 5. Negativos da Rue Vilin. Fonte: Lejeune, Philippe. Vilin Souvenirs. Georges Perec. In: Genesis, 1992. p. 139

Passada esta informação (e a visualização de algumas fotos, tais como foram encontradas no envelope das Souvenirs), resta agora nos concentrar naquilo que viriam a ser as tais evocações de memória. Já mencionamos a importância do local da primeira descrição (cf. página 7 do capítulo 1). Assim, podemos dizer que, para Perec, a primeira escrita a respeito das memórias da rue Vilin parece quase um ritual, num lugar onde possa 
se sentir bem, à vontade, entre os seus amigos, numa escrita tranquila e, por que não, inspirada também pela tranquilidade do lugar:

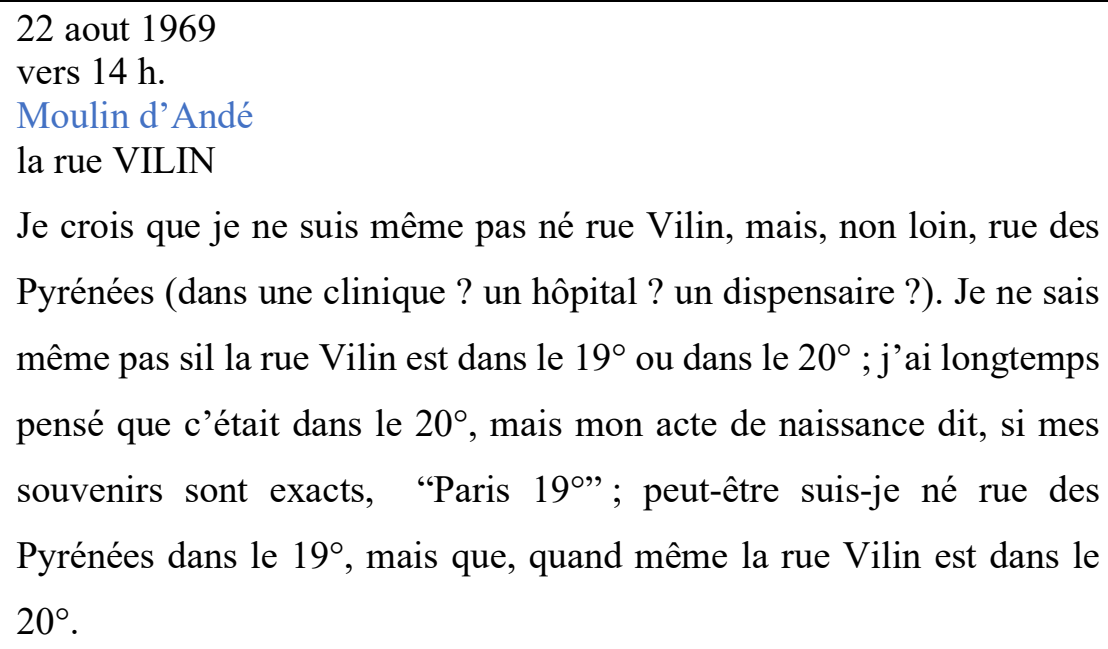

O primeiro trecho não soa nada parecido com aquilo que poderíamos imaginar como sendo as evocações de uma memória de infância (talvez estejamos batendo bastante na mesma tecla, mas é evidente que tenhamos uma expectativa maior em relação a esta parte do texto: esperamos algo mais subjetivo, emotivo, um tom mais lírico na escrita?). Podemos nos questionar quanto o que cada um pode esperar, mas o que se produz, o que se escreve, em se tratando de Perec, parece sempre estar de certa forma nos causando algum tipo de decepção. Se ao menos Perec soubesse onde nasceu! Se ao menos tivesse tido o trabalho de se informar sobre a correta localização do bairro, ou mesmo ter certeza do correto local de nascimento! São respostas que não encontraremos entre suas "memórias".

Perec continua no seu jogo de incertezas ou banalidades, o que quer que possamos pensar dessa escrita que pouco nos informa, nos decepciona e de certa forma nos diverte também. Afinal somos ou não somos todos um pouco esquecidos a respeito da nossa própria história? Quantas fabulações e conjecturas fazemos sobre nossa própria vida, que sequer checamos para ter certeza se aconteceram da maneira como nos contaram? De qualquer forma, Perec não se dá ao trabalho sequer de contar sua idade... para nos contar sobre sua próxima incerteza:

En principe j'ai vécu rue Vilin de ma naissance - mars 1936 à ma 8 ou $9^{\circ}$ année 42 ou 43, époque à laquelle je suis parti à Villard. En fait, il semble que ce soit plus compliqué (p. 131). 
Se nascido em 1936, em 1942 ou 1943 Perec deve ter entre 6 e 7 anos, e não 8 ou 9 como menciona acima. Mas os detalhes pouco importam, tão confusos quanto sua própria memória serão as diferentes versões que tem sobre o início de sua vida. Os trechos seguintes ao acima citado traz algumas especulações de como teria sido este período de sua vida, deixando claras as divergências a respeito das informações que recebeu de sua família ${ }^{62}$, citando três questionamentos sobre a época em que viveu na rue Vilin.

A primeira questão é ter frequentado com bastante frequência, segundo a família, a casa da tia Esther, no $16^{\text {ème }}$ arrondissement, em dois endereços distintos, sobre os quais não tem nenhuma lembrança ("Je ne me souviens d'aucun des deux endroits"). Afirma ainda que sua prima Lili lhe contou que foi durante essas visitas que aprendeu a andar de bicicleta, lembrança que lhe parece totalmente inexistente também ("Elle m'appris à faire du vélo et je poussai d'intenses cris de frayeur").

O segundo questionamento é em relação à época em que esteve em êxodo por causa da guerra, "à la campagne": ele não sabe exatamente onde ficou, por quanto tempo e nem quem cuidou dele ("Je crois me souvenirs que les allemands arrivèrent un jour ou plutôt traversèrent le village où j'étais réfugié"). Este trecho nos remete a uma ideia de memória ficcional, imaginada, pois não há nada que possa comprovar exatamente como os acontecimentos se passaram nesse momento de sua vida. O terceiro questionamento é sobre os dois endereços em que a família vivia na rue Vilin, como aparece no trecho abaixo:

il n'y a pas un seul lieu rue Vilin, mais deux : le 24 (je crois me souvenir maintenant que c'était le 24 j'ai longtemps cru que c'était le 7), où vivaient, si je ne m'abuse, mes grands-parents, mes parents et moi ; c'était au rez-de-chaussée (en fait c'était une sorte de loge de concierge) et le 1 , à je ne sais plus quel étage où vivaient mes grands-parents maternels et leur fille Fanny. Il est probable que je partageai mon temps entre l'un et l'autre de ces lieux (p. 132).

\footnotetext{
${ }^{62}$ Há um projeto, iniciado em 1967, intitulado L'Arbre, que consistiu em entrevistar pessoas da família na tentativa de reconstituir sua história de infância. Também não foi finalizado nem publicado, como Lieux.
} 
O que fica evidente é que todas estas hesitações são constantes na escrita, já que evocar memórias, intuir, imaginar, acreditar, inventar... são processos pelos quais Perec passará em seu processo de trabalho, em busca de uma pista para sua história e sua memória.

As informações objetivas e precisas do inventário de fevereiro de 1969 (Réels, já reproduzido parcialmente na seção anterior) aqui novamente se envolvem em dúvidas. A todo momento e em praticamente todas as "Souvenirs" haverá um momento de tratar dessas questões (quais eram os números, que confusões ocorreram, como se chegou a saber quais eram os imóveis da família etc.). Mais uma vez, vemos que a evocação de memórias falha e que o texto caminha para uma grande lista de suposições e dúvidas (os trechos em itálico ilustram as respectivas expressões). É como se aquela escrita do real, da observação, mostrada anteriormente, exigisse uma certa objetividade, uma certeza, (não há dúvidas quanto aos números dos imóveis). As informações podem ter sido dadas pelos familiares, e comprovadas por ele nas visitas que fez à rue Vilin, mas, no momento de refletir novamente a respeito disso, prevalece o texto confuso, incerto, não convincente das informações que tinha a respeito dos lugares descritos.

\subsubsection{Vilin Souvenirs e o processo de análise}

Todas estas hesitações na escrita, principalmente ao se referir a situações da própria vida não muito esclarecidas, remetem-nos a uma série de reflexões realizadas por Claude Burgelin acerca do processo de análise pelo qual Perec passou (e que coincide também com o período de escrita de Lieux). A partir do texto Les lieux d'une ruse ${ }^{63}$ (em que Perec descreve seu processo de análise), especificamente no trecho "De ce lieu souterrain, je n'ai rien à dire [...] Désormais la trace en est écrite en moi et dans les textes que j'écris", Burgelin levanta a questão de que a escrita pode ser, de certa forma, uma espécie de resumo ou exercício a ser realizado sobre a própria análise que vinha acontecendo, e que estas inúmeras hesitações ou dificuldades na escrita seriam, portanto, análogas ao processo de análise, quando o paciente ainda está trabalhando sobre os próprios pensamentos, levantando ainda questões sem solução e, acima de tudo, questões que ainda são impossíveis de serem ditas.

\footnotetext{
${ }^{63} \mathrm{O}$ texto "Les lieux d'une ruse" foi publicado em Penser/Classer, Hachette, 1985.
} 
Esse início do primeiro parágrafo dos "Lieux d'une ruse" impõe e opõe a evidência ou a necessidade de um silêncio (ou de uma pausa ou uma recusa ou uma greve ou uma fobia ou um puder ou uma aporia... "nada a dizer" - nada a dizer realmente?) e a íntima convicção de uma marca inscrita tanto na alma-corpo do escritor como em seus textos. (BURGELIN, 1996, p. 64). ${ }^{64}$

Ou seja, a escrita que se repete, confusa, funciona quase como o processo de análise em si, no sentido de inicialmente não conseguir dizer nada, seguido de um movimento de dizer e repetir até que se crie uma espécie de "verdade", movimento pelo qual se busca o aparecimento das palavras, como se algo realmente fosse acontecer, como se realmente a memória fosse reaparecer, simplesmente pelo fato de repetir insistentemente tais afirmações, mesmo que de maneira confusa e desorganizada. Como na análise, Perec escreve desorganizadamente, hesita, repete ideias, como se buscasse, finalmente, a partir da escrita, encontrar a verdade sobre a sua própria história. Além disso, podemos pensar que essa escrita confusa e repleta de hesitações seja inclusive um contraponto de subjetividade e expressão daquilo que ele pretende escrever sobre si, no meio de um texto tão objetivo e composto quase que exclusivamente de descrições minuciosas e precisas sobre o lugar. O sujeito acaba se sobrepondo, de certa forma, somente para evidenciar seus conflitos com a própria memória, trazendo para o leitor, mesmo que em apenas alguns trechos, curtas passagens subjetivas acerca de sua infância:

Quando tentava falar, dizer alguma coisa sobre mim mesmo, afrontar esse palhaço interior que fazia malabares tão bem com a minha história, esse mágico que sabia tão bem iludir a si próprio, imediatamente tinha a impressão de estar prestes a recomeçar o mesmo quebra-cabeça, como se esgotando uma a uma todas as combinações possíveis, poderia um dia chegar enfim à imagem que procurava. (PEREC, 1985, p. 69). ${ }^{65}$

Esta obsessão por retomar e repetir tais lembranças confusas deu início, durante o processo de análise de Perec, ao exercício de anotar absolutamente tudo que fosse possível, numa tentativa de preservar a memória do presente. Assim, ao mesmo tempo em que busca recuperar a memória do passado, o processo de análise traz à tona um Perec obsessivo, que pretende evitar que o esquecimento do presente se repita no futuro. Aqui

\footnotetext{
${ }^{64}$ Ce début du dernier paragraphe des "Lieux d'une ruse" pose et oppose l'évidence ou la nécessité d'un silence (ou d'un retrait ou d'un refus ou d'une grève ou d'une phobie ou d'une pudeur ou d'une aporie... "rien à dire" - rien à dire vraiment ?) et l'intime conviction d'une trace inscrite dans l'âme-corps de l'écrivain comme en ses textes.

${ }^{65}$ Lorsque j'essayais de parler, de dire quelque chose de moi, d'affronter ce clown intérieur qui jonglait si bien avec mon histoire, ce prestidigitateur qui savait si bien s'illusionner lui-même, tout de suite j'avais l'impression d'être en train de recommencer le même puzzle, comme si, à force d'en épuiser une à une toutes le combinaisons possibles, je pouvais un jour arriver enfin à l'image que je cherchais.
} 
vemos, de certa forma, que muitas das obras de Perec, incluindo longas listas, inventários e interrogações do cotidiano inúmeras vezes comentados até aqui, podem ter tido origem, portanto, deste processo de tentativa de conservação dos traços do presente, como um reflexo da ausência das memórias do passado.

O escritor que conhecemos, e que está presente em grande parte de suas obras, é aquele que questiona o hoje, que imagina ter controle sobre o que acontece agora, sobre o que é banal e que passa despercebido da maioria. Tendo tal controle, talvez supere as ausências do passado, representadas por escritas confusas e sem grandes conclusões acerca da própria história. Escrever, traçar as letras e anotar tudo o que é possível ver é, de certa forma, o movimento presente em todas as obras analisadas nesta pesquisa. Tratase de uma espécie de tentativa de inventário do presente, já que não há mais o que ser inventariado do passado: ele ficou para trás, e não deixou respostas. Outro trecho de Les lieux d'une ruse atesta esta ideia de uma acumulação obsessiva dos traços do presente:

Ao mesmo tempo se instaurou como uma falência da minha memória: comecei a ter medo de esquecer, como se, a menos que anotasse tudo, não poderia conservar nada da vida que fugia. Todas as noites, escrupulosamente, com uma consciência maníaca, comecei a manter uma espécie de diário: era o contrário mesmo de um diário: só registrava o que acontecera de "objetivo": hora que despertei, uso do tempo, meus deslocamentos, compras, o progresso - avaliado em linhas ou páginas - do meu trabalho, pessoas que havia encontrado ou simplesmente vislumbrado, o detalhe da refeição que tinha feito à noite em tal ou tal restaurante, minhas leituras, os discos que tinha escutado, os filmes que tinha visto, etc.(PEREC, 1985, p. 69). ${ }^{66}$

Burgelin afirma, assim como vimos em outros exemplos, como as obras de Perec serão totalmente influenciadas por esta ideia da acumulação, registro e conservação dos objetos, lugares e acontecimentos que o cercam no presente, traçando uma espécie de “conservação de espaços", sejam eles imaginários, reais ou relativos à memória. Burgelin classifica as obras La boutique obscure, Espèces d'espaces e W ou le souvenir d'enfance em cada uma destas categorias. Eu estenderia esta possibilidade a muitas outras obras, pensando que muitas delas acumulam inclusive mais de uma classificação, o que é bem

\footnotetext{
${ }^{66}$ En même temps s'instaura comme une faillite de ma mémoire : je me mis à avoir peur d'oublier, comme si, à moins de tout noter, je n'allais rien pouvoir retenir de la vie que s'enfuyait. Chaque soir, scrupuleusement, avec une conscience maniaque, je me mis à tenir une espèce de journal : c'était tout le contraire d'un journal intime : je n'y consignais que ce qui m'était arrivé d' "objectif": l'heure de mon réveil, l'emploi de mon temps, mes déplacements, mes achats, le progrès - évalué en lignes ou en pages de mon travail, les gens que j'avais rencontrés ou simplement aperçus, le détail du repas que j'avais fait le soir dans tel ou tel restaurant, mes lectures, les disques que j'avais écoutés, les films que j'avais vus, etc.
} 
comum nos escritos de Perec (não há, no autor, obras totalmente homogêneas ou de um único gênero).

Mas é interessante pensar que estas obras refletem sobre espaços bastante heterogêneos, visto que La boutique obscure faz uma reflexão sobre seus sonhos devidamente anotados; Espèces d'espaces faz uma reflexão sobre os espaços do "mundo real", enquanto $W$ reflete necessariamente sobre o lugar da própria memória, escassa, indizível, conforme nos explica Burgelin:

As três empreitadas de conservação de espaços imaginários, de espaços reais e de espaços da memória que são respectivamente La boutique obscure, Espèces d'espaces e W ou le souvenir d'enfance poderiam ser percebida como momentos de resistência, em todo caso de tensão ativa face à análise (que redobram esses momentos onde, paralelamente ao tempo do divã, Perec se coloca a guardar tudo e arquivar mesmo aquilo mais ridículo). (BURGELIN, 1996, p. 74) ${ }^{67}$

O que podemos concluir até aqui é que, para Perec, o pânico de perder seus traços fez com que se tornasse obsessivo pela escrita do banal, do cotidiano. O processo de análise desencadeou este exercício de escrita quase obsessivo, que o levou consequentemente a também conservar e classificar documentos. Ou seja, a escrita, juntamente com os objetos conservados, forma esta espécie de "tas de reliquats"68 e que seria uma maneira encontrada para iniciar o processo de rememoração.

A escrita começa necessariamente para preencher esta lacuna deixada pela memória, quase como numa continuação do processo de exercício (um diário) desenvolvido à época da análise. Quanto mais escrever, anotar, guardar todos os detalhes, mais recursos terá para se apoiar. Quanto mais papéis guardados e arquivados, mais “conservada" ficará sua memória do presente. É um processo contraditório, de certa forma, pois, como vimos, a escrita só reforça as dúvidas e hesitações sobre a própria história de vida.

Assim, o fato de continuar escrevendo, insistentemente, sobre detalhes de um passado inalcançável é quase como "simular" o processo de análise realizado (dizer, mesmo sem saber exatamente o que se diz, para que, em algum momento, surja uma

\footnotetext{
${ }^{67}$ Les trois entreprises de conservation des espaces imaginaires, des espaces réels et des espaces de la mémoire que sont respectivement La boutique obscure, Espèces d'espaces et $W$ ou le souvenir d'enfance pourraient être perçues comme des moments de résistance, en tout cas de tension active face à l'analyse (qui redoublent ces moments où, parallèlement au temps du divan, Perec se met à tout garder et archiver fût-ce le plus dérisoire)

${ }^{68}$ Referência ao artigo de Raoul Delemazure, "L'herbier des villes de Georges Perec: un tas de reliquats", a partir da página 203 dos Cahiers Georges Perec 12, de 2015.
} 
"cura" para o problema apresentado). Assim, podemos sinalizar um procedimento de análise que se incorpora à escrita, e por isso mesmo torna-a tão hesitante, deceptiva, mas que faz parte de um processo que pode leva-lo a conseguir dizer, a conseguir escrever sua própria verdade.

A única certeza do texto, que também fica bastante evidente em todas as "Souvenirs", é exatamente a da completa falta de memórias (deceptiva) a respeito da rue Vilin. Como se escrever sobre as memórias fosse, na verdade, afirmar e reforçar, o tempo todo, sua total ausência de memórias, de fato.

Il reste inconcevable que je n'ai aucun souvenir de la rue Vilin où j'ai dû pourtant passer l'essentiel des sept (ou six) premières années de ma vie ; j'insiste sur cet "aucun" cela signifie aucun souvenir des lieux, aucun souvenir des visages (p. 133).

\subsubsection{Escassez de lembranças, repetições na escrita}

A falta de memórias parece mesmo um norteador para a escrita de Perec. Parece também um norteador para a escrita deste trabalho. Neste sentido, vemos Perec criando suas estratégias de escrita infinitamente ligadas a esta questão da falta de memórias. Por exemplo: no mesmo trecho em que afirma não possuir nenhuma lembrança (trecho este que acabamos de transcrever), segue-se um outro comentário, que se coloca como memória relacionada à rue Vilin, mesmo que não tenha acontecido propriamente nesta rua: "Un dernier souvenir, mais il n'a même pas pour cadre la rue Vilin". Neste momento, ele conta sobre a cena da separação com a mãe, ocorrida na Gare de Lyon; ou seja, não há o que lembrar da rua (ele não se lembra dos rostos, da vida que teve ali), mas associa diretamente a última memória que tem da mãe a esta rua, mesmo sabendo que o local de despedida tenha sido outro.

É um jogo de lugares, tempos e espaços que está em movimento neste conflito de lembranças vividas, imaginadas ou contadas por outras pessoas. Tanto que em $W$ ou $a$ memória da infância há diferentes versões, ou seja, reformulações da mesma cena da despedida, escritas em diferentes momentos de sua vida. $\mathrm{Na}$ análise de Burgelin, que trata da questão da psicanálise na obra de Perec, fica evidente que a memória da mãe está diretamente ligada a um lugar, a um momento, já que a memória, em si, não existe: 
O texto de $\mathrm{W}$ diz: de minha mãe, a única lembrança que me resta é aquela onde ela me acompanha à estação de Lyon de onde, com um comboio da Cruz Vermelha, parto para Villard-de-Lans: mesmo que não tivesse quebrado nada, tenho uma tipoia no braço. Minha mãe comprou para mim um Carlitos intitulado Carlitos paraquedista.(BURGELIN, 1996, p. 82) ${ }^{69}$;

[...] A lembrança da mãe só existe na metonímia: um lugar, um momento, um objeto carregado de signos. Todo o sistema da memória se configura a partir desse buraco, desse apagamento. (idem, p. 83) ${ }^{70}$

O que ele sabe sobre a rue Vilin, como já mencionado, também é este misto de diferentes versões sobre o mesmo fato, repetidas diversas vezes ao longo do texto, como que reproduzindo estas diferentes versões que o próprio Perec recebeu a respeito da história da sua família. Além disso, valendo-se do recurso da escrita fechada em envelopes, notamos que Perec se repete também por este motivo: supostas informações recebidas da família, sobre seu passado, vêm à tona em diferentes momentos e são reescritas, de maneiras diferentes e em épocas diferentes.

\footnotetext{
Je sais que ma tante me l'a dit, que je suis retourné une ou deux fois rue Vilin après la guerre, que j'y ai revu un garçon de mon âge qui avait été mon voisin et mon copain de jeux, que je suis allé jouer avec lui dans la rue cependant que ma tante, je suppose, parlait avec ses parents de l'arrestation de ma mère, des grands parents etc... (p. 135, Souvenirs de 1969).
}

Logo a seguir, temos o trecho: “Ensuite très longtemps, j’ai oublié jusqu'à l'emplacement de la rue, je n'ai même plus su, consultant un plan de Paris, dire avec quelque précision dans quel quartier c'était". Aqui, retoma-se o primeiro trecho do manuscrito, quando há dúvidas sobre a localização do bairro e da própria rua.

\footnotetext{
${ }^{69}$ Le texte de $W$ dit : De ma mère, le seul souvenir qui me reste est celui du jour où elle m'accompagne à la gare de Lyon d'où, avec un convoi de la Croix-Rouge, je partis pour Villard-de-Lans : bien que je n'ai rien de cassé, je porte le bras en écharpe. Ma mère m'achète un Charlot intitulé Chartot parachutiste.

${ }^{70}[\ldots]$ Le souvenir de sa mère n'existe que dans la métonymie : un lieu, un moment, un objet chargé de signes. Tout le système de la mémoire s'est mis en place à partir de ce trou, de cet effacement.
} 
No mesmo trecho, em sequência, Perec narra algumas outras visitas feitas à rue Vilin quando mais velho, sem dar muita importância ao lugar; até o dia em que ficou sabendo da notícia de que a rua estaria em vias de ser demolida: neste momento, já com o projeto em mente, ele decide visitar o lugar e iniciar a escrita de Lieux.

Reforçando a ideia da repetição - tanto pelos motivos aqui apresentados quanto pela questão do processo de análise discutido -, observamos que no texto "Souvenirs" de 1971, ou seja, dois anos após os trechos aqui transcritos, novamente Perec se vale das informações de parentes na tentativa de escrever sobre alguma lembrança, já que se encontra nitidamente desprovido de qualquer outra memória: "Nul souvenir retrouvé de la rue $\mathrm{V}$. Très vague : après-guerre je serais revenu une fois rue $\mathrm{V}$ et $\mathrm{j}$ 'aurai joué avec un garçon de mon âge avec qui j'aurais joué avant-guerre, cependant qu'Esther parlait avec sa mère" (p. 143-144). Ou seja, Perec retoma, neste trecho, algo escrito dois anos antes, valendo-se da expressão "très vague": a memória falhou, ou ele apenas pode lembrar-se vagamente de já ter tratado deste assunto e, por isso, retoma-o, mesmo que de maneira mais breve.

Veremos logo adiante outras estratégias utilizadas por Perec neste manuscrito de “décembre 71" que deixam claras as dificuldades de continuar se expressando a respeito de um assunto do qual não tem outras informações, onde apenas o que resta latente é a afirmação (também repetitiva) da completa ausência de lembranças.

Como já vimos, Perec parece escolher a dedo seus lugares preferidos, afim de encontrar inspiração para um tema tão difícil, a escrita de suas memórias da rue Vilin. No ano de 1970, ele escolhe uma varanda à beira do lago:

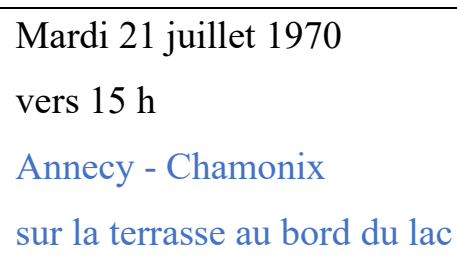

Interessante observar que, neste momento, Perec não apenas afirma a escassez de lembranças, mas também começa a se questionar a respeito do seu passado e do seu presente, o presente da escrita. Ele traz à tona a questão da "relation qu'existe entre la rue Vilin et ce site ; quel rapport entre l'enfant que je pouvais être et moi, aujourd'hui ici" (p. 136). Ou seja, ele questiona aqui o próprio lugar de escrita, de enunciação, seu papel de escritor na atualidade, em relação ao seu passado. 
Lembranças a respeito da letra hebraica que escreveu quando muito pequeno ${ }^{71} \mathrm{ou}$ do brinquedo preferido da infância, do qual guarda apenas uma foto ("la petite voiture rouge") aparecem como tentativas de evocação da memória, que logo a seguir se opõem, novamente, à certeza da falta de lembranças: “il ne reste pas de trace des lieux que j'ai habités (il n'ont pas gardé ma trace même si j'ai gardé la leur) j'ai choisi pour terre natale des lieux publics, des lieux comuns" (p. 136). Isto nos permite dizer que, por não haver memórias dos lugares que já habitou, sobretudo aqueles da infância, Perec vai procurar nos lugares públicos (nos doze lugares de Paris, por exemplo) traços que o liguem a determinados lugares, públicos, mas que ainda assim possam reconectá-lo a alguma lembrança do passado.

Além destas reflexões sobre a rue Vilin, neste texto de 1970 Perec cita um outro lugar que fez parte de sua infância, insistindo também na ausência de memórias a respeito dele:

lieux d'enfance, faux lieux, non-lieux d'enfance: lorsque je suis retourné à Villard de Lans (2 ou 3 ans après) je n'ai rien reconnu (p. 137) .

Villard de Lans é o lugar (no campo) para onde foi mandado no período da guerra, para evitar que fosse capturado na sua condição de filho de judeus ${ }^{72}$. Interessante pensar que não há nenhuma explicação ou menção sobre o tempo vivido lá, apenas a afirmação de ter voltado ao lugar e, exatamente como ocorre com a rue Vilin, não ter reconhecido nada.

\footnotetext{
${ }^{71}$ Segue o trecho em português no livro $W$ ou a memória da infância: "A primeira lembrança teria por cenário o fundo da loja de minha avó. Tenho três anos. Estou sentado no centro da peça, no meio de jornais iídiches espalhados [...] Todos se extasiam diante do fato de eu ter desenhado uma letra hebraica, identificando-a: o signo teria a forma de um quadrado aberto em ângulo inferior esquerdo [...]" (PEREC, 1995, p. 21).

${ }^{72}$ Perec viveu em Villard de Lands, em Vercors, do início de 1942 até setembro de 1945, cf. nota em entrevista (EC II, p 128).
} 
Interessante observar também que Burgelin, em um programa de rádio da France Culture $^{73}$, traz um novo significado para a letra $\mathrm{W}$, referência ao título do livro autobiográfico mais importante de Perec: Wou le souvenir d'enfance. Para ele, o "duplo V" (ou double $V$, como se pronuncia a letra $\mathrm{W}$ em francês) pode também se referir aos dois nomes de lugares que fazem parte da primeira infância de Perec, e dos quais ele não tem praticamente nenhuma lembrança: Rue Vilin e Villard de Lans, entre tantos outros significados que nos remetem à letra $W^{74}$ na referida obra.

Vale lembrar que, ao fim da guerra, Perec se reestabelece em Paris, adotado pelos $\operatorname{tios}^{75}$, e passa a viver em outra rua importante para a sua vida, e que também faz parte dos doze lugares de Lieux: a rue de L'Assomption. A série "Réels" do lugar foi publicada na revista $L$ 'Arc, sob o título “Allés et venues Rue de l'Assomption”, num título que quase deixa transparecer o movimento monótono de ir e vir pela rua, e que Perec descreve da seguinte forma, ao mencionar pela primeira vez o número 18, em 1969:

L'immeuble du n. 18 est celui où vivaient mon oncle et ma tante et où je vécus moi-même, complètement ou partiellement (étant, pendant l'année scolaire, interne au Collège Geoffroy Saint-Hilaire à Etampes, de 1946 à 1956) (p. 28). ${ }^{76}$

\footnotetext{
${ }^{73} \mathrm{Em}$ : https://www.franceculture.fr/emissions/les-chemins-de-la-philosophie/lespace-mode-demploi-24les-especes-despaces-de-georges-perec.

${ }^{74}$ Estudiosos de Perec atribuem a letra $W$ a vários significados, entre eles a própria estrela judaica; a letra hebraica "gimmel", que seria o M, invertida (que aparece como uma das primeiras lembranças do narrador autobiográfico); a letra suprimida do sobrenome da mãe, entre outros: o que fica claro é que parece haver interpretações subjetivas e históricas para a escolha da letra $W$.

${ }^{75}$ Há um documento datado de outubro de 1945 que comprova a adoção de Perec, concedendo a guarda ao tio, e que será disponibilizado na seção "Anexos" desse trabalho.

${ }^{76}$ De fato, mesmo afirmando não ter uma boa relação com o lugar, ele viveu no imóvel 18 da rue de l'Assomption em três períodos diferentes: de 1945 a 1957, como descreve no trecho; em 1957 e novamente em 1960 (sem informar o tempo de cada um dos últimos períodos, a informação está na nota de rodapé na p. 128 EC II).
} 


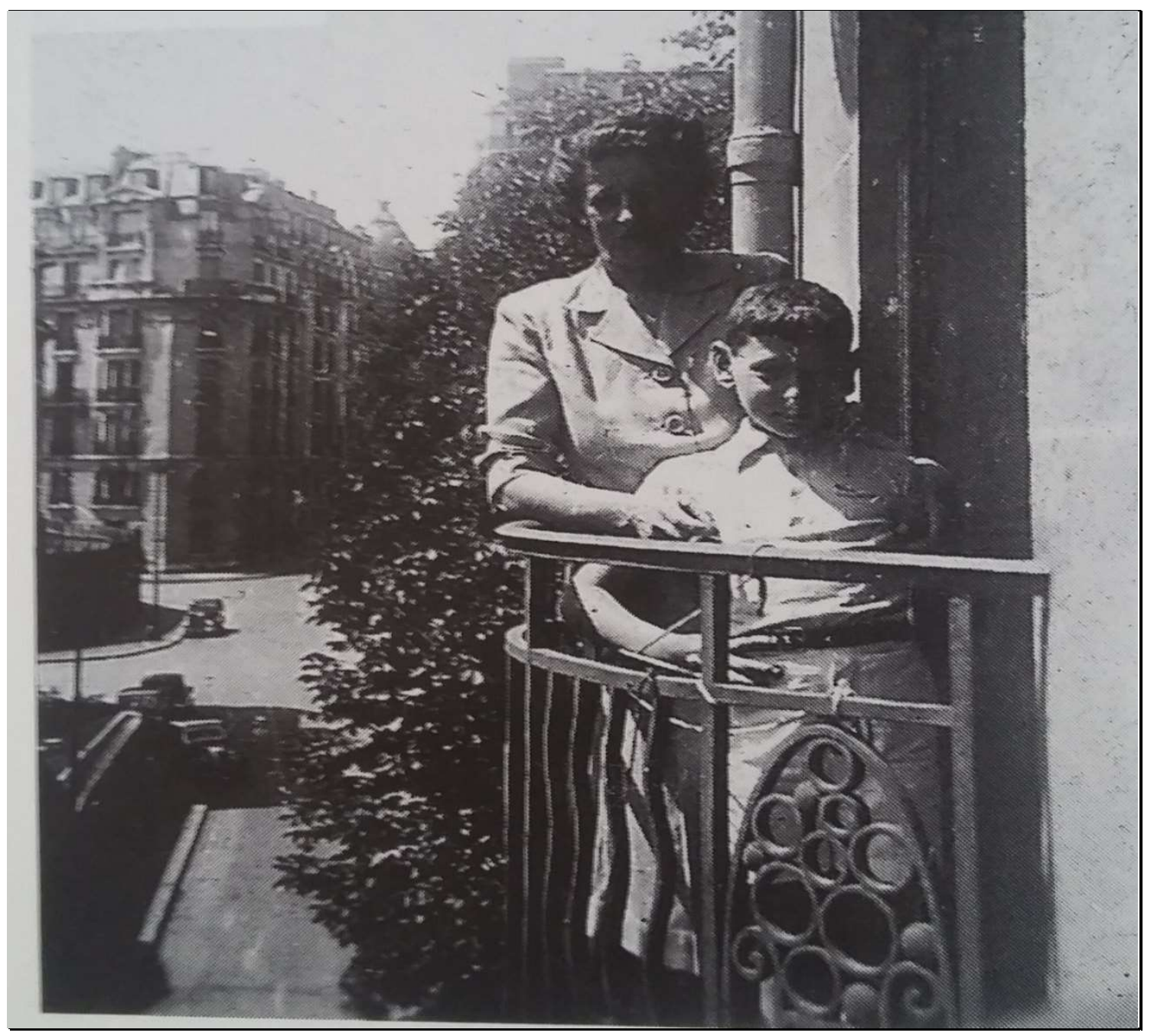

Figura 6. Perec e sua tia Esther no imóvel de lada rue de l'Assomption. Fonte: Album Georges Perec, 2017, p. 36.

Nos anos seguintes, surgem outras menções muito rápidas e impessoais; em 1970, ele escreve: "n. 18 jardins suspendus"; em 1972, "les fenêtres du 3 étage sont fermées"; em 1973, repete-se: “au 18, les volets du 3 étage sont fermés”. No último ano, 1975, o número 18 sequer é mencionado. Observamos apenas uma anotação um tanto quanto pessoal, no ano de 1971: “La rue de L'Assomption m'emmerde”, o que nos leva a crer que não há boas lembranças a serem anotadas a respeito deste lugar, justamente por evocar questões familiares: a falta de pertencimento, a ideia de ter perdido os pais, o fato de passar apenas curtos períodos no lugar, etc., como vemos na afirmação em entrevista: “mes parents adoptifs habitaient dans le seizième et j'avais une réaction negative vis-àvis de ce quartier" (EC II, p. 130). 


\subsubsection{A escrita que se transforma, as experimentações}

Voltando ao manuscrito de 1970, realizado à beira do lago, num ambiente calmo e inspirador, defrontamo-nos com outra curiosidade sobre o material produzido por Perec: uma ilustração, feita aparentemente com muito cuidado, onde desenha letras que representam o ano e o lugar.

Mais uma vez, a escrita já começa a dar lugar a outras expressões artísticas. Neste caso e em outros que veremos adiante, o desenho começa a aparecer, timidamente, entre as palavras um pouco mais soltas e dispersas, como se a imaginação necessária para acessar as memórias já estivesse dando lugar para outras formas de criatividade. Toda a reflexão feita neste momento de escrita, como acabamos de ver, a partir de um lugar neutro, de um ambiente tranquilo, resultou numa espécie de viagem ao longo dos anos, num movimento parecido com aquele em que nos distraímos quando estamos um pouco perdidos ou envoltos em pensamentos desconexos e um pouco soltos, e nos pegamos desenhando ou rabiscando a folha de papel mais próxima, como vemos na imagem que segue:

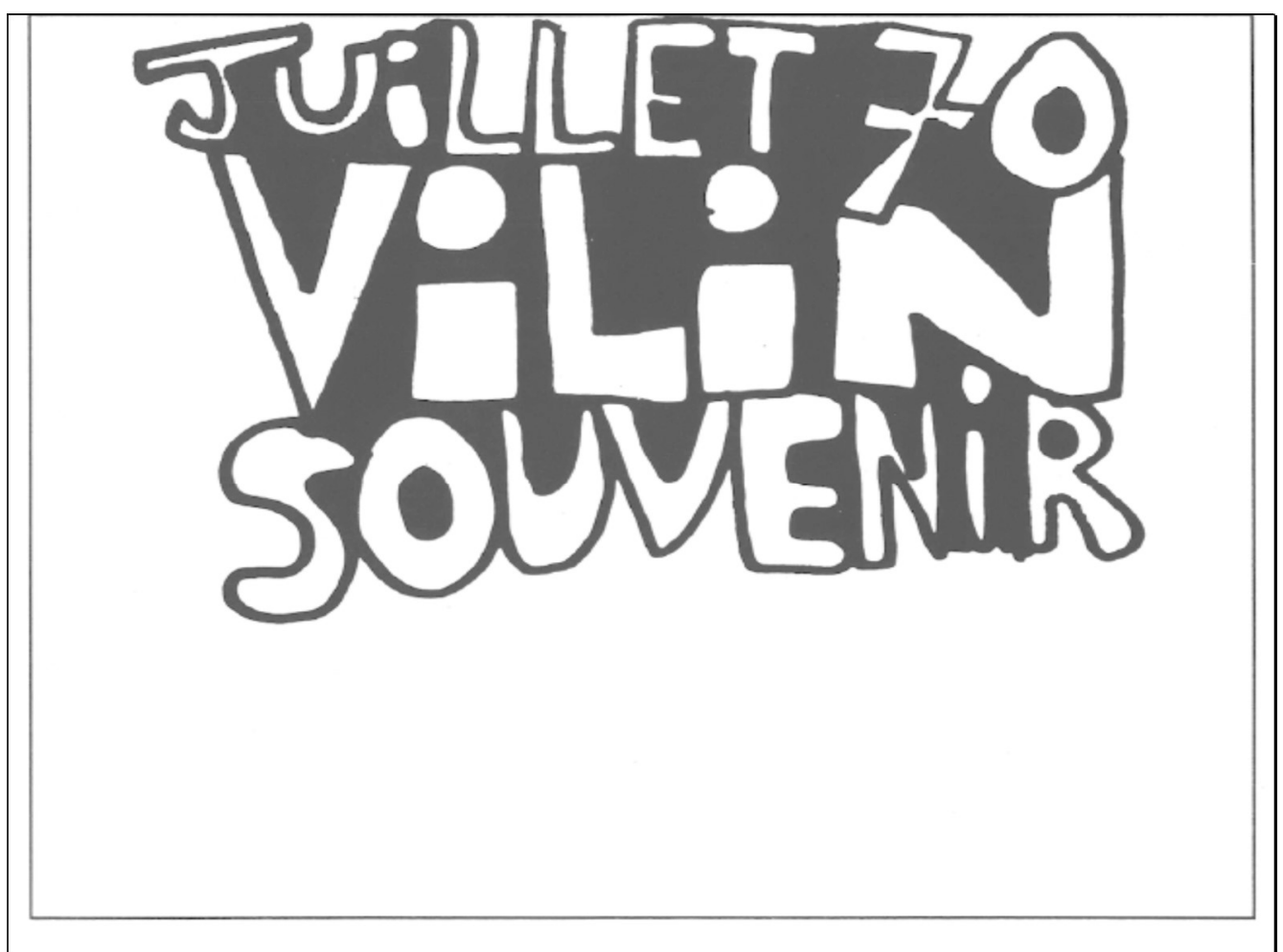

Figura 7. Um dos desenhos feitos ao longo da escrita de Lieux. Fonte: Lejeune, Philippe. Vilin Souvenirs. Georges Perec. In: Genesis, 1992, p. 142 
Damos sequência à leitura do documento do ano seguinte, 1971. Neste texto, onde Perec conta novamente a história da rue Vilin, repetição já mencionada na página 18 , ele anota na sequência alguns "souvenirs rappels", ou seja, escreve resumidamente sobre alguns itens que considera importantes e que são memórias de alguns acontecimentos da infância. Depois desta breve lista, ele reforça novamente a ideia da escassez de tais memórias, lamentando-se: “C'est peu...” (p. 144).

Este processo de transformação da escrita é bastante visível nos textos que seguem, pelos motivos vários que já expusemos até aqui, mas uma das principais imagens que deixam clara a falta de ritmo (ou a necessidade de pausas) de escrita aparece na página seguinte ao texto de 1971, reproduzido a seguir, que nada mais é que o orçamento de despesas de Perec, um documento totalmente inesperado no meio do processo de escrita, seguindo a tendência anterior de rabiscos e desenhos. Aqui, o pensamento vai mais longe ou se desconecta de certa forma, trazendo-o para a realidade cotidiana: o que poderia ser mais corriqueiro ou banal que uma anotação das próprias despesas, quando deveria estar se dedicando à escrever sobre algo mais "importante", suas memórias? É interessante pensar no contraponto a esta hipótese de "enfraquecimento" da memória, que é justamente o que faz com que Perec embarque em outras reflexões e, de certa forma, vá migrando do projeto Lieux para outras direções.

O suposto fracasso da memória, a partir de rabiscos, anotações de números, letras e outras banalidades pode ser, paradoxalmente, o momento em que Perec realiza suas pausas para refletir e reformular os projetos, ampliando suas ideias e partindo para novos desafios de escrita. 

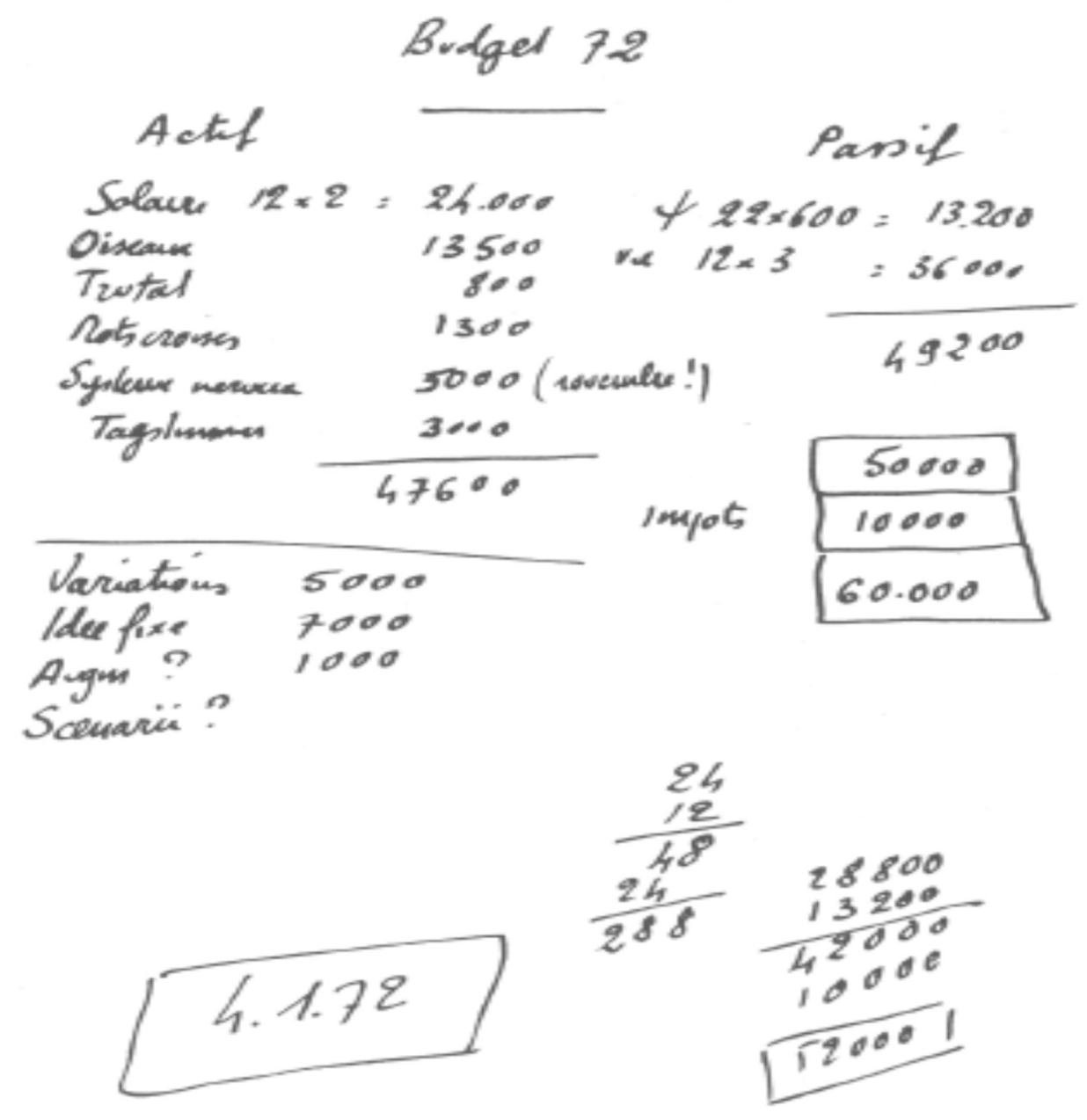

Figura 8. Manuscritos com anotações em meio à escrita de Lieux. Fonte: Lejeune, Philippe. Vilin Souvenirs. Georges Perec. In: Genesis, 1992, p. 145

\subsubsection{Experimentações, rumo ao fim das "Souvenirs"}

Perec parece se dar conta deste embate entre a dificuldade em escrever, as hesitações, as pausas para reflexão e os projetos que supostamente vêm sendo transformados, tanto que se vale de outro artifício para acompanhá-lo nesta batalha consigo mesmo para conseguir escrever: a música. Ele anota, nos dois trechos seguintes (ambos de 2 de dezembro de 1972) que realiza uma experiência de audição integral do Ring (faces 3 e 4 - trechos da ópera "A Valquíria", de Wagner). As versões originais seguidas das transcrições (feitas por mim) aparecem como exemplo desse momento de escrita onde busca inspiração a partir da música, e onde vemos os traços de números e letras de forma bastante experimentais: 


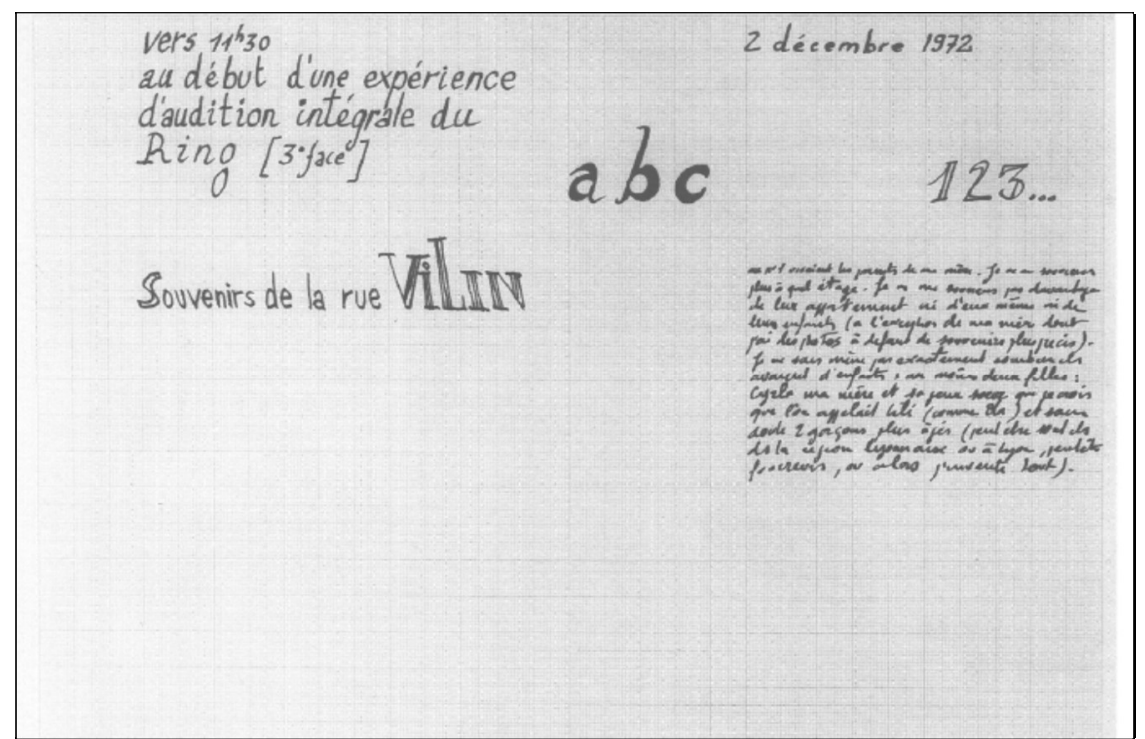

Figura 9. Manuscritos de Lieux. Fonte: Lejeune, Philippe. Vilin Souvenirs. Georges Perec. In: Genesis, 1992, p. 146.

\section{Vers $11 \mathrm{~h} 30$}

au début d'une expérience

d'audition intégrale du

Ring [ $3^{\circ}$ face]

Souvenirs de la rue VILIN

\section{2 décembre 1972}

$a b c$

$123 \ldots$

au no. 1 vivaient les parents de ma mère. Je ne me souviens plus à quel étage. Je ne me souviens pas davantage de leur appartement ni d'eux mêmes ni de leur enfants (à l'exception de ma mère dont j'ai des photos à défaut de souvenirs plus précis). Je ne sais pas même pas exactement combien ils avaient d'enfants, au moins deux filles : Cyrla ma mère et sa sœur qui que crois qu'elle s'appelait Lili (comme Ela) et sans doute 2 garçons plus âgés (peut-être sont-ils dans la région lyonnaise ou à Lyon, peut-être $[\ldots .$.$] ou alors, j'invente tout) (p. 146)$ 


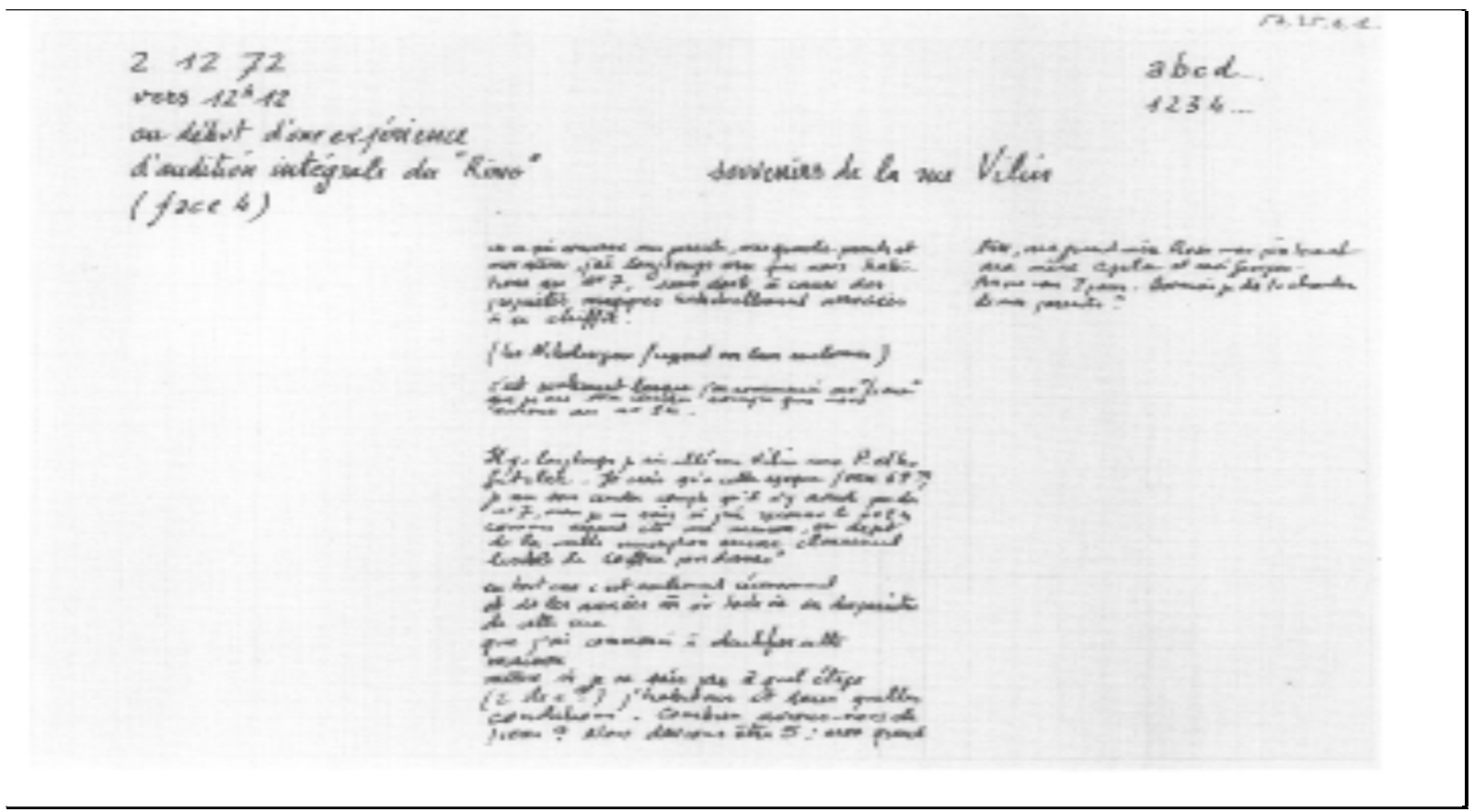

Figura 10. Manuscritos de Lieux. Fonte: Lejeune, Philippe. Vilin Souvenirs. Georges Perec. In: Genesis, 1992, p. 147.

21272

Vers $12 \mathrm{~h} 12$

Au début d'une expérience

d'audition intégrale du "Ring"

(face 4) a b c d...

\section{$1234 \ldots$}

Souvenirs de la rue Vilin

en ce qui concerne mes parents, mes grands-parents et moi-même,

j'ai longtemps cru que nous habitions au n. 7, sans doute à cause des

propriétés magiques habituellement associées à ce chiffre ${ }^{77}$

c'est seulement lorsque j'ai commencé ces « Lieux » que je me suis rendu compte

que nous vivions au n. 24

Il y a longtemps je suis allé rue Vilin avec P. Getzler. Je crois qu'à cette époque (vers 62 ?)

je me suis rendu compte qu'il n'y avait pas du n. 7, mais je ne sais si j'ai reconnu le n. 24

comme ayant été ma maison, en dépit de la vieille inscription encore clairement lisible de

« Coiffure pour dames"

en tout cas c'est seulement récemment et dans les années même où toute vie va disparaître de cette rue que j'ai commencé à identifier cette maison même si je ne sais pas à quel étage j'habitais et dans quelles conditions. Combien avions-nous de pièces ? Nous devions être $5:$ mon grand Père, ma grand-mère Rose mon père Icek et ma mère Cyrla et moi Georges.

${ }^{77}$ A referência mais evidente é sua própria data de nascimento, 7 de março. Esta ideia de ter confundido o número da sua residência de infância aparece em vários momentos da escrita de Lieux, e também é retomada na parte autobiográfica do texto de $W$ ou a memória da infância, no trecho: "Je ne parvins à identifier ni la maison où avaient vécu les Szulewicz, ni celle où j'avais passé les six premières années de ma vie et que je croyais, à tort, se trouver au numéro 7" (PEREC, 1975, p. 72). 
Avions-nous 2 pièces. Dormais-je dans la chambre de mes parents ? (p. 147).

Os dois blocos de anotações reproduzidos livremente aqui seguem um método bastante parecido de composição. Ao lado da data e da referência da música que escuta, Perec anota sequências de letras ou números de forma livre (como se pudesse desenhar ou preparar as letras, já que em tamanhos e formatos diferentes) para depois iniciar a escrita pretendida, em letras minúsculas e que necessitam de ampliação para serem lidas. O tema tratado nas duas folhas continua sendo a confusão anterior de não saber exatamente em que número eles viviam. Mas, para além das tentativas de explicar a própria história, o que percebemos neste texto, ou seja, neste processo de crise da escrita, é uma espécie de fabulação da própria história, recurso muito utilizado por Perec em textos autobiográficos, sobretudo em $W$ ou a memória da infância. Esta estratégia que questiona ou tenta dissuadir a si mesmo sem tanta certeza sobre os fatos aparece claramente no final do trecho do primeiro bloco: "ou alors, j'invente tout", ou em muitas hipóteses levantadas em trechos do segundo bloco: "Combien avions-nous de pièces? Nous devions être 5 : mon grand-père, ma grand mère Rose mon père Icek et ma mère Cyrla et moi Georges. Avions-nous 2 pièces. Dormais-je dans la chambre de mes parents ?".

Quatro dias depois das anotações ao som de Wagner, Perec escreve novamente outro trecho, comprovando que a ideia não pode ser executada da maneira como planejou, já que precisou interromper a audição devido à quantidade de tempo que dispensaria para completar a tarefa. Assim, conclui que sua tentativa resultou num "semi-échec", completando seu comentário com outro questionamento bastante pessimista: "La rue Vilin me semble si loin et je vis actuellement avec l'impression que je ne m'en rapprocherai plus jamais (m’en suis-je déjà approché, même?)", na página 150. No entanto, a questão da fabulação ou da memória indireta, como acabamos de reforçar, será a principal característica da escrita de $W$ ou a memória da infância e, felizmente para esta pesquisa, damo-nos conta de que grande parte dos escritos de $W$ também tiveram sua origem (ou ao menos foram reproduzidos parcialmente) no projeto Lieux. Prova disso são as passagens de memórias citadas aqui e desenvolvidas com mais detalhes na escrita definitiva do livro.

O encerramento dos manuscritos de Vilin Souvenirs, ao contrário de Vilin Réel, traz um sentimento dúbio: se, por um lado, acompanhamos e registramos todos os momentos de afirmação da falta de memórias e pessimismo em relação à escrita que não 
avança - ao mesmo tempo em que outros projetos vão tomando forma, provavelmente -, testemunhamos também este início de escrita de uma autobiografia oblíqua, indireta, que recorreu às fabulações para que pudesse ser realizada. Na última anotação, de 1974, diferentemente das anteriores (onde havia data, horário e local de escrita), o manuscrito traz dois parágrafos escritos de maneira bastante irregular (sem os métodos anteriores) e que já sinaliza a relação profunda entre o projeto que chega ao fim e o início de outro, a escrita de $W$ :

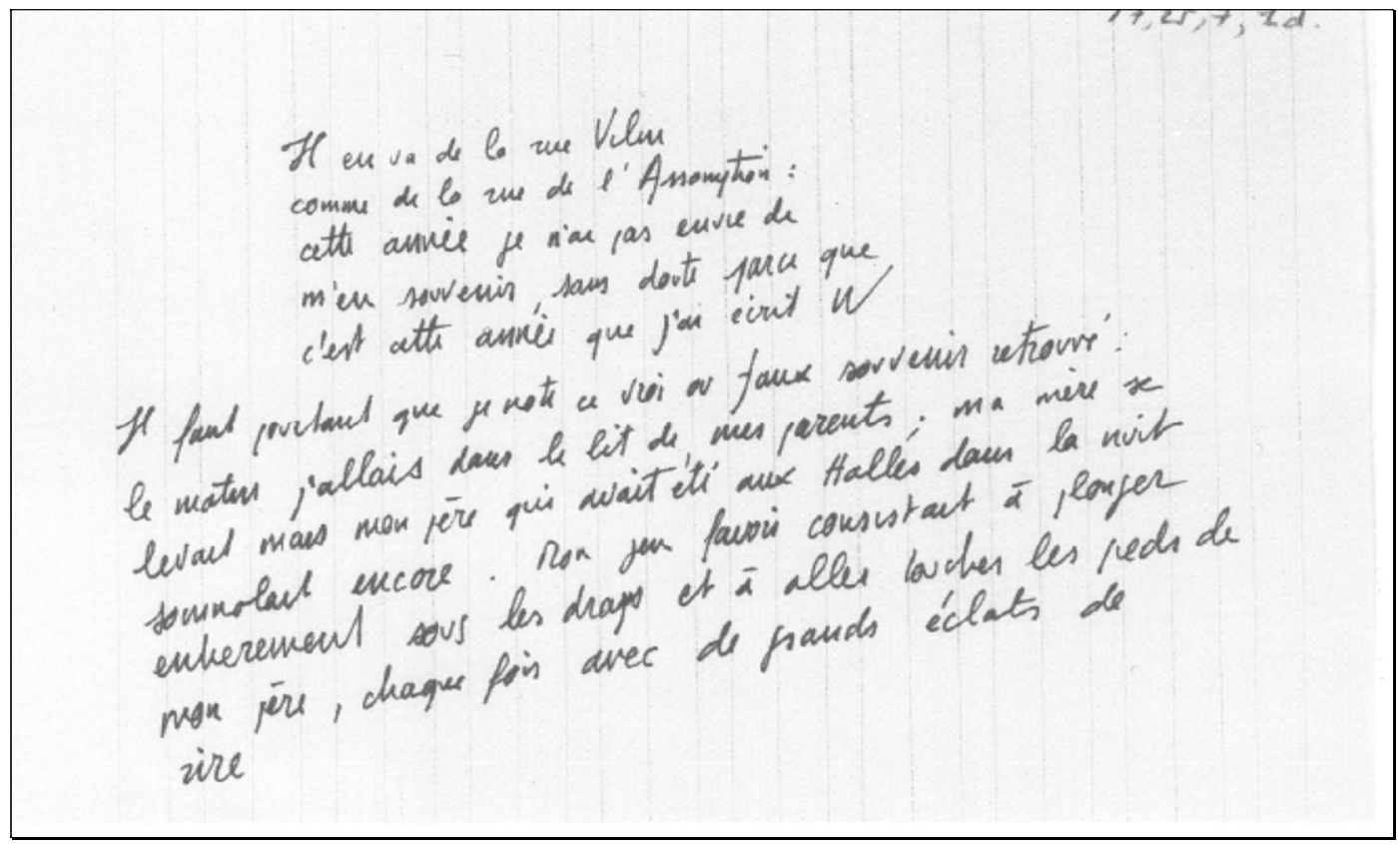

Figura 11. Manuscritos de Lieux. Fonte: Lejeune, Philippe. Vilin Souvenirs. Georges Perec. In: Genesis, 1992, p. 151

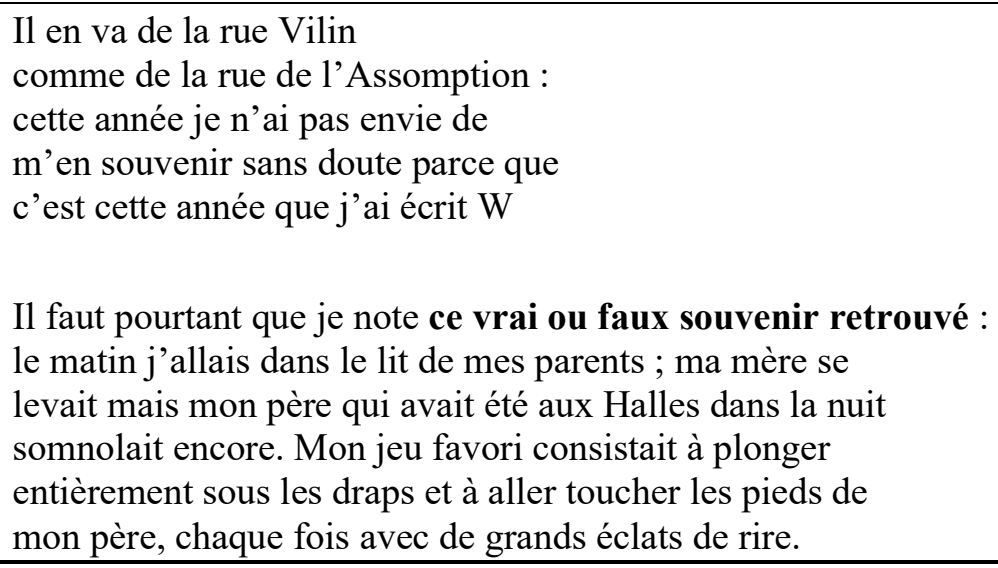


Esta passagem feliz (acredito que uma das poucas) encerra assim o último documento encontrado no envelope Vilin Souvenirs. Ao contrário da última anotação de Vilin Réel (Trabalho=tortura), que nos trouxe algumas questões para reflexão de maneira um tanto quanto pessimista, as memórias de Vilin (embora constantemente afirmadas como não existentes) dão lugar a um encerramento supostamente feliz. Verdadeira ou falsa, não importa: a lembrança está registrada e foi belamente reproduzida no livro $\mathrm{W}$ ou a memória da infância, livro com o qual toda a minha história de pesquisa começou, e com o qual encerramos as reflexões sobre o lugar mais importante da vida e, de certa forma, do processo de escrita das obras autobiográficas de Perec: a rua de sua infância, mesmo que fabulada, oblíqua, inexistente, mas carregada de uma escrita que se encerra de maneira otimista, singela, feliz.

Esta escrita fabulada dará lugar (ou caminhará juntamente) a uma escrita poética, numa nova transformação da rue Vilin, quando Perec cria poemas a partir das fotos tiradas no lugar. Assim, iniciamos a próxima seção do capítulo, onde texto e imagem recriarão novas paisagens e histórias sobre um mesmo lugar, só que agora sob um novo olhar.

\section{La Clôture: a transformação de Lieux em poesia com imagens}

A primeira edição de La Clôture, de 1976, um livro de poemas composto de "17 fotografias de Christine Lipinska acompanhadas de 17 poemas heterogramáticos ${ }^{78}$ de Georges Perec, em edição não comercial e através de assinatura"79 (NEEFS, 1993, p. 140), cujas páginas poderiam ser alteradas, dissociadas, já que dispostas em uma caixa, e não um livro convencional, evidencia mais um exemplo de obra em formato de "álbum". Constituía-se de fotos da rua Vilin, acompanhadas de textos de Perec (que na foto acima - figura 16 - aparece embalando os exemplares).

Perec apresentava esse livro a partir de um prospecto que mandava aos assinantes juntamente com a obra: "no curso desses últimos anos, voltei à rua Vilin para tentar descrever ao mesmo tempo as lembranças que me ligavam a essa rua e os vestígios cada

\footnotetext{
${ }^{78}$ Mireille Ribière, em seu trabalho sobre a descrição dessas fotos, destaca que são 17 textos para 16 fotos, sugerindo a participação do leitor na montagem entre textos e imagens. Em: La photographie dans La Clôture, Revista Cabinet d'amateur, 7-8, dezembro 1998.

${ }^{79}$ No original: "17 photographies de Christine Lipinska accompagnées de 17 poèmes hétérogrammatiques de Georges Perec, en édition hors commerce et par voie de souscription".
} 
vez mais apagados do que foi uma rua" ${ }^{\prime 80}$, texto no qual mencionava o trabalho de parceria com Lipinska. La Clôture, em sua edição original, é uma manifestação artística que trata de uma investigação do passado, a partir dos traços encontrados nas fotos e na observação do lugar, tão marcadamente ligado a sua infância.

Edições posteriores (comerciais) não trouxeram as fotos reproduzidas. Além de Lipinska, Pierre Getzler também acompanhou Perec algumas vezes à rua Vilin, sempre com o intuito de recuperar traços para a escrita de Lieux.

Fica evidente que este trabalho resulta de um primeiro momento de preparação, que consistia nas idas constantes aos lugares, acompanhado de fotógrafos, para descrevêlos e compor, juntamente com as fotos tiradas, material para futuras consultas no momento em que fosse finalmente escrever ou publicar/finalizar o projeto Lieux. Por algum motivo, estas fotos foram, muito antes de "encerrado" o prazo de doze anos, utilizadas lado a lado da escrita de poemas, o que nos mostra já uma "transformação". Como descrições detalhadas acompanhadas de fotos puderam dar origem a poemas que (para dificultar ainda mais o processo) seguiam uma regra fixa de escrita? Esse é mais um exemplo de transformação de Lieux em outro tipo de produção artística, neste caso a escrita poética acompanhada das fotografias.

Mais interessante ainda é perceber que esta edição foi limitada, ou seja, apenas poucas pessoas tiveram acesso a ela, como se fosse uma espécie de "presente" a alguns amigos mais próximos. A edição comercial, publicada depois, não trouxe as fotografias e nem o modelo de "caixa de memórias" criado inicialmente por Perec, muito provavelmente por questões de custo editorial. Mais uma vez, um projeto ambicioso parecia não ir adiante por questões que desconhecemos, mas que nos fazem pensar na "mutação" de Lieux em projetos criativos, inovadores, que puderam de certa forma se concretizar, mesmo que resultando em apenas poucos e raros exemplares.

$\mathrm{Na}$ transcrição do trecho completo em que Perec apresenta a obra, reproduzida a seguir, é curioso notar que a última frase do texto o classifica como um "duplo trabalho", já que resultado das descrições de Lieux e das fotos de Lipinska. Podemos, no entanto, ir um pouco além e pensar neste trabalho com uma segunda etapa do duplo trabalho, uma vez que a primeira resultou apenas em descrições e fotos e que, posteriormente, a escrita foi transformada em poesia para a composição final da obra.

\footnotetext{
${ }^{80}$ No original: "au cours de ces dernières années, je suis revenu rue Vilin pour tenter de décrire à la fois les souvenirs qui me rattachent à cette rue et les vestiges chaque fois plus effacés de ce qui fut une rue".
} 
Afirmar que na primeira etapa só existem descrições da rue Vilin é para nós uma constatação pensada a partir dos documentos analisados para pesquisa (em nenhum dos envelopes do projeto Lieux há qualquer menção ou anotação de textos poéticos que viriam a compor o livro La Clôture). Muito provavelmente Perec não escreveu estes poemas enquanto realizava o projeto Lieux, primeiramente porque, como já dissemos, não há tais anotações no material dos envelopes e, num segundo momento, porque a composição dos poemas (heterogramáticos) ${ }^{81}$ exigiu de Perec uma elaboração criteriosa, visto que os poemas seguem regras fixas de escrita (as contraintes, realizadas por ele e pelo famoso grupo do qual fazia parte, o Oulipo), uma atividade um tanto quanto complexa para se realizar em pé, com um bloco de anotações em mãos, tendo as descrições para serem anotadas e com todas as influências externas do local acontecendo em tempo real, enquanto caminha pelas calçadas da rue Vilin. Vale ressaltar a importância do grupo citado, o Oulipo, sigla criada para fazer referência ao grupo Ouvroir de Littérature Potentielle, que tinha como parâmetro seguir determinadas restrições no processo de escrita dos textos literários. Fundado por Raymond Queneau e François Le Lionnais em 1960, reagrupou também escritores de nacionalidades diversas, como Italo Calvino, Harry Mathews, e matemáticos como Claude Berge, escritores-matemáticos como Jacques Roubaud, um historiador e poeta como Marcel Bénabou. O trabalho realizado por esses artistas, em parceria, sabemos que influenciaria toda a carreira de Perec, sempre interessado em novas experimentações da literatura e sua1 relação com outras artes.

Além disso, fica evidente que o processo de escrita a partir das contraintes terá outros objetivos, como, por exemplo, evocar lembranças, como veremos em análises mais detalhadas a seguir. $\mathrm{O}$ uso das regras também será a maneira como Perec escolhe manipular seu texto literário, já que, a partir da escrita fechada e poética, faz-nos refletir a respeito de tais escolhas.

J'ai vécu rue Vilin de ma naissance, en 1936, à l'été 1942.

La rue Vilin, dans le $20^{\mathrm{e}}$ arrondissement, entre la rue des Couronnes et la rue Piat, est depuis plusieurs années en train de disparaître. Une à une les boutiques ont été fermées, les fenêtres ont été aveuglées, les maisons ont été abattues laissant place à des terrains vagues et à des palissades de ciment. À plusieurs reprises, au cours des dernières années, je suis revenu rue Vilin pour tenter de décrire à la fois les souvenirs qui me rattachent à cette rue (la maison de mes grands-parents au $\mathrm{n}^{\circ} 1$, la maison de mes parents et le magasin de coiffure de ma mère, au n $\left.{ }^{\circ} 24\right)$

\footnotetext{
${ }^{81}$ Segundo a definição do Atlas de Littérature Potentielle, um heterograma significa um " énoncé qui ne répète aucune de ses lettres" (p. 231).
} 
et les vestiges chaque fois plus effacées [sic] de ce qui fut une rue. En même temps, Christine Lipinska photographiait les traces de cette clôture. Le résultat de ce double travail est un livre que nous vous proposons aujourd'hui (OC II, 803).

O trabalho duplo necessário para a composição de La Clotture, como mencionado na citação, foi uma espécie de apropriação de Lieux, e uma reformulação a partir dele. Há ainda, assim parece, uma carga afetiva nessa relação do trabalho duplo entre Perec e Lipinska, conforme nos lembra David Bellos: "La filiation émotionnelle de La Clôture est complexe. Les dix-sept poèmes renvoient indirectement à Suzanne par le biais de sa fille, qui prit les photos, mais aussi par celui de Lieux, dont ils sont la suite et comme le détournement" (BELLOS, 1994, p. 605). Ou seja, além da carga afetiva que já conhecemos, por lidar com a rua da infância e todos os desdobramentos e questões que essa rua suscita, ainda temos uma parceira de trabalho, que tira as fotos (Christine) e que é a filha de Suzanne Lipinska, envolvida provavelmente em uma das questões vividas por Perec e, portanto, indiretamente responsável pelo início do projeto Lieux (iniciado com o final do relacionamento entre ela e Perec), situação já mencionada no primeiro capítulo.

Como vimos na seção anterior, quanto mais se avança nos anos, mais o texto se de Lieux se torna escasso, como se também se abandonasse rumo ao silêncio e à impossibilidade. Como se o lugar se esgotasse juntamente com a escrita. Quanto mais avança, há menos a dizer, menos a escrever. Perec, um escritor sempre interessado na escrita exaustiva, começa então a renunciar à escrita e ao projeto, ao longo de seis anos. Escrever sobre este lugar traz à tona o pressentimento do que acontecerá em breve: seu apagamento progressivo rumo à total destruição.

\subsection{O lugar fechado se transforma: poesia e regras de escrita}

O tema principal do texto de La Clôture, como o nome já diz, acaba sendo $o$ fechamento, o encerramento. O adjetivo "fechado" será usado muitas vezes para descrever cada prédio que observa ao longo dos anos: é como se ele observasse, assim, aquilo que permanece aberto, mas está em vias de fechar, aquilo que está fechado definitivamente e assim sucessivamente. Perec se torna, no lugar de sua infância, a testemunha deste encerramento, desta destruição (testemunha, neste caso, pode ser uma palavra ambígua, pensando na busca da identidade de um órfão da Segunda Guerra Mundial). 
La Clôture nos mostra o processo de "mutação" de Lieux em um projeto poético e fotográfico, contando ainda com uma regra fixa de escrita = ESARTULINOC, ou seja, palavras escritas utilizando as onze letras mais frequentes do francês, e uma $12^{\mathrm{a}}$ letra neutra (§) que varia a cada verso. As fotos e poesias não são paginadas, permitindo uma leitura mais livre. A essa escrita heterogramática podemos dizer que se acrescenta também uma escrita lipogramática, já que, limita-se ao uso de apenas onze letras.

Além do uso da letra neutra (que funciona como um "coringa" para a escrita), há também um jogo interessante na composição entre texto e imagem: se a montagem é livre, ela também deixa uma "falha", já que há apenas 16 imagens para serem compostas ou relacionadas com o total de 17 poemas. Por que esta "falha" aparece? Como uma ideia de falta, de ausência, ela está representada de várias maneiras na obra de Perec. E como ela aparece? Ela surge ao longo da obra perecquiana, seja na última peça de xadrez que falta no jogo de escrita de La vie mode d'emploi, seja na letra $e$ faltante no livro La disparition, seja no símbolo (...) que marca a divisão do livro $W$ ou a memória da infância, depois da cena de despedida com a mãe, entre outros.

Para os leitores de Perec, esta falta, este pequeno desvio de percurso é como uma peça de puzzle que não se encaixa, é como um mistério que deve ser desvendado pelo leitor, é a maneira escolhida pelo artista para que o leitor perceba esta leve "piscadela de olhos", para que o leitor de fato interaja com a obra, fique atento a estes pequenos detalhes tão sutis e tão fundamentais para a composição de escrita de Perec.

$\mathrm{O}$ uso das contraintes parece bastante significativo para a composição de determinadas obras de Perec, pois, como já dito, estas regras parecem mesmo ditar o efeito e a manipulação do texto que Perec pretende apresentar a seu leitor.

No caso da obra Les Revenentes, por exemplo, Perec parte da regra inversamente oposta àquela realizada em La disparition: escrever um livro usando apenas palavras compostas pela vogal e. Na quarta capa da obra, ele afirma que, passadas as duas experiências, pensou numa possível terceira obra, em que não pudesse usar as palavras utilizadas nas duas primeiras, ou seja: "usar numa terceira obra todas as palavras restantes da língua, o que você não pode utilizar nem no primeiro nem no segundo, todas aquelas que contenham, ao menos um 'c' e uma outra vogal”, afirma, dirigindo-se a si mesmo para, logo em seguida, mostrar-se nada animado para levar a ideia adiante: "mas comparado aos seus trabalhos anteriores, tal empreitada pareceria trivial e fútil, e você entenderia, enfim, que agora é hora de se deixar invadir por outra ideia fixa”. 
Ou seja, todo o trabalho de Perec parece sempre permeado por esta ideia fixa de composição. Em Lieux não foi diferente (pois havia a ideia de composição de 12 lugares, uma vez por ano, dois textos em cada vez) e não será diferente em La Clôture (escrita heterogramática nos poemas intercalada pelo uso de uma letra coringa a cada linha).

A própria ideia do uso do $E$ (contraditório em sua presença e ausência) também estará marcado na dedicatória de $W$ ou le souvenir d'enfance: "Pour E", significa, literalmente, que o livro foi escrito para "eles", seus pais mortos na guerra.

O uso das contraintes parece, de certa forma, funcionar como um "escape" ou uma "vestimenta" que esconde, por trás de si, as questões não elucidadas sobre a própria memória ou história que se deseja contar.

No caso dos poemas, Perec parece insistir no uso dos heterogramas, constituídos sob a mesma base: as dez letras mais utilizadas na língua francesa, (E, S, A, R, T, I, N, $\mathrm{U}, \mathrm{L}, \mathrm{O})$, acrescentadas de uma letra que varia conforme a obra produzida. No caso de Alphabets (composto ao mesmo tempo que La Clôture), o uso da décima primeira letra será sempre uma das 16 letras restantes do alfabeto, que são dezesseis.

Assim, teremos onze poemas com a sequência de letras mais B, onze com a sequência mais $\mathrm{C}$, e assim por diante... num total de 11 x $16=176$ poemas de onze versos. No caso de La Clôture, Perec usará a sequência de onze, e não dez letras mais utilizadas no francês $(E, S, A, R, T, I, N, U, L, O, C)$, mais a letra neutra representada por $\S$, como já apresentado.

Além disso, os poemas de Alphabets (que é uma clara alusão ao uso total das letras do alfabeto, como explicitado acima) são acompanhados de ilustrações de um artista conhecido de Perec ${ }^{82}$, enquanto os poemas de La Clôture são acompanhados de fotos, pelo menos na primeira edição. A seguir, temos a imagem de uma das páginas de Alphabets:

\footnotetext{
${ }^{82} \mathrm{O}$ artista é Dado, um pintor iugoslavo que vivia na França.
} 


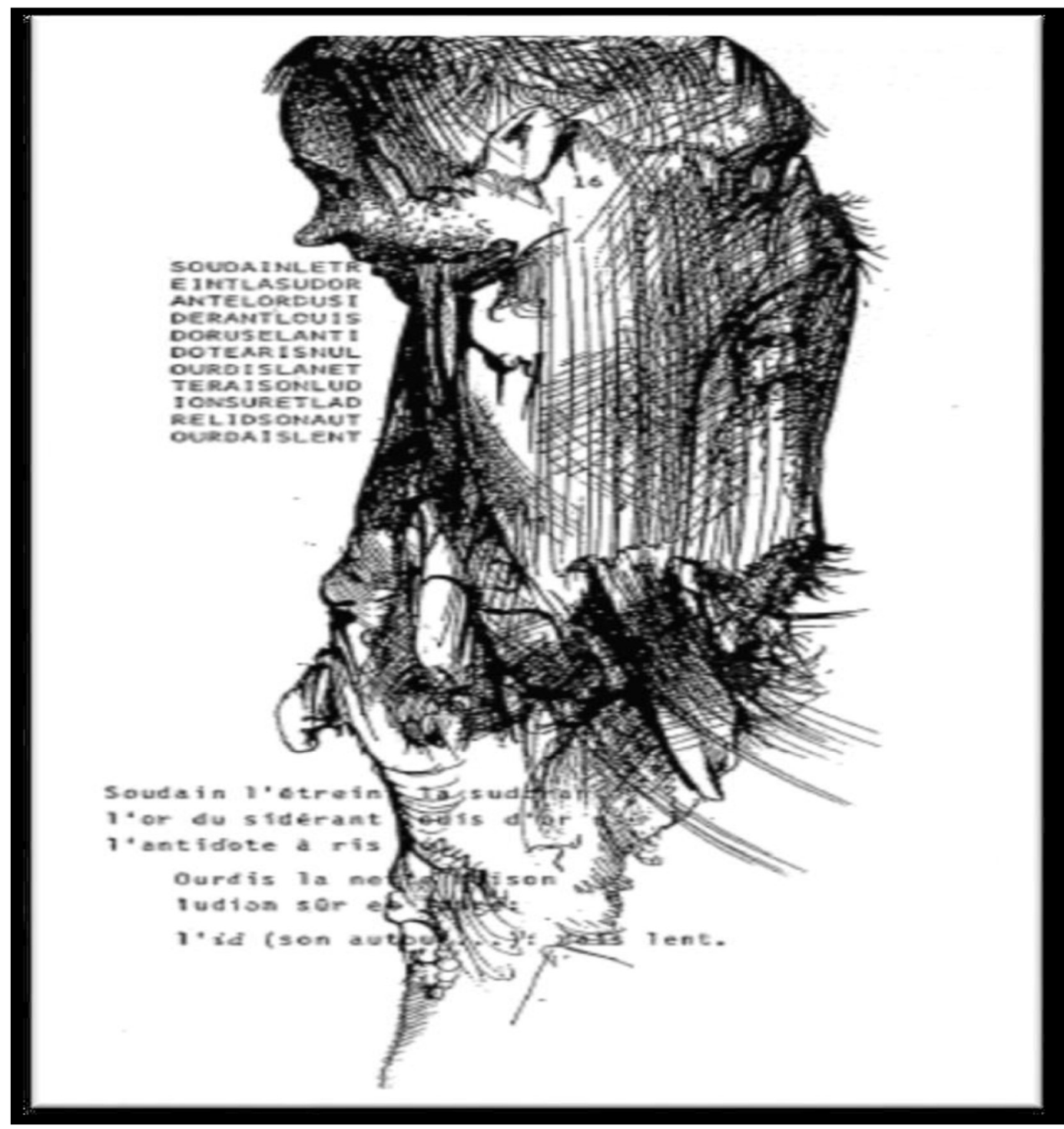

Figura 12. Página de Alphabets, com ilustração de Dado (Georges Perec Images, p. 145).

No caso de Ulcérations (imagem abaixo), outra obra heterogramática, Perec utiliza a mesma sequência de letras, conforme a definição do Atlas de Littérature Potentielle: “Le mot 'ULCÉRATIONS' est un hétérogramme composé des onze lettres les plus fréquentes de la langue française : E, S, A, R , T, I, N, U, L, O, C.” (p. 337). Ou seja, para além da ideia fixa de composição entre um livro sem e (La Disparition, em 1969) e outro somente com a letra $e$ (Les Revenentes, em 1972), parece que a ideia de escrever versos heterogramáticos entrou para a lista de outra suposta "ideia fixa" do autor, que publicou Ulcérations em 1974 e dois anos depois, La Clôture (em sua primeira edição) juntamente com Alphabets. 
TARECLUSION

T INOCULER A S

A N U I T L OR S E C

I A S T RE COI UN

ROIUNCASTEL

N U L S I A T R O C E

$S O U C I I A N T R E$

ROSE T UCA L I N

E S UNCORA I L I

OU T L A C S I R E N

EA L U ONCR I T

UA S CONTELIR

EOLUTINSACR

EARTICULONS

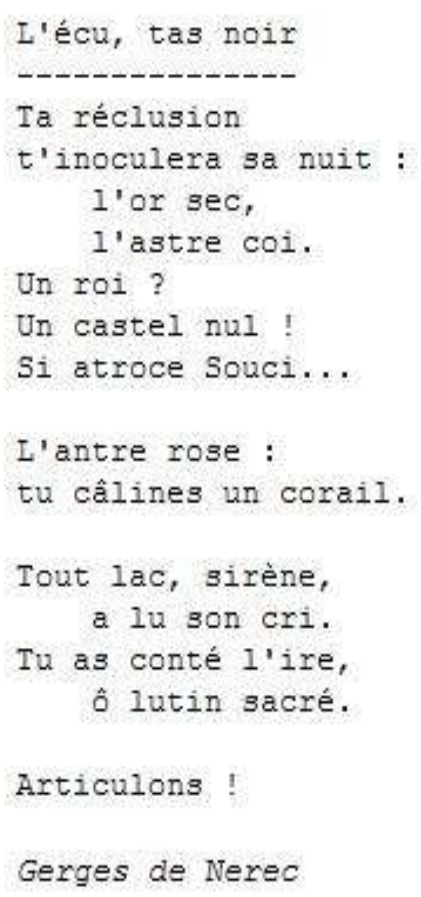

Figura 13. Exemplo de um texto de Ulcérations. Fonte: http://lexiconangel.blogspot.com/2016/04/ulcerationsgeorges-perec.html.

O que fica bastante evidente é que há um significado maior envolvendo a ideia do uso das onze letras utilizadas na composição dos versos. Dia 11 de fevereiro de 1943 é a data que consta no documento "Acte de disparition" de sua mãe, ou seja, a data em que foi deportada para os campos de concentração, conforme imagem a seguir.

Portanto, podemos reforçar a ideia do uso das contraintes na tentativa de esconder (ou deixar à mostra, só que de maneira indireta) com esse exemplo do uso das onze letras remetendo a uma data fatídica para Perec. Se é difícil ter memórias de infância, se não há o que lembrar ou imaginar sobre um período de convivência com os pais - e, sobretudo, com a mãe, que parece ter maior importância nessa luta contra o esquecimento -, há então que se criar uma forma fixa, capaz de substituir a escrita da lembrança, que não virá, mesmo que ele tente e faça tentativas de rememoração. Na impossibilidade de alcançar uma memória inexistente, o recurso a ser utilizado é criar uma regra para que ao menos a escrita possa começar. E, como vimos, a partir de tantas repetições e regras na escrita, a intenção de Perec é estimular esse exercício, como num processo de terapia: escrever muito, o tempo todo, repetir muitas vezes a escrita para, quem sabe, esperar que dela surjam as memórias que tenta ou espera fazer surgir. 


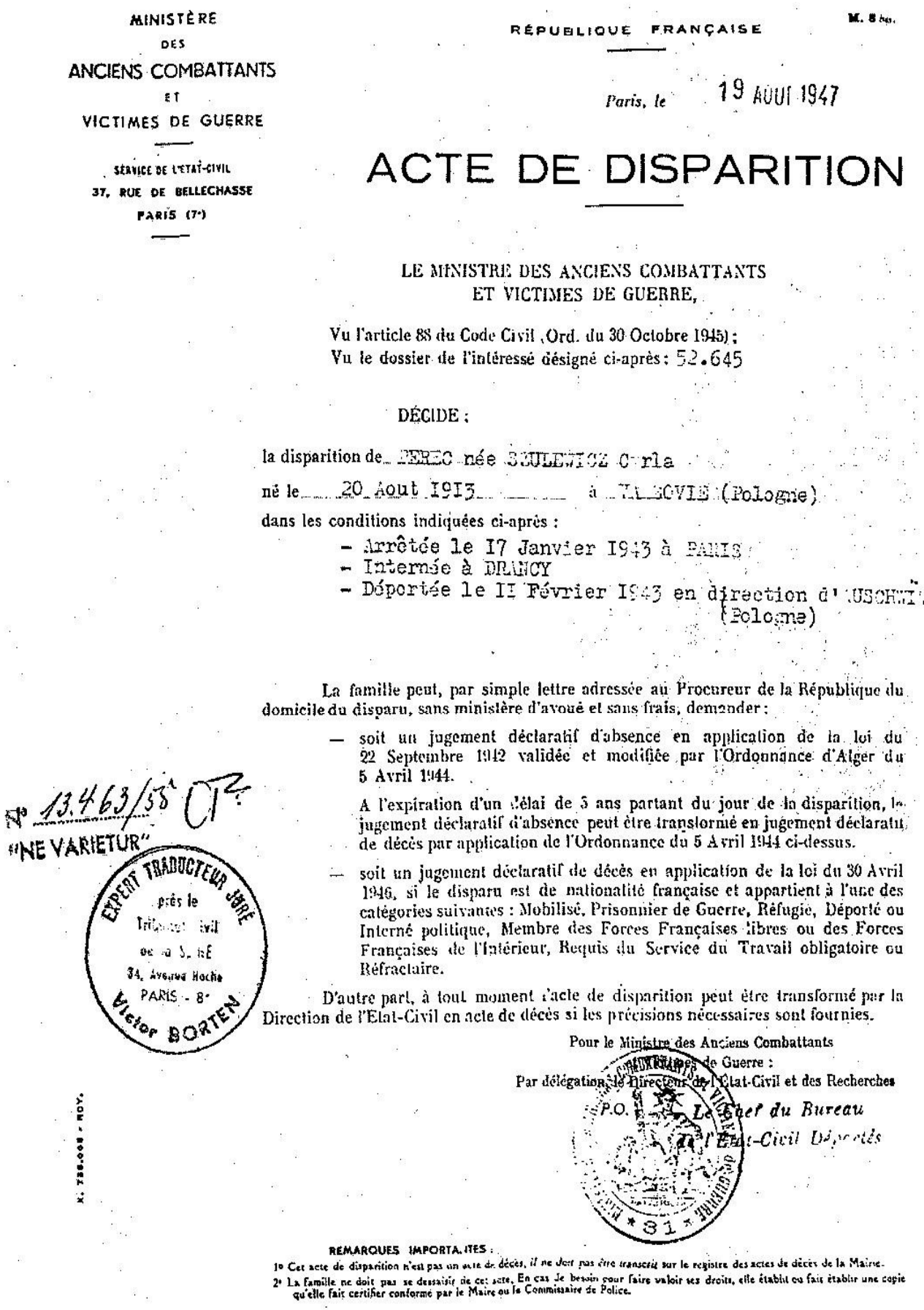

12.

Figura 14. Documento que comprova a deportação de Cyrla para os campos de concentração. Fonte: Georges Perec, une vie dans les mots, David Bellos, 1994 (encarte de fotos pp. 320-321). 


\subsubsection{Regras fixas em jogo, autobiografia desvelada}

É interessante também pensar no símbolo utilizado por Perec para o uso da letra coringa em cada verso. Mireille Ribière nos lembra, em seu artigo ${ }^{83}$, que o símbolo $\S$, que comumente interpretamos como significado de parágrafo, adquire um novo sentido: a superposição de duas letras S (SS, no sentido vertical) faz uma analogia ao nazismo, que está diretamente ligado à morte de seus pais. Concluindo, podemos pensar nestes pequenos detalhes ou regras, criados para a composição dos textos, como elementos que dizem muito sobre as questões autobiográficas, mesmo que de forma velada, como nos explica o artigo de Julie Magot ${ }^{84}$ :

Os textos oulipianos de Georges Perec revelam a necessidade para o poeta de se proteger de uma história pessoal difícil de identificar e de contar. Graças à experimentação poética, ele evita o registro da efusão onde a linguagem se revela impotente e vai mais longe quando se destaca do texto literário clássico, legível, coerente, onde o sentido é dominado. Georges Perec oulipiano torna-se como um possuidor legítimo da linguagem, objeto doravante manipulável, jogo de possibilidades infinitas. O domínio do escritor e do poeta é assim libertado de toda angústica, de todo investimento pessoal que viriam perturbar, "corromper" o poeta e sua poesia. (MAGOT, 2010, p. 3$)^{85}$

Criando uma regra fixa de escrita, ele parece colocar para si limites ao mesmo tempo em que se protege, não se deixa levar pelas questões pessoais, tão difíceis de serem tratadas, como já vimos em diferentes momentos da obra. Há, então, uma espécie de tentativa de controle do que será escrito, o que torna a escrita mais desafiadora para o autor e, ao mesmo tempo, faz com que Perec manipule a linguagem com uma direção certa a seguir. Não há, portanto, investimento pessoal na escrita, como Magot afirma, e sim disciplina para atingir uma regra fixa, mesmo que fique claro, para nós leitores, que todas as questões pessoais vão aparecer, nas entrelinhas, por pequenos detalhes que ficarão visíveis para os leitores mais atentos. Magot parece insistir na importância deste

\footnotetext{
83 "Le lieu et la forme dans La Clôture", de 2015.

84 "Essai de poétique comparée : Georges Perec et Jacques Roubaud", de 2010.

${ }^{85}$ Les textes oulipiens de Georges Perec révèlent la nécessité pour le poète de se protéger d'une histoire personnelle difficile à cerner et à raconter. Grâce à l'expérimentation poétique, il évite le registre de l'effusion où le langage se révèle impuissant et va même plus loin en se détachant du texte littéraire classique, lisible, cohérent, où le sens est maîtrisé. Georges Perec oulipien devient comme le possesseur légitime du langage, objet désormais manipulable, jouet aux possibilités infinies mais contenues. Le domaine de l'écrivain et du poète est ainsi débarrassé de toute angoisse, de tout investissement personnel qui viendraient perturber, "corrompre" le poète et sa poésie.
} 
processo de escrita como uma maneira de dominar os próprios sentimentos, transformando-os em textos, rigorosamente criados a partir de critérios pré-definidos. É como se tal controle nos fizesse refletir exatamente sobre as questões complexas que o envolvem, como a tensão entre o pleno e o vazio, entre o que se lembra e o que é esquecido, intermitentemente:

Os textos oulipianos constroem um todo artificial de signos dominados: a plenitude dos signos é a ausência de sentido oposta ao vazio da memória na qual se inclui uma forma de desarticulação, de decomposição da palavra, do signo linguístico. O poeta é oulipiano acima de tudo, como uma definição de si mesmo, a solução para expessar a ausência e o problema da memória. (MAGOT, 2010, p. 5) ${ }^{86}$

Paradoxalmente, a ideia de controle sobre a escrita e esta possível tentativa de "esconder" as questões autobiográficas funcionam, de certa forma, como um desafio para esta pesquisa, que se baseia sobretudo nestas questões autobiográficas que estão presentes, mesmo que de maneira indireta. No caso de La Clôture, a principal imagem à qual temos acesso (a porta do imóvel n. 24 da rue Vilin, lugar onde viveu na infância) já nos remete a essa ideia de fechamento, enclausuramento e, por que não, falta? É ali o lugar onde tudo deveria ser esclarecido, onde toda a memória deveria vir à tona, onde todos os mistérios da vida deveriam encontrar uma possível solução. Como vimos, a sensação de estar fisicamente presente no lugar corresponde exatamente à cena da foto de uma porta fechada (a visita não produz memória, não faz Perec se lembrar de nada, não traz à tona a resposta para seus questionamentos). É um caminho estreito, fechado, escuro, abandonado e que não leva a nenhum esclarecimento.

A poesia produzida para o livro La clôture homenageia este percurso de escrita e imagens que se fundem pelas caminhadas na rue Vilin. A escrita de Lieux, interrompida, dá lugar à recriação a partir da poesia, talvez como alternativa de preencher o vazio, a falta, não preenchidos apenas com as descrições objetivas e escassas do local. É como se a escrita em forma de poesia fosse uma alternativa, uma nova forma de fazer este vazio "falar".

E o que se espera da leitura de La clôture? Uma espécie de enigma que se coloca para o leitor, o reflexo do enigma provocado em Perec? Se não há nada a ser lembrado,

\footnotetext{
${ }^{86}$ Les textes oulipiens construisent un plein artificiel de signes maitrisés : le plein des signes, c'est l'absence du sens opposée au vide de la mémoire auquel s'ajoute une forme de désarticulation, de dé-composition du mot, (fin p. 4) du signe linguistique. Le poète est oulipien avant tout, comme une définition de lui-même, la solution pour exprimer l'absence et le problème de la mémoire.
} 
se apenas olhar não traz nenhum significado, como transportar este enigma de difícil resolução para a escrita poética, como fazer o leitor lidar com o enigma da escrita? De um lado, temos as fotografias que são um índice do real e, de outro, a ficcionalização desse real a partir da criação poética.

\subsubsection{O jogo com o leitor em La Clôture}

Podemos dizer que há um duplo jogo de adivinhação. Perec olha e descreve, tenta recompor as letras quase apagadas na inscrição "Coiffure dames", tenta entender o enigma daquele lugar: é assim que ele escreve para o seu leitor. Este terá que desvendar o que se passa dentro do "enclausuramento" de letras que se produz a cada verso dos poemas de La clôture.

Se, num primeiro momento, as letras quase compactadas e as palavras separadas algumas vezes por "§” produzem uma espécie de ilusão de ótica, não menos enigmática será a leitura "convencional" do poema, que segue abaixo da representação experimental inicial, como vemos na imagem:

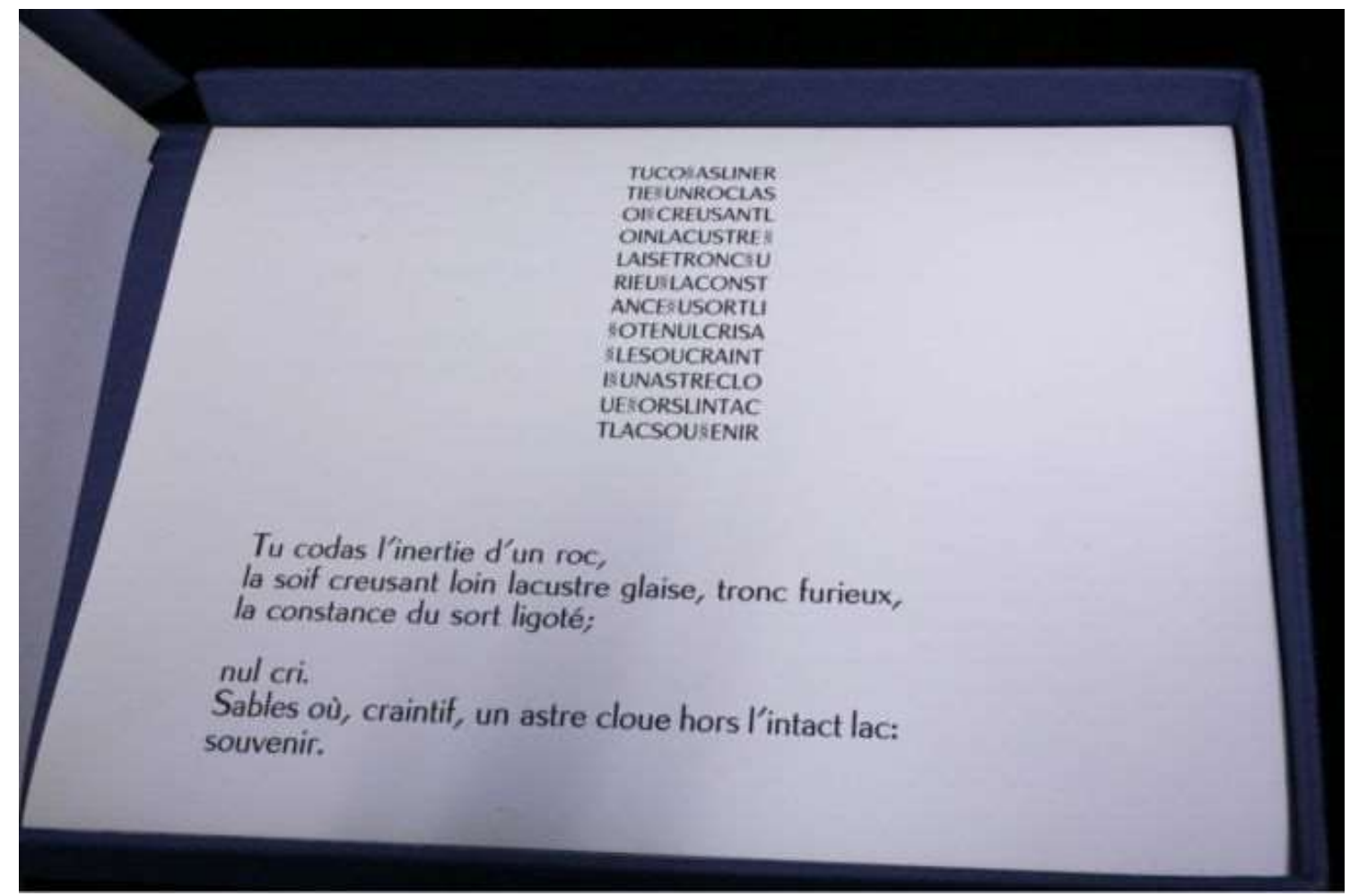

Figura 15. Imagens das páginas de La Clôture. Fonte: https://textualites.wordpress.com/2015/09/22/les-lieux-degeorges-perec-une-oeuvre-eclatee/ 
O texto aparece, como que desvendado para o leitor, abaixo da matriz heterogramática apresentada no alto da página. Ainda assim, sua leitura é hermética, fechada e, segundo a análise da seção Notices, nas Euvres, parece realizar uma homenagem a Mallarmé:

De fato, o livro presta uma homenagem a Mallarmé, com quem partilha o gosto pelo hermetismo. Se a indireção - ou mesmo a dificuldade - de sentido tornou-se na França, desde o fim do século XIX, uma marca usual do gênero poético, os textos super restritos de Perec só podem enriquecer essa opacidade: a significação é construída neles com uma grande relutância, em sucessões descontínuas de breves epifanias. (Euvres, vol II, p. 1189) ${ }^{87}$.

A leitura, portanto, torna-se também uma clôture, graças a sua opacidade. Não há pistas que possam ajudar na compreensão do sentido, a não ser as imagens que acompanham os poemas, e o pouco que sabemos a respeito do lugar, para tentar compor algum sentido entre todos os elementos. Tentamos adentrar esta leitura fechada, que parece simbolizar as fachadas muradas de uma rue Vilin em processo de desaparecimento, cercadas de brancos e vazios do texto que funcionam para nos lembrar do tema recorrente ali inseridos: estamos lendo poesia que trata, sobretudo, do tema da ausência. Assim, a análise segue apontando para um tipo de poesia que nos parece, portanto, um tanto quanto precária em sua composição:

Escreve-se assim, letra por letra, uma poesia precária, cujo sentido, sempre à beira do inconsciente, parece magnetizado por um silêncio ao qual o branco do papel fornece uma figura concreta, numa coleção composta, segundo o uso contemporâneo, de mais branco do que de texto, e cuja economia se baseia em uma série de ausências (Euvres, vol II, p. 1189) ${ }^{88}$.

São muitos os significados que podemos inferir a partir destas poucas imagens dos textos em sua edição original. Há uma dubiedade em todo o processo de escrita e na maneira como estas palavras aparecem dispostas, formando versos e, por fim, poemas. Se, por um lado, a escrita experimental e repleta de contraintes representa muito bem a escrita de Perec de maneira geral, há também a representação da ideia de enclausuramento

\footnotetext{
${ }^{87}$ Le livre rend, de fait, un hommage appuyé à Mallarmé, dont il partage le goût de l'hermétisme. Si l'indirection- voire la difficulté - du sens est devenue en France, depuis la fin du XIX ${ }^{\mathrm{e}}$ siècle, un marqueur usuel du genre poétique, les textes hypercontraints de Perec ne peuvent que renchérir sur cette opacité : la signification s'y construit avec une grande réticence, en successions discontinues de brèves épiphanies [...] ${ }^{88}$ S'écrit ainsi, lettre à lettre, une poésie précaire, dont le sens, toujours au bord de l'évanouissement, semble aimanté par un silence auquel le blanc du papier donne une figure concrète, dans un recueil composé, selon l'usage contemporain, de plus de blanc que de texte, et dont l'économie repose sur une série d'absences.
} 
das palavras, que dá origem à relação que fizemos com a imagem da porta do número 24 do imóvel da rue Vilin. Há também uma segunda questão. Perec, em muitas entrevistas, sempre deixou claro um duplo descontentamento: primeiro, que o público não percebesse a contrainte produzida e, num segundo momento, que a obra só fosse importante devido à contrainte, excluindo-se a importância de todo o restante (foi exatamente o que aconteceu no caso do livro La disparition, que não contém a letra $e$ como regra formal de escrita).

No caso de La clôture, Perec parece ter criado a regra e, ao mesmo tempo, ter "revelado" o enigma do texto, simplesmente publicando, na mesma página, o poema escrito da forma convencional (ou em versos livres, de fato e que, como vimos, ainda assim não favorece completamente a leitura e a compreensão dos versos). Segundo o autor, escrever só sob a forma de contraintes faria com que o público não tivesse a oportunidade de ler efetivamente os poemas, tais como aparecem na parte de baixo da página. Esta questão de deixar descoberto/esconder também é algo bastante recorrente na obra de Perec.

É sempre um duplo movimento de trabalho com o leitor, às vezes pregando peças e às vezes trazendo soluções, como se o quebra-cabeças viesse duas vezes na mesma caixa, um desmontado e o outro montado, para que se compreendesse como se chegou à montagem, num ciclo infinito de mostrar/descobrir/montar/desmontar. Assim como as folhas do livro, que chegam soltas para o leitor, permitindo todos os tipos de permutas e associações de inúmeras maneiras.

Impossível, assim, mesmo para os pesquisadores, encontrar um exemplar que pareça representar a configuração inicial imaginada por Perec, como nos descreve Mireille Ribière:

A edição de 1976 fez de La Clôture uma obra aberta cujos elementos são reordenáveis à vontade. Assim a composição das caixas que eu pude consultar varia de um exemplar a outro, sem que se possa afirmar que se trata da ordem original ou do resultado de manipulações de leitoresassinantes curiosos. De fato, se os poemas designados por seus incipit são numerados em uma lista à parte, a ordem das fotografias não é de forma nenhuma precisa: nenhum percurso de leitura é, dessa forma, imposto. $(2015 \text {, p. } 1-2)^{89}$

\footnotetext{
${ }^{89}$ L'édition de 1976 fait de La Clôture une œuvre ouverte dont les éléments sont réordonnables à volonté. Ainsi la composition des coffrets que j'ai pu consulter varie d'un exemplaire à l'autre, sans que l'on puisse affirmer s'il s'agisse-là de l'ordre originel ou du résultat des manipulations de lecteurs-souscripteurs curieux. En effet, si les poèmes désignés par leur incipit sont numérotés sur une liste à part, l'ordre des photographies n'est nullement précisé : aucun parcours de lecture n'est, de ce fait, imposé.
} 
Na verdade, a intenção provável é que houvesse realmente este trabalho de interação com o leitor a partir do livre manuseio das folhas, para que elas se permutassem da maneira como cada leitor pudesse imaginar. Aí está uma das questões bastante interessantes da obra: cada um destes leitores criou, para si, uma história sobre a rue Vilin, diferente, seguindo seus próprios gestos de leitura, montagem, desdobramentos e associações entre textos e imagens das mais variadas configurações. Talvez aqui possamos pensar num Perec que não tinha uma imagem única ou definitiva para oferecer sobre o lugar e que, portanto, sugere este jogo de quebra-cabeças para representar, de certa maneira, toda a complexidade de significações presentes na obra.

Encontramos em La Clôture, portanto, um texto com palavras que trazem um tom pesado, reforçando termos que remetem à ideia de enclausuramento, fechamento, ou à questão da memória inalcançável: “art inscrit à l'enfoui clôturé/ l'inertie d'un roc/ l'intac lac: souvenir/ crois le ciment, sa lourdeur/ la cour démolie". Além do léxico que remete ao enclausuramento, contamos com uma leitura fechada em si mesma, que recorre a um leitor que precisa tentar decifrar os enigmas, como nos explica Claude Burgelin"9: "Le texte fait se conjoindre cette exploration des pouvoirs de la langue mutilée et l'enquête sur les traces de son histoire". Essa língua mutilada, portanto, é o reflexo da imagem da ruína, presente tanto nas imagens da rua abandonada quanto na própria linguagem apresentada, ainda segundo Burgelin: "Il se crée en même temps un dialogue muet entre cette poésie ruinée et les images de cette rue aux portes murées, vouée à la destruction".

Para finalizar esta ideia do jogo, nada mais evidente do que pensar nas matrizes de escrita (os poemas "enclausurados") constituídas por doze blocos (ou linhas) de doze letras cada uma, remetendo-nos diretamente ao projeto 12 × 12 de Lieux (escrever doze anos sobre doze lugares).

É como se a escrita de La Clôture representasse uma imagem concreta, no sentido literal, pois há uma construção (em blocos) que nos remete a uma parede ou muro (no caso abaixo, também a imagem de uma cama, e a relação com a primeira palavra do poema: "lit"). Como se fosse uma espécie de poesia concreta formada por uma regra de escrita, mas também carregada de um forte componente visual, já que representa ou remete diretamente à materialidade e à visibilidade proporcionada pelas fotos que acompanham os textos.

\footnotetext{
${ }^{90}$ Os dois trechos de Burgelin citados no parágrafo estão na página 153 do Album Georges Perec, 2017.
} 


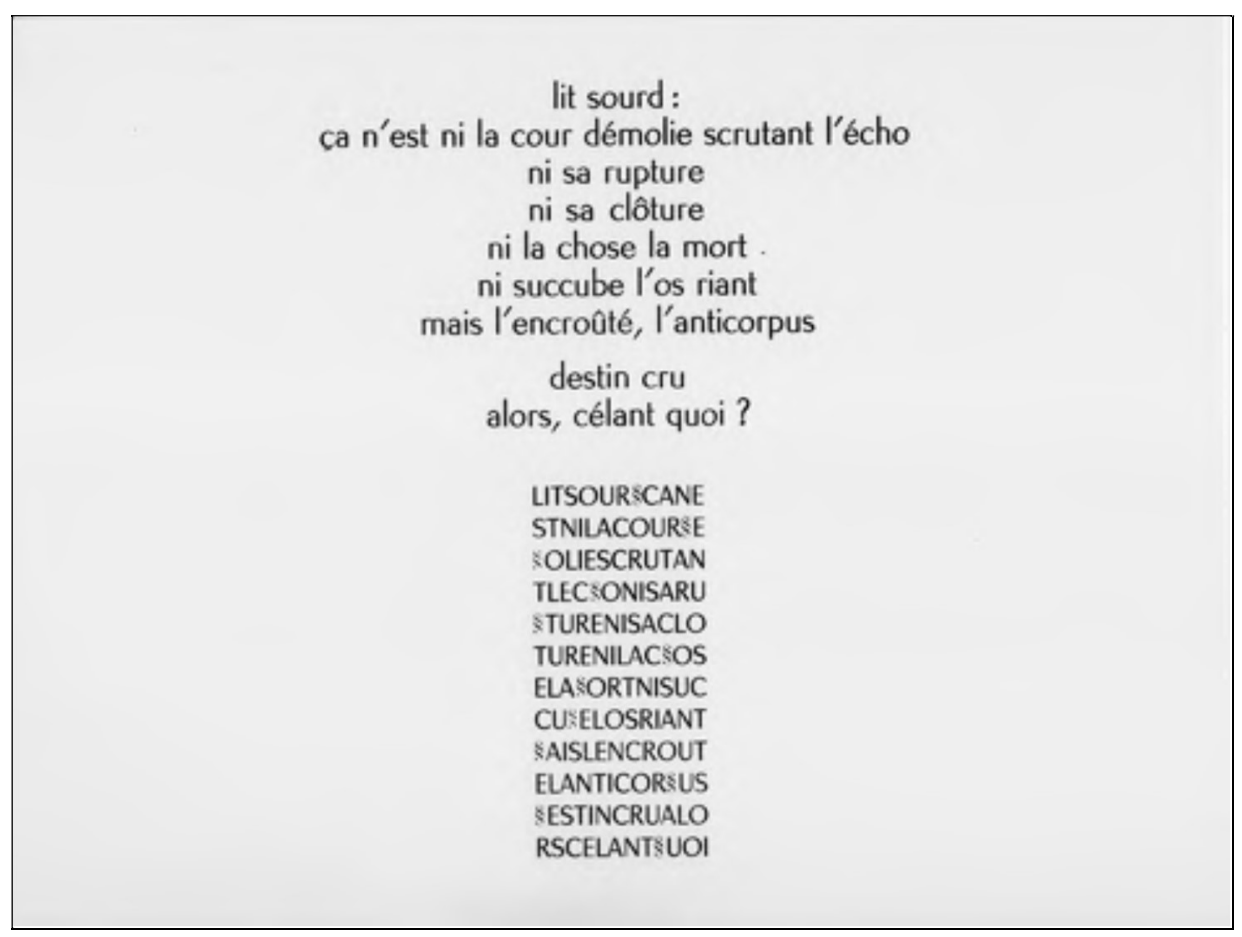

Figura 16. Páginas do livro La Clôture. Fonte: Artigo Le lieu et la forme dans La Clôture, 2015, p. 12.

Além da imagem que remete à cama, a ideia de abandono ou destruição do lugar é fundamental para a escolha das palavras: ou seja, além da contrainte de escrita estabelecida (número de letras limitado e seleção de letras específicas), há ainda a seleção do léxico que representa muito bem as imagens que acompanham todos poemas; no caso abaixo, temos, por exemplo, o uso das palavras "démolie, rupture, clôture, mort", entre outras.

Se observarmos o bloco de escrita abaixo, o formato retangular já fica bastante evidente e podemos pensar nesta relação com o formato das portas fechadas ou cimentadas recorrentes nas fotos tiradas da rue Vilin, como nos mostra Mireille Ribière, a partir de uma montagem, na página 12 do texto já citado.

Ela nos afirma que basta respeitar as proporções da matriz e da fotografia da porta do número 24 e chegaremos a esta sobreposição emblemática e que pode nos dar a pista da escolha do formato da matriz: 


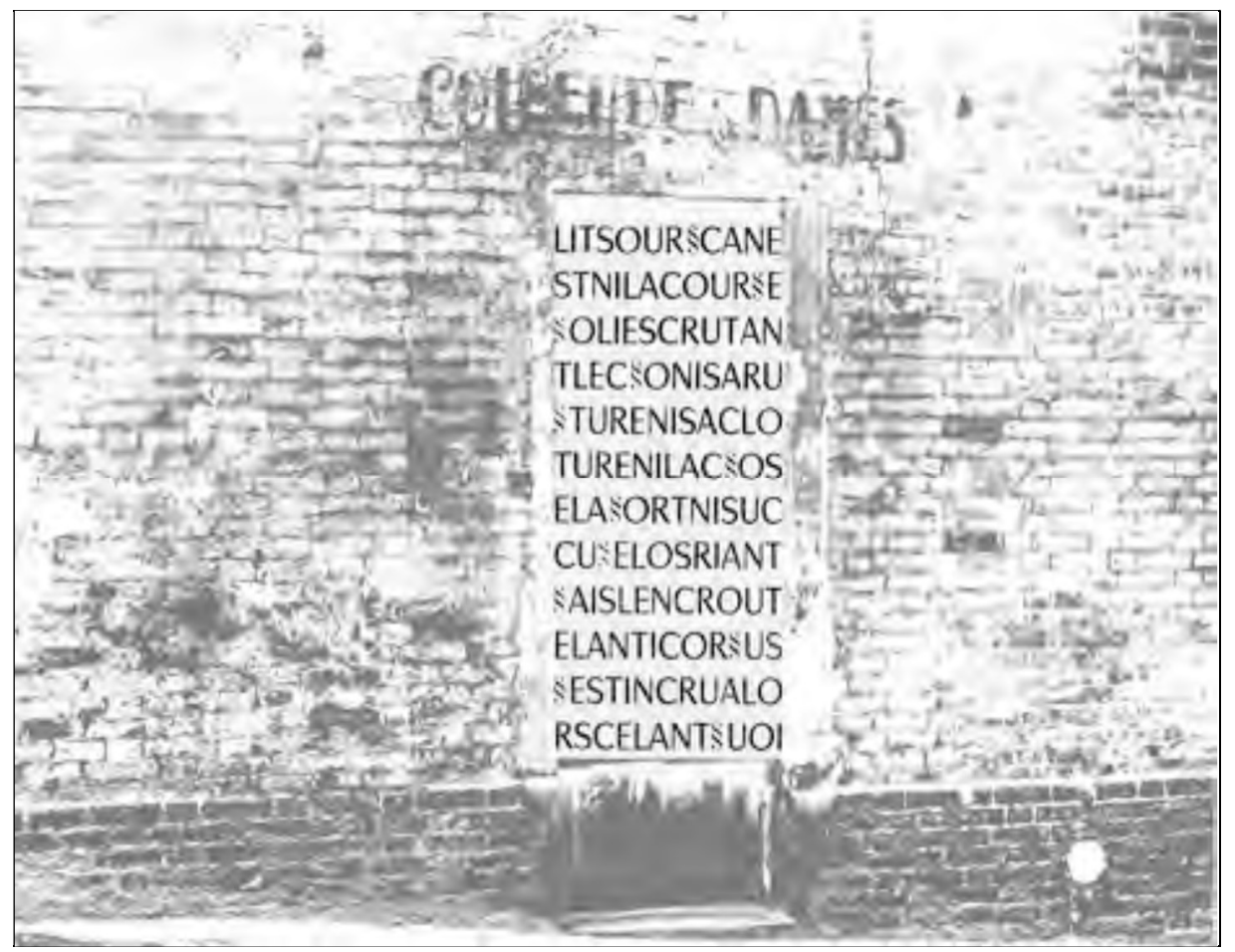

Figura 17. Montagem do texto sobre a foto do imóvel 24 da Rue Vilin. Fonte: Artigo Le lieu et la forme dans La Clôture, 2015, p. 12.

\subsection{A rue Vilin se recria}

Jean Luc-Joly afirma também, sobre La Clôture, que a obra constitui uma maneira de superar o 'fracasso' de Lieux, ou seja, de obter, de certa forma, uma espécie de apreensão total de um lugar parisiense. Sobre a questão do fracasso, muito já foi discutido aqui, anteriormente, ficando claro que o termo não é o mais adequado; assim, podemos falar de esgotamento, transformação e proliferação do projeto, constituindo outros projetos a partir dele. Além disso, se pensarmos na ideia de jogo e de compartilhamento com o leitor, esta apreensão total do lugar, também mencionada por Joly, parece-nos uma ideia bastante inviável. Pelo que vimos e analisamos até aqui, La clôture parece querer recuperar algo que não foi possível a partir de Lieux, mas não necessariamente expor ou apresentar uma "apreensão total do lugar".

Esta obra nos parece, pelo contrário, uma maneira de representar a rue Vilin exatamente como ela se parece para Perec: um lugar complexo, repleto de significados, em que não se chega a uma definição precisa, onde existem muitas contradições e dúvidas, onde o jogo da memória e da escrita está em vias de acontecer, mas nada ainda é definitivo, nem mesmo a apropriação do material, que será diferente para cada leitor, como se, de certa forma, esta complexidade e essa diferença fossem a única certeza de 
Perec, experiência que ele reproduz para os seus leitores. É como se estivéssemos realmente diante das ruínas daquilo que foi a rue Vilin, no momento em que nos deparamos com a leitura dos poemas.

Se não há o que se lembrar, se não há como se filiar a tal lugar, se não há como criar raízes ou memórias a partir dele, então o melhor caminho talvez seja este compartilhamento com os leitores, de forma que cada um crie, à sua maneira, sua própria rue Vilin e recrie, consequentemente, a história da rua e que, numa esfera coletiva, todos façam parte desse lugar, mesmo que indiretamente, a partir desta leitura lúdica e compartilhada entre o autor e todos os seus leitores. Ou seja, para além da ideia de uma obra de caráter pessimista de teor mais denso, ainda há na estratégia de escrita esta forma de brincar, de interagir com o leitor e fazer viver a arte, mesmo que o tema, de certa forma, remeta, mesmo que indiretamente, à morte, ao fim, ao encerramento do lugar/da memória/ da história do lugar:

Além das representações de imagens de abandono e ruína, o que se
afirma é a força viva da arte, da escrita como conquista sobre a morte e
sobre o silêncio. As conotações positivas do explícito dos poemas 11
("linceul naît corps") e 17 (L'accalmie (ton sûr port au silence /
conquis): l'art ?" são singularmente reforçadas. (RIBIËRE, 2015,
p.8). ${ }^{91}$

A arte, a escrita, a partir das fotos, e da poesia, o lúdico e as trocas com o leitor vão prevalecer, mesmo que o tema a ser tratado não seja dos mais leves, mesmo que haja muitas questões ainda não resolvidas. A escrita será uma maneira de transpor-se a estas questões, a arte será a conquista em face do silêncio da morte, do aniquilamento e do esquecimento daqueles que não estão mais presentes para contar sua história.

Analisando isoladamente as imagens, é inevitável não pensar na ideia de enclausuramento, de ruínas e (por que não?) confundirmos tais imagens com espécies de túmulos ou câmaras funerárias. A analogia não é mera coincidência, já que sabemos do histórico da perda dos pais de Perec, na Segunda Guerra Mundial. Mas as imagens, quando sobrepostas aos textos, a partir da ideia de jogo como aqui exploramos, faz com que olhemos novamente para tais imagens e, de certa forma, passemos a observá-las sob uma nova perspectiva: talvez devêssemos pensar em tais imagens como espécies de

\footnotetext{
${ }^{91} \mathrm{Au}$-delà des représentés, des images d'abandon et de ruine, ce qui s'affirme c'est la force vive de l'art, de l'écriture comme conquête sur la mort et sur le silence. Les connotations positives de l'explicit des poèmes 11 ("linceul naît corps") et 17 ("L'accalmie (ton sûr port au silence / conquis) : l'art ?") s'en trouvent singulièrement renforcées.
} 
relíquias de imagens (já que sabemos que não mais existem), ou como homenagens àqueles que um dia fizeram parte do lugar, mas sem que se trate do assunto de uma maneira direta, explícita ou incisiva.

O olhar é aquele que buscaremos dar, ao fazer possíveis associações dos textos com as imagens e perceber o jogo que se apresenta. Observar a partir destas páginas a efemeridade dos lugares como a efemeridade da vida, do que passa, do próprio tempo que se transforma ao nosso redor. Realizar uma leitura poética em todos os sentidos possíveis, desde a busca pelo enigma da construção dos poemas, passando pela forma em que se acomodam e se transformam em versos e, num último momento, como se intercambiam entre si, entre as fotos, como se fixam sob o olhar e nas mãos de cada leitor, individualmente, transformando-se em pequenas experiências coletivas aquilo que pode ter sido a própria experiência do autor ou vice-versa (transformando-se em pequenas experiências individuais aquilo que pode ter sido a própria experiência coletiva daqueles que viveram nesses lugares, há anos, e assim por diante...).

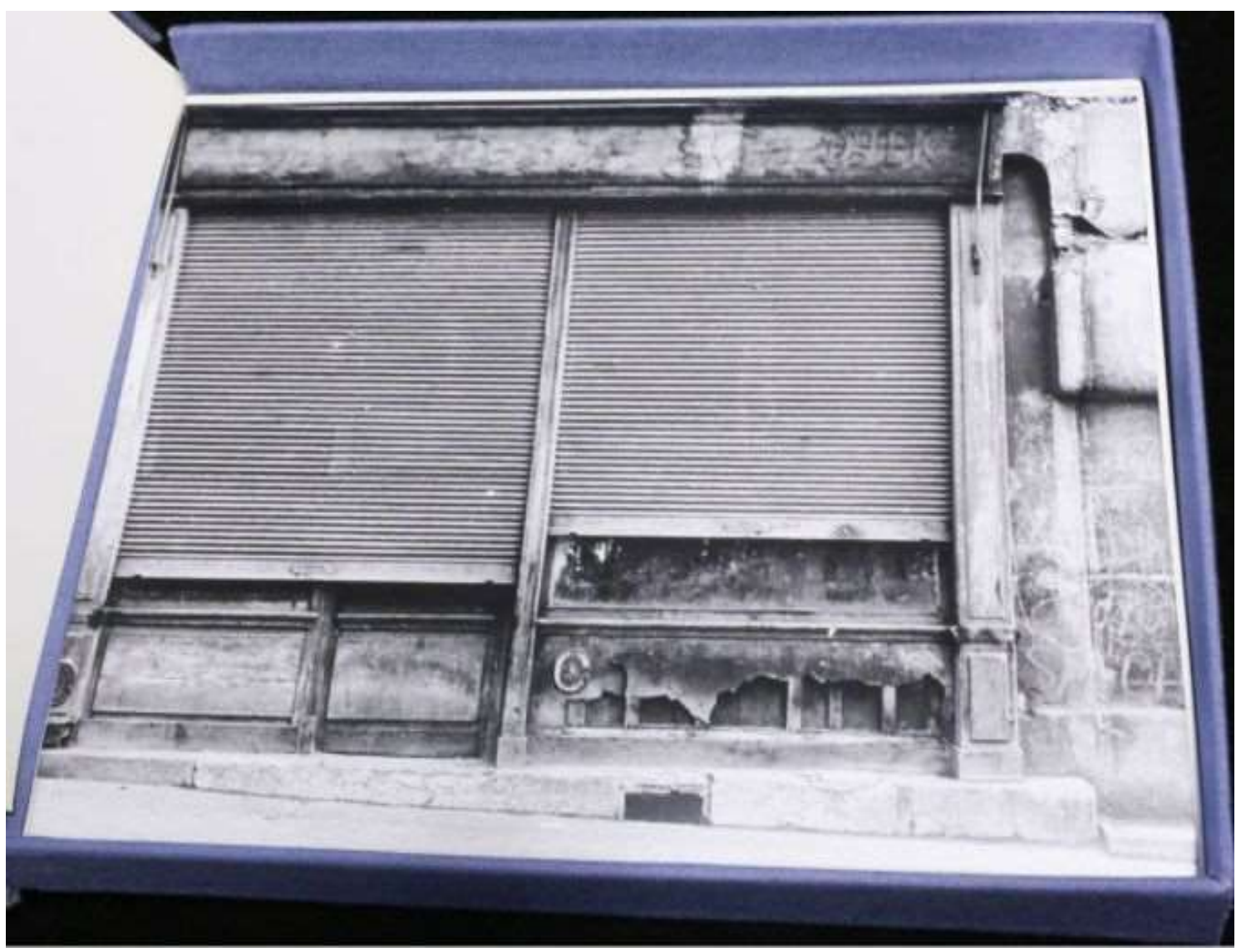

Figura 18. Imagens de fachadas abandonadas na Rue Vilin, que acompanham os textos de La Clôture. Fonte: https://textualites.wordpress.com/2015/09/22/les-lieux-de-georges-perec-une-oeuvre-eclatee 


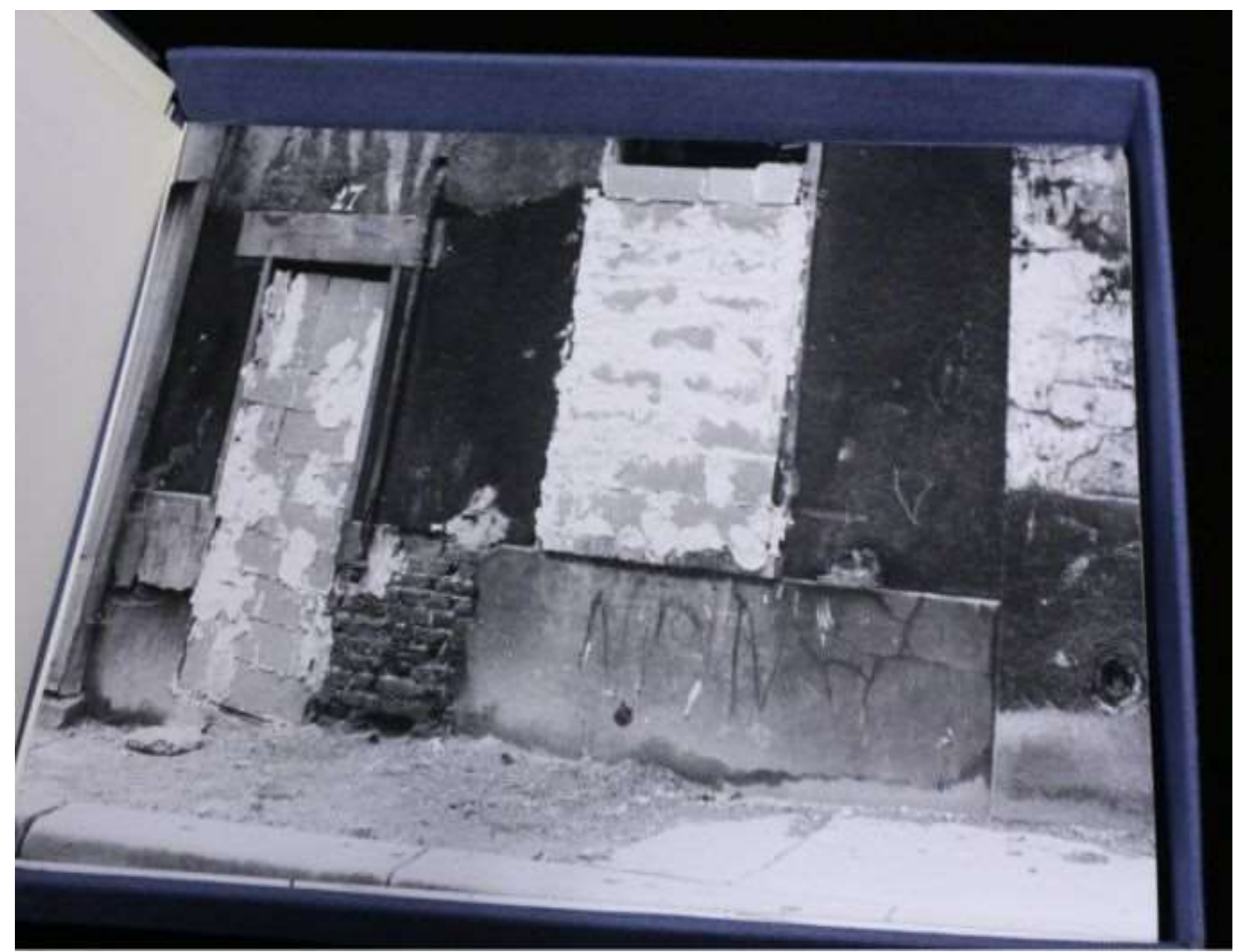

Figura 19. Imagens de fachadas abandonadas na Rue Vilin, que acompanham os textos de La Clôture. Fonte: https://textualites.wordpress.com/2015/09/22/les-lieux-de-georges-perec-une-oeuvre-eclatee/

Nossa experiência de leitura é fluida, assim como as páginas se fundem e se decompõem novamente. Infelizmente, no caso de La clôture, com o número de exemplares reduzido, temos apenas algumas imagens do que foi a obra em si, sem termos acesso integral a uma delas, sem ter a sensação real do processo de leitura vivido por aqueles leitores que receberam um dos cem exemplares confeccionados de forma quase artesanal à época da publicação.

A segunda edição traz apenas os poemas, deixando de lado o caráter lúdico da obra (as fotos estão ausentes e não há mais o jogo de palavras sob a contrainte; a matriz, em formato retangular e com uso do símbolo § para representar uma letra diferente a cada verso, desaparece). Se pensarmos na questão já discutida aqui (de que em determinado momento Perec deseja apenas que ser leitor leia o texto, o poema, e que a contrainte deixe de ter, contraditoriamente, a importância dada a ela quando da publicação inicial), passamos do lúdico para o poético, para a força da palavra, e o suporte da imagem não 
mais aparece, nem tampouco os enigmas de escrita. Se, num primeiro momento, Perec parece produzir esta obra "interativa" e lúdica, num segundo, o que prevalecerá será única e exclusivamente o texto poético em si, evidenciado na segunda edição. Desta forma, fica evidente que a intenção de "esconder" do autor aparece novamente, como nos explica Ribière. Esconder, neste caso, significa deixar de "dar a chave", desvendar o enigma, dando a ver apenas o texto poético:

Se excluir as matrizes, é se recusar a "dar a chave", não acontece diferente com as fotografias. Trata-se, tanto em um caso como no outro, de quebrar o impasse sobre as condições e modalidades de produção dos poemas afim de fazê-los atingir, segundo Perec, um estatuto verdadeiramente poético. (RIBIÈRE, 2015, p. 6)

Ribière chega a esta conclusão (de que Perec se recusa a dar a chave de leitura) a partir de uma declaração do próprio autor, quando trata da exclusão das matrizes e das fotos na segunda edição de La Clôture. Perec afirma : "sans donner la clé, le lecteur peut les recevoir comme um poème". Portanto, assim como já analisamos anteriormente neste texto, esta ambiguidade entre mostrar e esconder as regras de escrita se evidenciam, ao mesmo tempo em que o texto poético é exaltado por Perec que, na segunda edição, dá preferência única e exclusivamente a sua publicação, deixando o lúdico da obra em segundo plano.

Evidenciar o texto em detrimento das imagens que o acompanham é também uma estratégia encontrada em outras obras de Perec. Fica bastante evidente se analisarmos as descrições de fotos do livro $W$ ou le souvenir d'enfance. Ali, as imagens são descritas de maneira bastante detalhada, mas é o leitor quem criará a imagem a partir da leitura do texto $^{93}$. Sob este mesmo aspecto, Cécile de Bary comenta a série de desenhos produzida por Perec ao longo da escrita de $W$ ou le souvenir d'enfance, e que invariavelmente também não estará presente no momento da publicação do livro.

Sobre tais desenhos, de Bary afirma haver uma espécie de imagem "evacuada". 94 É interessante levantar dois pontos de vista diferentes sobre a mesma questão: enquanto de Bary usa tal termo para tratar da retirada de imagens do livro La Clôture, Mireille

\footnotetext{
${ }^{92} \mathrm{Si}$ exclure les matrices, c'est se refuser à "donner la clé", il n'en va guère autrement pour les photographies. Il s'agit, dans un cas comme dans l'autre, de faire l'impasse sur les conditions et modalités de production des poèmes afin de les faire accéder, selon Perec, à un statut véritablement poétique.

${ }^{93}$ Há um capítulo no meu trabalho de dissertação onde exploro a descrição das fotografias como produtora de escrita autobiográfica ficcional.

${ }^{94}$ Cécile De Bary, "L'image pré-texte", Agora. Revue d'études littéraires, n 4 : Perec - Aujourd'hui, op. cit., p. 116.
} 
Ribière cita a colega pesquisadora justamente para problematizar a ideia, sugerindo ou preferindo o termo "désancrage" no lugar da ideia de "evacuação" da imagem.

Ribière afirma que, na primeira edição, a foto funciona como "ancrage" do texto ao lugar (a rue Vilin), enquanto a matriz de doze letras funciona como "ancrage" do texto a um procedimento fixo (as doze permutações a partir de um heterograma-matriz). Portanto, segundo Ribière, o texto precisa desta "désancrage" para se constituir novamente como texto, a partir das convenções de escrita (o texto poético em versos livres). É claro que os termos "ancrage" / "désancrage" aparecem fortemente influenciados pelo próprio Perec, que os utiliza em um manuscrito de "Vilin Souvenir" de 1970:

O que há de extraordinário aqui, é que de fato, um lugar modelo, é o que somente passo, onde vejo as coisas (as "coisas", os sinais de ancoragem) [...] que eles me impõem sua nostalgia (lamento de um país natal, de um lar ancestral [...] minha única tradição, minha única memória, meu único lugar é retórico = sinal de tinta (la différance, la diff(icile) errance, ici l'errance) ${ }^{95}$ (LEJEUNE, 1992, P. 136). ${ }^{96}$

A partir dessa ideia de lugar como função de "ancrage" (algo a que se possa fixar), as coisas e os lugares com os quais Perec tem contato - em busca de encontrar uma possível estabilidade - são, portanto, lugares nos quais ele poderá refletir sobre a nostalgia de um país natal, suas memórias, num jogo de palavras que leva de ancrage a encrage (tinta/marca), différance/dffi(icile) errance, ici l'errance, ou seja, seu ponto de apoio (ancrage) será exatamente aquele instável, onde pode percorrer, errar; a errância será o ponto de apoio, num ciclo infinito de paradoxos, assim como na frase célebre "je cherche em même temps l'éternel et l'éphémère". Nesta escrita em movimento, nesta busca de um ponto onde possa finalmente encontrar certa estabilidade, o termo "ancrage" está presente em outros momentos de escrita de Perec. Um dos trechos mais marcantes de $W$ ou a memória da infância mostra exatamente a cena da visita ao túmulo do pai, como representação de um fim, o fim da morte abstrata e um lugar onde de fato a morte do pai encontra um ponto fixo ${ }^{97}$ :

\footnotetext{
${ }^{95}$ Este último trecho da citação não foi traduzido, a fim de preservar o jogo de palavras existente na língua francesa.

${ }^{96}$ Ce qu'il y a d'extraordinaire ici, ce qui en fait, un lieu modèle, c'est que je ne fais qu'y passer, que j'y vois les choses (les "choses", les signes d'ancrage) [...] qu'elles m'imposent leur nostalgie (regret d'un pays natal, d'une demeure ancestrale [...] ; ma seule tradition, ma seule mémoire, mon seul lieu est rhétorique $=$ signe d'encrage (la différance, la diff(icile) errance, ici l'errance).

${ }^{97}$ Além desse trecho sobre a visita ao túmulo do pai, há um documento expedido pelas autoridades francesas, no ano de 1958, dando a Icek o título de "Mort pour la France", em razão de um ferimento na guerra. O documento estará disponibilizado na seção "Anexos" desse trabalho.
} 
A descoberta do túmulo do meu pai, as palavras PEREC ICEK JUDKO seguidas de um número de matrícula, inscritas na cruz de madeira e ainda bastante legíveis, me causaram uma sensação difícil de descrever:[...] alguma coisa como uma serenidade secreta ligada à ancoragem no espaço, à tinta sobre a cruz, dessa morte que deixava enfim de ser abstrata [...] como se a descoberta desse minúsculo espaço de terra encerrava enfim essa morte que não tinha havia compreendido, jamais provado, jamais conhecida nem reconhecida, mas que me tinha feito, durante anos e anos, deduzir hipocritamente os sussurros mimados e os beijos suspirantes das mulheres. (PEREC, 1975, p. 54) ${ }^{98}$

\subsection{Lieux e suas constantes transformações}

Reiterando então a teoria de que o projeto Lieux está ligado a outros projetos de escrita, vimos em vários momentos o quanto os temas e as reflexões do projeto se reproduzem tanto na escrita de $W$ ou a memória da infância quanto na obra La Clôture. E, por tratar-se de um projeto complexo, que dá origem a diversas obras (e que de alguma maneira têm também relações entre si), é que encontramos as palavras ressoando de um projeto a outro, de um trabalho a outro, numa incessante atualização e reformulação das mesmas questões, em momentos diferentes. Além do termo "ancrage", que acabamos de analisar, é interessante observar como a noção de "clôture" também está presente em outra obra de Perec, Récits d'Ellis Island, que será tratada com maiores detalhes no último capítulo desta pesquisa.

O que está aqui não são em nada marcas, raízes ou traços, mas o contrário: algo sem forma, no limite do dizível, alguma coisa que posso chamar de fechamento, ou divisão, ou quebra, e que é para mim muito intimamente e muito confusamente ligado ao fato mesmo de ser judeu e não sei precisamente o que é ser judeu isso o que me faz ser judeu [...] não é um sinal de pertencimento [...] será mais um silêncio, uma ausência, uma pergunta, um questionamento, uma flutuação, uma inquietude (PEREC, 1980, p. 42-43) ${ }^{99}$

\footnotetext{
${ }^{98}$ La découverte de la tombe de mon père, des mots PEREC ICEK JUDKO suivis d'un numéro matricule, inscrits au pochoir sur la croix de bois, encore tout à fait lisibles, m'a causé une sensation difficile à décrire :[...] quelque chose comme une sérénité secrète liée à l'ancrage dans l'espace, à l'encrage sur la croix, de cette mort qui cessait enfin d'être abstraite $[\ldots]$ comme si la découverte de ce minuscule espace de terre clôturait enfin cette mort que je n'avais apprise, jamais éprouvée, jamais connue ni reconnue, mais qu'il m'avait fallu, pendant des années et des années, déduire hypocritement des chuchotis apitoyés et des baisers soupirants des dames.

${ }^{99} \mathrm{Ce}$ qui se trouve ici ce ne sont en rien des repères, des racines ou des traces, mais le contraire : quelque chose d'informe, à la limite du dicible, quelque chose que je peux nommer clôture, ou scission, ou coupure, et qui est pour moi très intimement et très confusément lié au fait même d'être juif je ne sais pas très précisément ce que c'est qu'être juif ce que ça me fait d'être juif [...] ce n'est pas un signe d'appartenance $[\ldots]$ ce serai plutôt un silence, une absence, une question, une mise en question, un flottement, une inquiétude.
} 
É inevitável não levantarmos tais questões, não realizarmos tais análises em casos tão evidentes como estes apresentados. O lugar que se busca, a partir da ideia de "ancrage", que se descobre ligada à ideia de "errance", tem seu ponto máximo de exploração na obra Récits d'Ellis Island (o tema principal da obra é a errância, como veremos), mas, ainda assim, está presente a noção de "clôture/scission/coupure" ou todos estes sentimentos relacionados à trajetória de vida e, principalmente, ao fato de o escritor pertencer a uma família judia, mesmo que este assunto só seja tratado direta e explicitamente na obra em questão.

Em Lieux, há apenas uma tentativa de se ancorar àqueles lugares, a partir de um trabalho longo, de errância e descrição; em La Clôture, há a materialização e o jogo de palavras que se transformam no próprio lugar de enclausuramento no primeiro momento e que, numa segunda edição, se liberta para se tornar texto, apenas. Finalmente, a saída de Paris, em direção a Nova Iorque, e a história de errância de outros pode se tornar lugar de "ancrage". Ao menos da escrita, neste caso, que se libera e que, dando voz aos outros, faz-se também voz de Perec e de seu parceiro em Ellis Island, Robert Bober.

Mesmo desejando que seus poemas sejam lidos, os versos de La Clôture, muitas vezes difíceis de serem apreendidos em seu sentido, são um desafio de leitura, quase como o desafio de encontrar um lugar ao qual se ancorar. Os poemas são, de certa forma, representações também daquilo que se repete em Ellis Island, como vimos no trecho transcrito acima; para retomar as palavras de Perec, as palavras em seu processo de "désancrage" da matriz e das fotos parecem em busca de uma resposta: temos de lê-las como "une mise en question, un flottement, une inquiétude".

O que parece ainda mais interessante é pensar que, nesta busca por um lugar onde possa se ancorar, fixar-se, Perec conta, invariavelmente, com a presença do outro ao seu lado: se investigar a rue Vilin (e errar pelo lugar) sozinho não foi suficiente, a fotógrafa e seu olhar o acompanharam nesta jornada. Do mesmo modo, a errância e a travessia de Paris a Nova Iorque também não foi solitária. Perec contou com o olhar de Bober para descobrir um lugar de apoio, onde pode refletir sobre todas as questões de Lieux, de La Clôture, de $W$ ou le souvenir d'enfance e, finalmente, chegar à escrita de Ellis Island. Todas estas obras são, de fato, desdobramentos de Lieux e das apropriações de Perec diante de si mesmo e também do olhar do outro. 


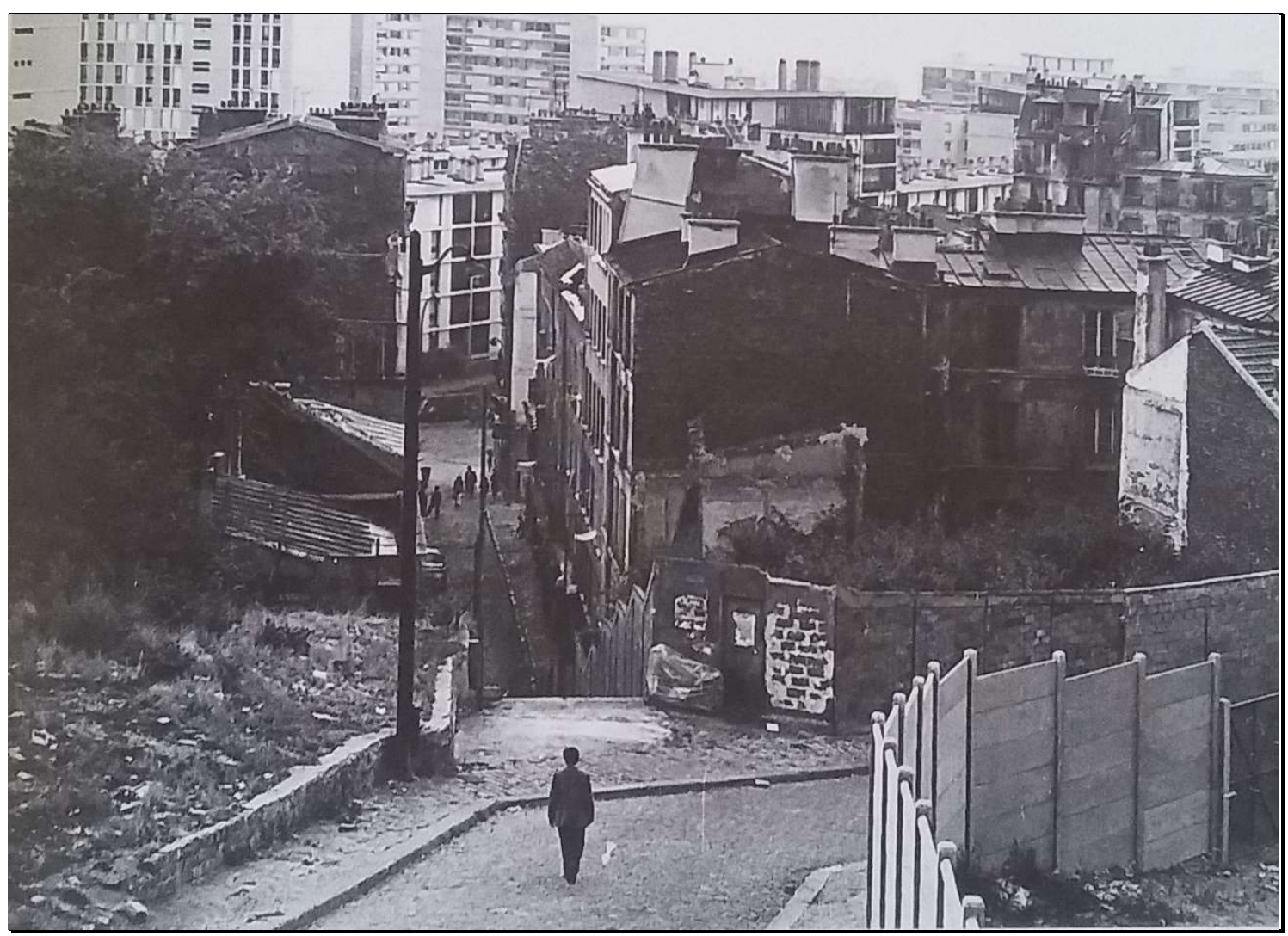

Figura 20. Cena final do filme "Um homme qui dort", que mostra o personagem andando pela rue Vilin. O vídeo completo do filme está disponivel em: https://www.youtube.com/watch?v=UaIXUXdYthA

A rue Vilin será, portanto, este possível lugar de ancrage. Ou ao menos a busca, como vimos até aqui. Segundo Pierre Nora, "a razão fundamental de ser de um lugar de memória é parar o tempo, é bloquear o trabalho do esquecimento, fixar um estado de coisa, imortalizar a morte, materializar o imaterial para prender o máximo de sentido num mínimo de sinais, é claro, e é isso que os torna apaixonantes" (1993, p. 22). Perec nos dará pistas deste lugar de memória, primordial, em vários momentos de sua obra e não apenas nos projetos aqui mencionados.

Nora completa definindo tais lugares de memória como uma espécie de lugar duplo: ao mesmo tempo fechado sobre si mesmo, mas constantemente aberto sobre a extensão de suas significações, exatamente como nos parece o lugar de infância de Perec. Para finalizar e ilustrar esta afirmação, relembro um trecho de entrevista em que, ao ser perguntado se os lugares que aparecem na filmagem de Un homme qui dort têm relação com os doze lugares de Lieux e, consequentemente, com aspectos da própria existência, Perec responde que sim, já que, mesmo aparecendo no filme de maneira indireta, todos 
os lugares “estão ligados a minha história pessoal”. Ele ainda complementa, afirmando que "o que é mais importante, é que o lugar do plano final é a rua onde nasci"100. Assim, encerramos este capítulo com a ideia de que o lugar de memória estará presente nos dando pistas, fazendo-nos refletir e funcionando com fator essencial para a escrita de Perec.

Podemos concluir, brevemente, que, com a obra La Clôture, Perec recria a seu modo a rue Vilin, partindo da transformação do antigo projeto Lieux em poesia e imagem. Veremos também transformações e recriações de outros lugares, na sequência do próximo capítulo, a partir da análise de dois filmes (La vie filmée e Les lieux d'une fugue), além de outras obras que trazem reflexões complementares às que foram até aqui realizadas, mas que carregam consigo ainda o projeto autobiográfico não concretizado de Lieux.

${ }^{100}$ Entretiens et conférences, vol. I, p. 161. 


\section{CAPÍTULO III}

Dando continuidade à reflexão sobre as transformações do projeto Lieux, analisaremos nesta parte do trabalho outras obras que dialogam com a nossa hipótese de pesquisa. O presente capítulo está dividido em duas partes: a primeira trata da análise do documentário La vie filmée, criado a partir de um conjunto de imagens amadoras compiladas para reproduzir os costumes da vida na França dos anos 30. Perec faz uma reflexão sobre uma época e também sobre a própria história. Essa reflexão, no entanto, baseia-se sobretudo em descrições de objetos, dando um destaque inicial exatamente para o uso da câmera, que era uma novidade naquela época.

A partir disso, realizamos uma análise da importância dos objetos em algumas obras de Perec (e sua descrição, muitas vezes exaustiva, como maneira de contar uma história, seja ela pessoal ou coletiva) e, especificamente, de alguns objetos que marcam uma época específica, como os carros, por exemplo. Assim, nossa análise parte da descrição dos objetos para sua relação direta com a tecnologia. Observaremos que é pela tecnologia que Perec tem acesso ao rádio e aos equipamentos que fazem com que seu texto, em alguns momentos, dê lugar a sua voz. Isso nos ajuda a refletir também sobre questão da voz e das produções sonoras de Perec nessa primeira parte, em especial na obra Tentative de description des choses vues au Carrefour Mabillon, de 1978. Assim, nas obras apresentadas nessa parte, já podemos perceber que a sua pretendida expansão para outros suportes começa a se realizar, já que La vie filmée e outras obras a serem mencionadas seguem o procedimento de Lieux: observar os lugares, os objetos, tentar fixar o tempo a partir dessas descrições.

Na segunda parte, o filme analisado será Les lieux d'une fugue: realizado em 1976, ele recria um texto autobiográfico de 1965 que narra a fuga de Perec quando criança, da escola, para andar sem rumo pelas ruas de Paris. Dois lugares importantes, rue de l'Assomption e Franklin Roosevelt, são também dois dos doze lugares de Lieux e terão destaque importante no documentário. O primeiro é a casa onde viveu com os tios, sua família adotiva e o segundo, o local onde sua aventura acontece nas cenas iniciais do filme. A relação com o projeto Lieux também fica evidente, principalmente ao constatarmos que, por mais que se trate de uma história autobiográfica, o narrador utiliza a terceira pessoa para contar a história. Há um "il" que não aparece na cena, substituído sempre pelas imagens dos lugares. Perec se valeu de um texto autobiográfico, incorporando a ele as imagens dos lugares percorridos durante o projeto Lieux, o que 
resultou numa história sem personagens visíveis, mas com uma carga autobiográfica estritamente ligada à memória em relação aos lugares observados e percorridos.

\section{La vie filmée des français (1974): olhar para imagens antigas, contar sua própria história}

Perec participa de um projeto para uma rede de televisão - programa intitulado "La vie filmée", de 1974 - para o qual escreveu os comentários, a partir de imagens antigas do bairro onde passou sua infância: "Trabalhei então com documentos onde quase encontrei minha própria história. Um desses filmes se passava no meu bairro de infância e era como se eu estivesse com minha mãe, meus pais, na imagem!" ${ }^{101}$. Neste caso, será interessante refletirmos sobre a importância da imagem para reconstruir um espaço, mesmo que seja um espaço de convivência (fictício) do qual não fez parte, mas a partir do qual pôde desenvolver sua escrita. A partir de imagens antigas, que remetem a um tempo remoto, em um acontecimento não vivido por ele, (mas talvez por seus pais, mesmo que nada se saiba a respeito), Perec elabora um texto que servirá de comentário a essas imagens que não lhe "pertencem" diretamente, mas que fazem parte de uma memória coletiva, transformada por ele em uma "possível memória familiar".

Pierre Nora, a partir da ideia dos lugares de memória, faz-nos refletir acerca desse olhar que dirigimos aos anônimos, como numa tentativa de resgatar nossa própria história:

Como não ver, nesse gosto pelo cotidiano no passado, o único meio de nos restituir a lentidão dos dias e o sabor das coisas? E nessas biografias de anônimos, o meio de nos levar a apreender que as massas não se forma de maneira massificada. Como não ler nessas bulas do passado que nos fornecem tantos estudos de micro-história, a vontade de igualar a história que reconstruímos à história que vivemos? (NORA, 1993, p.14).

A partir da experiência já realizada em Lieux, Perec agora não só descreverá o bairro, como contará com uma imagem para se inspirar e, inclusive, criar uma memória "ficcional" a respeito de sua própria família, utilizando-se de um espaço público para produzir sua obra. Esta ideia de produção de uma memória "ficcional" a partir de imagens perpassou grande parte da minha pesquisa de mestrado, e se mostra aqui ainda bastante latente. É inevitável pensar que imagens, neste caso, são ao mesmo tempo material para produzir descrições para um programa de televisão e também para produzir possíveis

\footnotetext{
${ }^{101}$ Citação do texto de Perec "Le travail de la mémoire", publicado em Je suis né, 1990, p.81.
} 
reflexões sobre a vida de sua família neste bairro, nesta mesma época, vida esta que permanece ainda com muitas lacunas a serem preenchidas.

Será interessante verificarmos trechos do texto (aliados a imagens do documentário) onde por vezes há a descrição característica, típica de projetos como Lieux, ao mesmo tempo em que cria este espaço fictício, que reproduz opiniões, suposições e desejos sobre o lugar que observa, partindo de mera descrição em direção a uma obra ficcional, onde a tensão entre memória coletiva e memória individual estará presente de maneira efetiva. Aqui ainda que percebamos que Perec se apropria de imagens já realizadas para compô-las com seu texto, veremos a seguir que ele não se limitará a textos, mas produzirá também imagens para compor sua obra, numa tentativa de esgotamento e descrição de lugares e de sua própria memória.

No desejo de observar e recontar aquilo que observa, tentando não perder nenhuma cena, tentando trazer a velocidade da fala para alcançar as imagens que vê, Perec descreve em detalhes cenas de uma época na qual está inserido, mas que dela não participou diretamente. $\mathrm{O}$ intervalo de tempo ao qual se refere o filme apresentado corresponde ao período dos anos 1930 a 1934; Perec nasceu em 1936 e, portanto, este período é para ele aquele em que ainda não existia, mas é também um lugar onde seus pais poderiam estar, passear, conviver, anos antes de seu nascimento.

É por isso que observar estas pessoas, em cenas do cotidiano, faz com que reviva ele também momentos da própria história que mal conhece ou da qual mal se lembra, e que, por isso, pode servir como ponto de apoio para uma escrita sobre si. Ainda que não se lembre, há ali uma memória coletiva sendo manipulada, descrita, como ocorre também no projeto Lieux e em tantas outras obras de Perec. Olhar para os outros como uma maneira de refletir sobre si e a própria história, tornando aquele lugar de observação um lugar híbrido, complexo. Ou, nas palavras de Pierre Nora, que define os lugares de memória como "híbridos e mutantes, intimamente enlaçados de vida e de morte, de tempo e de eternidade; numa espiral do coletivo e do individual, do prosaico e do sagrado, do imóvel e do móvel” (NORA, 1993, p.16).

Curioso observar que o vídeo se inicia com a descrição de uma câmera Pathé102, que já nos faz refletir sobre esta questão da mobilidade ou movimento das imagens, das relações destas imagens com o tempo, da ideia de espiral onde os tempos se reencontram.

\footnotetext{
${ }^{102}$ No texto de apresentação do filme e na transcrição dos comentários, intitulado "La vie filmée", nos Cahiers Georges Perec 9, há uma pequena explicação acerca do modelo descrito por Perec: "Lancée en 1923, la caméra Pathé-Baby a rencontré un grand succès, qui en France est resté durable" (2006, p. 73).
} 

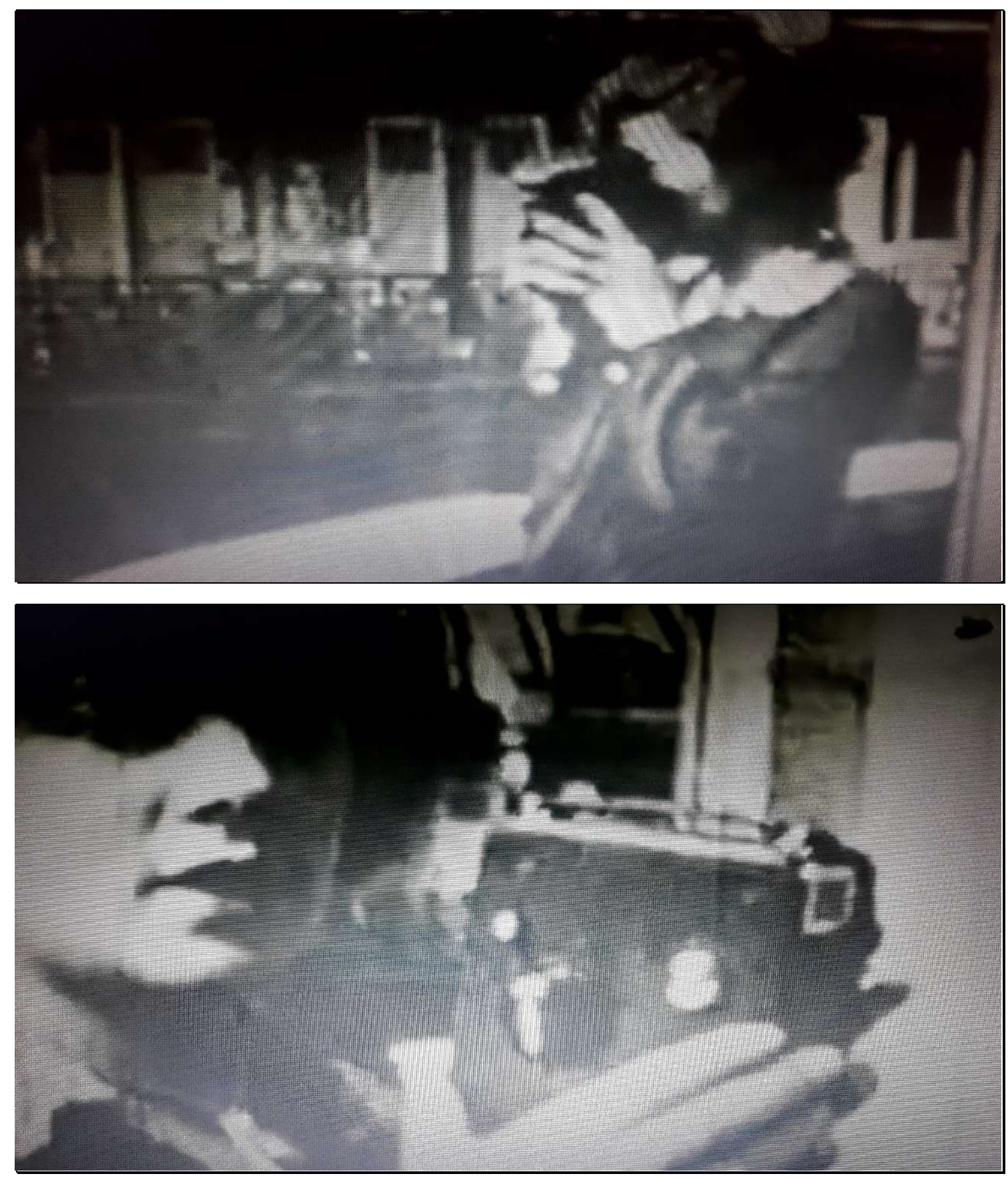

Figura 21. Cenas do filme La vie filmée des français.

Sur la caméra : C'est une petite boîte noire. On met la pellicule à intérieur. On remonte le ressort, comme si c'était un réveille-matin. Au lieu de prendre une photographie, on va en prendre plusieurs à la suite, assez vite pour donner l'illusion du mouvement, de la vie. C'est ça le cinéma. C'est aussi simple que ça. 
Com o avanço da tecnologia, portanto, pessoas comuns puderam fazer cinema em 1930, assim como nos explica McLuhan ${ }^{103}$, teórico canadense da área da comunicação: "O cinema, pela pura aceleração mecânica, transportou-nos do mundo das sequências e dos encadeamentos para o mundo das estruturas e das configurações criativas" (2009, p. 13). A novidade da câmera, que permite fazer cinema em casa com a própria família, é a mesma que sentimos hoje, com nossas câmeras digitais já ultrapassadas por aquelas que vêm no aparelho celular. Todos nós podemos, de certa forma, fazer nosso próprio cinema também, podemos ser criativos graças aos avanços e recursos tecnológicos, além de sentirmos certo fascínio pelos objetos tecnológicos "miniaturizados", como também nos explica Baudrillard, em seu $O$ sistema dos objetos $^{104}$; segundo ele, assistimos, com o progresso tecnológico, a uma miniaturização sempre mais acentuada do objeto técnico (como exemplos de objetos miniaturizados, Baudrillard cita o relógio de pulso e a máquina fotográfica), tais miniaturas foram substituídas na nossa geração por tablets, computadores pessoais e telefones, cada dia mais portáteis.

Perec se refere ao uso da câmera como algo que passa a ser natural entre as pessoas, no seu cotidiano, sobre a velocidade com que podíamos capturar as imagens com uma máquina tão simples e prática de manusear. É como se olhasse, maravilhado, para algo que já é bem comum à época em que escreve (ou comenta) ${ }^{105}$, mas que pareceu muito

\footnotetext{
${ }^{103} \mathrm{Na}$ obra Os meios de comunicação como extensões do homem, traduzido por Décio Pignatari, pela Ed. Cultrix, em 2009. Curioso destacar, segundo Bellos, que Perec tenha lido o teórico, instigado por Jean Duvignaud (antigo professor que se tornou seu mentor), em meio aos acontecimentos políticos e culturais da década de 60. Segundo Bellos, McLuhan publicou "panfletos apocalípticos" que anunciavam "o desaparecimento iminente da cultura escrita (no livro de 1962, The Gutenberg Galaxy), enquanto que na obra Pour comprendre les médias, de 1964, McLuhan proclamava em alto e bom som: "O meio é a mensagem", e veria o mundo funcionando unicamente a partir de uma "cultura audiovisual, eletrônica e tristemente transnacional" (BELLOS, 1994, p. 395). Apesar das previsões de McLuhan não terem sido tão radicais (caso contrário não estaríamos usando o meio da escrita, nos dias de hoje), certo é que, na época em que essas obras foram publicadas, havia exatamente essa mudança de paradigmas em relação aos meios de comunicação, principalmente com o advento do cinema e do rádio (anteriores) e que foram aos poucos também dando lugar a os aparelhos de televisão, e todas as espécies de eletrônicos que, hoje, de certa forma, são representados principalmente pela internet e sobretudo pelos aparelhos celulares portáteis.

104 Publicado em 2008, pela Ed. Perspectiva, em sua $5^{\text {a }}$ edição. Estamos apresentando as ideias, porém, de um livro que teve sua primeira publicação em 1968, época em que a sociedade de consumo na França estava em pleno desenvolvimento (um ano após a publicação de Les Choses, de Perec, que trata do mesmo tema), e que, inclusive, são análises contemporâneas a McLuhan, citado na nota anterior. Essas ideias influenciaram a geração dos anos 60 e faziam sentido ainda quando Perec fez os comentários para o documentário. Hoje, teríamos que repensar, por exemplo, a questão da miniatura dos objetos tecnológicos, visto que alguns deles são tão complexos e modernos que, muitas vezes, acabam sendo maiores que os aparelhos mais antigos. Mas aí entraríamos na discussão do objeto como algo que faz parte do cotidiano como algo indispensável, já que a partir dele desenvolvemos várias atividades do dia-a-dia e as consequências de um uso desmedido das tecnologias, como explicado na nota da página 6 , por exemplo, na obra de Pierre-Marc de Biasi, de 2018.

${ }^{105}$ Um exemplo desse uso da tecnologia contemporânea a Perec é a série de 39 fotos polaroïds tiradas por ele, na travessia realizada em um cargueiro no início dos anos 80 , da França para Nova Iorque, onde iniciaria as filmagens de Récits d'Ellis Island, obra que analisaremos com mais detalhes no quarto capítulo.
} 
revolucionário para o momento em que tais imagens foram capturadas: "Les parents, les amis, les réunions de famille, les départs, les arrivées, une partie de compagne [...] c'est tout cela, avec la caméra, que l'on va pouvoir garder" (2006, p. 75).

O verbo garder aqui nos faz pensar inevitavelmente na capacidade de guardar as memórias, de conservá-las nesta espécie de caixa mágica, a câmera portátil. Porém, para Perec, o mais importante parece não ser simplesmente a conservação destas imagens, mas acima de tudo, o olhar que daremos a elas, quando afirma: "mais avant de garder, il faut savoir regarder. Et regarder, ce n'est pas aussi simple. Et être regardé non plus. D'un côté comme de l'autre de la caméra, cinéastes amateurs et acteurs bénévoles mettent un certain temps à comprendre qu'on peut bouger, et même qu'on doit bouger, qu'il ne faut pas rester immobile" (2006, p. 75).

Perec, ao analisar estas cenas do passado, do seu passado, faz-nos refletir sobre o seu presente (ano em que escreve o comentário, 1975, quando a tecnologia já estava bem mais avançada), mas também sobre o nosso próprio presente: estamos em pleno século 21 e vivemos em uma época carregada de imagens rápidas e velocidade de comunicação.

Este trecho em que ele comenta que leva um tempo para as pessoas entenderem que devem se mexer e não permanecer imóveis, já que estão sendo filmadas, lembra-nos os movimentos de hoje, nossas fotos instantâneas, nossos risos quando vamos tirar uma foto no celular (quando ficamos todos imóveis) e depois descobrimos que estávamos filmando ao invés de fotografar, é uma situação que acontece de fato na cena do fotograma abaixo:

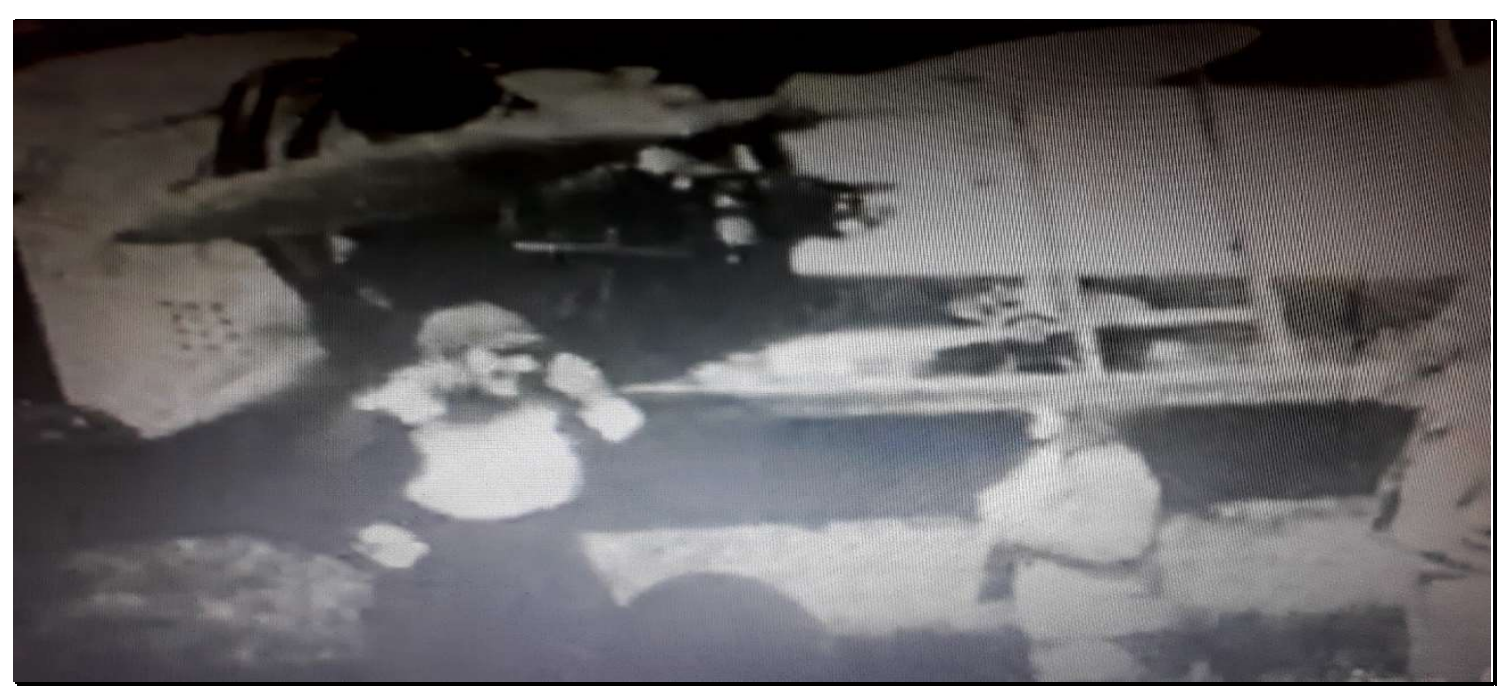


Utilizar estas pequenas câmeras nos anos 30 não era apenas como fazer o próprio cinema, era também criar memória sobre si e sua própria época. O fotograma, que representa a cena onde o comentário citado anteriormente foi feito, mostra pessoas tentando descobrir uma pose, como se fossem ser fotografadas, e assim perdendo a espontaneidade esperada para uma cena filmada.

Hoje, com nossos aparelhos eletrônicos portáteis, seguimos o mesmo fluxo de criação. É como se a evolução da tecnologia, tão presente nas nossas vidas, fossem também parte de da nossa história e da nossa maneira de lidar com o mundo ${ }^{106}$. Manipular estas máquinas e utilizá-las, deixando marcas e registros de nossa presença em áudio, vídeo ou fotos, é também uma maneira de contar nossa história. Neste caso, Perec conta uma história a partir do que vê, sem conhecer as pessoas ali apresentadas, apenas utilizando sua sensibilidade para buscar detalhes e pequenos gestos capazes de dizerem, por si só, algo sobre aquele grupo de pessoas ou sobre os lugares observados. É como se essas máquinas ou dispositivos nos transportassem, literalmente, para tempos e lugares em que não pudemos estar, que nos colocam no meio da ação, fazem-nos refletir sobre algo que não vivemos, comove-nos e nos alegra, emociona de alguma maneira: "On s'émerveille encore de ces machines mystérieuses qui ont apprivoisé la vitesse, comme on s'émerveille encore de ces autres boîtes magiques, les caméras, qui ont apprivoisé l'image et le mouvement, et les gramophones, qui ont emprisonné la voix" (2006, p. 75).

Aqui, novamente vemos as questões já discutidas nesta pesquisa, já que as caixas mágicas serão aquelas que podem conservar tanto imagem quanto movimento (talvez esta fosse a solução para a sua incessante busca da totalidade?). Além da câmera, Perec menciona os gramofones como aqueles que emprisionam a voz: seriam eles capazes de

\footnotetext{
${ }^{106}$ Na obra Pierre-Marc de Biasi, Le troisième cerveau. Petite phénoménologie du smartphone, de 2018, o autor trata das vantagens do avanço tecnológico e nos dá pistas de como será o nosso futuro a partir do uso dos aparelhos móveis: "avec la montée en puissance de l'Intelligence Artificielle et de la technologie $5 \mathrm{G}$, les dix années à venir vont donner naissance à un super Smartphone qui bouleversera encore plus profondément nos façons de vivre et de penser. Armé d'un assistant qui répondra au moindre de nos désirs, plaçant entre nos mains tous les acquis de la révolution numérique, il finira par faire de nous des sortes de simili héros dotés de superpouvoirs", ao mesmo tempo em que nos lembra que, com o uso de tais tecnologias, corremos o risco de desaprender, ou esvaziar nossa própria memória: "Mais, dans le même temps, il y a toutes les chances que ses travers d'aujourd'hui se métamorphosent en véritables difformités. Il nous a appris à désapprendre, à vider notre mémoire : il nous apprendra à réagir en assistés, à devenir totalement dépendants de ses applications ». É como se, de certa forma, estivéssemos imaginando um Perec nos dias de hoje, com todos as dificuldades de rememoração, recorrendo a tais recursos para tentar capturar todas as memórias possíveis, como ainda hoje fazemos, por exemplo, ao tirarmos uma enorme quantidade de fotografias das quais sequer nos lembramos depois, numa espécie de "fracasso" na tentativa de guardar tais memórias. $\mathrm{O}$ autor discute na obra, sobretudo, o tema aqui tratado também: "notre dévotion addictive envers l'objet fétiche de la culture numérique".
} 
dar conta de algo que nos escapa, que não conseguimos representar somente pela escrita. Façamos aqui uma pequena pausa para comentar outras questões a respeito dos objetos e tecnologias presentes em algumas destas obras de Perec, para em seguida nos determos na questão da voz propriamente dita (e seus desdobramentos diretamente ligados à tecnologia).

\subsection{Os objetos e a tecnologia}

De certa forma, os objetos tecnológicos e a maneira como aparecem na obra de Perec provocam certa reflexão, já que são o retrato de uma época, um traço de lembrança descrito e anotado em outros diferentes projetos. Assim como fica evidente em La vie filmée uma França que está em processo de modernização (com suas câmeras, carros, trens e aviões), em outros momentos de sua obra Perec parece desejar esboçar um retrato da sociedade a partir destes objetos que observa. Se em La vie filmée Perec se depara com objetos já antigos (as imagens são da década de 30-40), o efeito provocado por estes objetos em sua descrição, nos comentários, parece nos levar de volta no tempo: numa tentativa de captar este tempo que passou (e do qual não tem lembranças), Perec se ancora nestes objetos como espécies de relíquias a serem admiradas e cultivadas, no sentido proposto por Jean Baudrillard: os objetos antigos causam certo fetiche, nosso desejo vem mesmo do fato de terem existido antes de nós, já que "simbolizam uma transcendência interior, o fantasma de um núcleo de realidade de que vive toda a consciência mitológica e individual - fantasma da projeção de um detalhe que vem a ser o equivalente do eu e através do qual se organiza o resto do mundo" (2008, p. 87.)

Os textos de Perec podem ser, de certa forma, uma coleção de objetos fetichizados, principalmente se pensarmos no formato dos Je me souviens: um inventário de lugares, pessoas e objetos que pertencem a uma época que já passou, uma tentativa de criação de memória coletiva que substitua as lembranças individuais (poucas ou escassas). Assim, Perec cria esse jogo de dividir com o leitor a satisfação de reconhecer objetos ou marcas de determinada época que podem ser lidos e reconhecidos por toda uma geração.

Mas sabemos que as descrições de Perec não são apenas sobre objetos e questões ligadas ao passado; ao contrário, ele usa o procedimento do inventário do cotidiano seguindo o movimento contrário do tempo: guardar, inventariar, classificar e anotar o maior número possível de informações para preservar um presente do qual não quer se 
esquecer, numa tentativa de construção de sua própria “cápsula do tempo" para as futuras gerações.

A descrição de objetos tecnológicos que marca a passagem do tempo estará presente em várias obras de Perec, como espécies de inventários de uma época. Poderíamos pensar no próprio Les Choses, primeira obra publicada de Perec, como um romance escrito a partir da descrição de objetos, e que acabou sendo considerado como uma obra crítica ao consumismo da França nos anos 60. Seguindo a linha das listas e inventários, muito recorrentes nos projetos de escrita de Perec, percebemos que a obsessão de anotar e listar tudo que o cerca (com o objetivo de capturar o tempo e, ao mesmo tempo, criar sua produção literária a partir destes inventários) será um procedimento fundamental para criar esta espécie de "inventário do infraordinário", ou seja, um inventário daquilo que nos escapa e que passa despercebido na nossa vida cotidiana.

Annie Ernaux, num texto sobra a obra de Perec ${ }^{107}$, escreve de maneira contundente sobre a produção perecquiana, como uma espécie de sintoma daquilo que vivemos na nossa atualidade; para ela, Perec escreve numa "tentativa de esgotar o real em sua totalidade - a linguagem inclusa - e de colocá-lo em ordem, classifica-lo interminavelmente, mas sem jamais descobri-lo, dar a ele outro sentido além do que está lá". Além disso, ela acrescenta que essa escrita é uma espécie de “construção/desconstrução", única maneira encontrada por Perec de dizer a história de si, "de tirar do vazio a sua existência e a dos seus", ao mesmo tempo em que inaugura "uma outra maneira de falar sobre si: "ele alargou, como ninguém antes, o campo da autobiografia" (2016, p. 100).

Esta acumulação de descrições de objetos aparentemente sem grande utilidade é parte deste grande projeto de fixar o tempo e guardar as memórias. Assim, como veremos, a obra de Perec será construída a partir da descrição de objetos antigos, que marcam uma época (como no caso dos comentários para o filme La vie filmée, por exemplo, ou nas 480 lembranças enumeradas na obra Je me souviens), assim como na descrição e acumulação de objetos que fazem parte do presente, para que funcionem também como objetos a serem lembrados no futuro (as obras Tentative de description des choses vues au Carrefour Mabillon e Tentative d'épuisement d'un lieu parisien são aquelas que mais representam esse procedimento, assim como o próprio projeto Lieux).

\footnotetext{
${ }^{107}$ No texto “Rien, dans l'œuvre de Perec, n'est étranger à mes propres préoccupations d'écriture". Em Perec, Éd. de L’Herne, 2016.
} 


\subsubsection{Inventários, listas e objetos tecnológicos}

Pensando num inventário da obra de Perec que pudesse, de certa forma, ilustrar esta obsessão por descrever objetos e, principalmente, objetos tecnológicos que trazem consigo esta marcação temporal (modelos de carros, por exemplo), anotamos a seguir alguns excertos de Je me souviens ${ }^{108}$ e de Tentative d'épuisement... A partir destes trechos, podemos observar a incidência de descrições de carros, ônibus turísticos ou outros meios de transporte que poderiam ser vistos na Paris da época, em constante movimento. Interessante pensar no procedimento de escrita de Je me souviens em relação ao filme La vie filmée: se, no primeiro caso, as memórias individuais e autobiográficas fazem alusão a uma memória coletiva da época, no filme, as memórias coletivas registradas por anônimos ajudam Perec a refletir sobre a própria memória individual. Je me souviens é uma rememoração de lembranças individuais que trazem consigo as memórias coletivas da época à qual ele pertenceu, e o inventário de automóveis é algo muito presente entre as lembranças evocadas:

\begin{tabular}{|c|}
\hline $\begin{array}{l}\text { 2-Je me souviens que mon oncle avait une } 11 \mathrm{CV} \text { immatriculée } 7070 \\
\text { RL2 P. } 799\end{array}$ \\
\hline $\begin{array}{l}\text { 51-Je me souviens des autobus à plate-forme : quand on voulait } \\
\text { descendre au prochain arrêt, Il fallait appuyer sur une sonnette, mais ni } \\
\text { trop près de l'arrêt précédent, ni trop près de l'arrêt en question p. } 807\end{array}$ \\
\hline $\begin{array}{l}\text { 246- Je me souviens que Citroën utilisa la tour Eiffel pour une } \\
\text { gigantesque publicité lumineuse. } 838\end{array}$ \\
\hline $\begin{array}{l}471 \text { Je me souviens des voitures américaines: les "DeSoto", les } \\
\text { “Studebaker”, les "Pontiac", les “Oldsmobile”, les “Chevrolet”, les } \\
\text { "Packard”, et les V8 que l'on appelait ainsi parce qu'elles avaient "huit } \\
\text { cylindres en v". } 874 \text {. }\end{array}$ \\
\hline
\end{tabular}

\footnotetext{
${ }^{108}$ Todos os excertos referentes a Je me souviens apresentados nas tabelas contêm dois números: o primeiro indica a ordem numérica dos próprios Je me souviens, enquanto o segundo indica a página, a partir da edição Oeuvres, vol I., Gallimard, 2017.
} 
No caso de Tentative d'épuisement..., a descrição é feita na Paris em movimento e a quantidade de carros, outdoors, propaganda e grandes marcas é bastante expressiva, como também veremos em Tentative des choses vues au Carrefour Mabillon:

\begin{tabular}{|l|}
\hline Un car “Cityrama” à deux étages (p. 823) \\
\hline Les phares seuls signalent le passage des voitures (p. 841) \\
\hline Un car : "Percival Tours" (p. 844) \\
\hline Cityrama : une Japonaise absorbée dans ses écouteurs (p. 849) \\
\hline Car Paris-Vision (p. 851). \\
\hline
\end{tabular}

Descrever os ônibus turísticos, observar suas marcas, além dos carros (que em Mabillon terá inventários exaustivos, como veremos mais tarde) será também a estratégia de escrita de Tentative d'épuisement..., relembrando a importância da descrição como maneira de dar um novo sentido ao cotidiano, conforme a célebre reflexão de Perec publicada no texto "Approches de quoi?"109:

Descreva sua rua. Descreva uma outra. Compare.

Faça o inventário de seus bolsos, de sua bolsa. Interrogue-se sobre a proveniência, uso e sobre o futuro de cada um dos objetos que retirou de lá.

Questione suas pequenas colheres.

O que há sob seu papel de parede?

Quantos gestos são necessários para discar um número de telefone? Por quê?

Por que não encontramos cigarros nas mercearias? Por que não?

A mim importa pouco o que sejam essas questões, aqui, fragmentárias, pouco indicativas de um método, no máximo de um projeto. Importa para mim que pareçam triviais e fúteis: é precisamente o que as torna tão, se não mais, essenciais que tantos outras através daquelas tentamos em vão capturar nossa verdade. (PEREC, 1985, pp. 12-13) $)^{110}$

\footnotetext{
${ }^{109}$ Publicado em Penser/Classer, em 1985. O texto publicado em sua versão integral, será disponibilizado na seção "Apêndices", já que representa uma reflexão importante sobre todas as questões levantadas na pesquisa.

110 Décrivez votre rue. Décrivez-en une autre. Comparez.

Faites l'inventaire de vos poches, de votre sac. Interrogez-vous sur la provenance, l'usage et le devenir de chacun des objets que vous en retirez.

Questionnez vos petites cuillers.

Qu'y a-t-il sous votre papier peint?

Combien de gestes faut-il pour composer un numéro de téléphone ? Pourquoi ?

Pourquoi ne trouve-t-on pas de cigarettes dans les épiceries ? Pourquoi pas?

Il m'importe peu que ces questions soient, ici, fragmentaires, à peine indicatives d'une méthode, tout au plus d'un projet. Il m'importe beaucoup qu'elles semblent triviales et futiles : c'est précisément ce qui les rend tout aussi, sinon plus, essentielles que tant d'autres au travers desquelles nous avons vainement tenté de capter notre vérité.
} 
Será, então, a descrição exaustiva da place Sant-Sulpice, do Carrefour Mabillon e de tantos outros lugares aqui já citados, uma vã tentativa de captar nossa "verdade"? Que resultados podem ser percebidos a partir dessa busca incessante de Perec? Como podemos inferir o sentido de "verdade" a partir das reflexões apresentadas? Simplesmente mudando a nossa maneira de olhar para o que já está posto, procurando outros possíveis ângulos, questionando nossos gestos cotidianos e, por que não, nosso movimento de produção, seja ela literária ou não. O que eu observo e posso transformar, a partir do meu olhar? O que vejo no meu texto, ou em outros textos, que podem ser uma espécie de reflexão sobre uma possível verdade, já que intrinsecamente ligada à nossa própria vida? Onde está a "verdade", a não ser na vida banal e cotidiana que nos cerca, para todos os lados que olhamos?

Podemos pensar no projeto Tentative d'épuisement d'un lieu parisien como uma espécie de fechamento, de encerramento definitivo do projeto Lieux, da maneira como foi concebido originalmente, e que deu origem a tantos outros projetos, como já dito inúmeras vezes aqui. O curioso desse projeto específico é que recria fielmente o procedimento de escrita de Lieux, mas com a regra do tempo muito mais definida: apenas durante três dias (entre 18, 19 e 20 de outubro de 1974, como já explicamos no capítulo I.), alterando completamente a contrainte de doze anos estabelecida por Lieux.

Por ter sido escrita num curto período de tempo, a obra em questão passa inclusive uma falsa ideia de "trabalho cumprido", contrariamente ao que aconteceu com o projeto original, Lieux. A data da escrita também dá sinais evidentes de que seja uma última tentativa de fixar algo, mesmo que num período de tempo condensado. Lembramos que, a partir de 1975, Perec abandona definitivamente as visitas aos doze lugares. Sendo assim, podemos pensar na relevância de Tentative d'épuisement... como um projeto ao mesmo tempo derivado e condensado do anterior, na impossibilidade iminente já imaginada por Perec de dar continuidade à sua aventura inicial de registro de envelhecimento do tempo.

Tendo acesso recente a um áudio em que Perec descreve Tentative d'épuisement. ${ }^{111}$ como uma espécie de fechamento de Lieux, foi possível confirmar a nossa hipótese, no que se refere à continuidade e à transformação dos projetos. No link

\footnotetext{
${ }^{111}$ Para ouvir o áudio em que Perec levanta tais questões em relação ao projeto Lieux, seu desenrolar e sua transformação em outros projetos, basta clicar aqui.
} 
do áudio disponibilizado a seguir, podemos entender que escrever em poucos dias algo que estava programado para anos foi uma espécie de reformulação de Lieux, o que já vinha sendo aqui defendido. Vale também ressaltar outra fala de Perec, sobre a importância de Lieux para a escrita de $W$ (como já analisamos no capítulo anterior), visto que ele afirma ter retirado as fotos da rue Vilin de seus envelopes para auxiliá-lo no momento da escrita das memórias da infância. Como Tentative d'épuisement... foi publicado também em 1975, parece-nos se tratar da maneira encontrada para atravessar essa barreira, pôr um fim no projeto e iniciar os outros que estavam em fase de transformação e encerrar esse ciclo com a sensação de ter deixado ao menos algo "concluído, acabado", mesmo que isso seja bastante improvável em Perec, já que sabemos que há diversos projetos simultâneos, não publicados, em suspenso, durante o seu trabalho de escrita, sempre heterogêneo.

\subsubsection{Objetos como representantes de uma época, de uma memória}

Interessante pensar que Perec, curioso e observador dos carros (a descrição deles parece excessiva, em vários textos, em vários momentos), nunca dirigiu seu próprio automóvel e sempre preferiu andar pelas ruas de Paris. Se seguirmos a explicação de Baudrillard pelo fascínio exercido pelos carros (o crítico afirma que a posse do automóvel significa uma espécie de "diploma de cidadania", ou uma "credencial de nobreza mobiliária”), deparamo-nos com duas características que parecem não combinar em nada com um Perec que não se sente "em casa" em lugar algum, estrangeiro em qualquer lugar aonde vá ${ }^{112}$. Podemos pensar que ele talvez encontre um pouco deste sentimento de cidadania não em possuir um carro, mas em observá-los e entendê-los como integrantes daquela sociedade, cabendo a ele retratar a época a partir destes modelos de luxo e velocidade que estão no imaginário da população.

\footnotetext{
${ }^{112}$ Afirmação com base em vários depoimentos de Perec e na própria história de vida, marcada por questões de tensão entre o fato de ter nascido em família judaica e ter sido adotado e criado a partir da tradição cristã.
} 


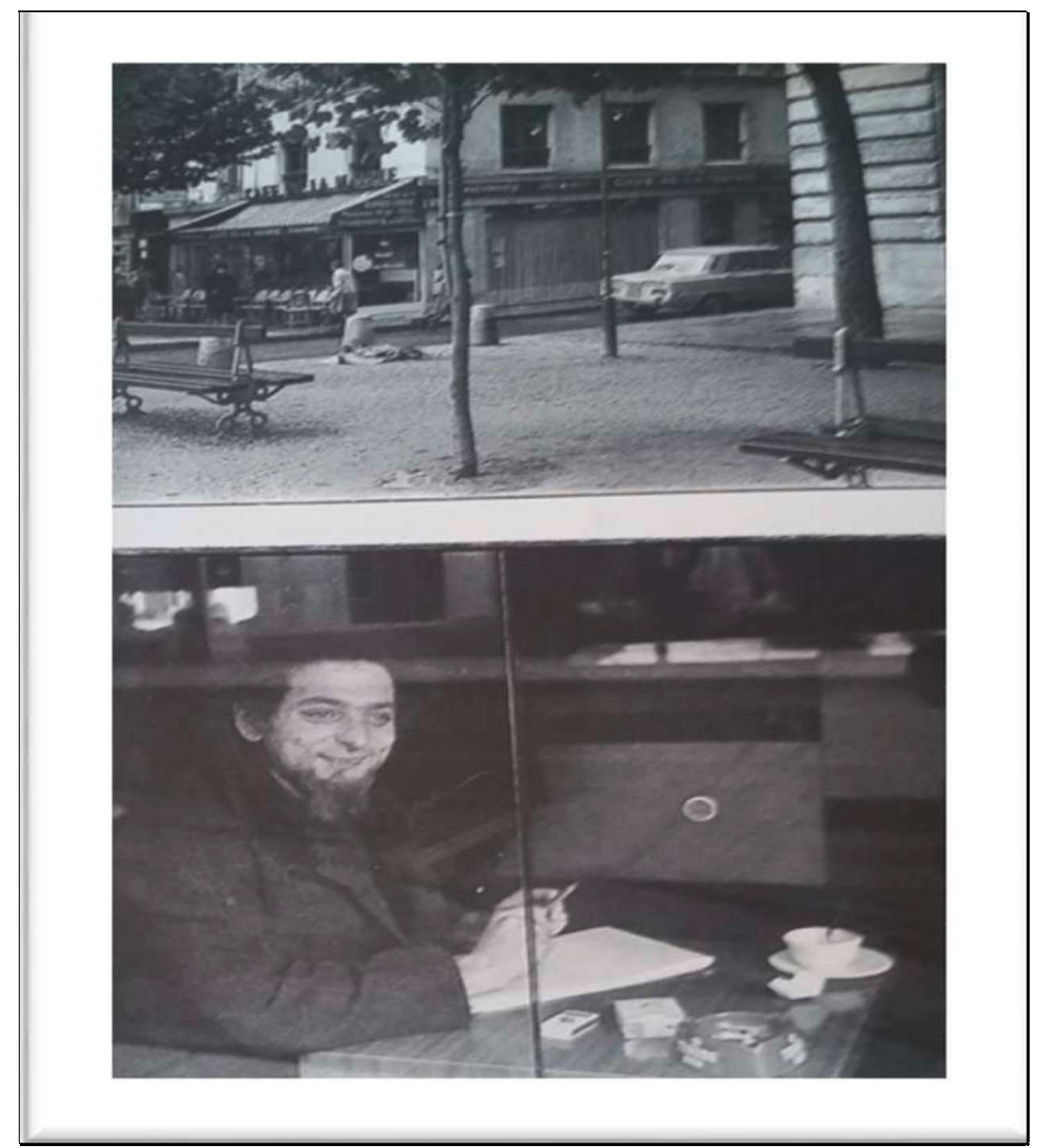

Figura 23. Georges Perec no Café de la Mairie, place Saint-Sulpice. Fonte: Album Georges Perec, 2017, p. 126.

Enumerar esses carros em locais públicos, observá-los e produzir literatura a partir destas descrições será para Perec o seu verdadeiro "diploma de cidadania” e não propriamente a posse do objeto.

Ele não apenas observa carros, mas nos mostra nomes de empresas, endereços, e outras marcas que nos fazem pensar na questão da tecnologia, do progresso, da sociedade em movimento e na velocidade das transformações. Sob a perspectiva de Barthes, em seu texto Mythologie de l'automobile ${ }^{113}$, podemos pensar que em 1963, ano em que foi escrito, já não existia um grande fascínio pelo carro, visto mais como mais um objeto doméstico, deixando seu status social para dar conta apenas das necessidades, tornandose assim um objeto banal, presente no cotidiano, ainda que de alto valor e não consumido

\footnotetext{
${ }^{113}$ Euvres Complètes, Vol, II, Éd. du Seuil, 2002, pp. 234-242. Não podemos deixar de mencionar, também, a importância da leitura das obras de Barthes para a própria escrita de Perec; aluno de alguns seminários, Perec muito provavelmente se inspirou nos escritos de Mythologies para a escrita do seu primeiro livro publicado, Les Choses, assim como pôde aproveitar as aulas do Cours de Linguistique e o seminário sobre a retórica para se inspirar em muitas de suas experimentações literárias.
} 
por toda a sociedade: "l'auto a cessé de fonctionner comme un signe de standing social: elle n'est plus ouvertement um objet de classe ou de promotion; l'homme ne peut plus investir sa vanité dans un instrument dont le projet d'achat est à peu près universel", e completa, colocando o carro na categoria de objeto de massa: "devenu objet de masse, l'auto cesse d'exciter, du moins en soi, une psychologie de la distinction: l'objet lui-même est devenu socialement neutre, il n'affiche plus".

Talvez essa reflexão ainda não esteja tão arraigada no pensamento de Perec, que, dois anos após o texto de Barthes, publica Les Choses, que não deixa de ser um livro crítico à sociedade de consumo da época. Já no momento em que descreve Paris, a partir dos projetos que estamos aqui analisando, Perec provavelmente já esteja imbuído desse pensamento, de uma mudança no status do automóvel, de objeto de desejo a apenas um objeto banal, do cotidiano. Nada mais coerente, então, que listar aquilo que parece existir de mais banal num cenário de grandes cidades. Qual o objetivo de enumerar modelos, marcas e quantidades de carros que passam a sua frente? O que há de especial nesses objetos, tão obsessivamente observados por Perec?

Menos o status social e, possivelmente, mais uma marca temporal e (por que não) uma reprodução fiel de uma sociedade que está em constante movimento, cada um dentro de sua própria máquina, da forma mais banal e cotidiana possível. Inclusive o próprio observador, Perec, conta com um automóvel (uma van) para se posicionar estrategicamente e poder realizar seu trabalho sem que pudesse ser observado, de certa forma. Ele é então um voyeur urbano, interessado sobretudo em captar aquilo que está ali todos os dias, e que passa com toda a velocidade sob seus olhos atentos e ávidos pela narração, pelo registro e pela produção dos inventários. Alguns outros dos seus Je me souviens, selecionados abaixo, nos trazem essa ideia das memórias relacionadas ao progresso: cinema, eletricidade, programas de rádio, anúncios publicitários:

129- Je me souviens qu'à Michel-Ange-Auteuil, là où il y a aujourd'hui
un Monoprix (ou n Prisunic), i y avait autrefois un cinéma. 819
325- Je me souviens de la grande panne d'électricité qui plongea New
York dans l'obscurité pendant plusieurs heures ${ }^{114} .851$

\footnotetext{
${ }^{114}$ Nas notas da obra diz-se que este fato ocorreu em 1965 (Oeuvres, Gallimard, 2017, vol. I, p. 1113).
} 


$\begin{aligned} & \text { 339- Je me souviens des programmes de radio (Comme il vous plaira) } \\ & \text { présentés par Jean-Pierre Morphée }{ }^{115} \text { et? } 854\end{aligned}$
$\begin{aligned} & \text { 413- Je me souviens de l'émission de radio du jeudi Les jeunes Français } \\ & \text { sont musiciens } 865\end{aligned}$
$\begin{aligned} & \text { 423- Je me souviens des publicités phosphorescentes pendant l'entracte } \\ & \text { au cinéma Royal-Passy } 866 .\end{aligned}$

$\mathrm{Na}$ imagem da próxima foto, vemos a adaptação do texto de Perec para o teatro, encenada por Sami Frey: há apenas um objeto como cenário (bicicleta), e a voz como instrumento de transformação do texto (a descrição, aqui no caso, a leitura dos 480 'Je me souviens' que causa uma espécie de vertigem no espectador), assim como no leitor, como nos lembra Burgelin em entrevista à Radio France Culture ${ }^{116}$, tratando especificamente das descrições e classificações dos lugares feitas no livro Espèces d'espaces que, segundo o crítico, é "le plus charmant livre de Perec".

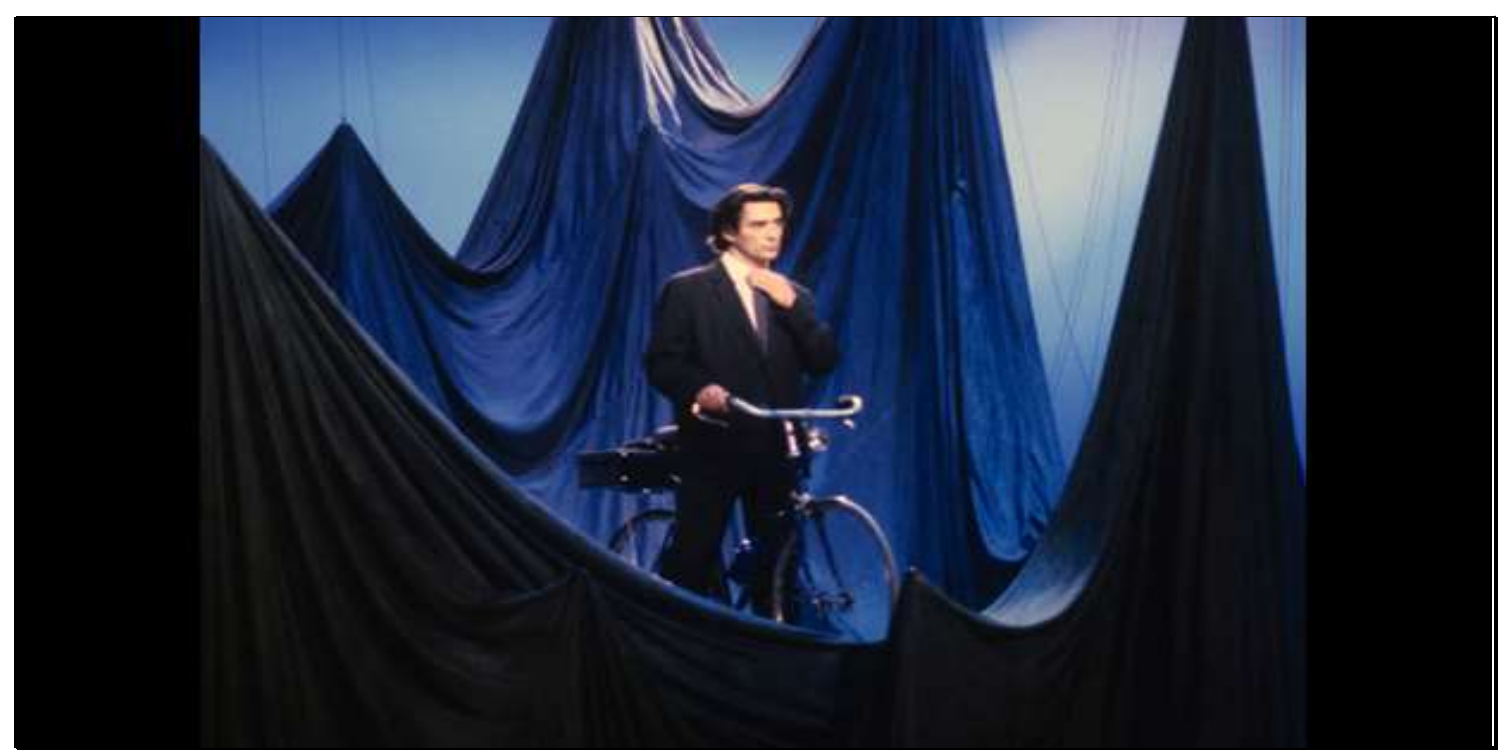

Figura 24. Fotograma do vídeo de Je me souviens produzido em 1990 pelo Institut National de L'Audiovisuel (INA), disponivel em: https://www.ina.fr/video/CPC90009080.

\footnotetext{
${ }^{115}$ A nota da edição Oeuvres diz que o nome correto do locutor é Pierre Morphé. Este é um dos trechos que mostram exatamente que Perec optou por deixar a frase incompleta, atestando assim a inexatidão ou falha de sua memória para completar a informação.

${ }^{116}$ A parceria começou com o próprio Perec, como vemos no artigo "Radio Perec", citado na próxima nota com referências completas, que explica, na p. 148: "Perec fut un compagnon de route ponctuel mais bien présent des émissions de Bertrand Jêrome, le grand inventeur de jeux radiophonico-littéraires sur France Culture et promoteur des jongleurs de mots de son époque à travers des émissions multiformes comme $\mathrm{Mi}$ fugue mi-raisin, Allegro ma non troppo, Le Cri du homard, Des Papous dans la tête...", nos anos 80, conforme alguns exemplos que aparecerão no corpo do texto.
} 
Nessa mesma entrevista, Burgelin relembra uma célebre frase de Perec, "pour être, besoin d'étai", do livro $W$ ou le souvenir d'enfance, seguido da explicação: "o suporte para existir, em Perec, encontra-se nos lugares”. E, assim como estes são inclassificáveis, a tentativa realizada em Espèces d'espaces também produzirá um livro inclassificável, já que passível de muitas dúvidas e questionamentos que, por isso, tornam-no tão interessante. Ainda segundo Burgelin, os espaços de Perec são frágeis e se opõem à ideia de lugares felizes de Bachelard (estáveis). Assim, se Espèces d'espaces é um "journal d'un usager de l'espace", devemos pensar em como entender o espírito de um lugar ou do espaço em geral. Burgelin acrescenta ainda que todos os lugares (ele cita Tentative d'épuisement e Carrefour Mabillon como exemplos) são impossíveis de esgotar, já que tudo que se observa é sempre sob um ponto de vista limitado; se se olha distraído para o lado algo já se perdeu. $\mathrm{O}$ fato de esses lugares serem inesgotáveis é que gera uma espécie de "opacidade" do cotidiano e, consequentemente, esta inquietação em interrogá-lo, fazendo com que Perec se torne um explorador, a fim de chegar à conquista do espaço. Curioso pensar em uma entrevista (sonora) incorporada à minha escrita, assim como também notar a quantidade de entrevistas e programas de rádio, em episódios dedicados à discussão da obra de Perec no site da rádio francesa. Essas discussões, juntamente com todas as reflexões sobre a tecnologia realizadas até aqui, fizeram-me pensar na questão da $v o z$ de Perec como um componente importante da sua produção literária.

\subsection{A tecnologia na voz de Perec: o texto que passa a ser som}

Em se tratando de produções sonoras, podemos afirmar que a voz terá papel fundamental em alguns projetos de Perec, incluindo na lista a própria obra com que iniciamos essa seção, La vie filmée: o texto de Perec é lido e, portanto, sua voz está presente em conjunto com as imagens do documentário. Há, portanto, obras exclusivamente sonoras, como é o caso de Tentative de description des choses vues au Carrefour Mabillon. Além desse trabalho, há inúmeras gravações de entrevistas onde a voz do autor se faz presente, deixando sua marca, sua identidade e o traço, vestígio de um tempo passado. Um outro exemplo a ser destacado, entre estas produções, é a gravação "Les 50 choses à ne pas oublier de faire avant de mourir", fatidicamente realizada pouco antes da sua morte, e que foi publicada postumamente na coletânea Je suis né, em 1990. 
É importante destacar que, antes de um produtor de material sonoro, Perec foi um voraz ouvinte de programas de rádio. Vale lembrar que, só entre os Je me souviens, há 21 deles que se referem ao rádio; alguns aparecem nos trechos destacados mais acima e que, além disso, o próprio texto dos Je me souviens foi gravado para ser difundido em episódios, no período compreendido entre fevereiro e maio do ano de 1980. Em artigo dedicado ao assunto ${ }^{117}$ e que traz estas informações, identificamos alguns programas favoritos de Perec e como eles influenciaram, de certa forma, sua escrita. Um exemplo é o programa de aventuras "Signé Furax"118 - programa de rádio criado por Francis Blanche e Pierre Dac, difundido no período de 1951 a 1960 -, que foi referência para a escrita de um programa sonoro em 1970, em forma de folhetim e, indiretamente, pode ter influenciado na escrita de $W$ ou le souvenir d'enfance, também iniciado sob a forma de folhetim (como veremos a seguir), com a diferença de ser escrito e não sonoro. Podemos inferir a importância do programa radiofônico por ter sido citado em dois dos Je me souviens publicados por Perec ${ }^{119}$. Sobre o folhetim escrito por Perec, podemos observar:

Perec escreveu em 1970 um folhetim radiofônico de 165 episódios para a rádio Abidjan [...] Trata-se das Extraordinárias aventuras do Sr. Eveready (nome da empresa de pilhas elétricas que financiou a produção). [...] quanto ao estilo radiofônico, só podemos pensar em Signé Furax (folhetim citado duas vezes em Je me souviens). (CHRISTOFFEL; BAUMGARTNER, 2016, p. 145)

Parece muito anedótico descobrir que Perec criou um folhetim radiofônico patrocinado pela empresa de pilhas Eveready, no momento em que estamos discutindo sobre objetos de tecnologia! Nada mais simbólico para pensar nesta questão da passagem

\footnotetext{
${ }^{117}$ Artigo "Les cocotiers sont arrivés", Radio Perec, de David Christoffel e Thomas Baumgartner, em Perec, Éd. de L'Herne, 2016, pp. 142-153.

${ }^{118} \mathrm{O}$ texto da série radiofônica, predominantemente de aventuras e peripécias (uma das leituras preferidas de Perec quando ainda jovem) foi importante influência no seu estilo de escrita, sobretudo em $W$ ou a memória da infância, seu primeiro livro autobiográfico, e ainda em 53 jours, último livro escrito e publicado, parcialmente finalizado, devido à morte precoce do autor.

${ }^{119}$ No primeiro, de número 21, ele compara um slogan de outro programa com aquele de Furax: "Je me souviens de 'Grégoire et Amédée présentent Grégoire et Amédée dans Grégoire et Amédée' (et de Furax aussi, bien sûr", fazendo referência primeiramente às esquetes de Roland Dubillard e Philippe de Chérisey (Nota nas Oeuvres, vol, I, Gallimard, 2017, p. 1105). A segunda referência à Signé Furax, está no Je me souviens de número 345: "Je me souviens que la mise en ondes de Signé Furax et de quelques autres émissions 'burlesques' était de Pierre Arnaud de Chassis-Poulet". A nota da p. 1113, no entanto, afirma que o nome correto do artista, que criou efeitos sonoros para o programa, é Pierre-Arnaud de ChassyPoulay, que não confere com o nome publicado nem tampouco com o nome existente nos manuscritos de Je me souviens ("Pierre-Arnaud de Chassy-Poulet").

${ }^{120}$ Perec écrit em 1970 um feuilleton radiophonique de 165 épisodes pour la radio ivoirienne RadioAbidjan. [...] Il s'agit des Extraordinaires aventures de Mr. Eveready (du nom de la firme de piles électriques qui finance la production) [...] quanto au style radiophonique, on ne peut que penser à Signé Furax (feuilleton cité deux fois dans Je me souviens).
} 
do tempo que vem sido retomada o fato de que, em algum momento, a pilha foi algo realmente inovador...

Também parece ainda mais anedótico descobrir que o protagonista do programa patrocinado pela empresa de pilhas (Mr. Eveready $)^{121}$ é um herói meio sobrenatural que se "materializa" através de um som abafado (uma voz) e que fala a partir de um rádio de um avião abatido. São ideias um tanto quanto inverossímeis. Em algum momento da trama, também aparecem espécies de homens-rã, que conversam numa linguagem incompreensível e que são chamados de "Oulipiens" pelo protagonista. Assim, o Oulipo se transforma em um país (Oulipie), e seus habitantes são todos considerados selvagens. Estas aventuras inverossímeis nos fazem pensar no folhetim produzido quinzenalmente e que deu origem ao livro autobiográfico $W$ ou le souvenir d'enfance - ambos foram escritos à mesma época (1970) -, um texto para a rádio e outro para a revista quinzenal, sendo compostos por aventuras e trazendo questões inverossímeis para as narrativas.

Afinal, Perec entende que, no rádio, tudo é possível. Isso também pode se comprovar a partir da emissão já mencionada, "50 choses à ne pas oublier de faire avant mourir". Na lista, composta por alguns desejos meio inverossímeis e outros possíveis, percebemos o mesmo formato bastante utilizado por Perec, em especial na escrita dos seus Je me souviens. Se compararmos a emissão de rádio das "50 choses" com o texto publicado $^{122}$, podemos verificar que a lista se expande, servindo apenas como uma referência para a leitura. No momento em que Perec diz, ele acrescenta detalhes que não estão na escrita, brinca com os apresentadores do programa, acrescenta fatos, faz comentários rápidos ou hesita frequentemente. Todos estes detalhes daquilo que está gravado e que pode ser ouvido (através da sua voz) se perdem um pouco no momento em que apenas o texto-base (usado como guia de leitura para as falas no rádio) segue para publicação. Vejamos um trecho em que há a transcrição do texto publicado postumamente, em $1990^{123}$ (e que serviu como esse possível guia de leitura para o programa de rádio), intercalado com a transcrição sonora, a partir da gravação disponível

\footnotetext{
${ }^{121}$ Material disponível na Bibliothèque de l'Arsenal, onde existe um texto datilografado original, sob a cota número 103 do Fonds Perec. Na biografia de Perec, escrita por David Bellos, consta a informação que o programa foi difundido de segunda a sábado pela Rádio Abidjan, da metade de abril até o final de outubro de 1970 (BELLOS, 1994, p. 755).

${ }^{122}$ A versão integral contendo as 37 coisas (propositalmente interrompidas e não as 50 , como informa o título), será disponibilizada na Seção "Apêndices".

${ }^{123}$ Trechos extraídos das páginas 12-13 da edição de Je suis né.
} 
no site da Rádio France Culture ${ }^{124}$, difundida pela primeira vez no programa "Mi-fugue mi raisin", em 14 de novembro de 1981, quatro meses apenas antes de sua morte, em março de 1982:

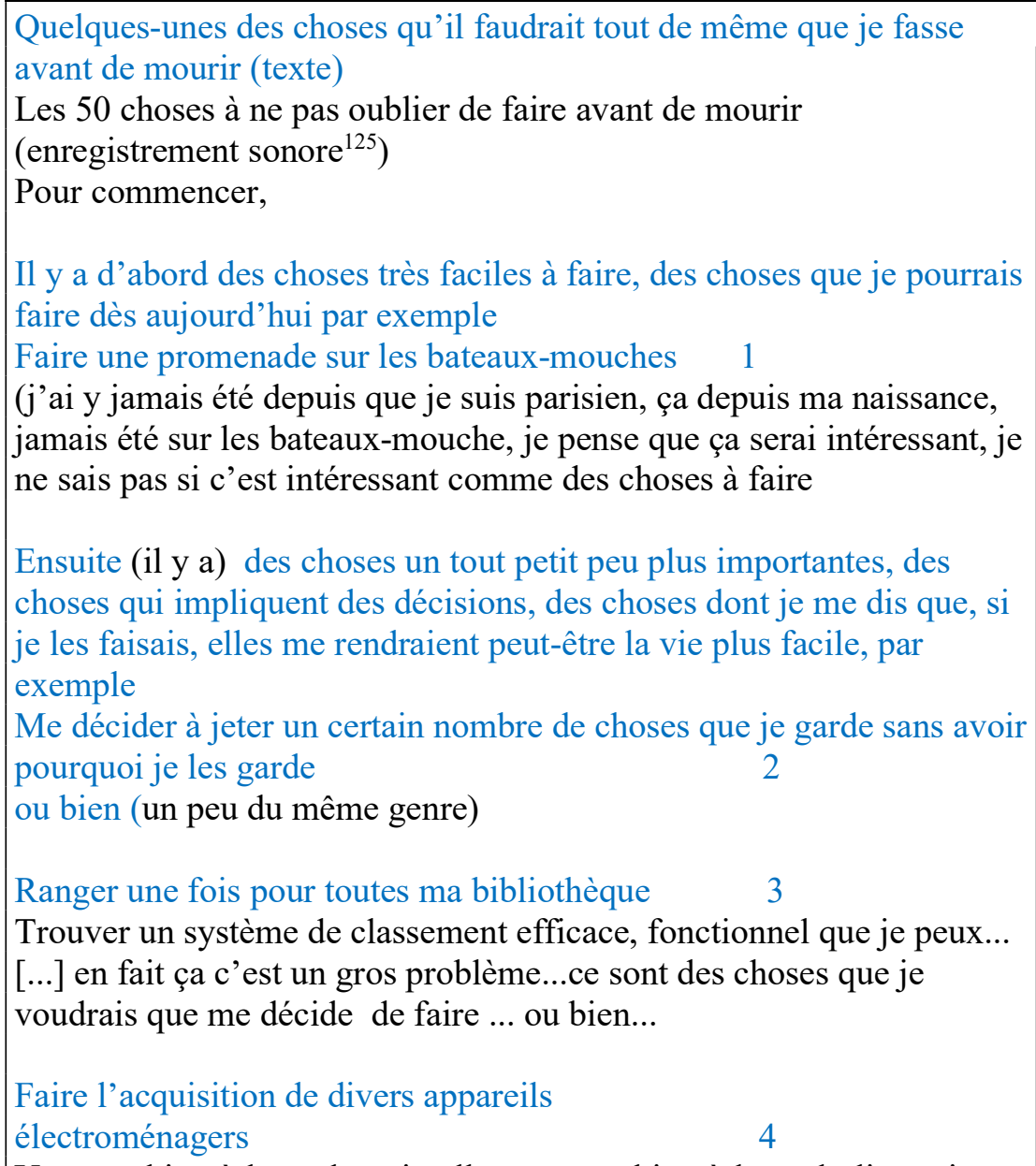

Une machine à laver la vaisselle, une machine à laver le linge, je me suis servi recentment pour la premr à la première fois de ma vie à une machine à laver le linge...

ou encore

M'arrêter de fumer

(avant d'y être obligé...)

5

ou bien encore, ça c'est un peu... je ne sais pas si c'est une chose que je souhaite faire, disons que $\mathrm{j}$ 'aimerais la faire avant que m'y oblige, m'arrêter de fumer.. je veux dire, le jour viendra, je suppose, un médecin me dira, malheureusement, " désormais, finis de fumer"

\footnotetext{
${ }^{124}$ A partir do link a seguir: https://www.franceculture.fr/emissions/les-nuits-de-france-culture/les-50choses-ne-pas-oublier-de-faire-avant-de-mourir-selon.

${ }^{125} \mathrm{O}$ texto em azul refere-se à cópia do que foi publicado, enquanto que os trechos em preto são as transcrições da gravação disponível no site. A escolha por intercalar as cores funciona como maneira de verificar as diferenças entre as duas versões.
} 


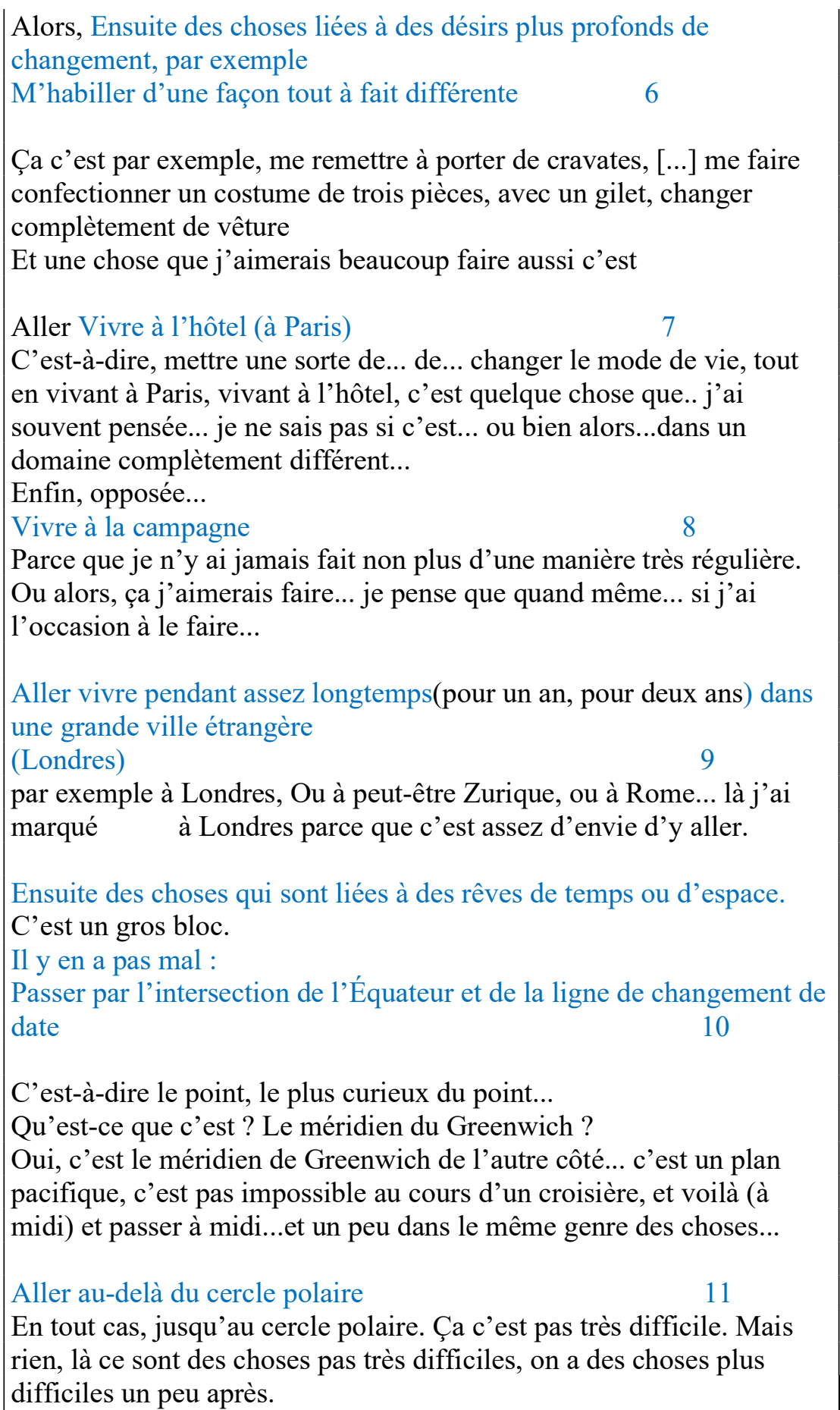

Fica mais fácil, a partir da transcrição entre texto escrito e falado, observarmos que as reações espontâneas e comentários a partir do texto-base foram essenciais para a criação de um texto sonoro, muito mais criativo, enriquecido pelas ideias no momento do que estava sendo dito, transformando o texto escrito em algo maior, em pleno trabalho de expansão, até porque o projeto era, desde o início, produzir um material sonoro, tendo o texto escrito apenas como base para o início das conversas. 
É curioso pensar que uma das coisas que Perec elencava como devendo serem feitas antes de morrer (deixar de fumar) tenha sido exatamente o motivo de sua morte (câncer de pulmão, quatro meses depois), como se ainda houvesse muito tempo para que isso se realizasse: "um dia algum médico me dirá que infelizmente preciso parar de fumar”, diria Perec, desconhecendo, talvez, que já estava acometido pela doença causada pelo excesso de fumo.

As experiências que viriam na sequência da transcrição acima, todas ligadas a deslocamentos espaciais, chamam atenção justamente por serem classificadas por Perec como aquelas mais difíceis de serem realizadas (como se mudar hábitos de vestimenta ou deixar de fumar fossem atitudes mais simples).

Nenhuma das primeiras resoluções parecem tão simples, já que entraram para uma lista de planos, mais ou menos como fazemos a cada passagem de ano novo, com resoluções que nos parecem bastante difíceis de cumprir. Aquelas que Perec considera ações difíceis de serem realizadas são coincidentemente ligadas a deslocamentos espaciais, ou seja, ajudam inclusive a confirmar mais uma vez essa importância do tema do espaço no âmbito pessoal e artístico de Perec, que poderia mesmo considerar tais deslocamentos como motivações para futuros projetos em diferentes suportes ou formatos. Seguem as experiências listadas, que são sequência do trecho anterior transcrito:

\begin{tabular}{|l|}
\hline Vivre une expérience hors du temps, \\
Faire une voyage en sous-marin, \\
Faire un long voyage sur un navire, \\
Faire une ascension ou un voyage en ballon ou dirigeable, \\
Aller aux îles Kerguelen (ou à Tristan da Cunha) \\
Aller du Maroc à Tombouctou à dos de chameau en 52 jours.
\end{tabular} 


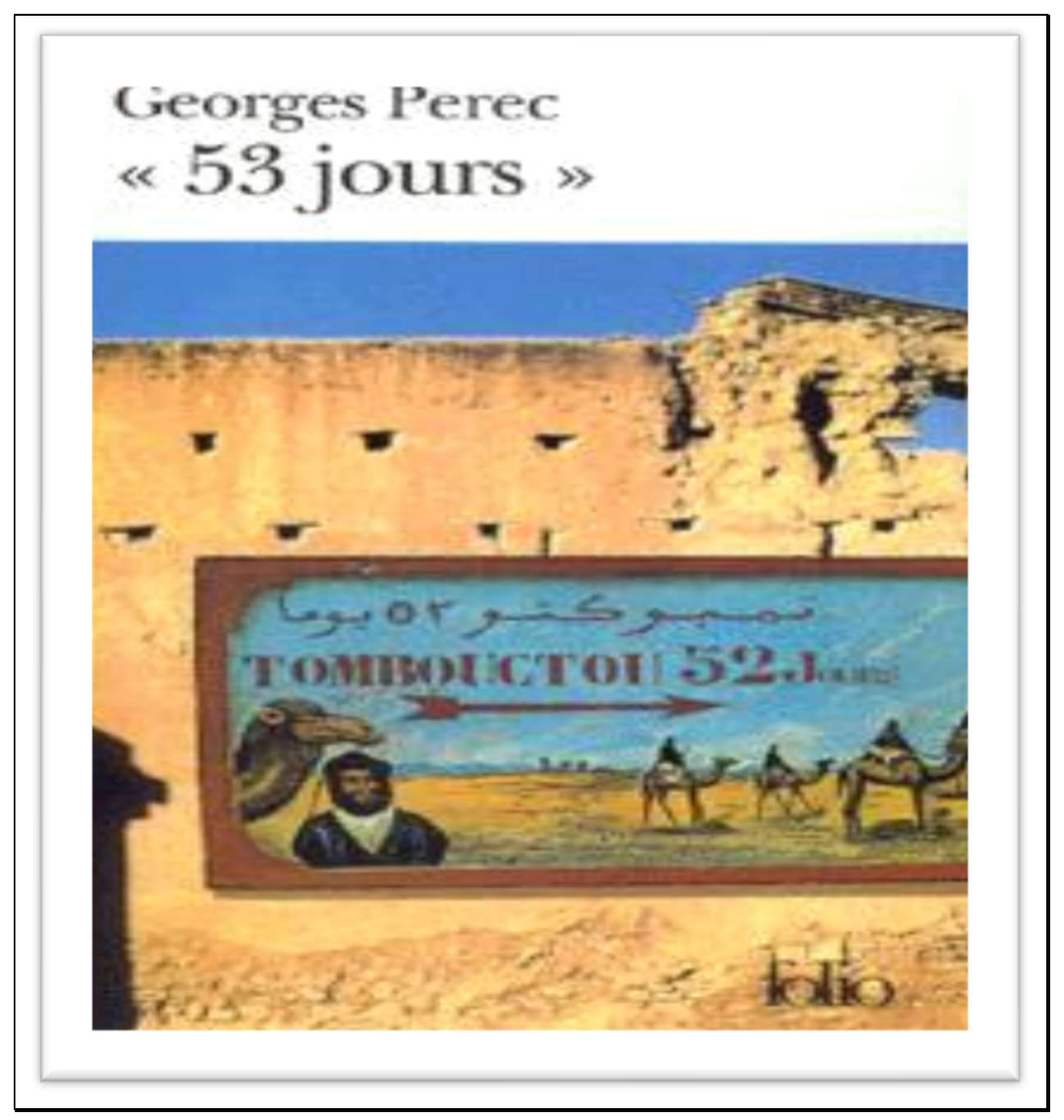

Figura 25. Capa do livro 53 jours, que mostra a ilustração do deserto de Zagora.

A ilustração do deserto de Zagora, no Marrocos, indicando a tão sonhada viagem de camelo que duraria 52 dias, com destino a Tombouctou, um dos desejos de Perec ligados aos deslocamentos espaciais, está presente na capa da edição Folio de 53 jours, obra que Perec não conseguiu finalizar antes de morrer, e que foi objeto de pesquisa da minha orientadora, Claudia Amigo Pino. Além da referência dessa viagem no título do livro, nessa gravação das "50 choses..." que acabamos de apresentar, Perec também lembra que "52 jours" foi o tempo que Stendhal levou para escrever A Cartuxa de Parma, relacionando essa viagem de camelos ao tempo da escrita do livro. Já no livro de Pino, verificamos a informação de que "Perec assinou um contrato com a Editora P.O.L., no qual se comprometia a escrever um romance policial cujo título seria '53 Jours', em homenagem ao tempo que Stendhal teria levado para escrever a "Cartuxa de Parma"' (PINO, 2004, p. 59). Havendo ou não confusão entre o número de dias (a quantidade de dias que Stendhal usou para escrever seu livro), o que importa é que uma das suas aspirações ou desejos considerados impossíveis de realizar, de certa forma, tomou um novo rumo no percurso de trabalho de Perec. 
Se a viagem de camelo não pode ser concretizada e muito menos o livro finalizado (o contrato foi assinado na primavera de 1981 e, em março de 1982, Perec faleceu), ao menos restou o manuscrito do trabalho, que, mesmo inacabado, traz à tona muitas discussões sobre a publicação tal como foi feita, assim como a pesquisa de Pino nos ajuda a refletir. Independentemente das intenções de Perec (de como gostaria que o livro fosse publicado, já que não houve tempo de finalizá-lo), o processo de criação do livro parece o ponto mais importante da discussão, já que faz com que o leitor participe ativamente do enredo, considerado alguns possíveis diferentes desfechos para a história.

Além disso, também é curioso saber que a descrição dessa ilustração real, entendida como um desejo do próprio Perec, entra na ficção de 53 jours, descrita em seus detalhes e, graças à inscrição “Tombouctou 52 jours" seguida de uma seta à direita, e um comentário de que a inscrição em outra língua parece oferecer a direção contrária (ou a ideia de um espelho), faz novamente alusão à própria estrutura do livro, uma combinação de duas partes onde a segunda destrói integralmente a versão do que foi escrito na primeira parte. ${ }^{126}$ Assim, um lugar, ou um sonho de um lugar a ser conhecido, acaba se tornando inspiração para uma descrição de um lugar fictício, dentro de um livro inacabado e de pistas falsas a serem seguidas pelo leitor.

\subsubsection{A voz como tentativa de representação de uma "totalidade"}

Voltando à ideia da expansão do texto, (como acabamos de demonstrar com a reprodução de trechos de "50 choses..."), que ocorreu para o formato voz, e consequentemente na questão da tecnologia e na hipótese já trazida à pesquisa (de que Perec desejava expandir o texto de Lieux para outros suportes), é interessante também pensar na análise de McLuhan no que diz respeito à voz, principalmente no que se refere à questão da recuperação da "totalidade do mundo" buscada por Perec, algo já bastante discutido no primeiro capítulo da pesquisa:

A palavra falada foi a primeira tecnologia pela qual o homem pôde desvincular-se de seu ambiente para retomá-lo de novo modo. As palavras são uma espécie de recuperação da informação que pode abranger, a alta velocidade, a totalidade do ambiente e da experiência.

\footnotetext{
${ }^{126}$ Maiores detalhes sobre o instigante enredo do livro podem ser conferidos na obra de Pino, "A Ficção da Escrita", pelo Ateliê Editorial, em 2004, versão adaptada de sua tese de doutorado, defendida na Universidade de São Paulo, em dezembro de 2001.
} 
As palavras são sistemas complexos de metáforas e símbolos que traduzem a experiência para os nossos sentidos manifestos ou exteriorizados. Elas constituem uma tecnologia da explicitação. Através da tradução da experiência sensória imediata em símbolos vocais, a totalidade do mundo pode ser evocada e recuperada, a qualquer momento (McLUHAN, 2009, p. 41).

A obra radiofônica que melhor representa nossos questionamentos a respeito da observação e reflexão dos lugares é aquela que analisaremos com mais detalhes na próxima seção, Tentative de description des choses vues au Carrefour Mabillon, de 1978. Mas, tratando ainda da questão da tecnologia e da voz, temos que destacar uma importante, senão decisiva, primeira participação de Perec na realização de uma peça radiofônica, dez anos antes de Mabillon, como convidado de um projeto alemão: a emissão (Hörspiel) encomendada pela rádio alemã, que buscava trazer para sua audiência os maiores escritores franceses experimentais do momento.

Perec, já participando do Oulipo, recebe então uma encomenda através de Eugen Helmlé (tradutor das obras de Perec para o alemão), para que produza uma peça radiofônica. O resultado será Die Maschine (1968) ${ }^{127}$, onde uma máquina é representada por cinco vozes diferentes: 'celle du 'speaker', celle, féminine, du 'contrôle', et trois voix représentant trois répertoires textuels", vozes estas que representam "la deconstruction, systématique et exhaustive, d'un poème allemand de Goethe, 'Über allen Gipfeln ist Ruh' (1780)" (HARTJE, 1997, p. 73). Ou seja, além de criar um jogo literário a partir de uma poesia tradicional, influenciado pela participação no grupo Oulipo, ainda há as vozes como personagens que dão "vida" a uma máquina, sendo assim uma maneira de criar uma relação entre texto escrito, manipulação e montagem das vozes, efeitos sonoros diversos e uso da tecnologia na composição do projeto, que foi bastante aclamado pelo público da época.

Sobre a participação nesse projeto, parece claro que o uso da tecnologia, do som e das vozes foi uma das alternativas para ampliar o horizonte de seu trabalho como escritor -como se o texto fosse, de certa forma, limitado para algumas experimentações possíveis a partir do som, como a sobreposição de vozes, por exemplo. Ou como o texto toma uma dimensão maior, com diferentes combinações, num trabalho de "quase" ficção científica, já que antecipa procedimentos da era digital, na maneira de manipular o texto,

\footnotetext{
${ }^{127}$ Para quem compreende a língua alemã, ou apenas por curiosidade em ouvir os trechos e as sobreposições de voz ou efeitos sonoros, a gravação original de Die Maschine está disponível em: https://www.youtube.com/watch?v=pu6TACgAdTI.
} 
e realizar diferentes combinações a partir dele e das diferentes vozes que dele se apropriam. É o que observamos neste trecho de reflexão sobre o trabalho no rádio, feito por Perec e citado por Bellos:

A arte do Hörspiel é praticamente desconhecida na França. Eu a descobri quando se impôs para mim a necessidade de novas técnicas e novas estruturas de escrita. Muito rápido, percebi que uma parte das minhas preocupações formais, de minhas questões sobre o valor, o poder, as funções da escrita poderiam nele encontrar respostas, soluções que não havia encontrado no conjunto de minhas pesquias puramente romanescas. O espaço privilegiado do Hörspiel - a troca de voz, de tempo medido, a fluidez lógica de uma situação elementar, a realidade dessa relação frágil e vital que a língua pode manter com a palavra tornaram-se assim para mim eixos primordiais de meu trabalho de escritor. (BELLOS, 1994, p. 407) $)^{128}$

\subsection{2. "Capturar" o efêmero, fixar o tempo, no projeto Carrefour Mabillon}

Nesta tentativa de descrição da "totalidade", vários projetos radiofônicos foram produzidos pelos grupos Groupe de Recherches musicales (GRM) e Atelier de création radiophonique, que proporcionavam aos autores a renovação da literatura a partir da palavra falada. Alguns projetos foram desenvolvidos em parceria destes grupos com Perec, sendo o mais famoso deles o intitulado Tentative de description de choses vues au Carrefour Mabillon, em maio de 1978. O que difere essa obra das outras é a apresentação das imperfeições da linguagem, do improviso, do barulho de fundo, ao mesmo tempo em que a voz de Perec se mostra segura, firme, pronta para descrever a maior quantidade de objetos possível. Essa nova criação, espontânea, veloz, ágil, é talvez aquela que Perec procurava ao estacionar uma van no Carrefour Mabillon:

Com "Tentativa de coisas vistas"... Perec persegue então uma mesma marcha em direção às expressões multiformes. É um trabalho sobre o tempo, disse Bernard Magné relemebrando o objetivo do autor, que não esperava nada além do traço de um tripo envelhecimento [...] Indo em direção ao rádio, Perec se confronta com um tempo real, ou ao menos com sua ilusão. Em um fluxo, de qualquer forma, na integração de seu

\footnotetext{
${ }^{128}$ L'art du Hörspiel est pratiquement inconnu en France. Je le découvris au moment où s'imposa pour moi le besoin de nouvelles techniques et de nouveaux cadres d'écriture. Très vite, je m'aperçus qu'une partie de mes préoccupations formelles, de mes interrogations sur la valeur, le pouvoir, les fonctions de l'écriture pouvaient y trouver des réponses, des solutions que je ne parvenais pas à trouver dans le cadre de mes recherches purement romanesques. L'espace privilégié du Hörspiel - l'échange de voix, de temps mesuré, le déroulement logique d'une situation élémentaire, la réalité de cette relation fragile et vitale que le langage peut entretenir avec la parole - sont ainsi devenus pour moi des axes primordiaux de mon travail d'écrivain.
} 
corpo (e seu possível cansaço físico) com o dispositivo.(CHRISTOFFEL ; BAUMGARTNER, 2016, p. 146) $)^{129}$

Perec descreve tudo sem ler, como uma espécie de comentarista esportivo (termo usado pelo técnico de som que o acompanhou na gravação), reproduzindo uma litania de recorrências de tudo aquilo que observa (ônibus com suas campanhas publicitárias, carros de diversos modelos, o trânsito, pedestres etc.). Segundo o técnico de som Michel Créîs ${ }^{130}$, que trabalhou ao lado de Perec no projeto, essa maneira espontânea de narrar, bem à vontade e a partir do improviso, impressionava-o, já que o ritmo acelerado das descrições (por isso, também, comparadas a partidas esportivas) causavam no técnico uma espécie de vertigem, de hipnose, em quem ouve a narração. É como se a narração fosse uma potencialização do efeito de "vertigem" já provocado na leitura de textos como Espèces d'espaces e Je me souviens, mencionados anteriormente.

A esta descrição pessoal e improvisada, mas dita sobre um tom igual que apenas o cansaço vem pouco a pouco ligeiramente desacelerar, sucede pontualmente a voz do ator Claude Piéplu, gravada fora dali em estúdio, e mixada em seguida. Ele lê uma lista que reúne cuidadosamente o número de ocorrências de tais ou tais elementos (guarda-chuvas, carros...) como uma versão objetivamente quantificada daquilo que vê o olho subjetivo de Perec. (CHRISTOFFEL; BAUMGARTNER, 2016, p. 146) $)^{131}$

Aqui, podemos encontrar mais uma característica em comum com o projeto Lieux: para desenvolver o trabalho, Perec precisa contar com outros parceiros (com o técnico de som, na gravação, e com o ator, para a montagem das vozes que mesclam a descrição real e os inventários com as quantidades totais produzidas e anotadas).

Assim, uma grande característica do texto sonoro, ágil e improvisado, será o cruzamento de vozes, sua sobreposição (o volume mais baixo da voz de Perec simultâneo à voz de Piéplu, um ator parceiro no projeto). Um trabalho em conjunto que produz um

\footnotetext{
${ }^{129}$ Avec Tentative de choses vues... Perec poursuit donc une même démarche aux expressions multiformes. C'est un travail sur le temps, dit Bernard Magné rappelant les propos de l'auteur, qui n'en attendait rien d'autre que la trace d'un triple vieillissement[...] En allant vers la radio, Perec se confronte à un temps réel, ou du moins à son illusion. À un flux, en tout cas, et à l'intégration de son corps (et à sa possible lassitude physique) dans le dispositif.

${ }^{130} \mathrm{Na}$ entrevista intitulada "Comme un commentateur sportif", p. 149-152, parte integrante do artigo Artigo "Les cocotiers sont arrivés", Radio Perec, de David Christoffel e Thomas Baumgartner, em Perec, Éd. de L'Herne, 2016, pp. 142-153.

${ }^{131}$ À cette description personnelle et improvisée, mais dite sur un ton égal que seule la fatigue vient petit à petit légèrement ralentir, succède ponctuellement la voix du comédien Claude Piéplu, enregistrée par ailleurs en studio, et mixée ensuite. Il lit une liste rassemblant soigneusement le nombre d'occurrences de tels ou tels éléments (parapluies, voitures...) comme une version objectivement quantifiée de ce que voit l'œil subjectif de Perec.
} 
efeito inesperado, a partir destas vozes que se intercruzam: de um lado, a voz espontânea e veloz de Perec, seu improviso; de outro, a objetividade, a quantificação, o método e as listas (sempre presentes) na voz do ator. Desta forma, "Tentative de description... est à la fois une pièce radiophonique marquante et reconnue des années après, un exercice formel et poétique radical, et la traduction radiophonique d'un projet littéraire multiforme (CHRISTOFFEL ; BAUMGARTNER, 2016, p. 146).

O efeito de hipnose mencionado fica evidente na declaração em entrevista dada pelo técnico de som: “C'est quand même une gageure, essayer de décrire tout ce qu'on voit, c'est impossible d'ailleurs, c'est ça qui est absolument fantastique. [...] c'était vraiment totalement hypnotique”, (CHRISTOFFEL ; BAUMGARTNER, 2016, p. 151). Também nos faz concordar com Barthes, quando diz, a respeito desse tipo de escritura em voz alta: seu objetivo não é clareza das mensagens, o teatro das emoções; o que ela procura (numa perspectiva de fruição) são os incidentes pulsionais, a linguagem atapetada da pele, um texto em que se possa ouvir o grão da garganta [...] $(2008, \text { p. } 78)^{132}$.

É interessante pensar, a partir dessa citação que, no momento em que escutamos a compilação dos textos editados, há essas duas vozes que se sobrepõem e que, de certa forma, não têm como objetivo emitir uma mensagem clara: ao contrário, apesar do texto ser minuciosamente composto por quantidades exaustivamente inventariadas, no momento em que as ouvimos, elas parecem ser o menos importante (aqui está talvez a intenção de Perec), para dar lugar a uma reflexão sobre esse som desorganizado, entrecruzado, que parece representar exatamente o barulho de um grande cruzamento em pleno movimento. As vozes são, portanto, espécies de representações desses milhares de ruídos que compõem a paisagem urbana observada.

Podemos também destacar a comparação da descrição de Perec com a de um narrador esportivo feita por Michel Créïs e já mencionada acima. Se ouvirmos alguns trechos, poderemos compreender o motivo de tal comparação. Por um lado, há momentos de frenéticas descrições, quase sem pausa, como se houvesse tanto a ser dito, como se o tempo da fala não desse conta da quantidade de coisas a dizer, a descrever, numa fala mais passional, acelerada, até ofegante. Em outros momentos, temos longas pausas, como se a partida de futebol (ou qualquer outra) estivesse morna, ou que nada de interessante estivesse acontecendo e que pudesse efetivamente ser descrito; a aceleração de alguns momentos, além disso, também causa cansaço, como o próprio técnico de som comenta.

\footnotetext{
132 O prazer do texto, Ed. Perspectiva.
} 
Assim, a gravação fica oscilando entre momentos de muita assertividade e aceleração com outros de pausa para descanso da voz e, para que haja tempo de que outras coisas passem diante do narrador, para que as coisas voltem a acontecer no ritmo frenético esperado para uma partida esportiva.

Curioso também encontrar uma outra analogia esportiva para a obra, não na questão da narração frenética, mas sim na questão do tempo que parece ser condensado, da mesma maneira como já analisamos em Tentative d'épuisement.... Trata-se da análise de Bernard Magné ${ }^{133}$, na qual o crítico compara o trabalho Carrefour Mabillon com uma corrida de velocidade, mais rápida, enquanto seu projeto Lieux poderia se comparar a uma maratona, mais longa. Magné acaba por classificar Carrefour Mabillon com uma espécie de "sprint descriptif" (p. 177), ou seja, a relação com o tempo, com a velocidade, fica muito evidente nessa analogia.

O material para análise dos áudios de Carrefour Mabillon e que terá alguns trechos reproduzidos nas próximas páginas, possui duas fontes diferentes: os áudios fazem parte de uma coleção de CD's que traz outras produções sonoras de Perec e o texto transcrito foi reproduzido no artigo de Andrée Chauvin ${ }^{134}$. Nossa intenção é levantar alguns pontos interessantes observados a partir da escuta de tais áudios juntamente com a leitura dos textos transcritos. A escuta dos áudios foi uma tentativa de reproduzir, mesmo que parcialmente, as hesitações, pausas, acelerações e todos os tipos de barulho provenientes da empreitada realizada por Perec. Não seria possível transmitir as seis horas brutas de gravação, muito menos as duas horas editadas. Optamos, então, por disponibilizar o material integral ao final do trabalho, utilizando aqui somente os trechos que podem nos ajudar na continuidade das reflexões até aqui suscitadas.

O material editado conta com dez inventários no total, cada um deles apresentando uma sequência semelhante: Piéplu, o ator, informa uma espécie de "inventário geral" com as quantidades já somadas, num ritmo aparentemente ensaiado, com sua voz bem

\footnotetext{
${ }^{133}$ No texto "Tentative de description de choses vues au carrefour Mabillon le 19 mai 1978 de Georges Perec", em Écritures Radiophoniques, CRLMC, 1997, pp. 173-182.

${ }^{134}$ Os textos dos inventários (1 a 10), incluindo sua transcrição e os áudios correspondentes às transcrições, serão disponibilizados e incorporados ao final do trabalho, nos "Anexos". Pela quantidade de informações e falas repetitivas, mostrou-se improdutivo reproduzi-los integralmente no corpo do texto. Os CD's fazem parte da coleção "Georges Perec, dialogue avec Bernard Noël (2 livres + coffret de 4 CD)". Éd. André Dimanche, 1997. Já artigo de Andrée Chauvin, intitulado "Les cocotiers sont arrivés" faz parte da publicação Semen [On line], 12 , 2000, publicado em 04 de maio de 2012, consultado em 16 abril 2018. Disponível em: http://journals.openedition.org/semen/1887.
} 
colocada, quase que como se estivesse nos apresentando um espetáculo que está prestes a começar.

Enquanto Piéplu está ainda apresentando as quantidades totais, já se ouve, mesmo que num volume mais baixo, Perec descrevendo/enumerando/narrando o que está vendo, causando um jogo de contrastes entre os dois discursos e confirmando a sobreposição de vozes que já havia sido mencionada: o discurso de Perec é da ordem da narração espontânea, improvisada, o real em sua forma bruta, a partir da percepção imediata, enquanto que o de Piéplu é uma elaboração realizada posteriormente, quando o material sofreu a montagem para se transformar numa obra a ser apresentada para o público, como nos explica Chauvin:

A descrição de Perec aparece, inicialmente, mais ao lado do real bruto e da percepção particular, enquanto o inventário de Piéplu coloca ordem nesse real, com sua palavra um pouco mecanizada, estaria do lado de uma língua informada pelas estruturas do saber enciclopédico, estruturante. $(2012, \text { p. } 4)^{135}$

Mas não se trata, apenas, de uma sobreposição de duas vozes: o trabalho aqui realizado por Perec e uma equipe de som foi capaz de produzir um discurso de duas vozes, porém repleto de camadas e sobreposições no momento da composição. Essa reflexão fica mais evidente com a leitura do texto de Magné, já citado, sobretudo na primeira página, onde nos explica que ambos os discursos fazem parte de um trabalho de reelaboração, onde primeiro temos uma gravação bruta de seis horas que sofre supressões na montagem; além disso, há acréscimo de fragmentos dos inventários lidos por Claude Piéplu, que também só pode ser feito graças a uma transcrição do material sonoro, realizada depois da gravação. Ou seja, é um trabalho constituído por várias fases de elaboração e, portanto, composta por discursos feitos em diferentes tempos e diferentes suportes. A própria leitura do inventário faz com que o objeto de observação deixe de ser o "real", aquilo que foi observado anteriormente, e passe a ser a reprodução do texto resultante daquela observação.

Magné também nos lembra, na página 175 do mesmo texto, que, ao lado da rue Vilin, Carrefour Mabillon será outro lugar a aparecer sob diferentes formas na obra de Perec: se a primeira passou do livro autobiográfico $W$ para a poesia de La Clôture e para as filmagens de Un homme qui dort, por exemplo, Carrefour Mabillon passará de meras

\footnotetext{
${ }^{135}$ La description de Perec apparaît dans un premier temps plutôt du côté du réel brut et de la perception particulière, alors que l'inventaire de Piéplu qui met de l'ordre dans ce réel, avec sa parole quelque peu mécanisée, serait du côté d'une langue informée par les cadres du savoir encyclopédique, structurante.
} 
descrições do real (no projeto Lieux) ${ }^{136}$ para um registro sonoro, bruto, que passará por uma nova transformação (editado e sob forma de inventário) até o formato a que temos acesso aqui, nesses trechos de áudio que serão analisados daqui por diante. ${ }^{137}$

\subsubsection{Tentativa de descrição de áudios e textos de Carrefour Mabillon}

Como dito anteriormente, são vários os pontos do texto de Magné que parecem dialogar com essa pesquisa, mesmo que o acesso ao texto tenha ocorrido tardiamente, quando muitas das ideias aqui apresentadas já estavam parcialmente colocadas em jogo. Uma das questões bastante interessantes é a composição do projeto e suas diferentes camadas de produção, além, é claro, da analogia esportiva, que parece inclusive dar um tom lúdico para a empreitada de Perec. Um ponto a mais em comum entre essa pesquisa e o texto de Magné, entretanto, parece fugir um pouco da questão do lúdico, adentrando as contraintes da escrita, principalmente no que se refere à dificuldade da regra imposta.

Nesse caso, Perec parece ter se dado uma missão bastante ambiciosa. Como descrever em tempo real? Como passar essa sensação de simultaneidade entre o que observa e o que fala, reproduz, num espaço de tempo tão veloz? O que é interessante na leitura de Magné - e que nos ajuda a pensar nessa questão da obsessão pela descrição, em particular dos carros e outros meios de transporte -, parece relacionar-se com a questão da dificuldade máxima imposta a si mesmo; ou seja, encontrar uma forma de escrita (transformada em som, nesse caso) que dê conta do minuto, do segundo, do real enquanto ele acontece.

E nada mais representativo disso do que descrever aquilo que não está estático, mas sim em movimento. Por isso mesmo, Magné dedica uma das seções do seu texto ao sub-item Mobilis em (auto) mobile: “Carrefour Mabillon n’énumère que les éléments mobiles de l'univers urbain: véhicules, passants et quelques rares animaux (chiens, pigeons) et ce seront em outre les seuls éléments repris dans les inventaires dits par Claude Piéplu" (P. 178). Assim, elementos que estejam em movimento serão, de certa forma, a própria representação dessa narração do real, em tempo real, no momento em que

\footnotetext{
${ }^{136}$ Publicados sob o título "Stations Mabillon", na Revista Action Poétique, n. 81, maio de 1980.

${ }^{137}$ Vale lembrar que Carrefour Mabillon faz parte dos doze lugares constantes no projeto Lieux e, segundo Lejeune, em sua obra La mémoire et l'oblique, esse endereço tem forte ligação com Paulette Perec, com quem Perec se casou em 1960, fazendo com que o lugar tenha uma carga afetiva significativa, além de ser uma clara transformação de Lieux, já que repete as descrições escritas do projeto passando, desta vez, para a descrição sob a forma de som, da própria voz. A lista com todos os doze lugares de Lieux e suas possíveis ligações autobiográficas estão na página 164 da referida obra de Lejeune, e será reproduzida na seção "Anexos", ao final do trabalho.
} 
acontece, inclusive com indicações dos movimentos repetitivos de determinados itens, como um luminoso de uma pizzaria que acende e apaga, por exemplo.

Magné brinca dizendo que descrever algo estático seria tão simples quanto criar um texto com lipogramas com a letra X ou Y, por exemplo. Ou seja, para ele, enquanto descreve objetos em movimento, Perec torna sua contrainte mais desafiadora e, portanto, muito mais interessante do ponto de vista artístico, já que lida com a questão da fugacidade, do efêmero: “pour ce type de performance descriptive, c'est l'éphémère qui pose problème, pas l'éternel et c'est donc lui qu'il s'agit de fixer sur la bande" (MAGNÉ, 1997, p. 179).

Para iniciarmos algumas reflexões, podemos partir de um trecho final do primeiro inventário:

Um carro amarelo. Uma dezena de pessoas atravessam o boulevard Saint Germain; três ou quatro têm guarda-chuvas abertos; passa um caminhão Solvay; duas pessoas atravessam, uma com um guarda-chuva preto e outra com um guarda-chuva, violeta ou vermelho, uma outra no sentido contrário com um guarda-chuva colorido. Um táxi, outro táxi, mais um táxi. ${ }^{138}$

A partir desse trecho, podemos exemplificar que há no texto/áudio constantes mudanças de tom da narração, ao longo de todos os inventários: por vezes, ela é bastante acelerada, seguida de vários momentos de silêncio do narrador e de hesitação, causando a sensação de estarmos ao lado de Perec, observando Paris e interagindo diretamente com ele, com suas reflexões e, por que não, com a própria Paris e seus constantes ruídos.

Por outro lado, essas mesmas descrições podem causar em nós, talvez, momentos eufóricos intercalados a momentos de mero cumprimento das regras, numa espécie de representação monótona do que está sendo observado (o que há de relevante em enumerar os tipos/cores de guarda-chuvas ou três táxis, como nas sequências grifadas, por exemplo?). É como se estivéssemos lá, ao lado de Perec, vendo e descrevendo objetos, alguns mais, outros menos interessantes, curiosos e ao mesmo tempo desimportantes, marcando apenas nossa presença como espectadores, criando uma memória coletiva, de um tempo que ficará lá, fixado, a partir do registro da voz.

O primeiro trecho do segundo inventário nos remete a uma nova enumeração (que será constante e, muitas vezes, trará a sensação de "vertigem" já comentadas algumas

\footnotetext{
${ }^{138}$ Une voiture jaune, sale. Une dizaine de personnes traversent le boulevard Saint Germain ; trois ont des parapluies ouverts ; passe un camion Solvay ; deux personnes traversent, l'une avec un parapluie noir l'autre avec un parapluie, violet, ou rouge, une autre dans l'autre sens avec un parapluie bariolé. Un taxi, un autre taxi, encore un taxi. (Clique aqui para ouvir o áudio do trecho, a partir do tempo 06:12).
} 
vezes): “un taxi, une deux chevaux, une voiture bleue; une camionnette Pignot ; plusieurs voitures, des gens qui traversent à quelques centimètres de moi"139; o segundo remete à ideia de descrição em movimento, já que traz o próprio movimento para a escrita: "Pizza Verdi allumé, éteint, allumé, éteint, allumé, éteint, allumé" ${ }^{140}$, conforme análise feita no início desta seção. A mais emblemática enumeração, entretanto, aparece no sexto inventário, quando somos bombardeados por "parapluies" de diversos tipos:

[...] quase todas as pessoas têm guarda-chuvas, um guarda-chuva verde, um guarda-chuva preto, um guarda-chuva com uma, decoração, geométrica, branco vermelho e preto; um guarda-chuva de flores, um guarda-chuva estampado, um guarda-chuva violeta, um guarda-chuva preto; um homem com impermeável sem guarda-chuva, um guardachuva com, decorado, um ônibus 63, um ônibus 96, um dois cavalos que tomam a rua onde estamos, um guarda-chuva com espécies de motivos geométricos, um guarda-chuva preto um guarda-chuva com uma decoração, não escocês mas com xadrez; um caminhão de entrega de batata o semáforo está vermelho, um guarda-chuva preto, um guarda-chuva com listras verdes e azuis e amarelas perdão, um guardachuva vermelho, um guarda-chuva sem cor. ${ }^{141}$

É claro que essa enumeração exaustiva tem relação direta com a escrita de Perec, como já dissemos, muito ligada à questão da elaboração de listas e da acumulação como tentativa de preservar a memória, como já vimos em diversas reflexões desde o início do texto.

Uma das características recorrentes será a hesitação de Perec, em diversos momentos. Ao descrever um cão, por exemplo, ele afirma não conhecer a raça à qual pertence: "Je ne sais pas comment s'appellent ces chiens", deixando evidente o improviso do texto/discurso/voz; ou ainda, em outro exemplo, no trecho: “j'arrive à compter six parapluies, un homme qui porte, un, qui pousse un diable dans lequel $\underline{\text { il y a quelque chose }}$ qui me fait penser à du du des poissons dans une caisse, en matière plastique blanche, je sais pas comment ça s'appelle" $^{\text {142 }}$, quando deixa claro não encontrar palavras para aquilo que está prestes a descrever.

\footnotetext{
${ }^{139}$ (Clique aqui para ouvir o áudio do trecho, a partir do tempo 01:35)

140 Idem

141 “[...]presque tous les gens ont des parapluies, un parapluie vert, un parapluie noir, un parapluie avec un, décor, géométrique, blanc rouge et noir, un parapluie à fleurs, un parapluie à motifs, un parapluie violet, un parapluie noir ; un homme en imperméable sans parapluie, un parapluie à, décoré, un autobus 63 , un autobus 96, une deux chevaux qui prend la rue où nous nous trouvons, un parapluie avec des espèces de motifs géométriques, un parapluie noir, un parapluie avec un décor, pas écossais mais à carreaux ; un camion livraison de pommes de terre, le feu est rouge, un parapluie noir, un parapluie à bandes vertes et, bleues et jaunes pardon, un parapluie rouge, très plat, un parapluie, sans couleur" (Clique aqui para ouvir o áudio do trecho, a partir do tempo 06:45)

142 (Clique aqui para ouvir o áudio do trecho, a partir do tempo 08:39)
} 
Outra constante na narração/descrição de Perec será incorporar o texto publicitário à sua própria voz: enquanto descreve, ele acaba se apropriando do discurso publicitário (lendo-o como está escrito), ou seja, tomando para si o discurso do outro, como pode ser observado em: "le feu est rouge boulevard Saint Germain, rue du Four passe une camionnette Uncle Bens le riz qui ne colle jamais; une camionnette Soliviandes Porc en gros qui tourne dans la rue de Buci" ${ }^{143}$. Outra frase que aparecerá centenas de vezes é a da publicidade na linha de ônibus que passa frequentemente a sua frente: "Passe un 63 Les cocotiers sont arrivés", utilizando a mesma técnica de incorporação do texto publicitário. A ideia de valorizar o efêmero fica evidente, também, conforme nos explicou Magné: trata-se de uma propaganda que talvez não seja conhecida pelas futuras gerações, mas que foi muito repetida naquela situação, naquele tempo, naquela época, na mesma medida em que Perec escreveu seus Je me souviens, que representa exatamente a memória coletiva de uma época.

Um outro trecho que chama a atenção para a questão da publicidade, incluindo também a questão do humor, está no trecho: “[...]un gros camion Déménagement Garnier Conflans Sainte Honorine 78700 tél 9166087 [rire] Déménagements toutes distances (5), qui s'arrête juste devant, mon regard"144. Aqui, Perec narra e ri da própria narração, como se questionasse a importância de ter dito (inclusive) o telefone da empresa que aparece na propaganda do caminhão. É uma forma indireta de se autocriticar, ou ao menos de refletir imediatamente sobre o que está fazendo no momento, e que fica registrado em meio as suas descrições intermináveis. Talvez ele se dê conta da ação mecanizada que acaba de realizar ou, talvez, veja um certo humor na situação. A partir do momento em que descreve exaustivamente, em constante velocidade, ele está produzindo estranheza em algo que deveria ser natural (a paisagem urbana), demonstrando essa paisagem como um lugar em que a acumulação acaba gerando essa velocidade, em acumular, em descrever, em produzir essa narração desenfreada. Ou seja, está olhando para essa paisagem e tentando tirar, do meio dessa multidão, alguns elementos que lhe pareçam peculiares, e nos mostrar tais elementos no meio de tantos outros, acumulados e rapidamente mencionados.

Cabe lembrar dois momentos também bem-humorados, quando Perec parece "sair" do automatismo da descrição e incorporar o olhar daquele que ele observa, o olhar do outro, nos trechos: "une voiture bleue, plein de petits enfants avec des imperméables

${ }_{143}$ (Clique aqui para ouvir o áudio do trecho, a partir do tempo 01:35)

144 (Clique aqui para ouvir o áudio do trecho, a partir do tempo 04:40) 
bleus, qui passent juste, à côté, de moi, dont une petite fille qui me tire la langue" 145 ou "[...] un homme qui me montre du doigt en passant, trois voitures, un oiseau, qui passe dans le ciel". ${ }^{146}$ Ao mesmo tempo em que parece haver humor na narração, notamos que, mesmo nessas situações inusitadas, a fala e o ritmo não se alteram; assim, as pessoas parecem descritas como partes dos objetos narrados; não há uma atenção ou narração especial para refletir sobre suas atitudes, apenas sua breve e rápida descrição. Como se no meio caótico da cidade, onde as pessoas passam rapidamente, os olhos de Perec examinassem e descrevessem rapidamente, independentemente do que está observando, e que tudo continuasse em seu movimento normal. A maneira escolhida por Perec para reagir àqueles que cruzam seu caminho não é alterar o tom de voz ou demonstrar indignação: ele prefere apenas continuar narrando, cada vez mais rápido, como se essa fosse a melhor forma de protestar, de reagir ao mundo, a essa velocidade desenfreada com a qual tem que lidar enquanto realiza seu experimento sonoro.

Para encerrar, cabe mostrar um último trecho, que nos parece um dos momentos em que a descrição/narração tem seu ritmo mais acelerado, ratificando nossa reflexão sobre a tentativa de dar conta de um tempo que escapa, de uma velocidade das coisas, do efêmero que deixa de existir antes mesmo de a próxima frase ser proferida:

[...] Rue du Four, duas mobiletes arrancam, carros, uma mobilete passa bem à nossa frente, táxi, méhari, táxi, carro azul, carro vermelho, táxi branco, táxi, táxi verde, táxi branco, mobilete com um homem usando um impermeável, um 2 CV azul, um Peugeot, um não sei o quê, branco, pessoas atravessam correndo pelo boulevard Saint Germain. ${ }^{147}$

Nesse trecho, confirma-se a sensação de vertigem, velocidade, efemeridade, todas elas muito bem apresentadas a partir da realização de Carrefour Mabillon. Lembrando que a obra tinha contraintes bastante definidas: uma produção oral, destinada a um programa de rádio, com uma duração estipulada (no caso da primeira versão, seis horas seguidas de gravação).

\footnotetext{
145 (Clique aqui para ouvir o áudio do trecho, a partir do tempo 04:54)

146 (Clique aqui para ouvir o áudio do trecho, a partir do tempo 06:48)

147 [...]rue du Four, deux mobylettes démarrent, des voitures, une mobylette passe juste devant nous, taxi, méhari, taxi, voiture bleue, voiture rouge, taxi blanc, taxi, taxi vert, taxi blanc, mobylette, avec un homme en imperméable, une deux chevaux bleue, une Peugeot une je sais pas quoi, blanche, des gens traversent en courant le boulevard Saint Germain. (Clique aqui para ouvir o áudio do trecho, a partir do tempo 03:54)
} 
O espaço também foi reduzido, fazendo com que Perec observasse um microuniverso a partir da janela da van em que se instalou. Talvez por isso haja tantas repetições: por ele estar no mesmo lugar, observando ações e objetos muito semelhantes, durante um espaço de tempo considerável. Seria uma tentativa de criar um microuniverso do real que poderia, depois, ser estendido ou definido como uma ideia de real em sua totalidade? Talvez se tratasse de uma tentativa de esgotar, esmiuçar e controlar o tempo, o espaço, de maneira bastante experimental, como muitos dos projetos de Perec. Um discurso marcado por repetições, reformulações e hesitações. Se não foi possível retratar um microuniverso do real, foi possível observar, de certa forma, as práticas de escrita e de trabalho, muito parecidas com as práticas de Perec em sua obra, repleta de regras, improviso, inacabamentos e hesitações.

Carrefour Mabillon pode ser, então, um microuniverso da própria experiência de esgotamento da fala, da escrita e, por que não, do trabalho de escritor, olhando pela janela e criando um mundo de possibilidades. Retomando outro texto de Magné ${ }^{148}$ para encerrar a sessão, voltamos à questão dúbia presente tanto no projeto Lieux, quanto em Carrefour Mabillon: escrever a partir da descrição exaustiva, criar uma espécie de acumulação, será uma maneira encontrada para preencher um vazio de uma autobiografia impossível de ser contada, da forma tradicional.

Assim, mesmo que Perec olhe para os outros, que descreva incessantemente todos os objetos presentes no lugar, é importante termos em mente que ambos os projetos estão ligados a lugares com os quais ele tem relação afetiva; é a partir desses lugares que ele tenta chegar na própria história, de maneira oblíqua. Essa escrita, que parte de algo externo para falar de si mesmo, estará em muitas das obras de Perec, analisadas ou não neste trabalho. Magné observa, de maneira bastante poética, uma relação entre um trecho final dos áudios de Carrefour Mabillon ("Un homme ayant l'air de souffrir de la pluie") com as últimas palavras do texto e filme homônimos, de Perec, Un homme qui dort: "Tu as peur, tu attends. Tu attends, place Clichy, que la pluie cesse de tomber". ${ }^{149} \mathrm{Se}$ em Mabillon Perec olha para o outro e o descreve exaustivamente, em Un homme qui dort ele estabelece a relação com um "tu” que muitas vezes pode ser substituído por "je”,

\footnotetext{
${ }^{148}$ Carrefour Mabillon, “ce qui passe, passe...", no livro que acompanha a coleção de CDs já mencionada na nota 28.

${ }^{149}$ Este é um dado também autobiográfico presente no livro Un homme qui dort, conforme afirmação de Perec em entrevista, quando fala das diferenças entre o final do filme (que se passa na rue Vilin) e do livro, que termina na place Clichy: "Dans le livre ça se passe place Clichy car c'est là que j'ai fini le livre un jour de pluie" (Entretiens et conférences, vol. I, p. 161).
} 
continuando seu eterno jogo entre falar do outro e falar de si, um projeto autobiográfico intermitente, presente em grande parte de suas obras.

\subsection{Re (escutando) a voz de Perec em La vie filmée}

Para concluir, pensando nas questões tratadas até o momento, retomo a obra que abriu o capítulo e que contribuiu para todas as reflexões que se seguiram até aqui: La vie filmée, que também tem como um dos aspectos principais a voz de Perec como objeto fundamental, já que representa a capacidade que Perec possui de lidar com imagens de pessoas e lugares praticamente desconhecidos, e transformar este material bruto em momentos importantes de sua própria reflexão como escritor (e, nesse caso especificamente, um escritor que lê, que produz som, e que transforma sua voz em parte integrante do filme).

Também fica evidente que observar estas imagens funciona como combustível para o processo de escrita, principalmente para uma escrita que se volta para as questões mais profundas e dolorosas de sua própria história, que são deixadas de lado por muito tempo. Refletir sobre este tempo passado e sobre estes desconhecidos que se encontram, interagem e confraternizam pode ter como pano de fundo uma grande necessidade de criar para si uma fábula sobre o próprio passado, uma vez que não há muito o que ser lembrado da própria vida. O banal e o cotidiano funcionam, mais uma vez, como motivação para uma escrita carregada de questões sobre si mesmo:

Sob a incerteza do passado e do futuro, a história feliz de uma família se perpetua através de imagens sorridentes destes adolescentes que fazem careta ou deste dinamarquês de boa aparência provando sua cordialidade a um bebê hoje há muito tempo adulto. (PEREC, 2006, p. 78) ${ }^{150}$.

A história de qualquer família pode ser a dele (aquela que não existiu). Por um instante, escrever detalhes banais sobre famílias que se reúnem para brincadeiras pode

\footnotetext{
${ }^{150}$ Sous l'incertitude du passé et du devenir, l'histoire heureuse d'une famille se perpétue à travers les images souriantes de ces adolescents faisant la grimace ou de ce danois débonnaire prouvant sa bonhomie humide à un bébé aujourd'hui depuis longtemps adulte Esta citação e as demais, onde Perec descreve as cenas do filme La vie filmée, fazem parte do texto "La vie filmée", de Georges Perec (o texto, de fato, é o resultado da transcrição dos comentários do filme, feita por Cécile de Bary), publicado nos Cahiers Georges Perec 9, Ed. Le Castor Astral, 2006, pp.73-82.
} 
parecer uma eternidade de felicidade para aquele que observa, em silêncio, as imagens. É reconfortante imaginar que aquele bebê da imagem hoje é um adulto formado. É a certeza do tempo que passou, da vida que seguiu seu curso. As imagens nos ajudam a questionar esta dinâmica veloz do tempo, nos ajudam também a criar nossas histórias, nossas ficções e, inclusive, reconstruir, de certa forma, nossas próprias memórias. O que a imagem nos diz? Parecem questões sem resposta, parecem-se com pequenos traços quase apagados, dentro da duração de um movimento, de maneira quase sutil. São os detalhes que nos fazem questionar: “Qui-est là? Que fait-il ? Un homme ouvre la bouche, il parle, il répond peut-être à celui qui est en train de le filmer. Mais que dit-il ? Les images sont muettes et restent muettes, on ne peut que les interroger sans fin... (PEREC, 2006, p.76). Assim, Perec afirma que se produz o "milagre da imagem": a partir destes pequenos detalhes que observamos, podemos encontrar neles um certo charme, uma doçura, um gesto que parecia esquecido, uma leitura quase poética do cotidiano.

O suporte da película carrega traços marcantes, para quem filma e também para quem assiste ao filme. Eventos irrisórios são responsáveis por muitas e agradáveis surpresas, desde que consigamos olhar além do que está nas imagens e, por isso, aprender a interrogá-las, a desconfiar delas, maravilhar-nos com sua simplicidade e grandiosidade. O processo de leitura do cotidiano é, mais uma vez, uma forma de recontar a própria vida. As imagens da câmera podem nos dar o que a fotografia não permite: o movimento, o inconstante, o que não deixa traços definitivos, aquilo que não se pode fixar.

Todas estas questões estão presentes nas obras analisadas nesta pesquisa: a ver, o interrogar do tempo e dos lugares como uma forma de escrever sobre si. O trecho em que Perec comenta o bairro de Ménilmontant é o ponto alto do filme, uma vez que podemos observar questões claramente autobiográficas, mesmo que, para isto, ele se valha de um material produzido por outra pessoa. A citação do próximo trecho, onde descreve o bairro em que sua família viveu, mostra detalhes de uma vida precária na França dos anos 30, local onde seus pais viveram antes mesmo de seu nascimento. As fachadas das casas, as crianças brincando nas ruas e os muros degradados lembram em muito o que ainda viria a ser o bairro que visitou no final dos anos 60, para o projeto Lieux. Ali, naquelas fotos, Perec já consegue reconhecer um pouco do que foi seu passado e do que é seu presente:

$\mathrm{O}$ acaso quis que esse filme fosse rodado no bairro onde nasci, em Ménilmontant. O homem que, durante um ano, em 1931, filmou estas fachadas, estas mulheres, estas crianças, estas escadas, percorreu as ruas nas quais, um pouco mais tarde, dei meus primeiros passos: a Rua Sorbier, a Rua Chevreau, a Rua Julien-Lacroix, a vila Faucheur, a rua 
da Mare, a Rua Vilin, a passagem Ronce, o impasse Dhéron, a Rua Piat, a vila Ottoz, a cité Billon, a Rua do Transvaal, a Rua dos Envierges, a Rua dos Couronnes. (PEREC, 2006, p. 80) $)^{151}$

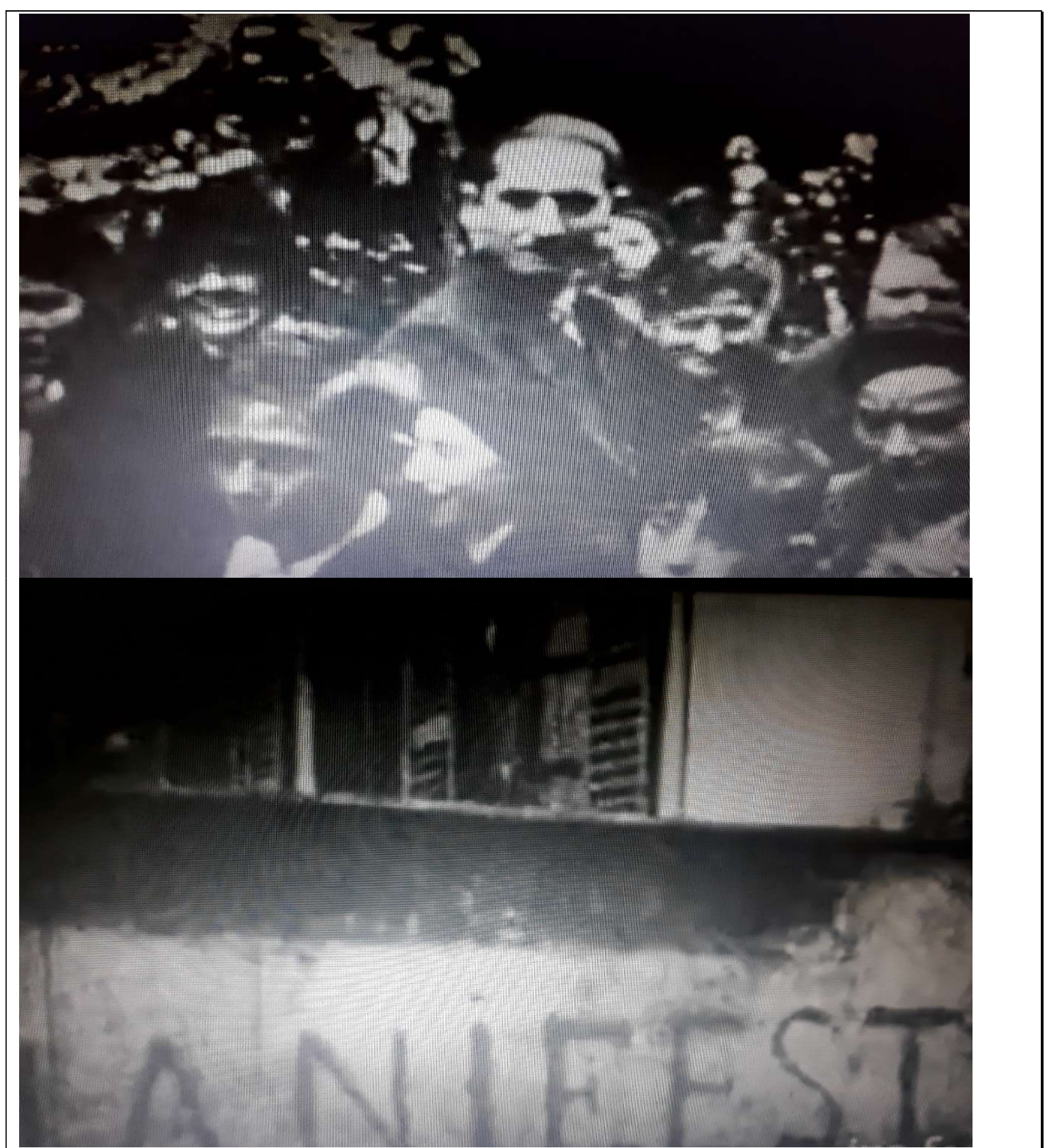

Figura 26. Os dois fotogramas acima fazem alusão ao bairro onde os pais viveram: rostos desconhecidos motivam Perec a escrever sobre a sua própria história, além das imagens do bairro degradado, relação direta com as ruas em que passou parte de sua infância

${ }^{151}$ Le hasard a voulu que ce film soit tourné dans le quartier où je suis né, à Ménilmontant. L'homme qui, pendant un an, en 1931, a filmé ces façades, ces femmes, ces enfants, ces escaliers, a parcouru les rues dans lesquelles, un peu plus tard, j'ai fait mes premiers pas : la rue Sorbier, la rue Chevreau, la rue Julien-Lacroix, la villa Faucheur, la rue de la Mare, la rue Vilin, le passage Ronce, l'impasse Dhéron, la rue Piat, la villa Ottoz, la cité Billon, la rue du Transvaal, la rue des Envierges, la rue des Couronnes. 
Todos os lugares e ruas citados por Perec são aqueles que ele conhece desde a infância, por isso a narração se torna mais interessante. Ele nos mostra que houve uma espécie de mise en abîme entre aquele que filmou o lugar (para a produção do documentário) e ele mesmo, já que está observando a partir das imagens da câmera de um outro, para escrever uma história coletiva, mas, ao mesmo tempo, muito íntima. Seria também este texto de pesquisa uma outra camada deste processo? Também estou aqui comentando os comentários de Perec, revendo o vídeo visto primeiro pelo realizador do filme e depois por Perec. Também estive nas ruas do bairro de Ménilmontant em busca de respostas para meus anseios de pesquisadora.

A minha caminhada por estes lugares pode ser considerada uma pesquisa que segue num movimento de mise en abîme? Perec observa alguém que esteve no lugar, assim como eu observo o lugar onde Perec esteve. É como se tudo girasse em torno deste tema (lugares), como se as buscas nestes lugares remetessem a outras questões importantes (memória, tempo, espaço). Sem ir diretamente aos lugares, Perec os observa pelo olhar de um outro, e ainda assim produz reflexões importantes e continua desenvolvendo seu trabalho de escrita e observação. Sobre as imagens mostradas no filme conclui: "alguma coisa um pouco ultrapassada que não pertence a ninguém, mas talvez pertença a um sonho que todos tínhamos, como uma memória fabulosa que fabrica essas milhares de memórias anônimas arrancadas do tempo perdido para projetá-los sem piedade na vertigem da nossa história." (PEREC, 2006, p. 80) $)^{152}$

Assim, considero as reflexões acerca de La vie filmée parte essencial para toda a discussão construída nesta primeira parte do capítulo, uma vez que possui algumas semelhanças, mas também diferenças, em relação a Lieux; se nesse projeto o foco foi apenas olhar para o lugar e descrevê-lo, na tentativa de guardar ou recuperar lembranças, nos comentários produzidos para o documentário La vie filmée Perec vai além: ele cria lembranças, a partir do momento em que entra em contato não só com os lugares, mas também com as pessoas que fazem parte daquele lugar.

\footnotetext{
152 “quelque chose d'un peu suranné qui n'appartient à personne, mais peut-être à un rêve que nous faisons tous, comme une mémoire fabuleuse qui brasse ces milliers de souvenirs anonymes arrachés au temps perdu pour les projeter sans pitié dans le vertige de notre histoire"
} 


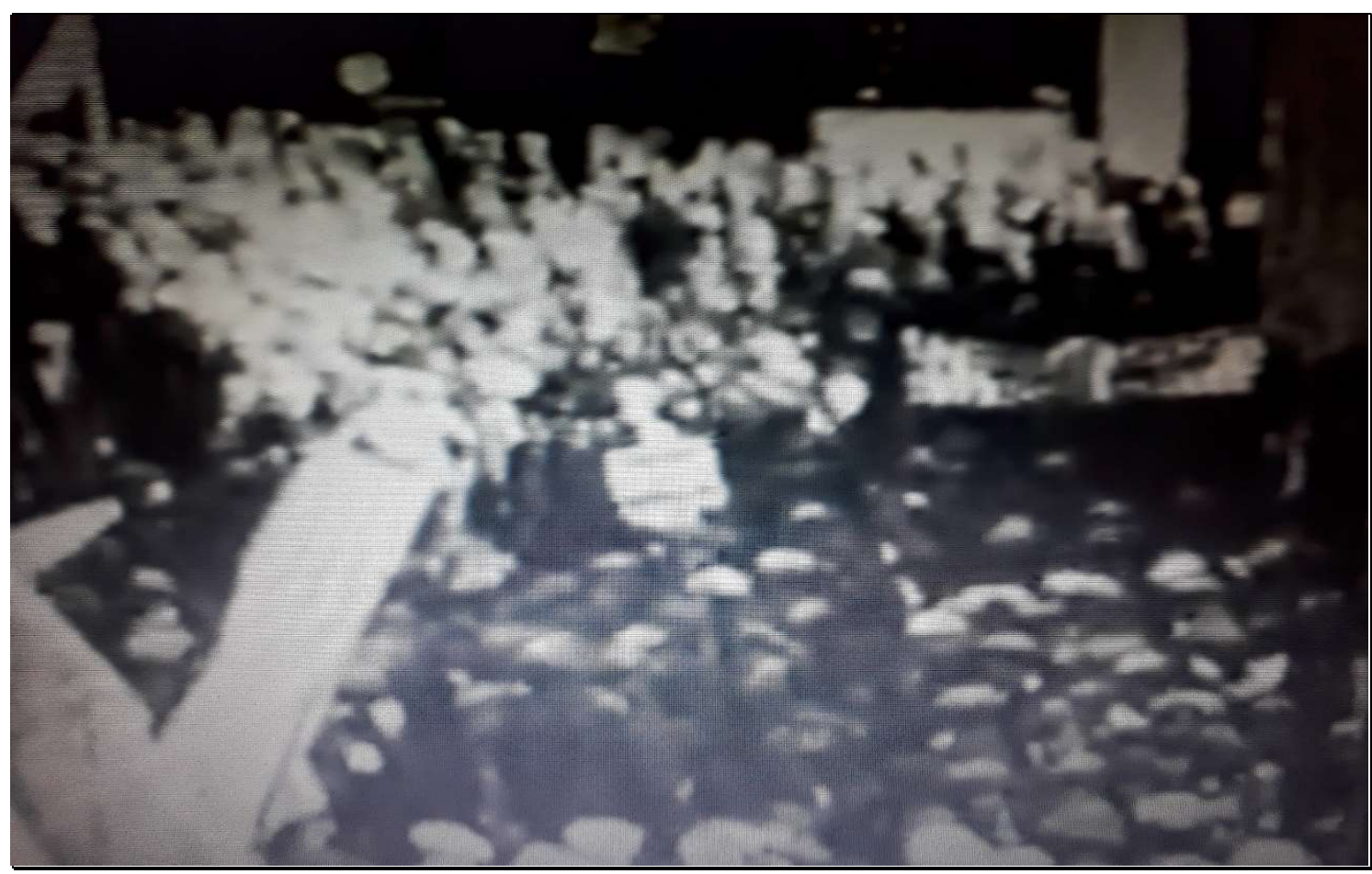

Figura 27. Cena do bairro Ménilmontant no documentário

"Mon père, ma mère, mes grands-parents se trouvent peut-être parmi cette foule qui, tous les dimanches matin, s'amassait sur le boulevard de Ménilmontant... Ou bien, peut-être, sont-ils près de l'autre, noyés dans ce cortège qui se forme, comme s'il s'en est si souvent formé en 1931, pour aller manifester contre le chômage" (PEREC, 2006, P. 80).

. Ao olhar para diversos lugares que não conhece, cria para eles histórias e lembranças possíveis, a partir do que vê no olhar daquelas pessoas ali filmadas. Quando vê o bairro em que os pais moraram, ainda assim reflete e imagina que tivessem passado pelas mesmas situações que aquelas pessoas passaram. Enfim, o contato com o outro será ainda mais produtivo para Perec: não só o lugar, mas as pessoas ali presentes são fundamentais para a escrita e para as reflexões realizadas no documentário. Esse movimento em direção ao outro ficará ainda mais evidente quando tratarmos de outro documentário, no próximo capítulo, Récits d'Ellis Island, onde o contato com o outro será também fundamental para a escrita e a produção do filme. 


\section{Les lieux d'une fugue: os lugares como protagonistas}

O filme Les lieux d'une fugue ${ }^{153}$ segue o mesmo procedimento adotado em La vie filmée e, evidentemente, no projeto Lieux: narrativas que têm os lugares como questão principal. No caso dos dois filmes, ambos são comentários narrados em voz-off (em $L a$ vie filmée, pela própria voz de Perec e, em Les Lieux d'une fugue, pelo ator Marcel Cuvelier) e, por isso, entendemos, como já foi dito, tratar-se de uma tentativa de extrapolar o texto de Lieux, metamorfoseado em outras produções. Apesar de narrar uma história pessoal, Perec terá os lugares como protagonistas das cenas apresentadas. Pensando nas diferenças, podemos lembrar que, se em La vie filmée Perec partia de rostos desconhecidos para descrever e narrar possíveis histórias (misturando-as à sua própria), em Les lieux d'une fugue, ao contrário, não há pessoas na maioria das cenas ${ }^{154}$, mesmo que haja uma história a ser contada. As pessoas anônimas de La vie filmée e que foram "personagens" da narrativa criada por Perec são substituídas, em Les Lieux d’une fugue, por muitas cenas de ruas vazias, bancos de praça, fachadas de edifício, estações de metrô.

Trata-se, assim, de uma autobiografia contada em terceira pessoa, na qual o protagonista não aparece e o que se põe a mostrar são os lugares públicos que marcaram uma lembrança de infância. Veremos, ao final, que existe uma ruptura entre terceira e primeira pessoas, mas, durante todo o filme, o que vemos são rostos desconhecidos e a narração que conta a aventura de um “il”, do qual não há nenhuma imagem (exceto uma imagem do "je" atual, como também veremos adiante).

Questionado sobre o fato de não haver atores no filme, Perec explica: “J'ai tout de suite écarté l'idée de le faire jouer par un enfant. Je ne voulais pas raconter la fugue vécue par l'enfant, mais la manière dont cette histoire était soudain revenue à l'esprit de l'adulte vingt ans après", e termina confirmando a predominância dos lugares na concepção do filme : “j’ai donc pensé à faire jouer un homme, puis, très vite, j'ai décidé de me consacrer aux lieux mêmes de cette fugue". ${ }^{155}$

\footnotetext{
153 O texto datilografado, integral, que deu origem ao filme e funcionou também como roteiro, será disponibilizado para consulta na seção "Anexos". Alguns trechos do mesmo texto estarão no corpo do texto ou funcionarão como legendas para os fotogramas apresentados.

154 “Ni l'enfant ni l'adulte ne sont joués, ni les quelques personnages qui apparaissent dans la nouvelle (l'homme qui conduit l'enfant au commissariat, les employés du métro, le marchand de journaux, les ouvriers qui montent le manège, etc." (p. 147). Texto: "Présentation des Lieux d'une fugue", transcrição de um documento pertencente ao dossiê n. 73 do Fonds Privé Georges Perec, realizada por Wilfrid Mazzorato e publicada nos Cahiers Georges Perec 9, pp.143-149.

${ }^{155}$ Entretiens et conférences, vol. I, p. 205.
} 
Mais uma vez, os lugares e a ausência (aqui representada por várias imagens: a ausência do protagonista, a ausência de pessoas em algumas longas cenas de rua, na avenida Champs Elysées ou em estações de metrô, por exemplo, lugares tipicamente lotados numa situação normal) parecem ser a tônica do processo de escrita do texto de 1965, e retomado, anos depois, para a realização do filme, em 1976 (notemos, também, que o texto passa a ser filme após a experiência de Lieux e, por isso, parece carregar traços e influências deste, para além do já contido no texto escrito muitos anos antes; a começar pela cena inicial, não existente no texto escrito: a fachada do imóvel da rue de l'Assomption, lugar onde viveu com os tios boa parte de sua infância) ${ }^{156}$.

\subsection{Rue de l'Assomption}

No texto de apresentação do filme destinado à INA (produtora responsável), contendo detalhes sobre o filme que pretendia dirigir, Perec explica como será a cena que mostrará o imóvel. Seu texto, como característica de sua escrita, divide o filme em duas partes: "Documentaire" e "Souvenirs", sendo a primeira parte dedicada às áreas externas e a segunda, apenas às duas cenas que mostram lembranças ligadas à família: o carro do tio, que vai buscá-lo na delegacia, e a cena que mostra detalhadamente a fachada do imóvel onde vivia e que assim descreve: "La porte et la façade d'un immeuble parisien (18 rue de l'Assomption dans le $16^{\circ}$ ) que l'on découvre, dans un long et lent travelling arrière après le générique de début, et en plan fixe, assez bref, avant le générique de fin" $(\text { p. 146) })^{157}$.

Creio que vale iniciar a reflexão já destacando que Perec classifica como "souvenirs" apenas aquilo que se refere à família e "partie documentaire" como todas as cenas externas das ruas e lugares públicos. Mas essa classificação imediatamente cai por terra quando assistimos ao filme e verificamos que as cenas externas e as (poucas) internas aparecem indissociáveis e, portanto, sem possibilidade de manutenção da divisão imposta inicialmente.

\footnotetext{
${ }^{156} \mathrm{O}$ texto criado para o projeto Lieux, pertencente à série Réel do lugar, foi publicado sob o título "Alées et venues rue de L'Assomption" na Revista L'Arc, n. 76, em 1979, pp. 28-34.

${ }^{157}$ Présentation des Lieux d'une fugue, transcrição de um documento pertencente ao dossiê n. 73 do Fonds privé Georges Perec, realizada por Wilfrid Mazzorato e publicada nos Cahiers Georges Perec 9, pp.143149.
} 
A primeira cena do filme se passa em total silêncio, apenas mostrando lentamente a fachada para, em seguida, focar no balcão onde vivia a família de Perec. Este é apenas um dos indícios de que a história pessoal estará em evidência. Mesmo que não haja o uso da primeira pessoa (e sim da terceira, como já observado), veremos ao final um procedimento semelhante, em alguns aspectos, ao texto escrito, que realiza a ruptura do pronome "il" para o "je”, desvendando assim o caráter pessoal da narrativa.

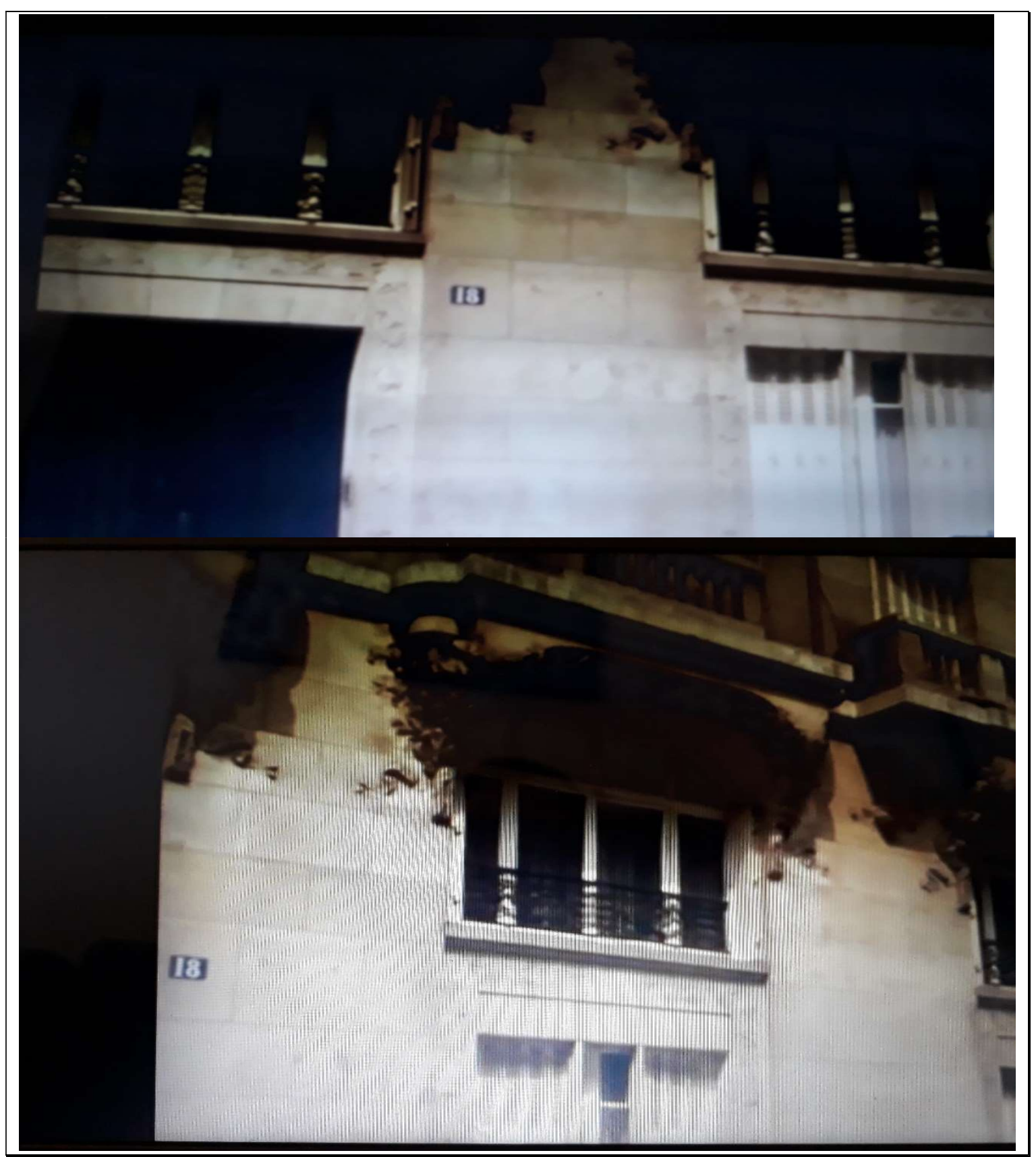

Figura 28. Les lieux d'une fugue: As duas imagens iniciais que mostram a fachada do imóvel no n. 18 da rue de l'Assomption, local onde viveu parte da infância com sua família adotiva. 


\subsection{Champs Elysées}

A cena inicial do texto aparece logo em seguida. Trata-se de uma descrição da avenida Champs Elysées totalmente vazia. Se pensarmos que não há nenhuma menção à rue de l'Assomption no início do texto, poderemos acreditar na influência de um dos doze lugares visitados para a realização de Lieux e na possível inclusão deste lugar no filme como uma espécie de chave de leitura autobiográfica não presente no texto de 1965, como também veremos adiante. Segue abaixo a cena com o respectivo texto, como publicado:

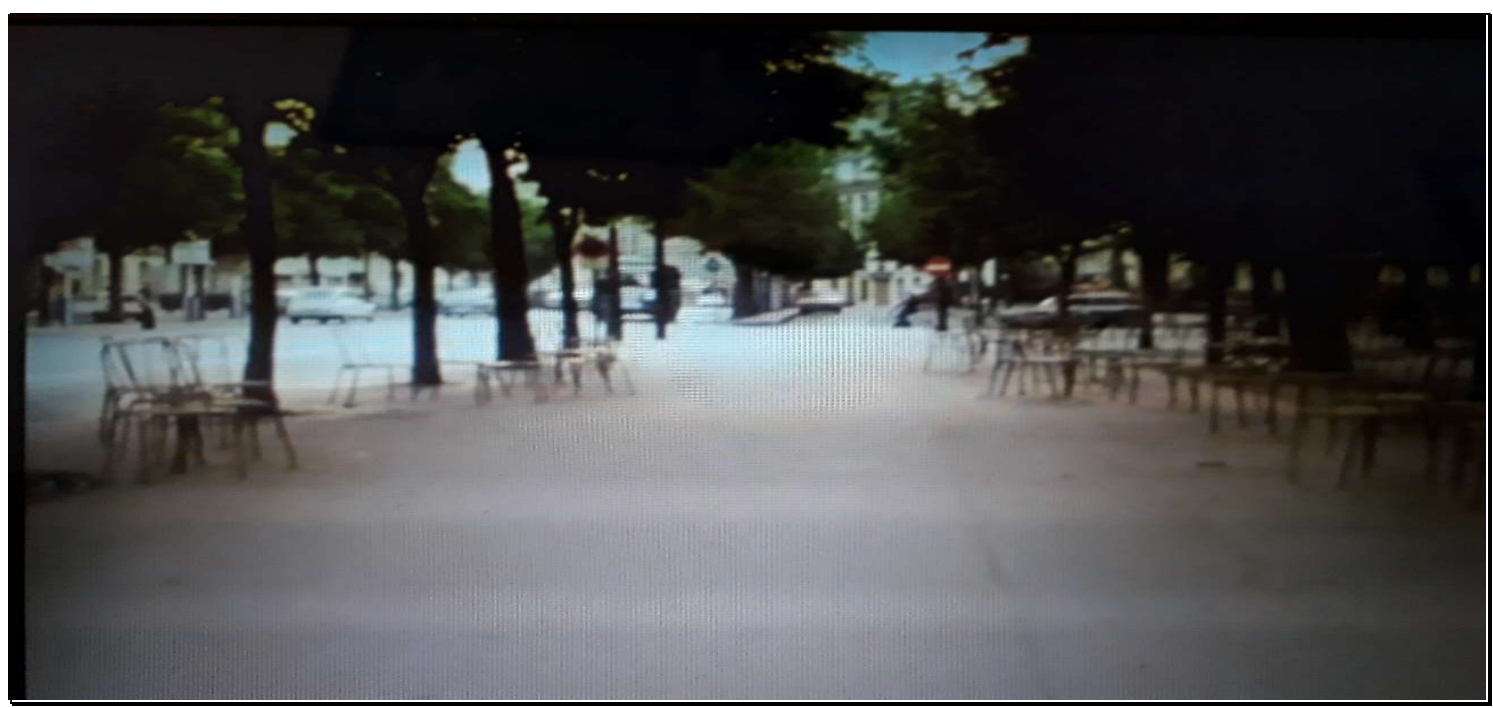

Figura 29. A cena do mercado de selos na Champs-Elysées

Le marché aux timbres des jardins des Champs-Elysées n'était ouvert que le jeudi et le dimanche.

Il le savait, mais il s'était dit qu'il rencontrerait peut-être quelqu'un, un vieux monsieur désœuvré qui regarderait son carnet, s'arrêterait sur le Blériot bistré, sur la Victoire de Samothrace, apprécierait la série des Marianne, ou le Pétain vermillon surchargé de La Croix de Lorraine. Mais il n'y avait personne, même pas un promeneur. Rien que des chaises de métal peintes en vert, alignées entre les arbres (p.15). ${ }^{158}$

${ }^{158}$ Os trechos em azul que aparecem após a legenda das figuras indica o texto lido durante a aparição de tais imagens. Vale ressaltar, a partir da relação entre texto e imagem, que nem sempre as informações coincidem entre o que comenta e o que realmente aparece na tela. 


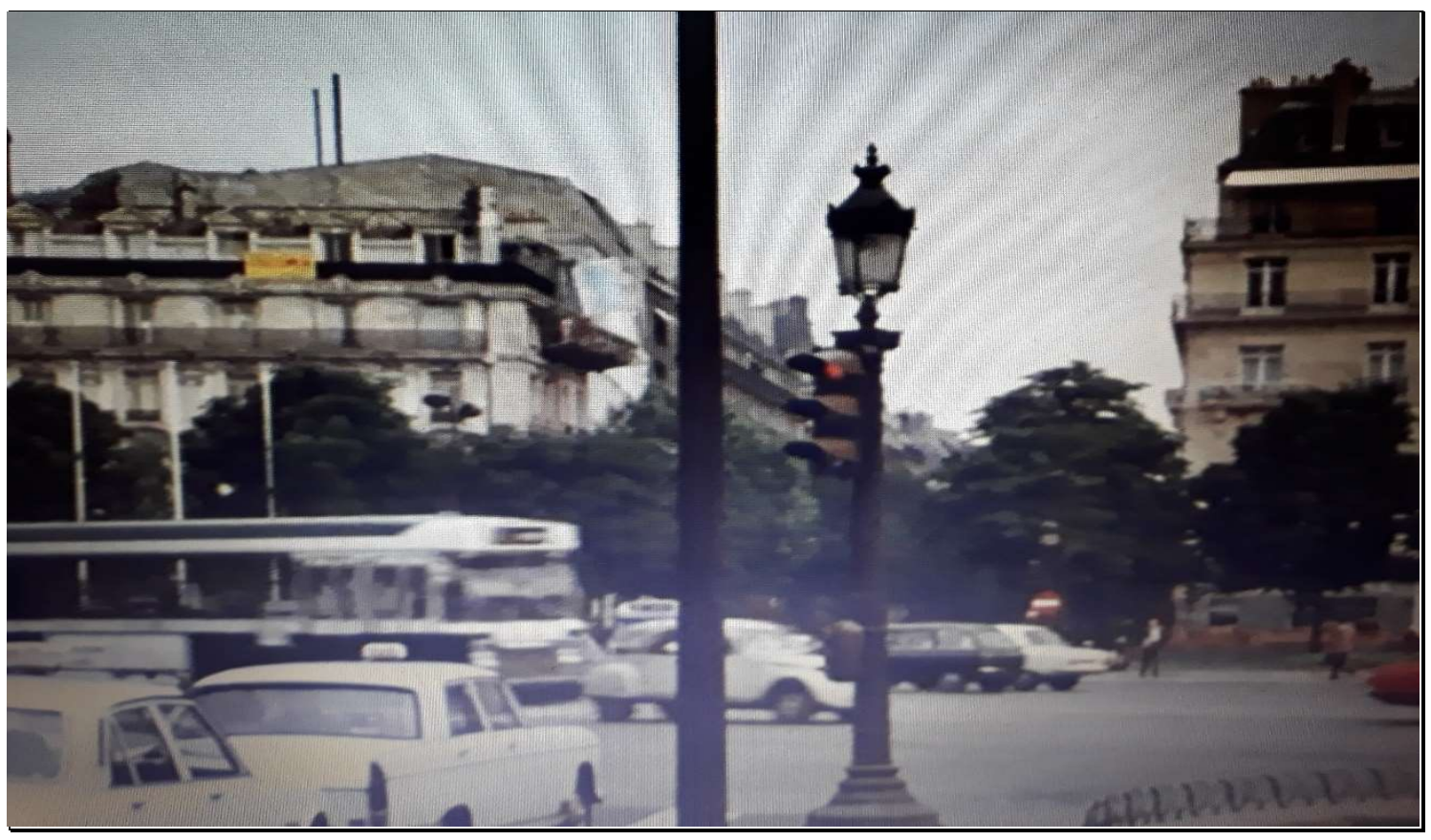

Figura 30. Cenas de Les lieux d'une fugue.

Il s'assit sur un banc et ouvrit son cartable. Il sortit son petit carnet de timbres, celui qui lui servait à conserver ses doubles. Il y avait longtemps déjà qu'il avait glissé dans la petite poche pratiquée dans la reliure les plus belles pièces de sa vraie collection, de son bel album relié que sa tante gardait sous clé, dans l'armoire, de sa chambre à côté de ses bijoux, et qu'elle ne lui laissait regarder qu'à contrecœur. (p.16).

Vemos no trecho acima que a descrição dos objetos muitas vezes não coincide com a cena mostrada, ou seja, nem o protagonista nem suas ações são mostradas: ao invés disso, o espectador cria sua própria imagem do protagonista, enquanto observa a paisagem da cidade em movimento. Vemos semelhante procedimento nas duas figuras seguintes, onde apenas um objeto da cena é focalizado por um longo período de tempo, suficiente para que as reflexões e narrações sejam concluídas, sem a presença física da personagem. Procedimento muito semelhante àquele realizado na escrita (em que a descrição exaustiva dos lugares substitui as histórias de infância inexistentes). Aqui, os objetos são mostrados em todos os detalhes e de maneira lenta, quase como se estivessem sendo descritos. A partir dessa sequência de observação dos objetos é que a personagem ganha vida, reflete, exprime seus sentimentos e deixa impressões subjetivas no espectador. 


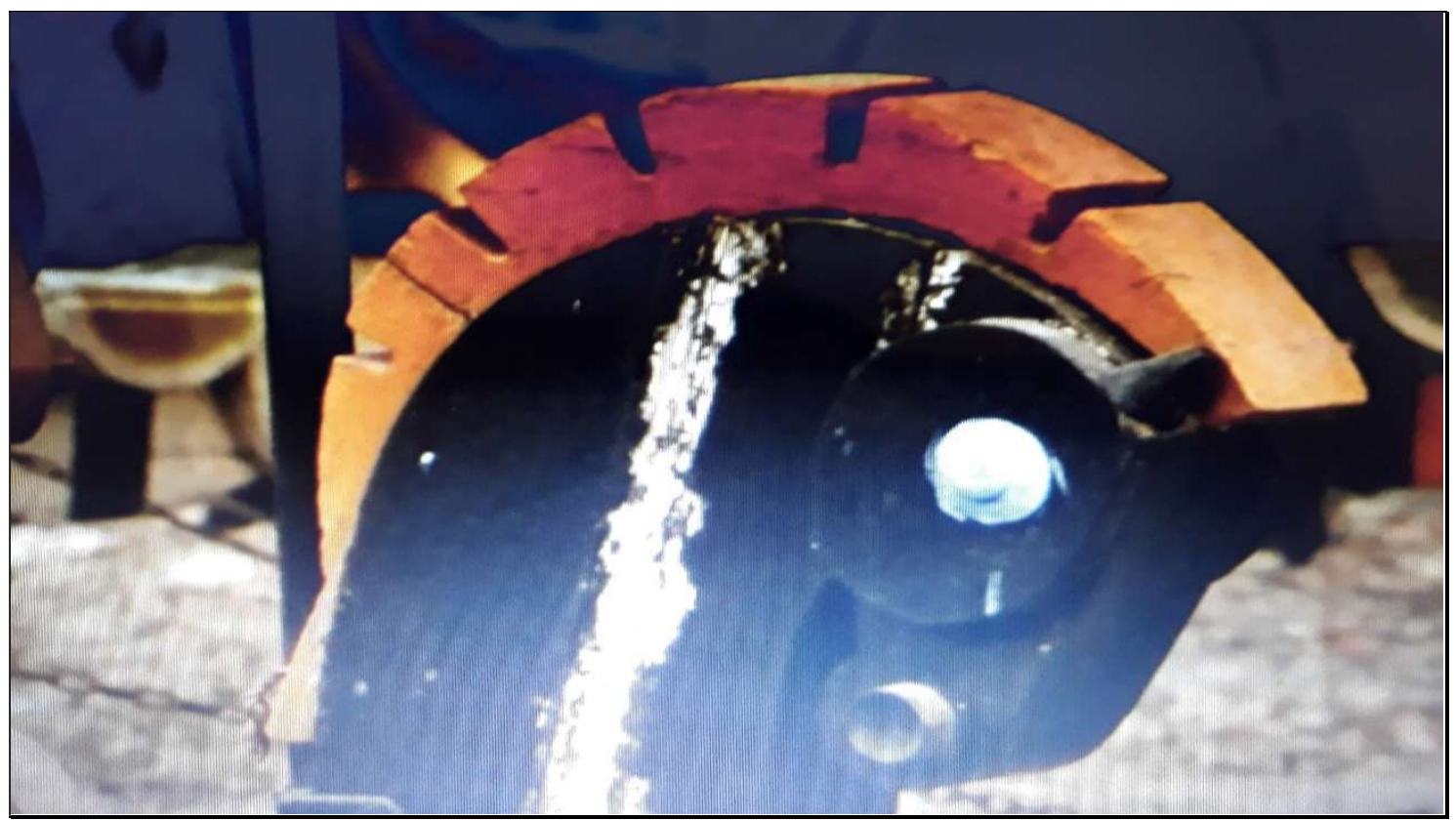

Figura 31. Cenas de Les lieux d'une fugue

Il sortit son cahier de textes. Ce jour-là, mercredi, il avait une heure de français et une heure de latin avec Monsieur Bourguignon, une heure d'histoire avec Monsieur Poirier, une heure d'anglais avec Monsieur Normand ; l'après-midi, une heure de dessin avec Monsieur Joly, une heure de sciences naturelles avec Monsieur Léonard.

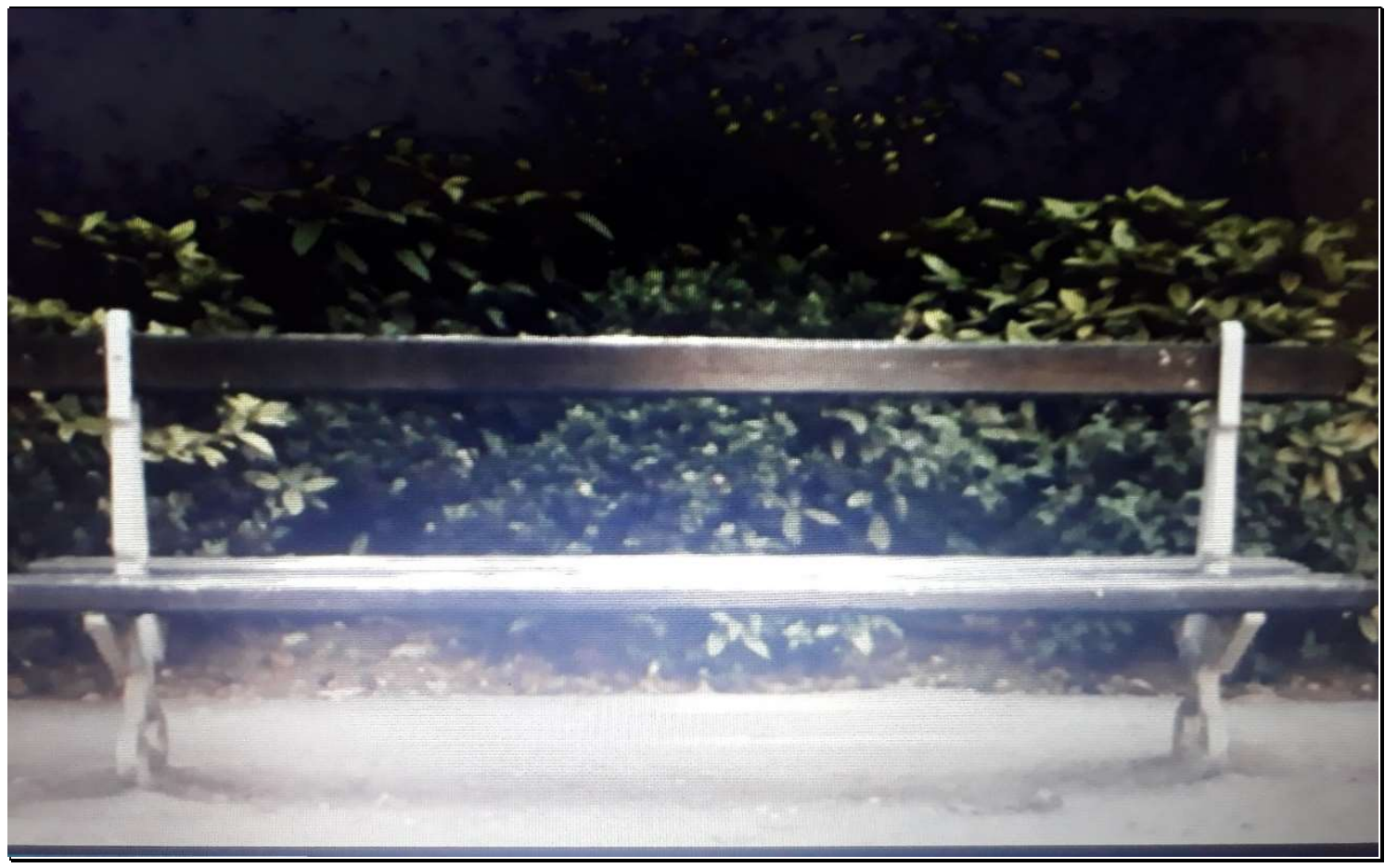

Figura 32. Cenas de Les Lieux d'une fugue

Il se dit un instant qu'il pourrait lui dire, lui expliquer. Mais il n'avait rien à dire. Il crut comprendre qu'il avait attendu cet instant toute la journée : que quelqu'un lui parle, le voie, vienne le chercher. Laissez-moi tranquille, dit-il. Allez, viens avec moi, dit 
l'homme. Il le prit par la mains et l'amena au commissariat de police du Grand Palais. Je l'ai trouvé sur un banc, au rond-point, à côté du Figaro, dit-il aux agents de police.

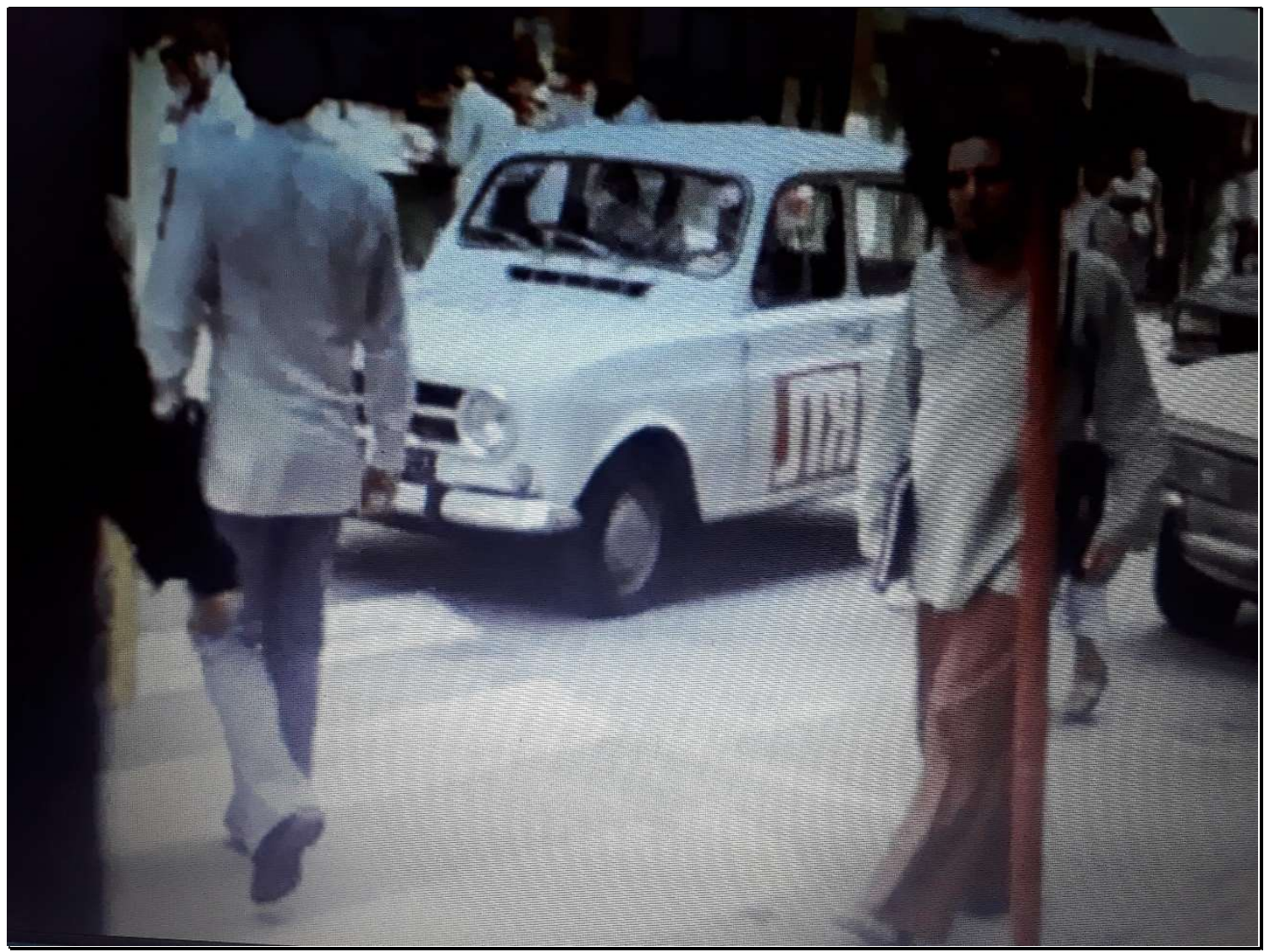

Figura 33. Cenas de Les Lieux d'une fugue

Il avait vingt-trois francs sur lui. Il les dépensa très vite. Vers le milieu de la matinée, il entra dans une boulangerie de la rue du Colissé et il acheta pour dix francs un petit pain au lait. Il le mangea lentement, par petites bouchées, tout en marchant.

\subsection{O "eu" está presente, mesmo que de relance}

A cena da boulangerie (acima) destoa um pouco do restante das imagens do filme, pois nela aparecem muitas pessoas, num espaço pequeno e concorrido, supostamente representando o lugar onde o personagem esteve durante sua aventura infantil. Mas, para além da quantidade de pessoas circulando na rua, o que chama mais atenção neste trecho do filme é a própria imagem de Perec, adulto (ele aparece rapidamente no reflexo do espelho de uma porta da boulangerie que se abre, como se alguém estivesse saindo do lugar), dando uma sensação de quase vertigem para quem consegue captar tal imagem.

O mais curioso é que isso acontece justamente no momento em que a última parte da frase transcrita acima é dita ("tout en marchant"), representando, assim, a caminhada do personagem num jogo de espelhos com a caminhada de Perec adulto e que parece 
apenas querer dar uma "piscadela de olhos" para quem assiste ao filme, já que numa aparição extremamente rápida e, portanto, quase invisível ao espectador menos atento. Assim, a partir da relação entre texto e filme (complementares, escritos em épocas diferentes e que marcam a passagem do tempo), a cena nos faz refletir sobre o projeto autobiográfico de Perec como uma constante reconstrução de memórias, nesse caso a partir de duas mídias diferentes (escrita e imagem), como afirma o artigo de Mazzorato ${ }^{159}$

[...] Les Lieux d'une fugue é notável no sentido em que nos coloca de volta evocando a "página branca", do texto anterior. Assim, o texto da história, guardado dez anos em uma gaveta, e publicada no momento de realização do filme, não passa de um tipo de rascunho da memória, lembrança que toma sua real medida na tela, paradoxo estilístico que faz de um texto um "avant-texte", metáfora que apresenta lembrança de uma fuga como um trabalho da memória que ele deve ser reproduzida para reconstruir, de um texto a outro, de uma mídia a outra (escrita/cinema), de um fragmento a outro. $\left(2003\right.$, p. 141) ${ }^{160}$

Mais uma vez, rostos anônimos fazem parte de uma lembrança pessoal: a história de uma fuga, realizada por uma criança, que enxerga os adultos de longe, já que são apenas rostos na multidão. A tentativa de reconstruir a cena traz pessoas de costas, em sequências lentas, como a criança estivesse ali observando, sem ser muito notada pelos demais. Já vimos que essa estratégia de utilizar rostos desconhecidos/anônimos foi bastante utilizada por Perec, tanto no filme La vie filmée quanto na obra a ser analisada no próximo capítulo, Récits d'Ellis Island.

\footnotetext{
${ }^{159}$ Artigo "Ne pas aller em cours et rédiger un devoir de mémoire À propos du film Les lieux d'une fugue" em Cahiers Georges Perec 9, 2003, p. 141.

160 [...] LLDF est remarquable dans le sens où elle nous replace, en évoquant " la page blanche", dans l'avant-texte. Alors le texte de la nouvelle, gardé dix ans dans un tiroir, publié au moment du tournage du film, n'est plus qu'une sorte de brouillon de la mémoire, souvenir qui prend sa véritable mesure à l'écran, paradoxe stylistique qui fait d'un texte un avant-texte, métaphore qui présente le souvenir d'une fugue comme un travail de la mémoire qu'il faut jouer à reconstruire, d'un texte à l'autre, d'un médium à l'autre (écriture/cinéma), d'une bribe à l'autre.
} 


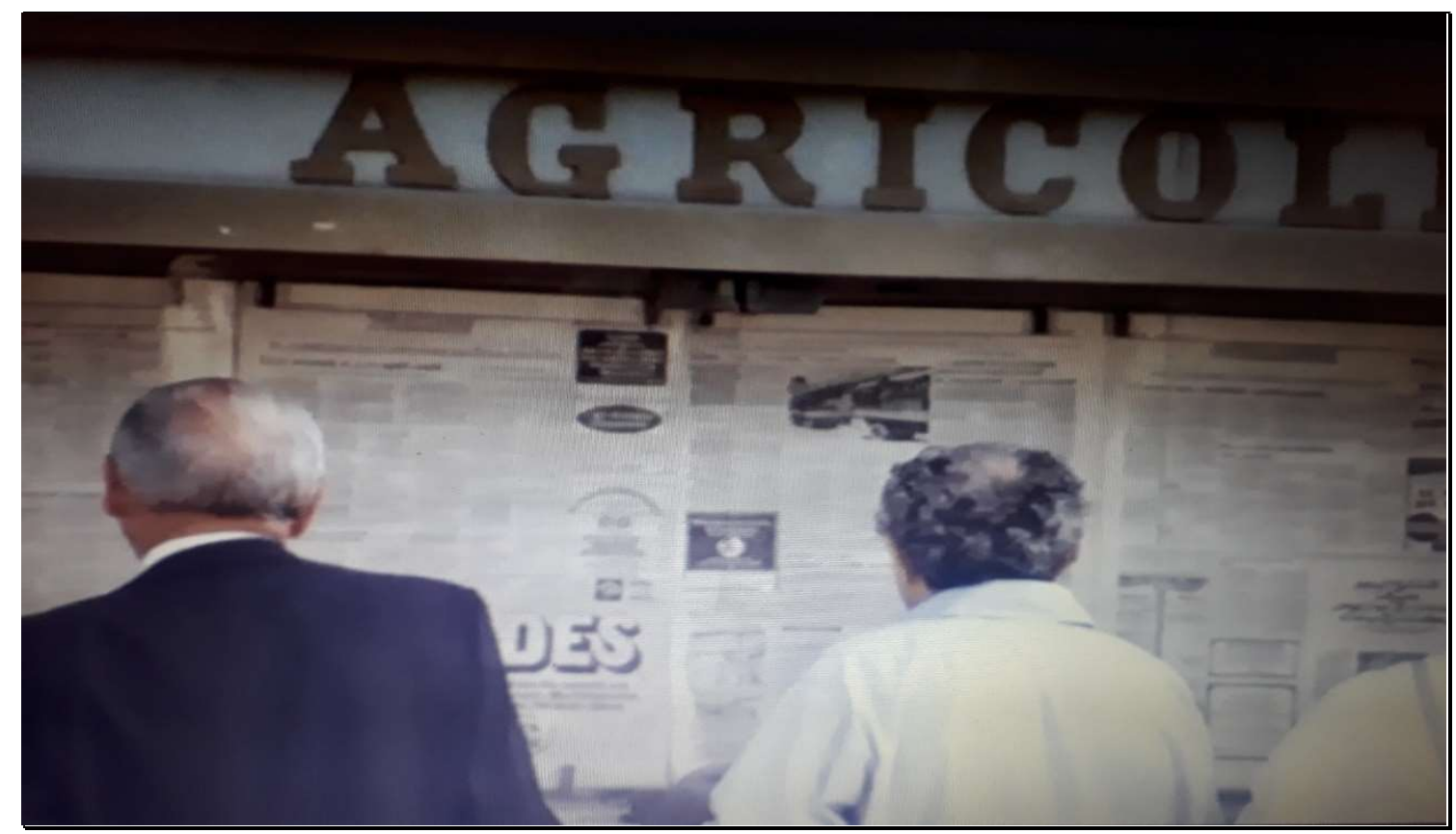

Figura 34. Cenas de Les Lieux d'une fugue

Plus tard, il se mêla aux badauds qui, à longueur de journée, lisent Le Figaro, Le Figaro Littéraire, Le Figaro agricole, qui sont affichés sur les murs de l'immeuble de l'avenue des Champs-Élysées.

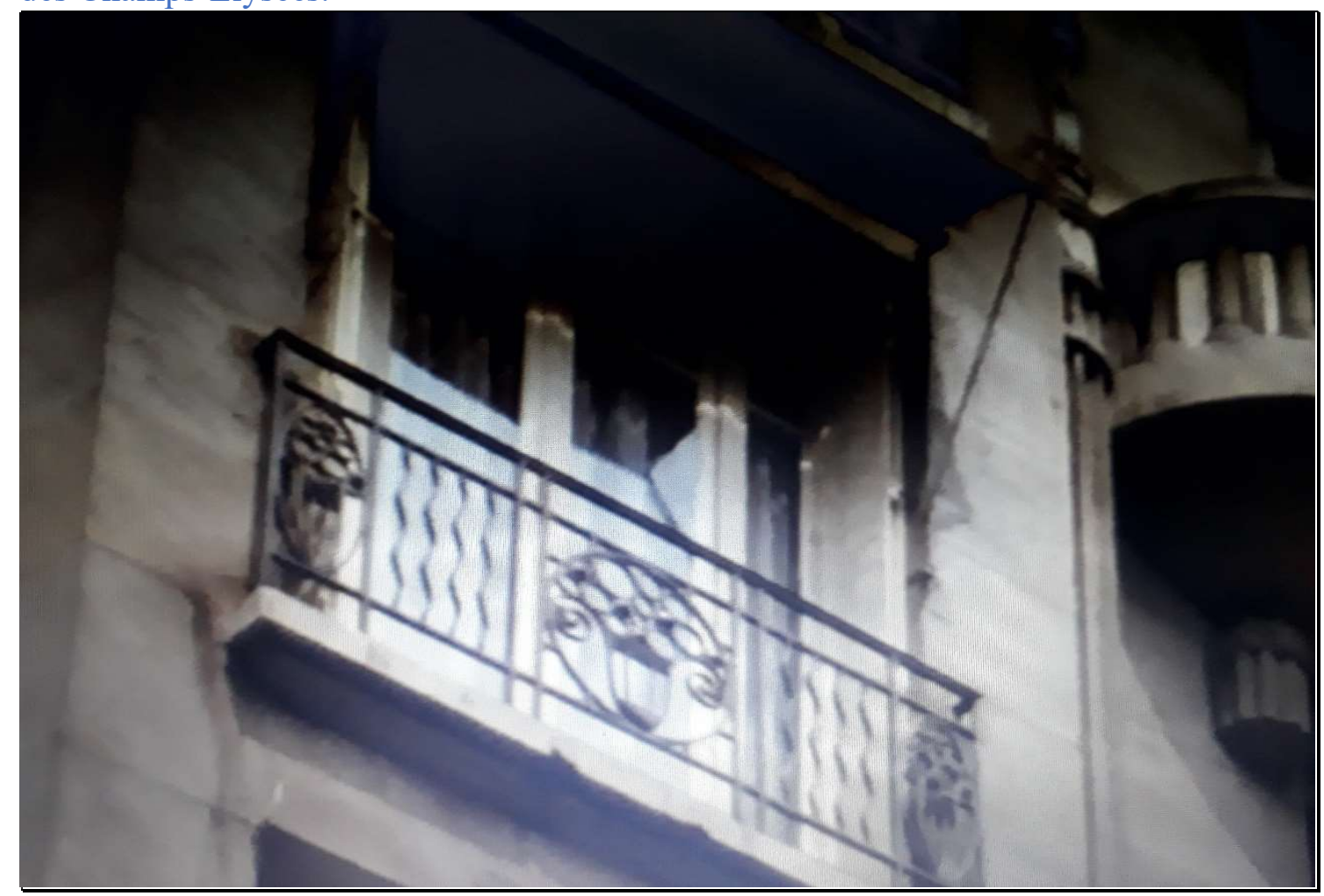

Figura 35. Cenas de Les Lieux d'une fugue

Les glaces du grand vestibule lui renvoyèrent, un instant, son image à l'infini. Il sortit. La rue de L'Assomption était tranquille, presque provinciale, encore endormie. 
Nas cenas finais, a câmera agora mostra lentamente a fachada do imóvel. Os tempos se misturam e a narração se volta para o começo de tudo, para antes da saída à fuga. O lugar, desta vez, é mencionado na narração e não mais apenas mostrado, sem nenhuma referência, como no início do filme.

\subsection{As tensões entre "il" e "je"}

Na sequência, apresentaremos alguns pontos de contato e algumas diferenças entre o texto publicado e o filme, o que nos ajuda a pensar nas tensões existentes entre o "il" e “je”, mostrando algumas consequências desse tipo de autobiografia oblíqua, escrita em terceira pessoa, e quais os efeitos dessas tensões para os leitores e também para os telespectadores.

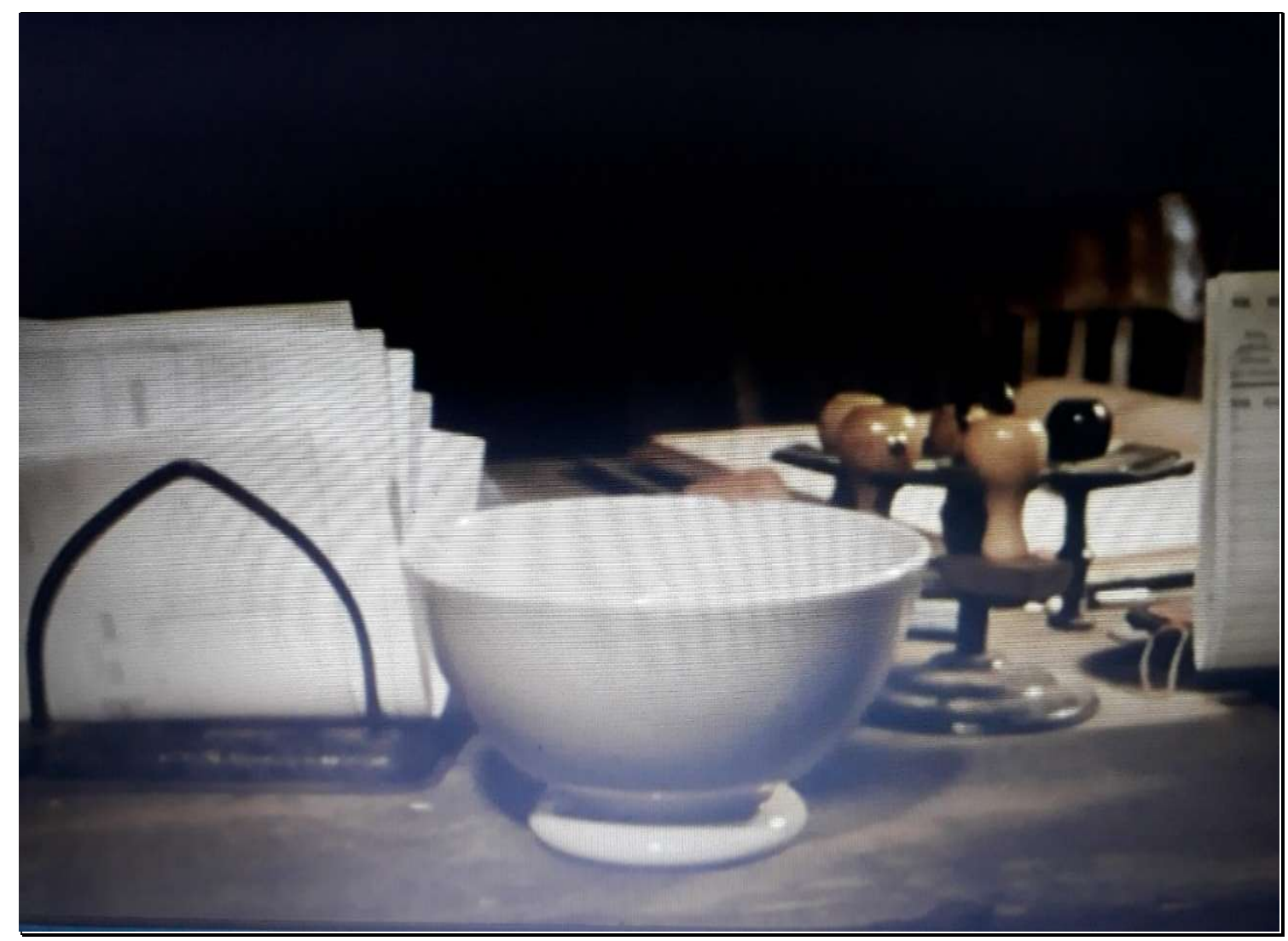

Figura 36. Cenas de Les Lieux d'une fugue

Un agent revint, tenant un bol rempli d'eau et lui tendit. Il posa le sandwich sur le buvard et saisit le bol à deux mains. C'était un bol énorme, profond, de faïence blanche, aux bords un peu ébréchés, au fond maculé de stries grisâtres. Il trempa ses lèvres dans l'eau et il but. 
Após toda a cena de captura da criança perdida e chegada à delegacia, - conforme fotograma acima - , onde será resgatado pelo tio, a memória da personagem parece tentar, novamente, se recompor a partir dos objetos e dos lugares ${ }^{161}$, como que numa espécie de retrospectiva de todas as peripécias vividas, a partir de uma lista apresentada no momento final do filme ${ }^{162}$ :

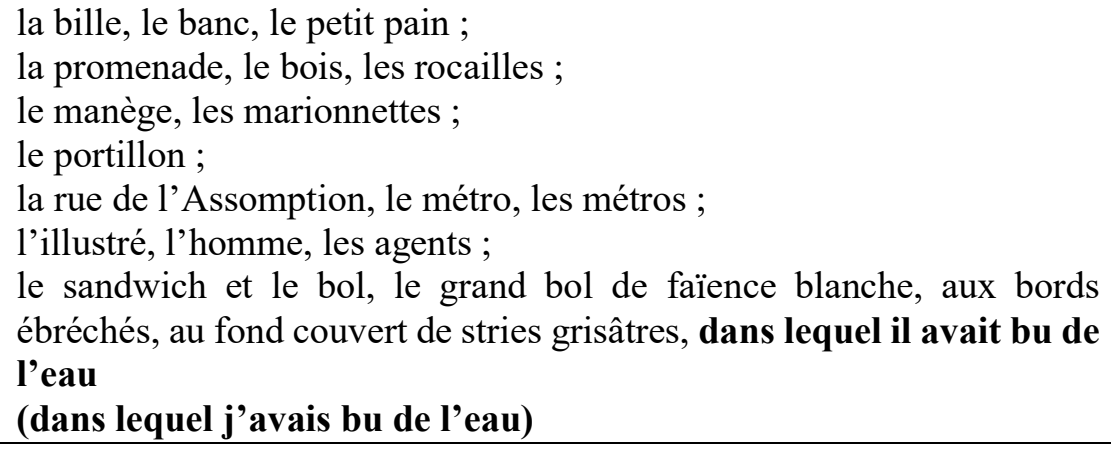

A passagem do pronome "il" para "je" na última frase é a chave de leitura autobiográfica, que só será apresentada ao leitor na última página do livro. Segue-se a este trecho a última oposição il/je que encerra a escrita do texto:

Et il demeura tremblant, un long moment, devant la page blanche (et je demeurai tremblant, un long moment, devant la page blanche)

No filme, ao optar por usar apenas o "je" nas duas últimas frases aqui transcritas, Perec elimina a ambiguidade e, ao mesmo tempo, nos mostra chave de leitura autobiográfica criada no texto escrito.

\footnotetext{
${ }^{161}$ A lista original datilografada, contendo os objetos necessários para compor o principal ambiente interno do filme, "Le comissariat", será disponibilizado na seção "Anexos", demonstrando a importância de tais objetos para a composição da narrativa.

${ }^{162}$ Reproduzimos a lista realizada e publicada no texto, que não coincide com a ordem em que os objetos e lugares são apresentados no trecho do filme, mas que não altera, de maneira nenhuma, a ideia de superposição da memória a partir dos itens apresentados, ou, melhor dizendo, acaba por representar a memória precária e hesitante de Perec, constante tema de suas obras autobiográficas.
} 


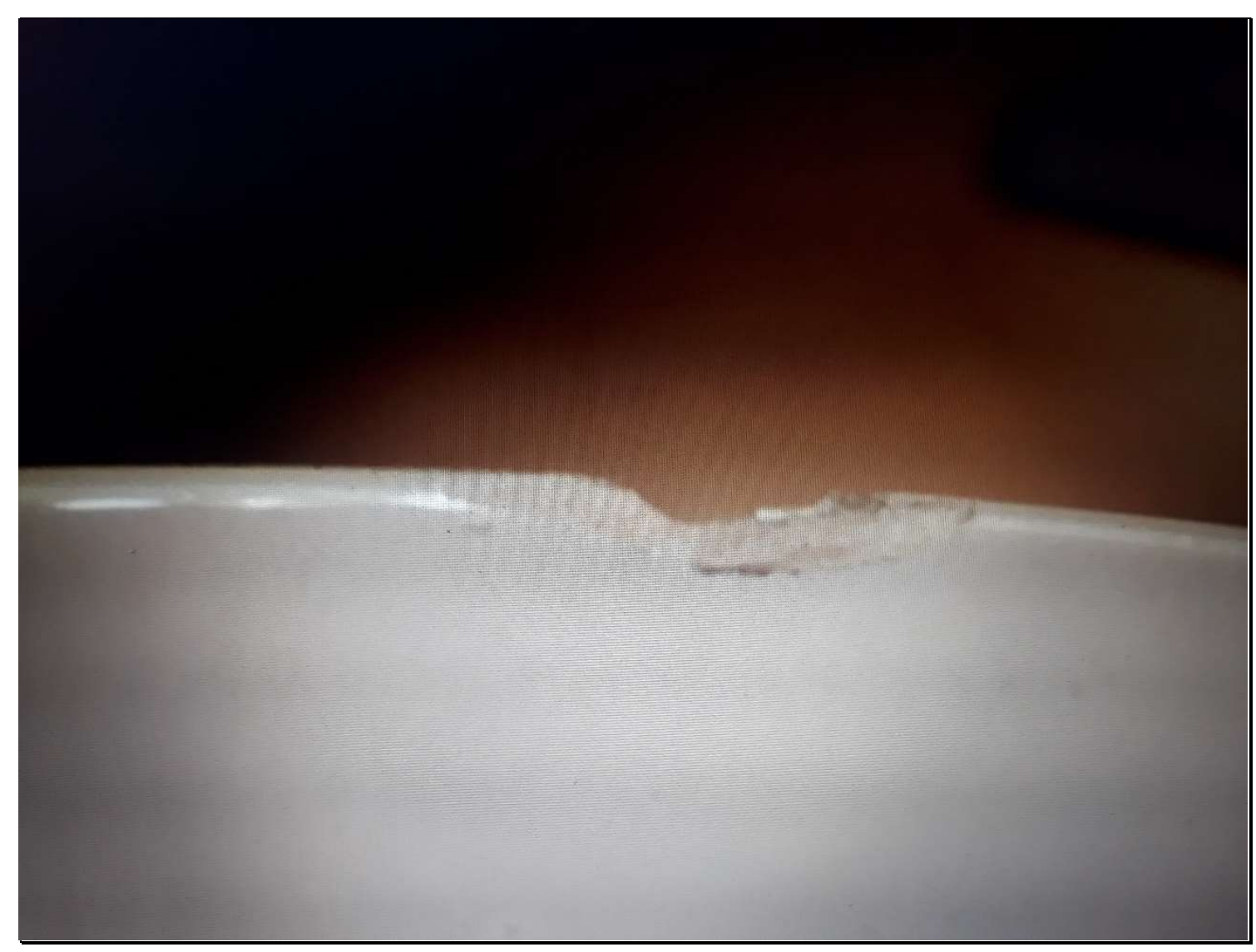

Figura 37. Cenas de Les Lieux d'une fugue

O objeto fissurado que aparece na imagem acima pode, então, substituir ou representar a quebra entre $i l$ e $j e$, assim como pode ser a chave de leitura do filme, a partir da ideia de quebra, cassure, cicatriz ${ }^{163}$ (aquilo que está ali, mas não observamos caso não estejamos tão atentos: aquilo que é infra-ordinaire, como já dito, temática recorrente na obra perecquiana). A imagem do bol quebrado, portanto, pode representar a quebra do ilje que não está no filme, e aparece como mais uma pista para ver no filme aquilo que pode nos parecer também invisível.

\footnotetext{
${ }^{163}$ A imagem da cicatriz aparece em alguns momentos dentro da obra de Perec: uma característica pessoal que aparece sobretudo em $W$ ou a memória da infância, conforme trecho a seguir: "Um dia, um de meus esquis escapou das mãos e bateu de leve no rosto do rapaz que estava a meu lado guardando seus esquis e que, furioso, pegou um de seus bastões de esquiar e me desferiu um golpe no rosto com a ponta do bastão, abrindo-me o lábio superior [...] a cicatriz que resulta dessa agressão ainda hoje é perfeitamente visível [...] tornou-se uma marca pessoal, um sinal distintivo [...]" (PEREC, 1995, p. 130). Há também, na parte I do texto da minha dissertação, um subitem intitulado "Portrait d'un homme, ou a história de uma cicatriz", que trata com mais detalhes da imagem da cicatriz e as relações autobiográficas com a obra de Perec.
} 


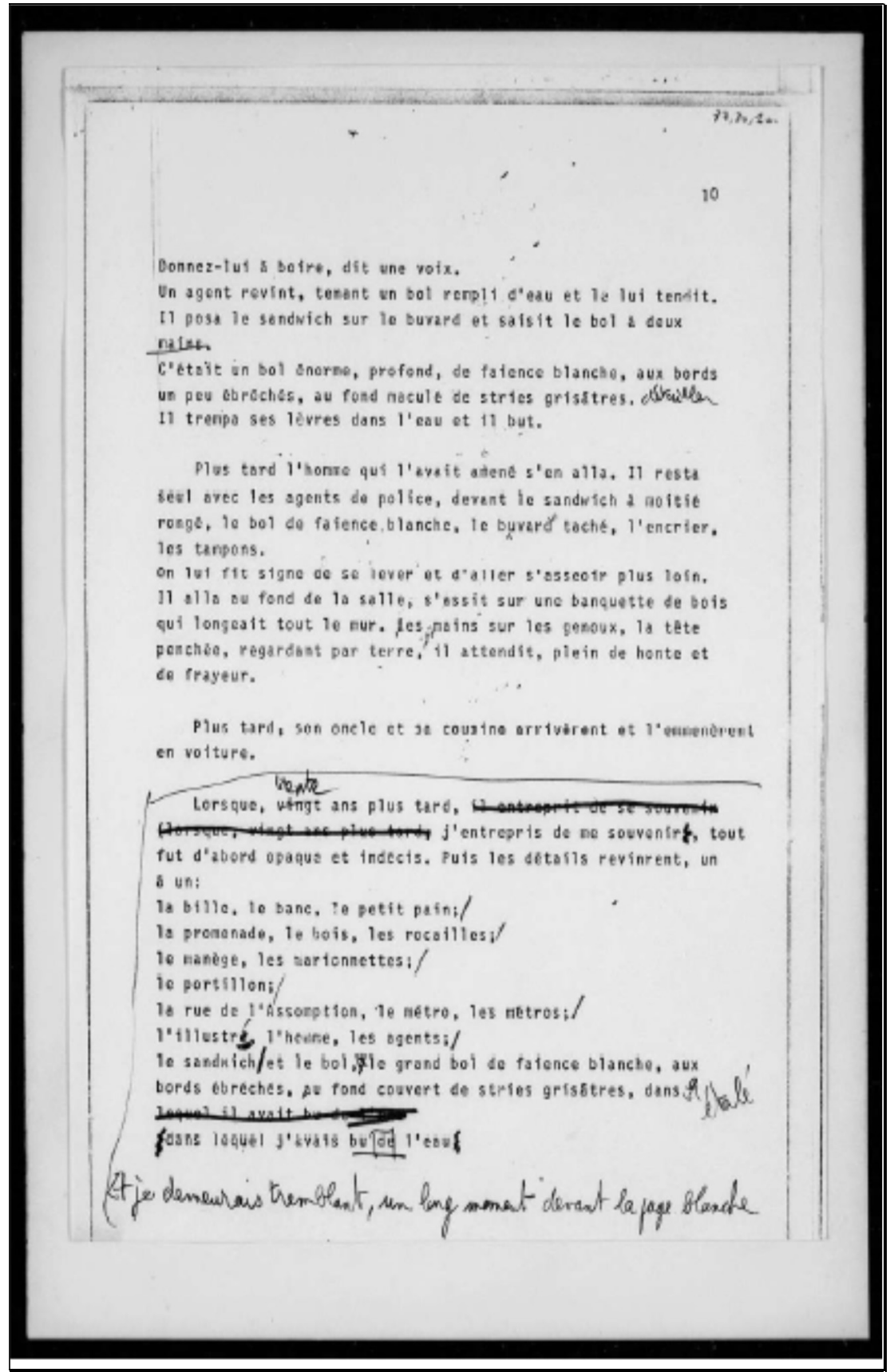

Figura 38. No texto datilografado, na última linha, observa-se a frase "et je demeurais tremblant, um long moment, devant la page blanche" escrita à mão, como um ajuste à aparição do "eu" no texto, que não é tão explícita no filme.

\subsection{Texto e filme, tempo e espaço}

Tanto o texto quanto o filme, com a imagem final da página em branco, faz com que pensemos na questão do tempo, da volta que se dá para chegar ao fim e anunciar que a lista descrita no final do livro/filme representa, de certa forma, o inventário de lembranças que constituirão o livro/filme que estão por vir, quase numa analogia a $\dot{A}$ Recherche du temps perdu, de Proust. No caso de Perec, poderíamos pensar em algo como 
"À la recherche de l'espace perdu" "64; como se toda a escrita sobre o espaço que o cerca fosse motivadora para a continuação para a escrita, mesmo que ela fosse continuar, de certa forma, a tratar da questão do espaço, a partir de outros desenvolvimentos, conforme lemos no artigo de Chantal Labre ${ }^{165}$ : “malgré les références proustiennes, Perec, c'est l'anti-Proust: non pas le temps retrouvé, mais le temps éparpillé, épars dans l'espace du livre, de la ville [...]" (2006, p. 130).

Não bastasse esta confissão de que está diante de uma página branca, de que as memórias estão por vir, Perec ainda anota a data da escrita, como último registro do texto: "Mai mil neuf cent soixante-cinq" (maio de 1965). Trata-se do ano em que se lembrou da fuga, que marca a chegada da memória e que representa, por consequência, uma diferença temporal também como o filme produzido em 1976. Não só isso: há também a diferença temporal entre o ato de enunciação da escrita da memória (ou sua efetivação, rememoração) e o momento onde todos os fatos ocorreram, que também aparece em determinado trecho do livro:

Foi em onze de maio de mil novecentos e quarenta e sete. Ele tinha onze anos e dois meses. Ele tinha acabado de fugir de casa, número dezoito da Rua de l'Assomption, no décimo sexto arrondissement: usava uma jaqueta de pano cinza com três botões, calças curtas azul marinho, sapatos marrons, linhas de lã azul. Carregava uma mochila preta de couro falso. $(1990, \text { p. } 23)^{166}$

O que nos leva a pensar na relação que Perec estabelece com o projeto Lieux e que parece também ser um fator de diferença entre o texto e o filme. Se o texto escrito se encerra com a oposição marcada entre il/je e a data que firma o momento da lembrança, o filme se encerra da mesma maneira como se iniciou: mostrando detalhes da fachada e focando na porta do imóvel da rue de l'Assomption, enfatizando a importância do imóvel para a aventura produzida. O filme é sobre uma fuga, mas sobretudo sobre a fuga de um lugar (ou sobre um lugar para onde parece não desejar voltar), a rue de L'Assomption, ou a casa de seus pais adotivos que, como vimos, não é aquele onde Perec tem suas melhores

\footnotetext{
${ }^{164}$ Essa expressão faz referência direta ao artigo de mesmo nome, de autoria de Claude-Henri Rocquet, em Perec, Ed. de L'Herne, 2006, p. 128, que trata, sobretudo, da obra Espèces d'espaces. Há por isso uma ligação bastante clara com a discussão que estamos desenvolvendo aqui. Além disso, as influências de Proust na escrita de Perec são explícitas, como já vimos em alguns exemplos do Capítulo I, como por exemplo, entre as páginas 31 e 33, quando trato da questão da relação de memória com o espaço do quarto e da cama.

${ }^{165}$ Artigo também publicado em Perec, Éd. de L'Herne, sob o título "Je me souviens", 2006, p. 130.

${ }^{166} \mathrm{C}$ 'était le onze mai mil neuf cent quarante-sept. Il avait onze ans et deux mois. Il venait de s'enfuir de chez lui, dix-huit rue de l'Assomption, seizième arrondissement : il portait une veste de drap grise à trois boutons, une paire de culottes courtes bleu marine, des chaussures marron, des chaussettes de laine bleue. Il portait un cartable de simili-cuir noir. O texto original, escrito em 1965, foi publicado na coletânea póstuma Je suis né, em 1990.
} 
lembranças ou com o qual criou laços afetivos. Um dos poucos vínculos criados no lugar é com a prima Ela Bienenfeld ${ }^{167}$, que ele homenageia com a música que é reproduzida em sequência durante todo o filme ${ }^{168}$. Ademais, podemos verificar em alguns momentos que se trata da memória de uma criança solitária, sobretudo. E que os lugares públicos, aparentemente, são de fato aqueles nos quais busca este vínculo, afeto ou proximidade, na ausência dos lugares íntimos e familiares, como vemos na passagem em que está dentro do metrô, por exemplo: "Le bruit du métro le réconfortait presque” (PEREC, 1990, p. 24).

É também importante ressaltar que há diferenças entre texto e filme que não parecem tão significativas (como a ordem de algumas sequências, por exemplo), mas, em relação a esta focalização no lugar (iniciar e terminar com a imagem da porta do imóvel da rue de l'Assomption), isso pode indicar que, se antes do projeto Lieux, em 1965, o texto trazia somente lembranças de um dia de fuga na infância, o filme, de 1976, indica esta influência direta de Lieux: mesmo que o texto se inicie com uma descrição da Champs-Elysées, e que haja muitas citações a lugares da infância, é somente no filme que o desejo de mostrar aquela fachada se concretiza, como se revelasse algo autobiográfico ainda não explícito no texto escrito anteriormente. Como vimos, no meio do texto há a menção sobre a rue de l'Assomption, designada como o ponto de partida da fuga; mas, a partir das investidas aos lugares ocorridas com o projeto Lieux, podemos imaginar que a filmagem do texto tenha se direcionado ainda mais para este lugar de infância, em tomadas lentas, representado em meio ao silêncio, produzindo uma reflexão talvez não tão possível de se realizar no texto escrito. Mostrar o lugar, no filme, é o mesmo que observá-lo de novo, partir de novo às ruas, agir a partir da memória que se tem sobre ele, criar arte a partir dele, a partir dos diferentes lugares. A escrita sobre eles aparece heterogênea, fragmentada, similar à memória autobiográfica. Segundo Mazzorato ${ }^{169}$, esses Lieux d'une fugue são, na verdade, “un ensemble fragmentaire, découpé. Ces lieux sont des pièces de puzzle: la fugue n'a pas de lieux fixe, mais constitue un ensemble, un assemblage, de lieux bribes, des miettes de lieux".

\footnotetext{
${ }^{167}$ A quem serei sempre grata, por ter autorizado o meu acesso aos manuscritos de Lieux no Fonds Perec, (no início do ano de 2016 e a poucos meses de seu falecimento) e, portanto, ter contribuído de maneira significativa para o desenvolvimento desse trabalho.

${ }^{168}$ Conforme relata David Bellos: "Les Kreisleriana de Schumann, joués de façon hésitante d'abord, puis avec de plus en plus d'assurance, servent de bande sonore à tout le film, et constituent une commémoration acoustique des exercices de Lili au piano, rue de L'Assomption" (BELLOS, 1994, p. 615). Vale ressaltar que Lili é o nome de família usado para designar a prima aqui mencionada, Ela Bienenfeld. Há também, no livro de Bellos, um texto que conta fatos sobre a permanência de Perec na rue de l'Assomption e seu convívio com a família. Trata-se do capítulo 9, "Rue de l’Assomption - 1945-1948”, p. 109.

${ }^{169}$ Op. Cit., p. 135.
} 
Para finalizar, não podemos esquecer outro lugar dentre os doze de Lieux, Franklin Roosevelt (estação que dá acesso à avenida Champs Elysées), por onde caminha quando adulto e se rememora da fuga da infância ao avistar uma loja de selos que frequentava ${ }^{170}$, e que dá origem ao texto escrito: lugar também onde praticamente toda a ação da fuga se desenrola e partir do qual muitas cenas são realizadas, em momentos que repetem o mesmo procedimento de observação de Lieux. Não há necessariamente uma menção direta aos lugares mostrados (apesar das várias referências, através das placas, estações, monumentos). Assim, de certa forma, os lugares observados para dar conta de Lieux serão retomados no filme, assim como o texto escrito em 1965 pode, por que não, também ter sido, inversamente, um dos pontos de partida para a própria ideia do projeto Lieux.

Não há como saber precisamente quais eram as intenções do autor e o que realmente pretendia mudar do texto para o filme, e esse aspecto também não nos parece relevante. O mais importante, sobretudo, é pensarmos no processo e no tempo percorrido entre um trabalho e outro, com todas as influências e mudanças de percurso, que transformou Les lieux d'une fugue não só em um texto adaptado para filme ou um filme realizado a partir de um texto: Les lieux d'une fugue tornou-se um novo projeto, multifacetado, composto por técnicas diferentes de expressão, especificamente o texto escrito e o cinema, como mais uma vez observa Mazzorato: “Les Lieux d'une fugue n'est ni tout à fait un texte ni tout à fait un film, mais un projet, qui s'inscrit à la fois dans les deux approches, textuelle et cinématographique, en même temps qu'il prend forme et place dans une histoire personnelle" (2003, p. 141).

Por fim, podemos pensar na hipótese de que Perec pode ter se dado conta de que seu texto de infância era mais ligado aos lugares do que à própria memória em si, bastante precária. Assim, a escrita de 1965 é retomada/reformulada - sob outro aspecto - quatro anos depois, em Lieux; em seguida, Perec se apropria novamente dessa escrita e a relaciona com imagens do filme, criado em 1976, para compor lentamente esta trama autobiográfica perecquiana intrinsecamente ligada aos lugares públicos.

É também importante frisar que essa tensão entre "il" e "je" é uma constante autobiográfica em Perec, não só no texto de Les lieux d'une fugue, mas em outras obras como, por exemplo, Un homme qui dort (escrito por um narrador que se dirige à segunda

\footnotetext{
${ }^{170}$ Como nos explica Mazzorato em seu artigo: "Rappelant ses fréquents retards en classe, Perec a évoqué dans $W$ ou le souvenir d'enfance (p.44) le fait qu'il utilisait l'argent qui lui donnait sa tante pour prendre le bus afin d'acheter des petits soldats de terre avec lesquels il rejouait symboliquement la mort de son père", em Cahiers Georges Perec 9, 2003, p. 137.
} 
pessoa, mesmo que saibamos que há aspectos autobiográficos presentes). Exatamente por isso, o próximo capítulo abordará com mais detalhes essa questão, uma vez que a obra Récits d'Ellis Island é uma espécie de autobiografia provável, ou seja, Perec vai falar dos outros como se tentasse, a partir deles, contar sua própria história e sua relação com as origens judaicas. Radicalizando ainda mais essa relação com o outro, também trataremos no próximo capítulo da relação que Robert Bober desenvolveu com Perec (principalmente a partir do trabalho em conjunto, o mesmo Récits d'Ellis Island) e como essa relação levou Bober a criar um documentário em homenagem a Perec, partindo, justamente, das fotos da rue Vilin, do projeto Lieux e de outras obras autobiográficas de Perec, numa espécie de reconstituição de sua memória. Assim, a pesquisa caminha agora para desenvolver de forma mais detida todas essas nuances e todas as manifestações artísticas resultantes desse processo de inter-relação entre o eu e o outro. 


\section{CAPÍTULO IV}

\section{Primeiras considerações sobre Récits $d^{\prime}$ Ellis Island}

Antes de iniciar as discussões desse capítulo, é importante fazer uma breve recapitulação do assunto aqui analisado em relação à minha trajetória de pesquisa desde o final da escrita da dissertação. Ao final da minha pesquisa de mestrado, algumas questões ficaram evidentemente inconclusas, justamente porque o espaço não permitiu que outros aspectos fossem desenvolvidos de maneira satisfatória. Apesar de ter analisado as obras W ou a memória da infância e Récits d'Ellis Island e suas relações com a fotografia, a segunda obra teve uma análise limitada à relação dos textos com as descrições fotográficas. Outro aspecto interessante ainda ficou em estado de espera, como veremos a seguir.

Recapitulando a pesquisa, apenas para contextualizar a relação entre as duas obras, retomo o trecho da dissertação em que as apresento brevemente: a primeira, $W$ ou a memória da infância, é um texto escrito de maneira dupla, com dois textos alternados, como explica Perec na quarta capa: "há nesse livro dois textos simplesmente alternados; poderia quase parecer que eles não têm nada em comum, mas são entretanto inextricavelmente interligados, como se nenhum dos dois pudesse existir sozinho"171. Perec reafirma a importância da leitura de ambos os textos como um só, ou, ainda, que a leitura só funciona a partir da intersecção dos dois textos: "como se de seu encontro apenas, dessa luz distante que lançam um sobre o outro, pudesse se revelar o que não é de maneira nenhuma dito em um, nem dito no outro, mas somente na sua frágil intersecção" ${ }^{" 172}$. Assim, a estrutura do texto é composta por uma parte ficcional que se intercala, a cada capítulo, com um texto autobiográfico.

A ficção gira em torno de uma ilha em que jogos esportivos levam seus atletas às mais diversas e cruéis provações físicas. Já o texto autobiográfico nos traz uma escrita neutra, hesitante, bastante repetitiva, e que nos leva em muitos momentos a

\footnotetext{
${ }^{171}$ No original: "Il y a dans ce livre deux textes simplement alternés; il pourrait presque sembler qu'ils n'ont rien en commun, mais ils sont pourtant inextricablement enchevêtrés, comme si aucun des deux ne pouvait exister seul" (PEREC, 1975).

${ }^{172}$ No original: "comme si de leur rencontre seule, de cette lumière lointaine qu'ils jettent l'un sur l'autre, pouvait se révéler ce qui n'est jamais tout à fait dit dans l'un, jamais tout à fait dit dans l'autre, mais seulement dans leur fragile intersection" (PEREC, 1975).
} 
identificar trechos do texto de Lieux, sobretudo aqueles em que descreve a rua onde viveu a infância. A parte das “Souvenirs” de Lieux é uma espécie de laboratório para a futura escrita de $W$ ou a memória da infância. Sem memórias, o autor se valerá, em muitos momentos, da descrição do lugar, na tentativa de contar a própria história.

Em poucas palavras, podemos dizer que $W$ é um dos textos autobiográficos mais importantes escritos por Perec e tem como particularidade escrever a história de si a partir da intersecção de dois textos distintos. Philippe Lejeune afirma que a escrita autobiográfica de Perec é oblíqua ${ }^{173}$, e é exatamente $W$ a obra que mais pode ilustrar essa afirmação. Minha intenção, na pesquisa de mestrado, foi mostrar pontos em comum entre essa obra e outra, também de caráter autobiográfico, escrita sob forma de texto e também realizada como documentário. Na minha dissertação, a apresentação da obra, em linhas gerais, define a obra literária e cinematográfica de Perec comparando-a a aspectos já presentes em $W$ ou a memória da infância, já que, nesse texto, Perec escolherá também uma maneira indireta para contar sua história: não mais a partir de uma ilha ficcional, mas uma real (o lugar onde milhares de pessoas reais chegaram, no início do século XX, a Ellis Island, em Nova Iorque).

A diferença é que Perec não fará uma escrita alternada, como em $W$, mas escreverá uma história coletiva (real) para que, a partir dela, ressoem aspectos de sua própria autobiografia. Será, portanto, uma espécie de retomada de questões ainda não resolvidas no livro $W$. Críticos de Perec consideram Ellis Island como o ponto alto da sua escrita sobre a condição de judeu, algo que não havia conseguido ainda desenvolver em outras obras e que, em $W$, aparece de maneira bastante sutil. A utilização de imagens também será um ponto comum entre as duas obras: se em $W$ Perec utiliza fotos antigas (não publicadas no livro) para escrever uma espécie de autobiografia ficcional, em Récits d'Ellis Island o autor se apropriará das imagens antigas (à época da imigração), sobrepostas às imagens da ilha atual, na tentativa de recriar possíveis histórias a partir dessas imagens.

A manipulação de fotografias foi uma das características principais para a composição das duas obras literárias. Procurei discutir, no mestrado, a importância de fotos antigas para a reconstituição da memória, não como forma de rememoração direta, mas como geradora de escrita autobiográfica, mesmo que, em muitos momentos,

\footnotetext{
${ }^{173}$ Um estudo de Lejeune, decisivo para o início da pesquisa de mestrado, encontra-se no livro La mémoire et l'oblique. Georges Perec autobiographe, que trata de vários projetos autobiográficos do autor, a partir da ideia de uma memória oblíqua, lacunar, indireta, como principal característica de todos esses projetos.
} 
essa escrita possa produzir um texto ficcional.

A imagem, em geral, e principalmente as fotografias, serão fundamentais para o processo de escrita em Perec. No momento em que realizava as análises das relações entre as fotografias antigas e a escrita autobiográfica de ambos os artistas, um aspecto interessante se mostrou no decorrer da pesquisa: por que relacionar o filme documentário com a escrita de um texto dito autobiográfico? E como enxergar a partir do documentário, para podermos identificar as relações autobiográficas dos realizadores com a história com " $\mathrm{H}$ " maiúsculo, apresentada principalmente a partir dos depoimentos dos entrevistados? Haveria uma relação intrínseca entre o trabalho autobiográfico e o filme documentário?

Algumas dessas questões foram, inclusive, brevemente discutidas na pesquisa, mas não suficientemente voltadas para a realização do filme documentário: pela dimensão do trabalho e pelas possibilidades de escrita, a pesquisa se limitou principalmente a tratar da relação direta do texto literário com as fotografias descritas nesse texto. A partir de agora, portanto, a questão inicial que se pretende colocar é: se o documentário funciona como registro de um momento histórico, em que medida o trabalho autobiográfico se faz presente?

Vale lembrar que essas questões já foram lançadas no capítulo anterior, principalmente quando tratamos do documentário La vie filmée. Já discutimos consideravelmente a questão do uso da imagem de terceiros na tentativa de recuperação ou reconstrução da própria memória, e a importância dos lugares para essa busca autobiográfica, sobretudo no filme Les lieux d'une fugue. Aqui, nesse capítulo, as duas questões parecem se fundir: temos em Récits d'Ellis Island (e, mais adiante, em outro filme, En remontant la rue Vilin) aspectos semelhantes aos que já surgiram nas discussões anteriores. Perec e Robert Bober utilizarão a imagem e a fala do outro (na seção de entrevistas, por exemplo, ou no uso das imagens de desconhecidos) como uma tentativa de mostrar as imagens possíveis de sua história, as falas possíveis de um passado que não puderam realizar.

Minha hipótese, que já vem sendo desenvolvida nessa pesquisa, é que os realizadores buscaram investigar a memória do outro para, assim, terem acesso a sua própria. Se pensarmos a partir de Ricoeur ${ }^{174}$, afirmamos que a prática da memória, mesmo que individual, está intrinsecamente ligada à memória e à história coletiva:

174 Em seu texto "Histoire et mémoire", p. 18. 
A princípio não nos lembramos sozinhos, mas com a ajuda da lembrança do outro, na simples troca da conversa que constitui uma verdadeira partilha de memórias. Além disso, a memória pessoal continua a ser emprestada das histórias dos outros, que ela guarda como as suas próprias. (RICOEUR, 2008, p. 18)

Podemos também lembrar Godard, ao definir o cinema como "ce double mouvement qui nous projette vers autrui en même temps qu'ils nous ramène au fond de nous-même"176.

A partir dessas breves citações, levanto a questão: escrever e fazer cinema podem, portanto, serem vistos sob o mesmo ângulo? A partir desses primeiros pressupostos, posso iniciar uma reflexão de que a escrita ou a produção de filmes, ao mesmo tempo em que se dirigem ao outro, refletem, de certa forma, algo sobre seu realizador, mesmo que indiretamente. Dessa maneira, pretendo afirmar que todas as obras a serem discutidas aqui, tanto literárias quanto fílmicas, farão parte dessa relação de busca de uma memória individual a partir de uma memória coletiva e, por isso, escrever/filmar o outro poderá ser uma tentativa de escrever/filmar a própria história, tanto em Perec quanto em Bober, como veremos.

Assim, o que se pretende daqui por diante é continuar ou aprimorar a discussão já iniciada no capítulo anterior, sobre essa possível inter-relação entre a escrita autobiográfica e o documentário, tendo como foco as parcerias de trabalho entre o "escritor-cineasta" Georges Perec e o "cineasta-escritor" Robert Bober. ${ }^{177}$

\subsection{Origens comuns, projeto de parceria}

É importante relembrar, entretanto, um fato bastante relevante: ambos os artistas aqui mencionados são de família judia e de origem polonesa, porém essas famílias imigraram para a França e lá se estabeleceram. Por esse motivo, esses autores, em várias de suas obras, procuraram traços dessa identidade perdida.

\footnotetext{
${ }^{175}$ D'abord on ne se souvient pas seul mais à l'aide du souvenir d'autrui, dans le simple échange de la conversation qui constitue un véritable partage des mémoires. En outre la mémoire personnelle ne cesse d'emprunter aux récits d'autrui, qu'elle tient pour des souvenirs propres.

${ }^{176}$ François Niney, no texto "L'épreuve du réel à l'écran: essai sur le principe de réalité documentaire", (p. 100), nos traz essa citação de Godard com a seguinte referência: (Pierrot mon ami, in Jean-Luc Godard par Jean-Luc Godard, éd. Cahiers du Cinéma, Paris 1985, p. 263).

177 Nascido em Berlim (1931), trabalhou desde 1967 como documentarista. Um dos seus filmes mais importantes, "Réfugié provenant d'Allemagne, apatride d'origine polonaise", reproduz a menção escrita nos seus primeiros documentos de identidade obtidos depois da Segunda Guerra, cf. Entretiens et conférences, vol. II, p. 139.
} 
Seu trabalho em conjunto é Récits d'Ellis Island, projeto $^{178}$ que deu origem a um livro e a um documentário - homônimos - que retratam o local que representou a porta de entrada de emigrantes europeus nos Estados Unidos, no início do século XX. Antes de trabalharem juntos, porém, já havia essa intenção de busca pela identidade que Perec pôde observar e admirar já no primeiro trabalho documentário de Bober, que marcou o início da amizade entre os artistas:

$\mathrm{Na}$ fonte do projeto encontra-se a amizade entre o escritor-cineasta Georges Perec e o cineasta-escritor Robert Bober. De uma maneira simbólica, ela começou muito antes: Robert Bober integra $\mathrm{W}$ ou a memória da infância de Perec no seu filme autobiográfico Réfugié provenant d'Allemagne, apatride d'origine polonaise para, como afirmou em artigo publicado na revista TEM de 1997, expressar seu pertencimento a uma história coletiva. A simbiose do icônico e do escritural, ainda muito discreta neste filme, predeterminaria o próximo encontro dos dois criadores e sua cooperação afetiva ${ }^{179}$.

Podemos observar, portanto, que, a partir de um documentário anterior de Bober, Perec percebeu que ambos partilhavam alguns interesses e, a partir da amizade, surgiu a ideia da realização do projeto Récits d'Ellis Island. O livro $W$, inclusive, foi uma das fontes de inspiração para que Bober iniciasse seu trabalho documentário em Réfugié provenant d'Allemagne. Nesse primeiro documentário, a investigação do passado a partir dos traços e vestígios, com a constatação da ausência desse passado e dessa confusão entre os tempos, questões bastante recorrentes em Récits..., já eram temas inquietantes para Bober, como se esse trabalho pudesse ter sido um início de reflexões sobre a relação entre uma memória individual e uma coletiva; vendo os lugares de ausência, ele se dará conta da importância desse olhar:

\footnotetext{
${ }^{178}$ Há um texto de Perec intitulado "Ellis Island, Description d'un projet" escrito em primeira pessoa e que explica de forma geral suas motivações para iniciar o projeto, refletindo sobre sua condição de judeu e explicando o tema será explorado em seu texto. Publicado em Je suis né (1990), a versão integral do texto será disponibilizada na seção "Apêndices" desse trabalho.

${ }^{179}$ À la source de ce projet se trouve l'amitié entre l'écrivain-cinéaste Georges Perec et le cinéaste-écrivain Robert Bober. D'une manière symbolique, elle a commencé bien avant: Robert Bober intègre $\mathrm{W}$ ou le souvenir d'enfance de Perec dans son film autobiographique Réfugié provenant d'Allemagne, apatride d'origine polonaise pour, comme il le dit dans son article paru dans TEM en 1997, exprimer son appartenance à une histoire collective. La symbiose de l'iconique et du scriptural, encore très discrète dans ce film, prédéterminera la prochaine rencontre des deux créateurs et leur coopération affective. Citação do texto "L'autre île", de Monica Lawniczak, nos Cahiers Georges Perec 9, p. 229.
} 
[...] Foi então que tomei consciência, na Polônia, filmando túmulos ausentes, violados, de um cemitério judeu, que o importante não é filmar o que está, mas o que desapareceu. Perec pode ter se sensibilizado com isso. É aí que a importância do olhar me foi revelada, e que compreendi que era necessário filmar no tempo presente. Essa experiência, eu a transpus para o diário que tem Raphaël, em Quoi de neuf sur la guerre? Esse personagem, classificando as fotos de Nathan (que é um personagem parcialmente inspirado a partir de Perec) entende essa importância do olhar e ao mesmo tempo da ausência, a partir do olhar. ${ }^{180}$

Vemos aqui as primeiras relações entre os trabalhos de Perec e de Bober. Esse último filma Réfugié... já tendo como referência a leitura de $W$ - identificando-se, portanto, com a difículdade de rememoração e com a reflexão do passado a partir do presente, entre outras questões presentes na obra - e inspirando-se em Perec, inclusive, para a criaçãoliterária de Quoi de neuf sur la guerre? (texto de caráter autobiográfico) e, posteriormente, para a filmagem de En remontant la Rue Vilin, como veremos adiante.

Um fato corriqueiro levará ao primeiro trabalho de parceria dos artistas: Bober descobre, a partir de um anúncio de jornal, que Ellis Island será reaberta para visitação turística e, ao dizer isso a sua mãe, ela relata a história do bisavô que lá esteve e foi recusado. A ideia imediata é lançar a proposta ao amigo, também de origem polonesa, que compartilhava com ele essas questões de busca de identidade.

Perec se sente bastante atraído pelo projeto e, tempos depois, ambos já planejam uma viagem a Nova Iorque para recolher dados e conhecer o local da filmagem, com financiamento do Institut National de L'Audiovisuel (INA). Assim, nesse primeiro contato com o lugar, com os documentos e com as histórias contadas, as primeiras linhas vão sendo escritas, para depois darem voz ao filme de Bober. Assim o cineasta descreve o início dos trabalhos com Perec:

Uma vez que obtivemos o sinal verde da INA, continuamos a nos documentar, mas tínhamos necessidade de ver os lugares. Eu não sou capaz de filmar sem que haja uma relação com um lugar real. É talvez por isso que me especializei em documentários. Estivemos então em Nova York, durante duas semanas, um ano antes da filmagem. Víamos as pessoas: recuperamos endereços de pessoas mais ou menos

\footnotetext{
${ }^{180}$ [...] Ce dont j'ai pris conscience, en Pologne, en filmant les tombes absentes, volées, d'un cimetière juif, c'est que l'important n'est pas de filmer ce qui est, mais ce qui a disparu. Perec y a sans doute été sensible. C'est là que l'importance du regard m'a été révélée, et que j'ai compris qu'il fallait filmer au présent. Cette expérience, je l'ai transposée dans le journal que tient Raphaël, dans Quoi de neuf sur la guerre ? Ce personnage, en classant des photos de Nathan (qui est en partie un personnage inspiré par Perec) comprend cette importance du regard et en même temps de l'absence, à travers le regard. Trecho da entrevista concedida por Bober, sob o título "Le regard et l'absence" nos Cahiers Georges Perec 9, p. 253.
} 
interessadas pela questão, a partir de amigos. Foi assim que fui à New York Public Library, ver fotos dos lugares. Conhecia algumas, de Lewis Hine, em especial, mas me deu conta que havia um fundo considerável. Para Perec, essas duas semanas de sondagem, deu a ele toda uma provisão de pequenas histórias. E um pouco antes da filmagem, ele me deu uma quinzena de páginas, não numeradas, escritas ou não. Eram essas histórias, que ele me disse que poderia usar ou não, independentemente da ordem. ${ }^{181}$

O texto de Perec, em tom subjetivo, acrescido das imagens captadas por Bober, faz com que reflitamos sobre o documentário não mais como mera representação de um fato histórico, mas também como um ponto de partida para a reflexão do trabalho autobiográfico dos dois realizadores.

A partir desse olhar peculiar, entramos em contato com uma memória comum, nesse lugar em que eles poderiam, talvez, ter escrito sua própria história. Não por acaso, Perec afirma que Ellis Island é um "lugar de ausência", ou "um não-lugar"182, e também o lugar de sua autobiografia provável. A investigação de vestígios do passado ressoa na escrita autobiográfica; olhar para o outro e investigá-lo resulta, de certa forma, em olhar para si mesmo.

É, por isso, curioso constatar que, partindo do ponto inicial dessa pesquisa (que é analisar a importância dos espaços e a proliferação de transformação do projeto Lieux), vemos que Perec chega ao oposto daquilo que sempre buscou em se tratando da observação dos lugares: para ele, Ellis Island será um não-lugar, uma vez que considerado neutro, ou nunca antes visitado por ele ou seus parentes, mas que funciona como uma espécie de matéria-prima para a produção da sua própria história, já que esta é a primeira obra em que trata diretamente da questão judaica, representada outras vezes de forma breve ou indireta. Assim, o lugar que ele chama de não-lugar, na verdade, será aquele em que ele será capaz de observar o outro, refletir sobre a própria história e conseguir trazer à tona questões antes bastante delicadas e tratadas como indizíveis.

\footnotetext{
${ }^{181}$ Une fois qu'on a obtenu le feu vert de l'INA, on a continué de se documenter, mais on avait besoin de voir les lieux. Moi, je ne peuxpas filmer sans une relation avec un lieu réel. C'est peut-être pour ça que je me suis spécialisé dans les documentaires. On a donc été à New York, pendant deux semaines, un an avant le tournage. On voyait des gens : on avait récupéré des adresses de gens plus ou moins intéressés par la question, par des amis. C'est là que je suis allé aussi à La New York Public Library, pour voir des photos des lieux. J'en connaissais déjà certaines, de Lewis Hine, en particulier, mais je me suis rendu compte qu'il y en avait un fonds considérable. Pour Perec, ces deux semaines de repérage, ça lui a donné toute une provision de petites histoires. Et juste avant le tournage, il m'a donné une quinzaine de pages, non numérotées, écrites ou non. C'étaient ces histoires, dont il m'a dit que je pouvais les utiliser ou non, dans n'importe quel ordre. Idem, p. 247.

${ }^{182}$ Retomo aqui a expressão "não-lugar", já desenvolvida no primeiro capítulo, a partir das ideias de Marc Augé e do texto de Foucault.
} 
Além de Récits d'Ellis Island, temos um segundo trabalho cinematográfico como foco: outro documentário de Robert Bober, En remontant la rue Vilin, produzido em 1992, ou seja, dez anos após a morte de Perec.

Mesmo com essa evidente ausência, veremos que o trabalho de parceria será efetivo, uma vez que Bober utilizará, na composição e montagem do documentário, material do arquivo de Perec, destinado ao projeto Lieux. Dessa vez, Bober também tratará de um espaço específico (a rue Vilin, onde Perec passou os primeiros anos de infância, e que foi aqui citada inúmeras vezes como sendo um dos lugares mais importantes para o escritor, em Paris), mas não contará mais com a presença do amigo e parceiro. Podemos pensar, portanto, no ciclo que se fecha em torno dessa pesquisa: se começamos levantando a importância de Lieux, finalizaremos esse capítulo trazendo esse projeto novamente à tona, dessa vez sendo utilizado como matéria-prima para a composição do filme de Robert Bober - filme no qual Perec será o personagem principal, mesmo não estando fisicamente presente para participar do projeto. É como se as pontas se unissem e tentassem dar uma coerência para essa etapa da escrita que vem chegando a sua fase final.

É como se houvesse, portanto, nesse último documentário, uma retomada ao trabalho de parceria anterior - Récits d'Ellis Island-, sem a presença do escritor; nesse trabalho, Bober utilizará as fotos e os textos guardados por Perec para a criação de uma reconstituição cinematográfica a partir da manipulação dessas fotos e documentos, como nos explicam Delage e Guigueno ${ }^{183}$ :

É a partir desses textos, impressos ou escritos a mão, que se apoiará Bober para realizar em 1992, o filme En Remontant la rue Vilin. Isso porque, sem analisar toda a complexidade do lugar ocupado no trabalho de Georges Perec pela escrita em si; convém, entretanto, lembrar-se da dimensão metódica das questões. Perec costumava dizer ou escrever: ele não quer se esquecer, tendo consciência que aquilo que pode ser revivido apenas revelará ainda mais a vertigem do esquecimento. É nessa tensão que deve ser compreendido do projeto Lieux, preparação para a deambulação retrospectiva da rue Vilin.

\footnotetext{
${ }^{183}$ C'est sur ces textes, imprimés ou manuscrits, que s'appuiera Bober en réalisant, en 1992, En remontant la rue Vilin. C'est pourquoi, sans analyser dans toute sa complexité la place occupée dans le travail de Georges Perec par l'écriture sur soi, il convient cependant d'enrappeler la dimension méthodique et les enjeux. Perec l'a souvent dit ou écrit : il ne veut pas oublier, tout en ayant conscience que ce qui pourra être ravivé ne fera que révéler davantage le vertige de l'oubli. C'est dans cette tension qu'il faut comprendre le projet des Lieux, préparatoire à la déambulation rétrospective dans la rue Vilin. Em trecho do artigo "Ce qui est donné à voir, ce que nous pouvons montrer", p. 5.
} 
Novamente estará em jogo o trabalho documentário que trata da memória do outro, como ambos realizaram no documentário anterior. Aqui, a memória do outro estará presente (os documentos e as fotos de Perec), e a tentativa de escrever sobre o outro será também uma maneira indireta de escrever sobre si. Essa incapacidade de reconstituição do tempo, que já era evidente em Récits..., será também retomada em En remontant... Mais uma vez, haverá a realização de um documentário, com a manipulação de fotos antigas, na tentativa de reconstituir uma memória alheia, que não pertence àquele que realiza o documentário, mas que funciona, ao menos, como ponto de partida para a sua própria reflexão autobiográfica.

Assim, não está em jogo apenas a importância de ambos para pensar a literatura autobiográfica francesa do século XX: podemos ampliar a questão para a literatura autobiográfica em relação com outras artes - principalmente, nesse caso, com o cinema documentário produzido por esses artistas a partir de e em relação a essas obras autobiográficas. O trabalho de colaboração com outros artistas é uma marca importante da carreira literária de Perec, assim como ocorreu com frequência no projeto Lieux e nas obras que dele derivaram, como já vimos (fotógrafos, diretores de cinema, técnicos de som, atores, radialistas, entre outros).

Podemos reafirmar e reiterar a importância dessa colaboração entre os artistas, em diferentes níveis, a partir da leitura do artigo de Myriam Soussan ${ }^{184}$, que retrata o trabalho dos dois artistas da seguinte maneira: um corpus composto de elementos heterogêneos e que refletem os diferentes níveis de sua mútua colaboração (como, por exemplo, fotografias tiradas por Bober e comentários feitos por Perec a partir dessas fotos, além da importante utilização do material de Lieux para o documentário de Bober)

Vemos que os trabalhos de ambos vão formando uma espécie de rede de colaboração mútua, uma vez que possuem interesses e motivações semelhantes na composição de suas obras artísticas: tanto a escrita autobiográfica quanto seus desdobramentos a partir de documentários; o uso de imagens antigas na produção de tais filmes, na tentativa de reconstituição dessas memórias (tanto individuais quanto coletivas) são elementos que parecem sinalizar parte desses interesses em comum.

\footnotetext{
184 "La mémoire vivante des lieux - Georges Perec et Robert Bober", p. 1. Disponível em: http://www.litterales.com/document_disparu.php?id=647\&table=litterature. Consulta em 15 de abril de 2019.
} 
Bober terá uma influência muito forte das fotografias em seu trabalho, que parece ainda mais intensa quando ele as incorpora em seu trabalho como cineasta e/ou escritor. Um dos seus livros, de caráter autobiográfico - como já observado -, Quoi de neuf sur la guerre?, tem como protagonista um jovem que se torna fotógrafo, como o próprio autor, e que nos leva a re fletir novamente sobre a importância das imagens em relação à escrita autobiográfica, buscando fotografar "não mais o que existe, mas o que já desapareceu, pois é a ausência que dá a ver". ${ }^{185}$

Antes de escrever seus livros, porém, andando pelas ruas de Paris, em sua juventude, antes ainda de tornar-se assistente do cineasta François Truffaut ${ }^{186}$, Bober já tinha uma verdadeira paixão pelas fotografias da cidade, como relata na mesma entrevista, já citada anteriormente. De certa maneira, esses dois trabalhos cinematográficos estabelecerão essa relação de busca pela identidade, a partir do uso e da manipulação de fotos para uma tentativa de reprodução de um tempo ao qual não se pode retornar. Perguntado sobre os motivos dessa verdadeira admiração pela fotografia, Bober nos explica:

A fotografia foi muito importante na minha formação. Uma das minhas primeiras paixões foi caminhar por Paris E quando descobri as fotografias de Doisneau, me dei conta que gostava de poder encontrar uma expressão artística, eu que não tinha tido de forma alguma, acesso a essa cultura, durante minha infância. [...] Foi me documentando, em Paris, em Nova York, situando e descobrindo todas as fotografias que decidi ampliá-las para confrontar com o lugar real, no lugar onde elas foram fotografadas. As fotos tinham a aparência mais recentes que o próprio lugar, totalmente destruído. ${ }^{187}$

Perec, por sua vez, mesmo na profissão de escritor (embora tivesse exercido um trabalho como documentalista durante anos, antes de ganhar fama com seus textos) é um apaixonado pelo cinema e trabalhou em vários projetos cinematográficos em paralelo à carreira de escritor; o cinema sempre esteve presente em sua vida, seja como

\footnotetext{
${ }^{185} \mathrm{Idem}, \mathrm{p} .2$.

${ }^{186}$ Nos anos 50, Bober trabalhará como assistente de Truffaut em três filmes: Les Quatre Cents Coups (1959), Tirez sur le pianiste (1960) e Jules et Jim (1962).

${ }^{187}$ La photographie a été très importante dans ma formation. Une de mes premières passions a été de marcher dans Paris. Et quand j'ai découvert les photographies de Doisneau, je me suis rendu compte que ce que j'aimais pouvait trouver une expression artistique, moi qui n'avais pas tellement eu accès à cette culture, pendant mon enfance. [...] C'est en me documentant, à Paris, à New York, en situant et en découvrant toutes ces photographies quej'ai décidé de les faire agrandir pour les confronter au lieu réel, au lieu où elles avaient été photographiées. Les photos avaient l'air souvent plus récentes que le lieu lui-même, complètement délabré. Trecho da entrevista concedida por Bober, sob o título "Le regard et l'absence" nos Cahiers Georges Perec 9, p. 249.
} 
ávido espectador, como roteirista ou nas parcerias com outros cineastas ${ }^{188}$.

Delage e Guigueno ${ }^{189}$ retomam uma fala de retirada de um manuscrito de Perec, citada por Hartje e Neefs (no livro Georges Perec Images), que afirma: "Nous étions cinéphiles: c'était notre péché mignon, nous y succombions chaque soir, ou presque. Nous aimions les films, les images, pour peu qu'elles soient belles, qu'elles nous entrainent et nous emmènent, nous ravissent, nous amusent".

Com Perec, especialmente em Récits..., Bober poderá entrar em contato com os emigrantes europeus do começo do século, tanto a partir de fotos antigas (tiradas no início do século XX e que foram o primeiro contato deles com o lugar) quanto a partir de entrevistas que ambos realizaram com as pessoas que por ali passaram.

Já no filme En remontant..., Bober se valerá das fotos tiradas por colaboradores de Perec, em seu trabalho conjunto para a realização de Lieux, e que, ao serem manipuladas por Bober, também já serão fotos antigas (considerando que o projeto de Perec se inicia em 1969 e o documentário de Bober é finalizado em 1992).

Assim, esse retorno ao passado a partir da manipulação das fotos será o grande elo entre esses dois documentários. No primeiro caso, as fotos antigas foram colocadas e montadas exatamente no local onde foram registradas muitos anos antes, causando um surpreendente efeito de sobreposição. Esse procedimento fará com que o texto poético de Perec ganhe ainda mais força, já que somos inevitavelmente convidados a refletir sobre essa passagem do tempo. Como afirma Niney ${ }^{190}$, esse uso de imagens de um tempo passado nos fará levantar algumas questões: "Que montraient-elles à l'époque? Que voulaient-elles dire? Y a-t-il un écart entre ceci et cela? Qu'y voyonsnous aujourd'hui? Quels liens établir avec d'autres images d'époque ou des témoignages contemporains?" Não somente observaremos essas fotos do passado, como procuraremos, a partir dessa observação, relações do passado com o nosso presente, com os testemunhos dados pelos entrevistados nos dias de hoje, para, enfim, trazer à tona as reflexões propostas pelos realizadores.

\footnotetext{
${ }^{188}$ Para maiores detalhes, entre outros, podemos citar o texto de Mireille Ribière, "Les projets inaboutis de Georges Perec", publicado nos Cahiers Georges Perec 9 (p. 151).

${ }^{189}$ Op. Cit., p. 12.

${ }^{190}$ Op. cit., p. 255
} 


\subsection{A imagem do outro: ponto de partida para o filme/livro}

Estar nesse lugar de ausência é poder falar, finalmente, da própria ausência das raízes e das tradições judaicas que não lhe foram transmitidas, como Perec afirma: "Je suis en somme juif par absence, avec un sentiment de dépossession... J'ai donc été tenté de faire ce film avec Bober pour mieux cerner ce problème biographique”. Ele completa afirmando: "La recherche de mon identité passe par la description de ce lieu, Ellis Island, symbole de cette absence : ce n'est pas encore l'Amérique et ce n'est plus Europe... une sorte de purgatoire".

Será então, a partir desse purgatório, desse lugar de ausências, que Perec e Bober poderão deixar falar as vozes que por ali passaram e, assim, buscar para si também uma voz, uma história, uma memória. Traces, a primeira parte do filme, é resultado de uma visita ao lugar, em 1979, e as reflexões, imagens e textos produzidos a partir desse encontro. As imagens de Bober vão tomando forma à medida em que o texto de Perec vai sendo narrado, criando uma composição de texto-imagem/tempoespaço bastante interessante. A intenção dos realizadores não foi reconstituir a época, mas levantar uma reflexão a partir de tudo que ali existiu antes, transformando-se num lugar de memória. A segunda parte, Mémoires, dedica-se a entrevistar os sobreviventes que passaram por Ellis Island (aqueles que entraram em Nova Iorque e os que foram recusados) e como esse lugar repercutiu em seus destinos.

Os lugares, fotografados e registrados no presente, a partir da sobreposição de fotos, faz com que nos aproximemos dos vestígios do passado que ali se encontram, e que se entrecruzam com as imagens do presente, nesse movimento constante de Perec contra o esquecimento, um verdadeiro embate com a própria memória (e, nesse caso, também uma maneira de recuperar uma memória coletiva abandonada, que deixou para trás vestígios e restos de um lugar que já não existe, pelo menos não da mesma maneira como existia à época da chegada dos emigrantes, no começo do século XX). Assim, esses lugares tornam-se espécies de registros de fragmentos da história, como nos explica Bertharion:

Os lugares são como registros de fragmentos da história que devem ser preservados do esquecimento, armazéns de um saber transmissível aos sucessores. A descrição de monumentos arquiteturais supõe um 
reengajamento dos discursos, sinais e histórias que se relacionam com esses lugares. $(1998, \text { p. } 232)^{191}$

Perec se vale das informações coletadas e das imagens para produzir seu texto literário, muitas vezes em forma de listas, dando-nos novamente a sensação de que algo está sendo exaustivamente descrito ou enumerado para evitar que seja esquecido.

No trecho a seguir, na página 28 do livro-álbum ${ }^{192}$, na seção "Description d'un chemin" - em que explica como foi a chegada desse milhares de emigrantes a Nova Iorque -, já nos dá essa sensação de que o tema a ser tratado não conta uma história particular, de um único povo, mas trata dessa questão da universalidade e, especificamente, do fato de muitas nacionalidades terem em comum ser judeu.

Além disso, o trecho traz ainda a sensação de entrarmos em contato direto com esse tempo passado, ao disponibilizar um texto seguido de uma imagem emblemática: há pessoas que olham para a câmera e que parecem também nos observar quando as olhamos, mas que não estão mais aqui, algo que provoca em nós o efeito de "punctum" explicado por Barthes: "ça a été" ${ }^{93}$, isso foi, isso aconteceu, não existe mais: é o que prende nossa atenção e que causa em nós esse prazer e, ao mesmo tempo, um certo desconforto em olhar para a imagem. O texto que acompanha a foto diz muito sobre a diversidade de origem das pessoas e, também, revela nossa facilidade em nos identificar com elas, já que não está em jogo de onde vieram, mas o que poderão se tornar se conseguirem passar por Ellis Island e finalmente chegar a Nova Iorque:

la plupart de ceux qui, au terme de leur harassant voyage, découvraient Manhattan émergeant de la brume, savaient que leur épreuve n'était pas tout à fait terminée

il leur fallait encore passer par Ellis Island, cette île que,

\footnotetext{
${ }^{191}$ Les lieux sont comme des enregistrements de fragments d'histoire qu'il faut préserver de l'oubli, dépôts d'un savoir transmissible aux successeurs. La description de monuments architecturaux suppose une réembrayage des discours, des signes, des récits qui s'attachent à ces lieux.

192 A edição em questão, publicada em 1995, pela P.O.L., em parceria com o INA, traz uma coletânea contendo textos lidos no filme (a maioria em forma de listas ou poemas), imagens da filmagem, fotos utilizadas na montagem das cenas, além dos textos integrais das entrevistas reproduzidas no filme.

${ }^{193}$ Expressão utilizada por Barthes em sua obra Câmara Clara para definir esse sentimento em relação a algo que nos toca profundamente ao observarmos uma foto do passado: "O nome do noema da Fotografia será então: 'Isso-foi', ou ainda: o Intratável. Em latim (pedantismo necessário porque esclarece nuances), isso seria sem dúvida: "interfuit": isso que vejo encontrou-se lá, nesse lugar que se estende entre o infinito e o sujeito (operator); ele esteve lá, e todavia de súbito foi separado; ele esteve absolutamente, irrecusavelmente presente, e no entanto já diferido" (BARTHES, 1984, pp. 115-116).
} 
dans toute les langues d'Europe,

on a surnommé l'île des larmes (PEREC, 1995, p. 28).

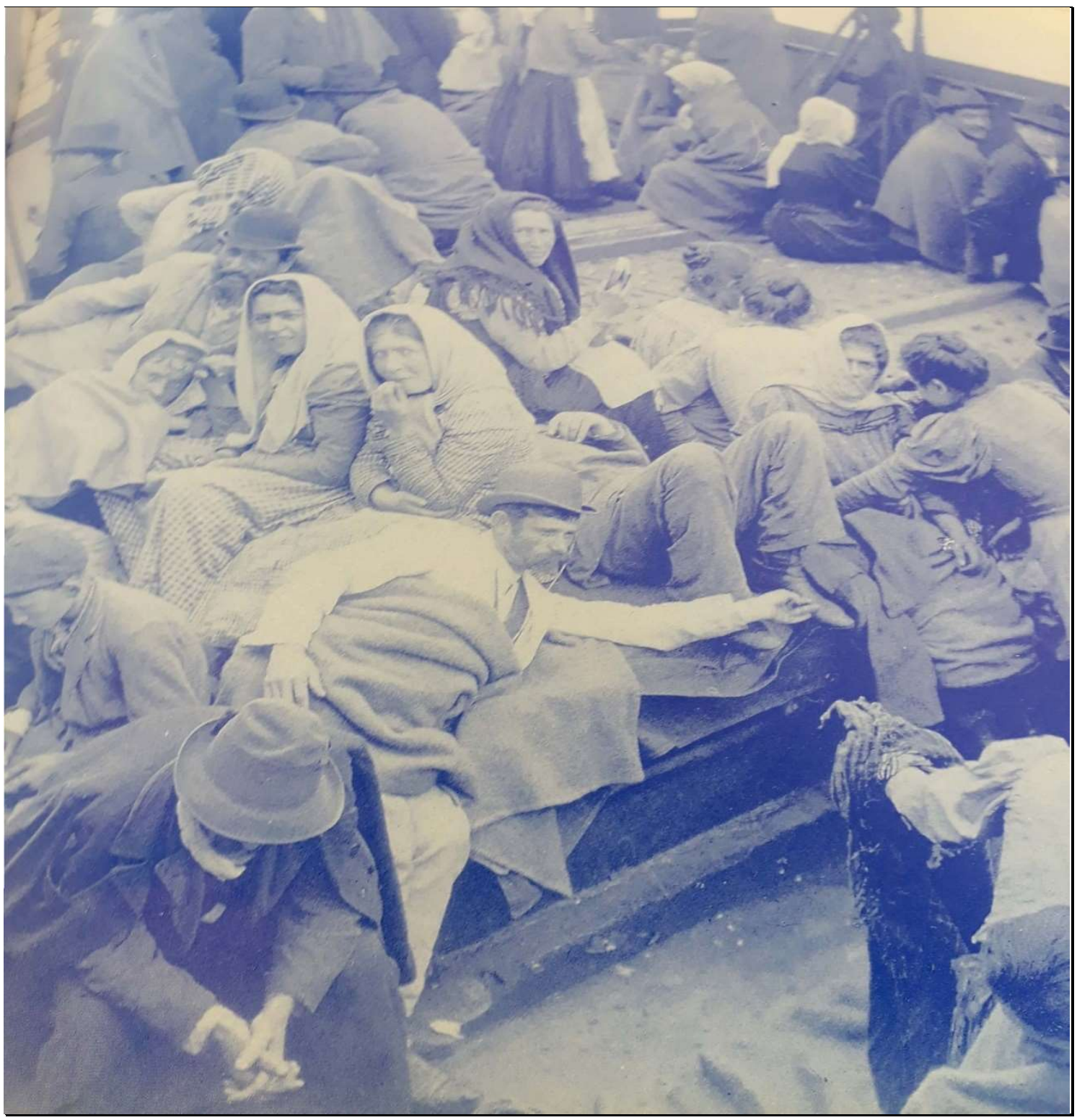

Figura 39. Foto da página 29 do livro-álbum Récits d'Ellis Island.

Assim como nos mostra a chegada das pessoas, e nos comove com as imagens de rostos desconhecidos, a obra também nos leva a refletir sobre a passagem do tempo e suas transformações: a vida das pessoas que por ali passaram, e também a transformação do próprio lugar. A reflexão segue, evidentemente, as mesmas preocupações do que já havia apontado para a escrita do projeto Lieux: o envelhecimento dos lugares também faz parte da criação e reprodução de uma memória. 


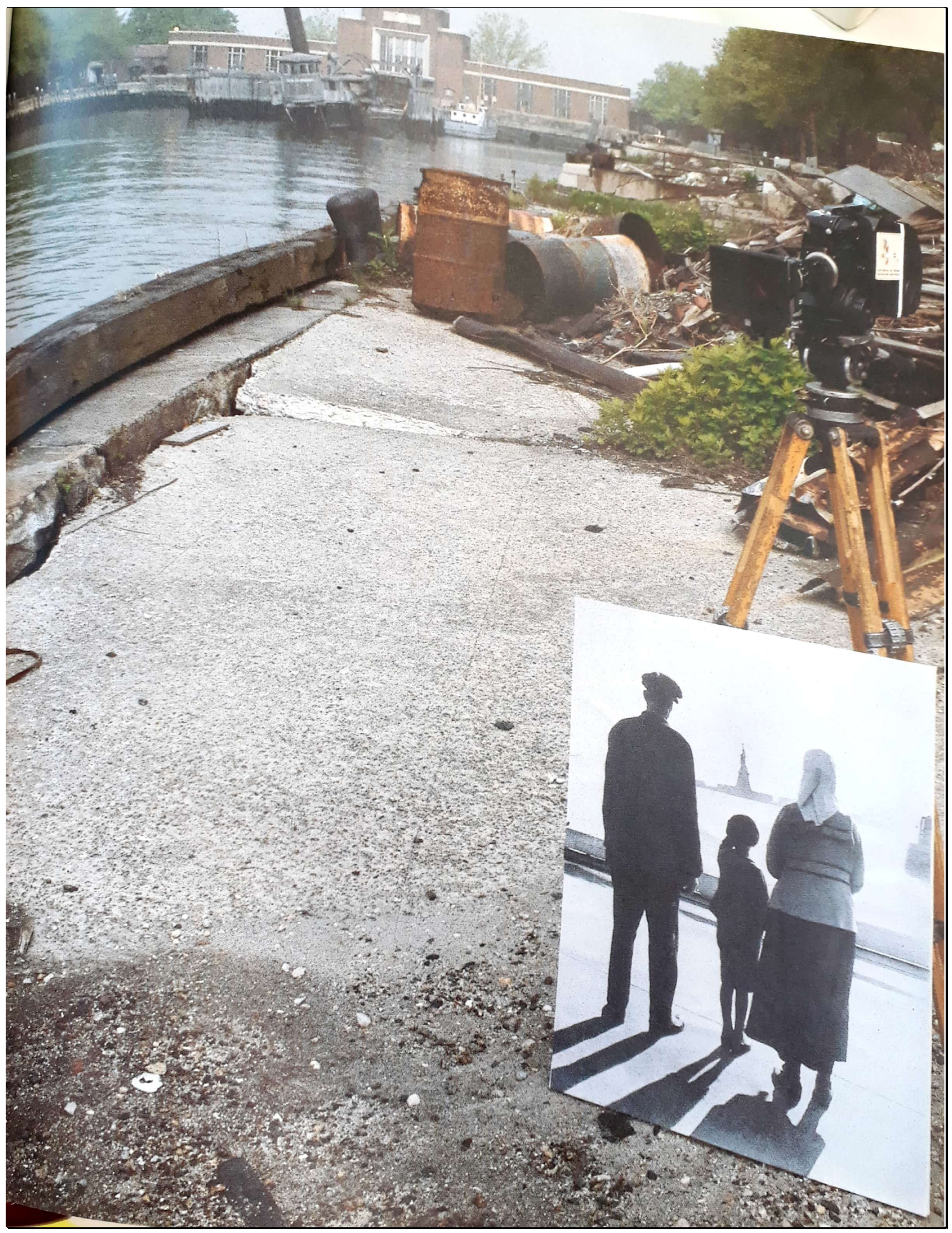

Figura 40. Cena da filmagem que mostra a clara destruição atual do lugar, com a foto antiga sobreposta.

Perec faz, inclusive, uma reflexão sobre os tempos atuais (a década de 80), afirmando que, apesar de Ellis Island ter deixado de existir como forma de chegada aos 
Estados Unidos, existem ainda muitos povos que tentam chegar ao país a partir das mais diversas localidades, sonhando com um futuro melhor. Se pensarmos nas questões atuais e contemporâneas a nós, vamos também chegar à conclusão que o problema da imigração continua no mundo, com pessoas tentando se deslocar dentro da própria Europa ou em direção aos Estados Unidos. Os deslocamentos em busca de uma vida melhor são, afinal, uma maneira de contar as histórias dessas famílias, além de contar também as histórias de nossas gerações passadas e presentes:

laissés à l'abandon depuis 1954, les bâtiments d'Ellis Island, que les architectes Barling et Tilton avaient construits dans le style de la Renaissance française, ont été, en 1976, à l'occasion du bicentenaire des États-Unis, classés monuments historiques et rouverts au public.

Mais l'émigration vers les États-Unis avait commencé bien avant que commence Ellis Island et ne s'est pas terminée avec sa fermeture.

Les Mexicains, les Porto-Ricains, les Coréens, les Vietnamiens, les Cambodgiens, ont pris la relève (PEREC, 1995, p. 34).

Essa ideia de que esses deslocamentos continuam existindo, e que a história continua sendo escrita por essas pessoas, (a quem se refere como os Boat People) mesmo que de forma anônima, é um dos fatores motivantes para essa escrita que se torna quase autobiográfica. Pois ao utilizarem, no final da frase, as mesmas palavras que estão no título do livro/filme "Errance/espoir", estão ainda acreditando que essas pessoas encontrarão seu lugar, seu refúgio definitivo; poderão um dia contar sua história para seus sucessores, ou seja, continuarão escrevendo a história coletiva a partir de suas histórias familiares, como vemos no trecho seguinte:

Peut-être les juifs, peuple sans terre, depuis presque toujours voués à l'exode, à la survie au milieu de cultures différentes de la leur, étaientils plus sensibles que d'autres à ce qui était, pour eux, en jeu ici, mais Ellis Island n'est pas un lieu réservé aux juifs il appartient à tous ceux que l'intolérance et la misère ont chassés et chassent encore de la terre où ils ont grandi

à l'heure où les Boat People continuent d'aller d'île en île à la recherche de refuges de plus en plus improbables, il aurait pu sembler dérisoire, futile, ou sentimentalement complaisant de vouloir encore 
une fois évoquer ces histoires déjà anciennes

mais nous avons eu, en le faisant, la certitude d'avoir

fait résonner les deux mots qui furent au cour même de cette longue aventure : ces deux mots mous, irrepérables, instables et fuyants, qui se renvoient sans cesse leurs lumières tremblotantes, et qui s'appellent l'errance et l'espoir. (PEREC, 1995, p. 63).

As fotos abaixo revelam outra imagem de sobreposição entre presente e passado: a primeira indicando o ferry que transportava as pessoas liberadas da ilha para Nova Iorque e, a segunda, o mesmo ferry em estado de abandono, na década de 80 , quando ocorreu a filmagem. Dessa maneira, ocorre uma reflexão sobre esses dois tempos e, consequentemente, sobre um futuro que continuará repetindo esses processos de deslocamento e busca por refúgio (principalmente por aqueles povos que enfrentam situações de guerra que, como sabemos, estão presentes e em número considerável, em várias partes do mundo, ainda hoje). 


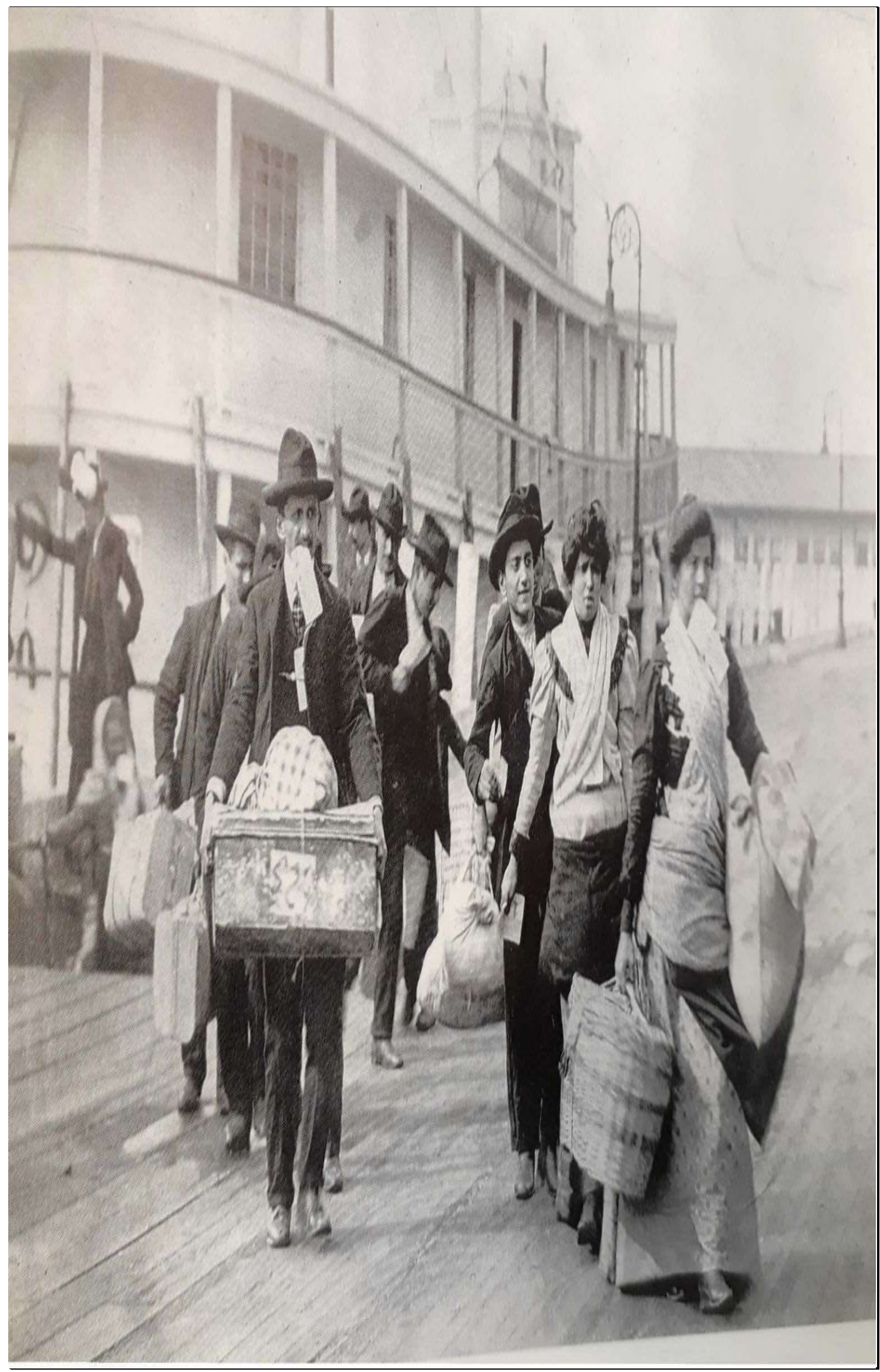

Figura 41. "Arrivée à Ellis Island. Les immigrants serrent entre leurs dents leur carte d'immatriculation. 


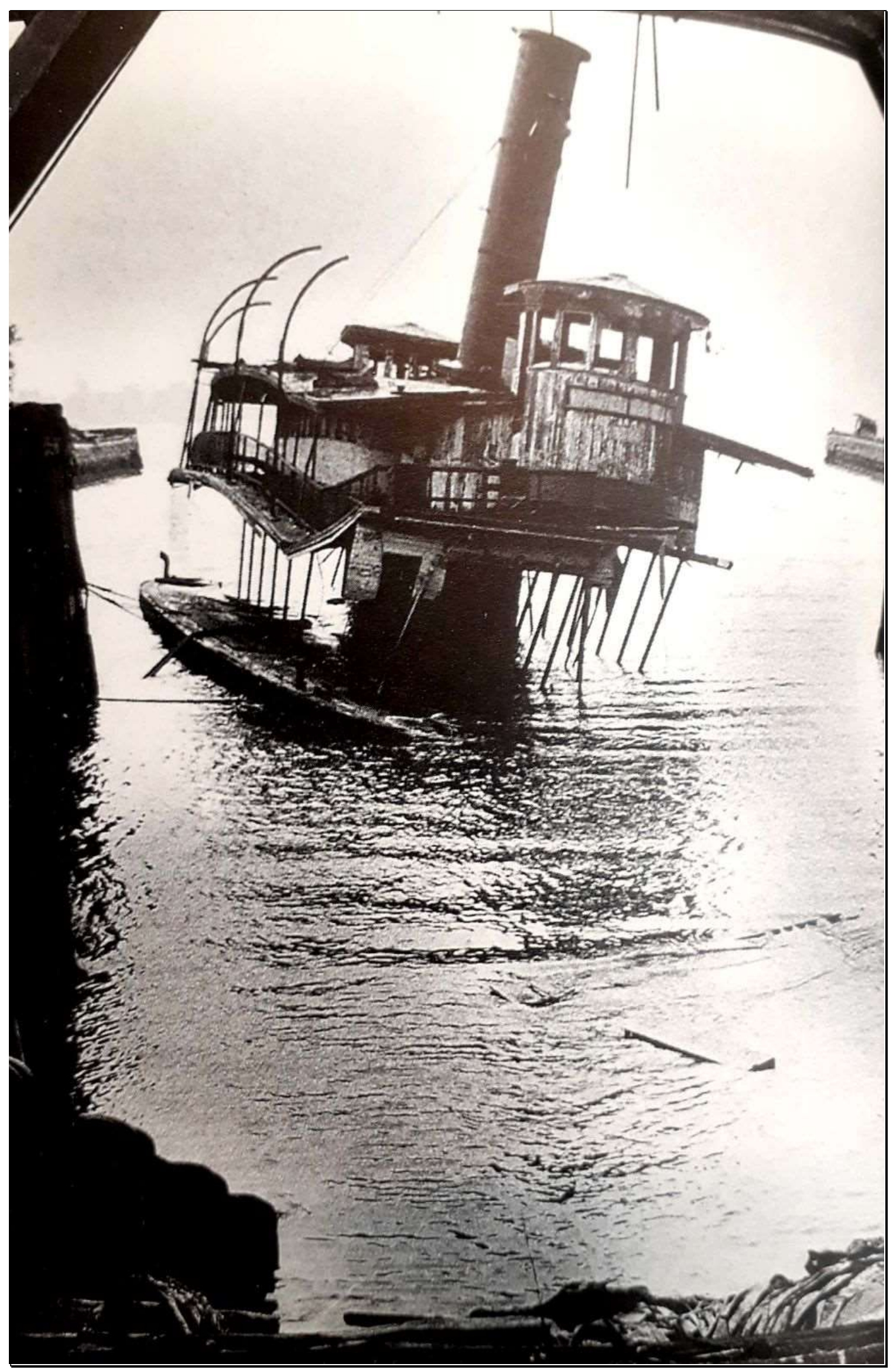




\subsection{A palavra do outro: entrevistas que contam a passagem por Ellis Island}

A partir do que discutimos até aqui, fica clara a dificuldade de Perec em lidar com as questões do passado, principalmente em se tratando da não transmissão da cultura judaica, consequência da morte dos pais na Segunda Guerra.

Como analisamos na seção anterior, ver as imagens do outro será uma maneira indireta de olhar para si e contar a própria história. Mais, ainda, ouvir a história, dar voz à palavra do outro, como vemos na seção "Mémoires", composta por entrevistas daqueles que passaram por Ellis Island, aceitos ou recusados, mas que têm uma história para contar a partir da lembrança do lugar. Talvez seja essa a grande questão de Perec para a composição do livro, partindo das histórias e memórias dos outros: a ele foi negada a possibilidade de dar continuidade à cultura e à tradição dos pais, já que não pôde nascer no mesmo lugar que eles, e não recebeu a transmissão de seus valores culturais. O lugar de origem, então, também passa a ser uma impossibilidade:

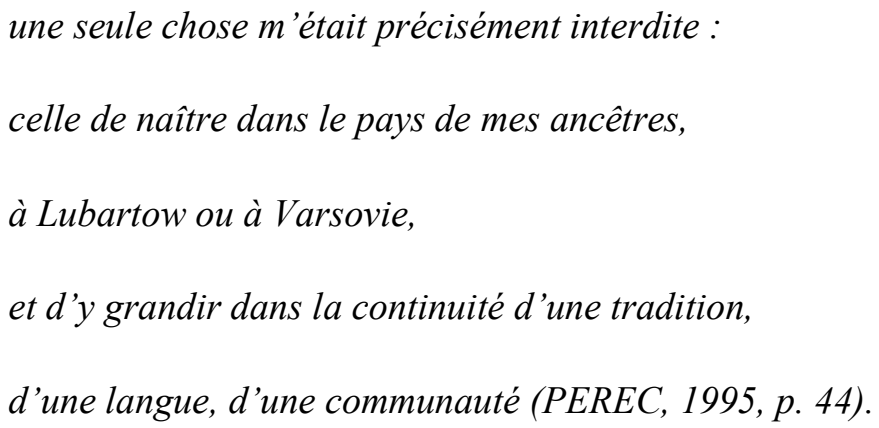

Esta sensação de não-pertencimento a uma coletividade ou comunidade faz também com que Perec olhe para todas essas pessoas, vindas de diferentes nacionalidades, e encontre nelas uma espécie de cumplicidade. Todos foram forçados a emigrar e a deixar suas tradições e cultura para viver num país estranho, onde tiveram que recomeçar em todos os sentidos. Uma anedota contada pelo guia, que recebe os visitantes na ilha, nos anos 80 , aparece no documentário como uma espécie de contraste de discursos: o guia conta da forma mais literal e direta como foi a vida das pessoas que passaram por ali. Enquanto ele dá muitos detalhes, números, estatísticas, utilizando um discurso mais informativo, Perec e Bober preferem um olhar mais subjetivo, no intuito de provocar uma reflexão sobre o que restou, o que não era tão importante, mas que, 
para eles, seguindo a lógica de escrita de Perec, (o infra-ordinário) era exatamente o que pretendiam mostrar para o público espectador do documentário. Essa anedota contada pelo guia mostra como uma simples dificuldade na comunicação transformava literalmente a identidade das pessoas, que entravam na ilha com nomes já americanizados:

Aconselharam um velho judeu de escolher um nome americano que as autoridades de estado civil não tivessem problemas em transcrever. Ele pediu conselho a um empregado da sala das bagagens, que propôs Rockfeller. O velho judeu repetiu muitas vezes em sequência Rockfeller, Rockfeller, para ter certeza que não esqueceria. Mas quando, várias horas depois, o oficial de estado civil perguntou-lhe seu nome, ele tinha esquecido e respondeu em yiddish: Schon vergessen. (eu já esqueci) e assim foi inscrito sob o nome americano de John Ferguson. Essa história é talvez muito bela para ser real, mas pouco importa, no fundo, que seja verdadeira ou falsa. Para os emigrantes ávidos da América, mudar de nome poderia ser considerado como um ato de bondade. (PEREC, 1995, p. 17-18) $)^{194}$

Para Perec, mais importante que as anedotas contadas para os turistas é entrar em contato com as pessoas que passaram pela ilha, entender suas motivações e investigar o paradeiro de algumas delas, na década de 80. Por isso a importância da seção “Mémoires", onde os depoimentos serão o centro do texto. A voz dessas pessoas estará em evidência, ajudando-nos a reconstituir, ainda que parcialmente, pedaços de memórias do tempo vivido por eles na chegada à ilha, e que rumos suas vidas tomaram desde então. Para as pessoas que chegavam, desembarcar em Ellis Island era a promessa de uma vida nova, repleta de esperança, como Perec descreveu:

c'était là, tout près, presque à portée de la main,

l'Amérique mille fois rêvée, la terre de liberté où tous les hommes étaient égaux,

le pays où chacun aurait enfin sa chance,

le monde neuf, le monde libre

où une vie nouvelle allait pouvoir commencer (PEREC, 1995, p. 48).

\footnotetext{
194 On conseilla à un vieux Juif russe de se choisir un nom bien américain que les autorités d'état-civil n'auraient pas de mal à transcrire. Il demanda conseil à un employé de la salle des bagages qui lui proposa Rockefeller. Le vieux Juif répéta plusieurs fois de suite Rockefeller, Rockefeller pour être sûr de ne pas l'oublier. Mais lorsque, plusieurs heures plus tard, l'officier d'état-civil lui demanda son nom, il l'avait oublié et répondait, en yiddish : Schon vergessen (j'ai déjà oublié) et c'est ainsi qu'il fut inscrit sous le nom bien américain de John Ferguson. Cette histoire est peut-être trop belle pour être vraie, mais il importe peu, au fond, qu'elle soit vraie ou fausse. Pour des émigrants avides d'Amérique, changer de nom pouvait être considéré comme un bienfait.
} 
Essa ideia de sonho de liberdade fica evidente ao lermos, também, o depoimento de um dos entrevistados, Monsieur Semyon Shimin. Hoje pintor e ilustrador de livros infantis, ele nasceu na Rússia em 1902 e chegou à América com a família em 1912: “Bien sûr, je me souviens aussi de mon excitation le jour où on m'a dit que nous allions peut-être partir pour l'Amérique... On nous racontait toutes sortes d'histoires sur l'Amérique, on recevait des lettres, on nous disait que c'était le pays où tout le monde avait sa chance..." (p. 129). Ao mesmo tempo em que conta esse sentimento de esperança vivido por ele e sua família, o entrevistado narra, na sequência, uma tragédia que, provavelmente, foi vivida por muitas famílias na mesma situação. Perguntado sobre quantas pessoas havia na família que desembarcou em Ellis Island, respondeu: "Nous étions six avec mes parentes... Il y avait un bébé, une petite fille... Malheureusement elle a attrapé une pneumonie sur le bateau et elle est morte, deux mois après notre arrivée..." (p. 129).

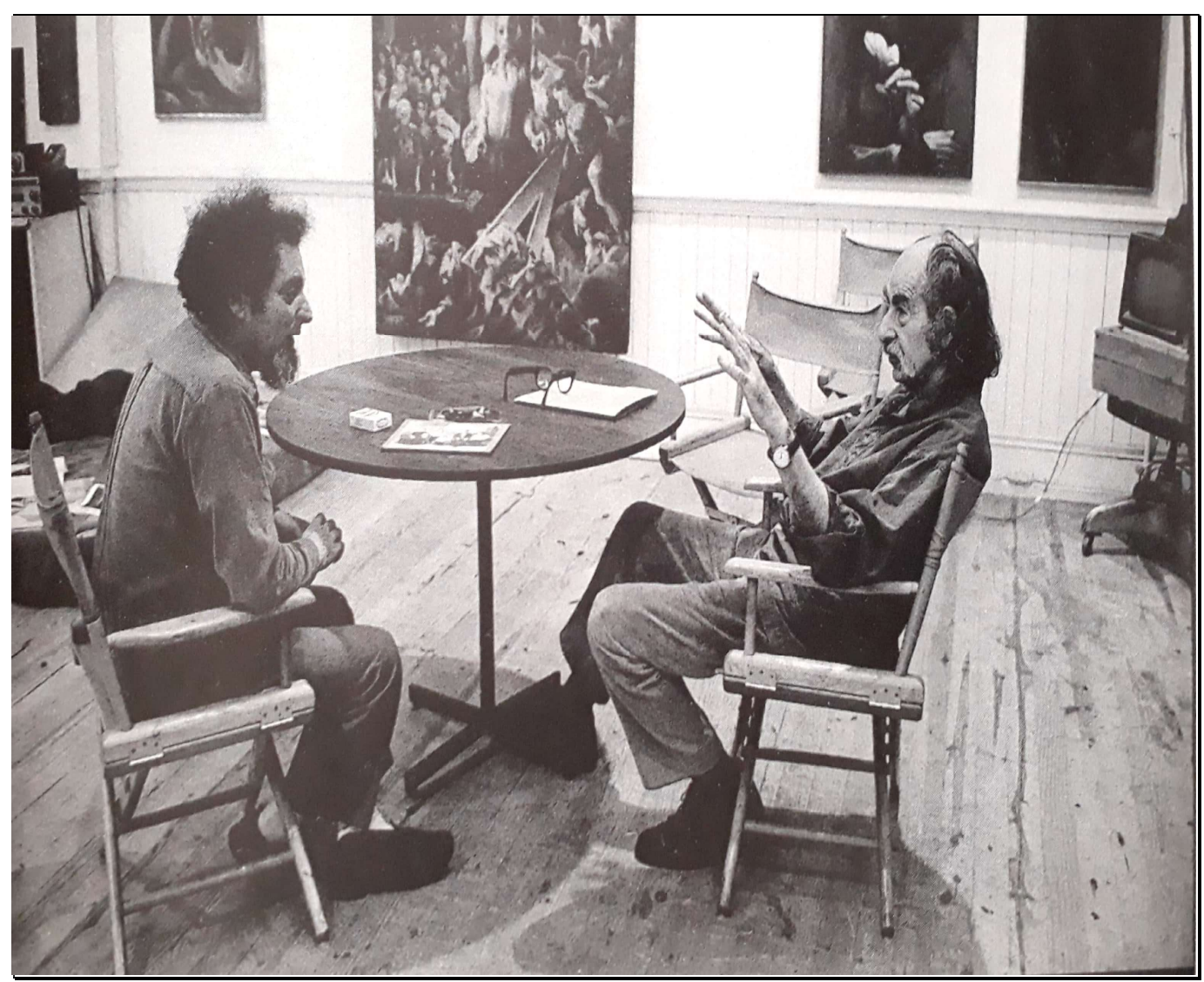

Figura 43. Georges Perec e Semyon Shimin, em entrevista concedia em seu ateliê, em 23 de maio de 1979. A foto consta do mesmo livro, p. 131. 
Assim, vemos em diversos depoimentos sentimentos opostos: a esperança de uma nova vida e a chegada nem sempre acolhedora, num lugar que triava as pessoas e as recusava de acordo com seu estado de saúde. Isso somente ocorria em relação às pessoas com baixo poder aquisitivo, a maioria delas vindo por questões de sobrevivência, fugindo de guerras ou perseguições. Aquelas com condições financeiras, que haviam comprado os bilhetes de viagem mais caros, eram levadas diretamente a Nova Iorque, sem ter que passar pela triagem. Outro depoimento que deixa claro essa diferença entre o que era imaginado e a situação real, na chegada à ilha, vem de Madame Schwartz, refugiada vinda de Rússia em 1921, que confidencia:

Bom, quando desembarcamos, esperávamos descobrir um mundo diferente, mas o que descobrimos, foi Ellis Island, uma grande sala com barras de aço nas janelas, uma prisão. Foi uma terrível decepção para nós; era essa a bela América: não havia sequer um par de cadeiras ou bancos para que nos sentássemos, todo mundo se sentava no chão, no meio da sujeira! Depois de uma viagem tão dura, parecíamos ter chegado, no fim, à antiga Rússia dos czares e da Romênia fascista, esperávamos encontrar alguma coisa quente, alguma coisa limpa, ao invés de ter que nos sentar no chão. (p. 134) ${ }^{195}$

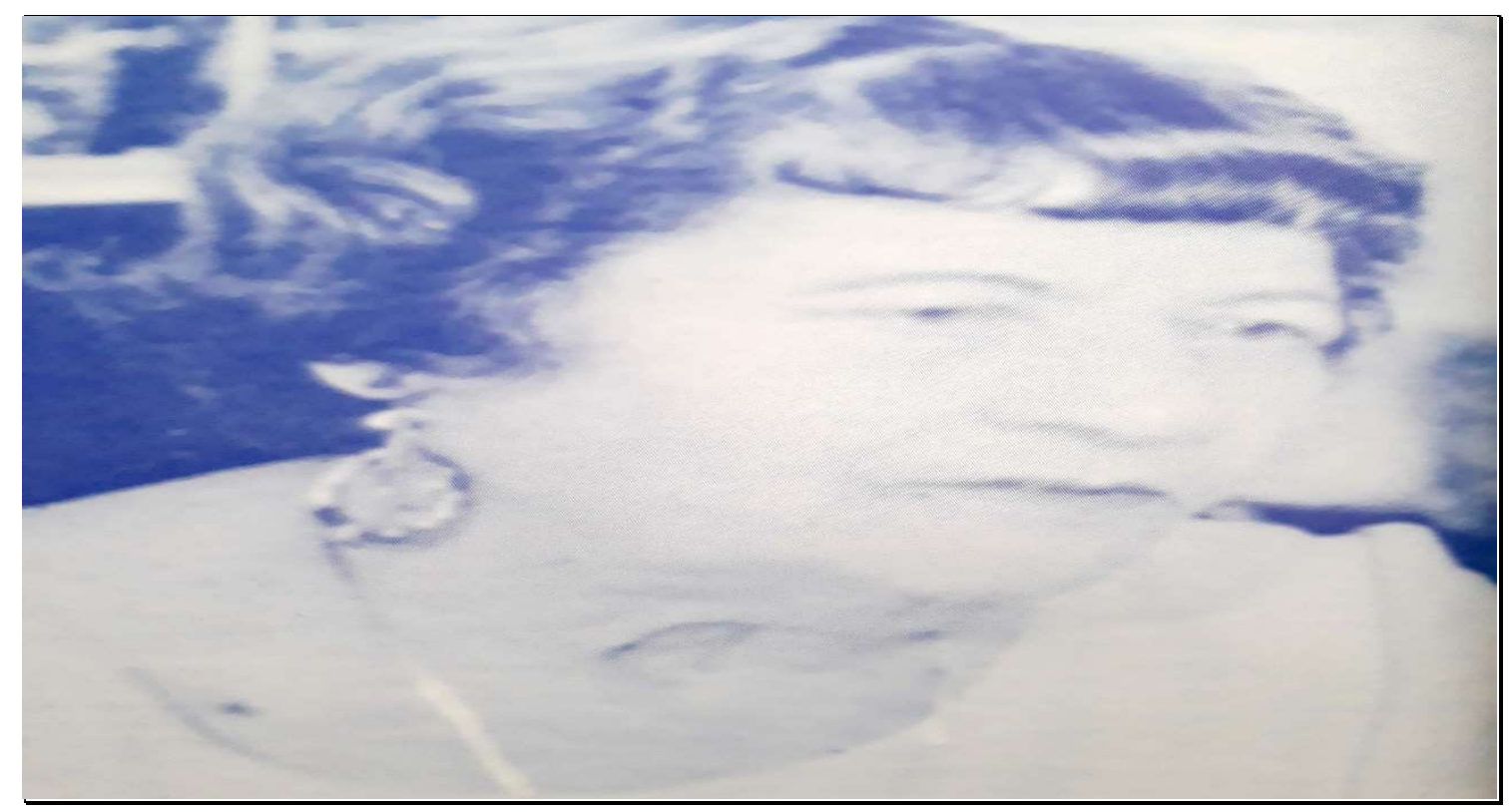

Figura 44. Mme. Rose Schwartz, entrevistada no Bronx, em 25 de maio de 1979, p. 132.

\footnotetext{
${ }^{195}$ Eh bien, quand nous avons débarqué, nous nous attendions à découvrir un monde différent, mais ce que nous avons découvert, c'est Ellis Island, une grande salle avec des barreaux d'acier aux fenêtres, une prison. Ça a été une terrible déception pour nous ; c'était ça la belle Amérique : il n'y avait même pas de chaises ou de bancs pour s'asseoir, toute le monde s'asseyait par terre, dans la saleté ! Après un voyage si dur, on croyait en avoir fini avec l'ancienne Russie des tsars et la Roumanie fasciste, on espérait trouver quelque chose de chaud, quelque chose de propre, mais au lieu de s'asseoir par terre.
} 
De todas as entrevistas, a última parece ser aquela com a qual Perec se identifica de maneira evidente, já que Madame Rabinovici foi recusada, junto com a irmã, por serem muito jovens e não terem família na América. Vindas da Romênia, para lá retornaram, mas a irmã conseguiu retornar a Ellis Island pouco depois da Primeira Guerra. Ela viveu sozinha desde então na França, vindo apenas visitar a irmã nos Estados Unidos, ocasionalmente. Ela ainda guarda na memória a experiência do fracasso, por ter sido recusada, e a sensação de liberdade nunca alcançada. Mesmo vivendo na França por 47 anos, não conseguiu naturalizar-se francesa. De certa forma, essa história ressoa na história da família de Perec. Por mais que tenha nascido na França, ele sente a perda de identidade e história da família polonesa, já que os pais não puderam passar adiante sua história.

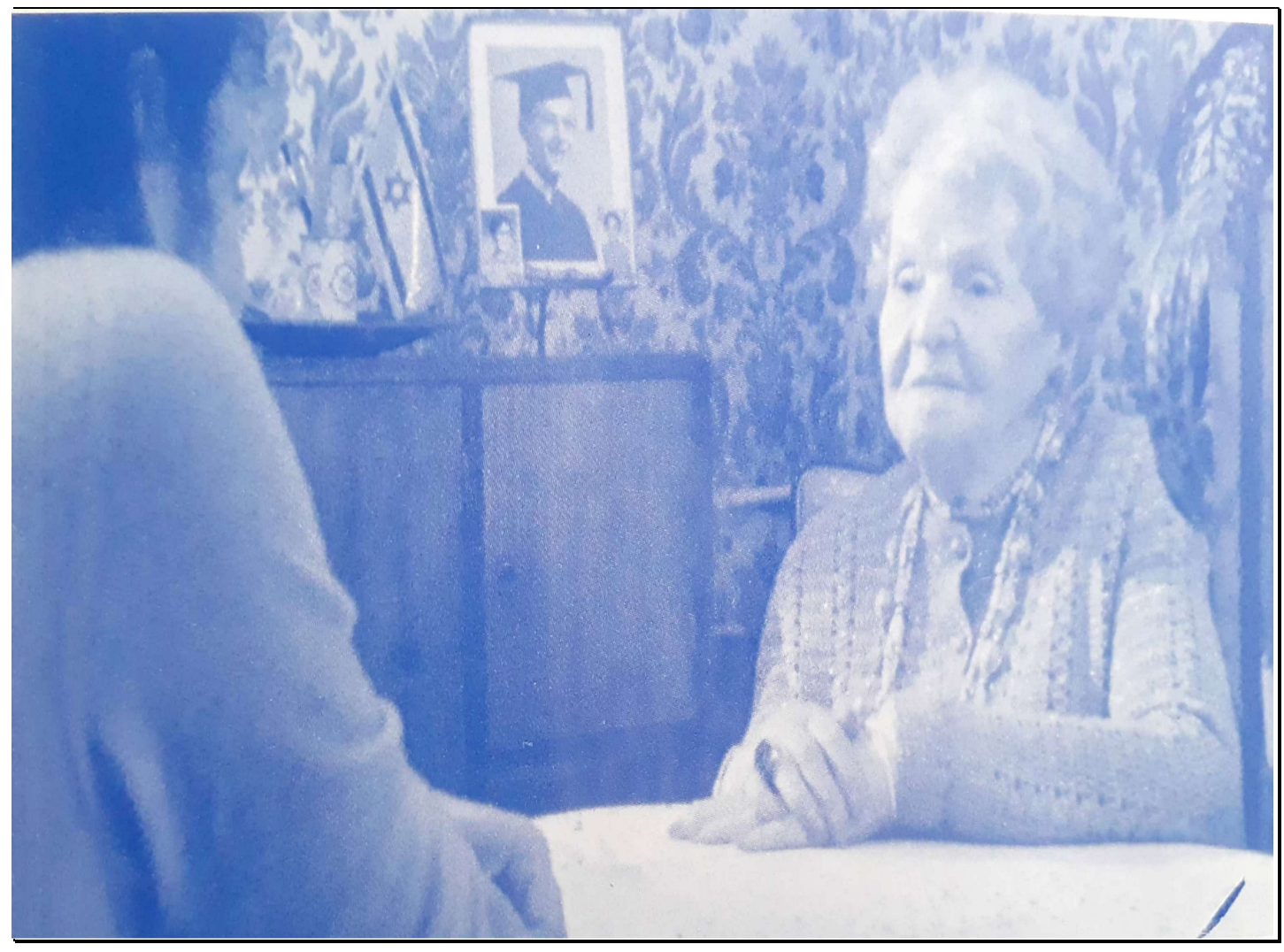




\subsection{A ilha como lugar na escrita de Perec}

A partir dessa ideia de sentir-se estrangeiro no lugar onde vive, mesmo que por razões distintas, como no caso de M. Rabinovici, voltamos à questão da busca de identidade de Perec, que parte de certa forma nesta procura por um lugar onde possa se ancorar. É interessante pensar que a imagem da ilha, nesse caso, ressoe em alguns de seus trabalhos como se, de alguma maneira, a falta de identidade o levasse a se sentir isolado do mundo ou, ainda, que a imagem da ilha servisse como pano de fundo para alguns de seus trabalhos, numa espécie de metáfora de sua relação com o mundo.

Assim, para encerrar a nossa seção sobre Ellis Island, e dar andamento às reflexões sobre o documentário de Bober, é interessante pensarmos na imagem da ilha, presente nas duas obras bastante importantes e citadas nesse capítulo: assim como em Récits..., em $W$ ou a memória da infância há uma ilha chamada $W$ (no texto ficcional, que se intercala com o autobiográfico), na qual acontecem competições esportivas e que, ao final da leitura, mostra-se como uma alegoria dos campos de concentração.

Após uma descrição detalhada de um campo de concentração, ao final do livro, conseguimos finalmente associar as imagens da ilha $\mathrm{W}$ e suas competições esportivas às condições em que viviam os deportados nos campos. Perec se vale de um trecho do livro L'Univers concentrationnaire de David Rousset para criar essa analogia. No último parágrafo, após a descrição de Rousset, Perec finalmente associa a ilha $\mathrm{W}$ à Terra do Fogo e, consequentemente, aos regimes ditatoriais:

Esqueci as razões que, há doze anos, me fizeram escolher a Terra do Fogo para lá instalar W: os fascistas de Pinochet se encarregaram de dar ao meu fantasma uma última ressonância: diversas ilhotas da Terra do Fogo são hoje campos de deportação. (PEREC, 2017, p. 778) ${ }^{196}$

O texto de Perec, citado aqui a partir do volume I de Euvres, vem seguido de uma nota de rodapé, na página 1093, em que explica que o regime de Pinochet utilizou muitas ilhotas chilenas como centros de detenção depois do golpe de 1973, principalmente a ilha Dawson, que está localizada na Terra do Fogo.

\footnotetext{
196 J'ai oublié les raisons qui, à douze ans, m'ont fait choisir la Terre de Feu pour y installser W : les fascistes de Pinochet se sont chargés de donner à mon fanstasme une ultime résonance : plusieurs îlots de la Terre de Feu sont aujourd'hui des camps de déportation.
} 


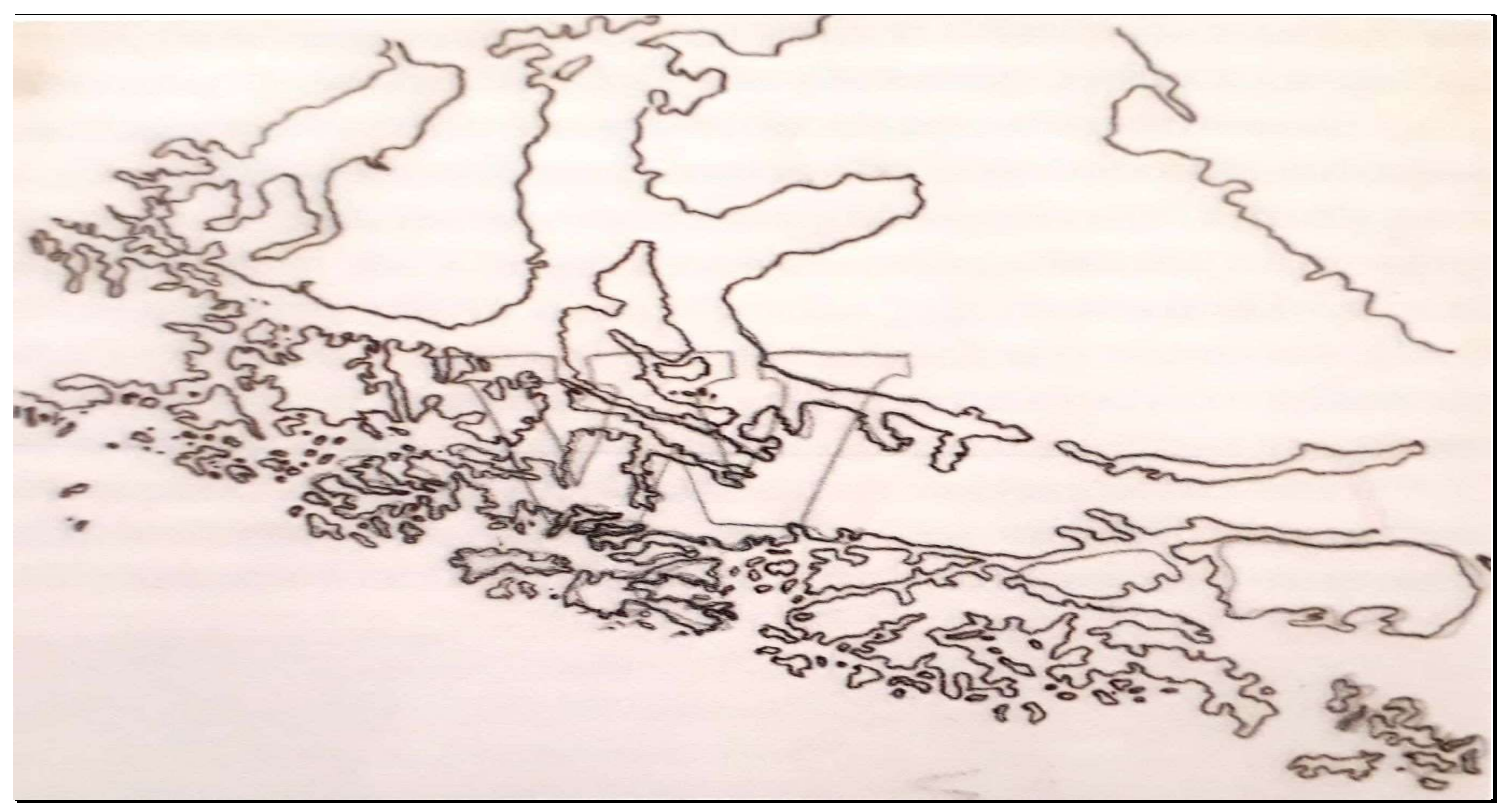

Figura 46. Decalque de um mapa da Terra do Fogo feito por Perec e conservado com o manuscrito de W. Album Georges Perec, p. 138.

Há, ainda, um trabalho de juventude de Perec, em parceria com um colega de sala, Bernard-Quilliet, realizado para amenizar o tédio do curso de filosofia que faziam juntos em 1954-55, onde escreve textos para ilustrações de uma história de aventuras chamada "Les aventures extraordinaires d'Enzio, le petit roi de Sardagne" e que tem como ponto de partida, na primeira ilustração, o desenho de uma ilha. ${ }^{197}$

Ainda em relação à imagem da ilha, fortemente associada à história de perdas de sua própria família, mas também a uma memória coletiva, como vimos em $W$, podemos pensar que a ilha, para Perec, pode funcionar como esse universo próprio, onde ele pode se isolar, já que se sente, muitas vezes, isolado e não pertencente ao mundo em que vive, em busca de um tempo e um espaço nos quais possa se ancorar. É o que fica evidente a partir da citação em uma entrevista de 1979: "Je me sens par rapport au monde un peu comme Robinson Crusoé sur son île, qui avait besoin tous les jours de tracer quelque chose pour continuer à avoir un repère de temps ${ }^{198}$ ". Essa ideia de fixar o tempo, na

\footnotetext{
${ }^{197}$ As ilustrações e o texto de Perec (ainda que inacabado) foram publicados integralmente em Perec, Éd. de L'Herne, pp.13-26. É interessante pensar nessa obra, mesmo que inacabada, como algo totalmente esquecido pelo próprio Perec, uma vez que enumera, dentre as "50 coisas a fazer antes de morrer", que vimos no capítulo 3, "travailler avec un dessinateur de BD", algo já feito nesse texto, mesmo que parcialmente, na juventude.

${ }^{198}$ Entretiens et conférences, vol. II, p. 235. Interessante também ressaltar que na obra La vie mode d'emploi há outra referência a Robinson Crusoé e à questão da passagem do tempo: "Un tableau sur bois, datant sans doute de la première moitié du XIXe siècle. Il s'intitule Robinson cherchant à s'installer aussi commodément que possible dans son île solitaire. Au dessus de ce titre [...] on voit, assez naïvement
} 
tentativa de evitar o esquecimento, ressoa nessa ideia de isolamento, paradoxal, inclusive, em relação ao fato de descrever incessantemente a cidade de Paris, repleta de pessoas, objetos e paisagens mutáveis.

Esse modo de lidar com o mundo, totalmente contraditório, pois ao mesmo tempo em que deseja dar conta dessa totalidade (a partir da descrição de cenas do real, como representações dessa realidade, nesses pequenos universos que observa), está no meio dessa multidão, dessa metrópole que é Paris, mas sente-se isolado numa ilha, dentro do seu próprio universo.

Trazendo a ilha para a escrita, ele pode, talvez, lidar com esse mundo com o qual não se identifica, onde não encontra um porto no qual pode se ancorar. É assim, nessa contradição entre o viver no próprio mundo e descrever exaustivamente o mundo, que a escrita de Perec se produz e, por isso, também cria em nós, leitores, sentimentos muito contraditórios em relação a sua escrita, visto que também somos tocados por esse estranhamento diante do mundo, aliado a nossa curiosidade em conhecê-lo, a partir das diferentes realidades que Perec nos descreve, e nos ajuda a refletir sobre elas.

No final das contas, podemos pensar que todas essas ilhas imaginárias, todos esses lugares descritos exaustivamente foram a forma encontrada para deixar vir à tona o lugar sobre o qual não há lembranças: a rue Vilin estará presente, indiretamente, na escrita de todos esses outros lugares. E é por isso que encerraremos esse trabalho com o documentário En remontant la rue Vilin, para termos uma visão de Perec a partir de um outro, seu parceiro de trabalho, Robert Bober. Perec não olhará mais para o outro, mas será olhado por ele, fechando assim nosso ciclo de reflexões, tendo a rue Vilin como ponto de partida, em nossas análises do segundo capítulo, e como ponto de chegada, rumo à escrita final do trabalho.

\section{En remontant la rue Vilin... O documentário que recria Lieux}

Podemos resumir o enredo do documentário em três partes: a primeira recupera a história oficial da rua e de sua nomeação, em 1863, como rue Vilin, em homenagem ao arquiteto do mesmo nome que ali fora proprietário e prefeito. Esta situação urbana se mantém até 1982, quando a rua é avaliada pelos órgãos de higiene pública como

représenté, Robinson Crusoé [qui] trace sur l'arbre qui lui sert à mesurer l'écoulement du temps, une barre de dimanche" (CH. LXXXVI, pp. 491-492). 
insalubre, sendo as moradias condenadas à extinção. A segunda mostra a reforma urbana do bairro nos anos 80 para, então, Bober poder finalmente conectar a história da rua com a história de Perec, conforme nos explica o artigo de Rocha e Eckert: ${ }^{199}$

\begin{abstract}
A segunda [história] indica as definições cardinais e matemáticas do "quartier", re- situando a Rua Vilin nos pés desta colina que, na época, conhece uma importante política de reurbanização dando lugar ao Jardim de Belleville como mostram as imagens fotográficas coloridas mais recentes que documentam uma inauguração ocorrida em 1988. A terceira as duas anteriores, re-situando-as no interior das lembranças de um morador local, o escritor e poeta Georges Perec e de sua tentativa de compreender os meandros da passagem do tempo a partir do registro sistemático das suas formas na paisagem urbana parisiense de sua infância (p.10-11).
\end{abstract}

Bober recria, portanto, uma parte da história da rua, marcada por uma questão temporal, mas nos leva diretamente à história passada de Perec no bairro onde viveu sua infância: a partir da história de Perec, ele poderá, como veremos, contar um pouco da própria história e homenagear todos aqueles que sofreram algum tipo de trauma ou perda na Segunda Guerra. Bober criará uma espécie de texto fílmico, uma vez que a montagem das imagens atreladas aos textos de Perec ecoarão reflexos da obra e do projeto Lieux, aqui, mais uma vez, transformado em outra expressão artística, um documentário de Bober que servirá como uma homenagem ao mesmo tempo pessoal e coletiva.

Em se tratando das análises sobre En remontant la rue Vilin ${ }^{200} \ldots$, o maior desafio estará na tentativa de retraçar a trajetória de Bober, em busca desse arranjo de fotos intercaladas, que deu origem ao filme documentário. A intenção de Bober, entretanto, já pode ser brevemente esboçada: a impossibilidade de criar uma reconstituição linear ou perfeita a partir da transposição de fotos numa sequência é um fator a ser considerado. Assim também será a nossa reconstituição do documentário: não pretendemos recriar o documentário exatamente como foi realizado, mas mostrar aquilo que de fato dialoga mais profundamente com as questões levantadas na pesquisa, sobretudo em relação aos fatores autobiográficos e sua relação com o outro, no caso, a relação de Bober e Perec, e como o primeiro se vale da história do segundo para criar,

\footnotetext{
${ }^{199}$ Um dos raros artigos em português sobre a obra de Perec e, mais especificamente, sobre o documentário En remontant la rue Vilin: "O infra-ordinário na paisagem urbana como condição da produção de etnografias sonoras e visuais". In: Iluminuras: série de publicações eletrônicas do Banco de Imagens e Efeitos Visuais, LAS, PPGAS, IFCH e ILEA, UFRGS. Porto Alegre, RS. N. 10 (2004), p. 19. ${ }^{200} \mathrm{O}$ vídeo completo pode ser acessado pelo link: https://www.youtube.com/watch?v=8HfvFHQ-j6s.
} 
indiretamente, uma história para si.

Ainda assim, ao assistirmos ao documentário, por vezes nos esquecemos dessa impossibilidade, já que somos transportados a essa perfeição ilusória da reconstituição do lugar, provocada pela montagem das fotos - perfeição essa nunca admitida ou buscada por Bober -, conforme nos mostram novamente Delage e Guigueno ${ }^{201}$ :

O cineasta não renuncia à tentação panorâmica "perfeita" sobre uma série contínua de fotografias: ele a efetua no fim do filme, quando nos inclui na descoberta de nove fotografias do espaço "Rue Vilin", tiradas em 1955 com o cuidado de obter a conexão mais precisa possível. Diante dessa paisagem, cujo ângulo de amplitude excede os duzentos graus, o comentário supera os textos de Georges Perec.

Mas a montagem panorâmica perfeita logo dará vazão ao trabalho artístico, ao sonho e à imaginação, ao se deparar com a imagem de um garotinho pela rua. Logo, seu ângulo de visão sofrerá esse desvio, ou seja, o olhar oblíquo diante das imagens nos proporcionará uma visão subjetiva, imaginativa, criativa e - por que não dizer? fictícia, mesmo dentro de um filme documentário:

Enquanto a câmera gira num lento movimento, da esquerda à direita dessa vez, Bober tenta seguir o percurso de um garotinho de três anos que, como ele imagina, Perec poderia ter feito ao retornar de sua escola em direção à Rue Vilin, dando a mão a sua mãe: "Gostaria de me lembrar, mas só posso continuar imaginando esse garotinho que corre na calçada da passagem Vilin. ${ }^{202}$. (grifos meus)

Assim, a partir das fotos e documentos retirados do arquivo de Perec, Bober conseguirá ir além: reproduzirá também, em "voz off”, trechos de textos de Perec, criando novamente essa inter-relação entre texto e imagem. Essas montagens cinematográficas criadas a partir da sobreposição de fotos (em diferentes procedimentos) permitirão diversas análises, para que possamos chegar a uma questão comum entre elas: observar a foto, manipular a foto, montar um documentário a partir da foto: são ações que podem conduzir ao trabalho da escrita autobiográfica?

Em Récits..., os traços autobiográficos são evidentes, como já vimos na primeira

\footnotetext{
${ }^{201}$ Le cinéaste ne renonce pourtant pas à la tentation du panoramique "parfait" sur une série continue de photographies : il l'effectue à la fin du film, quand il nous fait part de la découverte de neuf photographies de l'espace "rue Vilin", prises en 1955 avec le souci d'obtenir d'emblée le raccord le plus exact possible. Devant ce paysage dont l'angle d'amplitude dépasse les deux cents degrés, le commentaire s'affranchit des textes de Georges Perec. Op. cit., p. 7.

${ }^{202}$ Idem. Alors que la caméra pivote dans un lent mouvement, de la gauche vers la droite cette fois, Bober essaye de suivre le parcours d'un petit garçon de trois ans qui comme, il l'imagine, Georges Perec aurait pu le faire revient de son école vers la rue Vilin, en donnant la main à sa mère : "J'aurais aimé me souvenir mais je ne peux que continuer à imaginer ce petit garçon qui court sur les pavés du passage Vilin.
} 
parte, principalmente quando levantamos as questões pessoais e reflexões produzidas no texto, muitas delas influenciadas pelas fotos tiradas do lugar no momento atual, em comparação às fotos da época da imigração. Também foi possível perceber que Perec se valeu dos depoimentos pessoais (olhar para o outro), buscando, nesses personagens da vida real fatos e situações que poderiam ter sido a vida que seus pais teriam, a que ele próprio teria, caso tivessem emigrado para os Estados Unidos, antes de terem sido mortos pela guerra.

No filme En remontant..., contudo, poderemos ir um pouco além na reflexão: é possível que esses procedimentos realizados por Perec e Bober, num primeiro momento, tenham levado ao desejo de continuidade, ou ao menos inspiraram Bober para, depois, realizar outro filme, dessa vez sozinho?

Se pensarmos que ele filmará um documentário que se dirige ao outro - já que tem esse outro como sujeito principal, a partir da manipulação e montagem de fotos poderá, de certa forma, substituir a escrita de um texto sobre si. Poderemos nomear as duas iniciativas cinematográficas, portanto, de documentários autobiográficos.

Para afirmar isso, podemos recorrer inicialmente à relação intrínseca que se observa entre aquilo que Bober já filmou em Réfugié... e aquilo que realizará em En remontant... Se no primeiro filme, explicitamente autobiográfico, Bober mostra a situação de sua chegada a Radom, quando conhece a casa onde os pais moraram, anos depois, em 1992, ele irá utilizar-se de fotos tiradas por Perec e seus colaboradores à época de Lieux para reconstituir a chegada de Perec à rue Vilin - e sua experiência de encontro com um local que não faz parte de suas memórias de infância e que, portanto, ele também não reconhece. As duas cenas, entrecruzadas, podem aparentar, a princípio, quase uma reconstituição, por parte de Bober, da própria experiência de Radom, a partir da experiência posterior de Perec.

Assim, podemos pensar que Bober desejará reviver, na rue Vilin (da época de 1969 a 1975, quando as fotos para Lieux foram tiradas) trazida à tona por ele somente em 1992, momento em que filma En remontant...) sua própria experiência de Radom, ocorrida em Réfugié.... Bober descreve, no trecho abaixo, a importância do retorno de Perec à rue Vilin, na realização do projeto de Lieux:

Retornar a essa rua era um passo difícil para ele: certamente havia uma falta que $\mathrm{W}$ não poderia ter preenchido. Chegando em frente ao número 24 , onde sua mãe tinha um salão de cabeleireiro, ele não entrou. Foi 
nesta abordagem literária de Lieux, misturando a rue Vilin a outras ruas de Paris que ele venceu essa angústia. ${ }^{203}$

Bober (re)filmará Radom a partir da rue Vilin, ao realizar o documentário En remontant..., parece ter em mente o objetivo já vislumbrado por Perec ("tentar descrever ao mesmo tempo as lembranças que me ligavam a essa rua e os vestígios cada vez mais apagados do que foi uma rua" ${ }^{204}$ ). Enquanto trabalha na reconstituição da rua Vilin, a partir da montagem de centenas de fotos, ele tenta alcançar os mesmos resultados: ao mesmo tempo em que pretende descrever as lembranças que ligavam Perec ao local, deixa visíveis, a partir das mesmas imagens, os vestígios e o aspecto de abandono presentes no local.

Partindo do princípio geral de que documentários são criações que nos conduzem a refletir sobre fatos históricos do passado, podemos pensar que a concepção de documentários como representações de uma memória autobiográfica (individual ou coletiva) possa nos trazer uma nova maneira de olhar para tais filmes, pensando mais nos gestos autobiográficos aparentes do que nas técnicas documentárias tradicionais.

Bill Nichols, um dos principais teóricos sobre documentário, afirma, em sua obra Representing Reality (p. 156), que "a subjetividade e a identificação são bem menos frequentemente exploradas no documentário do que na ficção”. Ao aprofundar seus estudos, em obra posterior, porém, o crítico vai reavaliar essa definição, comentada aqui por outro teórico, Michael Renov ${ }^{205}$ : “Certamente chegou o momento (como o próprio Nichols demonstrou em sua nova obra, Blurred Boundaries) de uma reavaliação, do reconhecimento explícito de que o sujeito no documentário tornou-se, com uma intensidade surpreendente, o sujeito do documentário".

Essa reavaliação de Nichols reafirma a hipótese de que dificilmente um documentário será apenas um relato de algum fato histórico. Subjetividade e história estarão presentes, em diferentes níveis, nas diversas definições de tipos de documentários propostas por Nichols.

Ao analisarmos, mesmo que de forma breve, definições possíveis para um tipo de documentário em que tanto Récits... quanto En remontant... pudessem se classificar,

\footnotetext{
${ }^{203}$ Retourner dans cette rue était une démarche difficile pour lui: il y avait certainement un manque que $W$ n'avait pas reussi à combler. Arrivé devant le numéro 24, où sa mère tenait un salon de coiffure, il n'est d'ailleurs pas entré. C'est dans la démarche littéraire des Lieux, en mêlant la rue Vilin à d'autres rues de Paris qu'il a vaincu cette angoisse. Em entrevista concedida no livro de Christian Delage e Vincent Guigueno, L'historien et le film, p. 256-257.

${ }^{204}$ Esse trecho está na apresentação da primeira edição de La Clôture, de 1976, já transcrito integralmente no capítulo 2.

${ }^{205}$ Em seu texto: "Investigando o sujeito: Uma Introdução", p. 393.
} 
verifica-se que, de certa forma, os documentários produzidos por Perec e Bober podem ser constituídos a partir de uma fusão de vários tipos, simultaneamente e, talvez por isso, a singularidade e particularidade inerentes a eles nos fazem crer na sua relevância como obra de arte cinematográfica. Se levarmos em conta a definição dos tipos de documentários segundo Nichols, analisada por Rosenstone ${ }^{206}$, temos: "Todas as seis formas de documentário contêm montes de informação a respeito do passado, embora algumas tenham propensão para dados macro-históricos e outras, para dados microhistóricos".

Essa definição nos faz pensar que, tanto em Récits... quanto em En remontant..., há um hibridismo entre os tipos de documentários justamente porque não há uma ruptura entre os dados micro e macro-históricos: ao contrário, eles dialogam entre si e, graças a esse hibridismo, podemos relacionar a história dos realizadores com as de seus entrevistados, em Récits..., por exemplo. Graças a isso, também é possível a Bober filmar En remontant..., contando, a partir dele, a história de um bairro (ou de uma rua, de uma pessoa) dentro de uma mesma história e - por que não? - contar ainda sua própria história, a partir de todas as outras. A subjetividade será uma das maneiras possíveis para abarcar todas essas histórias e permitir esse hibridismo na realização do filme documentário.

O texto autobiográfico em Perec, como sabemos, flui por toda a sua obra e se mescla a outros gêneros textuais. Podemos dizer, então, que Bober estaria seguindo os mesmos passos de Perec, ou sendo influenciado por sua obra, ao trazer a poética autobiográfica para seus trabalhos fílmicos. Vale ainda pensar que não se tratam de filmes autobiográficos em si, mas de olhares ou nuances autobiográficos presentes nos filmes documentários, que nos conduzirão a essa possível relação entre duas linguagens: a cinematográfica e a literária.

\subsection{Em busca de uma reconstituição}

Se pensarmos que foram por volta de 500 fotos passadas pelas mãos de Bober na tentativa de reconstituição da rue Vilin, podemos ter a noção do trabalho realizado pelo cineasta. Verificamos que, mais uma vez, o projeto Lieux extrapola o formato da escrita, que novamente será matéria-prima para realização desse documentário. Assim, teremos materializado um outro projeto, em forma de filme, a partir dos textos de Perec,

${ }^{206}$ No capítulo, intitulado "Documentário", (p. 114) do texto: "A história nos filmes, os filmes na história". 
sobretudo Lieux, e das fotos utilizadas a partir do material de Perec, mas também pela investigação realizada por Bober para encontrar outras imagens do lugar, em diferentes épocas.

Seguindo um conselho de Queneau, Bober nos lembra da importância que Perec deu à luta contra o esquecimento: "Faut que j'aille voir avant que tout ça ne disparaîsse". Seguindo seus conselhos, Perec inicia a série de descrições que já vimos até aqui e que terá continuidade no trabalho de Bober. Ao citar Queneau, Bober reforça as referências de Perec ao mesmo tempo que reitera que seu trabalho andará no mesmo sentido. Além de citar Queneau, Bober cita diretamente os textos de Perec, como se estivesse reafirmando o poder de sua escrita e de sua reflexão como influência direta para a realização do documentário. Isso fica evidente nos trechos citados "Notez le lieu, l'heure, la date", "Y-a-t-il quelque chose qui nous frappe?", “Écrire sur ce qui n'a pas d'intérêt, ce qui n'est pas évident".

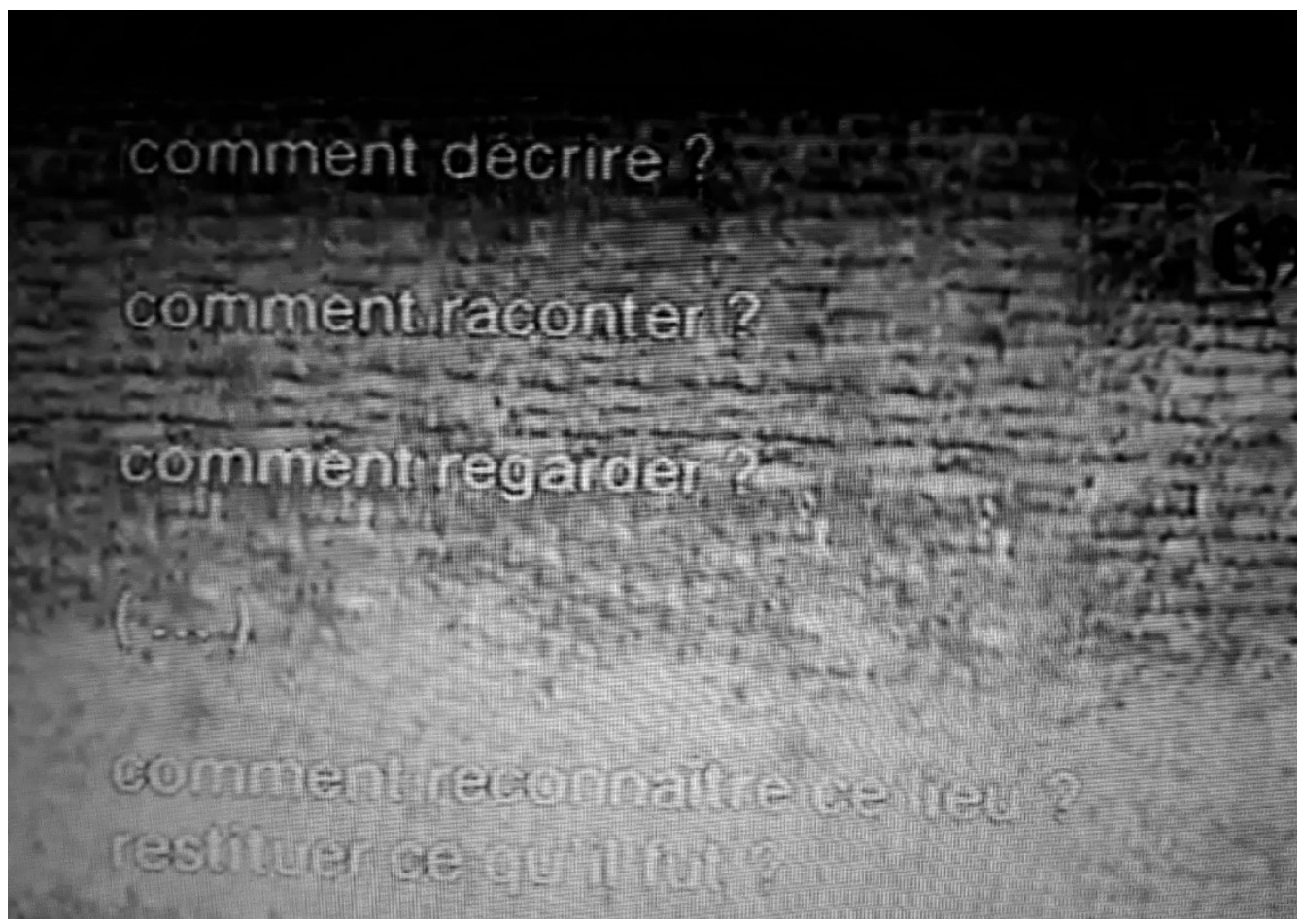

Figura 47. Cenas do documentário de Bober.

Uma das primeiras cenas mostra fachada do número 24 da rue Vilin, com a referência direta ao texto de Récits d'Ellis Island. O texto de Perec para o documentário é uma referência direta à rue Vilin. Assim, Bober, sobrepõe a imagem do lugar ao texto de Perec ao longo do documentário. 
Além de sabermos da quantidade de fotos manipuladas para realizar a reconstituição da rue Vilin, é interessante observar a manipulação de tais fotos pelo próprio Bober, como se ele estivesse nos incluindo no seu processo de criação (11:57). Ao mostrar a justaposição das fotos, o cineasta cria em nós a sensação de trabalho em curso, ao mesmo tempo em que nos faz refletir sobre os processos envolvidos na realização do filme. Como sabemos, a parceria entre ele e Perec se mantém, uma vez que os textos do escritor serão reproduzidos; assim, a parceria artística acontecerá novamente, mesmo que Bober tenha que se valer apenas de documentos, fotos e manuscritos de Perec. Enquanto seleciona e organiza todo esse material, Bober incorpora a ideia perecquiana de "former un ensemble comme dans um puzzle". Assim, o processo de arranjar e sobrepor as fotos nos é mostrado, citando diretamente o puzzle da obra La vie mode d'emploi.

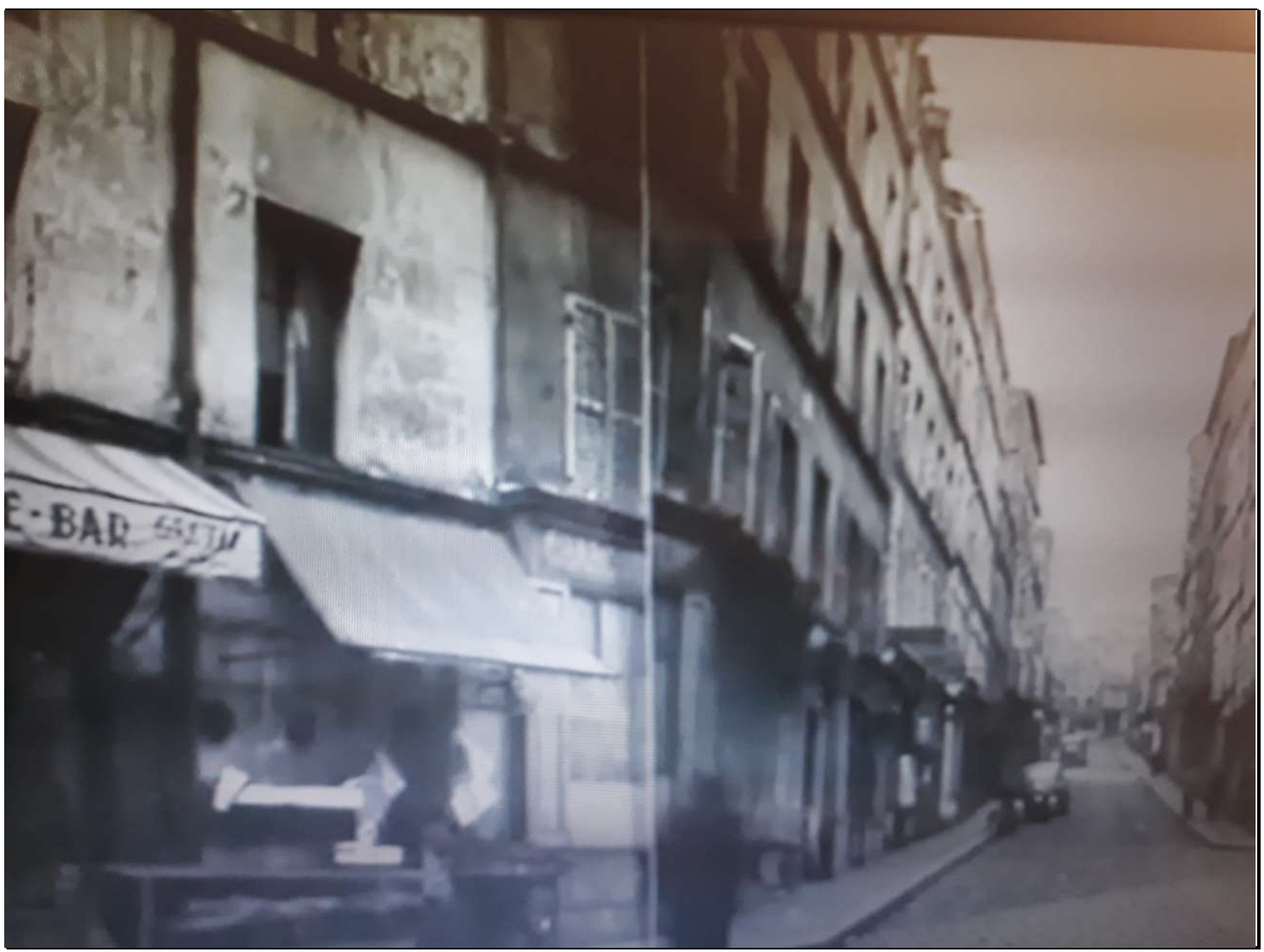

Figura 48. Duas fotos sobrepostas, marcadas pela linha no meio da imagem, representam o processo de reconstituição da rue Vilin no filme de Bober. 
Bober nos mostra o processo de sobreposição, enquanto explica a ordem e a numeração da rua, que será respeitada. "Difficulté à établir le parcours, à restituer ce espace". Verificamos, nesse trecho, que a dificuldade principal é em organizar fotos que foram tiradas em períodos diferentes e fora de uma sequência, o que aumenta ainda mais a dificuldade do trabalho. Assim, ele reforça a ideia de uma montagem que requer a mesma minúcia de um "fabriquant de puzzle, bien qu'imparfaitement". Ou seja, o trabalho de montagem de um documentário sobre a escrita de Perec será também uma forma de representar a escrita de Perec, de prestar uma homenagem ao escritor, pensando em termos de regras para a produção do filme, bastante semelhantes às de Perec: descrever, classificar, organizar, citar, fazer com que o leitor (e no caso de Bober, o espectador) participe ativamente da reflexão sobre o processo de criação.

Uma data importante será mostrada ao espectador do documentário: “27 fév 69" - data da primeira descrição da rue Vilin lida por Bober, ao mesmo tempo em que sobrepõe as imagens. É interessante observar que Bober vai lendo a descrição de Perec enquanto a câmera se move e passa pelos mesmos números citados. Bober também verifica números que estão na foto, mas que Perec não mencionou. Assim, observamos que, para além da descrição precisa do local em relação às fotos, Bober vai nos fazer refletir também sobre o que está ou não na descrição, ou seja, o que se quis mostrar na descrição de Perec. É claro que, em se tratando de uma obra de caráter autobiográfico, teremos maior destaque nas descrições para imóveis que tenham alguma relação direta com suas memórias de infância (ou a completa falta delas).

Por exemplo, quando se chega ao número 24 , Bober nos mostra a cena em que Perec para em frente à porta e termina com a citação: "Eu não entrei”. Segue-se a esse momento bastante importante (já que o número 24 é o lugar onde Perec viveu parte de sua infância), outra citação fundamental de Perec sobre o projeto Lieux e que Bober utiliza para criar essa relação direta entre a observação dos lugares e a memória autobiográfica: "Je ne veux pas oublier. Peut-être est-ce le noyau de tout ce livre" (25/04/70 - aux environs de 18 heures). 


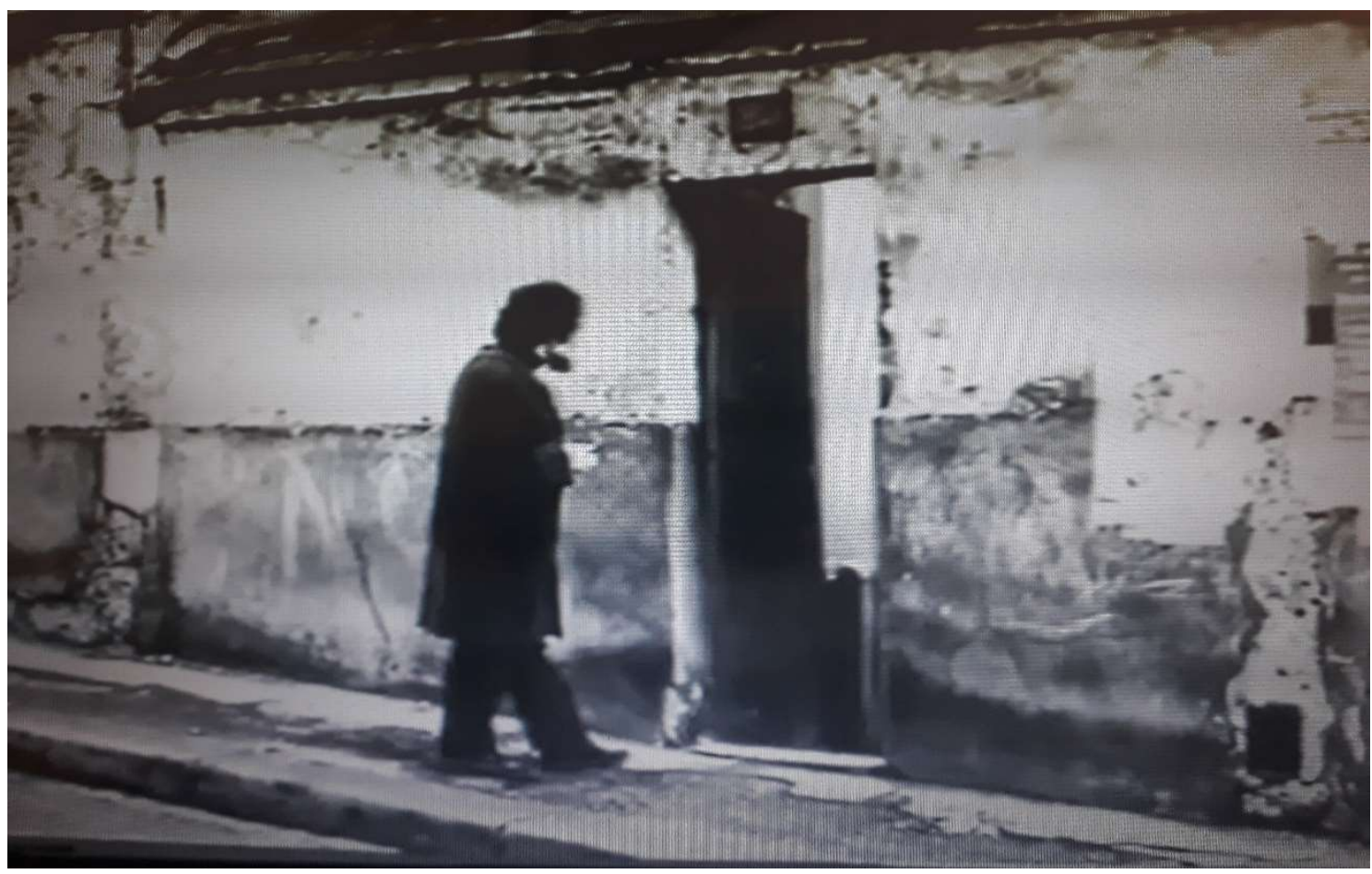

Figura 49. A cena em que Perec observa o número 24 da rue Vilin, retomada por Bober

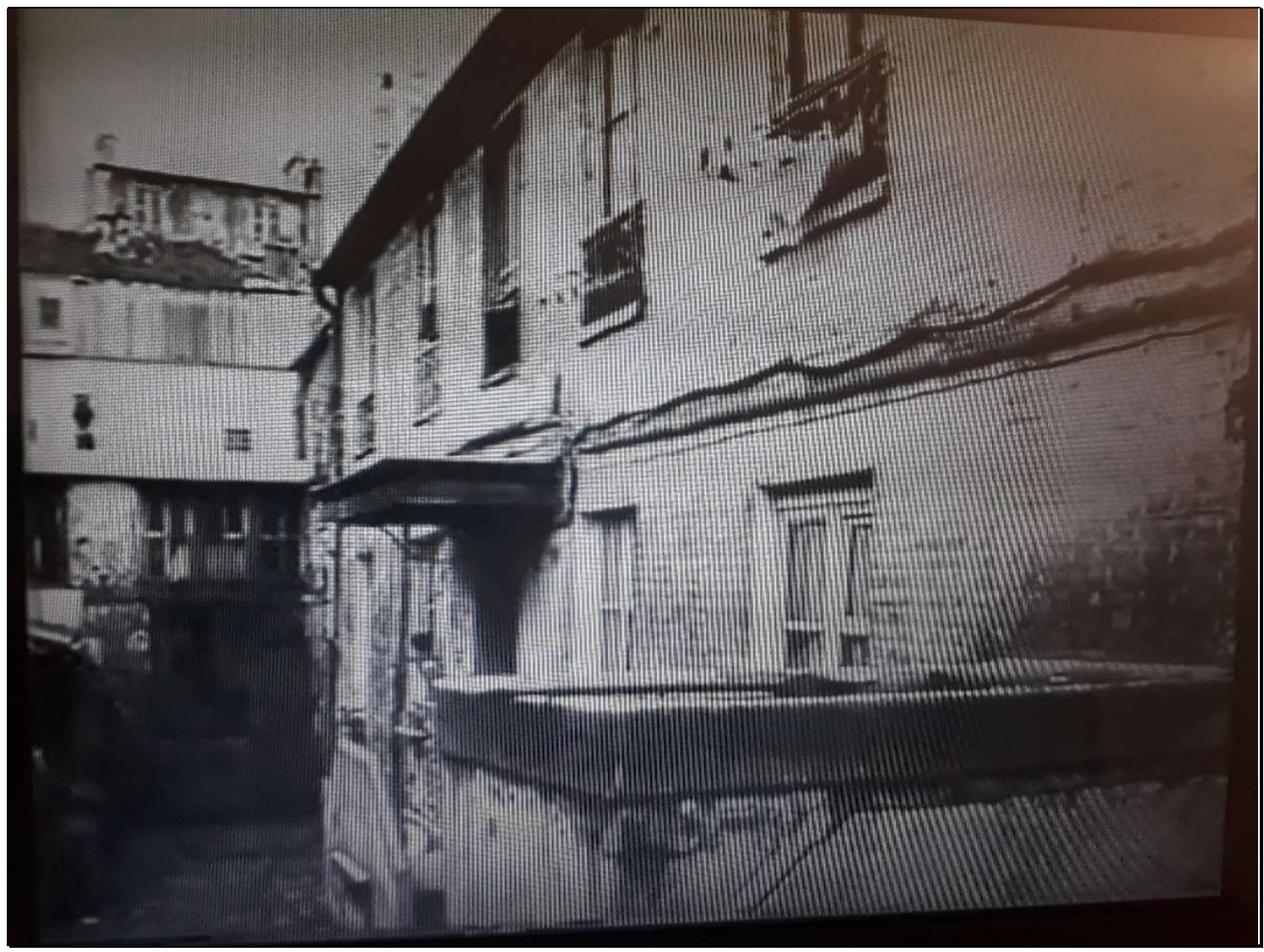

Figura 50. Perec observa o lugar de fora: a descrição se baseia apenas no que vê pela porta (o pátio interno onde passou a infância). Bober mostra as fotos enquanto lê o texto de Lieux. 
Como vimos no primeiro capítulo, que descreve os Réels e Souvenirs da rue Vilin de Perec, os primeiros anos são compostos por textos mais completos, enquanto que, com o passar do tempo, vão se tornando mais rápidos, quase que em forma de listas. Assim, para marcar também essa diferença, Bober lê as anotações de um texto de 5 de novembro de 1972, tentando reconstituir os números a partir das fotos, novamente. Nesse momento, pelas imagens, pode-se observar que os imóveis já são descritos como parcial ou totalmente destruídos e, a partir das fotos selecionadas por Bober, podemos reafirmar o já descrito no texto.

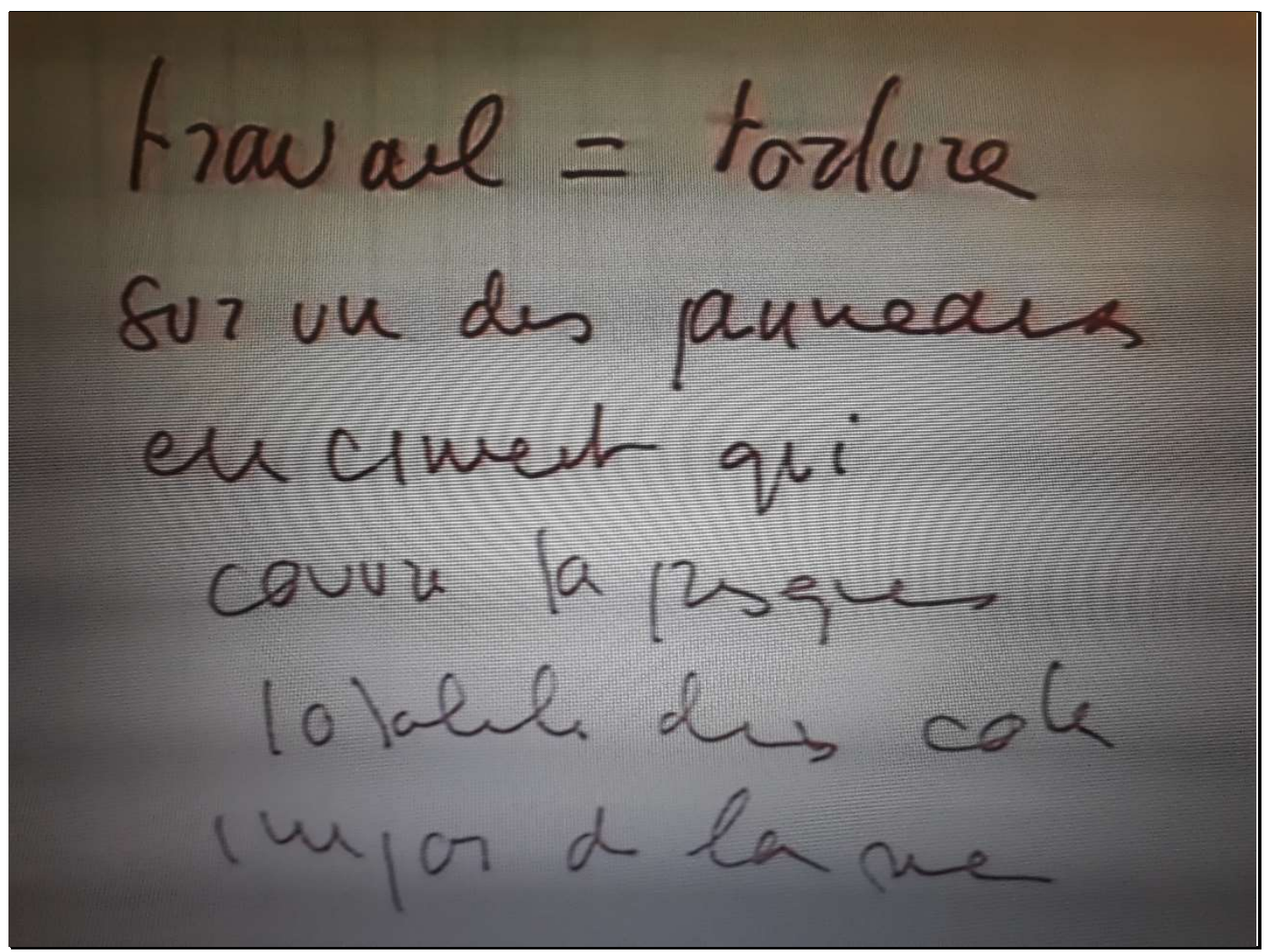

Figura 51. Bober utiliza manuscrito de Lieux em seu documentário.

O manuscrito do último texto de Lieux "Réels", que traz a inscrição "travail=torture" já analisada no primeiro e no segundo capítulos. Bober mostra ao espectador a fonte de sua pesquisa, o manuscrito com a letra de Perec. 


\subsection{Desaparecimento do lugar, desaparecimento das pessoas}

Bober manuseia, mostra, reproduz, e chega a grifar vários trechos de manuscritos nos quais Perec descreve o iminente desaparecimento do lugar. Depois dessa constatação do desaparecimento, Bober mostra a cena de um cemitério (em cores) e inicia toda uma reflexão sobre a comunidade judaica que se reúne para comemorar os mortos. Aqui, podemos observar e refletir sobre a forte relação entre as origens do escritor e do cineasta, e como o desaparecimento dos lugares citado por Perec leva diretamente a uma reflexão sobre tantos outros desaparecidos, desconhecidos, mas que carregam em si uma história em comum: a perseguição e desaparecimento de milhares de pessoas na segunda Guerra, simplesmente pela condição de serem judeus. Ou seja, Bober faz uma relação direta, saindo da imagem do número 24 da rue Vilin e indo à imagem do cemitério. O lugar, a rua em destruição é consequência, também, dos desaparecimentos e perseguições daqueles que ali habitavam. A referência à própria história de vida, sua condição judaica e as consequências dessa condição para o escritor Georges Perec estão aqui explicitamente apontadas.

Na cena do cemitério, uma lista de nomes é lida como em uma litania. Bober realiza, dessa maneira, uma homenagem pessoal e coletiva. Segue-se à leitura dos nomes uma imagem assim descrita: "1978 - Le memorial de la déportation des juifs de France". Para deixar ainda mais evidente que se trata de uma homenagem ao mesmo tempo coletiva e pessoal, Bober lança mão de dois documentos: uma lista com os nomes, data e lugar de nascimento de 751.721 pessoas. Em seguida, abre a página que contém o nome de "Cyrla Perec 20.08.13 Varsovie", texto que é novamente sublinhado por ele. Depois, buscando na lista de nomes com a letra S, encontra o sobrenome "Szulewicz Aaron, 30.04.83 Varsovie" e "Szulewicz Fanny 05.10.26 Paris). São os nomes do pai e da irmã mais nova de sua mãe, que viveram no número 1 da rue Vilin. 


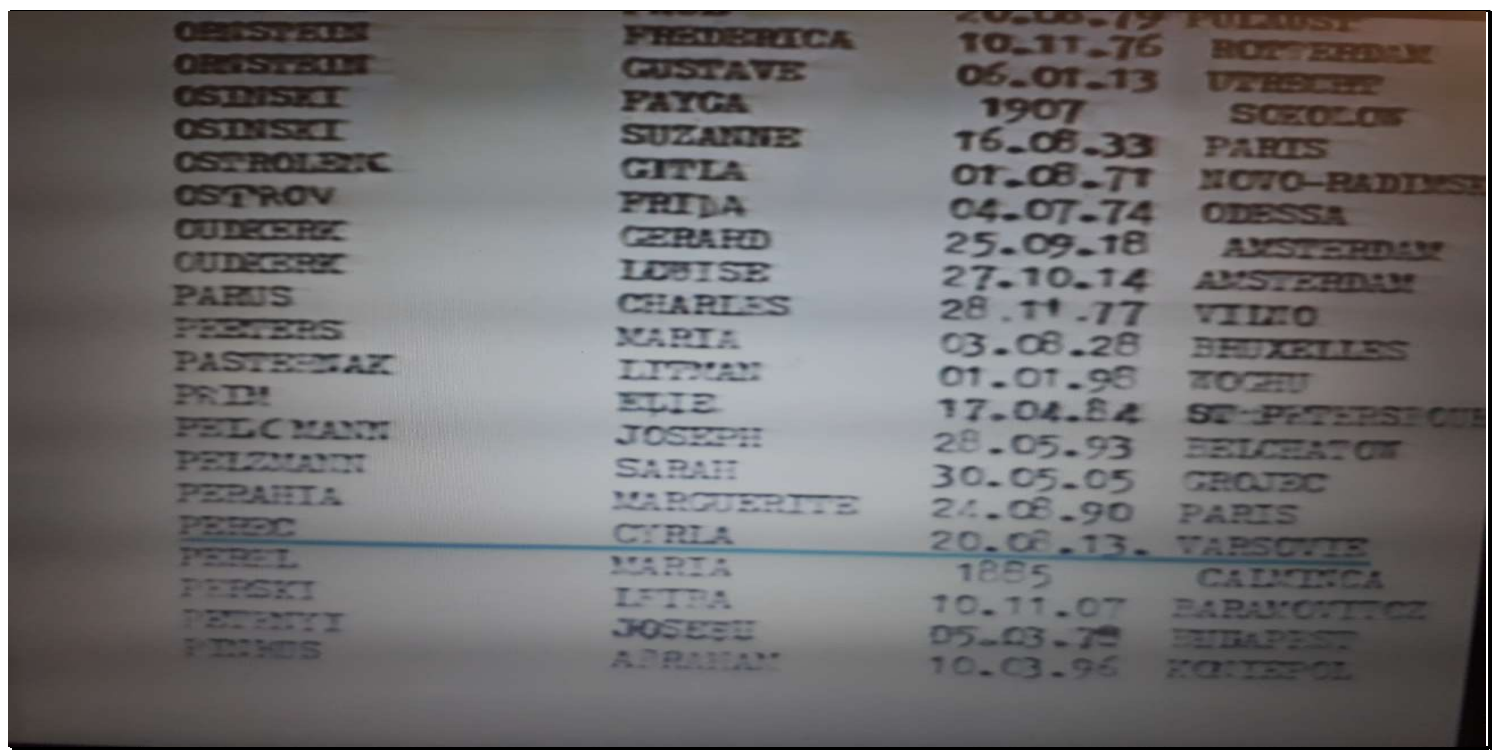

Figura 52. Bober folheia o documento, encontra e sublinha os nomes dos parentes mortos de Perec. Na foto, cena em que sublinha o nome de Cyrla, mãe de Perec.

Voltando ao manuscrito de 27 de fevereiro de 1969, Bober recupera a descrição de um "S três allongé" por Perec, seguida por imagens e o próprio manuscrito onde aparece o trecho, comparando o "S allongé" à sigla SS (mostrada com a própria letra de Perec), seguida também de um mapa dessa curva em $\mathrm{S}$ da rue Vilin. Mais uma vez, claramente, os traços dessa rua abandonada vão ecoando junto às memórias de Perec na homenagem de Bober, já que a analogia em relação ao nazismo acaba sendo também uma maneira de impedir que se esqueça o que aconteceu e, assim, homenagear novamente os familiares de Perec.

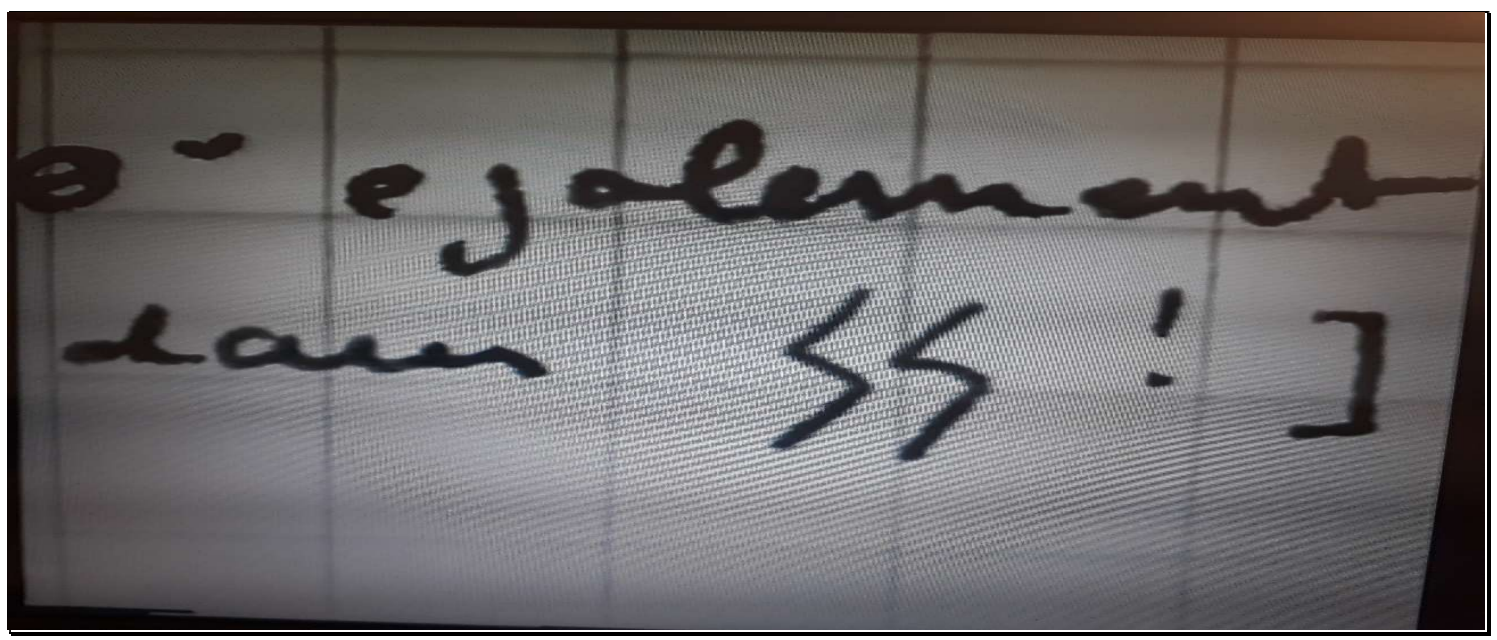

Figura 53. Manuscrito de Lieux mostrado por Bober com as letras "SS", referência direta ao nazismo, que faz parte das descrições do projeto e foi também incorporada no livro autobiográfico W ou a memória da infância. 


\subsection{A sobreposição das fotos e dos tempos}

Bober mostra alguns aspectos interessantes em relação à passagem do tempo. Em descrição do número 49, por exemplo, Perec menciona que o imóvel é da cor amarela. Esse efeito de colorização do imóvel, criado por Bober, remete a essa volta no tempo, ou, ao menos, a uma reconstituição mais precisa do que foi o lugar. Veremos muitos desses momentos em que os tempos parecem nos confundir ou nos transportar para essas diferentes épocas, como também no trecho em que Perec descreve uma mulher em frente ao número 47, Madame Rayda, que está na janela. Bober recupera tal imagem e ainda acrescenta uma outra foto da mesma pessoa, no mesmo imóvel, tirada em 1953 por Robert Doisneau.

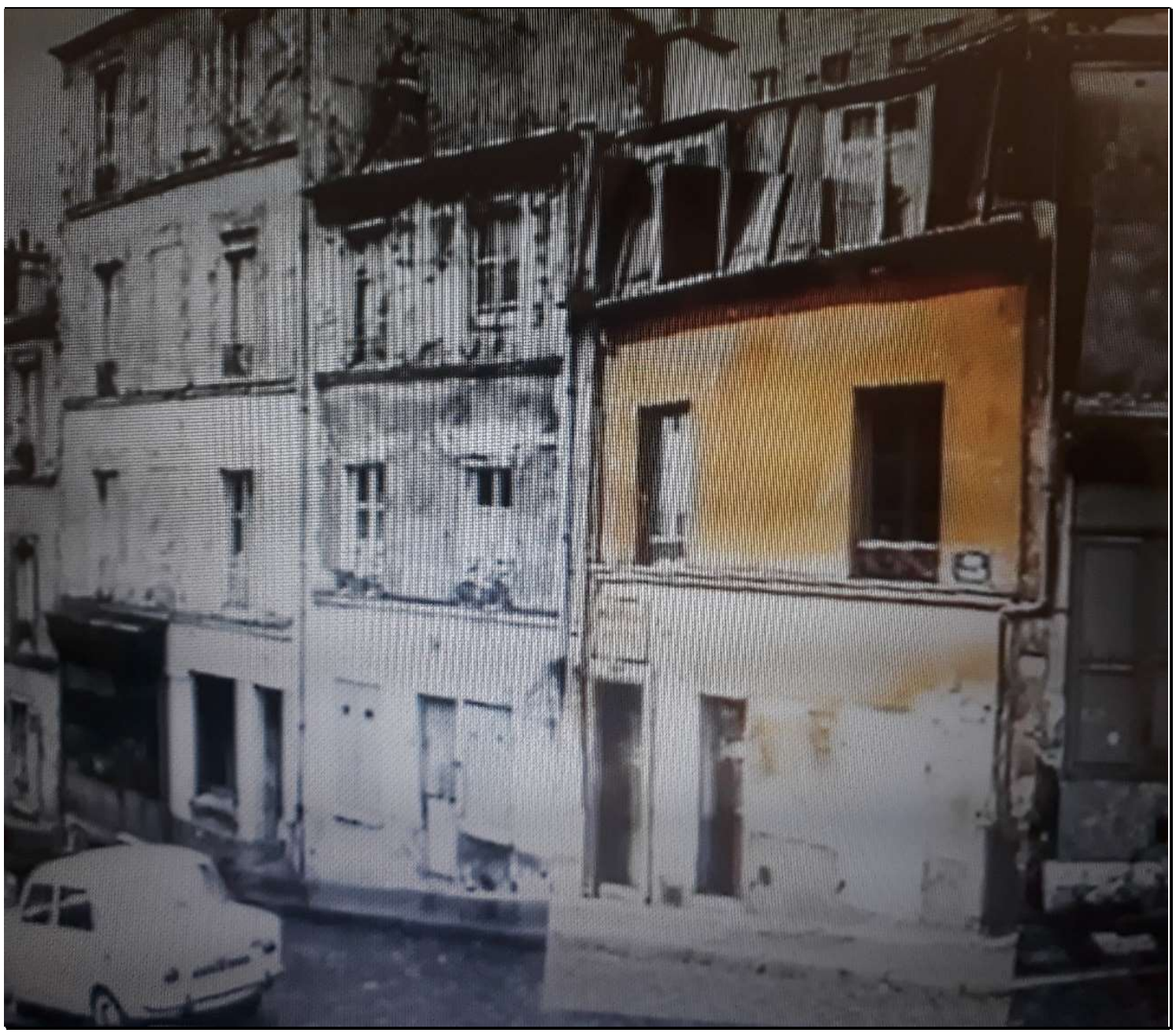

Figura 54. A foto do número 49, pintada de amarelo, causando essa espécie de confusão dos tempos a partir das diferentes épocas que surgem no processo de reconstituição. 
A partir das imagens de 1970, Bober constata que a casa está abandonada e com as janelas fechadas. O número 49 parece condenado (aquele já pintado por ele de amarelo na sequência anterior). A mesma janela é mostrada fotografada três anos antes, mas também diferente daquela de 1953. Assim, seguimos a reconstituição dos diversos olhares, a partir dos registros feitos em épocas diferentes por mais de um fotógrafo.

Uma foto a seguir, datada de 1936/1937, mostra o mesmo ângulo da esquina a partir do número 49. Bober não está certo da data: "Un enfant est devant la maison et regarde le photographe (René Jacques)". O olhar da criança que mira o fotógrafo é o olhar que nos cruza também depois de tantos anos, essa é a reflexão realizada por Bober.

Após nos mostrar essas diferentes versões de um mesmo imóvel, Bober nos lembra que o número 49 é quase em frente ao 24 e se volta novamente à imagem e aos dizeres emblemáticos do imóvel (“Coiffure dames") 207 (27: 00). Bober, curiosamente, nos confidencia possuir outras sete fotos do número 24 , afirmando na sequência: "Nada nos mostra sobre Perec". Assim, Bober reitera o processo de "lente disparition" do imóvel, já que faz diversas tentativas de investigação a partir das sete diferentes fotos.

Como não há uma possibilidade real de reconstituir o lugar, como já vimos em várias discussões até aqui, Bober se vale de uma citação de W ou a memória da infância, uma espécie de memória ficcional de Perec, uma vez que cria uma fantasia de infância, que fica evidente principalmente pelo uso do verbo condicional: “J'aurais aimé aider ma mère..." . Bober lê toda a citação, uma lembrança imaginária, segundo ele, uma vez que, Para Perec, a rue Vilin será uma espécie de "blessure". Bober trata da dificuldade de memória de Perec, mostrando-nos a estratégia utilizada pelo escritor (criar memórias de infância fictícias) e trazendo novamente a imagem do número 24 à tona, ampliando e aperfeiçoando a reflexão sobre a dor produzida em Perec a partir dessa falta de memórias. Já que trata das memórias de infância de Perec, tão escassas e ligadas diretamente ao desaparecimento do lugar, Bober vai tratar também da primeira lembrança de infância de Perec. Ao citar tal lembrança, está se referindo ao que foi relatado no livro Wou a memória da infância, quando, Perec desenha uma letra hebraica.

\footnotetext{
${ }^{207}$ Inscrição no imóvel onde vivia com os pais e sobre o qual soube, por entrevistas com vizinhos e com a família adotiva, ser a sua mãe a cabeleireira que trabalhava no salão que contava com essa fachada.
} 


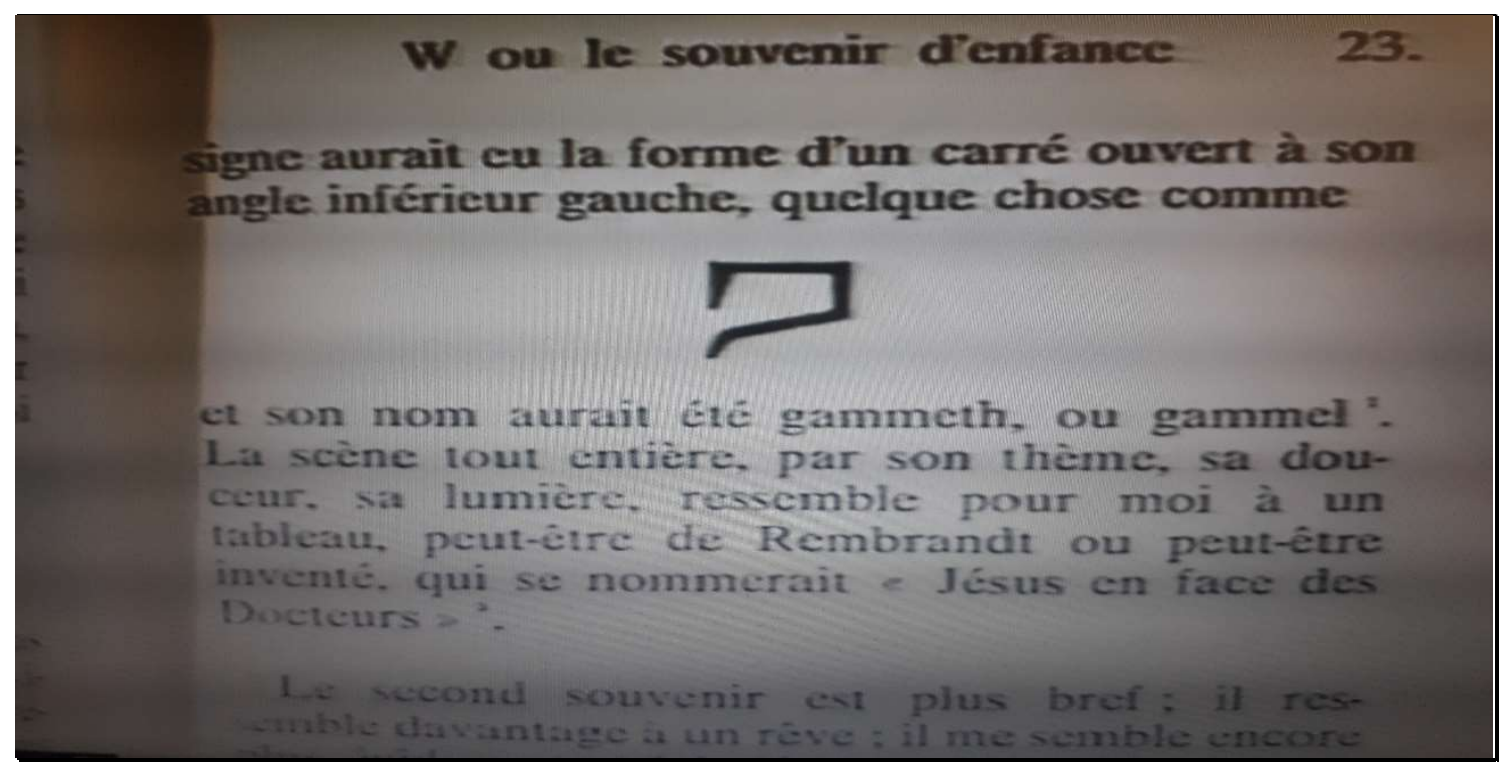

Figura 55. Trecho do livro W ou a memória da infância, retomado por Bober

No documentário, há a leitura e referência direta de $W$ diante dos olhos do espectador. Enquanto lê, Bober nos mostra as fontes de consulta, inclui o espectador no processo de criação do filme. Nesta cena, há a menção à lembrança da escrita da letra hebraica.

Há diferentes versões da mesma lembrança no livro, evidenciando algo que já foi bastante discutido: aquilo que é lembrado versus aquilo que é construído ou imaginado, devido à escassez de memórias. Bober, no entanto, faz um exercício interessante ao mostrar o texto de Perec seguido de nota que o contraria e, a seguir, mostrar a imagem de uma verdadeira letra hebraica, deixando evidente os possíveis erros ou hesitações nas memórias de Perec. É frutífero também pensar a relação que Bober estabelece entre o nome de Perec escrito em letra hebraica, explicando que as vogais em hebraico não aparecem, ou seja, os "es" de Perec podem desaparecer sem perder o sentido da palavra. Essa observação de Bober faz uma outra alusão direta a duas obras de Perec. A primeira, sem dúvida, La disparition, já que escrita inteiramente sem a vogal "e", e a segunda à $W$ ou a memória da infância, uma vez que a dedicatória do livro (“À E.") pode nos remeter à palavra eux, ou seja, o livro foi dedicado os pais mortos na guerra.

Assim, as questões da origem hebraica, somadas à suposta primeira memória de infância, fazem com que Bober nos ajude a refletir sobre os ecos que tais questões podem ter criado na composição da obra literária de Perec (nesse caso, especificamente, com a questão da vogal "e" nas duas obras citadas). 
2.4. Uma memória de Perec, inventada por Bober

Após nos mostrar as reflexões de Perec sobre o projeto Lieux e o processo de destruição do bairro, com as cenas de demolição registradas ao longo do tempo, Bober coloca em cena a foto de uma criança correndo e, em seguida, fixa seu olhar em uma sequência de nove fotografias que são colocadas lado a lado. Apesar de não conhecer o fotógrafo, ele sabe que o ano é 1955, e o mês é fevereiro. Essas fotos dão uma visão panorâmica da paisagem da rua. Fazendo uma relação entre esse mês de fevereiro e outro, no ano de 1939, Bober descobre uma foto de Perec na escola maternal ${ }^{208}$.

Com essa imagem, novamente trabalha com as nuances de tempo, uma vez que nos transportamos para as cenas das duas crianças, com um intervalo de tempo relativamente curto, e buscamos nessas imagens algumas semelhanças.

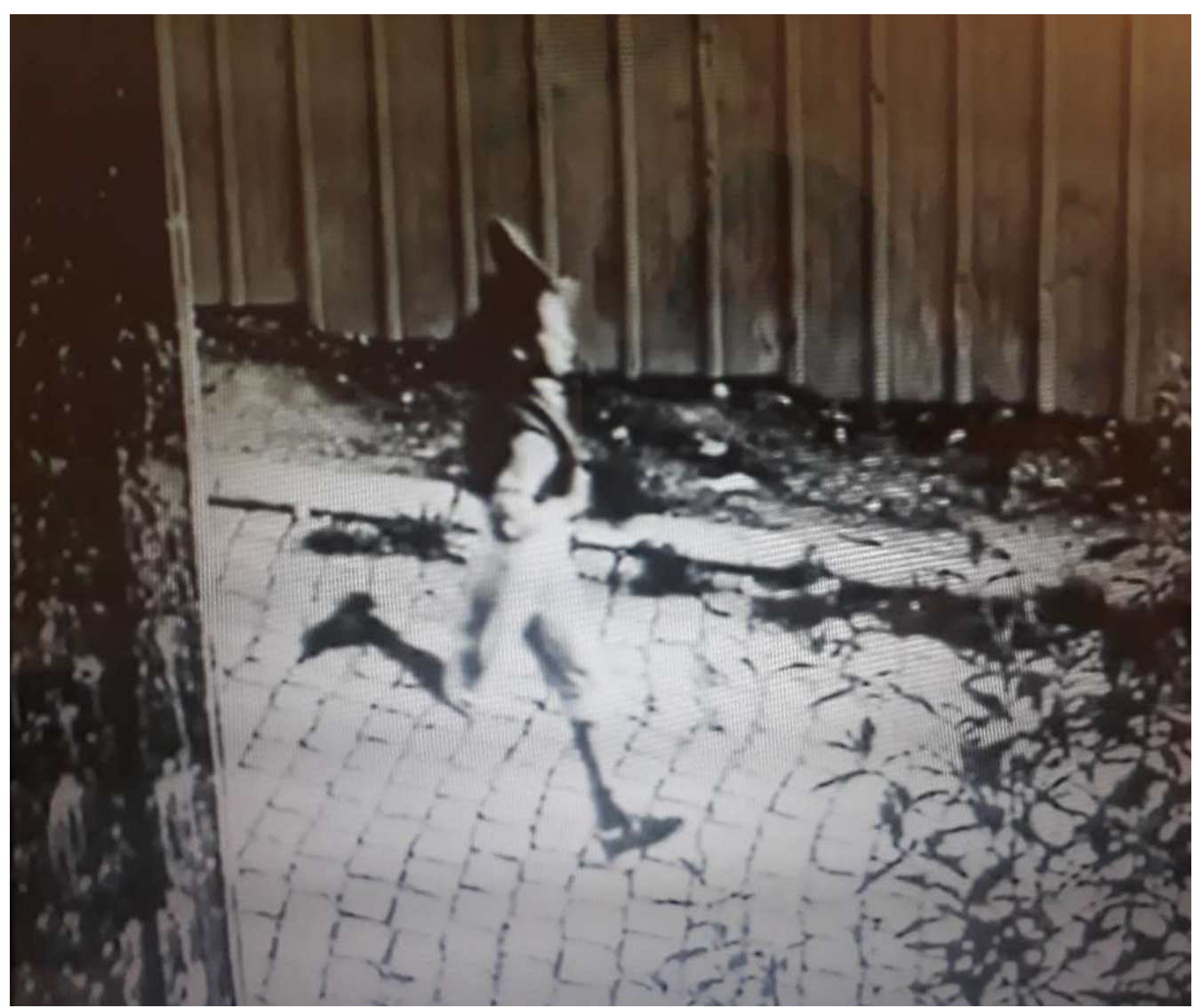

Figura 56. A primeira foto, de uma criança correndo, é o motor para a escrita ficcional e poética de Bober.

\footnotetext{
${ }^{208}$ Foto à qual nem o próprio Perec teve acesso, em suas investigações sobre a própria história, e que Bober conseguiu ao investigar os arquivos da escola localizada no número 94 da rue des Couronnes, quando pesquisava material e fotos para o documentário.
} 


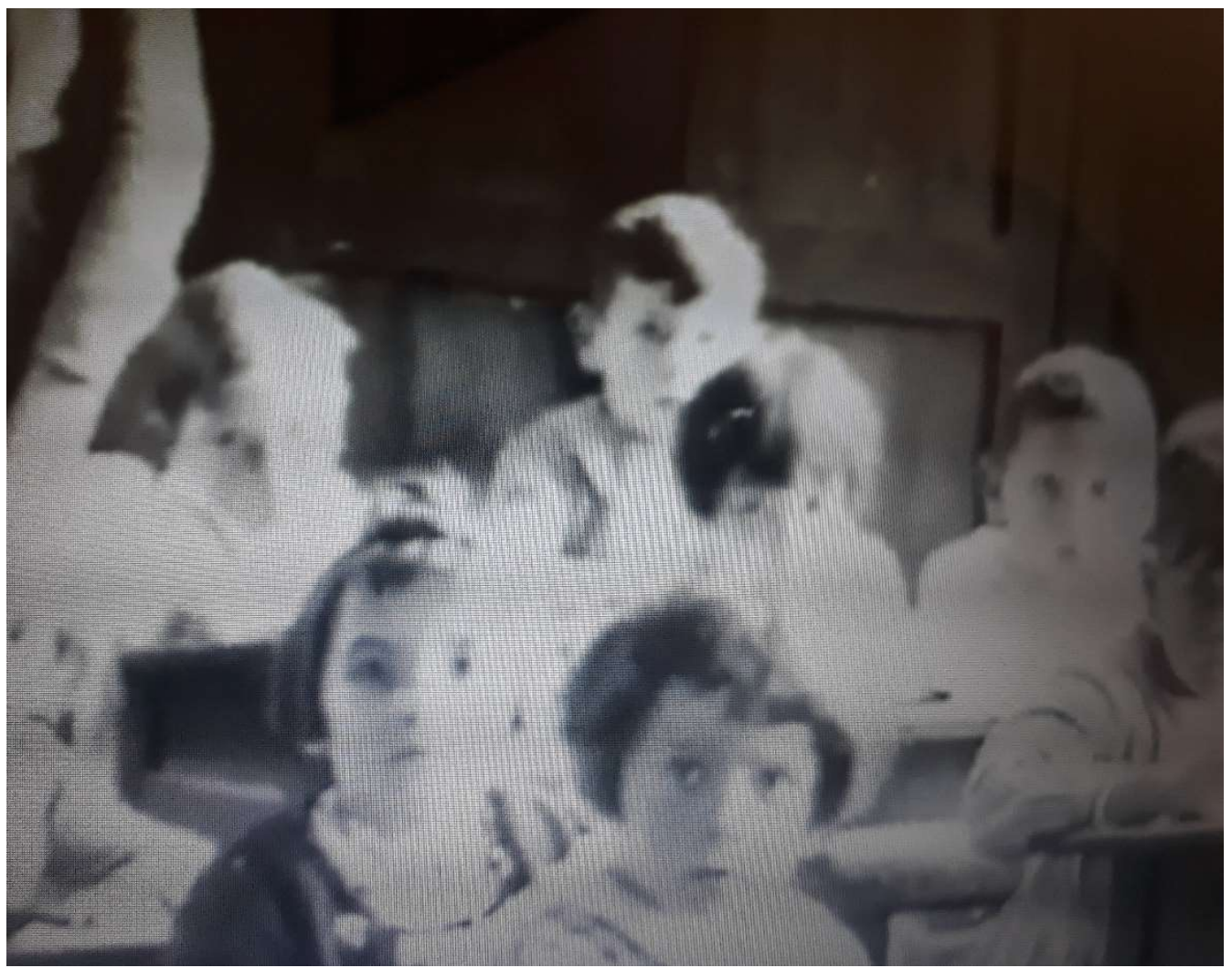

Figura 57. A segunda foto, logo acima, é de Perec, quando aluno da escola maternal (no canto direito). É um dos achados importantes da pesquisa biográfica de Bober.

Bober, ao avistar o pequeno garoto de 1955, logo imagina a própria Cyrla, mãe de Perec, no mesmo percurso, indo buscá-lo, encontrando o filho e dando as mãos para juntos atravessarem a rua. Vemos, aqui, como foi importante trabalhar inclusive com as memórias ditas ficcionais de Perec, para que o próprio Bober também se inspirasse para contar uma espécie de ficção nesse trecho. Por falta de memórias de Perec, e tendo acesso aos textos de Perec e às imagens, ambos foram essenciais para a criação poética de Bober, mesmo que num documentário, como vimos, já que apresenta estatísticas, dados, citações, mas também criação, poesia e subjetividade. Assim, ele poderá recriar os passos dessa criança até o número 24 , onde ele poderia finalmente ler a inscrição "Coiffure de dames".

Bober cita novamente a passagem em que Perec escreve "Coiffure dames", na descrição de Lieux, e afirma que essa foto que acabou de mostrar não é antiga, pelo contrário: é a última conhecida do número 24 , já que “faite à la fin d'année 81 ”. 


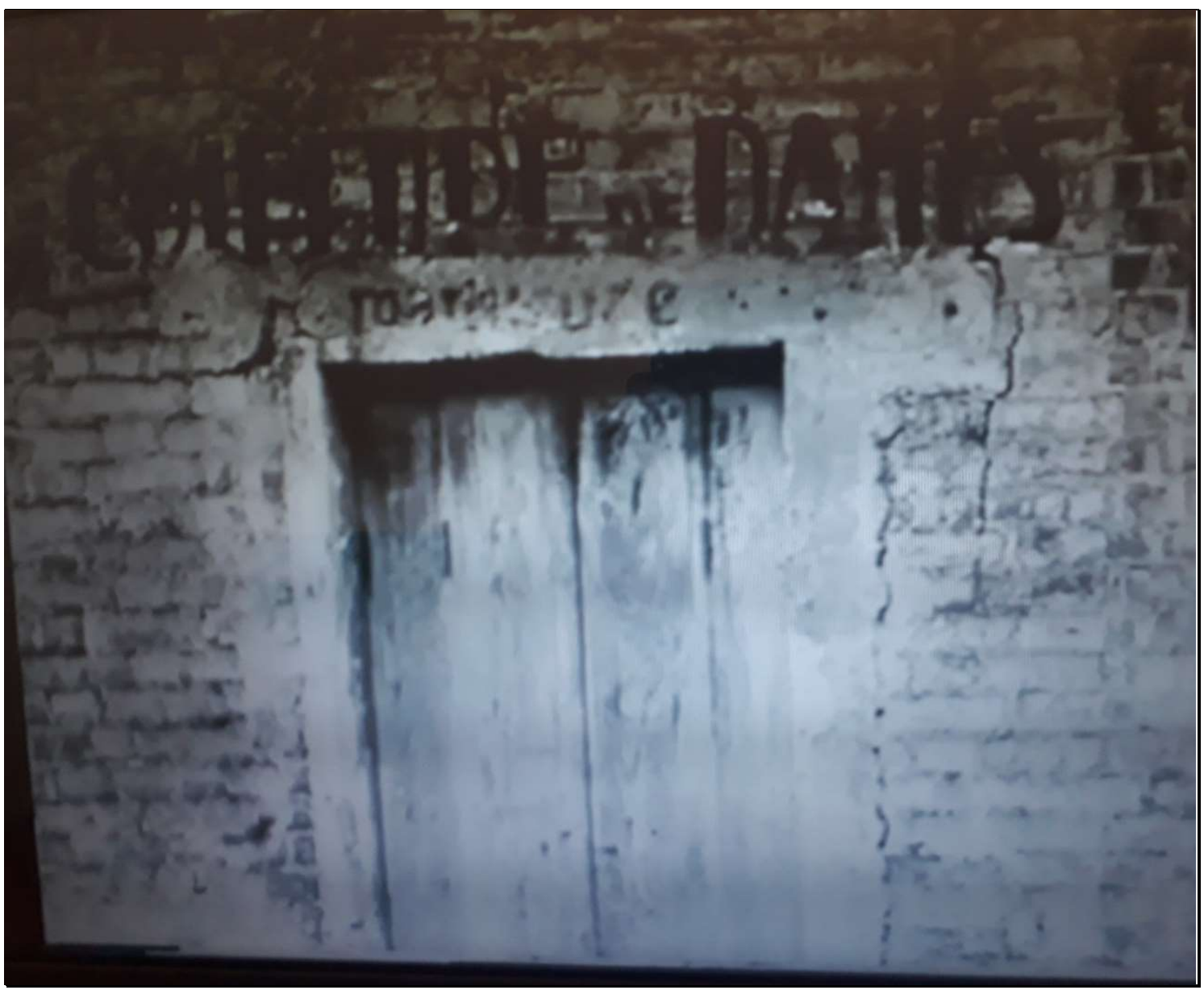

Figura 58. O segundo achado de Bober: descobrir a expressão "Coiffure de dames" na foto mais recente, antes da demolição do número 24.

Para confirmar essa informação (que é seu segundo achado importante, depois da foto da escola), ele compara o café ao lado (completamente fechado) com a foto de 1969, ainda em funcionamento, ao lado do número 24 (com a descrição idêntica à de Perec, "Coiffure dames"). É muito significativo verificar que, em meio ao processo de desaparecimento contínuo, algo parece, incrivelmente, ter se reconstituído. A foto de 1981 com a última inscrição "Coiffure de dames" é também a última comprovação do que afirma Bober: "La photographie est un défi à la disparition". Se a memória de Perec não foi totalmente recuperada ou reconstituída, se a rue Vilin não foi totalmente recuperada, houve ao menos esse trabalho de exploração do material de Lieux, compartilhado com o espectador, que fez parte do processo de criação e re(criação) da rua, trazendo à tona as reflexões mais importantes de Perec sobre a memória, o lugar, os espaços aqui mostrados e manipulados. 


\section{CONSIDERAÇÕES FINAIS}

O objetivo dessa pesquisa concentrou-se na análise de diferentes obras do escritor Georges Perec. Todas elas tiveram influência de um importante projeto autobiográfico intitulado Lieux. Minha intenção foi apresentar de que maneira esse projeto foi importante para que essas obras fossem iniciadas, mesmo que sob outros formatos que não o livro, tendo em comum com o projeto original o fato de discutir a questão da memória autobiográfica, sempre ligada à observação e descrição de lugares.

O primeiro capítulo aponta as principais motivações de Perec para o início da escrita do projeto e também apresenta a justificativa para a importância do espaço em sua obra, de uma maneira geral, a partir da análise de alguns importantes textos, sobretudo a obra Espèces d'espaces.

No segundo capítulo, pretendi mostrar de que forma as séries Réels e Souvenirs da rue Vilin, dentro do projeto Lieux, deram origem a um trabalho composto por fotografias e poesia, La Clôture. Partindo do uso das contraintes, Perec criou uma escrita fechada em si mesma, como uma espécie de enigma/jogo a ser desvendado pelo leitor.

No capítulo seguinte, tratei de temas relacionados à observação dos lugares partindo da análise de dois documentários: La vie filmée e Les lieux d'une fugue. O primeiro consistiu em um comentário criado por Perec a partir de imagens da vida cotidiana de franceses nos anos 30. O segundo, autobiográfico, utilizou as imagens dos lugares como pano de fundo para recriar uma memória autobiográfica, sua fuga da escola quando criança. Tratei também do uso de objetos que marcam uma época, passando pela questão do uso da tecnologia e da voz, para analisar ainda alguns projetos sonoros de Perec.

No último capítulo, a intenção foi apresentar as discussões sobre o olhar do outro a partir da produção de documentários. Em Récits d'Ellis Island, Bober e Perec partiram de imagens antigas, testemunhos e fotografias para pensar sobre a sua possível história de vida, caso seus pais tivessem emigrado para os Estados Unidos. Bober, depois, recria a rue Vilin, no documentário En remontant la rue Vilin, a partir da tentativa de reconstituição de fotos tiradas à época em que Perec descrevia os lugares em Lieux, demonstrando assim como o projeto pode continuar em movimento. Bober, portanto, recria a obra de Perec, ao mesmo tempo em que presta homenagem a sua memória. 
Essas foram as linhas gerais do trabalho realizado até aqui. Resta agora refletir sobre questões ainda inconclusas e que podem servir de parâmetro para a novas possibilidades de pesquisa. Voltemos a uma importante citação de Perec, que está em Récits d'Ellis Island:

Em qualquer lugar, eu sou estrangeiro em relação a alguma coisa de mim mesmo; em qualquer lugar, eu sou "diferente", mas não diferente dos outros, diferente dos "meus": eu não falo a língua que meus pais falavam, eu não compartilho nenhuma das lembranças que eles pudessem ter, alguma coisa que fosse deles, que fizesse com que eles fossem eles, sua história, sua cultura, sua esperança, não me foram transmitidos (PEREC, 1995, p. 59).

No momento final da escrita, tive a honra de participar de uma Jornada de Estudos que discutiu a obra de Perec e seus reflexos nos dias atuais, ou seja, na arte contemporânea a nós, na cidade do México. Neste lugar, onde não se fala a minha língua, tive contato com muitas pesquisas interessantes, e que dialogam com várias de minhas inquietudes atuais. Sair um pouco do meu próprio mundo e entrar em contato com pessoas estrangeiras, com olhares tão diversos do meu me fizeram, novamente, recuperar um pouco de fôlego para prosseguir, já que pude ver um pouco além do meu próprio horizonte e, sobretudo, ouvir os outros.

Algo que parece evidente nessa pesquisa é que são muitas as questões colocadas e muitas ainda não totalmente resolvidas. Sinto-me renovada por ter passado por essa experiência e ser capaz de perceber certas coincidências impostas pelo percurso até aqui traçado. Uma delas diz respeito à primeira intervenção no evento: a conferência de uma escritora muito conhecida no país, Margo Glantz, que fez uma clara homenagem a Perec quando publicou seu livro "Yo también me acuerdo", com influência dos Je me souviens e também dos "I Remember" de Brainard. A coincidência está no fato de ter sido aconselhada a ler esse texto na banca de Qualificação, (pela professora Paloma Vidal) mas não ter podido adquiri-lo à época e ter deixado essa leitura em suspenso. Ver Margo Glantz numa conferência significou, para todos os presentes, ter alguém contemporâneo a Perec que fala sobre ele, que o homenageia e faz também com que possamos refletir sobre essa passagem do tempo, tantas vezes evocada por Perec e destacada por mim, ao longo desse trabalho. Glantz, nascida alguns anos antes dele, está em plena atividade artística. É um pouco do que imaginei discutir num possível quinto capítulo, que finalmente, por diversas razões, não foi realizado. 
A partir da discussão que propus no terceiro capítulo, sobretudo sobre o uso da tecnologia, pensei que essa seria uma maneira de nos ajudar a refletir sobre como esses objetos tecnológicos sempre afetaram nossa vida, e hipoteticamente pensar em quais seriam os projetos de Perec hoje, possivelmente voltados para a tecnologia ou para a experimentação artística, a partir de novos dispositivos. Glantz, de origem judaica, também não aprendeu o $y d d i s h$, não recebeu a tradição de seus pais, mas o que a difere de Perec é que sua família, da Ucrânia, conseguiu imigrar e se instalar no México. Seus fragmentos de "Yo también me acuerdo" foram inicialmente publicados no Twitter, para que, depois, compilados e acrescentados de muitos outros, fossem publicados no formato livro. Seu trabalho, como leitora de Perec e escritora que se vale de suas influências, é um dos exemplos de que a relação entre os tempos é fluida, a relação entre a escrita e o formato livro impresso é apenas uma das opções, dentre tantas outras. Glantz, célebre escritora mexicana, compara os Récits d'Ellis Island de Perec e Bober com as condições dos imigrantes mexicanos hoje, que pretendem entrar nos Estados Unidos.

De alguma forma, sua fala atualiza a discussão de Perec, realizada em 1980, mas que já se referia a algo do passado, mais precisamente ao início do século XX. Estamos já um século a frente, mas determinados povos ainda são obrigados e se deslocar de suas terras para buscar oportunidades de vida fora de lá. Essa discussão foi levantada, mesmo que brevemente, no último capítulo, ao tratarmos do documentário Récits d'Ellis Island. Podemos pensar, mais amplamente, na questão dos deslocamentos ilegais na Europa, feito por vários povos que passam por situações de guerra, por exemplo. Os "boat people" aos quais Perec se refere em Récits d'Ellis Island estão ainda buscando um lugar para se ancorar. Glantz cita o trecho de Perec retomado acima, já que também se considera na mesma situação que o autor, por não ter podido viver na terra onde seus pais nasceram e, consequentemente, não ter recebido a herança cultural de sua família. Glantz trabalha também com a ideia do infraordinário em seus "Yo también...", já que, como ela mesma afirma, a atividade de descrever algo, exaustivamente, afasta Perec da realidade (porque não é capaz de falar sobre a realidade, de fato). O real que se descreve é então, paradoxalmente, uma maneira de fugir desse mesmo real.

Outra intervenção que me chamou muito a atenção também se relacionava com a questão da tecnologia e da atualização da obra de Perec. Trata-se de um conjunto de gravações de vários "Yo me acuerdo" intitulado "Recuerdos de la generación del fin del siglo XX”, realizado pelo poeta experimental David Rojas Azules. A apresentação trouxe uma sessão de escuta e apresentação da peça coletiva de memórias de tal geração. 
Ouvimos trechos sonoros com a voz de Perec dos seus "Je me souviens", intercalado com vários "Yo me acuerdo" anônimos: é também uma maneira de atualizar sua obra. Mesmo que em outra época e em outro lugar, o exercício de falar as próprias memórias ativa o espectador. Muitas das referências dadas eram desconhecidas para mim, como brasileira, mas para o público mexicano havia referências passíveis de causar riso e bastante interação. Toda a sessão de escuta provocou sensações e reações das mais diversas no público. Este é um indício que pode também confirmar minha hipótese de que a obra de Perec trata da memória fazendo, frequentemente, referências a alguma época e que, portanto, várias gerações podem continuar com seus "Je me souviens", atualizando-os e mantendo-os sempre em movimento. Não há como negar também o fato de eu ter presenciado uma apresentação sonora, que vai ao encontro de muitas discussões feitas aqui em relação ao uso da tecnologia e do uso da voz como instrumento que extrapola o texto escrito. Assim, como diz a própria Margo Glantz, "Je me souviens" é uma espécie de autobiografia "pulverizada", já que pode se espalhar, contaminar a todos. Ela usa uma expressão que também define de forma bastante interessante esse processo de escrita presente tanto em Perec quanto em Brainard (mesmo que sob diferentes abordagens, como já vimos) e, sobretudo, presente também em sua própria obra: os fragmentos iniciados por : "I Remember/Je me souviens/Yo me acuerdo" são para ela "cacos" de vida, como se o conjunto de tais cacos, assim como um vidro ou cerâmica quebrados, fosse impossível de se reconstituir, mas pode proporcionar uma nova reconfiguração da escrita: há uma recolha aleatória de fatos e informações, mas que têm em geral uma coerência, mesmo que apresentada de forma fragmentada. Os cacos de vida de Margo são bastante parecidos tanto para ela quanto para Perec: por terem origem judaica, há de certa forma um parentesco, mesmo que literário, que os une, no momento em que escreve um livro que homenageia o escritor francês. Há quem diga que existem inclusive semelhanças físicas entre os dois. Esses "cacos" de memória são os mesmos produzidos pela peça coletiva anteriormente descrita. O público, mais inteirado com as referências dos "Yo me acuerdo" do que eu (já que se tratam de memórias da população mexicana e não brasileira), interagem com tais gravações, muitas vezes rindo, pois os narradores fazem um movimento a partir das estratégias utilizadas na escrita de Perec: descrever aquilo mais cotidiano e banal possível, para marcar possíveis atitudes e maneiras de viver de uma geração.

Outra questão bastante importante e que não foi resolvida plenamente na minha pesquisa diz respeito ao uso do humor, ou ainda o humor que se provoca em nós, leitores, 
quando entramos em contato com a obra de Perec. No terceiro capítulo, falo brevemente do humor de Perec ao rir daquilo que descreve no Carrefour Mabillon, como sendo uma espécie de autocrítica ou reflexão sobre seu trabalho. Para além, poderíamos inferir algumas outras possibilidades de pensar no uso do humor em sua obra. Que fique registrado, então, que seriam necessárias outras pesquisas mais aprofundadas para que chegássemos a uma conclusão ou pouco mais elaborada sobre essa questão. Ainda assim, em outra feliz coincidência, participei de uma mesa em que certa pesquisadora discutia a questão do luto e da perda a partir da obra de Perec. A especialista de Perec, Mireille Ribière (com quem tive a felicidade de dividir uma mesa também - ela como mediadora e eu como apresentadora) comentou que, ao lermos Perec, “on ne s'ennuie pas" mas também "on ne pleure pas". Fiquei pensando sobre essa frase e, em outro momento, perguntei a ela sobre a questão do humor: como podemos encontrar humor numa obra que, muitas vezes, trata de temas como a perda ou a morte? Ela me respondeu que, mesmo em La disparition, obra onde temos uma clara metáfora sobre a morte dos pais, o enredo está repleto de humor, quase que numa espécie de escrita do absurdo. Mesmo que se trate da morte ou da perda, o texto perecquiano muitas vezes está ligado ao jogo, à transformação, recriação, esgotamento do texto. O pano de fundo pode ser algo trágico, mas a estratégia de escrita cria uma história cômica, em alguns momentos. Pensei também sobre como a última lembrança da mãe - publicada em diferentes versões em $W$ ou $a$ memória da infância - contém a imagem de uma revista "Charlot", ou seja, de um personagem cômico (ou tragicômico) que habita nosso imaginário. Não há texto dramático em Perec, mesmo quando se trata de falar diretamente das mortes ou das perdas em seus livros autobiográficos. A sensação de neutralidade é mais evidente, e em situações pontuais o humor parece também ser uma espécie de intermédio para uma escrita que gira em torno de temas mais sóbrios. Podemos incluir nessa reflexão o uso do lúdico nas contraintes que, como vimos, também têm a função de substituir uma escrita do indizível, como no caso dos poemas de La Clôture. São apenas pistas que aparecem de maneira breve, mas que poderiam ser desenvolvidas com mais calma em algum momento futuro da pesquisa.

Muitas outras intervenções dialogaram diretamente com a minha pesquisa, como foi o caso de um grupo de arquitetos que se consideram "caminhantes profissionais". Todas as falas giraram em torno de uma ideia comum: não importa sobre qual lugar falamos, mas sim do sentimento de estrangeiros que temos em relação a essa cidade ou espaço. Faz bastante sentido pensar nessa ideia a partir de Perec: essa curiosidade se aflora 
em nós, ao buscarmos observar com um olhar estrangeiro, curioso, buscando aquilo que passa despercebido aos outros. Para mim, faz muito sentido pensar que essa relação com os espaços realmente se faz muito profícua, justamente por deixarmos de lado nosso olhar, muitas vezes acostumado a uma paisagem, ser contaminado por olhares novos, curiosos, que nos instiguem a descobrir o lugar como se fosse a primeira vez que estivéssemos diante dele, mesmo que já conhecido por nós.

É possível finalizar um trabalho que, já sabemos, continua em movimento, justamente porque ainda inconcluso? Precisei fazer esse movimento de escuta para entender o que os outros tinham a dizer e também compreender melhor o meu próprio trajeto de pesquisa.

A pesquisadora Eléonore Hamaide-Jager, que estuda as relações entre o espaço da cidade e a literatura infanto-juvenil, fez uma intervenção sobre a minha apresentação que me pareceu bastante elucidadora, e que está já muito presente em toda a minha escrita até aqui. Ela comentou que era interessante verificar como Perec sai de um projeto solitário, Lieux, passa pelas imagens, pelo contato com o outro, até que sua obra passa a ser coletiva, ou seja, nós podemos participar dela: entrar em contato com esses espaços, modificá-los.

Bober, ao manipular o material de Lieux e fazer reviver a rue Vilin, produz um movimento quase cíclico que nos leva de volta à obra de Perec. Esse contato com o outro era algo que já tinha sido também destacado pela minha orientadora como uma questão muito importante no meu trabalho de escrita. Precisei ouvir delas para compreender que há uma certa coerência no percurso da escrita que chegou até esse ponto.

Quando digo que podemos participar da obra de Perec, de certa forma quero dizer - e teria dito, talvez, de forma mais detalhada, se houvesse um quinto capítulo dedicado a essa questão - mais ou menos o que disse, em outro momento, Mireille Ribière em relação à Margo Glantz: mesmo sem conhecer a obra da escritora, e considerando ainda que seus "Yo me acuerdo" são muito mais íntimos que os "Je me souviens" de Perec, o que a aproxima mais dos “I Remember" de Brainard, se dá conta de um valor e reconhecimento internacional da obra de Perec, já que a escrita de Glantz funciona como essa possível atualização da memória de Perec, em outro lugar, em outra época, mas que evoca consigo muitas das questões inerentes a ele, quase como se Perec tivesse sido "globalizado".

Para encerrar, penso nas inúmeras possibilidades de abertura da obra de Perec para outros suportes e intervenções artísticas, como outras maneiras de participar de sua obra.

Christl Lidl, artista visual e professora de artes, com quem tive a alegria de dividir alguns momentos bastante produtivos ao longo do evento, foi autora de uma exposição 
interativa que partia das viagens de Bartlebooth, de La vie mode d'emploi, para criar uma espécie de simulação da viagem para os participantes da exposição. Com um tablet e um aplicativo criados para esse fim, o público podia interagir selecionando no mapa (do tamanho de uma parede) quais lugares gostaria de conhecer. Clicando nele sobre o mapa, apareceriam os textos de La vie mode d'emploi que descreve tais lugares, acompanhados por suas respectivas imagens (e por vezes sons). Há também várias capas de livros das quais Perec retirou citações e referências. Clicando nessas capas, o aplicativo mostrava o texto como numa tela, em movimento, seguido de sua transcrição sonora. Havia também uma forma de interagir com os movimentos do polígrafo do cavalo, como forma de fazer referência à maneira em que a obra foi concebida. A ideia de criar um aplicativo para trabalhar a questão da realidade aumentada (sobretudo com a interação do espectador com os mapas) é um modo de ver, com meus próprios olhos, a obra de Perec tomando outras formas a partir de artistas contemporâneos, o que confirma minha hipótese de que a obra é heterogênea, atual, manipulável e aberta a infinitas possibilidades, o que torna ainda mais difícil de pensar em uma conclusão para essa pesquisa: ao contrário, chegar até o fim comprova que ela está em pleno movimento, potencialmente aberta e constantemente renovada, para que interaja com outros espectadores e leitores, durante ainda muitas outras gerações. 


\section{REFERÊNCIAS BIBLIOGRÁFICAS:}

AUGÉ, Marc. Não-lugares: introdução a uma antropologia da supermodernidade. Campinas: Papirus, 1994.

BACHELARD, Gaston. A poética do espaço. São Paulo: Martins Fontes, 2000.

BARTHES. Roland. Mythologie de 1'automobile. Oeuvres Complètes, Vol. II. Paris : Éd. du Séuil, 2002.

. Sémiologie et urbanisme. L’aventure sémiologique. Paris: Seuil, 1991.

1984.

- A câmara clara: nota sobre a fotografia. Rio de Janeiro: Nova Fronteira,

BARY, Cécile De. Récits d'Ellis Island (Georges Perec). Des récits contestés. In: Cahiers de Narratologie [En ligne], consultado em 26 jun. 2014. Disponível em: http://narratologie.revues.org/942

. «L’image pré-texte », Agora. Revue d'études littéraires, n. 4 Perec

Aujourd'hui, p. 116.

BAUDRILLARD, Jean. O sistema dos objetos. São Paulo: Perspectiva, 2008

BELLOS, David. Georges Perec - Une vie dans les mots. Paris : Seuil, 1994.

. La pudeur de Perec. Revista Poésie, no 94, 2002.

BERTHARION, Jacques-Denis. Poétique de Georges Perec « ...une trac, une marque ou quelques signes ». Librairie Nizet, 1998.

BERTELLI, Dominique ; RIBIÈRE, Mireille. Entretiens et conférences. Vol I. (19651978). Nantes : Joseph K, 2013

. Entretiens et conférences. Vol II. (1979-1981). Nantes : Joseph K, 2013

BOBER, Robert ; PEREC, Georges. Récits d'Ellis Island - histoires d'errance et d'espoir. Paris : P.O.L., 1995

BOBER, Robert. (Entrevista). Le regard et l'absence. Cahiers Georges Perec 9. Le cinématographie. Textes réunis par Cécile De Bary. Le Castor Astral, 2006.

BURGelin, Claude. Les Parties de dominos chez Monsieur Lefèvre : Perec avec Freud, Perec contre Freud. Strasbourg : Circé, 1996.

. Album Georges Perec. Paris: Gallimard, 2017.

- Perec et Pontalis - Une histoire de lettres, d'enveloppe et de destinataire. In : Perec. Dir.: BURGELIN, Claude; HECK, Maryline ; REGGIANI, Christelle. Éd. de L'Herne, 2016.

Entrevista France Culture Disponível em: $\overline{\mathrm{https}: / / \mathrm{w} w w . f r a n c e c u l t u r e . f r / e m i s s i o n s / l e s-c h e m i n s-d e-l a-p h i l o s o p h i e / l e s p a c e-m o d e-}$ demploi-24-les-especes-despaces-de-georges-perec 
CAHIERS GEORGES PEREC 1. Colloque de Cerisy (juillet 1984) sous la direction de Bernard Magné. P.O.L., 1985

CAHIERS GEORGES PEREC 2. W ou le souvenir d'enfance : une fiction ? Actes du séminaire Georges Perec (1986-1987). TEXTUEL 34/44, vol. 21, Université Paris VII, 1988.

CAHIERS GEORGES PEREC 6. L'Oeil d'abord... Georges Perec et la peinture. Travaux réunis par Éric Beaumatin et Hans Hartje. Le Seuil, 1996.

CAHIERS GEORGES PEREC 9. Le cinématographie. Textes réunis par Cécile De Bary. Le Castor Astral, 2006.

CAHIERS GEORGES PEREC 12. Espèces d'Espaces perecquiens. Bordeaux : Le Castor Astral, 2015.

CAVALARI, Tatiana Barbosa. Instantâneos de ausências - Perec e as relações entre texto, fotografia e memória. 2014, 144 f. Dissertação (Mestrado). Faculdade de Filosofia, Letras e Ciências Humanas, Universidade de São Paulo, 2014.

CERTEAU, Michel de. A invenção do cotidiano. Petrópolis: Vozes, 2012.

CHAUVIN, Andrée ; MADINI, Mongi. La remontée des images (sur les Récits d'Ellis Island). In : LE CABINET D'AMATEUR, nº 6. Toulouse : PUM, 1997.

CHAUVIN, Andrée. « Les cocotiers sont arrivés » In : Semen [On line], 12 , 2000, publicado em 04 mai 2012. Disponível em : http://journals.openedition.org/semen/1887 CHRISTOFFEL, David; BAUMGARTNER, Thomas. Les cocotiers sont arrivés - Radio Perec. In: Perec. Dir.: BURGELIN, Claude ; HECK, Maryline; REGGIANI, Christelle. Éd. de L'Herne, 2016, p. 142-153

CONSTANTIN, D. Sur Lieux où j'ai dormi de Georges Perec. In : Item. Disponível em : http://www.item.ens.fr/index.php?id=76107. Acesso em 08 set. 2016.

DE BIASI, Pierre-Marci, Le troisième cerveau. Petite phénoménologie du smartphone. Paris : CNRS, 2018

DELAGE, Christian; GUIGUENO, Vincent. "Ce qui est donné à voir, ce que nous pouvons montrer", Études photographiques, 3 | Novembre 1997, [En ligne], 19 nov. 2002. URL: http://etudesphotographiques.revues.org/290.

L'historien et le film. Paris: Gallimard, 2004.

DELEMAZURE, Raoul. L'herbier des villes de Georges Perec: un tas de reliquats. In : Cahiers Georges Perec 12. Espèces d'Espaces perecquiens. Bordeaux : Le Castor Astral, 2015.

ERNAUX, Annie. Rien, dans l'oeuvre de Perec, n'est étranger à mes propres préoccupations d'écriture. In : Perec. Dir.: BURGELIN, Claude ; HECK, Maryline ; REGGIANI, Christelle. Éd. de L’Herne, 2016

FOUCAULT, Michel. "Des espaces autres - Hétérotopies" Revue Architecture, Mouvement, Continuité (1984). 
GARRAMUÑO, Florencia. Frutos estranhos: sobre a inespecificidade na estética contemporânea. Trad. Carlos Nougué. Rio de Janeiro: Rocco, 2014.

GLANTZ, Margo. Yo también me acuerdo. Cidade do México: Ed. Sexto Piso, 2014.

GRISON, Laurent. Le « vieillissement des lieux ». Photographier, décrire-écrire. L'espace géographique, 1998, p. 276-279. Disponível em : https://www.persee.fr/doc/spgeo $0046-2497 \quad 1998$ num $27 \quad 3 \quad 1168$

L’ARC. Georges Perec. Librairie Duponchelle, nº 76, 1990.

LABRE, Chantal Labre . Je me souviens. In : Perec. Dir.: BURGELIN, Claude ; HECK, Maryline ; REGGIANI, Christelle. Éd. de L'Herne, 2016, p. 130.

LAWNICZAK, Monica. L'autre île. Cahiers Georges Perec 9, p. 229. Le cinématographie. Textes réunis par Cécile De Bary. Le Castor Astral, 2006.

LE CABINET D'AMATEUR. Perec et l'image, No 7-8, Presses Univ. du Mirail, 1998.

LEJEUNE, Philippe. La mémoire et l'oblique. Georges Perec autobiographe. Paris : P.O.L. 1991. . Vilin Souvenirs. In: Genesis I, 1992, p. 127-151

JOLY, Jean-Luc. "La mémoire totale des lieux". In: La mémoire des lieux dans l'oeuvre de Georges Perec, (Actes du coloque - textes réunis par Rabâa Abdelkéfi). Les Éditions Sahar, 2009.

MACIEL, Maria Esther. A memória das coisas: ensaios de literatura, cinema e artes plásticas. Rio de Janeiro: Lamparina, 2004.

MAGNÉ, Bernard. Tentative de description de choses vues dans tentative de description de choses vues au carrefour Mabillon le 19 mai 1978 de Georges Perec. In : Écritures Radiophoniques. Clermont-Ferrand: Université Blaise Pascal, CRLMC, 1997, p. 173182.

. Carrefour Mabillon, "ce qui passe, passe...", Georges Perec, dialogue avec Bernard Noël. Éd. André Dimanche, 1997

MAGOT, Julie. Essai de poétique comparée : Georges Perec et Jacques Roubaud. Le

Cabinet d'amateur. Revue d'études pérecquiennes, 2010. Disponível em : http://associationgeorgesperec.fr/IMG/pdf/JMagot.pdf

MAZZORATTO, Wilfrid. Ne pas aller em cours et rédiger un devoir de mémoire À propos du film Les lieux d'une fugue. In : Cahiers Georges Perec 9, 2003, p. 141. . Le cinématographie. Textes réunis par Cécile De Bary. Le Castor Astral, 2006.

NEEFS, Jacques; HARTJE, Hans. Georges Perec: images. Paris: Seuil, 1993 
NICHOLS, Bill. Blurred boundaries: questions of meaning in contemporary culture. Bloomington: Indiana University Press, 1994. . Introdução ao documentário. São Paulo: Papirus, 2008

Representing reality: issues and concepts in documentary. Bloomington: Indiana University Press, 1991.

NINEY, François. L'épreuve du réel à l'écran: essai sur le principe de réalité documentaire. Bruxelles: De Boeck, 2011.

NORA, Pierre. Entre memória e história. A problemática dos lugares. Trad. Yara Aun Khoury. In: Proj. História, São Paulo, 10 dez 1993.

PEREC, Georges. 53 Jours. Paris : Gallimard, 1993.

Espèces d'espaces. Galilée, 1992

Je me souviens. Paris : Hachette, 1994.

Je suis né. Paris : Seuil, 1990.

La disparition : roman. Paris : Denoël, 1988.

. La vie mode d'emploi : romans. Paris : Hachette, 1991.

Les choses : une histoire des années soixante. Paris : Julliard, 1991.

Les revenentes. Paris : Julliard, 1994

. L.G. Une aventure des annés soixante. Paris: Seuil, 1992.

. L’infra-ordinaire. Paris : Seuil, 1989

. Euvres (I, II) Paris : Bibliothèque de la Pléiade, 2017.

. Penser, classer. Paris : Hachette, 1985.

. Un homme qui dort. Paris : Denoël, 1993.

. W ou le souvenir d'enfance. Paris: Denöel, 1975.

. W ou a memória da infância. São Paulo: Companhia das Letras, 1995.

PINO, Claudia Amigo. A ficção da escrita. Cotia, SP: Ateliê Editorial, 2004

2006.

O espaço modo de usar: Georges Perec. In: Lettres Françaises. Araraquara, n.7,

PONTALIS, Jean-Bertrand. L'amour des commencements. Paris : Gallimard, 1994

PROUST, Marcel. À la recherche du temps perdu, vol. I, Paris, Gallimard, coll. « La Pléiade », 1954, p. 5.

RAMOS, Fernão Pessoa. Mas afinal... o que é mesmo documentário? São Paulo: Senac, 2008.

. (org.). Teoria contemporânea do cinema - documentário e narratividade ficcional - Volume II. São Paulo: Senac, 2005. 
RÉMY, Matthieu Rémy. Georges Perec dans l'air du temps situationniste. Archives et documents situationnistes, $n^{\circ} 4$, automne 2004

RÉCITS D'ELLIS ISLAND. Traces. Direção: Robert Bober e Georges Perec. Institut National de l'Audiovisuel, 1980, DVD (58 min.)

- Mémoires. Direção: Robert Bober e Georges Perec. Institut National de l'Audiovisuel, 1980, DVD (60 min.)

REGGIANI, Christelle. Perec: une poétique de la photographie. In: Littérature, $n^{0} 129$, 2003, Matières du roman, p. 77-106.

L'éternel et l'éphémère. Temporalités dans l'œuvre de Georges Perec. Amsterdam/Nova Iorque : Rodopi, 2010.

RENOV, Michael. Investigando o sujeito: uma introdução. In: MOURÃO, Maria Dora e LABAKI, Amir (orgs.). O cinema do real. São Paulo: Cosac Naify, 2014.

. The subject of documentary. Londres: University of Minnesota Press, 2004.

RIBIÈRE, Mireille. La photographie dans La Clôture. In : Cabinet d'amateur, 7-8, dezembro 1998.

Le lieu et la forme dans La Clôture. In :Le cabinet d'amateur. Revue d'Études perecquiennes, 2015. Disponível em :https://associationgeorgesperec.fr/IMG/pdf/mribiere_2.pdf

Les projets inaboutis de Georges Perec. In: Cahiers Georges Perec 9. Le cinématographie. Textes réunis par Cécile De Bary. Le Castor Astral, 2006.

RICOEUR, Paul. Histoire et mémoire. In: BAECQUE, Antoine de [et al]. De l'histoire au cinéma. Paris: Complexe, 2008.

ROCHA, Ana Luiza Carvalho da; ECKERT, Cornelia. O infra-ordinário na paisagem urbana como condição da produção de etnografias sonoras e visuais. In: Iluminuras: série de publicações eletrônicas do Banco de Imagens e Efeitos Visuais, LAS, PPGAS, IFCH e ILEA, UFRGS. Porto Alegre, RS. N. 10 (2004). Disponível em: https://lume.ufrgs.br/handle/10183/30101

ROCQUET, Claude-Henri. À la recherche de l'espace perdu. In : Perec. Dir.: BURGELIN, Claude ; HECK, Maryline ; REGGIANI, Christelle. Éd. de L’Herne, 2016, p. 128

ROPARS-WUILLEUMIER, Marie-Claire. Écrire l'espace. Saint Denis: Presses Universitaires de Vincennes, 2002.

ROSENSTONE, Robert A. A história nos filmes, os filmes na história. São Paulo:

ROUILLÉ, André. A fotografia: entre documento e arte contemporânea. Tradução de Constancia Egrejas. São Paulo: Senac, 2009 
SCHILLING, Derek. Mémoire du quotidien: Les Lieux de Perec. Presses Universitaires de Septentrion, 2006.

SHERINGHAM, Michael. Traversées du quotidien. Des surréalistes aux postmodernes. Paris : Presses Universitaires de France, 2013.

SILVA, Edson Rosa da. Inventário e imaginação - Escrever/escavar o(s) espaço(s) etc. In: Espécies de Espaço - Territorialidades, Literatura, Mídia. Belo Horizonte: Editora UFMG, 2008.

SIRVENT, Michel. Georges Perec ou le dialogue des genres. New York : Rodopi, 2007.

SOUSSAN, MYRIAM. La mémoire vivante des lieux . Georges Perec et Robert Bober", p. 1. Disponível em :

http://www.litterales.com/document_disparu.php?id=647\&table=litterature

STAROBINSKI, Jean. La relation critique. In : L'Oeil Vivant II. Paris, Seuil, 1970.

THIBAULD, Jean-Paul, TIXIER, Nicholas. "L'ordinaire du regard". Le cabinet d'amateur, Perec et l'image, No 7-8, Presses Univ. du Mirail, 1998.

\section{Documentários:}

En remontant la rue Vilin. Robert Bober, réalisateur; Georges Perec, auteur; Denis Cuniot, compositeur; Marcel Cuvelier, voix, 1992 (49 min.). Disponível em :

https://www.youtube.com/watch?v=8HfvFHQ-j6s

La vie filmée des français, 2ème partie (1930-1934); réalisation de Michel Pamar et Claude Ventura, commentaire de Georges Perec; voix de Georges Perec; production INA, 1975. (52 min.)

RÉCITS D'ELLIS ISLAND. Traces. Direção: Robert Bober e Georges Perec. Institut National de l'Audiovisuel, 1980, DVD (58 min.); Mémoires. Direção: Robert Bober e Georges Perec. Institut National de l'Audiovisuel, 1980, DVD (60 min.)

Réfugié d'Allemagne, apatride d'origine polonaise. Réalisation de Robert Bober. 1976 (90 min.)

\section{Material sonoro:}

Georges Perec, dialogue avec Bernard Noël (2 livres + coffret de 4 CD). Éd. André Dimanche, 1997

Emissão sonora 50 choses à ne pas oublier de faire avant de mourir. France Culture.

Disponível em: https://www.franceculture.fr/emissions/les-nuits-de-france-culture/les50-choses-ne-pas-oublier-de-faire-avant-de-mourir-selon.

\section{Outros vídeos citados:}

Die maschine: https://www.youtube.com/watch?v=pu6TACgAdTI

Je me souviens (trecho): https://www.ina.fr/video/CPC90009080

Un homme qui dort : https://www.youtube.com/watch?v=UaIXUXdYthA 


\section{ANEXOS}

ANEXO 1- Dedicatória de Perec a J.B. Pontalis, no livro W ou le souvenir d'enfance

\section{Georges \\ Perec \\ W \\ ou \\ le souvenir \\ d'enfance \\ Pour JB Poutalin}

an deli de l'ici et du maintenant

ces rraces qu'l wia aidé à

Les Lettres Nownelles

19, rue Amélie, Paris $T$

Denoêl utrovier aver mos avitu

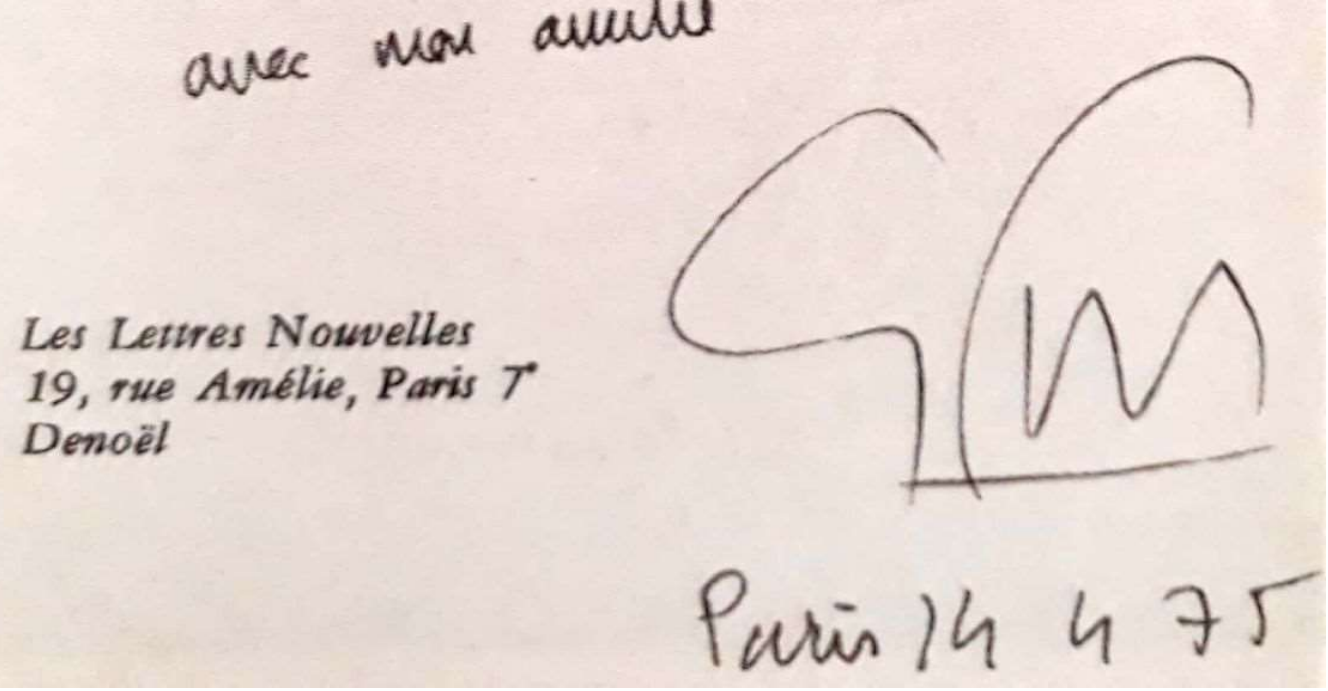


ANEXO 2- Documento que atesta a adoção de Perec pelos tios

GREFFE

ta TRIBdsab te fre INSTANCB

tet a serime

ae Putuis on Jestuce

a Panis

Clambre da Conseil

\section{PUPILLES DE LA NATION}

(Loi de 27 Juillet 1917)

\section{NOTIFICATION D'UN JUGEMENT}

Le Greffier du Tribunal de $I^{\text {re }}$ Instance du Departemext de la Signe, notifie d $M$

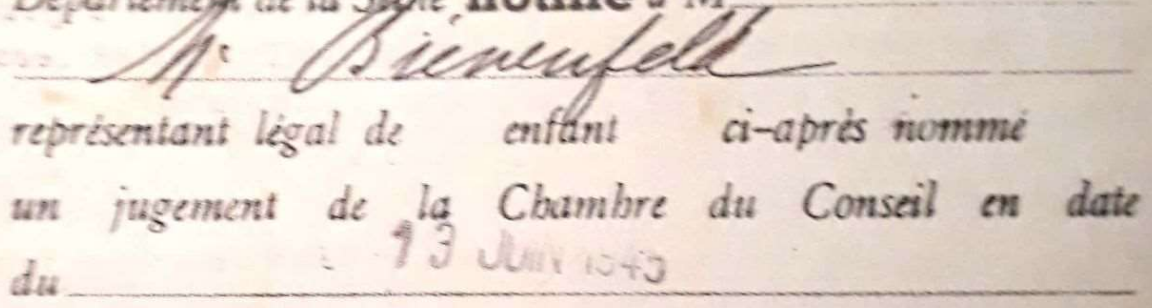

aux termes duquel le Tribunal a declaré que :

- Ia Nation adopte l e mineur .

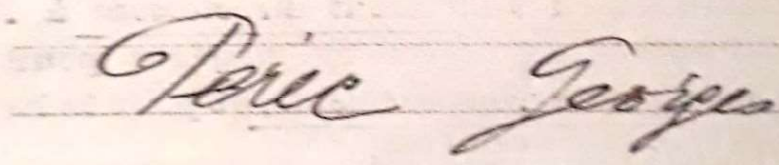

Pous Notificarton :

Paris, le Le Garmok : 
ANEXO 3- Declaração de « Mort pour la France », de Icek Judko Perec.

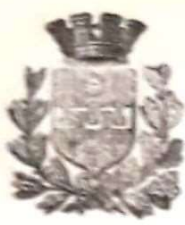

VILLE de

MOGENT-SUT-SEINE (Aube)

TELEPHONE: 73 I0 84

$\mathrm{PBR} \mathrm{BC}$

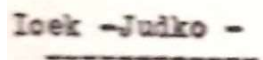

Yort pour la

Prance
Nogent-sur-Seine, le

MXTAIT DES KEGISTRES DE L'BTAT CIVIL

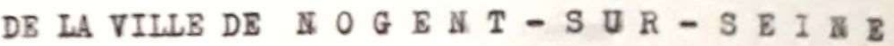

$-2-8-t-2-8-2-$

Le seize Juin mil neuf cent quarante est décédé a 1 'Hopltal des Prisonniers de guerre (Bglise), Ioek, Judko P B R B C, Soldat au I2 ème Régiment étranger, reorutecent $\mathrm{B} \nabla, \mathrm{n}^{\circ}$ matricule 37I6, fondeur, domiollié à Paris, rue $\mathrm{V} 11 \mathrm{in}$ 24,né à Lubartow (Pologne) 10 dix neuf Juin mil neuf cent neuf, 1118 de David Pereo et de Surakojaa Walerszteix, époux, domiclisés à Paris, rue Pilin Savlewioj. Dressé le jour susdit a neuf heures sur la tributions tributions Indirectes,âgé de trente neup ans, donlo1lí́ en après lecture laite a sions lir Périer, numéro I3.Lequel Gallés, Vaire de Nogent-sur-seine.

Certifié conforme aux registres de l'Btat olv11 Nogent-sur-Seine le dix neuf Décembre mil neue
uante huit. cent oinquante huit.

Le Malre,

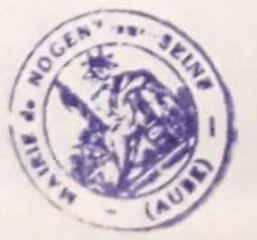

POUR i: MAIRE

L'Adjolat-Doliegus

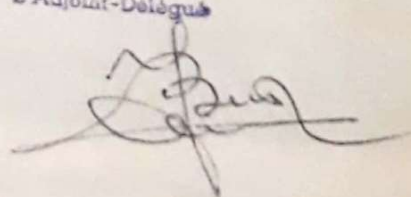


ANEXO 4- Inventários transcritos e links para escuta dos áudios de Carrefour Mabillon

[Inventaire [1] « 475 véhicules à deux roues, dont... »] (Clique aqui para ouvir o áudio do trecho integralmente, ou escolha os intervalos de tempos discriminados abaixo, de acordo com os trechos que desejar ouvir)

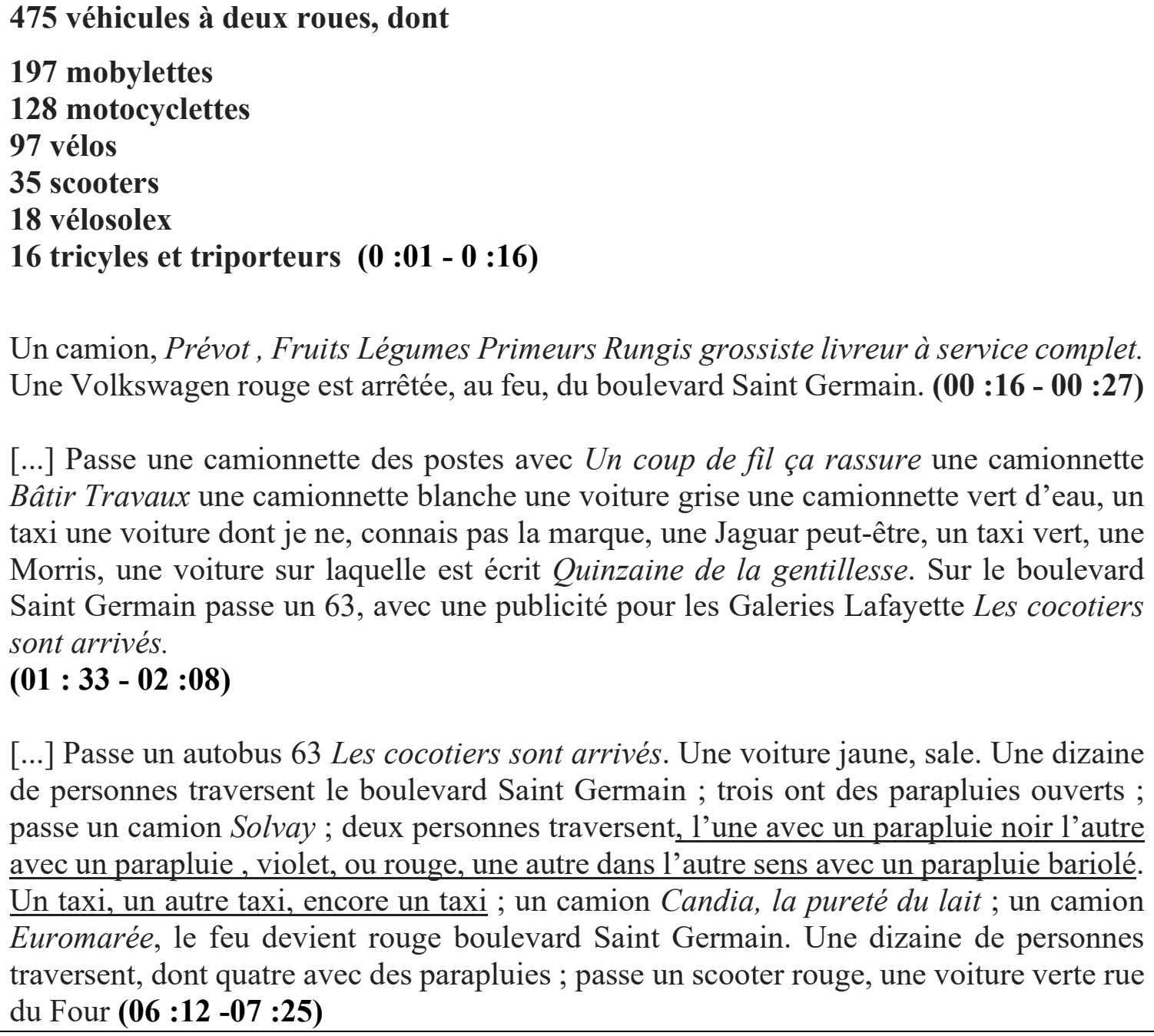
taxi une voiture dont je ne, connais pas la marque, une Jaguar peut-être, un taxi vert, une Morris, une voiture sur laquelle est écrit Quinzaine de la gentillesse. Sur le boulevard Saint Germain passe un 63, avec une publicité pour les Galeries Lafayette Les cocotiers sont arrivés.

(01 : 33 - 02 :08)

[...] Passe un autobus 63 Les cocotiers sont arrivés. Une voiture jaune, sale. Une dizaine de personnes traversent le boulevard Saint Germain ; trois ont des parapluies ouverts ; passe un camion Solvay; deux personnes traversent, l'une avec un parapluie noir l'autre avec un parapluie, violet, ou rouge, une autre dans l'autre sens avec un parapluie bariolé. Un taxi, un autre taxi, encore un taxi ; un camion Candia, la pureté du lait ; un camion Euromarée, le feu devient rouge boulevard Saint Germain. Une dizaine de personnes traversent, dont quatre avec des parapluies ; passe un scooter rouge, une voiture verte rue du Four (06:12 -07:25)

[Inventaire [2] « 3287 véhicules automobiles, dont... »] (Clique aqui para ouvir o áudio do trecho integralmente, ou escolha os intervalos de tempos discriminados abaixo, de acordo com os trechos que desejar ouvir)

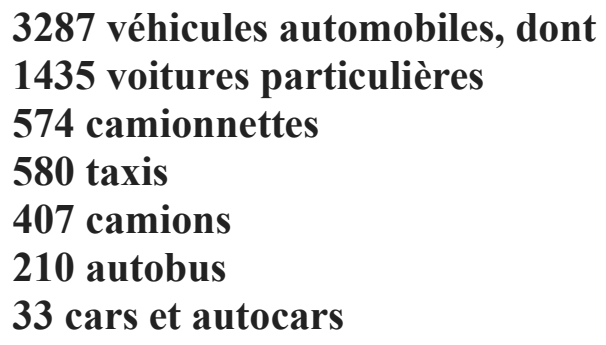


18 véhicules de la police

17 ambulances

12 auto-écoles

1 corbillard $(00: 01-0: 25)$

1- [.....] Plusieurs personnes attendent pour traverser, dont quatre avec des parapluies ouverts, une dame, qui tire une poussette, qui tire un sac à provision.// Le feu devient rouge, une dizaine de personnes traversent, il y a cinq parapluies ouverts. Passe une camionnette sur laquelle est écrit Oeufs beurre, une autre sur laquelle est écrit Cent mille, Chemises ; un taxi, une deux chevaux, une voiture bleue ; une camionnette Pignot; plusieurs voitures, des gens qui traversent à quelques centimètres de moi. // La pizza voisine de la Rhumerie, Pizza Verdi, est ouverte, un enseigne néon Pizza Verdi clignote. Pizza Verdi allumé, éteint, allumé, éteint, allumé, éteint, allumé ; le feu est rouge boulevard Saint Germain, rue du Four passe une camionnette Uncle Bens le riz qui ne colle jamais ; une camionette Soliviandes Porc en gros qui tourne dans la rue de Buci, qui tourne de la rue de Buci vers le boulevard Saint Germain ; une moto, une Volkswagen, orange //; il n'y a plus personne à la terrasse du café le Mabillon, (01 : 35 - 04 :09)

2 - [...] le feu devient rouge boulevard Saint Germain. Une dizaine de personnes traversent, cinq ou six avec des parapluies deux avec des chiens. // Je ne sais pas comment s'appellent ces chiens. Des espèces de briquets. Rue du Four passe un camion, bâché qui livre des pommes de terre, cinq voitures de front sont arrêtées boulevard Saint Germain, derrière deux camionnettes. D'autres voitures arrivent, le feu devient vert, toutes le voitures partent, pas toutes en même temps; passe un autobus 70 qui va à l'Hôtel de ville avec une publicité pour Véronique Sanson ( 05 : 25 - 06 :12)

3 - [...] une DS une mobylette ; (une fille très grande avec un grand imperméable, avec un grand parapluie jaune, une autre avec un chapeau, un petit chien et un imperméable, un parapluie bleu, une autre avec des longs cheveux et un parapluie, à fleurs ; un homme qui pousse une espèce de diable, deux même.[...] (06: 31 - 07 :00)

[Inventaire [3] « 407 camions, dont... »] (Clique aqui para ouvir o áudio do trecho integralmente, ou escolha os intervalos de tempos discriminados abaixo, de acordo com os trechos que desejar ouvir)

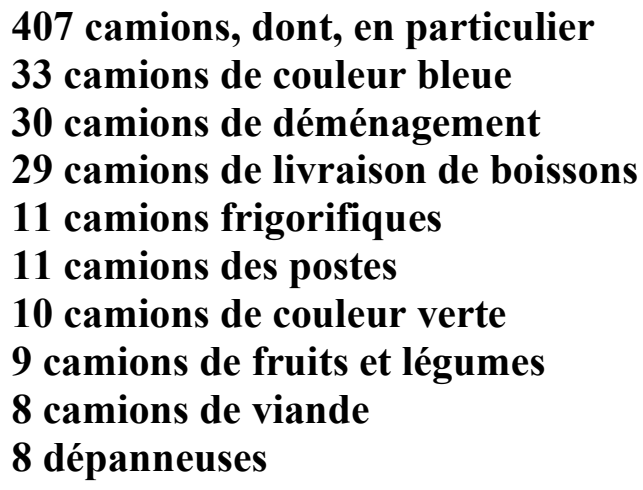




\section{8 camions-citernes}

7 camions à benne

6 camions à remorque

6 camions de transport de fonds

4 camions de lait $(0: 01$ - $00: 33)$

Un camion Documentation technique automobile, un autre Bois charbons qui tourne dans la rue où nous nous trouvons (1), quelqu'un qui descend presque en marche au coin du boulevard Saint Germain et de la rue du Four, et qui rentre à la BNP, un 63 Les cocotiers sont arrivés $(00: 36$ - 01 :03)

$[\ldots]$ une dame avec un parapluie qui tire un panier à provision monté sur roulettes, un taxi ; un autobus 87 avec une publicité pour Véronique Sanson, une Renault vert pomme, trois taxis, une dizaine de voitures particulières, des taxis ; deux mobylettes //; quatre personnes traversent le boulevard Saint Germain se dirigeant vers la rue de Buci, deux tirent des paniers à provision, deux autres femmes, remontent le boulevard Saint Germain vers la rue de Buci, traînant des paniers à provision, toutes les deux avec leur parapluie ouvert, une promène un chien, deux femmes avec leur paraluie ouvert toutes les deux promenant un chien se croisent en traversant le boulevard Saint Germain (01 :20 - 02 :42) [...] 1 y a de nouveau un homme en béret à la terrasse du Mabillon, je pense que c'est le même que tout à l'heure. (04 : 13 - 04 :20)

[...] Rue de Buci l'enseigne du magasin Au cor de chasse qui représente un cor de chasse est allumée. Passe un 63 Les cocotiers sont arrivés (06 :09 - 06 :26)

$[\ldots]$ est bientôt dix heures et quart (07:38 - 07 :45)

[Inventaire [4] « 574 camionnettes, dont... »] (Clique aqui para ouvir o áudio do trecho integralmente, ou escolha os intervalos de tempos discriminados abaixo, de acordo com os trechos que desejar ouvir)

574 camionnettes, dont, entre autres

55 camionnettes de couleur bleue

45 camionnettes des postes

26 camionnettes de couleur blanche ( $0: 01$ - $00: 15)$

Onze heures vingt. Passe un laveur de carreaux, sur une mobylette, un homme avec un imperméable, une barbe des lunettes et un paquet enveloppé dans du papier kraft, une dame qui boîte légèrement, plusieurs personnes traversent la rue du Four, le feu est rouge boulevard

Saint Germain (00 :16 - 00 :41)

[...] un homme qui a dans sa poche un journal sur lequel je peux lire les mots le juge Pasc un camion Hédiard, une fille avec un, une casquette assez amusante, blanche, une 
camionnette Vacances 2000, Sernam Service national des Messageries SNCF//, une camionnette Heureux, non une voiture Heureux comme comme un 51 dans l'eau ; un grand parapluie blanc tenu par un homme en imperméable, avec des blue jeans, un autocar, Mercedes, avec peu de monde dedans, dont une dame, habillée en rouge avec un chapeau blanc //; un petit tricycle des postes avec écrit derrière arrêt fréquent (06 :31$07: 42)$

[...]un homme avec un imperméable court une grosse sacoche plutôt un cabas d'ailleurs une dizaine de personnes traverse le boulevard Saint Germain, j'arrive à compter six parapluies, un homme qui porte, un, qui pousse un diable dans lequel il y a quelque chose qui me fait penser à du du des poissons dans une caisse, en matière plastique blanche, je sais pas comment ça s'appelle (08:39 - 09 :28)

[Inventaire [5] « 580 taxis, dont [...] 5 jaunes, 1 orange »] (Clique aqui para ouvir o áudio do trecho integralmente, ou escolha os intervalos de tempos discriminados abaixo, de acordo com os trechos que desejar ouvir)

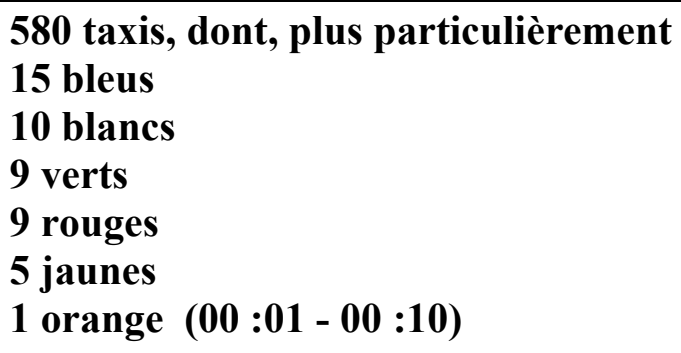

un autobus 87 publicité pour Véronique Sanson, plein de voitures particulières, un taxi, une voiture Ted Lapidus //; un homme avec des cheveux longs et un catogan, une fille avec un blouson vert, cinq personnes, six, une dizaine de personnes avec six parapluies, une femme qui pousse, un bébé dans une poussette et qui tient un petit garçon par la main (00 : $14-00$ :53)

[...]un gros camion Déménagement Garnier Conflans Sainte Honorine 78700 tél 9166087 [rire] Déménagements toutes distances (5), qui s'arrête juste devant, mon regard, fait une marche arrière, part en marche arrière dans la rue où nous nous trouvons; se gare derrière nous. $(04: 40 \quad 05: 05)[\ldots]$

[Inventaire [6] « 210 autobus, dont... »] (Clique aqui para ouvir o áudio do trecho integralmente, ou escolha os intervalos de tempos discriminados abaixo, de acordo com os trechos que desejar ouvir)

210 autobus, dont

46 portant des publicités pour « Les cocotiers sont arrivés » 47 portant des publicités pour Véronique Sanson

56 de la ligne 63

42 de la ligne 96

38 de la ligne 86

37 de la ligne 87 


\section{2 de la ligne 20}

2 de la ligne 48

1 service spécial transports d'enfants (0:01 - 00 :28)

[...]Une jeune femme, porte une panière, pleine de pain, et traîne une grande, heu, une grande poussette, métallique avec une, un plastique dedans. Boulevard Saint Germain passe un 70, avec une publicité pour Véronique Sanson ; une bonne douzaine de voitures, un camion blanc style frigorifique, une camionnette, $j$ ' peux pas lire ce qu'y a dessus c'est trop loin JCB France; une camionnette Carniato à la carte, (01 :28 - 02 :09)

[...]La livreuse de pain repart, traverse en courant la rue de Buci, et le boulevard Saint Germain. Non la rue du Four et le boulevard Saint Germain. Midi dix, passe un 63, un 86 , un camion qui transporte je ne sais quoi, des trucs compliqués, un 96 ; il pleut de plus en plus fort, il fait de plus en plus sombre. (03 :21 - 04 :03)

[...]au centre du carrefour, sur une mobylette, un laveur de carreaux, qui n'a pas l'air gai (04 :29 - 04:35);

[...]camionnette Pierre d'Alby, une voiture rouge, genre sport, une voiture bleue, plein de petits enfants avec des imperméables bleus, qui passent juste, à côté, de moi, dont une petite fille qui me tire la langue $(04: 54$ - $05: 13)$;

[...]presque tous les gens ont des parapluies, un parapluie vert, un parapluie noir, un parapluie avec un, décor, géométrique, blanc rouge et noir, un parapluie à fleurs, un parapluie à motifs, un parapluie violet, un parapluie noir ; un homme en imperméable sans parapluie, un parapluie à, //décoré, un autobus 63, un autobus 96 , une deux chevaux qui prend la rue où nous nous trouvons, un parapluie avec des espèces de motifs géométriques, un parapluie noir, un parapluie avec un décor, pas écossais mais à carreaux ; un camion livraison de pommes de terre, le feu est rouge, un parapluie noir, un parapluie à bandes vertes et, bleues et jaunes pardon, un parapluie rouge, très plat, un parapluie, sans couleur $(06: 45-07: 52)$

[Inventaire[7] « 1435 voitures particulières, dont... »] (Clique aqui para ouvir o áudio do trecho integralmente, ou escolha os intervalos de tempos discriminados abaixo, de acordo com os trechos que desejar ouvir)

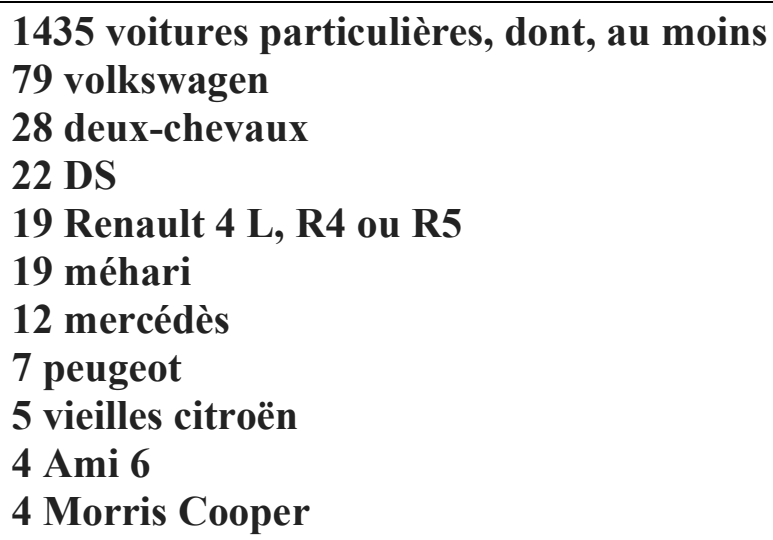


4 Landrover ou assimilés

3 Fiat 500

1 Ford Mustang

1 Jaguar

1 Matra

1 Rolls-Royce

1 Simca

1 Volvo (00 : 01 - 00 :33)

Il a l'air de moins pleuvoir. Un homme avec, une, chemise bleue à la main traverse le boulevard Saint Germain, une chemise en carton, pas une chemise heu, un homme en mobylette avec une grande sacoche, un autre, $[\ldots]$ 00 :34 - 00 :45)

[Inventaire [8] « 79 Volkswagen, dont... » ] (Clique aqui para ouvir o áudio do trecho integralmente, ou escolha os intervalos de tempos discriminados abaixo, de acordo com os trechos que desejar ouvir)

79 Volkswagen, dont, plus précisément

15 blanches dont 2 décapotables

10 jaunes

8 rouges

8 bleues

5 noires dont 1 décapotable

4 grises

1 dorée

1 violette (00:01 - 00 :20)

[...] camionnette, une DS, un, tricycle à moteur, rouge, deux voitures, le feu est vert boulevard Saint Germain, une deux trois, six, neuf, dix douze voitures, une camionnette des PTT, un car Air Suzanne complètement vide, une voiture jaune qui tourne dans la rue du Four, un taxi, une Volkswagen orange, un taxi, une voiture qui va très vite (00 : 49 $01: 22)$

[...]une demi-douzaine de parapluies qui traverse(nt) le boulevard (02 :46 - 02:50)

[...]les voitures redémarrent boulevard Saint Germain, une deux chevaux rouge, une DS avec un chauffeur et un, heu conduit, plein de voitures particulières, un taxi (04:06 04 :19)

[...] un homme qui me montre du doigt en passant, trois voitures, un oiseau, qui passe dans le ciel (06:48 - 07 :00) 
[...] deux personnes sur une petite moto, encore un instant d'accalmie ; un cycliste, [...] (07:17 07: 30)

[Inventaire [9] « 78 deux chevaux, dont... »] (Clique aqui para ouvir o áudio do trecho integralmente, ou escolha os intervalos de tempos discriminados abaixo, de acordo com os trechos que desejar ouvir)

78 deux-chevaux, dont, entre autres,

18 vert-pomme

11 rouges

8 oranges

7 jaunes

6 bleues

3 grises

2 vertes

2 blanches (00:01 - $00: 12)$

[...] un cycliste, un mo, un [...]mobylettiste, deux oiseaux, trois oiseaux dans le ciel, encore une mobylette, une moto, une mobylette $(01$ :01 - 01 :13)

[...] Il est à peu près deux heures moins cinq. Il pleut beaucoup moins, une fille avec des pantalons orange passe en vélo sur le boulevard Saint Germain (01 :51 - 02:05) ;

[...]voiture(s) sur le boulevard Saint Germain, un autocar, avec pas mal de gens dedans, dont un Japonais, une Volkswagen, un taxi (04 :01- 04 :16) [...]

[Inventaire [10] « 1172 voitures de marques diverses, parmi lesquelles... »] (Clique aqui para ouvir o áudio do trecho integralmente, ou escolha os intervalos de tempos discriminados abaixo, de acordo com os trechos que desejar ouvir)

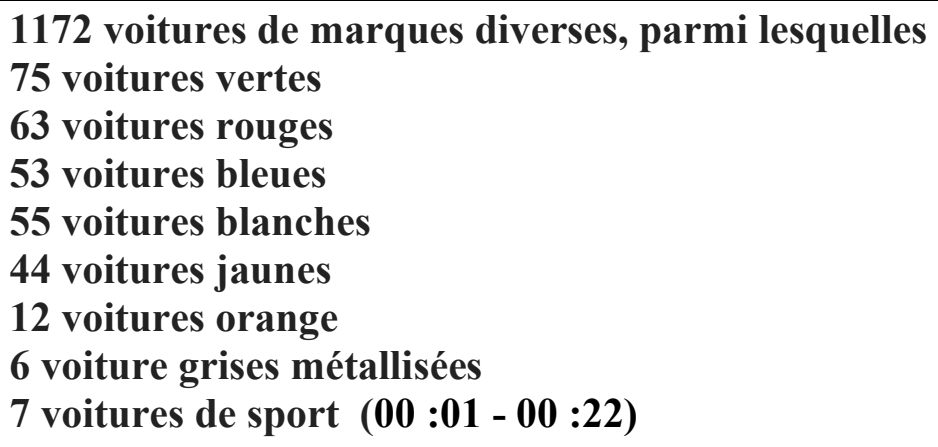

[...]un homme qui a peut-être acheté la première édition du Monde, un camion qui livre des pommes de terre et des oignons $(01: 26$ - $01: 31)$

[...] un homme à vélo, deux flics en mobylette, un taxi, rouge un taxi bleu, un taxi blanc, (02:57 - 03 :10) 
[...]rue du Four, deux mobylettes démarrent, des voitures, une mobylette passe juste devant nous, taxi, méhari, taxi, voiture bleue, voiture rouge, taxi blanc, taxi, taxi vert, taxi blanc, mobylette, avec un homme en imperméable, une deux chevaux bleue, une Peugeot une je sais pas quoi, blanche, des gens traversent en courant le boulevard Saint Germain, (03:54 - 04 :24)

$[\ldots]$ deux voitures dont une rouge (07 :25 - 07 :26 )

[...] des voitures, plein de voitures. Pas mal de voitures; (07 :40 - 07:43) 
ANEXO 5 - A ligação entre os lugares e a autobiografia de Perec, segundo Lejeune

1. Rue Vilin: (1936-1942, do nascimento até o embarque para Villard-de-Lans);

2. Rue de l'Assomption: (onde mora sua tia Esther e onde viveu entre 1945 e 1960);

3. Franklin-Roosevelt (lugar da fuga que fez em 1947 e que inspirou Lieux d'une fugue);

4. Avenue Junot (onde moravam sua tia Berthe e seu primo Henri);

5. Rue de la Gaîté (ligada a seu amigo Jacques Lederer);

6. Place de l'Italie (graças ao quarto de seu amigo Michel, onde, no inverno entre 1955 e 1956, datilografou seu primeiro romance, Les Errants);

7. Place de La Contrescarpe (próxima à rue Blainville e de seus amigos do albergue de estudos tunisianos, foi entre 1956 e 1957 "qqc comme une mère patrie");

8. Rue Saint-Honoré (dois quartos que ocupa no primeiro semestre de 1957 e no primeiro semestre de 1959);

9. Carrefour Mabillon (ligado a Paulette, com quem se casou em 1960);

10. Place Jussieu (perto da rue Quatrefages, onde morou com Paulette de 1960 a 1966) Sobre o décimo primeiro lugar, Passage Choiseul, Lejeune cita uma frase de Perec, indefinida sobre a escolha do lugar: ("Porquoi le passage Choiseul? Il ne m'y est rien arrivé. J'aime les passages") e sobre o décimo segundo, L'île SaintLouis, há apenas a menção da letra ("S.")

*A lista original em francês está na página 164 de "La mémoire et l'oblique" 
ANEXO 6 - Les Lieux d'une fugue: texto original datilografado

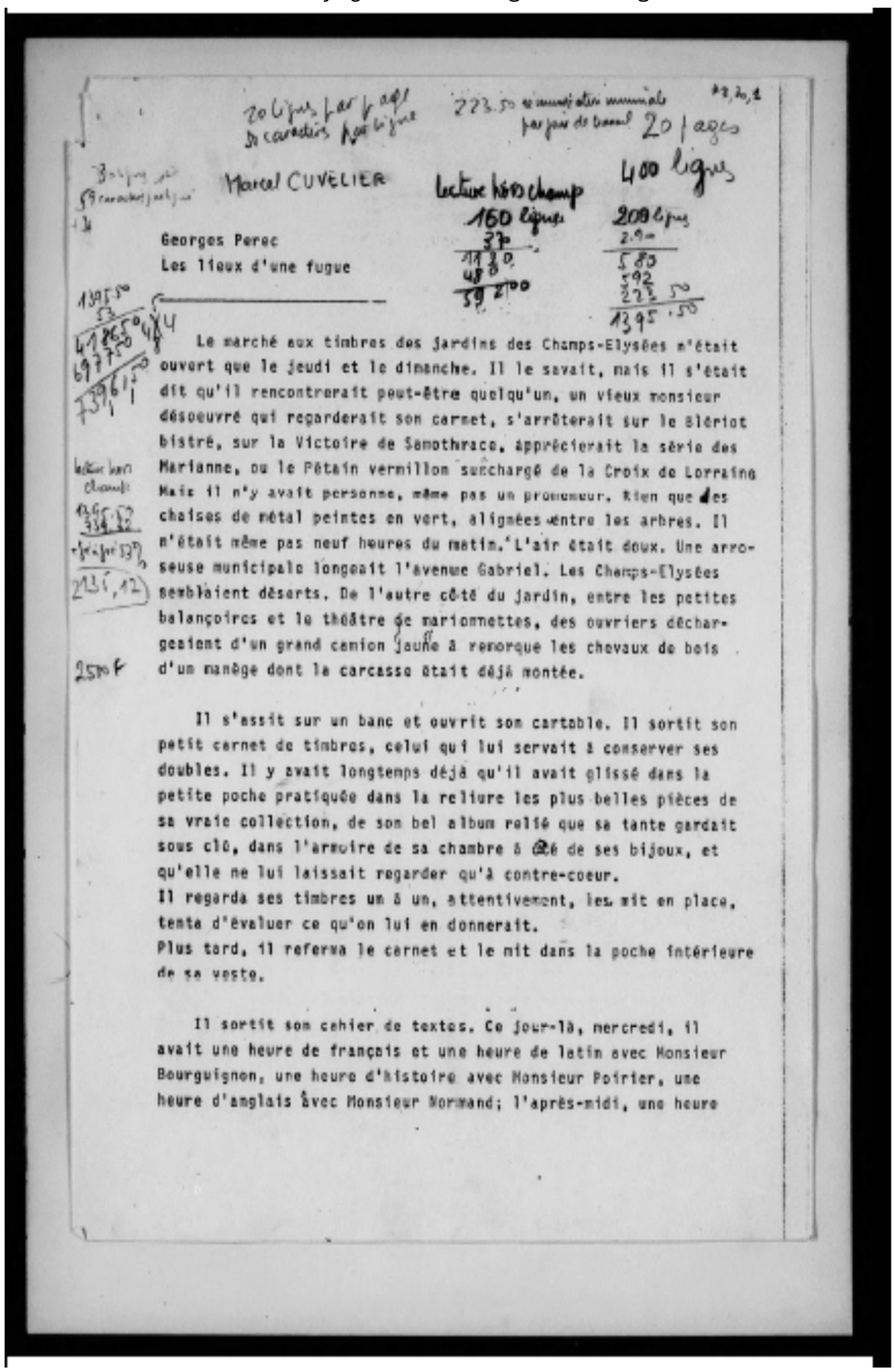




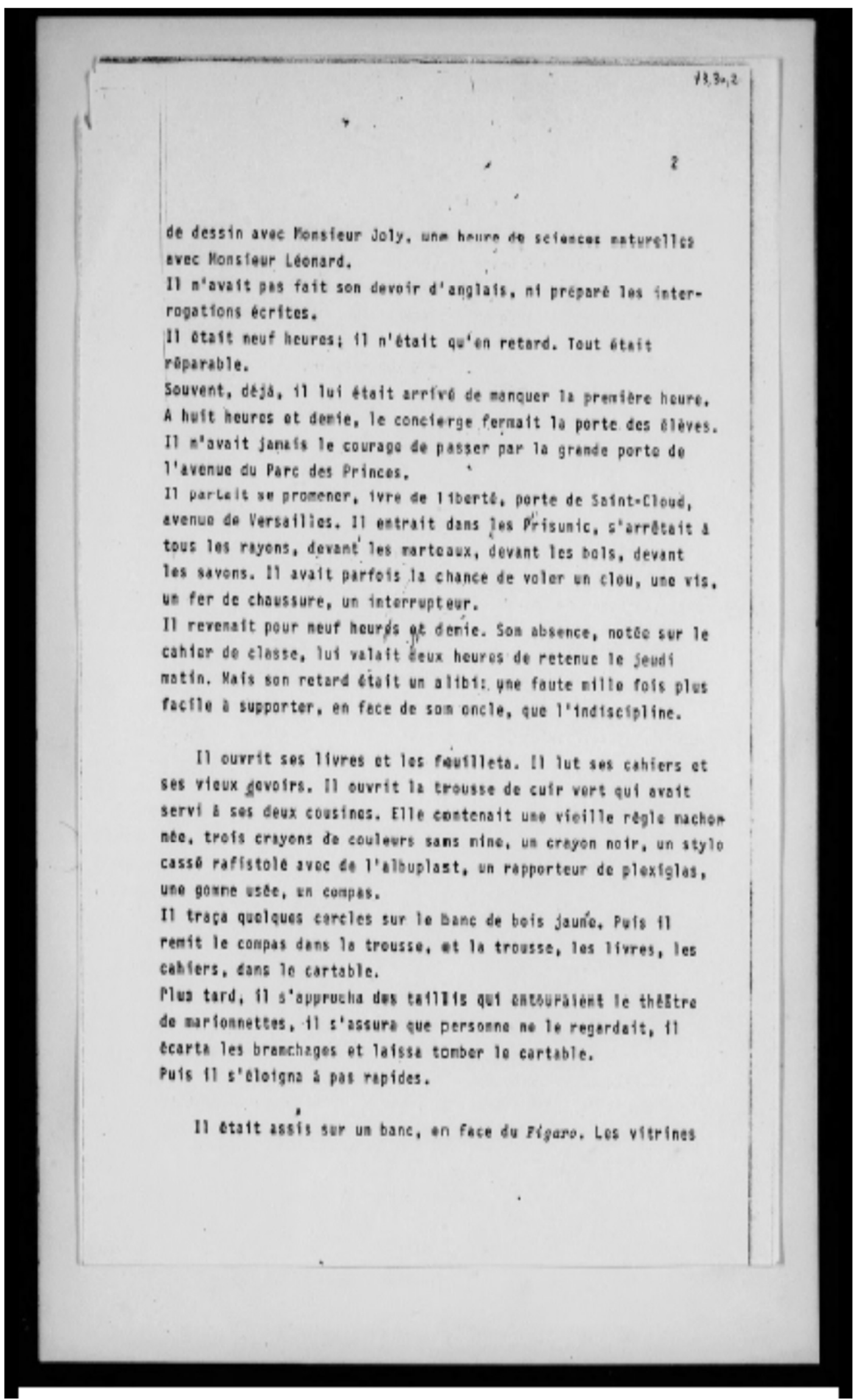




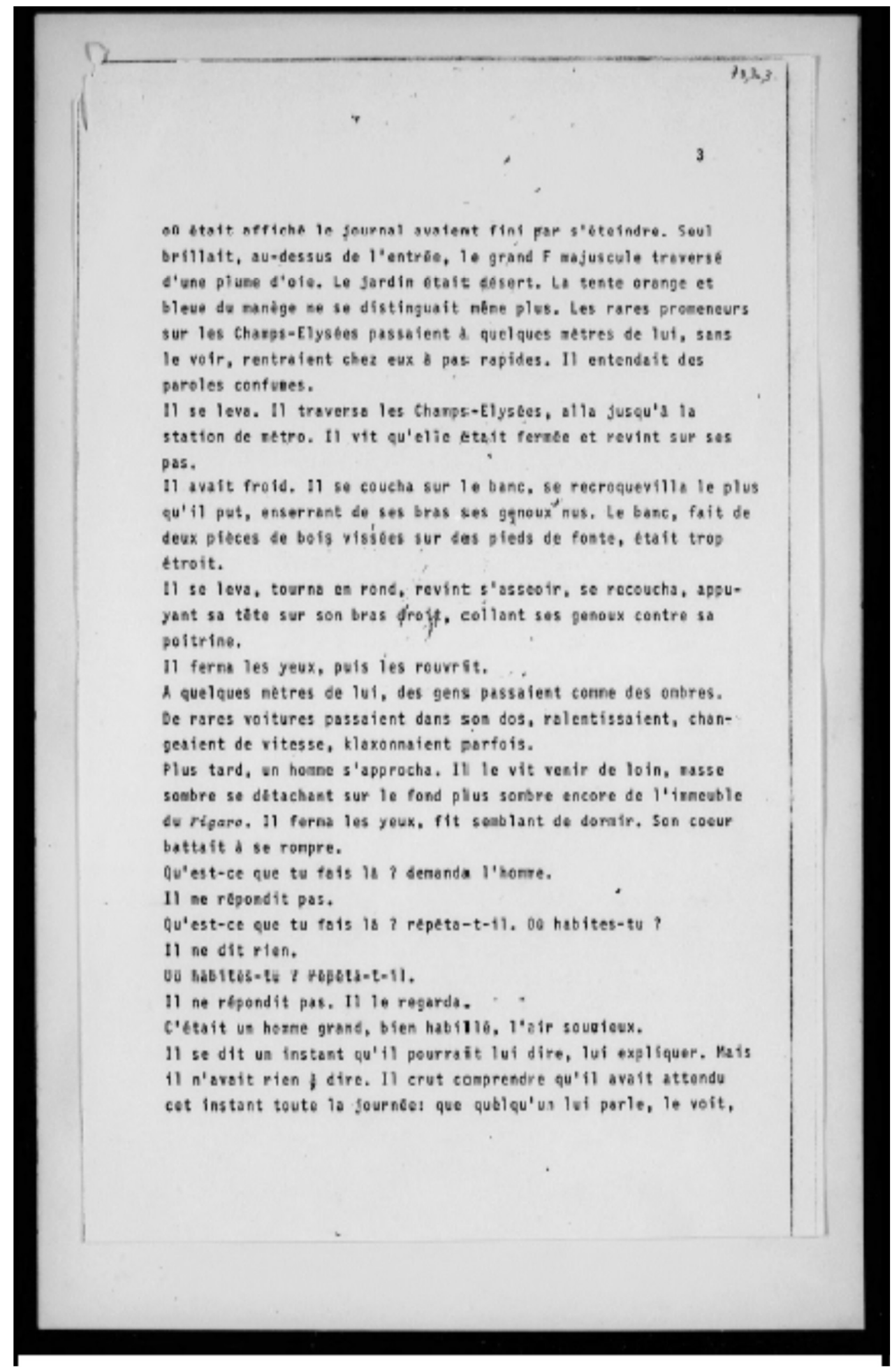




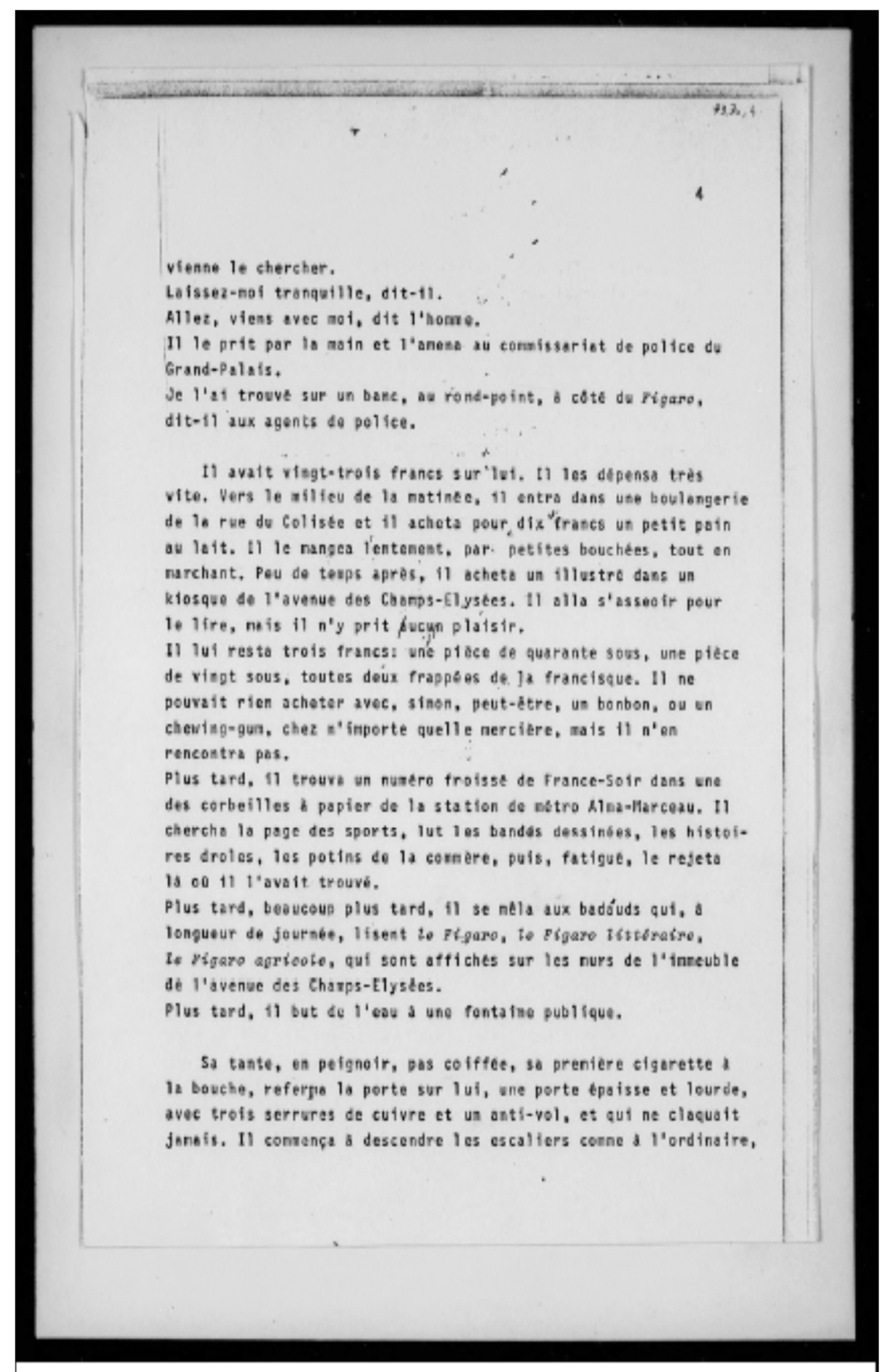




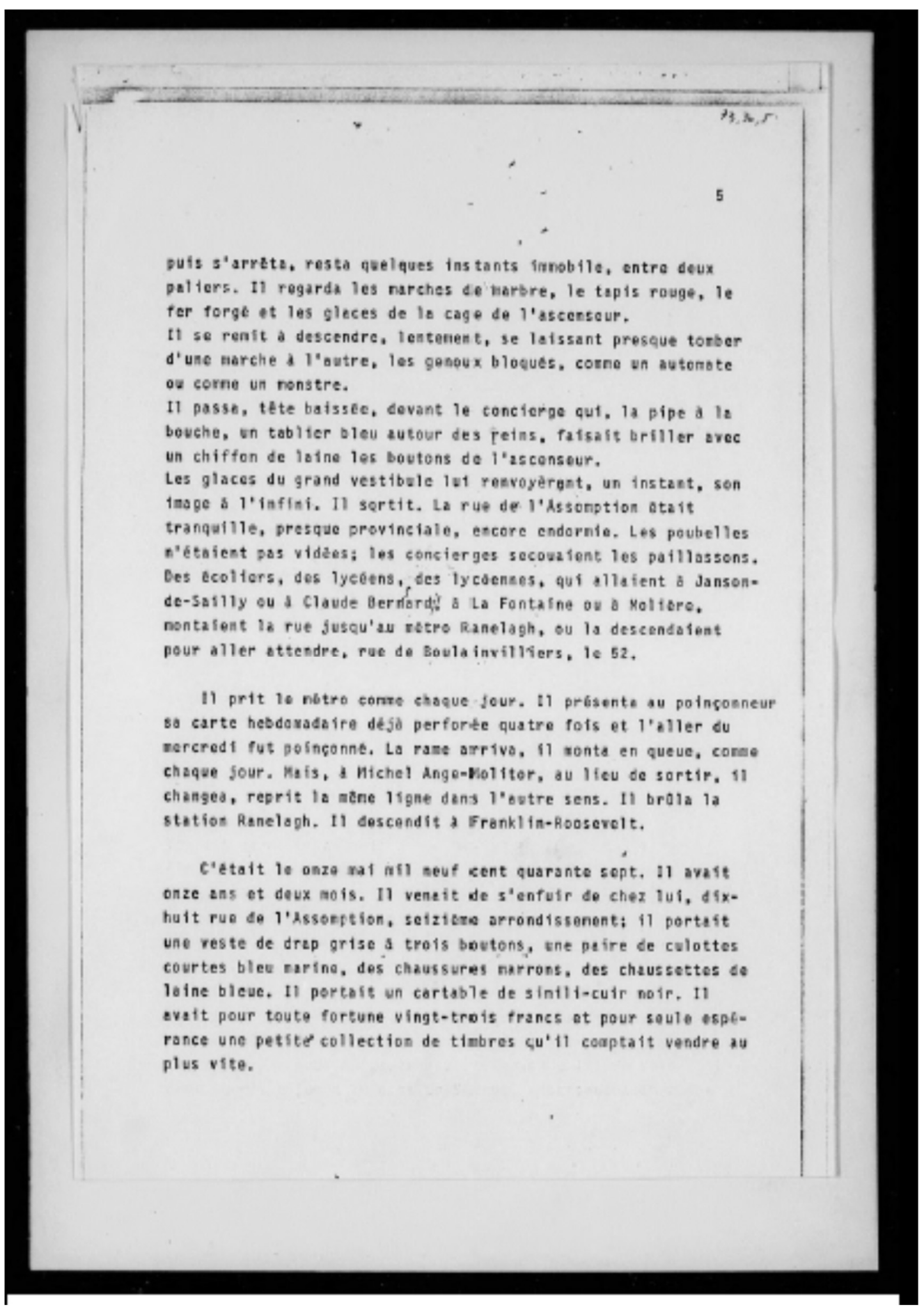




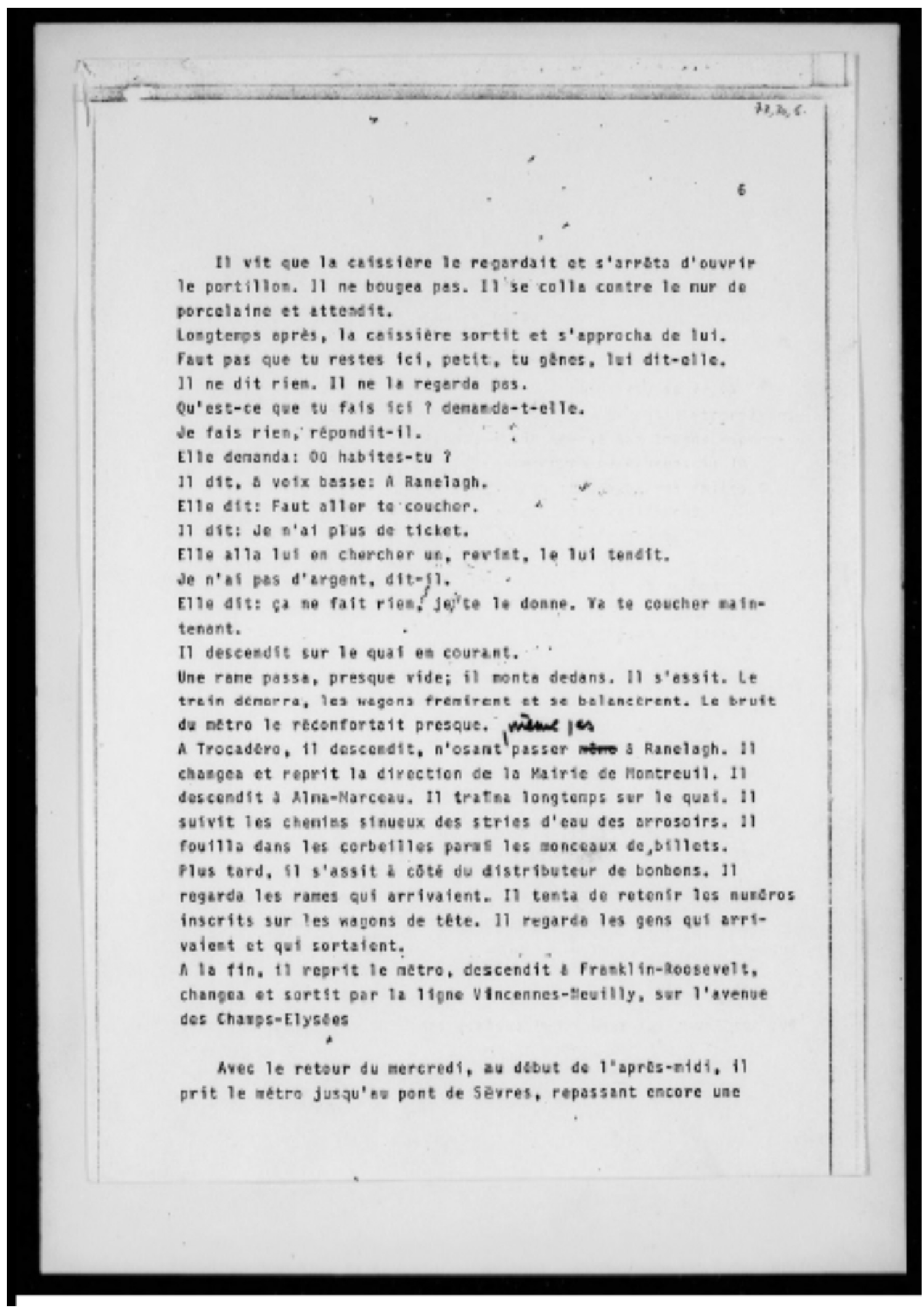




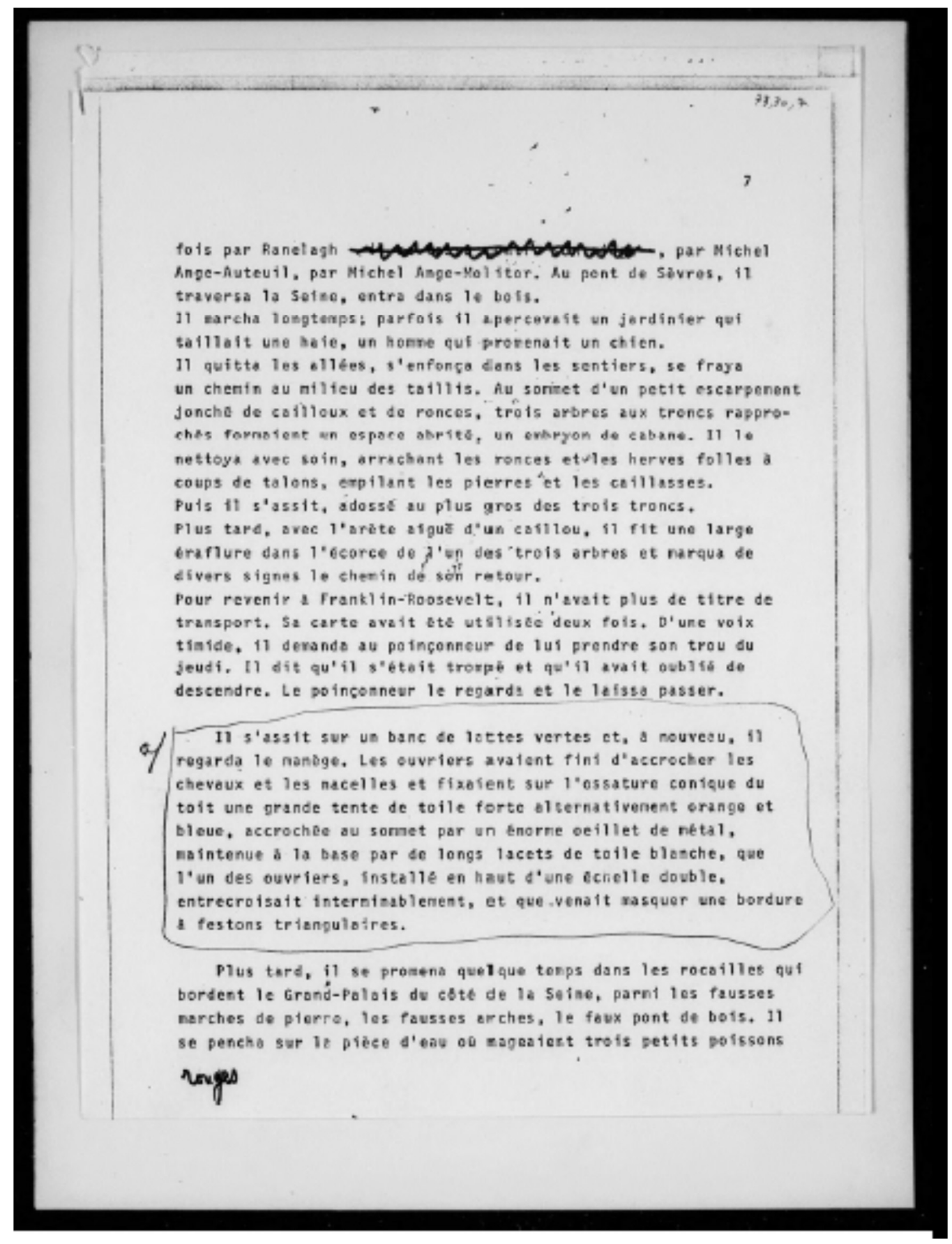




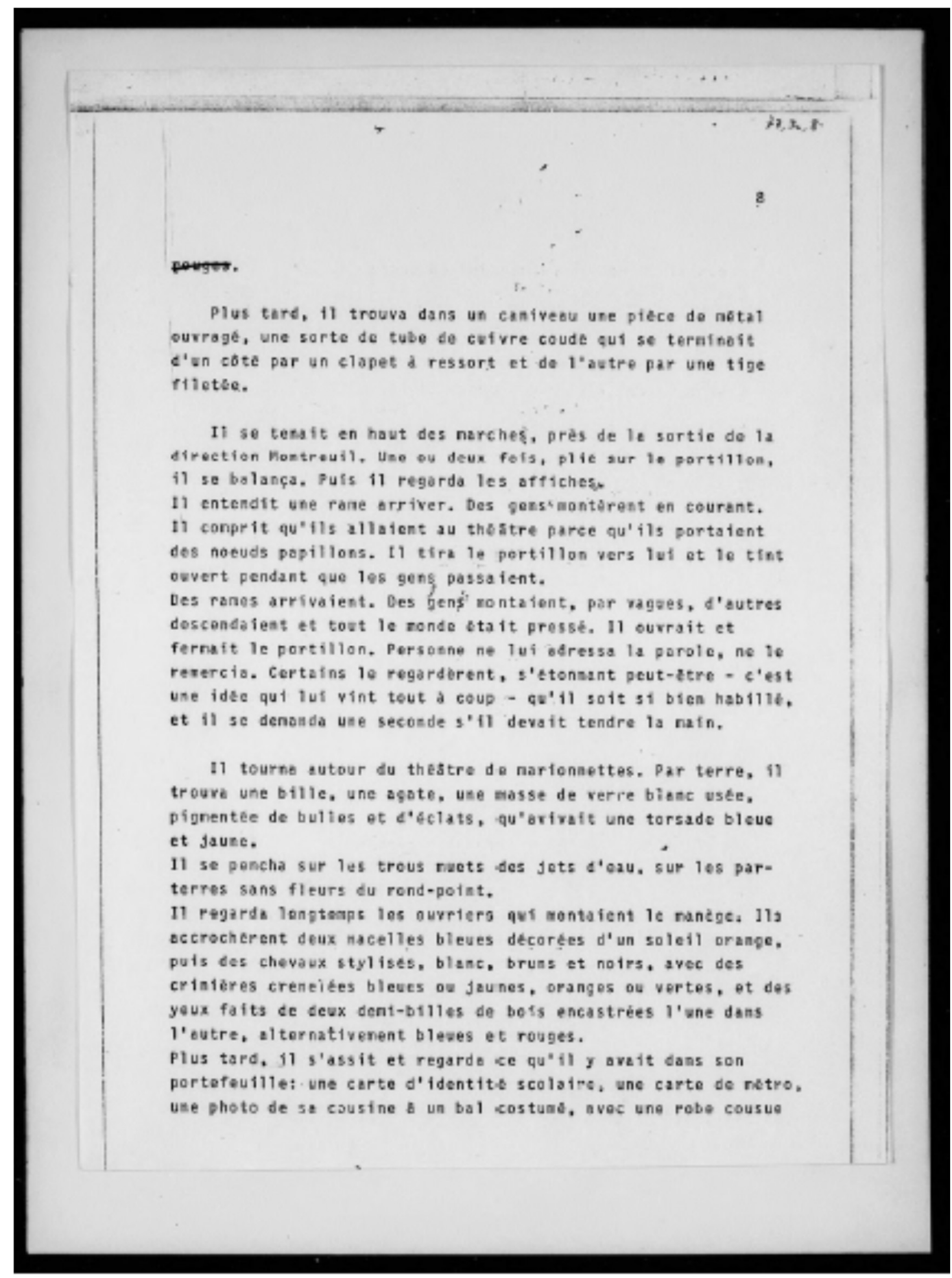




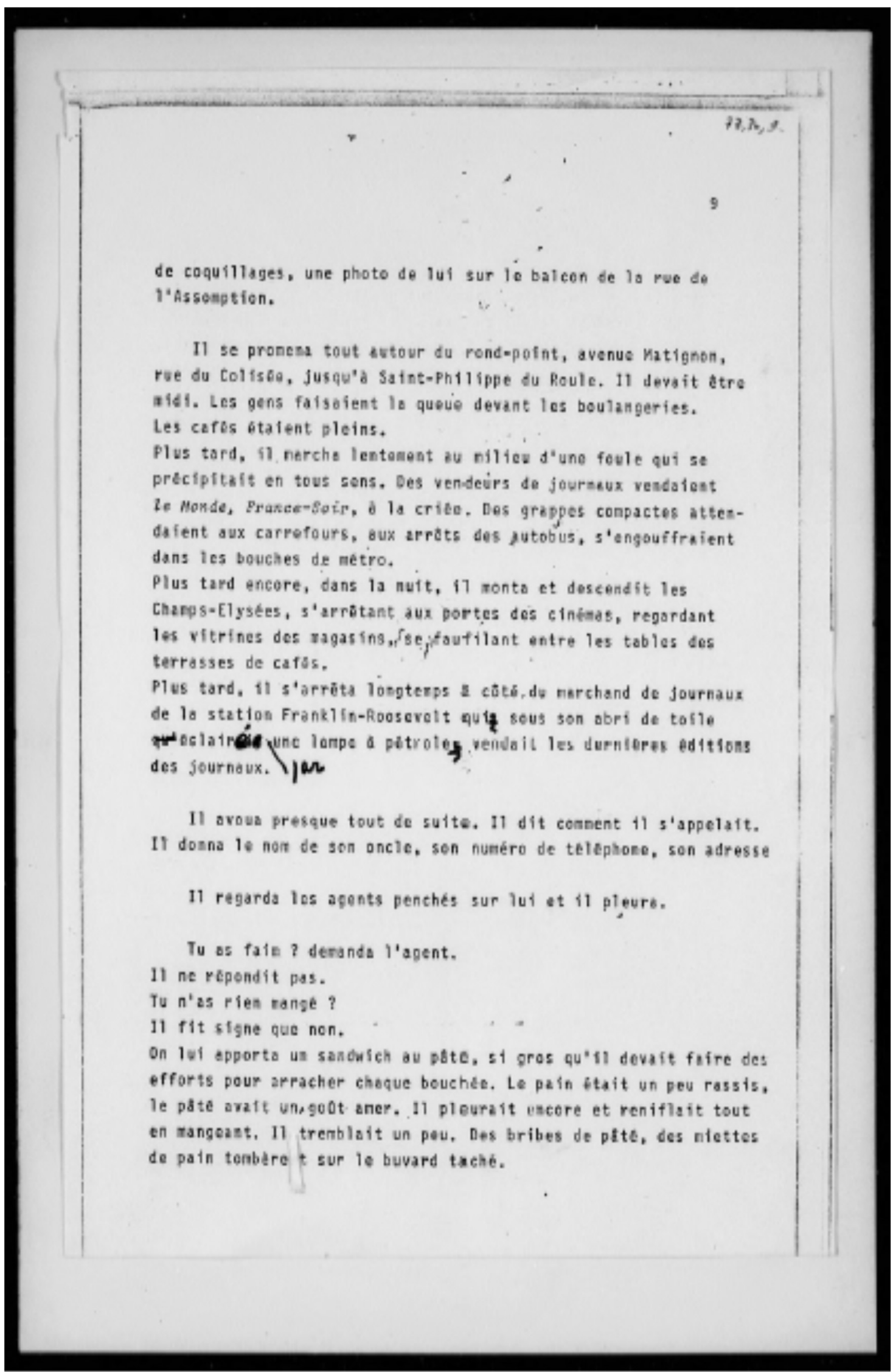




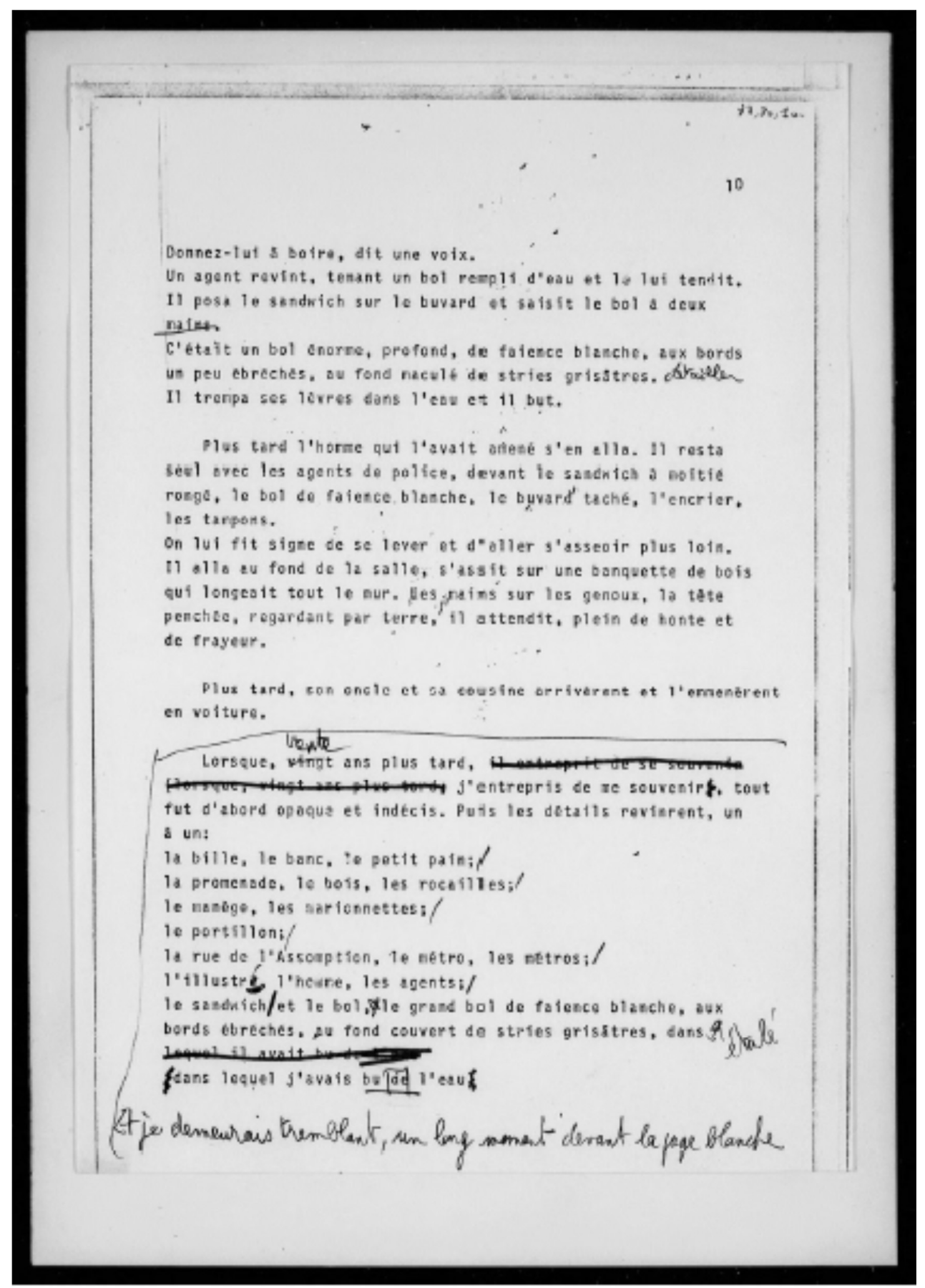




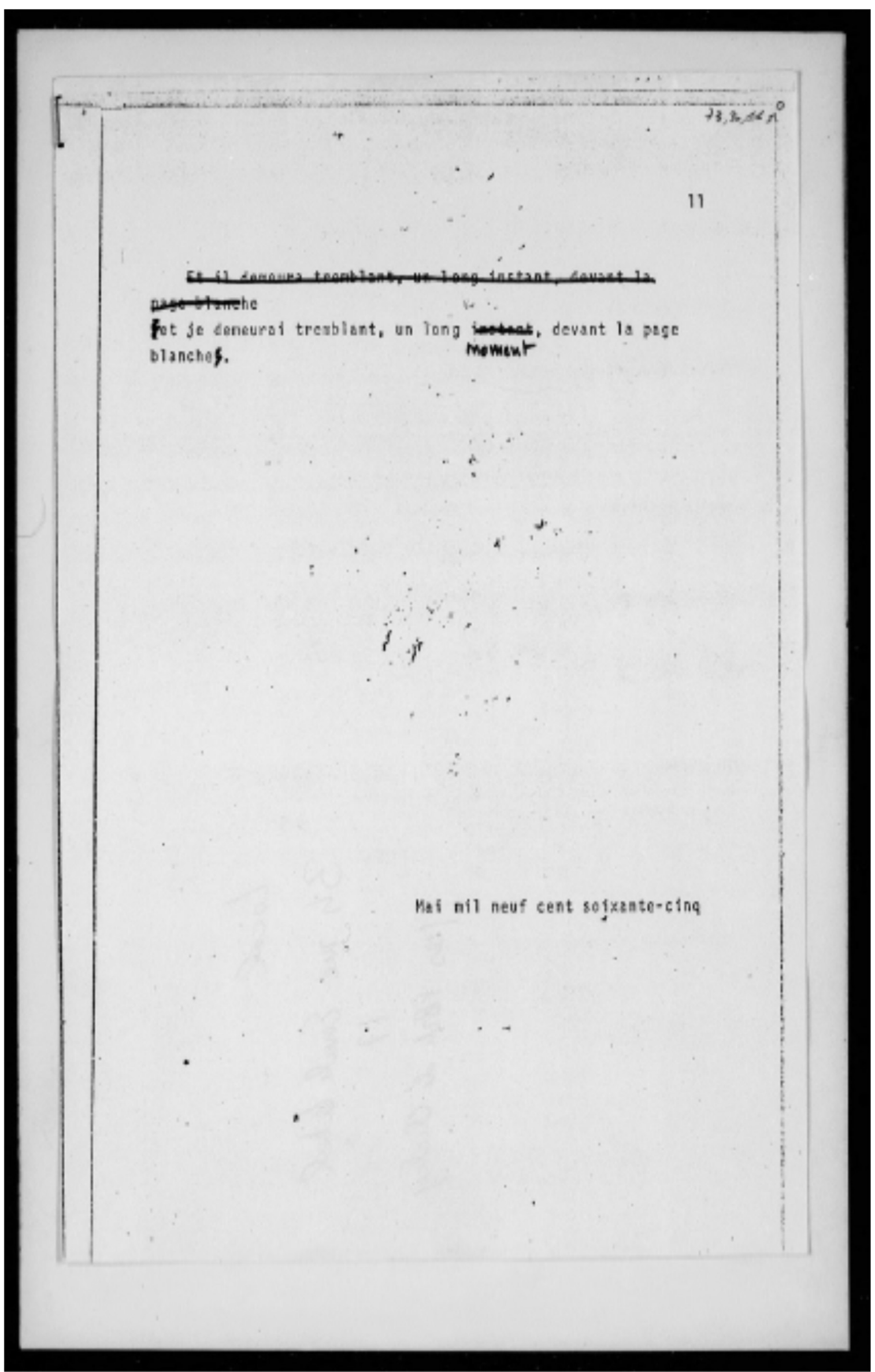


ANEXO 7 - Lista original datilografada, contendo os objetos que compõem cena do "comissariat" em Les lieux d'une fugue

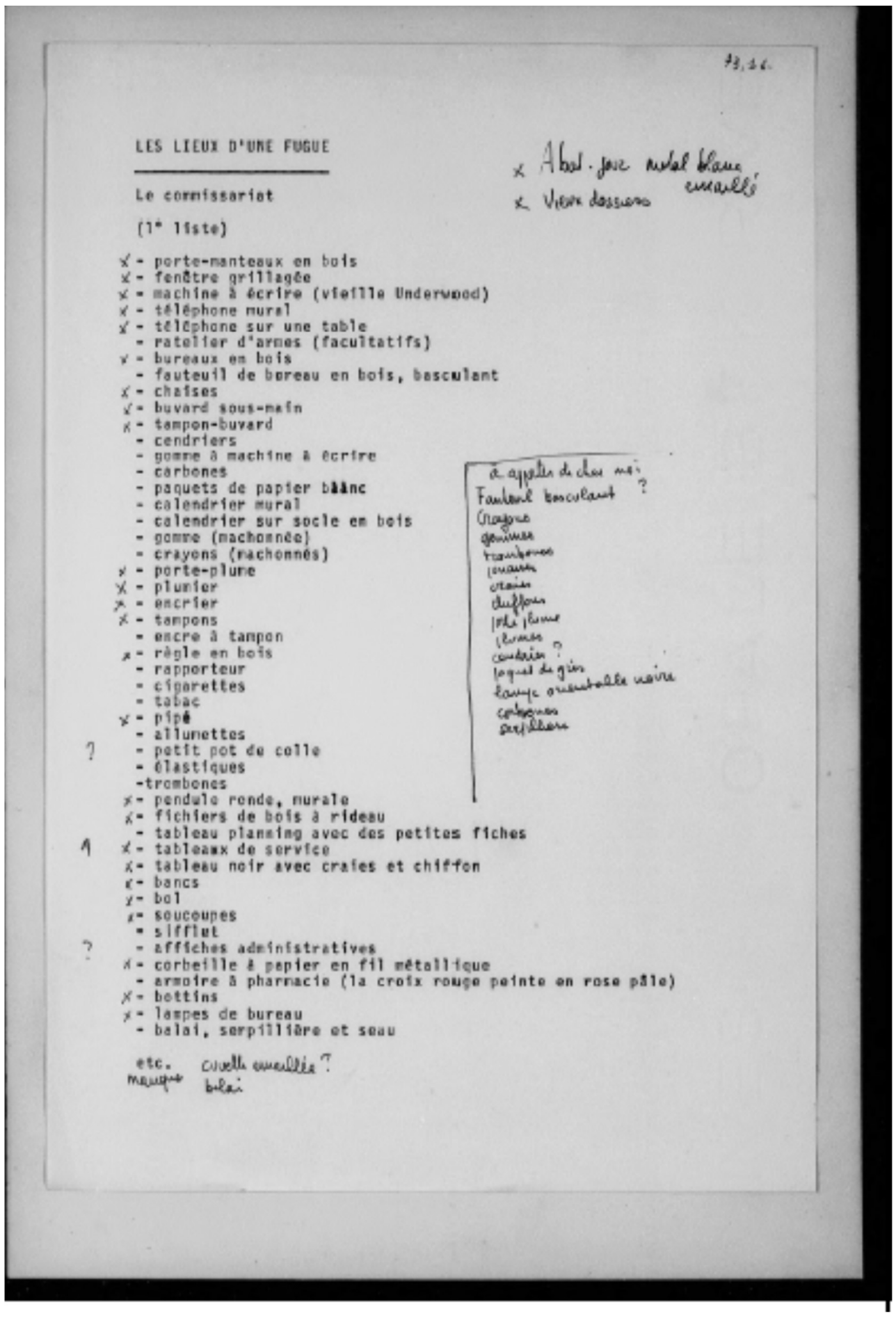




\section{APÊNDICES \\ APÊNDICE 1 - Trechos de Espéces d'espaces que relatam a concepção do projeto \\ Lieux e reflexões gerais sobre o espaço}

$\underline{\text { Les lieux }}$

(Notes sur un travail en cours)

En 1969, j'ai choisi, dans Paris, 12 lieux (des rues, des places, des carrefours, un passage), ou bien dans lesquels j'avais vécu, ou bien auxquels me rattachaient des souvenirs particuliers.

J'ai entrepris de faire, chaque mois, la description de deux de ces lieux. L'une de ces descriptions se fait sur le lieu même et se veut la plus neutre possible : assis dans un café, ou marchant dans la rue, un carnet et un stylo à la main, je m'efforce de décrire les maisons, les magasins, les gens que je rencontre, les affiches, et, d'une manière générale, tous les détails qui attirent mon regard. L'autre description se fait dans un endroit différent du lieu : je m'efforce alors de décrire le lieu de mémoire, et d'évoquer à son propos tous les souvenirs qui me viennent, soit des événements qui s'y sont déroulés, soit des gens que j'y ai rencontrés. Lorsque ces descriptions sont terminées, je les glisse dans une enveloppe que je scelle à la cire. A plusieurs reprises, je me suis fait accompagner sur les lieux que je décrivais par un ou une ami (e) photographe qui, soit librement, soit sur mes indications, a pris des photos que j'ai alors glissées, sans les regarder (à l'exception d'une seule) dans les enveloppes correspondantes ; il m'est arrivé également de glisser dans ces enveloppes divers éléments susceptibles de faire plus tard office de témoignages, par exemple des tickets de métro, ou bien des tickets de consommation, ou des billets de cinéma, ou des prospectus, etc.

Je recommence chaque année ces descriptions en prenant soin, grâce à un algorithme auquel j'ai déjà fait allusion (bi-carré latin orthogonal, celui-ci étant d'ordre 12), premièrement, de décrire chacun de ces lieux en un mois différent de Tannée, deuxièmement, de ne jamais décrire le même mois la même couple de lieux.

Cette entreprise, qui n'est pas sans rappeler dans son principe les «bombes du temps », durera donc douze ans, jusqu'à ce que tous les lieux aient été décrits deux fois douze fois. Trop préoccupé, l'année dernière, par le tournage de "Un homme qui dort » (dans lequel apparaissent, d'ailleurs, la plupart de ces lieux), j'ai en fait sauté l'année 73 et c'est donc seulement en 1981 que je serai en possession (si toutefois je ne prends pas d'autre retard...) des 288 textes issus de cette expérience. Je saurai alors si elle en valait la peine: ce que j'en attends, en effet, n'est rien d'autre que la trace d'un triple vieillissement: celui des lieux eux-mêmes, celui de mes souvenirs, et celui de mon écriture. 
l'espace (suite et fin)

J'aimerais qu'il existe des lieux stables, immobiles, intangibles, intouchés et presque intouchables, immuables, enracinés; des lieux qui seraient des références, des points de départ, des sources :

Mon pays natal, le berceau de ma famille, la maison où je serais né, l'arbre que j'aurais vu grandir (que mon père aurait planté le jour de ma naissance), le grenier de mon enfance empli de souvenirs intacts...

De tels lieux n'existent pas, et c'est parce qu'ils n'existent pas que l'espace devient question, cesse d'être évidence, cesse d'être incorporé, cesse d'être approprié. L'espace est un doute : il me faut sans cesse le marquer, le désigner ; il n'est jamais à moi, il ne m'est jamais donné, il faut que j'en fasse la conquête.

Mes espaces sont fragiles : le temps va les user, va les détruire : rien ne ressemblera plus à ce qui était, mes souvenirs me trahiront, l'oubli s'infiltrera dans ma mémoire, je regarderai sans les reconnaître quelques photos jaunies aux bords tout cassés. Il n'y aura plus écrit en lettres de porcelaine blanche collées en arc de cercle sur la glace du petit café de la rue

Coquillière: «Ici, on consulte le Bottin » et «Casse-crô̂te à toute heure ».

L'espace fond comme le sable coule entre les doigts. Le temps l'emporte et ne m'en laisse que des lambeaux informes :

Écrire : essayer méticuleusement de retenir quelque chose, de faire survivre quelque chose : arracher quelques bribes précises au vide qui se creuse, laisser, quelque part, un sillon, une trace, une marque ou quelques signes. 
APÊNDICE 2 - VILIN RÉEL, publicado como "La rue Vilin"

\section{La rue Vilin}

1

Jeudi 27 février 1969, vers 16 heures

La rue Vilin commence à la hauteur du n 29 de la rue des Couronnes, en face d'immeubles neufs, des HLM récentes qui ont déjà quelque chose de vieux.

Sur la droite (côté pair), un immeuble à trois pans : une façade sur la rue Vilin, une autre sur la rue des Couronnes, la troisième, étroite, décrivant le faible angle que font les deux es entre elles; au rez-de-chaussée, un café-restaurant à la devanture bleu ciel agrémentée de jaune.

Sur la gauche (côté impair), le n 1 a été ravalé récemment. C'était, m'a-t-on dit, l'immeuble où vivaient les parents de ma mère. Il n'y a pas de boîtes aux lettres dans l'entrée minuscule. Au rez-de-chaussée, un magasin, jadis d'ameublement (la trace des lettres MEUBLES est encore visible), qui se réinstalle peut-être en mercerie à en juger par les articles que l'on voit en devanture. Le magasin est fermé et n'est pas éclairé.

Du n 2 parvient une musique de jazz, du revival (Sidney Bechet? ou, plutôt, Maxim Saury).

Du côté impair : un magasin de couleurs

l'immeuble n 3 , récemment ravalé

Confection Bonneterie

«AU BON TRAVAIL »

«LAITERIE PARISIENNE »

A partir du n ${ }^{\circ} 3$, les immeubles cessent d'être ravalés.

$\mathrm{Au}$ 5, une teinturerie « Au Docteur du Vêtement », puis : BESNARD Confection

En face, au 4 : Boutonniériste

Au 7, enseigne de métal découpé : POMPES sur la façade Pompes Couppez et Chapuis : le magasin a l'air fermé depuis longtemps.

Puis, toujours du côté impair, une petite boutique non identifiable.

$\mathrm{Au}$ 9, Restaurant-Bar Marcel

Au 6, Plomberie Sanitaire

Au 6, Coiffeur Soprani

Aux 9 et 11, deux boutiques fermées

$\mathrm{Au}$ 11, Vilin Laverie 
Une palissade de béton, après le 11, fait le coin de la rue Julien-Lacroix.

Au 10, Parage de peaux à façon

$\mathrm{Au} 10$, une ancienne papeterie mercerie

Au 12, faisant le coin : H. Selibter, Pantalons en tous genres.

Il y a des voitures presque tout le long du trottoir impair.

La pente reste sensiblement la même (assez forte) sur toute la rue. La rue est pavée. La rue Julien-Lacroix la croise à peu près au milieu de sa première — et plus longue — portion.

Au croisement (côtés pairs des deux rues), une maison en réfection avec un balcon de fer forgé au premier et la mention, deux fois répétée :

\section{ATTENTION ESCALIER}

Il n'y a pas trace d'escalier ; on comprend un peu plus tard qu'il s'agit des escaliers qui terminent la rue : pour une voiture, à partir de la rue Julien-Lacroix, la rue Vilin devient une impasse.

$\mathrm{Au}$ croisement (côté impair de la rue Vilin, côté pair de l'autre), un magasin d'alimentation dépositaire des Vins Préfontaines (à en croire un panonceau sur la porte) et des Vins du Postillon (d'après la toile pare-soleil).

$\mathrm{Au}$ 19, une longue maison à un seul étage.

$\mathrm{Au}$ 16, un magasin fermé qui aurait pu être une boucherie.

Au 18, un hôtel meublé flanqué d'un café-bar : Hôtel de Constantine.

$\mathrm{Au} 22$, un vieux café, fermé, sans lumières : on distingue une grande glace ovale au fond. Au-dessus, au deuxième étage, un long balcon de fer forgé, du linge qui sèche. Sur la porte du café, un écriteau :

\section{LA MAISON EST FERMÉE LE DIMANCHE}

Au 24 (c'est la maison où je vécus) : 
D'abord un bâtiment à un étage, avec, au rez-de-chaussée, une porte (condamnée) ; tout autour, encore des traces de peinture et au-dessus, pas encore tout à fait effacée, l'inscription

\section{COIFFURE DAMES}

Puis un bâtiment bas avec une porte qui donne sur une longue cour pavée avec quelques décrochements (escaliers de deux ou trois marches). A droite, un long bâtiment à un étage (donnant jadis sur la rue par la porte condamnée du salon de coiffure) avec un double perron de béton (c'est dans ce bâtiment-là que nous vivions; le salon de coiffure était celui de ma mère).

Au fond, un bâtiment informe. A gauche, des espèces de clapiers.

Je ne suis pas rentré.

Un vieil homme, venant du fond, a descendu les trois marches qui menaient à « notre » logement. Un autre vieil homme est entré avec un lourd ballot (de linge ?) sur le dos. Puis, à la fin, une petite fille.

$\mathrm{Au} 25$, en face, une maison à double porche donnant sur une cour longue et sombre et un magasin qui semble fermé mais d'où émane un bruit régulier : comme des coups de marteau, mais plus « mécanique » et moins fort ; à travers une vitre sale, on peut identifier une machine à coudre, mais nul artisan.

$\mathrm{Au}$ 27, un magasin fermé « La Maison du Taleth » avec, encore visibles, des signes hébraïques et les mots MOHEL, CHOHET, LIBRAIRIE PAPETERIE, ARTICLES DE CULTE, JOUETS sur une façade d'un bleu délavé.

A l'emplacement du 29, une palissade en moellons d'un blanc récent. Des traces de chambres à papiers peints jaunes et jaunis sont visibles sur le flanc du 31 .

Le 31 est une maison condamnée. Les fenêtres des deux premiers étages sont bouchées. Il y a encore des rideaux au troisième. Au rez-de-chaussée un magasin condamné

FORCE

LUMIÈRE

\section{A. MARTIN}

BOBINAGE

MOTEUR

INSTALLATION GÉNÉRALE D’USINE 
Au 33, un immeuble condamné.

La rue fait alors, sur la droite, un angle d'environ $30^{\circ}$. Du côté pair, la rue s'arrête au n 38 ; il y a ensuite une cabane de briques rouges, puis l'arrivée d'un escalier venant du passage Julien-Lacroix qui part lui aussi, mais un peu plus bas que la rue Vilin, de la rue des Couronnes. Puis un grand terrain vague, avec des caillasses et des herbes pelées.

Du côté impair, la rue fait, à la hauteur du n ${ }^{\circ} 49$, sur la gauche, un deuxième angle, également d'environ $30^{\circ}$ : cela donne à la rue l'allure générale d'un $\mathrm{S}$ très allongé (comme dans le sigle 4 ५).

Du côté impair, la rue se termine à la hauteur des n ${ }^{\text {os }} 53-55$ par un escalier, ou plutôt par trois escaliers esquissant eux aussi une double sinusoïté (moins la forme d'un S que celle d'un point d'interrogation à l'envers).

Le 49 est une maison jaune avec un deuxième étage mansardé en zinc. Deux fenêtres au premier. A l'une (celle de droite pour moi), une vieille dame qui me regarde. Au rez-de-chaussée, il y avait (autrefois ?) une « ENTREPRISE DE MAÇONNERIE ».

u 47, une maison condamnée avec des traces de peinture rouge sur les murs. Au 45, un magasin fermé et un immeuble à trois étages qui fut l'

\section{HÔTEL DU MONT-BLANC}

Chambres et Cabinets Meublés

$\mathrm{Au}$ 34, un ancien Vins et Liqueurs.

Partout des fenêtres aveugles.

Au 53-55, il y avait un Vins \& Charbons «AU REPOS DE LA MONTAGNE » : l'immeuble s'est fendu en son milieu, de haut en bas, le 5-4-68 (ce sont les dates inscrites sur les plâtres-tests). On a muré les trois portes aux trois fenêtres au premier.

En haut des escaliers, on arrive à un petit carrefour donnant sur la rue Piat à gauche, la rue des Envierges en face, la rue du Transvaal à droite. Au croisement de la rue des Envierges et de la rue du Transvaal, il y a une belle boulangerie ocre. Le long de la balustrade de l'escalier, à côté d'un lampadaire, il y a un vélomoteur bariolé de couleurs vives imitant une peau de fauve. Deux Algériens s'accoudent un instant. Deux Noirs montent les escaliers. Malgré le temps plutôt couvert, on découvre un panorama assez vaste : des églises, de hauts immeubles neufs, le Panthéon?

Dans le terrain vague, deux enfants se battent en duel avec des épées-tringles. 
A sept heures du soir, je suis repassé, presque en courant, pour voir à quoi la rue Vilin ressemblait la nuit tombée. Il y a très peu de fenêtres allumées — à peine deux par immeuble — dans la portion supérieure de la rue, mais davantage au début. Le vieux café du 22 était allumé, plein d'Algériens. C'est également un hôtel (j'ai vu un écriteau « Prix des Chambres »).

Plusieurs magasins que j'avais cru définitivement fermés sont éclairés.

2

Jeudi 25 juin 1970 vers 16 heures

On installe le marché sur le boulevard de Belleville. Travaux de voirie qui se continuent rue des Couronnes. Immeuble en construction au coin de la rue J.-P.-Timbaud. Tout un pâté de maisons détruit au coin de la rue des Couronnes. Un peu plus loin sur le boulevard, des cars de CRS (incidents récents entre Juifs et Arabes).

La rue Vilin est en sens interdit; on ne peut la monter. Les voitures sont garées du côté impair.

Le 1 et le 3 sont ravalés. Au 1, il y a un magasin d'alimentation fermé et une mercerie encore ouverte. Au deuxième étage, un homme est à sa fenêtre.

Au 3, un magasin de couleurs et une bonneterie. La marchande du magasin de couleurs me prend pour un officiel :

- Alors, vous venez nous détruire?

$\mathrm{Au}$ 2, un café-restaurant, au 4, un boutonniériste. Travaux de voirie : installation du gaz de Lacq.

Au 5, Laiterie Parisienne, Au Docteur du Vêtement, Teinturerie Réparations. Besnard Confection.

On entend venant de plus haut de la musique arabe.

Au 6, Plomberie Sanitaire. Coiffure A. Soprani, Nocturne le Jeudi (le magasin semble refait à neuf).

Au 7, Pompes COUPEZ (fermé) : deux étages sur trois sont murés. Un autre magasin fermé. Une petite annonce aux crayons-feutres, effacée sauf le rouge : Je vends mardi mercredi

Le 8 est une maison à trois étages, avec deux femmes aux fenêtres. Au 9, le restaurant-bar MARCEL et une boutique fermée. Au 10, fermé, Parage de Peaux à Façon et fermée également une papeterie-mercerie. Au 11, un magasin fermé ; au 13, une laverie à la façade d'un bleu délavé. Un appartement est muré au second étage. Le 12 est un 
immeuble de cinq étages. Au rez-de-chaussée, Selibter, Pantalons en Tous Genres. Au 14, une maison condamnée et aussi au 15 (croisement de la rue Julien-Lacroix). Au 16, une ancienne boucherie ? Au 17, un ancien magasin d'alimentation est devenu un barcafé (on a peint « BAR CAFÉ » en blanc sur la porte). Au 18 : Hôtel de Constantine Hôtel meublé Café-Bar. Le 19, le 21 et le 23 sont des maisons à un étage, délabrées ; le 20 est une maison de quatre étages, délabrée, le quatrième étage semble condamné. Au 22, un café-hôtel ? Au 24, dans la courette, il y a un chat sur une soute à charbon. L'inscription COIFFURE DAMES est encore visible. Affiches du PC. Au 25, un magasin fermé. Au 26, un rez-de-chaussée condamné. Au 27, un magasin fermé. Puis, jusqu'au n 41, une palissade en ciment. Au 30, une maison de deux étages, partiellement murée ; un magasin de mode. Au 32, des boutiques condamnées (Vins \& Liqueurs). Le 34 est presque entièrement muré. Après le $\mathrm{o}^{\mathrm{o}} 36$ commence le terrain vague.

Du n $^{\circ} 41$ au n ${ }^{\circ} 49$, presque tous les immeubles sont murés, dont, au n ${ }^{\circ} 45$, l'HÔTEL DU MONT-BLANC. Au n ${ }^{\circ} 49$, une maison jaune, ancienne maçonnerie, il y a une dame à la fenêtre du premier. Le 51, le 53, le 55 sont des survivances (A LA MONTAGNE, Vins \& Liqueurs).

3

Mercredi 13 janvier 1971

Froid sec. Soleil.

u-dessus de la porte du $\mathrm{n}^{\mathrm{o}} 1$, il y a un fronton triangulaire. Le magasin de gauche, peint en bleu, avec une tente rouge déchirée pendante, est fermé. Le magasin de droite vend peut-être des fournitures pour tailleurs. Au n 3 , un magasin de couleurs et « Au bon accueil », Confection, Bonneterie. Au n ${ }^{\circ}$, café-restaurant. Au n ${ }^{\circ} 4$, boutonniériste. Au $\mathrm{n}^{\circ}$ 5, Laiterie Parisienne et Au Docteur du Vêtement, Teinturerie, Pressing, Besnard, Confection. Au 7, un immeuble démoli, avec une palissade sur laquelle La Cause $d u$ peuple est affichée. Au 6, Plomberie Sanitaire et Coiffure. Au 9, un café restaurant bar : MARCEL'S, et un magasin fermé. Au 11, un magasin fermé et VILIN-LAVERIE (au coin de la rue Julien-Lacroix) :

Pour Expropriation

Fermeture Définitive

le 24 décembre

Au 10, Parage de peaux à façon et une papeterie-mercerie fermée. Au 12, Pantalons en tous genres. Au 14, une maison fermée, au 15, une maison démolie. Au 17, Bar Caves ; sur la tente : CHEZ HADDADI FARID; sur la porte : 


\section{Novo Otvoren}

Jugoslovenski

Cafe-restoran

Kod Milene

La boucherie verte est fermée, ainsi qu'un autre magasin. Au n ${ }^{0} 18$ : HÔTEL DE CONSTANTINE, café-bar ; au 22, un hôtel-café ; au 19 et au 21, maisons condamnées ? au 26 ? Au 24 : coiffure dames (pas le magasin, seulement la trace de l'enseigne peinte sur le mur) ; dans la cour du 24, des poutrelles de métal ; des ouvriers en face réparent un toit (d'un immeuble rue des Couronnes ?) Au loin des grues.

5, 27 : des magasins fermés ; à partir du 27 : des palissades. Au 28, une maison encore habitée ; au 30, un magasin de modes avec l'inscription MODES en anglaises ; au 32 : Vins \& Liqueurs fermé. Le 34 et le 36 sont des taudis. Du 36, une dame sort : elle vit là depuis 36 ans; elle n'était venue que pour trois mois; elle se souvient très bien de la coiffeuse du 24 :

— Elle n'est pas restée très longtemps.

Le 41, le 43, le 45 (Hôtel du Mont-Blanc), le 47 sont des immeubles bouchés. Ensuite des palissades.

Des voitures tout au long de la rue. Quelques passants.

$\mathrm{Au} 49$, une dame tousse à la fenêtre. Le 51 est une maison condamnée. Le 53-55 (Le Repos de la Montagne, vins) est fermé. Tout en haut un terrain vague. Un hangar avec un panonceau neuf :

\section{APPLICATIONS PLASTIQUES}

4

Dimanche 5 novembre 1972 vers quatorze heures

Le n 1 est toujours là. Le 2, le 3 : couleurs et confection « Au bon accueil »; le 4 : Boutonniériste (fermé) ; le 5 : Laiterie devenue plomberie ? Le 6 : coiffure. Le 7 détruit. Le 8, le 9 ? Le 10 : parage de peaux; le 11 détruit; le 12 : Selibter, le 13 détruit; le 14 : un immeuble détruit, une boutique encore debout; le 15 entièrement détruit. Le 16 ? Le 17 : bar-caves. Le 18 : Hôtel de Constantine. 19 ? 20 ? 21 détruit. 22 : Hôtel-café. 23 ? 24 toujours intact, 25 : un magasin fermé ; 26 : des fenêtres murées, 27 muré, 28, 30, 36 toujours debout.

Un chat tigré et un chat noir dans la cour du 24. 
Après le 27, côté impair, plus rien ; après le 36, côté pair, plus rien. Sur l'immeuble du n 30, des affiches de Johnny Halliday.

Tout en haut : APPLICATIONS PLASTIQUES.

Dans le terrain vague il y a un chantier de démolitions.

Des pigeons, des chats, des carcasses de voitures.

J'ai rencontré un enfant de 10 ans ; il est né au 16 : il part dans son pays, Israël, dans huit semaines.

5

Jeudi 21 novembre 1974, vers 13 heures

Les HLM en bas de la rue des Couronnes sont terminées.

Le bas de la rue Vilin semble encore un peu vivant : tas d'ordures amoncelées, du linge qui pend aux fenêtres.

Le 1 est encore intact. Au n 7, il y a un terrain vague et une palissade ; Besnard Confection, au 5, est fermé ; au 9, le restaurant bar MARCEL'S est fermé ; au 6, il y a un magasin (de coiffure) ouvert et un magasin fermé ; au 4, un boutonniériste ?

Au croisement de la rue Vilin et de la rue Julien-Lacroix, il n'y a plus de debout que Selibter, Pantalons ; les trois autres coins sont occupés, deux par des terrains vagues, l'autre par un immeuble entièrement muré.

Le 18 et le 22 sont des cafés hôtels encore debout, ainsi que le 20 et le 24 .

Du côté impair, le 21 est en démolition (on voit des bulldozers, des excavatrices, des feux), le 23 et le 25 sont éventrés. Après le 25 plus rien.

A la place du 26, une petite remorque aménagée en cabane. Des carcasses de voitures.

Tas d'ordures non ramassées (rue Julien-Lacroix, des soldats du contingent remplacent les éboueurs en grève).

Un moineau mort au milieu de la chaussée.

Au n 30 , une affichette :

Bulletin municipal officiel de la ville de Paris

25-26-27 août 1974

Expropriation du 28 et 30

Création d'un espace libre public à Paris $20^{\mathrm{e}}$ 
Rien au-delà du 30. Des palissades, des terrains vagues où s'affairent des casseurs de voitures. Des affiches électorales sur les palissades.

6

27 septembre 1975, vers 2 heures du matin

La quasi-totalité du côté impair est couverte de palissades en ciment. Sur l'une d'elles un graffiti :

TRAVAIL $=$ TORTURE 
APÊNDICE 3 - Approches de quoi?

\section{Approches de quoi ?}

Ce qui nous parle, me semble-t-il, c'est toujours l'événement, l'insolite, l'extraordinaire : cinq colonnes à la une, grosses manchettes. Les trains ne se mettent à exister que lorsqu'ils déraillent, et plus il y a de voyageurs morts, plus les trains existent; les avions n'accèdent à l'existence que lorsqu'ils sont détournés; les voitures ont pour unique destin de percuter les platanes : cinquante-deux week-ends par an, cinquante-deux bilans : tant de morts et tant mieux pour l'information si les chiffres ne cessent d'augmenter ! Il faut qu'il ait derrière l'événement un scandale, une fissure, un danger, comme si la vie ne devait se révéler qu'à travers le spectaculaire, comme si le parlant, le significatif était toujours anormal : cataclysmes naturels ou bouleversements historiques, conflits sociaux, scandales politiques...

Dans notre précipitation à mesurer l'historique, le significatif, le révélateur, ne laissons pas de côté l'essentiel : le véritablement intolérable, le vraiment inadmissible : le scandale, ce n'est pas le grisou, c'est le travail dans les mines. Les « malaises sociaux » ne sont pas « préoccupants » en période de grève, ils sont intolérables vingt-quatre heures sur vingt-quatre, trois cent soixante-cinq jours par an.

Les raz-de-marée, les éruptions volcaniques, les tours qui s'écroulent, les incendies de forêts, les tunnels qui s'effondrent, Publicis qui brûle et Aranda qui parle ! Horrible! Terrible! Monstrueux! Scandaleux ! Mais où est le scandale ? Le vrai scandale ? Le journal nous a-t-il dit autre chose que : soyez rassurés, vous voyez bien que la vie existe, avec ses hauts et ses bas, vous voyez bien qu'il se passe des choses.

Les journaux parlent de tout, sauf du journalier. Les journaux m'ennuient, ils ne m'apprennent rien; ce qu'ils racontent ne me concerne pas, ne m'interroge pas et ne répond pas davantage aux questions que je pose ou que je voudrais poser.

Ce qui se passe vraiment, ce que nous vivons, le reste, tout le reste, où est-il ? Ce qui se passe chaque jour et qui revient chaque jour, le banal, le quotidien, l'évident, le commun, l'ordinaire, l'infra-ordinaire, le bruit de fond, l'habituel, comment en rendre compte, comment l'interroger, comment le décrire ?

Interroger l'habituel. Mais justement, nous y sommes habitués. Nous ne l'interrogeons pas, il ne nous interroge pas, il semble ne pas faire problème, nous le vivons sans y penser, comme s'il ne véhiculait ni question ni réponse, comme s'il n'était porteur 
d'aucune information. Ce n'est même plus du conditionnement, c'est de l'anesthésie. Nous dormons notre ie d'un sommeil sans rêves. Mais où est-elle, notre vie ? Où est notre corps ? Où est notre espace?

Comment parler de ces «choses communes», comment les traquer plutôt, comment les débusquer, les arracher à la gangue dans laquelle elles restent engluées, comment leur donner un sens, une langue : qu'elles parlent enfin de ce qui est, de ce que nous sommes.

Peut-être s'agit-il de fonder enfin notre propre anthropologie : celle qui parlera de nous, qui ira chercher en nous ce que nous avons si longtemps pillé chez les autres. Non plus l'exotique, mais l'endotique.

Interroger ce qui semble tellement aller de soi que nous en avons oublié l'origine. Retrouver quelque chose de l'étonnement que pouvaient éprouver Jules Verne ou ses lecteurs en face d'un appareil capable de reproduire et de transporter les sons. Car il a existé, cet étonnement, et des milliers d'autres, et ce sont eux qui nous ont modelés.

Ce qu'il s'agit d'interroger, c'est la brique, le béton, le verre, nos manières de table, nos ustensiles, nos outils, nos emplois du temps, nos rythmes. Interroger ce qui semble avoir cessé à jamais de nous étonner. Nous vivons, certes, nous respirons, certes ; nous marchons, nous ouvrons des portes, nous descendons des escaliers, nous nous asseyons à une table pour manger, nous nous couchons dans un lit pour dormir. Comment? Où ? Quand ? Pourquoi ?

Décrivez votre rue. Décrivez-en une autre. Comparez.

Faites l'inventaire de vos poches, de votre sac. Interrogez-vous sur la provenance, l'usage et le devenir de chacun des objets que vous en retirez.

Questionnez vos petites cuillers.

Qu'y a-t-il sous votre papier peint ?

Combien de gestes faut-il pour composer un numéro de téléphone ? Pourquoi ?

Pourquoi ne trouve-t-on pas de cigarettes dans les épiceries ? Pourquoi pas ?

Il m'importe peu que ces questions soient, ici, fragmentaires, à peine indicatives d'une méthode, tout au plus d'un projet. Il m'importe beaucoup qu'elles semblent triviales et futiles : c'est précisément ce qui les rend tout aussi, sinon plus, essentielles que tant d'autres au travers desquelles nous avons vainement tenté de capter notre vérité. 
APÊNDICE 4 - Quelques-unes des choses qu'il faudrait tout de même que je fasse avant de mourir

Il y a d'abord des choses très faciles à faire, des choses que je pourrais faire dès aujourd'hui, par exemple

Faire une promenade sur les bateaux-mouches[1]

Ensuite des choses un tout petit peu plus importantes, des choses qui impliquent des décisions, des choses dont je me dis que, si je les faisais, elles me rendraient peut-être la vie plus facile, par exemple

Me décider à jeter un certain nombre de choses que je garde sans savoir pourquoi je les garde[2]

ou bien

Ranger une fois pour toutes ma bibliothèque[3]

Faire 1'acquisition de divers appareils électroménagers[4]

ou encore

M'arrêter de fumer[5]

(avant d'y être obligé...)

Ensuite des choses liées à des désirs plus profonds de changement, par exemple

M'habiller d'une façon tout à fait différente[6]

Vivre à l'hôtel (à Paris)[7]

Vivre à la campagne[8]

Aller vivre pendant assez longtemps dans une grande ville étrangère (Londres) [9]

Ensuite des choses qui sont liées à des rêves de temps ou d'espace. Il y en a pas mal :

Passer par l'intersection de l'Équateur et de la ligne de changement de date[10]

Aller au-delà du cercle polaire[11]

Vivre une expérience « hors du temps » (comme Siffre)[12]

Faire un voyage en sous-marin[13]

Faire un long voyage sur un navire [14]

Faire une ascension ou un voyage en ballon ou dirigeable[15]

Aller aux îles Kerguelen (ou à Tristan da Cunha)[16]

Aller du Maroc à Tombouctou à dos de chameau en 52 jours[17] 
Ensuite, parmi toutes les choses que je ne connais pas encore, il y en a certaines que je voudrais avoir le temps de bien découvrir :

J'aimerais aller dans les Ardennes[18]

J'aimerais aller à Bayreuth, mais aussi à Prague et à Vienne[19]

J'aimerais aller au Prado[20]

J'aimerais boire du rhum trouvé au fond de la mer (comme le capitaine Haddock dans

Le Trésor de Rackham le Rouge)[21]

J'aimerais avoir le temps de lire Henry James (entre autres)[22]

J'aimerais voyager sur des canaux[23]

ly a ensuite beaucoup de choses que j'aimerais apprendre, mais je sais que je ne le ferai pas, parce que cela me prendrait trop de temps, ou parce que je sais que je n'y arriverais que très imparfaitement, par exemple

Trouver la solution du cube hongrois [24]

Apprendre à jouer de la batterie[25]

Apprendre 1'italien[26]

Apprendre le métier d'imprimeur[27]

Faire de la peinture[28]

Ensuite des choses liées à mon travail d'écrivain. Il y en a beaucoup. Ce sont, pour la plupart, des projets vagues; les uns sont tout à fait possibles, ne dépendent que de moi, par exemple

Écrire pour de tout petits enfants[29]

Écrire un roman de science-fiction[30]

d'autres dépendent de demandes qui pourraient m'être faites :

Écrire un scénario de film d'aventures dans lequel on verrait, par exemple, 5000 Kirghizes cavaler dans la steppe [31]

Écrire un vrai roman-feuilleton[32]

Travailler avec un dessinateur de BD

Écrire des chansons (pour Anna Prucnal par exemple)[34] 
Il y a encore une chose que j'aimerais faire, mais je ne sais pas où elle se place, c'est Planter un arbre (et le regarder grandir)[35]

Et il y a enfin des choses qu'il est désormais impossible d'envisager mais qui auraient été possibles il n'y a pas si longtemps par exemple

Me soûler avec Malcolm Lowry[36]

Faire la connaissance de Vladimir Nabokov[37]

etc. etc.

Il y en a certainement beaucoup d'autres

Je m'arrête volontairement à 37 


\section{Ellis Island \\ Description d'un projet}

La statue de la Liberté, qu'il observait depuis longtemps, lui apparut dans un sursaut de lumière. On eût dit que le bras qui brandissait l'épée s'était levé à l'instant même, et l'air libre soufflait autour de ce grand corps.

Franz Kafka, L'Amérique.

Être émigrant, c'était peut-être très précisément cela: voir une épée là où le sculpteur a cru, en toute bonne foi, mettre une lampe. Et ne pas avoir réellement tort. Car au moment même où l'on gravait sur le socle de la statue de la Liberté les vers célèbres d'Emma Lazarus

Donnez-moi ceux qui sont las, ceux qui sont pauvres,

Vos masses entassées assoiffées d'air pur,

Les rebuts misérables de votre terre surpeuplée,

Envoyez-les-moi, ces sans-patrie ballottés par la tempête,

Je lève ma lampe près de la porte d'or...

toute une série de lois était mise en place pour tenter de contrôler et un peu plus tard de contenir l'afflux incessant des émigrants venus d'Italie du Sud, d'Europe centrale et de Russie. Pratiquement libre jusque vers 1875, l'entrée des étrangers sur le sol des États-Unis avait été progressivement soumise à des mesures restrictives, d'abord élaborées et appliquées à l'échelon local (autorités municipales et portuaires), ensuite regroupées au sein d'un Secrétariat à l'Immigration dépendant du gouvernement fédéral. Ouvert en 1892 sur un petit îlot de quelques hectares situé à quelques centaines de mètres de Liberty Island, le centre d'accueil d'Ellis Island marque la fin d'une émigration quasi sauvage et l'avènement d'une émigration officialisée, institutionnalisée et, pour ainsi dire, industrielle. De 1892 à 1924, près de seize millions de personnes passeront par Ellis Island, à raison de cinq à dix mille par jour. La plupart n'y séjourneront que quelques heures; deux à trois pour cent seulement seront refoulés. En somme, Ellis Island ne sera rien d'autre qu'une usine à fabriquer des Américains, une usine à transformer des émigrants en immigrants, une usine à l'américaine, aussi rapide et efficace qu'une charcuterie de Chicago : à un bout de la chaîne, on met un Irlandais, un Juif d'Ukraine ou un Italien des Pouilles, à l'autre bout - après inspection des yeux, inspection des poches, 
vaccination, désinfection - il en sort un Américain. Mais en même temps, au fil des années, les conditions d'admission deviennent de plus en plus strictes. Petit à petit, se referme la «golden door» de cette Amérique fabuleuse où les dindes tombent toutes rôties dans les assiettes, où les rues sont pavées d'or, où la terre appartient à tous. En fait, à partir de 1914, l'émigration commence à s'arrêter, d'abord à cause de la guerre, ensuite à cause d'une série de mesures discriminatives qualitatives (Literacy Act) et quantitatives (quotas) interdisant pratiquement aux « rebuts misérables » et aux «masses entassées » l'entrée des Etats-Unis. En 1924, les formalités d'immigration seront confiées aux consulats américains en Europe et Ellis Island ne sera plus qu'un centre de détention pour les émigrants en situation irrégulière. Pendant et immédiatement après la Seconde Guerre mondiale, Ellis Island, allant jusqu'au bout de sa vocation implicite, deviendra une prison pour les individus soupçonnés d'activités anti-américaines (fascistes italiens, Allemands pronazis, communistes ou présumés tels). En 1954, Ellis Island sera définitivement fermé. C'est aujourd'hui un monument national, comme le mont Rushmore, l'Old Faithful et la statue de Bartholdi, administré par des Rangers coiffés de chapeaux scouts qui le font visiter, six mois par an, quatre fois par jour.

Mon propos n'est pas ici d'évoquer ce que purent être les rêves et les désillusions de ces millions d'émigrants pour qui Ellis Island fut la première étape d'une vie qu'ils voulaient nouvelle, ni de retracer les circonstances qui m'ont conduit à faire avec Robert Bober un film sur Ellis Island, mais seulement de mieux cerner ce que peut être ma propre attache à ce lieu : il est pour moi le lieu même de l'exil, c'est-à-dire le lieu de l'absence de lieu, le lieu de la dispersion. En ce sens, il me concerne, me fascine, m'implique, me questionne, comme si la recherche de mon identité passait par l'appropriation de ce lieu dépotoir où des fonctionnaires harassés baptisaient des Américains à la pelle, comme s'il était inscrit quelque part dans une histoire qui aurait pu être la mienne, comme s'il faisait partie d'une autobiographie probable, d'une mémoire potentielle. Ce qui se trouve là, ce ne sont en rien des racines ou des traces, mais le contraire : quelque chose d'informe, à la limite du dicible, que je peux nommer clôture, ou scission, ou cassure, et qui est pour moi très intimement et très confusément lié au fait même d'être juif.

Je ne sais pas précisément ce que c'est qu'être juif, ce que ça me fait que d'être juif. C'est une évidence, si l'on veut, mais une évidence médiocre, une marque, mais une marque qui ne me rattache à rien de précis, à rien de concret : ce n'est pas un signe d'appartenance, ce n'est pas lié à une croyance, à une religion, à une pratique, à une culture, à un folklore, à une histoire, à un destin, à une langue. Ce serait plutôt une 
absence, une question, une mise en question, un flottement, une inquiétude : une certitude inquiète derrière laquelle se profile une autre certitude, abstraite, lourde, insupportable : celle d'avoir été désigné comme juif, et parce que juif victime, et de ne devoir la vie qu'au hasard et qu'à l'exil. Mes grands-parents ou mes parents auraient pu émigrer en Argentine, aux États-Unis, en Palestine, en Australie ; j'aurais pu naître, comme des cousins proches ou lointains, à Haïfa, à Baltimore, à Vancouver, mais dans l'éventail à peu près illimité de ces possibles, une seule chose m'était précisément interdite, celle de naître dans le pays de mes ancêtres, en Pologne, à Lubartow, à Pulawy ou à Varsovie, et d'y grandir dans la continuité d'une tradition, d'une langue, d'une appartenance.

Je suis né en France, je suis français, je porte un prénom français, Georges, un nom français, presque : Perec. La différence est minuscule : il n'y a pas d'accent aigu sur le premier $e$ de mon nom, parce que Perec est la graphie polonaise de Peretz. Si j'étais né en Pologne, je me serais appelé, mettons, Mordechai Perec, et tout le monde aurait su que j'étais juif. Mais je ne suis pas né en Pologne, heureusement pour moi, et j'ai un nom presque breton, que tout le monde orthographie Pérec ou Perrec : mon nom ne s'écrit pas exactement comme il se prononce.

A cette insignifiante contradiction s'accroche le sentiment ténu, mais insistant, insidieux, incontournable, d'être quelque part étranger par rapport à quelque chose de moi-même, d'être «différent», mais non pas tellement différent des «autres » que différent des « miens » : je ne parle pas la langue que mes parents parlaient, je ne partage aucun des souvenirs qu'ils purent avoir. Quelque chose qui était à eux, qui faisait qu'ils étaient eux, leur histoire, leur culture, leur croyance, leur espoir, ne m'a pas été transmis.

La conscience de cette dépossession ne s'accompagne d'aucune nostalgie, d'aucune prédilection pour ce qui serait plus proche de moi parce que juif. J'écris, depuis plusieurs années, à partir des souvenirs que m'a transmis ma tante, une histoire de ma famille, essayant de retracer ce que fut leur aventure, leur errance, ce long cheminement improbable qui les a menés partout et nulle part, cet éclatement continuel dont les survivants n'ont plus rien de commun sinon d'avoir tous été, quelque part, privés de leur histoire. Mais je n'ai pas envie d'aller vérifier si la grande maison carrée que mon grandpère fit construire à Lubartow est toujours debout. D'ailleurs elle ne l'est plus : il n'y a plus de Juifs à Lubartow, pas plus qu'il n'en reste à Radom où Robert Bober est allé en vain rechercher les souvenirs de son père.

Ce que je suis allé chercher sur Ellis Island, c'est l'image même de ce point de nonretour, la conscience de cette rupture radicale. Ce que j' ai voulu interroger, mettre en 
question, mettre à l'épreuve, c'est mon propre enracinement dans ce non-lieu, cette absence, cette brisure sur laquelle se fonde toute quête de la trace, de la parole, de l'Autre.

A l'heure où des dizaines de milliers de Vietnamiens et de Cambodgiens dérivent sur des embarcations pourries à la recherche de refuges de plus en plus hostiles, il peut sembler sinon tout à fait futile, du moins singulièrement complaisant, de revenir s'apitoyer sur ces histoires déjà anciennes. Mais à travers l'approche de cette île abandonnée, à travers le dialogue que j'ai tenté de nouer avec quelques-uns de ceux - Juifs et Italiens - qui passèrent jadis par Ellis Island, il me semble que je suis par instants arrivé à faire résonner quelques-uns de ces mots qui sont pour moi inexorablement attachés au nom même de Juif : le voyage, l'attente, l'espoir, l'incertitude, la différence, la mémoire, et ces deux concepts mous, irrepérables, instables et fuyants, qui se renvoient sans cesse l'un l'autre leurs lumières tremblotantes, et qui s'appellent Terre natale et Terre promise. 